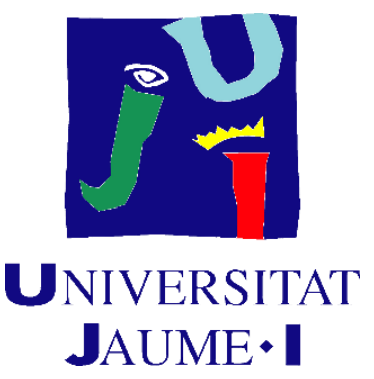

Programa de Doctorado en Derecho

Escuela de Doctorado de la Universitat Jaume I

\title{
EL RÉGIMEN JURÍDICO DE LA COMPENSACIÓN EQUITATIVA POR COPIA PRIVADA EN ESPAÑA Y SU INCORPORACIÓN EN AMÉRICA LATINA Y EL CARIBE
}

Deilyn Caridad Ramos Hernández

Tesis doctoral

Prof. Dra. María Victoria Petit Lavall

Prof. Dr. Jesús Olavarría Iglesia 



\section{EL RÉGIMEN JURÍDICO DE LA COMPENSACIÓN EQUITATIVA POR COPIA PRIVADA EN ESPAÑA Y SU INCORPORACIÓN EN AMÉRICA LATINA Y EL CARIBE}



A mi madre y a mi padre... 

«La virtud está en el término medio»

ARISTÓTELES 



\section{ÍNDICE}

ABREVIATURAS ……….......................................................................................XVII

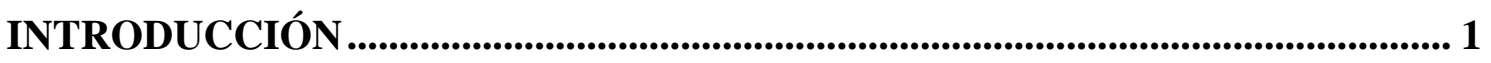

I. JUSTIFICACIÓN E IMPORTANCIA DE LA COMPENSACIÓN EQUITATIVA

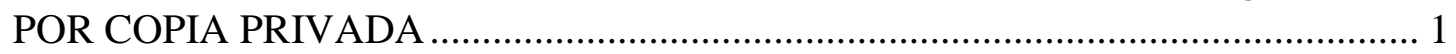

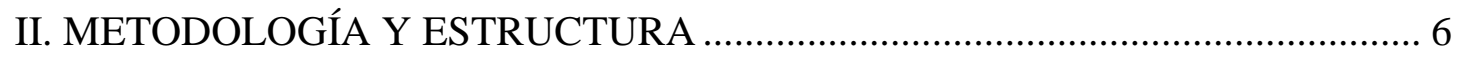

CAPÍTULO I: EL DERECHO DE REPRODUCCIÓN COMO DERECHO DE EXPLOTACIÓN ................................................................................................9

I. EL DERECHO DE REPRODUCCIÓN: SU CONTEXTUALIZACIÓN DENTRO DEL CONTENIDO DE LA PROPIEDAD INTELECTUAL ..................................... 11

II. LOS DERECHOS DE EXPLOTACIÓN …………………………………...... 15

1. Definición y características .............................................................................. 15

2. El fundamento de los derechos de explotación .................................................... 21

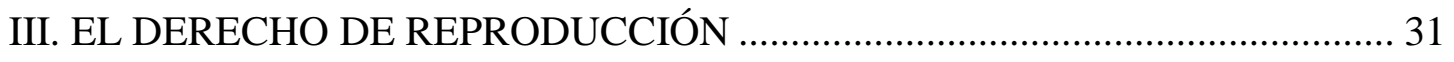

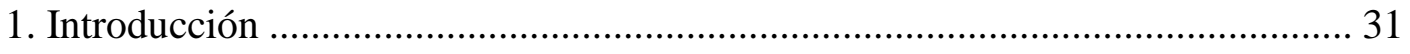

2. El derecho de reproducción en la legislación internacional, europea y nacional 32

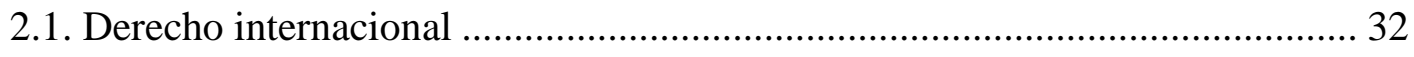

2.2. Derecho de la Unión Europea ........................................................................ 39

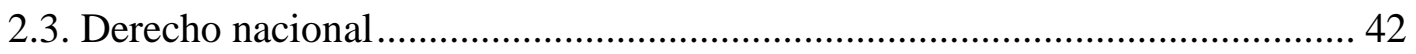

2.3.1. Definición y régimen legal ............................................................................. 42

2.3.2. Requisitos legales del derecho de reproducción ............................................ 45

2.3.2.1. Fijación y comunicación u obtención de copias............................................. 45

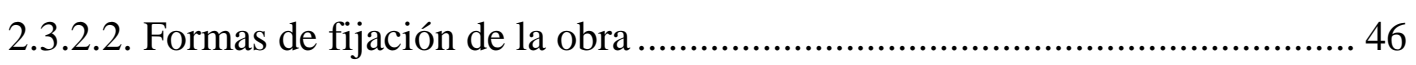

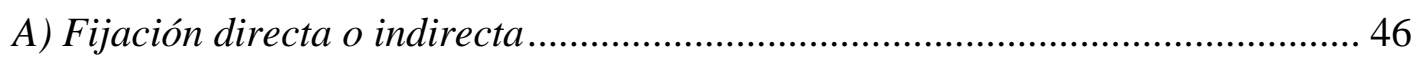

B) Fijación por cualquier medio y en cualquier forma .......................................... 47

C) Fijación de toda la obra o de parte de ella...................................................... 48

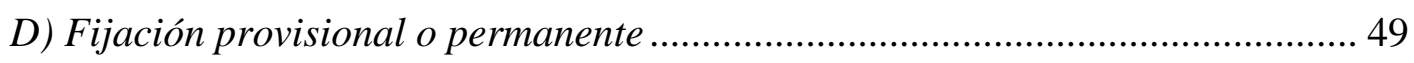

CAPÍTULO II: LOS LÍMITES A LOS DERECHOS DE PROPIEDAD INTELECTUAL: UNA VISIÓN GENERAL ............................................................. 65

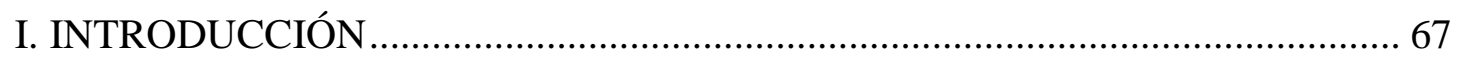

II. LOS LÍMITES A LOS DERECHOS DE PROPIEDAD INTELECTUAL ............ 69

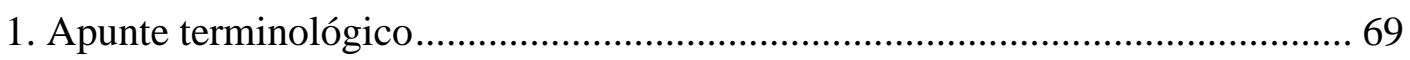

2. Los grupos de intereses en la regulación de la Propiedad Intelectual: la búsqueda de un punto de equilibrio......................................................................................... 71 
3. El fundamento de las excepciones o limitaciones a los derechos de propiedad

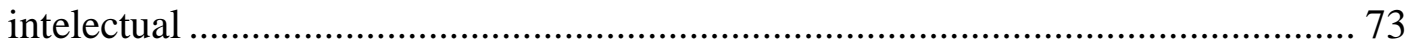

4. El régimen legal de las excepciones o limitaciones a los derechos de propiedad

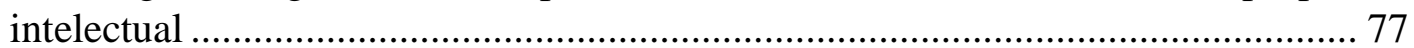

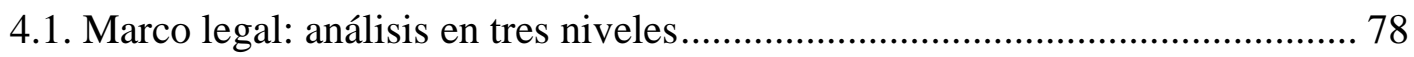

4.1.1. El régimen legal de las excepciones en el Derecho internacional................. 78

4.1.2. El régimen legal de las excepciones en la Unión Europea............................ 82

4.1.3. El régimen legal de las excepciones en el Derecho español ......................... 84

4.2. Derecho continental versus copyright: panorámica general .......................... 85

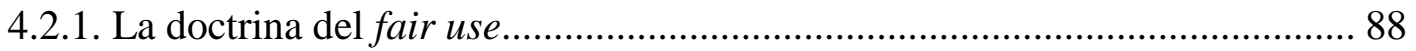

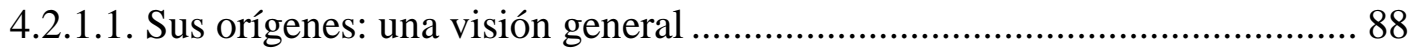

4.2.1.2. Los factores de la doctrina del fair use ..................................................... 94

A) La finalidad y el carácter del uso ...................................................................... 94

B) La naturaleza de la obra protegida ............................................................. 98

C) La cantidad y sustancialidad de la parte utilizada en relación con la obra en su

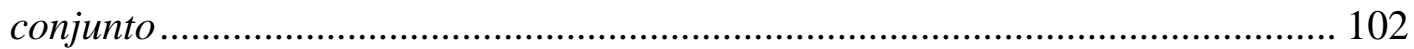

D) El efecto de la utilización de la obra en el mercado potencial o en el valor de la

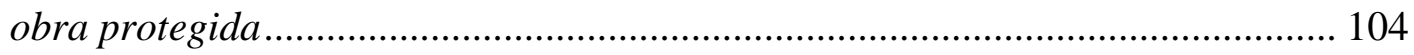

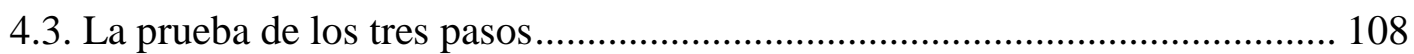

4.3.1. La decisión del Grupo Especial de la OMC en relación con el art. 13 del Acuerdo sobre los ADPIC en la interpretación de la prueba de los tres pasos ..... 111

4.3.1.1. Generalidades ................................................................................ 111

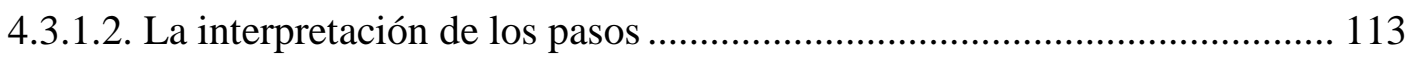

4.3.2. La prueba de los tres pasos y el fair use ..................................................... 120

4.3.3. La prueba de los tres pasos en la DDASI y en el ordenamiento jurídico

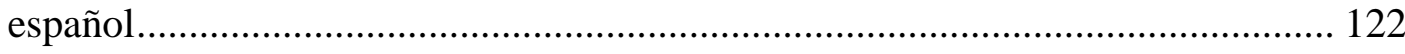

III. LA NECESIDAD DE REAJUSTAR EL SISTEMA DE LÍMITES A LOS DERECHOS DE PROPIEDAD INTELECTUAL EN LA UE ............................. 129

1. Hacia una aplicación menos restrictiva de los límites a los derechos de propiedad intelectual

2. Por un modelo renovado y más armonizado del sistema de límites a los derechos

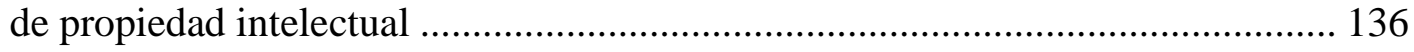

CAPÍTULO III: LA COPIA PRIVADA COMO LÍMITE AL DERECHO DE

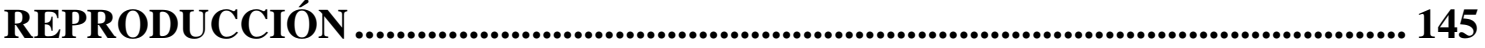

I. DE LA COPIA ANALÓGICA A LA COPIA DIGITAL: SU RECONOCIMIENTO COMO LÍMITE AL DERECHO DE REPRODUCCIÓN EN LA LEY DE PROPIEDAD INTELECTUAL ....................................................................... 147

II. LOS FUNDAMENTOS DE LA COPIA PRIVADA............................................ 151 
III. LA DELIMITACIÓN DE LA NOCIÓN DE COPIA PRIVADA Y SU

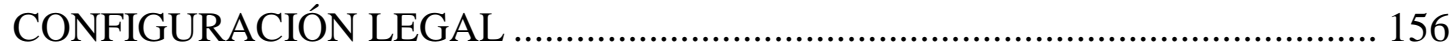

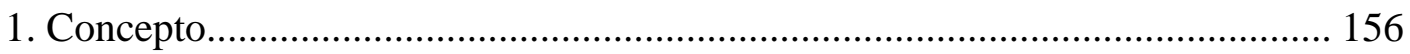

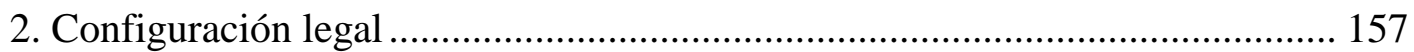

2.1. La regulación de la copia privada en el Derecho de la Unión Europea ......... 157

2.2. La regulación de la copia privada en España ............................................... 163

2.2.1. Cuestiones generales sobre la evolución del marco normativo................... 163

2.2.2. El objeto del límite de copia privada....................................................... 165

2.2.3. Los presupuestos del límite de copia privada........................................... 172

IV. LA SUJECIÓN DE LA COPIA PRIVADA A LA REGLA DE LOS TRES

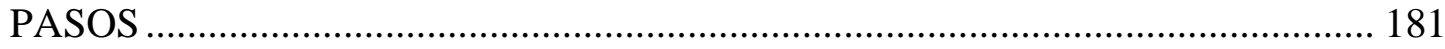

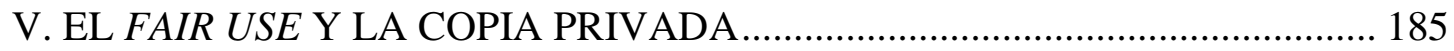

VI. LAS MEDIDAS TECNOLÓGICAS DE PROTECCIÓN Y LA COPIA

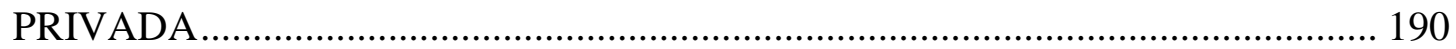

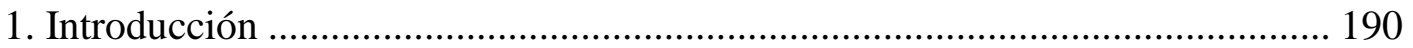

2. Aspectos generales sobre las medidas tecnológicas de protección .................... 191

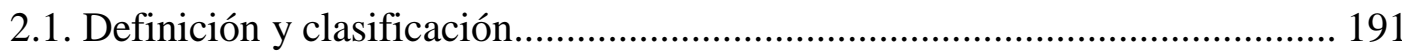

2.2. Marco general de protección de las medidas tecnológicas en la DDASI y en ordenamiento jurídico español ......................................................................... 193

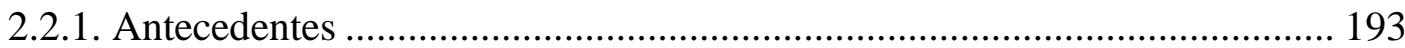

2.2.2. Esquema general de protección jurídica de las medidas tecnológicas en la DDASI

2.2.3. Esquema general de protección jurídica de las medidas tecnológicas en el TRLPI. 198

3. Limitaciones al derecho de autor y medidas tecnológicas de protección .......... 199

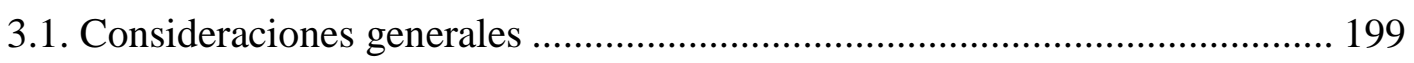

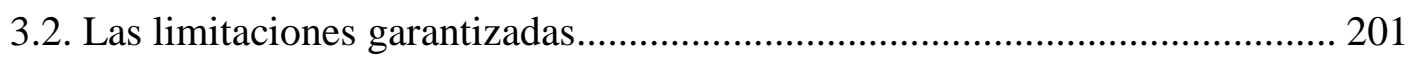

3.3. Las limitaciones no garantizadas............................................................ 202

3.4. La desarticulación del régimen de garantía de las limitaciones frente a las medidas tecnológicas y su subordinación a lo dispuesto contractualmente.......... 204

4. El caso particular de la copia privada: La facultad de garantizar el disfrute del límite de copia privada en la DDASI y su expresión en el TRLPI ....................... 206

VII. LA INEXISTENCIA DE UN DERECHO DEL USUARIO A LA COPIA

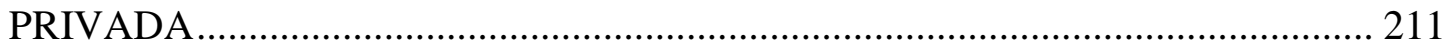

VIII. EL INTERCAMBIO DE ARCHIVOS EN LAS REDES P2P Y LA COPIA

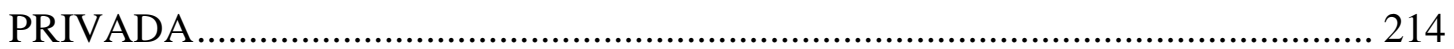

CAPÍTULO IV: EVOLUCIÓN LEGISLATIVA DE LA COMPENSACIÓN EQUITATIVA POR COPIA PRIVADA EN ESPAÑA: ESPECIAL 


\section{REFERENCIA A LA COMPENSACIÓN CON CARGO A LOS PRESUPUESTOS GENERALES DEL ESTADO ............................................ 225}

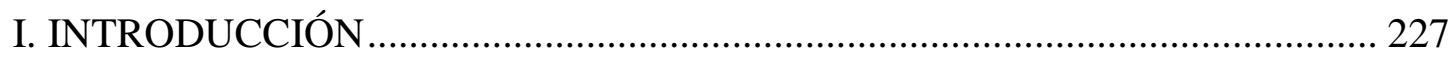

II. EVOLUCIÓN DEL MARCO LEGISLATIVO ................................................ 228

1. La compensación equitativa por copia privada: origen y evolución en Derecho interno. 228

1.1. Origen legal del sistema de compensación equitativa por copia privada en España: la Ley 22/1987, de 11 de noviembre, de Propiedad Intelectual 228

1.2. En busca de una regulación más eficiente: la Ley 20/1992, de 7 de julio, de modificación de la Ley 22/1987, de 11 de noviembre de Propiedad Intelectual .. 231

1.3. Nuevas reformas al sistema compensatorio: la Ley 43/1994, de 30 de diciembre y su incidencia en el art. 25 LPI

1.4. La aprobación del TRLPI: meros ajustes sistemáticos e insuficiencia regulatoria frente al escenario digital 238

2. La compensación equitativa por copia privada en el Derecho de la Unión Europea: su influencia en el Derecho interno 240

2.1. La DDASI como respuesta a los retos de la "Sociedad de la Información" en la Propiedad Intelectual. 240

2.2. La Ley 23/2006, de 7 de julio: norma de transposición de la DDASI al Derecho

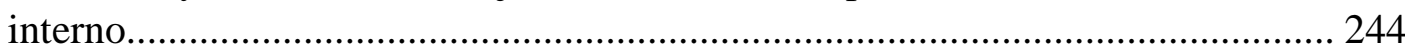

2.3. La Orden PRE/1743/2008, de 18 de junio 248

3. La financiación de la compensación con cargo a los Presupuestos Generales del Estado. 253

3.1. Instrumentación legal 253

3.2. La consolidación del modelo mediante la Ley 21/2014, de 4 de noviembre. 258

3.3. Crisis del modelo. 259

3.3.1. Observaciones generales .259

3.3.2. La resolución por el TJUE de la cuestión prejudicial planteada por el ATS (Sala de lo Contencioso-Administrativo), de 10 de septiembre de 2014 y su repercusión en el Derecho interno 262

3.3.2.1. Las conclusiones del Abogado General: el intento de legitimación del modelo de compensación con cargo a los Presupuestos Generales del Estado .... 262

3.3.2.2. La posición del TJUE 265

3.3.2.3. La repercusión del pronunciamiento del TJUE en el ordenamiento jurídico interno. 267

CAPÍTULO V: EL RÉGIMEN JURÍDICO DE LA COMPENSACIÓN EQUITATIVA POR COPIA PRIVADA EN EL ORDENAMIENTO JURÍDICO

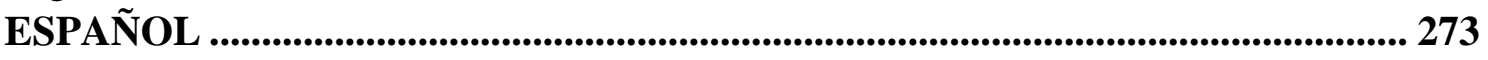

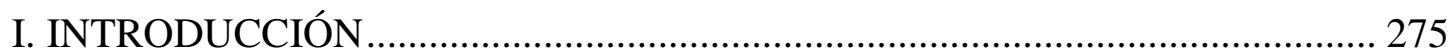


II. LA COMPENSACIÓN EQUITATIVA POR COPIA PRIVADA:

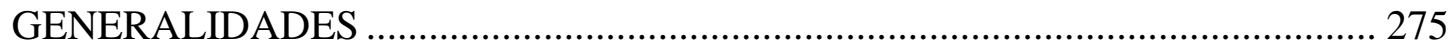

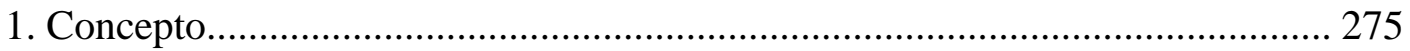

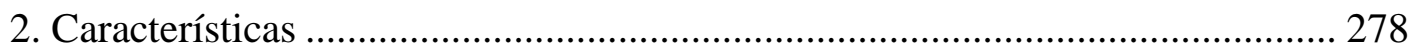

3. Naturaleza jurídica ……………………………………………………… 283

III. LOS SUJETOS DE LA COMPENSACIÓN EQUITATIVA................................ 291

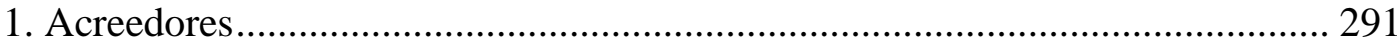

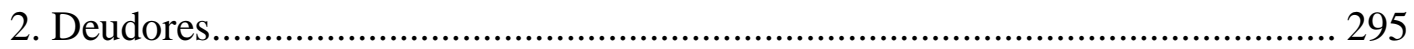

IV. EL NACIMIENTO DE LA OBLIGACIÓN DE COMPENSAR ……………...... 301

V. EL SISTEMA DE EXCEPTUACIONES Y REEMBOLSOS .............................. 302

1. Las excepciones ex ante del pago de la compensación ....................................... 302

2. Los supuestos de reembolso ex post de la compensación ................................... 309

VI. LOS EQUIPOS, APARATOS Y SOPORTES MATERIALES IDÓNEOS A EFECTOS DEL PAGO DE LA COMPENSACIÓN …………………………....... 312

1. El criterio de idoneidad .............................................................................. 312

2. El criterio de idoneidad objetiva en relación con la presunción de utilización de los equipos, aparatos y soportes materiales para la copia privada ......................... 315

3. Los equipos, aparatos y soportes materiales de reproducción sujetos a la compensación: el tránsito de lo analógico a lo digital ............................................. 326

3.1. Los equipos, aparatos y soportes materiales de reproducción analógica ........ 326

3.2. Los equipos, aparatos y soportes materiales de reproducción digital ............. 329

3.2.1. El régimen provisional de la Disposición Transitoria única de la Ley

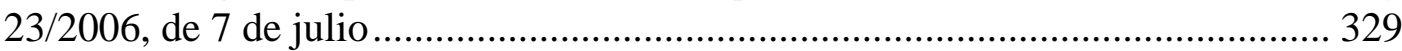

3.2.2. La Orden PRE/1743/2008, de 18 de junio .................................................. 330

3.2.3. La Disposición Transitoria segunda del Real Decreto-ley 12/2017, de 3 de julio.

3.2.4. El establecimiento de un nuevo régimen definitivo tras la etapa de

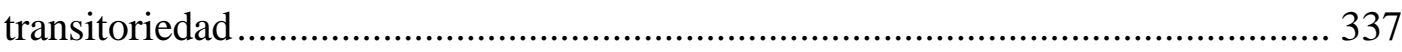

VII. LA CUANTÍA DE LA COMPENSACIÓN EQUITATIVA ………………….... 338

1. El perjuicio como elemento base del cálculo de la compensación ..................... 338

2. Criterios objetivos para la determinación de la cuantía de la compensación.... 343

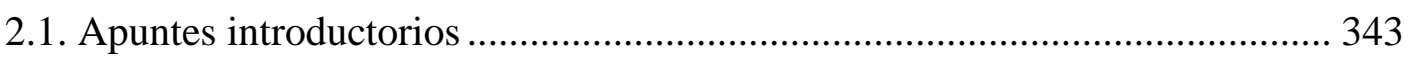

2.2. Los criterios objetivos del art. 25.5.a) del TRLPI.......................................... 344

2.2.1. La intensidad de uso de los equipos, aparatos y soportes materiales.......... 344

2.2.2. La capacidad de almacenamiento de los equipos, aparatos y soportes materiales y la importancia de la función de reproducción...................................... 346

2.2.3. El impacto del límite legal de copia privada sobre la venta de ejemplares de las obras y el precio de la unidad de cada modalidad reproducida ........................ 348 
2.2.4. El carácter digital o analógico o la calidad y el tiempo de conservación de las reproducciones

2.2.5. La disponibilidad, grado de aplicación y efectividad de las medidas tecnológicas y su impacto en las reproducciones realizadas al amparo del límite legal de copia privada. 351

2.2.6. La consideración de las cuantías aplicadas en otros Estados miembros de la

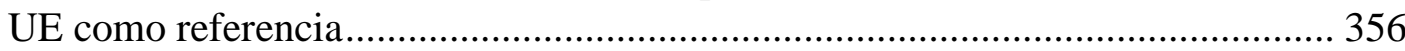

3. El procedimiento para la determinación de la cuantía de la compensación...... 357

4. La cuantía de la compensación en el régimen transitorio ................................. 360

VIII. LA GESTIÓN DE LA COMPENSACIÓN EQUITATIVA POR COPIA

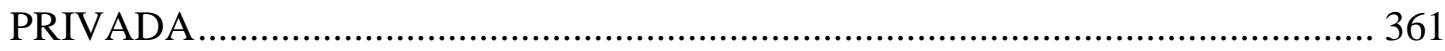

1. Las entidades encargadas de la gestión ........................................................ 361

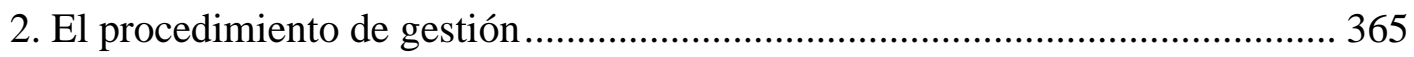

3. La distribución y posterior reparto de la compensación entre los acreedores... 372

CAPÍTULO VI: LA COPIA PRIVADA Y LA COMPENSACIÓN POR COPIA PRIVADA EN AMÉRICA LATINA Y EL CARIBE ............................................. 377

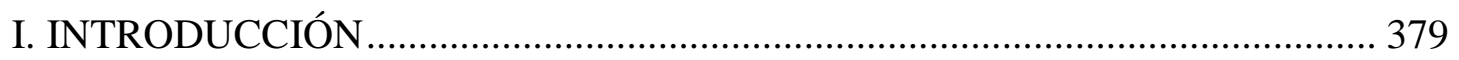

II. MARCO LEGAL DE LA PROPIEDAD INTELECTUAL EN AMÉRICA

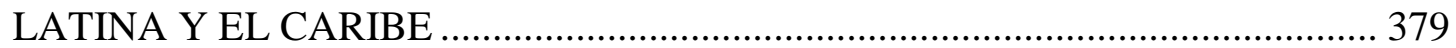

1. El origen de las leyes de propiedad intelectual en los países de la región ......... 379

2. Primeros pasos en la implementación de la protección internacional................ 381

3. El marco regulatorio actual de los derechos de autor en el contexto

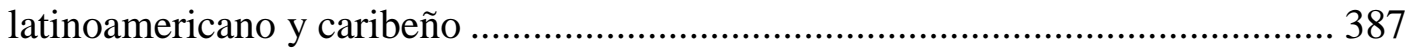

III. PANORAMA GENERAL DE LAS EXCEPCIONES Y LIMITACIONES A LOS DERECHOS DE AUTOR EN AMÉRICA LATINA Y EL CARIBE ...................... 392

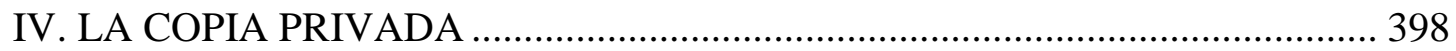

V. LA COMPENSACIÓN POR COPIA PRIVADA …............................................ 407

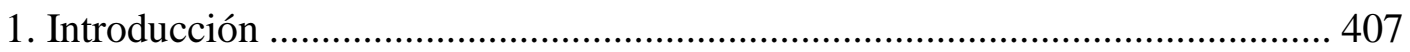

2. Examen comparativo de las legislaciones ...................................................... 410

VI. BREVE EXAMEN DE LA SITUACIÓN ACTUAL DE ALGUNOS PAÍSES EN LOS QUE NO ESTÁ AUTRIZADA LA COPIA PRIVADA …............................. 426

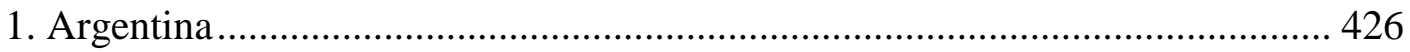

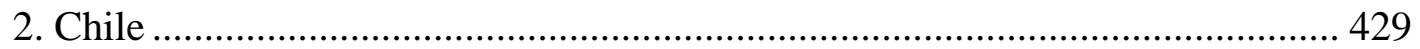

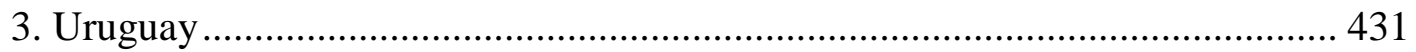

VII. CUBA. LA PROTECCIÓN DEL DERECHO DE AUTOR Y SU SUBORDINACIÓN A LOS INTERESES SOCIALES Y CULTURALES ............ 433

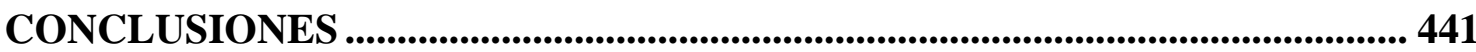


FUENTES............................................................................................................................................. 455

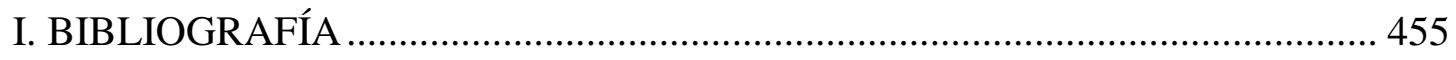

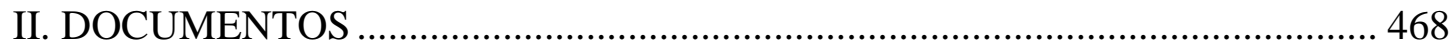

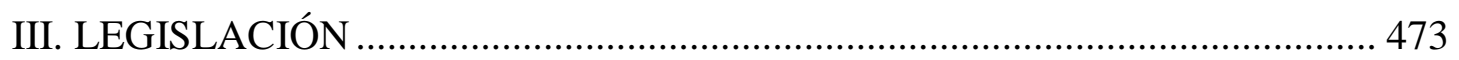

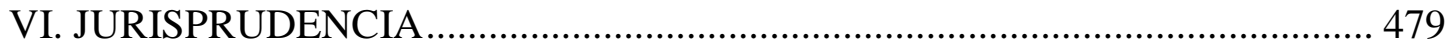

ANEXOS ................................................................................................................................ 485 



\section{ABREVIATURAS}

AAP

AA.VV.

ADEPI

AETIC

AGEDI

AHRA

AI

AIE

AIPPI

AISGE

ANAIE

APDAYC

Apdo. (s.)

APSAV

Art. (s)

ASIMELEC

ATS

B.O.E.

Cap.

CB

$\mathrm{CC}$

CD

CE

CGPJ

cit.

cit. por.

Coord. (s.)

CR

DAMA

DDASI

DINAPI

Dir. (s)

DMCA
Auto de la Audiencia Provincial

Autores varios

Asociación para el Desarrollo de la Propiedad Intelectual

Asociación Española de Empresas de Electrónica, Tecnologías de la Información y Telecomunicaciones de España

Asociación de Gestión de Derechos Intelectuales

Audio Home Recording Act

Asociación de Internautas

Sociedad de Artistas Intérpretes o Ejecutantes de España

Asociación Internacional para la Protección de la Propiedad Intelectual

Artistas Intérpretes Sociedad de Gestión

Asociación Nacional de Artistas Intérpretes y Ejecutantes

Asociación Peruana de Autores y Compositores

Apartado (s)

Asociación Peruana de Artistas Visuales

Artículo (s)

Asociación Multisectorial de Empresas Españolas de Electrónica y Comunicaciones

Auto del Tribunal Supremo

Boletín Oficial del Estado

Capítulo

Convenio de Berna para la Protección de las Obras

Literarias y Artísticas

Código Civil

Compact Disc

Constitución española

Consejo General del Poder Judicial

Citada

Citado por

Coordinador (es)

Convención Internacional sobre la protección de los artistas intérpretes o ejecutantes, los productores de fonogramas y los organismos de radiodifusión

Entidad de gestión colectiva de Derechos de Autor de Medios Audiovisuales

Directiva 2001/29/CE del Parlamento Europeo y del Consejo, de 22 de mayo de 2001, relativa a la armonización de determinados aspectos de los derechos de autor y derechos afines a los derechos de autor en la sociedad de la información

Dirección Nacional de Propiedad Intelectual

Director (es)

Digital Millennium Copyright Act 
D.O.C.E.

D.O.F.

D.O.U.E.

DVD

Ed. (s.)

ed.

EE.UU.

EGEDA

et al.

etc.

F.J.

$\mathrm{Gb}$

GIU

HTML

ICV

IV

IEPI

INDECOPI

JIPITEC

J.O.R.F.

$\mathrm{Kg}$

LEC

LFDA

LPI

LSSI

$\mathrm{Mb}$

Mod.

MP3

N. ${ }^{\circ}$

$\mathrm{OMC}$

OMPI

ONDA

ONU

op. cit.

p.

PGE

pp.

P2P

Ram

$R D P$

SAP

SAN

SCCR
Diario Oficial de las Comunidades Europeas

Diario Oficial de la Federación

Diario Oficial de la Unión Europea

Digital Versatile Disc

Editor (es)

Edición

Estados Unidos

Entidad de Gestión de Derechos de los Productores Audiovisuales

Et aliter

Etcétera

Fundamento jurídico

Gigabyte

Grupo Izquierda Unida

HyperText Markup Language

Iniciativa per Catalunya Verds

Izquierda Verde

Instituto Ecuatoriano de la Propiedad Intelectual

Instituto Nacional de Defensa de la Competencia y de la Protección de la Propiedad Intelectual

Journal of Intellectual Property, Information Technology and Electronic Commerce Law

Journal Officiel de la République française

Kilogramo

Ley de Enjuiciamiento Civil

Ley Federal de Derecho de Autor

Ley de Propiedad Intelectual

Ley de servicios de la sociedad de la información y de comercio electrónico

Megabyte

Moderadora

MPEG-1 Audio Layer III o MPEG-2 Audio Layer III, (Formato de compresión de audio digital)

Número

Organización Mundial del Comercio

Organización Mundial de la Propiedad Intelectual

Oficina Nacional de Derecho de Autor (República

Dominicana)

Organización de Naciones Unidas

Obra citada

Página

Presupuestos Generales del Estado

Páginas

Peer to Peer

Random Access Memory

Revista de Derecho Privado

Sentencia de la Audiencia Provincial

Sentencia de la Audiencia Nacional

Standing Committee on Copyright and Related Rights 
Secc.

SGACEDOM

SGAE

SODAIE

SODINPRO

STC

STJUE

STS

TJUE

TODA

TOIEF

TRLPI

UE

UNESCO

UNIMPRO

U.S.

v. $g r$.

Vid.

Vol.

vs.
Sección

Sociedad General de Autores, Compositores y Editores Dominicanos de Música

Sociedad General de Autores y Editores

Sociedad Dominicana de Artistas Intérpretes y Ejecutantes

Sociedad Dominicana de Productores fonográficos

Sentencia del Tribunal Constitucional

Sentencia del Tribunal de Justicia de la Unión Europea

Sentencia del Tribunal Supremo

Tribunal de Justicia de la Unión Europea

Tratado de la OMPI sobre Derecho de Autor

Tratado de la OMPI sobre Interpretación o Ejecución y

Fonogramas

Texto Refundido de la Ley de Propiedad Intelectual

Unión Europea

Organización de las Naciones Unidas para la Educación, la Ciencia y la Cultura

Unión Peruana de Productores Fonográficos

United States

Verbi gratia

Véase

Volumen

Versus 



\section{INTRODUCCIÓN}

\section{JUSTIFICACIÓN E IMPORTANCIA DE LA COMPENSACIÓN EQUITATIVA POR COPIA PRIVADA}

La propiedad intelectual confiere a los titulares de derechos de autor y derechos conexos facultades exclusivas para autorizar o prohibir el uso de sus creaciones. Sin embargo, al mismo tiempo, las leyes en la materia configuran lo que pudieran llamarse “espacios de libre utilización" en los que el uso de las obras no queda supeditado al previo consentimiento del titular de los derechos, si bien habrán de cumplirse los presupuestos que, en cada caso, las leyes determinen.

Estos “espacios", comúnmente conocidos o denominados excepciones, limitaciones o límites a los derechos de propiedad intelectual ${ }^{1}$ se establecen, en definitiva, debido a la existencia de otros derechos e intereses sociales que, se entiende, justifican la restricción del poder omnímodo otorgado legalmente al titular sobre su creación. En efecto, no puede perderse de vista que la creación intelectual también es fruto del acervo colectivo y tiene un valor fundamental en el desarrollo educativo, cultural y social de la humanidad. Por ello, aun cuando el Derecho de Propiedad Intelectual sitúa en su centro al autor -así como, en su caso, a los titulares de derechos conexos ${ }^{2}$ - establece límites a su derecho una vez divulgada la obra. Así, en la regulación de esta materia se tiene en cuenta la existencia de determinados derechos e intereses colectivos, aunque con matices diferentes según se trate de países del ámbito del Civil Law y del Common Law, así como de cada legislación particular.

Ambas cuestiones, el reconocimiento de derechos exclusivos en favor de los titulares de derechos de autor y derechos conexos, por un lado, y la existencia de otros

\footnotetext{
${ }^{1}$ Sobre el uso y significado de dichos vocablos vid. epígrafe II. 1 del Capítulo II. No obstante, se adelanta desde aquí que en este trabajo son utilizados indistintamente, como sinónimos.

${ }^{2}$ A los titulares de derechos conexos son aplicables, por remisión del artículo 132 del Real Decreto Legislativo 1/1996, de 12 de abril, por el que se aprueba el texto refundido de la Ley de Propiedad Intelectual, regularizando, aclarando y armonizando las disposiciones legales vigentes sobre la materia (en adelante TRLPI) (B.O.E. núm. 97, de 22 de abril de 1996), las disposiciones contenidas en el artículo 6.1, de la sección 2. a del capítulo III, del Título II (derechos de explotación) y en el capítulo II del Título III (límites), salvo lo establecido en el párrafo segundo del apartado segundo del artículo 37, ambos del Libro I.
} 
derechos e intereses colectivos dignos de tutela, por otro, conllevan que las normas de propiedad intelectual no puedan descuidar la necesidad de establecer un equilibrio entre ambos intereses contrapuestos.

Además, debe destacarse que los límites a los derechos de autor no son estáticos, como tampoco lo son los derechos mismos, pues las circunstancias que dan lugar a un marco normativo determinado varían inevitablemente con el transcurso del tiempo, sobre todo a consecuencia del desarrollo tecnológico. Los avances tecnológicos no sólo marcaron en su día el nacimiento de la Propiedad Intelectual, sino que también han provocado una necesaria reconfiguración de ésta. En efecto, el desarrollo de nuevas tecnologías -analógicas, inicialmente, y digitales, con posterioridad y actualmente- han obligado a adaptar el marco legal tradicional de esta materia ${ }^{3}$.

Es un hecho evidente la repercusión que han tenido las tecnologías digitales e Internet en la sociedad de finales del siglo XX e inicios del siglo XXI. Asimismo, es unánimemente aceptada la influencia que ejercen estas tecnologías en el ámbito de la Propiedad Intelectual, que participa de lo que se ha dado en llamar "digital dilemma"4. En efecto, la tecnología digital ha revolucionado los modos tradicionales de acceso, distribución y explotación de los contenidos culturales; ha hecho posible prescindir de un soporte tangible para la reproducción, comunicación pública y distribución de las obras; ha permitido obtener copias idénticas a los originales; ha reducido los costos de la copia; y ha facilitado el intercambio de las creaciones a escala global y el acceso masivo a las mismas. A su vez, la relativa facilidad con que se puede acceder a los productos tecnológicos y el acceso masivo a los medios digitales ha transformado la forma en que los individuos consumen las creaciones intelectuales. En definitiva, el marco digital ha venido a agudizar la tradicional confrontación de intereses entre los

\footnotetext{
${ }^{3}$ Carbajo Cascón, F., Publicaciones electrónicas y Propiedad Intelectual, Colex, Madrid, 2002, pp. 8287.

${ }^{4}$ Committee on Intellectual Property Rights and The Emerging Information Infrastructure, The Digital Dilemma: Intellectual Property in the Information Age, National Academy Press, Washington, D.C., 2000 , pp. 1-3. La expresión "digital dilemma" es utilizada para describir las promesas y peligros que supone la transformación digital: al tiempo que multiplica las posibilidades de acceso a las obras, conduce a soluciones técnicas y legales que pueden restringir el acceso al patrimonio intelectual y cultural.
} 
titulares de derechos de autor, los usuarios de las creaciones intelectuales y las industrias de productos y servicios tecnológicos y culturales.

Por ello, ha sido preciso replantear la configuración de los límites a los derechos de autor y derechos conexos para adoptar soluciones legales ajustadas a la nueva realidad y, dentro de ellos, el límite de copia privada que, en términos generales permite la reproducción de la obra sin ánimo de lucro para fines privados. Este límite es habitualmente consagrado en los ordenamientos jurídicos nacionales, aun cuando no es exigido por las normas internacionales, ni por la normativa europea.

No obstante, no puede perderse de vista que la Directiva 2001/29/CE del Parlamento Europeo y del Consejo, de 22 de mayo de 2001, relativa a la armonización de determinados aspectos de los derechos de autor y derechos afines a los derechos de autor en la sociedad de la información ${ }^{5}$ (en adelante DDASI), exige que, si se introduce la excepción de copia privada en la ley, se establezca una compensación equitativa en favor de los titulares de los derechos. La razón de esta exigencia no es otra que la necesidad de compensarles de los perjuicios económicos que les supone la copia privada, pues, en un entorno donde la tecnología pone a disposición de todos la posibilidad de hacer copias, el límite de copia privada pone en peligro la explotación normal de la obra y los legítimos intereses de sus titulares, sobre todo teniendo en cuenta el amplio alcance que tiene el derecho de reproducción a día de hoy en la legislación comunitaria e interna ${ }^{6}$.

Sin perjuicio de lo anterior, la compensación equitativa por copia privada no era ajena al ordenamiento jurídico español antes de la transposición de la DDASI, si bien su introducción en el acervo comunitario obligó al legislador español a hacer ajustes normativos, tanto en el momento de su transposición a la legislación interna, como con posterioridad para adaptar la regulación española al entorno digital y a la jurisprudencia del TJUE.

\footnotetext{
${ }^{5}$ D.O.U.E núm. L 167 de 22 de junio de 2001.

${ }^{6}$ Carbajo Cascón, F., Publicaciones electrónicas..., op. cit., p 145.
} 
En cualquier caso, las reformas legislativas no han sido pacíficas. Los espacios de discusión no sólo se han suscitado en el ámbito académico, doctrinal o jurisprudencial ${ }^{7}$, sino también en las organizaciones de empresarios, sindicatos, ciudadanos ${ }^{8}$, o en el Consejo de Consumidores y Usuarios ${ }^{9}$, entre otros entes y grupos. La importante relevancia temática de la materia ha sido incluso mediática, de forma tal que atrajo mi atención en el momento de seleccionar el tema de investigación del trabajo final de máster en el año 2010. Aquél fue, pues, el comienzo de mis estudios sobre la compensación equitativa por copia privada en la legislación española, cuya regulación era ajena a mi formación, toda vez que no existe tal compensación en el ordenamiento jurídico cubano (punto de partida de mis estudios en Derecho).

Eran muchas las dudas e interrogantes que se suscitaban: por qué el marco regulatorio de la compensación equitativa por copia privada había estado en constante adaptación; por qué resulta difícil encontrar un punto de equilibrio en su regulación; o de qué manera el TRLPI conseguiría adaptarse mejor a la doctrina del TJUE y generar cierta aceptación y vocación de permanencia en la legislación. Posteriormente, se sumó la curiosidad por explorar si en otros países de la región de América Latina y el Caribe existía una regulación al respecto, así como el interés por conocer la posible influencia, en su caso, de la regulación española sobre dichos ordenamientos jurídicos.

\footnotetext{
${ }^{7}$ Vid. por todos, Xalabarder Plantada, R. (Mod.); Martín-Prat, M.; Malmierca, M. y Ramírez, J., "La copia privada digital. Mesa redonda", IDP. Revista de Internet, Derecho y Política, núm. 1, 2005, pp. 35-55; MARcos Fernández, F., SAntalo Mediavilla, J., SÁnChEz Graells, A., Consideraciones sobre el Dictamen de la Comisión Asesora de la Sociedad de la Información: "Evaluación crítica de la propuesta del derecho a compensación por copia privada (canon) en el marco del proyecto de reforma de la Ley de Propiedad Intelectual", Madrid, 2006, pp. 3 y ss., disponible en: http://www.sgae.es/recursos/pdf/comunicacion/Econlaw.pdf (consultado: 20/11/2017); PADRÓs REIG, C., "Debilidades y retos del régimen jurídico vigente de protección de la copia privada", en PADRÓs REIG, C. y LÓPEZ SinTAS, J. (Dirs.), El canon digital a debate. Revolución tecnológica y consumo cultural en un nuevo marco jurídico-económico, Atelier, Barcelona, 2011, pp. 222-227.

${ }^{8}$ La plataforma "todos contra el canon" (www.todoscontraelcanon.es) ilustra lo expuesto. Esta plataforma fue una iniciativa para la recogida de firmas en contra la compensación equitativa por copia privada digital. Su nombre se debe a que la compensación equitativa por copia privada digital ha sido tradicionalmente llamada "canon digital", pese a que la figura no ostenta una naturaleza jurídica tributaria.

${ }^{9}$ Vid. Informe aprobado por el órgano de representación y consulta del Consejo de Consumidores y Usuarios en reunión plenaria celebrada en Madrid, en fecha 27 de diciembre de 2007, disponible en: http://www.internautas.org/archivos/pdf/INFORME_SOBRE_EL_PROYECTO_D_EORDEN_PARA_L. pdf (consultado: 25/11/2017).
} 
Pues bien, con todo, la presente tesis efectúa un análisis de la controvertida figura de la compensación equitativa por copia privada como solución adoptada por el legislador para paliar los perjuicios económicos a los titulares de los derechos de autor y derechos conexos causados por la realización de copias privadas. El estudio analiza el marco legal español actual, así como los sucesivos cambios legislativos que se han producido, ilustrando la problemática que supone la regulación de la institución. De hecho, precisamente durante la elaboración, se han producido dos grandes reformas al TRLPI: la primera en 2014, mediante la promulgación de la Ley 21/2014 de 4 de noviembre ${ }^{10}$, que ratificó el sistema compensatorio por copia privada introducido en el ordenamiento jurídico español mediante el Real Decreto-Ley 20/2011, de 30 de diciembre $^{11}$, haciéndolo depender de los Presupuestos Generales del Estado (en adelante PGE); la segunda, muy recientemente y cuando prácticamente estaba finalizada la tesis, en 2017, con la publicación del Real Decreto-ley 12/2017, de 3 de julio) ${ }^{12}$, que ha supuesto la esperada vuelta al sistema precedente, donde la compensación equitativa depende nuevamente de una cantidad establecida legalmente sobre los equipos, aparatos y soportes materiales de reproducción idóneos para la copia privada ${ }^{13}$.

Como se verá, puede decirse que la regulación actual de la compensación equitativa por copia privada en el ordenamiento jurídico español - adaptada al Derecho de la Unión Europea- ofrece una mejor solución que la anterior con cargo a los PGE. En este sentido debe destacarse que la reciente promulgación del Real Decreto-ley 12/2017, de 3 de julio, sitúa nuevamente a la legislación española dentro del modelo de regulación de la compensación equitativa por copia privada mayoritariamente implementado en los países del entorno. En todo caso, el presente trabajo también analiza la normativa europea, dado que la legislación española, como no puede ser de otro modo, responde a las pautas marcadas por la Unión Europea, lo que resulta además un estudio útil a

\footnotetext{
${ }^{10}$ B.O.E. núm. 268, de 5 de noviembre de 2014.

${ }^{11}$ B.O.E. núm. 315, de 31 de diciembre de 2011.

${ }^{12}$ B.O.E. núm. 158 , de 4 de julio de 2017.

${ }^{13}$ Esta reciente reforma, cuando estaba prácticamente finalizada la tesis, obligó a un importante cambio en su estructura.
} 
efectos de su comparación con el sistema seguido por los países de América Latina y el Caribe.

\section{METODOLOGÍA Y ESTRUCTURA}

La tesis analiza la institución de la compensación equitativa por copia privada siguiendo la metodología jurídica clásica, esto es, el estudio exhaustivo de la legislación vigente, basado en el examen de los antecedentes, la interpretación efectuada por los tribunales de justicia y la doctrina, así como de la situación en otros ordenamientos jurídicos de nuestro entorno. No obstante, la investigación no se limita a un plano estrictamente teórico-exegético ${ }^{14}$, sino que pretende ser de utilidad práctica en aquellos países de América Latina y del Caribe que cuentan, bien con una legislación obsoleta o bien carecen de regulación de la figura.

La investigación se estructura en seis capítulos. El primero y el segundo analizan, respectivamente, el derecho de reproducción en el contexto de los derechos de explotación y los límites a estos derechos, ambas cuestiones imprescindibles para comprender los fundamentos tanto de estos derechos como de sus límites y, más concretamente, el fundamento de la copia privada como límite al derecho de reproducción y la continua búsqueda del equilibrio de intereses en la Propiedad Intelectual.

En particular, el capítulo primero trata el derecho de reproducción y su régimen legal a nivel internacional, comunitario y español, dentro del conjunto de derechos que conforman el contenido de la Propiedad Intelectual. El capítulo segundo, por su parte, aborda el tema de las limitaciones a estos derechos examinando el régimen jurídico de éstas y haciendo especial referencia a la distinta configuración del sistema de límites en

\footnotetext{
${ }^{14}$ La exégesis jurídica ha sido fundamental en la interpretación de las normas, no sólo apoyada en una interpretación literal de las mismas, sino también en una interpretación sistemática -buscando que las proposiciones de los textos jurídicos sean congruentes unas con otras-; una interpretación histórica conforme al contexto en el que actúa el legislador y una interpretación teleológica según la finalidad de la norma. Vid. CORREAS, O., Metodología Jurídica II. Los saberes y las prácticas de los abogados, Ediciones Coyoacán, México, D.F., 2006, pp. 222-228 y 230-234.
} 
los países del Civil Law y los países del Commmon Law, a fin de comprender el alcance que tienen en una y otra tradición jurídica y evaluar el rumbo del sistema de límites en la Unión Europea, así como la conveniencia de su flexibilización.

Seguidamente, el capítulo tercero examina la copia privada como una de estas limitaciones al derecho de reproducción. En concreto, analiza el régimen jurídico de la copia privada en el Derecho español, profundizando en el estudio de su regulación y su relación con las medidas tecnológicas de protección, todo ello sin perder de vista los distintos intereses implicados en la Propiedad Intelectual. Como parte de este análisis se hace referencia igualmente al marco normativo de la Unión Europea y a la doctrina del fair use del sistema angloamericano para comprender cómo se instrumenta la copia lícita con fines privados en un sistema jurídico en el que las excepciones a los derechos de autor y derechos conexos no están tasadas en la ley.

Tras el estudio de la excepción por copia privada, los capítulos cuatro y cinco analizan el régimen jurídico de la compensación equitativa por copia privada. El cuarto capítulo lo hace desde una perspectiva histórico-cronológica, con la finalidad no sólo de ilustrar los distintos cambios normativos que se han venido sucediendo, sino también su alcance, aciertos y desaciertos. Especial relevancia tiene en esta parte de la tesis el examen del cambio de modelo de satisfacción de la compensación equitativa por copia privada basado en un canon compensatorio, a un régimen jurídico con cargo a los PGE, así como el retorno al modelo de canon. El capítulo cinco, por su parte, se centra en el estudio de la actual regulación española, tras la reciente modificación del TRLPI llevada a cabo por el Real Decreto-ley 12/2017, de 3 de julio, comparando su contenido con el que tenían las normas anteriores, sin perjuicio de que todavía falta por saber cómo se instrumentarán diferentes cuestiones que el legislador ha reservado a ulterior desarrollo reglamentario.

Finalmente, el capítulo seis analiza el régimen legal de la copia privada y de la compensación por copia privada de los principales países de América Latina y el Caribe. En concreto, se han estudiado las legislaciones sobre derechos de autor y derechos conexos o afines a los derechos de autor de diecinueve países de la región: Argentina, Bolivia, Brasil, Chile, Colombia, Costa Rica, Cuba, Ecuador, El Salvador, Guatemala, Honduras, México, Nicaragua, Panamá, Paraguay, Perú, República Dominicana, Uruguay y Venezuela. Ello permite obtener una panorámica general sobre 
la situación legislativa de este límite al derecho de autor existente en dichos Estados. No obstante, cabe precisar que los comentarios que se realizan se centran, fundamentalmente, en las disposiciones que contemplan la copia privada como límite al derecho de autor y establecen una compensación asociada a dicho límite. Esto es, se efectúa un examen de aquellas disposiciones que regulan expresamente la copia privada contrastando las mismas fundamentalmente con la analizada legislación española.

En fin, la tesis ofrece una serie de conclusiones que son el resultado del estudio y análisis realizados a lo largo de toda la investigación. 


\title{
CAPÍTULO I: EL DERECHO DE REPRODUCCIÓN COMO DERECHO DE EXPLOTACIÓN
}

\author{
SUMARIO: I. EL DERECHO DE REPRODUCCIÓN: SU CONTEXTUALIZACIÓN \\ DENTRO DEL CONTENIDO DE LA PROPIEDAD INTELECTUAL. II. LOS \\ DERECHOS DE EXPLOTACIÓN. 1. Definición y características. 2. El fundamento de \\ los derechos de explotación. III. EL DERECHO DE REPRODUCCIÓN. 1. \\ Introducción. 2. El derecho de reproducción en la legislación internacional, europea y \\ nacional. 2.1. Derecho internacional. 2.2. Derecho de la Unión Europea. 2.3. Derecho \\ nacional. 2.3.1. Definición y régimen legal. 2.3.2. Requisitos legales del derecho de \\ reproducción. 2.3.2.1. Fijación y comunicación u obtención de copias. 2.3.2.2. Formas \\ de fijación de la obra. A) Fijación directa o indirecta. B) Fijación por cualquier medio y \\ en cualquier forma. C) Fijación de toda la obra o de parte de ella. D) Fijación \\ provisional o permanente.
}





\section{EL DERECHO DE REPRODUCCIÓN: SU CONTEXTUALIZACIÓN DENTRO DEL CONTENIDO DE LA PROPIEDAD INTELECTUAL}

Antes de abordar los aspectos fundamentales que permiten delimitar el contenido del derecho de reproducción, es necesario, en primer término, ubicar la posición que este derecho ocupa dentro de los derechos de propiedad intelectual. Así pues, muy a grandes rasgos, hay que partir de que la Ley de Propiedad Intelectual española (Real Decreto Legislativo 1/1996, de 12 de abril, por el que se aprueba el texto refundido de la Ley de Propiedad Intelectual, regularizando, aclarando y armonizando las disposiciones legales vigentes sobre la materia ${ }^{15}$, en adelante TRLPI) reconoce a los titulares de derechos de propiedad intelectual ciertos derechos, tanto de índole moral como patrimonial. Los primeros ostentan un carácter personal y se hacen eco del vínculo íntimo existente entre la obra y el autor, mientras que los segundos tienen un carácter pecuniario y delimitan el contenido de las facultades patrimoniales, es decir, aseguran a los titulares el control de la explotación de la creación y, como consecuencia, la percepción de una remuneración por su trabajo intelectual ${ }^{16}$. En efecto, los derechos de contenido patrimonial se deben a la propia vocación de las obras y prestaciones destinadas a ser disfrutadas por personas ajenas al creador, con lo cual, cobra sentido que éste reciba una recompensa por esa actividad creativa, una remuneración cuyo fundamento se ha intentado explicar a través de las teorías que han dado soporte a la existencia de la Propiedad Intelectual como disciplina, entre las que destacan la teoría del derecho de propiedad, la teoría del trabajo, la teoría del contrato social, o la teoría de la personalidad, entre otras.

Pues bien, el reconocimiento de derechos de naturaleza moral al autor ha sido tardío en relación con el reconocimiento de derechos patrimoniales. No es hasta la revisión de 1928 del Convenio de Berna para la Protección de las Obras Literarias y Artísticas, de 9 de septiembre de 1886 (en adelante CB) -ya en el siglo XX-, cuando se

\footnotetext{
${ }^{15}$ B.O.E. núm. 97, de 22 de abril de 1996.

${ }^{16}$ Bondía Román, F., Propiedad Intelectual. Su significado en la sociedad de la información, Trivium, Madrid, 1988, p. 200.
} 
reconoce en el plano internacional el derecho moral de los autores ${ }^{17}$, mediante el art. 6.bis, que señala en su apartado primero:

"Independientemente de los derechos patrimoniales del autor, e incluso después de la cesión de estos derechos, el autor conservará el derecho de reivindicar la paternidad de la obra y de oponerse a cualquier deformación, mutilación u otra modificación de la misma o a cualquier atentado a la misma que cause perjuicio a su honor o a su reputación”.

En cambio, el contenido patrimonial de los derechos de propiedad intelectual es patente desde las primeras leyes en la materia. De hecho, es la vertiente patrimonial de este derecho la primera en ser reconocida mediante la protección de la facultad de reproducción del autor, aun cuando ésta, sorprendentemente, no fue incluida en el CB hasta el Acta de Estocolmo, en 1967. Sin embargo, otras facultades patrimoniales ya eran contempladas desde los orígenes del Convenio, como el derecho a realizar traducciones y a representar públicamente dichas traducciones, ámbito que se fue ampliando de acuerdo a las necesidades y circunstancias de cada momento ${ }^{18}$.

Debe resaltarse que, según se adopte una postura monista o dualista del contenido de la propiedad intelectual en los diferentes ordenamientos jurídicos, los derechos morales y patrimoniales se configuran como un único núcleo de poder jurídico o como dos derechos diferenciados. En efecto, la teoría monista defiende que el derecho de autor no se compone de dos derechos distintos, sino de un único derecho formado por un sólo grupo de facultades en el que están presentes tanto elementos morales como patrimoniales que se entremezclan ${ }^{19}$. Por el contrario, la disociación bipartita del núcleo del derecho de autor divide al derecho de propiedad intelectual en dos tipos de derechos, uno de carácter personal y otro de carácter patrimonial, con base en las llamadas teorías dualistas $^{20}$. Como resultado, el derecho de propiedad intelectual se integra -bajo una concepción dualista- por un derecho de tipo real, equiparable al derecho de propiedad,

\footnotetext{
${ }^{17}$ Vid. Plaza PenadÉs, J., El derecho de autor y su protección en el art. 20.1.b) de la Constitución, Tirant lo Blanch, Valencia, 1997, pp. 93-97.

18 GARrote FernándeZ-DíEZ, I., “Artículo 9”, en BerCovitz RodríGuez-CANO, R. (Coord.), Comentarios al Convenio de Berna para la Protección de las Obras Literarias y Artísticas, Tecnos, Madrid, 2013, p. 707.

${ }^{19}$ PlAZA PENADÉS, J., El derecho de autor y su protección..., op. cit., pp. 140 y 150 y ss.

${ }^{20}$ Ibídem, pp. 140 y 144-150.
} 
que garantiza un disfrute absoluto sobre su objeto -salvo los límites legales- y compuesto por el conjunto de facultades patrimoniales; y por un derecho de tipo moral o personal, equiparable a los derechos de la personalidad, cuyo contenido incluye el conjunto de las facultades morales.

El TRLPI contiene una clara distinción entre los derechos de carácter moral y los derechos de carácter patrimonial, denominados derechos de explotación, algo que se puede apreciar con nitidez desde la Ley 22/1987, de 11 de noviembre, de Propiedad Intelectual (en adelante LPI) ${ }^{21}$. Sin embargo, ello no quiere decir que sea la tesis dualista la que predomine en España, pues la formulación del art. 2 (redacción que se mantiene hasta la actualidad) permite también defender la virtualidad de la tesis monista. En efecto, el precepto reconoce, de hecho, que "la propiedad intelectual está integrada por derechos de carácter personal y patrimonial, que atribuyen al autor la plena disposición y el derecho exclusivo a la explotación de la obra, sin más limitaciones que las establecidas en la Ley". Ello ha dado lugar a apreciar tanto la inexistencia de un único derecho (confluyen, por el contrario, derechos de carácter personal y patrimonial diferenciados), como la existencia de un derecho subjetivo único del que nacen distintos derechos ${ }^{22}$. No obstante, como señala PlazA PENAdÉs, de una interpretación histórico-legislativa y literal, parece deducirse que el Derecho español se decanta por la concepción monista, postura que es confirmada por la jurisprudencia ${ }^{23}$. En este sentido, quizás la más ilustrativa sea la STS (Sala de lo Civil), de 3 de junio de $1991^{24}$, que pone de relieve:

${ }^{21}$ B.O.E. núm. 275 , de 17 de noviembre de 1987.

22 RiBera Blanes, B., El derecho de reproducción del autor y sus límites, Tesis doctoral, Facultad de Derecho, Universidad de Alicante, Alicante, 2002, p. 313.

${ }^{23}$ Plaza PenadÉs, J., El derecho de autor y su protección..., op. cit., p. 166. En el mismo sentido, VATTIER FuENZALIDA, C., "La Propiedad Intelectual (Estudio sistemático de la Ley 22/1987)", Anuario de Derecho Civil, núm. 3, Madrid, 1993, p. 1048.

${ }^{24}$ ECLI:ES:TS:1991:2898. En sentido similar la STS (Sala Civil), de 2 de marzo de 1992 [ECLI: ES:TS:1992:12588], la cual refrenda en su F.J. $2^{\text {o “ }[\ldots] ~ e l ~ d e r e c h o ~ d e ~ a u t o r ~ e s ~ u n ~ d e r e c h o ~ s u b j e t i v o, ~ d e ~}$ carácter absoluto, con monopolio jurídico, temporalmente limitado y que no tiene exclusivamente naturaleza patrimonial o económica, pues junto a tal aspecto, tiene un contenido extrapatrimonial que no es otro que el derecho moral antes aludido, con facultades personalísimas, aunque no sea derecho de la personalidad por carecer de la nota indispensable de la esencialidad, al no ser consustancial o esencial a la persona, dado que no toda persona es autor; pero creada la obra de arte, no puede desconocerse su 
"El derecho de autor, que es inescindible y ha de ser contemplado en unicidad, tiene un contenido plural de facultades propias y proyecciones -abundando en lo expuesto-, que pueden encuadrarse en dos grupos: a) Uno de contenido patrimonial, derivados de la explotación económica de la obra, y nos lleva a la configuración de derechos previstos y protegidos en el Ordenamiento Jurídico y en la consideración de propiedad especial, b) Otro contenido, de carácter personal, que son las facultades o derechos morales de los autores, como consecuencia de la paternidad de las obras, que por su talento, arte, inspiración e ingenio, ha logrado realizar" (F.J. $4^{\circ}$ ).

Con todo, lo que finalmente interesa destacar es que la propiedad intelectual se integra por derechos morales y patrimoniales o de explotación; los primeros, contemplados en el art. 14 del TRLPI ${ }^{25}$, y los segundos, en los arts. 17 y siguientes de ese texto legal, a través de diversas facultades mediante las cuales el autor hace efectiva su exclusiva de explotación ${ }^{26}$. Y precisamente dentro de estos derechos patrimoniales o de explotación se encuentra el derecho de reproducción, por lo que conviene examinar las características y fundamentos de estos derechos, que dan cobertura al derecho de reproducción, como premisa necesaria para un examen posterior del mismo.

vocación o llamada a la exteriorización, aspecto material del derecho inmaterial que al autor asiste, de forma tal que en todo contrato en el que se tienda a la difusión de la obra creada ha de contemplarse ese doble aspecto patrimonial y espiritual o moral, comprendiendo éste la paternidad de la obra, su integridad, la reputación y buen nombre de su creador, etc., en cuanto que jurídicamente las obras de la inteligencia son una derivación y emanación de la personalidad, aspecto en modo alguno negado por la vieja ley aludida, ni por el Código Civil".

${ }^{25} \mathrm{El}$ derecho moral lo integran el derecho del autor a decidir si la obra ha de ser divulgada y en qué forma (con su nombre, bajo seudónimo o signo, o anónimamente); el derecho a exigir el reconocimiento de su condición de autor de la obra; a exigir el respeto a la integridad de la obra e impedir cualquier deformación, modificación, alteración o atentado contra ella que suponga perjuicio a sus legítimos intereses o menoscabo a su reputación; el derecho a modificar la obra respetando los derechos adquiridos por terceros y las exigencias de protección de bienes de interés cultural; el derecho a retirar la obra del comercio, por cambio de sus convicciones intelectuales o morales, previa indemnización de daños y perjuicios a los titulares de derechos de explotación; y el derecho a acceder al ejemplar único o raro de la obra, cuando se halle en poder de otro, a fin de ejercitar el derecho de divulgación o cualquier otro que le corresponda. No sólo al autor se le reconocen derechos de índole moral, sino también al artista intérprete o ejecutante. En virtud del art. 113 del TRLPI éste goza del derecho irrenunciable e inalienable al reconocimiento de su nombre sobre sus interpretaciones o ejecuciones, excepto cuando la omisión venga dictada por la manera de utilizarlas, y a oponerse a toda deformación, modificación, mutilación o cualquier atentado sobre su actuación que lesione su prestigio o reputación.

${ }^{26}$ Bondía Román, F., Propiedad Intelectual. Su significado..., op. cit., p. 217. 


\section{LOS DERECHOS DE EXPLOTACIÓN}

\section{Definición y características}

Los derechos de explotación constituyen un conjunto de facultades reconocidas al autor que forman parte -junto con los derechos morales- del contenido del derecho de propiedad intelectual.

Los derechos de explotación están contemplados de forma genérica en el art. 17 del TRLPI. Este precepto establece que "corresponde al autor el ejercicio exclusivo de los derechos de explotación de su obra en cualquier forma y, en especial, los derechos de reproducción, distribución, comunicación pública y transformación, que no podrán ser realizadas sin su autorización, salvo en los casos previstos en la presente Ley".

La norma se refiere, como puede apreciarse, a los derechos de reproducción, distribución, comunicación pública y transformación. Sin embargo, la lista no es exhaustiva, tal y como se deriva del uso de la expresión "en especial" en el texto del precepto. Por el contrario, resulta una enumeración ejemplificativa, con lo cual, otros actos de explotación diferentes podrían también encontrar acogida dentro de la categoría de derechos de explotación. De este modo, más allá de las cuatro categorías de derechos mencionadas, cualquier otra forma susceptible de disfrute o explotación de la obra ${ }^{27}$, que pueda surgir en el futuro, quedará contenida en el derecho de autor, siendo indiferente la forma concreta que adopte el derecho correspondiente (art. 17 del TRLPI) ${ }^{28}$.

El derecho de reproducción fue la primera manifestación de derecho de explotación, asociado en sus orígenes a la obtención de copias impresas de la obra original. Sin embargo, a lo largo de los años ha venido adoptando formulaciones más

\footnotetext{
${ }^{27}$ CARbajo Cascón, F., Publicaciones electrónicas..., op. cit., p. 79.

${ }^{28}$ Bercovitz RodríGuez-CANo, R. et al., Manual de Propiedad Intelectual, Tirant Lo Blanch, $5^{\mathrm{a}}$ ed., Valencia, 2012, p. 21.
} 
amplias para dar cobertura a nuevas formas de reproducción, diferentes de la obtención de ejemplares físicos de la obra ${ }^{29}$.

Con el tiempo, se han ido configurando otros derechos de explotación diferentes del derecho de reproducción. En este sentido, el derecho de distribución ha venido a garantizar al autor la posibilidad de definir las modalidades de puesta a disposición del público de los ejemplares de la obra y, como tal, es reconocido en el art. 19 del TRLPI $^{30}$. Por su parte, el reconocimiento de la facultad de comunicación pública obedece al hecho de que la obra no sólo es reproducida en ejemplares físicos, sino que, igualmente, se hace accesible al público de forma inmaterial, a través del derecho de representación ${ }^{31}$, diferente e independiente del derecho de reproducción. Así, por ejemplo, una obra dramatúrgica puede tanto ser reproducida en ejemplares físicos, como representada mediante su puesta en escena, configurándose en favor del autor una facultad diferente en cuanto a su explotación por esta vía, distinta de la obtención previa de ejemplares de la misma. Como resultado, la autorización concedida por el autor para la reproducción no otorga el derecho a su representación y viceversa. Por el contrario, se trata de dos facultades independientes. Fue, de hecho, esta diferenciación la que dio lugar, en su día, al reconocimiento legal de un nuevo derecho, en sus inicios identificado con la representación o ejecución pública de las obras, pero que, en su configuración actual, comprende un conjunto de actos que van más allá de la representación de obras teatrales en un escenario o de la ejecución de una obra musical. La facultad de comunicación pública engloba, por tanto, otros actos que tienen en común la no distribución de ejemplares, como son, entre otros, la proyección o exhibición pública de las obras cinematográficas y de otras obras audiovisuales; la emisión de cualesquiera obras por radiodifusión o por cualquier otro medio que sirva para la difusión inalámbrica de signos, sonidos o imágenes; la transmisión de

\footnotetext{
${ }^{29}$ A este derecho se hará referencia en el epígrafe siguiente, razón por la cual no se ahonda más en su contenido en el presente epígrafe.

${ }^{30} \mathrm{El}$ art. 19 dispone: "se entiende por distribución la puesta a disposición del público del original o de las copias de la obra, en un soporte tangible, mediante su venta, alquiler, préstamo o de cualquier otra forma".

${ }^{31}$ Bondía Román, F., Propiedad Intelectual. Su significado..., op. cit., p. 224.
} 
cualesquiera obras al público por hilo, cable, fibra óptica u otro procedimiento análogo, sea o no mediante abono, hoy regulados en su amplia extensión en el art. 20.2 del TRLPI.

De ese modo, los contornos el derecho de comunicación pública quedan definidos en el art. 20.1 del TRLPI, entendiéndose, como tal, "todo acto por el cual una pluralidad de personas pueda tener acceso a la obra sin previa distribución de ejemplares a cada una de ellas". No se considerará pública la comunicación, sin embargo, cuando se celebre dentro de un ámbito estrictamente doméstico que no esté integrado o conectado a una red de difusión de cualquier tipo.

Finalmente, otra manifestación típica de los derechos de explotación es el derecho de transformación (art. 21 del TRLPI). La obra creada por el autor puede transformarse en una nueva obra sin perder su esencia, como cuando se realiza una adaptación cinematográfica de una obra literaria o se efectúa una traducción. La transformación de una obra comprende, de hecho, su traducción, adaptación y cualquier otra modificación en su forma de la que se derive una obra diferente, así como la reordenación, en el caso de las bases de datos a las que hace referencia el art. 12 del TRLPI ${ }^{32}$. En estos casos, la obra primigenia sirve de base a la obra posterior, dando lugar a una nueva obra relacionada con la preexistente, por cuanto deriva de aquélla; pero diferente y susceptible de protección como obra independiente, por lo que gozará también de la originalidad requerida por la propiedad intelectual para dotar de tutela jurídica a una creación. La creación de la nueva obra requiere, en todo caso, la autorización del titular de derechos de la obra preexistente; y, una vez creada con el consentimiento de éste, otorga al autor de la obra resultante de la transformación, los derechos de propiedad intelectual sobre esta última, sin perjuicio del derecho del autor de la obra preexistente de autorizar, durante todo el plazo de protección de sus derechos sobre ésta, la explotación de esos resultados en cualquier forma y, en especial, mediante su

\footnotetext{
${ }^{32} \mathrm{El}$ art. 12.2 del TRLPI dispone que "se consideran bases de datos las colecciones de obras, de datos, o de otros elementos independientes dispuestos de manera sistemática o metódica y accesibles individualmente por medios electrónicos o de otra forma".
} 
reproducción, distribución, comunicación pública o nueva transformación (art. 21.2 del TRLPI) ${ }^{33}$.

Por otra parte, hay que señalar que todos estos derechos ostentan características comunes. En primer lugar, se trata de derechos exclusivos en el sentido de que sólo al autor le corresponde la facultad de autorizar o prohibir la explotación económica de su obra. Tal carácter es reconocido expresamente en el mencionado art. 17 del TRLPI, precepto que atribuye al autor el ejercicio exclusivo ${ }^{34}$ de los derechos de explotación, en concordancia con lo establecido en el art. 2 del TRLPI, que brinda al autor la plena disposición de la obra y el derecho exclusivo ${ }^{35}$ a su explotación sin más limitaciones que las establecidas legamente ${ }^{36}$. La exclusividad se manifiesta de dos maneras distintas: por un lado, por cuanto el autor ejercita sus derechos en cualquier forma sin más límites que los que establece la ley (vertiente positiva); y, por otro, porque el autor detenta un ius prohibendi que le permite impedir la explotación de la obra por parte de terceros que no hayan recabado, previamente, su autorización (vertiente negativa). De esta forma, salvo en los casos en los que el legislador limita este derecho estableciendo ciertas restricciones al contenido del derecho de explotación (limitaciones o excepciones ${ }^{37}$ ) o fijando el ejercicio temporal de estos derechos (duración de la protección), será el autor -o titular del derecho en caso de cesión- quien ostente el derecho de explotación, exclusivo y absoluto, sobre su creación intelectual.

33 Vid. Rivero HernándeZ, F., “Artículo 21”, en BERCOVITZ RodríGUEZ-CANO, R. (Coord.), Comentarios a la Ley de Propiedad Intelectual, $3^{\mathrm{a}}$ ed., Tecnos, Madrid, 2007, p. 387; y MARISCAL GARRIDO-FAlla, P., Derecho de transformación y obra derivada, Tirant Lo Blanch, Valencia, 2013, p. 336.

${ }^{34}$ Énfasis añadido.

${ }^{35}$ Énfasis añadido.

${ }^{36}$ En el mismo sentido, el art. $428 \mathrm{CC}$ : "El autor de una obra literaria, científica o artística, tiene el derecho de explotarla y disponer de ella a su voluntad"; y el art. 348 CC: "La propiedad es el derecho de gozar y disponer de una cosa, sin más limitaciones que las establecidas en las leyes".

${ }^{37}$ Las limitaciones o excepciones al derecho de autor se estudian en el capítulo siguiente. No obstante, valga apuntar desde aquí que las mismas restringen el ejercicio exclusivo de los derechos de autor de acuerdo con ciertos objetivos de política legislativa, unas veces a partir de una enumeración taxativa de éstas en la ley ( $v . g r$. citas y reseñas e ilustración con fines educativos o de investigación científica, parodia, copia privada, etc.), propia de los países del sistema continental de Derecho; otras veces, a modo de cláusula general, estableciendo unos requisitos que, de cumplirse, legitiman la utilización de la obra sin el consentimiento del titular de derechos, característica de los países pertenecientes a la tradición del Common Law. 
En segundo lugar, los derechos de explotación son también derechos temporales en la medida en que no son perpetuos en el tiempo, sino que, por el contrario, tienen una duración limitada ${ }^{38}$. Asimismo, son derechos patrimoniales (art. 2 del TRLPI), porque aseguran al autor y demás titulares de derechos una remuneración por su trabajo intelectual. Al respecto, debe señalarse que el ánimo de lucro es, básicamente, un presupuesto del derecho de explotación, pues los actos de explotación son, en esencia, de contenido patrimonial, pero la ausencia de ánimo de lucro no excluye, per se, que la obra pueda ser utilizada sin previo consentimiento del autor ${ }^{39}$..

Se caracterizan, además, por ser derechos de carácter general, en el sentido de que el autor puede explotar sus obras "en cualquier forma" (ex. art. 17 LPI); absolutos, en tanto pueden ser opuestos por el titular frente a terceros (erga omnes $)^{40}$; transmisibles inter vivos y mortis causa, debido a la posibilidad de cederlos en vida y transmitirlos después de la muerte (art. 42 y ss. del TRLPI); e independientes, porque existe autonomía funcional entre cada uno de ellos, haciéndose valer cada uno por separado, siendo exigible la autorización del autor para cada utilización que involucre la explotación de cada uno de ellos (art. 23 LPI). Además, son embargables e hipotecables (art. 53 del TRLPI).

Asimismo, destaca el carácter público o colectivo de la utilización ${ }^{41}$. Es fácilmente apreciable que los derechos de explotación se identifican por desbordar el ámbito privado, por cuanto son actividades que traspasan este tipo de usos, toda vez que

\footnotetext{
${ }^{38}$ Así pues, los derechos de explotación de la obra durarán toda la vida del autor y setenta años después de su muerte o declaración de fallecimiento (art. 26 del TRLPI). En el caso de las obras anónimas o seudónimas, el plazo de protección será, con carácter general, de setenta años desde su divulgación lícita (a salvo otros supuestos contemplados en el art. 27 del TRLPI). En el caso de los artistas intérpretes o ejecutantes, los productores de fonogramas y videogramas y los organismos de radiodifusión, la protección suele ser de cincuenta o setenta años, según diversos supuestos refrendados en el TRLPI, de acuerdo a la forma en que estas creaciones se hagan accesibles al público. Vid. art. 112 (artistas intérpretes o ejecutantes), art. 119 (productores de fonogramas), art. 125 (productores de grabaciones audiovisuales) y art. 127 (entidades de radiodifusión).

${ }^{39}$ RIVERO HERnÁNDEZ, F., “Artículo 17”, en BERCOVITZ RodRíGUEZ-CANO, R. (Coord.), Comentarios a la Ley de Propiedad..., $3^{\mathrm{a}}$ ed., op. cit., p. 271.

${ }^{40}$ En paralelo al deber de respetar el derecho, surge el de no perturbar el señorío que ostenta su titular sobre la obra, Ibídem, p. 160.

${ }^{41}$ Marco Molina, J., La propiedad intelectual en la legislación española, Marcial Pons, Madrid, 1995, p. 214.
} 
se dirigen a hacer accesible la obra al público ${ }^{42}$. Este carácter también se aprecia por las limitaciones legales que tiene el autor para interferir en el uso que se hace de la obra en el ámbito privado, lo que corrobora el art. 31.2. a) del TRLPI al permitir la reproducción de obras ya divulgadas cuando se lleve a cabo por una persona física exclusivamente para su uso privado (copia privada), y asimismo, por la previsión que hace el legislador de no aplicar las medidas comprendidas en el art. 139 del TRLPI, relativas al cese de la actividad ilícita por infracción de derechos de propiedad intelectual a los ejemplares adquiridos de buena fe para uso personal (art. 139.4 del TRLPI).

Por último, es oportuno mencionar que existen otros derechos que, aunque se asemejan a los de explotación, no lo son en sentido técnico-jurídico. Estos son conocidos por la doctrina como "derechos de simple remuneración", por medio de los cuales el autor recibe una suma de dinero de producirse ciertos actos, pero dicha remuneración no es consecuencia de la cesión o autorización concedida por el autor a un tercero para la explotación de la obra. Como señala RIBERA BLANES la diferencia entre ambos, derechos de explotación y derechos de remuneración, "parece estar en el papel activo o pasivo que juega el autor en cuanto al control de la utilización de su obra"43. Más concretamente, en el caso de los derechos de simple remuneración, escapa del control del titular de derechos la facultad de autorizar o prohibir la explotación de la obra o prestación intelectual, razón que lleva al legislador a establecer una remuneración a su favor.

Normalmente, dentro de estos derechos de simple remuneración se encuentran aquellos que son fruto del establecimiento de licencias legales, como el derecho de remuneración de los autores de obras audiovisuales por el alquiler y la comunicación

\footnotetext{
${ }^{42}$ La reproducción es una actividad de explotación que permite fijar la obra de forma tal que posibilite su comunicación o la obtención de copias. La distribución y la comunicación pública facilitan el acceso a la obra a una pluralidad de personas; y la transformación, por su parte, permite obtener obras, siendo común a todas estas prerrogativas el carácter de utilización colectiva. Vid. ídem, p. 215.

${ }^{43}$ RIBERA BlANES, B., El derecho de reproducción en la propiedad intelectual, Dykinson, Madrid, 2002, pp. 195-196. En la misma línea CABEDO SERNA, L. L., El derecho de remuneración del autor, Dykinson, Madrid, 2011, p. 162 quien señala: "Se afirma que la diferencia esencial entre el derecho de simple remuneración y la remuneración que nace del ejercicio del derecho de explotación radica en que esta última tiene su origen en un derecho absoluto exclusivo mientras que el primero nace de la pérdida de exclusividad por parte del autor".
} 
pública de las mismas (art. 90.2, 3 y 4 del TRLPI) ${ }^{44}$. También se suele reconocer dentro de ellos el derecho de participación o droit de suite ${ }^{45}$ y la compensación equitativa por copia privada, esta última inserta dentro de la Sección $3^{a}$, Capítulo III, del Título II del TRLPI, denominada "Otros derechos" ${ }^{46}$. Sin embargo, ha de destacarse que la compensación equitativa por copia privada más que un derecho de simple remuneración es un derecho pecuniario de compensación, por la relación que se establece entre dicha compensación y el perjuicio causado al titular de derechos. En efecto, más que una remuneración por una determinada utilización, el titular de derechos recibe una compensación por el daño que se le ha causado. Valga añadir que la compensaión equitativa por copia privada se distingue de un derecho de explotación por su indisponibilidad, toda vez que es intrasmisible inter vivos e irrenunciable para los autores y artistas intérpretes y ejecutantes (art. 25.2 del TRLPI); y por tratarse de un derecho de gestión colectiva obligatoria (ex art. 25.9 del TRLPI).

\section{El fundamento de los derechos de explotación}

El autor ostenta derechos exclusivos sobre la explotación de su obra. La exclusividad de estos derechos descansa en los propios fundamentos que dan lugar al reconocimiento de la Propiedad Intelectual como disciplina jurídica. En efecto, dos justificaciones fundamentales explican el derecho de remuneración del autor, o lo que es lo mismo, la vertiente patrimonial de los derechos de propiedad intelectual: por un lado, la recompensa por el trabajo creativo; y, por otro, el papel social de la creación ${ }^{47}$. Y

\footnotetext{
${ }^{44}$ Bercovitz RodríGuez-CANo, R. (Coord.) et al., Manual de Propiedad Intelectual..., op. cit., p. 23.

${ }^{45}$ El derecho de participación o droit de suite es aquel derecho que tienen los autores de obras de arte gráficas o plásticas, tales como los cuadros, collages, pinturas, dibujos, grabados, estampas, litografías, esculturas, tapices, cerámicas, objetos de cristal, fotografías y piezas de vídeo-arte, a percibir del vendedor una participación en el precio de toda reventa que de las mismas se realice tras la primera cesión realizada por el autor.

${ }^{46}$ El derecho de participación o droit de suite también estaba recogido en la Sección $3^{\text {a }}$, Capítulo III, del Título II del TRLPI, concretamente, en el art. 24 del TRLPI. Sin embargo, ha sido derogado por la letra a) de la disposición derogatoria de la Ley 3/2008, de 23 de diciembre, relativa al derecho de participación en beneficio del autor de una obra de arte original, ahora reguladora de este derecho (B.O.E. núm. 310 , de 25 de diciembre de 2008).

${ }^{47}$ CABEdo Serna, L. L., El derecho de remuneración..., op. cit., pp. 118 y ss. La autora, al explicar el fundamento del derecho a la remuneración del autor, toma en cuenta estas justificaciones doctrinales y
} 
estas justificaciones se hacen patentes en las tesis que, a lo largo de la historia, han servido de fundamento teórico para explicar la existencia de derechos sobre las creaciones intelectuales.

Hay que partir del hecho de que el surgimiento de la propiedad intelectual se asocia a las posibilidades de reproducción de las obras a partir de la creación de la imprenta, un progreso tecnológico que extendió las posibilidades de acceso a las obras por el público. Ni en la Antigüedad clásica, ni en la Edad Media se reconoció al creador alguna prerrogativa patrimonial sobre su obra pues, por entonces, a la creación no parecía reconocérsele un valor económico per se, más allá de su valor espiritual ${ }^{48}$. En cambio, desde mediados del siglo XV, la aparición de la imprenta propició que los impresores y libreros reivindicaran sus derechos a obtener un monopolio sobre la reproducción de las obras ${ }^{49}$, otorgándose privilegios a su favor ${ }^{50}$. Posteriormente, estos privilegios se fueron extendiendo, convirtiéndose, a mediados del siglo XVII, en la forma común de explotación de las creaciones intelectuales ${ }^{51}$.

En consecuencia, hasta ese momento no había sido necesario justificar teóricamente la naturaleza de estos derechos exclusivos. Sin embargo, las confrontaciones que se sucedieron en Francia entre los libreros parisinos y los de provincia, con motivo de la extensión y concentración de las prerrogativas otorgadas a los grandes editores de la capital, dieron lugar a que los impresores de provincia, en defensa de sus intereses, comenzaran a invocar el interés público y la utilidad del no

agrega, como otro fundamento para el reconocimiento legal al autor de un derecho patrimonial exclusivo que le asegure una remuneración: "la regulación del mercado de obras intelectuales", la cual analiza unida a la segunda idea mencionada (la razón de la protección del trabajo creativo radica en la utilidad que dicho trabajo proporciona a la sociedad), al vincular ambas razones.

${ }^{48}$ Ibídem, pp. 169-170 y 179-184.

${ }^{49}$ Ibídem, p. 47.

${ }^{50}$ La concesión de los primeros privilegios data del siglo XV. Se cree que el primer privilegio se otorgó en la República de Venecia en el año 1469, concedido al impresor alemán John Speier, por un período de cinco años. RogEL VIDE, C., Estudios completos de Propiedad Intelectual, Vol. IV, Reus, Madrid, 2013, p. 15.

Los privilegios eran otorgados por el Rey y aseguraban al editor una protección contra la concurrencia de los otros editores. Vid. STROWEL, A., Droit d auteur et copyright. Divergences et Convergences. Étude de droit comparé, Bruylant, Bruselas, 1993, p. 83.

${ }^{51}$ Los privilegios no sólo fueron concedidos a editores y libreros, sino que existieron también a favor de los autores, mediante los llamados "privilegios de autor". Vid. BAYlos CORROZA, H., Tratado de Derecho Industrial, Aranzadi, Pamplona, 2009, p. 187. 
reconocimiento perpetuo de estos privilegios ${ }^{52}$. En efecto, estos últimos sostenían que la obra era propiedad del autor en la medida en que la obra no era divulgada. Se pensaba, además, en el carácter social implícito en la creación, con lo cual, ésta no era considerada únicamente fruto de la labor de su autor ${ }^{53}$. En cambio, los libreros parisinos pretendían desarrollar una teoría jurídica que evitara que los textos impresos por ellos, hasta el momento explotados exclusivamente por los mismos, se transformaran en cosas comunes y, por tanto, accesibles a todos los impresores ${ }^{54}$.

Es así como comenzó a plantearse la idea de propiedad del autor sobre su obra, toda vez que ésta es el resultado de su trabajo personal ${ }^{55}$. Esta postura llevaba implícita la noción de propiedad natural del autor sobre la creación ${ }^{56}$ e, inspirada en las ideas de J. LOCKE $^{57}$, permitió considerar que el autor no necesitaba de privilegio alguno para gozar del provecho económico que le brindaba su obra porque ésta le correspondía ${ }^{58}$. El trabajo personal del autor justificaba su propiedad sobre la obra ${ }^{59}$.

${ }^{52}$ Haddadin, S., Essai sur une Théorie Générale en Droit d'Auteur, tesis doctoral, Universidad de Poitiers, Facultad de Derecho y Ciencias Sociales, presentada y leída públicamente el 22 de noviembre de 2008, pp. 6-7.

${ }^{53}$ Ibídem, p. 9.

${ }^{54}$ Ibídem, p. 11.

${ }^{55}$ STROWEL, A., Droit d’auteur..., op. cit., pp. 84-85.

${ }^{56}$ Ibídem, p. 85.

${ }^{57}$ LOCKE no concibió su teoría con el ánimo de justificar la propiedad sobre bienes inmateriales. Sin embargo, su idea ha sido fundamental en el reconocimiento de los derechos de autor. Sostenía LOCKE: "Le travail de son corps et l'ouvrage de ses mains, nous le pouvons dire, sont son bien propre [...]. Son travail distingue et sépare alors ces fruits des autres biens qui sont communs; il y ajoute quelque chose de plus que la nature, la mère commune de tous, n'y a mis; et, par ce moyen, ils deviennent son bien particulier. [...]. Le travail, qui est mien, mettant ces choses hors de l'état commun où elles étaient, les a fixées et me les a appropriées", Tremblay, J. M. (Ed.), Two Treatises of Government [LOCKE, J. 1690, traducción francesa de David MAZEL (1795), a partir de la 5ª edición de Londres de 1725], Québec, 2002, p. 32 , disponible en: http://classiques.uqac.ca/classiques/locke_john/traite_du_gouvernement/traite_du_gouv_civil.pdf (consultado: 3.05.2016). Sobre la influencia de la teoría de la propiedad de LOCKE sobre el derecho de autor Vid. SHIFFrIN, S. V., "Lockean Arguments for Private Intellectual Property", New Essays in the Legal and Political Theory of Property, Cambridge University Press, Cambridge, 2001, pp. 138-167; DUSOLliER, S., Droit d'auteur et protection des ouvres dans l'univers numérique. Droits et exceptions à la lumière des dispositifs de verrouillage des auvres, Larcier, Bruselas, 2005, pp. 217-219.

${ }^{58}$ BAYlos CORROZA, H., Tratado..., op. cit., p. 189.

${ }^{59}$ Strowel, A., Droit $d$ 'auteur..., op. cit., pp. 188-189; MARCO MolinA, J., "Bases históricas y filosóficas y precedentes legislativos del Derecho de autor", Anuario de Derecho Civil, núm. 1, Madrid, 1994, p. 130. 
La recepción de la concepción de la propiedad natural del autor sobre su creación resaltó la idea de propiedad en detrimento de la de privilegio ${ }^{60}$. Como consecuencia, la concepción del derecho de autor como un derecho natural, resultado de la apreciación del vínculo obra-autor, se hizo evidente en la positivización del derecho de autor francés ${ }^{61}$, al tiempo que inspiró la tradición jurídica continental ${ }^{62}$.

No obstante, la noción sobre una protección general al autor se había positivizado, con anterioridad, mediante la promulgación por el Parlamento Británico del Estatuto de la Reina Ana, en 1709, siendo reconocida como la primera ley sobre derechos de autor $^{63}$. En efecto, resultó ser la primera vez que los autores se beneficiaron de un derecho de propiedad sobre sus obras como resultado del reconocimiento de su trabajo. Puede decirse que la doctrina de J. LOCKE acerca de la apropiación de los recursos por el trabajo fue la que inspiró el texto y estas ideas alcanzaron también a las primeras leyes norteamericanas ${ }^{64}$. Sin embargo, la protección al autor no significó el desconocimiento de los intereses públicos, que fueron también tenidos en cuenta en las legislaciones en la medida que garantizaban que el público pudiera acceder a las obras ${ }^{65}$.

De hecho, la referencia tímida al derecho natural y el acento puesto en los intereses públicos permitió el desarrollo de una concepción positivista del derecho de autor, tanto en los Estados Unidos como en Gran Bretaña, rechazando la idea del derecho natural y consolidando un enfoque utilitarista del copyright ${ }^{66}$. La idea de un contrato social entre el autor y la sociedad, expresión de una concepción utilitarista, permitió reconocer derechos y obligaciones tanto para el autor como para el público

\footnotetext{
${ }^{60}$ Ibídem, p. 85.

${ }^{61}$ Un ejemplo resulta la ley francesa de 1957 (art. L. 111-1 del CPI 1992). Para ampliar referencia Vid. STROWEL, A., Droit d' auteur..., op. cit., pp. 137-138.

62 Baylos Corroza, H., Tratado..., op. cit., pp. 187-188.

${ }^{63}$ PlaZA PENADÉS, J., El derecho de autor y su protección..., op. cit., pp. 62-63; OMPI, La protección internacional del derecho de autor y de los derechos conexos, p. 2, disponible en: http://www.wipo.int/export/sites/www/copyright/es/activities/pdf/international_protection.pdf (consultado: 14.02.2016).

${ }^{64}$ Vid. Colin, C., Droit d'utilisation des ouvres, Larcier, Bruselas, 2012, p. 509.

${ }^{65}$ Ibídem, p. 510.

${ }^{66}$ Ibídem, p. 511.
} 
destinatario de las obras y, bajo este enfoque, los derechos de dicha colectividad tomaron la forma de excepciones al derecho de autor ${ }^{67}$.

Por su parte, el Decreto francés de $1777^{68}$ marcó igualmente un punto de inflexión en el reconocimiento legislativo de la propiedad intelectual y en la distinción entre las facultades de los autores y de los editores. Este Decreto, aun cuando reconoció privilegios a favor de los impresores, diferenció sus fundamentos de aquellos concedidos a los autores. Así, mientras que para los impresores estos privilegios representaban una "liberalidad", un reembolso por sus inversiones y gastos; para los autores, se trataba una "propiedad de derecho"; una recompensa a su trabajo ${ }^{69}$.

Posteriormente, con la Revolución francesa (1789) quedó abolido completamente el régimen de los privilegios. En 1790 se presentó ante la Asamblea Nacional francesa un primer proyecto de ley que no llegó a someterse a referéndum debido a las críticas que recibió ${ }^{70}$. Posteriormente, se promulgaron el Decreto 13-19 enero 1791 y el Decreto 19-24 julio $1793^{71}$, que permitieron dar cobertura legal a una justificación social del reconocimiento de los derechos de autor en Francia ${ }^{72}$ y evidenciaron la importancia dada a la creación y conservación de un espacio público literario fuerte que, al tiempo que garantizaba una protección al autor, aseguraba la salvaguarda de las obras en la esfera pública ${ }^{73}$. Estos Decretos reconocieron a los autores de obras dramáticas o musicales -el primero-, así como a los autores de escritos de cualquier género, los compositores de música, los pintores y los dibujantes -el segundo-, un derecho

\footnotetext{
${ }^{67}$ Vid. Colin, C., Droit..., p. 512.

${ }^{68}$ Arrêt du Conseil du Roi, portant règlement sur la durée des privilèges en librairie du 30 août 1777; disponible en: $\underline{\text { http://www.mshparisnord.fr/controverses-PI-XIX/archives/arc arret 1777.pdf }}$ (consultado: 25.11.2015).

${ }^{69}$ STROWEL, A., Droit d’auteur..., op. cit., p. 85.

${ }^{70}$ Ibídem, p. 89.

${ }^{71}$ Ibídem, pp. 89-90.

${ }^{72}$ Vid. Colin, C., Droit..., op. cit., p. 514.

${ }^{73}$ Vid. Dusollier, S., Droit..., op. cit., p. 225 y pp. 220-226, para ampliar sobre el nacimiento de la esfera pública en el S. XVIII y el nacimiento de la propiedad intelectual en este contexto. Según esta autora, la esfera pública es un terreno para el ejercicio de un razonamiento público, un espacio que se interpone entre la esfera privada, especialmente integrada por el intercambio de bienes y servicios, y la esfera del poder público del Estado. Véase también, FERnÁndez SANTILlán, J., El despertar de la sociedad civil. Una perspectiva histórica, Océano, México D.F., 2003 (Introducción); y HABERMAS, J., The Structural Transformation of the Public Sphere, obra traducida por Thomas Burger con la asistencia de Frederick Lawrence, MIT Press, Cambridge, 1991, p. 29.
} 
exclusivo sobre sus obras durante toda su vida $\mathrm{y}$, post mortem auctoris, a favor de sus herederos o cesionarios, poniendo de relieve el carácter patrimonial de estos derechos y el reconocimiento de la propiedad intelectual como un derecho de propiedad, resultado del vínculo entre la obra y su autor ${ }^{74}$.

Ahora bien, habiendo sido la propiedad intelectual concebida como la propiedad del autor sobre su obra, íntimamente ligada al concepto de "persona" propio de los pensadores de la Ilustración y estrechamente vinculada al concepto de "libertad"75, RENOUARD, detractor de la idea de propiedad, consideró que el autor realizaba un servicio en beneficio de la sociedad y que su trabajo debía ser por ello compensado garantizándole un derecho sobre su obra, pero no como derecho de propiedad en sí, sino más bien como monopolio de explotación de la misma por un tiempo limitado $^{76}$. Su tesis fue expresión de la apreciación convergente de intereses públicos y privados y de cómo una ley no debía sacrificar aquéllos intereses del autor a favor del público, ni los del público a favor del autor. Afirmaba RENOUARD:

"Qu'une loi sur cette matière ne saurait être bonne qu'à la double condition de ne sacrifier ni les droits des auteurs à celui du public, ni le droit du public à celui des auteurs" $" 77$.

Otras teorías también indagaron en la naturaleza jurídica de los derechos de propiedad intelectual. PouILLET, por ejemplo, defensor de la tesis de la propiedad como fundamento del derecho de autor, la describió, sin embargo, como una propiedad particular, de una naturaleza especial ${ }^{78}$.

Asimismo, con la intención de suplir las carencias propias de las teorías mencionadas y, a su vez, dado el reconocimiento de facultades morales al autor, hacia finales del siglo XIX, otras teorías intentaron explicar la naturaleza jurídica de este

\footnotetext{
74 PlazA PenAdÉs, J., El derecho de autor y su protección..., op. cit., pp. 69-70.

${ }^{75}$ STROWEL, A., Droit d’ auteur..., op. cit., p. 93.

76 Ibídem, p. 96.

${ }^{77}$ Renouard, A. Ch., Traité des droits d'auteurs: dans la littérature, les sciences et les beaux-arts, Libraire de Jules Renouard et C., Vol. I, tomo 1, París, 1838, p. 437; disponible en: http://gallica.bnf.fr/ark:/12148/bpt6k5739469p/f2.image (consultado: 10.11.2015).

${ }^{78}$ STROWEL, A., Droit d auteur..., op. cit., p. 96.
} 
derecho. Entre ellas se encuentran la teoría del derecho de la personalidad, la teoría sobre los bienes inmateriales y la teoría sobre los derechos intelectuales.

La teoría de la personalidad fue elaborada por la doctrina alemana a finales de los años $1880^{79}$. Desde esta perspectiva, desarrollada por GIERKE e inspirada en las ideas precursoras de KANT y HEGEL, se consideró que la obra forma parte de la esfera personal del autor ${ }^{80}$. El derecho de autor es un derecho de la personalidad en la medida en que su objeto, la obra del espíritu, es una cosa incorporal que forma parte de esa esfera personal ${ }^{81}$. Esta tesis fue una consecuencia de la concepción del derecho de autor como un derecho natural, un derecho que emana de la naturaleza humana, cuyo reconocimiento y defensa tiene su origen en el propio acto de creación. Sin embargo, la externalidad del objeto de protección respecto de la persona del autor y el momento en que nace el derecho, que surge a partir del acto de creación y, por tanto, no unido al nacimiento del mismo, como sucede en el caso de los derechos de la personalidad, sirvieron como fundamentos para criticar esta concepción ${ }^{82}$.

KHOLER introdujo, por su parte, una perspectiva crítica a la concepción adoptada por GIERKE, con su teoría sobre los bienes inmateriales. Sostenía que el derecho de autor sobre la obra como producto inmaterial tenía su origen en la creación; pero descomponía este derecho en un derecho individual, que garantizaba al autor el ejercicio de las facultades de paternidad e integridad de la obra, debiendo considerarse como un derecho de la personalidad que debía quedar fuera del derecho de autor; y un derecho sobre el objeto inmaterial, de contenido patrimonial, al que concebía como un derecho real de naturaleza especial ${ }^{83}$. Se entendía que la obra no era únicamente el soporte en el

\footnotetext{
${ }^{79}$ Ibídem, p. 98.

80 FISHER, W., "Theories on Intellectual Property", p. 9; disponible en: http://cyber.law.harvard.edu/people/tfisher/iptheory.pdf (consultado: 10.11. 2015); STROWEL, A., Droit $d$ ' auteur..., op. cit., pp. 517-520.

${ }^{81}$ STROwel, A., Droit d auteur..., op. cit., p. 99.

82 Ídem.

${ }^{83}$ Vid. Strowel, A., Droit d auteur..., op. cit., pp. 101 y 520-521, PlaZA Penadés, J., El derecho de autor y su protección..., op. cit., p. 143.
} 
cual se exteriorizaba (corpus mechanicum); era también una realidad distinta de éste: la creación intelectual en sí misma considerada (corpus mysticum) ${ }^{84}$.

La teoría sobre los derechos intelectuales fue explicada por PICARD, quien en su artículo Embryologie Juridique (1883), propuso englobar los derechos que atañen a las producciones del espíritu dentro de la categoría de derechos intelectuales como derechos sui generis, pretendiendo abandonar la denominación de propiedad intelectual y añadir así esta categoría a la clasificación tripartita de derechos establecida por el Derecho romano presente en las legislaciones europeas: derechos reales, derechos personales y derecho de obligaciones, que consideraba incompleta ${ }^{85}$. Esta teoría proponía superar las críticas que arrastraba la teoría sobre los bienes inmateriales como concepción eminentemente patrimonialista del derecho de autor, incluyendo los derechos de naturaleza intelectual ${ }^{86}$. No obstante, aun cuando destacaba el carácter peculiar de los derechos intelectuales y sus elementos moral y patrimonial, fue poco satisfactoria al no precisar las características de esta nueva categoría e impedir delimitar la naturaleza jurídica del derecho de autor en relación con otros derechos intelectuales, como las invenciones o las marcas ${ }^{87}$.

Por otra parte, la teoría de los derechos de la clientela, sostenida por RoUBIER, exaltó el valor patrimonial de la creación ${ }^{88}$. En la base de esta teoría está la idea de la obtención de beneficios en la concurrencia económica, destacando a la clientela como un valor necesario para el reconocimiento de los derechos de propiedad intelectual de contenido patrimonial ${ }^{89}$. En virtud de esta teoría estos derechos no se constituyen y establecen frente a la clientela, sino frente a los competidores que concurren en el mercado de explotación de las creaciones intelectuales, donde los derechos de propiedad

\footnotetext{
${ }^{84}$ PlazA PENADÉs, J., El derecho de autor y su protección ..., op. cit., p. 118.

${ }^{85}$ PICARD, E., "Embryologie Juridique", Journal du droit international privé, Clunet, 1883, pp. 565-585; disponible en: http://pascontent.sedrati-dinet.net/index.php/static/Embryologie-juridique (consultado: 30.11.2015).

${ }^{86}$ Vid. PlaZA PENADÉs, J., El derecho de autor y su protección ..., op. cit., pp. 146-147.

${ }^{87}$ Strowel, A., Droit d auteur..., op. cit., p. 103; SAlAZAR REYES-ZUMETA, L., “Aproximación teórica a la naturaleza jurídica de los bienes intelectuales y del Derecho de Propiedad Intelectual", Revista Propiedad Intelectual, núm. 13, Mérida, 2010, p. 59.

${ }^{88}$ STROWEl, A., Droit d auteur..., op. cit., p. 104.

${ }^{89}$ BAylos Corroza, H., Tratado..., op. cit., p. 564.
} 
intelectual -conjuntamente con los de propiedad industrial ${ }^{90}$ - "tienen por objeto «fijar ciertas posiciones en provecho de sus titulares, que las casas concurrentes deberán respetar»" $" 91$. A pesar de las críticas que esta teoría recibió, su valor radica en ofrecer una perspectiva más amplia de estos derechos ${ }^{92}$, apelando a un concepto extrajurídico, de orden económico, para explicar su naturaleza jurídica ${ }^{93}$.

En resumen, la evolución de la noción de propiedad intelectual tiene reflejo en diversas teorías que persiguen explicar la naturaleza jurídica de los derechos de propiedad intelectual. Así pues, el derecho exclusivo de explotación del autor, en el Derecho continental, encuentra su primer fundamento en la idea de un derecho natural, en el que se enmarcan las nociones de propiedad, trabajo y justicia. En efecto, los defensores del derecho de propiedad encuentran su fundamento en el trabajo creativo, que justifica el nacimiento de un vínculo personal indisoluble ente la obra y el autor y amerita que éste reciba una compensación económica como fruto de su trabajo intelectual, lo que responde, en definitiva, a una razón de justicia. La utilidad social de la creación, por su parte, constituye un presupuesto esencial para el reconocimiento de este derecho y sirve, a su vez, como límite al mismo ${ }^{94}$.

De este modo, el vínculo no se establece sólo entre la obra y el autor, sino que es preciso tener en cuenta también, en la regulación de esta disciplina, la existencia de intereses colectivos, culturales y sociales, aun cuando esta afirmación adquiera matices diferentes según se trate del Derecho continental o anglosajón. En efecto, para el Derecho anglosajón, el interés del público cobra mayor relevancia que en los países de tradición continental, donde la protección se centra en la figura del autor. No obstante,

\footnotetext{
${ }^{90}$ La propiedad industrial tiene por objeto las patentes de invención, los modelos de utilidad, los dibujos o modelos industriales, las marcas de fábrica o de comercio, las marcas de servicio, el nombre comercial, las indicaciones de procedencia o denominaciones de origen, así como la represión de la competencia desleal. Así lo enuncia el art. 1.2 del Convenio de la Unión de París para la protección de la Propiedad Industrial, aprobado el 20 de marzo de 1883, primer texto internacional dirigido a proteger estos derechos. El texto del citado Convenio está disponible en: http://www.wipo.int/treaties/es/text.jsp?file id=288515 (consultado: 26.04.2017).

${ }^{91}$ BAYlos CORROZA, H., Tratado..., op. cit., p. 565.

92 Ibídem, p. 566.

${ }^{93}$ STROWEL, A., Droit d auteur..., op. cit., p. 105.

${ }^{94}$ CABedo SernA, L. L., El derecho de remuneración..., op. cit., p. 152.
} 
aun cuando pueda afirmarse que cada sistema otorga preponderancia a los intereses que considera esenciales, no son excluidas del todo otras consideraciones. En este sentido refiere STROWEL que "on doit seulement parler de dominance d'une justification déterminée dans un système donnê" 95 .

Con todo, en el sistema continental, la teoría del derecho de propiedad cobra preeminencia entre las tesis mencionadas ${ }^{96}$, a pesar de las críticas que recibe ${ }^{97}$. Y aun cuando pareciera que el desarrollo histórico nos alejara de esta tesis, la legislación francesa es un buen ejemplo del retorno a esta concepción ${ }^{98}$. En efecto, el Derecho francés reconoce el derecho del autor sobre su obra como "derecho de propiedad incorporal". Así queda expresado en la vigente Loi $n^{\circ} 92-597$ du ler juillet 1992 relative au code de la propriété intellectuelle9" “L'auteur d'une ouvre de l'esprit jouit sur cette œuvre, du seul fait de sa création, d'un droit de propriété incorporelle exclusif et opposable à tous". En consecuencia, el hecho de la creación se impone frente al enfoque utilitarista que se asomaba en los decretos revolucionarios. Es decir, el fundamento del derecho de autor se asienta en el propio acto de creación, consagrando la ley un derecho natural preexistente.

\footnotetext{
${ }^{95}$ STROWEl, A., Droit d 'auteur..., op. cit., p. 177.

${ }^{96}$ BAYlos Corroza, H., Tratado..., op. cit., p. 663.

${ }^{97}$ Acerca de estas críticas a la tesis del derecho de propiedad Vid. BAYlos CorROZA, H., Tratado..., op. cit., pp. 527-534. El autor expone resumidamente las diferencias esenciales entre los derechos de propiedad y los derechos de los creadores, entre las cuales interesa destacar: a) El derecho de los creadores carece de la nota del dominio, característica del derecho de propiedad sobre los bienes materiales y representa, a su vez, un plus frente al dominio, por las facultades que conserva el autor aun trasmitida la propiedad del soporte material que contiene la obra; b) No existe una identificación plena en el derecho de autor, tal y como se aprecia en el derecho de propiedad, entre el derecho mismo y la cosa sobre la que la propiedad recae, por el carácter inapreciable del objeto y porque el contenido del derecho no implica facultades de goce y disfrute del bien, sino más bien de obtención de ganancias en el sentido de que ha de ponerla a disposición del público para obtener beneficios patrimoniales, a diferencia del derecho de propiedad donde típicamente se aplican directamente las cosas a la satisfacción de las necesidades del propietario; c) El poder jurídico que se incluye en el contenido del derecho de los creadores tiene un carácter exclusivo y excluyente y se establece para prohibir a los terceros la explotación de la obra, a diferencia de los derechos sobre cosas corporales que se establecen, ante todo, para asegurar a los titulares el goce privativo de esas cosas; y d) La temporalidad del derecho de los creadores frente a la perpetuidad que caracteriza a las situaciones de dominio.

${ }^{98}$ Strowel, A., Droit d’auteur..., op. cit., p. 108. Hay que agregar que, en el contexto del derecho de la UE, la DDASI declara que la propiedad intelectual ha sido reconocida como una parte integrante del derecho de propiedad (Considerando 9).

${ }^{99}$ J.O.R.F. núm. 0153, 3 julio 1992.
} 
A diferencia de la ley francesa, el TRLPI español no hace referencia expresa a la propiedad incorporal que ostenta el autor sobre su obra, derivada del acto de creación, lo que no quiere decir que la idea de propiedad no esté implícita, de algún modo, en la norma. En efecto, el concepto de propiedad parece extenderse a la propiedad intelectual. De hecho, el artículo 429 in fine del Código Civil ${ }^{100}$ permite aplicar con carácter supletorio las reglas comunes de la propiedad para integrar las lagunas derivadas de la legislación especial sobre propiedad intelectual ${ }^{101}$, sin perjuicio de la especialidad de este derecho derivada de su contenido moral ${ }^{102}$. Asimismo, la jurisprudencia también reafirma la configuración de la Propiedad Intelectual como un derecho de propiedad, si bien matizada por su carácter especial, dado sobre todo el carácter inmaterial de su objeto. En tal sentido sirva de ejemplo la STS (Sala de lo Civil), de 11 de abril de $2000^{103}$ cuando señala:

"La propiedad intelectual se configura como un derecho de propiedad, con determinadas peculiaridades que justifican su especialidad y que derivan fundamentalmente de la naturaleza de su objeto que es un bien inmaterial, aunque respecto a ello hay que destacar que comprende no sólo el derecho sobre el bien inmaterial -«corpus misticum»-sino también sobre la cosa corporal, soporte material, en el que recae el derecho -«corpus mecanichum»- y sobre uno y otro recaen acciones correspondientes a la propiedad, debidamente adaptadas, como la reivindicatoria, y acciones específicas que prevé la Legislación específica de Propiedad Intelectual" (F.J. $1^{\circ}$ ).

\section{EL DERECHO DE REPRODUCCIÓN}

\section{Introducción}

El derecho de reproducción (rectius, facultad) ${ }^{104}$ constituye la primera prerrogativa de la que, históricamente, ha disfrutado el autor, siendo así la primera

\footnotetext{
${ }^{100}$ B.O.E. núm. 206, de 25 de julio de 1889.

101 Bercovitz Rodríguez-CANo, R., "Artículo 1", en Bercovitz RodríGuez-Cano, R. (Coord.), Comentarios a la Ley de Propiedad..., $3^{\mathrm{a}}$ ed., op. cit., p. 21.

102 Ídem.

${ }^{103}$ RJ $2000 \backslash 2434$.

${ }^{104}$ En sentido estricto el llamado "derecho de reproducción”, más que un derecho en sí, es una facultad de las que comporta el contenido patrimonial del derecho de autor, en el sentido de posibilidad de autorizar o prohibir la reproducción de la obra. Esta facultad se consagra como parte del elenco de facultades que
} 
manifestación de las facultades reconocidas a éste y piedra angular del sistema de la Propiedad Intelectual. Este derecho sigue siendo hasta hoy una facultad esencial dentro de las formas de explotación patrimonial de las creaciones intelectuales, sin desdeñar la importancia del resto de las facultades y, en particular, del derecho de comunicación pública, por la gran utilización de los modos de comunicación inmaterial para hacer accesible la obra al público, como la radiodifusión, hilo, cable, fibra óptica, etc.

Sin embargo, la noción del derecho de reproducción no ha permanecido invariable desde su reconocimiento legal hasta hoy. Más bien, por el contrario, ha tenido que irse adaptando al panorama cambiante del desarrollo tecnológico y, en particular, a la digitalización y a la llegada de las redes informáticas, que han planteado nuevas cuestiones sobre la extensión y vigencia de este derecho en un entorno donde las obras circulan "desmaterializadas" 105 . En efecto, la llegada de la tecnología digital e Internet han impuesto un nuevo examen de los márgenes del derecho de reproducción, así como de la necesidad de reajustar los límites de este derecho ${ }^{106}$, tanto en el plano internacional como nacional.

\section{El derecho de reproducción en la legislación internacional, europea y nacional}

\subsection{Derecho internacional}

El reconocimiento internacional expreso del derecho de reproducción dentro de las facultades patrimoniales del autor no tuvo lugar hasta la segunda mitad del siglo XX,

comportan los llamados “Derechos de explotación” en el TRLPI, regulados en la Sección 2a, Capítulo III del Título II. Vid. Rivero HernándeZ, F., “Artículo 17”, en BERCOVITZ RodríGUEZ-CANo, R. (Coord.), Comentarios a la Ley de Propiedad..., $3^{\mathrm{a}}$ ed., op. cit., p. 271, quien destaca al respecto la deficiencia terminológica del TRLPI: "cómo los que llama 'derechos' de explotación son en realidad facultades de la misma clase y contenido patrimonial, posibilidades de actuación en ese ámbito que cuando son actuadas por su titular se traducen in actu en paralelas formas de explotación -que a veces la propia ley llama «modalidades de explotación» (arts. 43.2, 57.2, 90.1) o «modalidades de utilización» (art. 43.5)-".

105 GARrote FernándeZ-DíEZ, I., El Derecho de Autor en Internet, 2 ${ }^{\mathrm{a}}$ ed., Comares, Granada, 2003, p. 275.

${ }^{106}$ Así, por ejemplo, hubo necesidad de evaluar si los actos de reproducción provisional que facilitan el proceso de transmisión de la obra en la Red quedaban o no comprendidos dentro del derecho de reproducción. 
con el Acta de Estocolmo del CB, de 14 de julio de 1967, como ya hubo ocasión de mencionar. Con anterioridad, sólo se pueden nombrar algunas referencias vagas a este derecho en el ámbito de la regulación internacional de la propiedad intelectual ${ }^{107}$.

La razón del reconocimiento tardío del derecho de reproducción ha sido atribuida al proceso lento de configuración del $\mathrm{CB}$, al que se fueron añadiendo facultades patrimoniales y morales al autor de acuerdo a las circunstancias de cada momento ${ }^{108}$. Sin perjuicio de lo anterior, el derecho de reproducción se presuponía implícito en otras facultades contenidas en el $\mathrm{CB}$, o como requisito previo a la existencia de límites al derecho de propiedad intelectual.

Pues bien, el art. 9 (apartados 1 y 3) del Acta de Estocolmo del CB constituye el primer precepto que otorga cobertura internacional al derecho de reproducción del autor. En efecto, este artículo ha reconocido expresamente el derecho de reproducción como un derecho patrimonial exclusivo del autor y, aunque no ofrece una definición legal del mismo, la interpretación general entre los miembros de la Unión de Berna ha sido entender que la noción de reproducción lleva implícita la previa fijación de la obra en un soporte material como medio para hacerla accesible al público y permitir la

\footnotetext{
${ }^{107}$ La Convención Universal sobre Derecho de Autor, de 6 de septiembre de 1952, establece en su art. V (apartado primero) que "el derecho de autor comprende el derecho exclusivo de hacer, de publicar y de autorizar que se haga y se publique la traducción de las obras protegidas por la presente Convención", entendiendo por publicación, a tenor del art. VI, "la reproducción de la obra en forma tangible a la vez que el poner a disposición del público ejemplares de la obra que permitan leerla o conocerla visualmente". De ello puede colegirse que el derecho exclusivo reconocido al autor lleva implícito, desde entonces, el derecho a autorizar la reproducción de la obra, aunque no pueda decirse que el derecho de reproducción gozara en virtud de esta norma de un reconocimiento independiente como facultad patrimonial. Otra referencia se encontraba en el art. 13.1 del propio CB (Acta de Bruselas de 26 de junio de 1948). Éste contemplaba la reproducción de las obras musicales mediante instrumentos capaces de reproducirlas mecánicamente, bajo la rúbrica de "derechos de reproducción mecánica". Asimismo también el Acta de Bruselas del CB-, en su art. 14.1. (i) contenía de forma expresa la reproducción de obras por medio de la cinematografía (redacción proveniente del Acta de Berlín de 13 de noviembre 1908), para dar al autor el derecho a autorizar la adaptación de una obra literaria al cine, así como para autorizar o prohibir la ulterior reproducción de la obra audiovisual resultante de la adaptación. Sin embargo, en ninguno de los dos casos existía un reconocimiento del derecho de reproducción como facultad general.

108 Garrote FERnÁndez-DíEz, I., “Artículo 9”, en Bercovitz Rodríguez-CANo, R. (Coord.), Comentarios al Convenio de Berna..., op. cit., p. 707.
} 
obtención de ulteriores copias, diferenciándose así este derecho del de representación o ejecución públicas previsto en el art. $11 \mathrm{CB}^{109}$.

El art. 9.1 CB se limita a señalar que la reproducción puede ser realizada por cualquier procedimiento y bajo cualquier forma. El art. 9.3 CB aclara que las grabaciones sonoras y visuales serán consideradas reproducciones a efectos del propio Convenio. Y, por su parte, el art. 9.2 CB contiene la conocida regla de los tres pasos ${ }^{110}$, cuyo estudio se reserva al capítulo siguiente dedicado a los límites al derecho de autor. No obstante, puede adelantarse que, conforme establece el $\mathrm{CB}$, se trata de una regla que ordena el sistema de límites al derecho de reproducción, en virtud de la cual los límites establecidos legalmente tendrán que responder a determinados a casos especiales, que no atenten contra la explotación normal de la obra, ni causen un perjuicio injustificado a los intereses legítimos del autor.

Pese a la falta de una definición del derecho de reproducción en el $\mathrm{CB}$, del contenido del art. 9.1 se extrae claramente la idea de la irrelevancia del procedimiento o de la técnica empleada para realizar la reproducción. Al respecto, la fórmula utilizada es amplia, lo cual da cobertura jurídica no sólo a las formas tradicionales de reproducción, como las realizadas mediante impresión o edición, el grabado, la litografía, la fotocopia, entre otras, sino también a otras modalidades de reproducción surgidas a partir de las innovaciones en el área de las nuevas tecnologías, como las grabaciones en discos compactos (en adelante CD por las siglas en inglés de Compact Disc) o discos versátiles (en adelante DVD por las siglas en inglés de Digital Versatile Disc). Además, el tenor empleado en el CB "por cualquier procedimiento y bajo cualquier forma" da cobertura jurídica tanto a los actos de reproducción realizados mediante los procedimientos actualmente existentes como a aquellos que puedan surgir en el futuro ${ }^{111}$.

Nada dice el art. 9 del CB acerca de si la reproducción parcial de la obra queda sujeta a la autorización del autor. Por tanto, esta cuestión ha quedado al arbitrio de los

\footnotetext{
${ }^{109}$ Ibídem, p. 715.

${ }^{110}$ Esta regla está contenida también en el art. 5.5 de la DDASI y en el art. 40.bis del TRLPI.

111 Garrote FernándeZ-DíEZ, I., "Artículo 9", en BERCOVITZ RodríGUEZ-CANo, R. (Coord.), Comentarios al Convenio de Berna..., op. cit., p. 719.
} 
países miembros del Convenio ${ }^{112}$. No obstante, su trascendencia es mayor en los países del ámbito anglosajón en donde la sustantividad del fragmento copiado repercute en la valoración de si ha habido infracción o no del derecho de propiedad intelectual en los supuestos en que esta reproducción tiene lugar sin el consentimiento del titular de derechos $^{113}$.

En el plano internacional, también se hace eco del derecho de reproducción, tal y como lo concibe el CB, el art. 9.1 del Anexo 1C del Acuerdo por el que se establece la Organización Mundial del Comercio, aprobado mediante el Acta Final de la Ronda de Uruguay firmada en Marrakech el 15 de abril de 1994, conocido como "Acuerdo sobre los Aspectos de los Derechos de Propiedad Intelectual relacionados con el Comercio" (en adelante, Acuerdo sobre los ADPIC) $)^{114}$. El art. 9.1 del Acuerdo sobre los ADPIC establece que sus Miembros observarán los artículos del 1 a 21 del CB (Acta de París, 1971) ${ }^{115}$. Por tanto, estarán a lo dispuesto en el art. 9.1 CB sobre el derecho de reproducción.

Debe destacarse que el derecho de reproducción no sólo es una facultad reconocida en el plano internacional en favor de los autores, sino que se extiende además a los titulares de derechos afines, vecinos o conexos, esto es, a los artistas intérpretes o ejecutantes, los productores de fonogramas y videogramas y los organismos de radiodifusión. Ya desde la Convención de Roma sobre la protección de los artistas intérpretes o ejecutantes, los productores de fonogramas y los organismos de radiodifusión, de 26 de octubre de $1961^{116}$ (en adelante, CR), la protección prevista a favor de estos titulares de derechos de propiedad intelectual comprendía la facultad de

${ }^{112}$ El TRLPI español prevé expresamente en su art. 18 que el derecho de reproducción comprende la fijación directa o indirecta de la obra, de toda o parte de ella; por tanto, la reproducción parcial está incluida en el caso español dentro del monopolio exclusivo del autor.

${ }^{113}$ Vid. Sección 16 (3) a), Copyright, Designs and Patents Act of 1988 (Reino Unido) y Sección 107, Copyright Act of 1976 (EE.UU.).

${ }^{114}$ Disponible en: https://www.wto.org/spanish/docs_s/legal_s/27-trips.pdf (consultado: 18.01.2017).

${ }^{115}$ El 24 de julio de 1971 se firmó el Acta de París del CB, posteriormente enmendado el 28 de septiembre de 1979. Sin embargo, ello no supuso ninguna modificación del art. 9 CB, tal y como fue introducido mediante el Acta de Estocolmo (1967).

116 Disponible en: http://www.wipo.int/wipolex/es/treaties/text.jsp?file id=289796 (consultado: 18.01.2017). 
impedir la reproducción de la fijación de la ejecución para el caso de los artistas intérpretes o ejecutantes (art. 7.1); el derecho de autorizar o prohibir la reproducción directa o indirecta de sus fonogramas para los productores de fonogramas (art. 10); y el derecho de autorizar o prohibir la reproducción de las fijaciones de las emisiones hechas sin el consentimiento de los organismos de radiodifusión, así como de las realizadas con arreglo a lo establecido en el art. 15 (excepciones autorizadas), si la reproducción se hacía con fines distintos a los previstos en dicho artículo [art. 13. c)]. La protección a dichos titulares de derechos afines en relación con la facultad de reproducción también es reconocida en el art. 14 del Acuerdo sobre los ADPIC.

El CB también ha resultado ser un punto de referencia en la regulación del derecho de reproducción en el Tratado de la OMPI sobre Derecho de Autor (en adelante TODA), adoptado en Ginebra el 20 de diciembre de $1996^{117}$, al consignar en su art. 1(4) que "las Partes Contratantes darán cumplimiento a lo dispuesto en los Artículos 1 a 21 y en el Anexo del Convenio de Berna", lo que claramente incluye el art. 9.1 CB.

Sin embargo, las relaciones entre el art. 9.1 del CB y el TODA son complejas. En efecto, si bien existía consenso en la doctrina internacional sobre la aplicación del derecho de reproducción del art. 9.1 del CB al entorno digital en supuestos como la reproducción de una obra en formato digital, o la carga o subida de una obra en un servidor de Internet y su descarga posterior, no ocurría lo mismo respecto a las reproducciones provisionales o temporales ${ }^{118}$ que tienen lugar en el proceso de

\footnotetext{
${ }_{117}$ Disponible en: http://www.wipo.int/treaties/es/text.jsp?file_id=295166 (consultado: 18.01.2017).

${ }^{118}$ Comprende reproducciones técnicas, efímeras o intermedias que son las que se efectúan en los puntos intermedios de la Red; las copias caché locales que son las creadas en el ordenador del usuario de forma automática por el navegador y las copias caché del sistema que son las que los servidores web realizan sistemáticamente y que no se almacenan en ordenadores del usuario sino en ordenadores intermedios de Internet; así como las copias RAM que se producen en el ordenador del usuario permitiendo el proceso de visualización o audición de la obra en pantalla y que desaparecen cuando la obra desaparece de la pantalla o se apaga el ordenador. También el concepto de reproducciones provisionales o temporales engloba las reproducciones temporales en sentido estricto, que pueden ocurrir tanto en el ordenador del usuario como en los ordenadores de los servidores web que albergan páginas ajenas, que permiten el acceso a la obra y posterior utilización. Vid. GARROTE FERNÁNDEZ-DíEZ, I., El Derecho de Autor ..., op. cit., pp. 280 y ss.
} 
transmisión de las obras en las redes digitales ${ }^{119}$. La problemática se debía a la falta de una definición legal del derecho de reproducción en el $\mathrm{CB}$, aun cuando contiene una amplia formulación del mismo ("por cualquier procedimiento y en cualquier forma"), por lo que generaba interpretaciones dispares. En efecto, al carecer el CB de una definición del derecho de reproducción, hay que estar a lo establecido en las legislaciones nacionales de los países miembros de la Unión de Berna.

No obstante, mediante la Declaración Concertada respecto del art. 1(4) del TODA $^{120}$ se pactó que el derecho de reproducción, tal como se establece en el art. 9 del $\mathrm{CB}$, y las excepciones permitidas en virtud del mismo, resultan totalmente aplicables en el entorno digital, en particular, en la utilización de obras en formato digital. Se acordó, además, que el almacenamiento en forma digital en un soporte electrónico de una obra protegida constituye una reproducción en el sentido del citado art 9 del CB. Sin embargo, toda vez que esta Declaración fue concertada sin el consentimiento de todas las Partes contratantes, su virtualidad ha quedado reducida debido a que para que la interpretación del texto convencional sea vinculante, es necesario el acuerdo de todas éstas $^{121}$, de conformidad con lo establecido en el art. 31.2.a) del Convenio de Viena sobre Derecho de los Tratados, de 23 de mayo de $1969^{122}$. Consecuentemente, la cuestión no queda resuelta con el TODA y hay que atender a lo dispuesto en las legislaciones internas de cada una de las Partes. No obstante, debe admitirse que, en caso de que la interpretación sea la de incluir en el derecho de reproducción del autor la facultad de autorizar o prohibir las reproducciones temporales o provisionales, los países miembros del TODA y de la Unión de Berna pueden acudir al art. 9.2 CB para establecer excepciones o limitaciones que permitan que la mera transmisión de

\footnotetext{
${ }^{119}$ Para un análisis pormenorizado sobre los problemas de interpretación del art. 9.1 CB en el entorno digital Vid. GARrote FernándeZ-Díez, I., “Artículo 9”, en BERCOVITZ RodríGuez-CANO, R. (Coord.), Comentarios al Convenio de Berna..., op. cit., pp. 719 y ss.

${ }^{120}$ Disponible en: http://www.wipo.int/treaties/es/text.jsp?file id=295166 (consultada: 26.04.2017).

${ }^{121}$ Ibídem, p. 728.

${ }^{122}$ Instrumento de adhesión de 2 de mayo de 1972 del Convenio de Viena sobre el Derecho de los Tratados, adoptado en Viena el 23 de mayo de 1969 (B.O.E. núm. 142, de 13 de junio de 1980).
} 
contenidos por parte de los intermediarios o la visualización de los mismos en el ordenador queden excluidas del derecho exclusivo de reproducción del autor ${ }^{123}$.

Asimismo, el Tratado de la OMPI sobre Interpretación o Ejecución y Fonogramas (en adelante TOIEF), adoptado igualmente en Ginebra el 20 de diciembre de $1996^{124}$, parte del respeto de las obligaciones que las Partes Contratantes tuvieran en virtud de la mencionada $\mathrm{CR}$, u otro derecho u obligación ostentados en virtud de otro tratado. Pues bien, también los arts. 7 y 11 del TOIEF hacen referencia expresa al derecho de reproducción. El art. 7 del TOIEF reconoce que los artistas intérpretes o ejecutantes gozarán del derecho exclusivo de autorizar la reproducción directa o indirecta de sus interpretaciones o ejecuciones fijadas en fonogramas, por cualquier procedimiento o bajo cualquier forma. En términos similares se pronuncia el art. 11 del TOIEF cuando reconoce este derecho en favor de los productores de fonogramas, respecto a sus fonogramas. En ambos casos, lo dispuesto en estos artículos se aplica plenamente al entorno digital, esto es, a la utilización de interpretaciones o ejecuciones y fonogramas en formato digital, aclaración que queda contenida en la Declaración Concertada realizada respecto de los arts. 7.11 y 16 del TOIEF $^{125}$.

Los Tratados de la OMPI -como se les conoce al TODA y el TOIEF- son una importante muestra de la preocupación y necesidad que existía entonces de adaptar los contornos del derecho de reproducción al entorno digital, al tiempo que inspiran la actuación de la UE en la adopción de la Directiva 2001/29/CE del Parlamento Europeo y del Consejo, de 22 de mayo de 2001, relativa a la armonización de determinados aspectos de los derechos de autor y derechos afines a los derechos de autor en la sociedad de la información (en adelante DDASI), así como las legislaciones de otros

123 Garrote Fernández-DíEz, I., “Artículo 9”, en Bercovitz RodríGuez-CANO, R. (Coord.), Comentarios al Convenio de Berna..., op. cit., pp. 719-730.

124 Disponible en: http://www.wipo.int/wipolex/es/treaties/text.jsp?file id=295478 (consultado: 18.01.2017).

125 Disponible en: http://www.wipo.int/treaties/es/text.jsp?file_id=295579\#P114_13575 (consultada: 26.04.2017). 
países, como por ejemplo, la estadunidense, con la promulgación de la Digital Millennium Copyright Act $(1998)^{126}$.

Por último, otro texto internacional más reciente también hace expresa mención al derecho de reproducción. Se trata del Tratado de Beijing sobre Interpretaciones y Ejecuciones Audiovisuales ${ }^{127}$, adoptado el 24 de junio de 2012 en la Conferencia Diplomática de Beijing sobre la protección de las interpretaciones y ejecuciones audiovisuales, firmado por España el 26 de junio de $2012^{128}$, pero aún no ratificado (en adelante Tratado de Beijing). El mismo reconoce a los artistas intérpretes o ejecutantes el "derecho exclusivo a autorizar la reproducción directa o indirecta de sus interpretaciones o ejecuciones fijadas en fijaciones audiovisuales, por cualquier procedimiento o bajo cualquier forma" (art. 7) ${ }^{129}$.

\subsection{Derecho de la Unión Europea}

En el ámbito de la UE, la DDASI cobra protagonismo en la regulación de los derechos de propiedad intelectual. No obstante, conviene precisar que varias de las Directivas dictadas con anterioridad a la DDASI, relativas a la Propiedad Intelectual, ya contenían disposiciones respecto de las facultades de explotación y, en particular, del derecho de reproducción ${ }^{130}$. Así, por ejemplo, cabe mencionar que el art. 4.a) de la Directiva 91/250/CEE del Consejo, de 14 de mayo de 1991, sobre la protección jurídica

\footnotetext{
${ }^{126}$ Plaza Penadés, J., Propiedad Intelectual y Sociedad de la Información (Tratados de la OMPI, Directiva 2001/29/CE y Responsabilidad Civil en la Red), Aranzadi, Navarra, 2002, p. 151.

127 Disponible en: http://www.wipo.int/wipolex/es/treaties/text.jsp?file id=295840 (consultado: 02.02.2017).

128 Puede consultarse una lista de las Partes Contratantes en: http://www.wipo.int/treaties/es/ShowResults.jsp?lang=es\&treaty_id=841 (consultado: 25.04.2017).

${ }^{129}$ Sobre este Tratado se adoptaron el 24 de junio de 2012, en Beijing, por la Conferencia Diplomática sobre la Protección de las Interpretaciones y Ejecuciones Audiovisuales, varias Declaraciones concertadas, entre ellas una relativa al art. 7 que refrenda: "El derecho de reproducción, según queda establecido en el artículo 7 y las excepciones permitidas en virtud de ese artículo y de los artículos 8 a 13, se aplican plenamente al entorno digital, en particular a la utilización de interpretaciones o ejecuciones en formato digital. Queda entendido que el almacenamiento de una interpretación o ejecución protegida en formato digital en un medio electrónico constituye una reproducción en el sentido de este artículo".

${ }^{130}$ CAStelló PAstor, J. J., “Artículo 18. Reproducción (Comentario)”, en PAlau Ramírez, F. y PALAO Moreno, G. (Dirs.), Comentarios a la Ley de Propiedad Intelectual, Tirant Lo Blanch, Valencia, 2017, p. 323.
} 
de programas de ordenador ${ }^{131}$, establecía que los derechos exclusivos del titular incluían, entre otros, el derecho de realizar o de autorizar la reproducción total o parcial de un programa de ordenador por cualquier medio y bajo cualquier forma, ya fuera permanente o transitoria. Reconocía, asimismo, que cuando la carga, presentación, ejecución, transmisión o almacenamiento de un programa necesitaran la reproducción del mismo, estos actos estarían sujetos a la autorización del titular del derecho; ello sin perjuicio de lo dispuesto en los arts. 5 y 6 de la Directiva 91/250/CEE, en los que se exoneraban ciertos supuestos de la autorización de dicho titular ${ }^{132}$. Es el caso, igualmente, de la Directiva 92/100/CEE del Consejo, de 19 de noviembre de 1992, sobre derechos de alquiler y préstamo y otros derechos afines a los derechos de autor en el ámbito de la propiedad intelectual ${ }^{133}$, que también se refiere en su art. 7.1 al derecho de reproducción, preceptuando que los Estados miembros concederán el derecho exclusivo de autorizar o prohibir la reproducción directa o indirecta a los artistas intérpretes o ejecutantes respecto de las fijaciones de sus actuaciones, a los productores de fonogramas respecto de sus fonogramas, a los productores respecto de las primeras fijaciones de películas del original y de las copias de sus películas, y a las entidades de radiodifusión respecto de las fijaciones de sus emisiones de radiodifusión ${ }^{134}$. Otro ejemplo lo constituye la Directiva 96/9/CE del Parlamento Europeo y del Consejo, de 11 de marzo de 1996, sobre la protección jurídica de las bases de datos ${ }^{135}$, que asimismo reconoce en su art. 5.a) al autor de una base de datos, el derecho exclusivo, respecto de la forma de expresión de dicha base de datos susceptible de la protección de los derechos de autor, de realizar o autorizar la reproducción temporal o permanente, total o parcial, por cualquier medio y de cualquier forma de la misma.

${ }^{131}$ D.O.C.E. núm. L 122, de 17 de mayo de 1991. Tras varias modificaciones, "en aras de una mayor racionalidad y claridad", la Directiva 91/250/CEE fue codificada, dando lugar a la Directiva 2009/24/CE del Parlamento Europeo y del Consejo, de 23 de abril de 2009, sobre la protección jurídica de programas de ordenador (D.O.U.E. núm. 111, de 5 de mayo de 2009).

${ }^{132}$ El derecho de reproducción mantiene el mismo tenor con la Directiva 2009/24/CE del Parlamento Europeo y del Consejo, de 23 de abril de 2009.

${ }^{133}$ D.O.C.E. núm. L 346, de 27 de noviembre de 1992.

${ }^{134} \mathrm{El}$ art. 7 de la Directiva 92/100/CEE es derogado posteriormente por el art. 11.1 de la DDASI. Como consecuencia, pasa a regir lo dispuesto en el art. 2 de la DDASI.

135 D.O.C.E. núm. L 077, de 27 de marzo de 1996. 
Ahora bien, aunque la DDASI no es la primera norma comunitaria que acoge el derecho de reproducción en su seno y tampoco la única que lo define en términos $\operatorname{amplios}^{136}$, sí que es cierto que la misma tiene una importante trascendencia porque se ocupa de la regulación de este derecho de manera mucho más extensa, en el sentido de que no lo hace respecto a un determinado tipo de obra, sino en términos generales, esto es, respecto de todas las creaciones intelectuales a las que se refiere la misma ${ }^{137}$. A su vez, la DDASI viene a definir el derecho de reproducción de forma amplia, de manera que se pueda adaptar a las peculiaridades del desarrollo tecnológico y de la explotación de las obras y prestaciones en el entorno digital, persiguiendo además un objetivo armonizador que brinde seguridad jurídica dentro del mercado interior ${ }^{138}$.

A diferencia de los Tratados de la OMPI, la DDASI no deja lugar a dudas sobre el alcance de este derecho. En efecto, el art. 2 de la DDASI declara que los Estados miembros establecerán el derecho exclusivo a autorizar o prohibir la reproducción "directa o indirecta, provisional o permanente, por cualquier medio y en cualquier forma, de la totalidad o parte" de las obras y prestaciones intelectuales. Con este tenor se elimina la polémica sobre si las reproducciones temporales forman parte del derecho exclusivo de reproducción, al menos en términos generales, al margen de las dudas sobre si ciertas reproducciones que se producen en el proceso de circulación de las creaciones intelectuales por las redes digitales deben estar sujetas al control del titular de derechos o si deben enmarcarse, por el contrario, dentro de algunas de las excepciones o limitaciones al derecho del titular. Se trata, en definitiva, de un concepto de amplio alcance que permite cubrir los posibles actos de reproducción que pueden tener lugar tanto en el entono off line como on line ${ }^{139}$.

\footnotetext{
${ }^{136}$ Sirva de ejemplo la referencia hecha a la Directiva 96/9/CE.

${ }^{137}$ Vid. art. 10 de la DDASI.

${ }^{138}$ Reconoce el Considerando $21^{\circ}$ de la DDASI que “[...] Es necesaria una definición general de tales actos [los actos protegidos por el derecho de reproducción] para garantizar la seguridad jurídica dentro del mercado interior".

139 Plaza Penadés, J., Propiedad Intelectual..., op. cit., p. 182; Serrano CAÑAS, J. M. "La transposición de la Directiva 2001/29/CE. Una visión comparada”, en GARCíA PÉREZ, R. y LÓPEZ SuÁREZ, M. A. (Eds.), Nuevos retos para la Propiedad Intelectual. (II Jornadas sobre la Propiedad Intelectual y el Derecho de autor/a), Universidad de La Coruña, A Coruña, 2008, p. 57.
} 


\subsection{Derecho nacional}

\subsubsection{Definición y régimen legal}

Las leyes de Propiedad Intelectual españolas no siempre han atribuido un reconocimiento expreso y una definición legal al derecho de reproducción. Así, por ejemplo, la Ley de 10 de enero de 1879 de Propiedad Intelectual ${ }^{140}$, más bien hacía referencia implícita a su reconocimiento al prohibir la reproducción de obras ajenas sin el permiso de su propietario (art. 7, LPI 1879) y al establecer la obligación de recabar autorización del autor para poder copiar o reproducir las obras de arte originales existentes en galerías públicas en vida de sus autores" (art. 10, LPI 1879). Sin embargo, a pesar de no regular este derecho, sí hacía mención expresa al mismo cuando se disponía que los derechos adquiridos con la enajenación de una obra de arte, salvo pacto en contrario, no llevaban consigo la enajenación del derecho de reproducción ${ }^{141}$ (art. 9, LPI 1879). Pero, en ningún caso, esta Ley conceptualizaba este derecho.

Fue la Ley 22/1987, de 11 de noviembre, sobre Propiedad Intelectual (en adelante LPI), la que reconoció explícitamente la existencia de un derecho de reproducción en favor del autor y de otros titulares de derechos ${ }^{142}$, a la vez que lo dotó de una definición legal, "la fijación de la obra en un medio que permita su comunicación y la obtención de copias de toda o parte de ella", y que desde entonces tuvo un espacio reservado en el art. 18, con algunas modificaciones. La reproducción, que había sido antiguamente la antesala de la publicación o edición -reconocida la propiedad intelectual, no sólo, pero sí como un derecho a publicar (arts. 7, 11, 16, 40 de la Ley de 1879) ${ }^{143}$ - adquiere, en consecuencia, sustantividad propia al dejar de identificarse, necesariamente, con la idea de multiplicación de la obra y de obtención de copias y pasar a definirse por la "fijación

\footnotetext{
${ }^{140}$ B.O.E. núm. 12 , de 12 de enero de 1879.

${ }^{141}$ Énfasis añadido.

${ }^{142}$ Así, al autor se le reconoció un derecho de reproducción en virtud del art. 17 de la Ley 22/1987, de 11 de noviembre. También este derecho fue reconocido a otros titulares: al artista intérprete y ejecutante (art. 102), al productor de fonogramas (art. 109), al productor de grabaciones audiovisuales (art. 113), a las entidades de radiodifusión [art. 116. b)], al realizador de meras fotografías (art. 118), y al editor de obras inéditas que estén en el dominio público (art. 119).

${ }^{143}$ MARCo MolinA, J., La propiedad intelectual..., op. cit., p. 225.
} 
de la obra en un medio"144. En efecto, la reproducción pasa a ser, con la Ley de 1987, la propia fijación en sí y no la multiplicación de la obra por medio de la imprenta y otros medios mecánicos ${ }^{145}$. Basta incorporar la obra a un soporte distinto del original para consumar la actividad de reproducción. Es decir, es suficiente que la obra se fije en un medio tangible o intangible que permita su comunicación o la obtención de copias.

A día de hoy, el derecho de reproducción es reconocido al autor en virtud del art. 17 del TRLPI, como también es reconocido en favor de otros titulares de derechos mencionados en la ley. Así pues, ostentan también este derecho de reproducción el artista intérprete o ejecutante (art. 107 del TRLPI), el productor de fonogramas (art. 115 del TRLPI), el productor de una grabación audiovisual (art. 121 del TRLPI), las entidades de radiodifusión [art. 126. b) del TRLPI], el realizador de meras fotografías (art. 128 del TRLPI), así como quien divulgue lícitamente o edite una obra inédita que esté en el dominio púbico (art. 129 del TRLPI).

Respecto a la definición legal del derecho de reproducción, el art. 18 del TRLPI señala:

"Se entiende por reproducción la fijación directa o indirecta, provisional o permanente, por cualquier medio y en cualquier forma, de toda la obra o de parte de ella, que permita su comunicación o la obtención de copias".

Esta es la redacción dada al precepto mediante la Ley 23/2006, de 7 de julio, por la que se modifica el TRLPI, aprobado por el Real Decreto Legislativo 1/1996, de 12 de abril $^{146}$, que no ha sufrido modificación alguna hasta el presente. Y esta definición no

\footnotetext{
${ }^{144}$ Ibídem, p. 227. De hecho, sirva de ejemplo la definición de "obras" contenida en el Real Decreto de 3 de septiembre de 1880 por el que se aprueba el Reglamento para la ejecución de la Ley de 10 de enero de 1879 sobre Propiedad Intelectual (B.O.E. núm. 250, de 6 de septiembre de 1880) para comprender cómo la propia noción de obra estaba asociada a la posibilidad de multiplicación de la misma. Señalaba el art. 1, "Se entenderá por obras, para los efectos de la Ley de Propiedad Intelectual, todas las que se producen y puedan publicarse por los procedimientos de la escritura, el dibujo, la imprenta, la pintura, el grabado, la litografía, la estampación, la autografía, la fotografía o cualquier otro de los sistemas impresores o reproductores conocidos o que se inventen en lo sucesivo".

${ }^{145}$ El surgimiento de otros medios para reproducir las obras - como el fonógrafo o el magnetófono-, diferentes de la imprenta, hace que se acuñe en la doctrina el término de "derecho de reproducción mecánica", puesto que la reproducción de la obra requería de uso de dispositivos mecánicos como los discos o las cintas magnéticas.

${ }^{146}$ B.O.E. núm. 162, de 8 de julio de 2006.
} 
resulta ser muy diferente de la existente en las leyes españolas de Propiedad Intelectual desde la promulgación de la Ley 22/1987, de 11 de noviembre. No obstante, se trata de una definición más completa que la establecida en las antecesoras, por cuanto hace referencia explícita a las formas de reproducción ("directa o indirecta, provisional o permanente, por cualquier medio y en cualquier forma"), sin perjuicio de que estas formas de fijación ya pudieran considerarse implícitas en los textos anteriores toda vez que no existía previsión en contrario. Se trata, en definitiva, de una amplia formulación legal del derecho de reproducción, "un concepto lo bastante amplio y flexible como para abarcar todo tipo de fijación de la obra o prestación en un soporte, cualquiera que sea su naturaleza y durabilidad, con vistas a su comunicación por cualquier medio y a la obtención de copias de toda o parte de ella" ${ }^{147}$.

La norma prácticamente reproduce los términos del art. 2 de la DDASI, puntualizando, a diferencia de éste, que la fijación "permita su comunicación o la obtención de copias".

Ahora bien, lo que sí resulta más trascendente dentro del articulado de la Ley 23/2006, es la modificación que introduce al art. 31.1 del TRLPI, referida a las llamadas "reproducciones provisionales". Este precepto viene a delimitar, en sentido negativo, el derecho de reproducción, convirtiéndose así en un complemento importante al art. 18 del TRLPI. En virtud del mismo quedan excluidas del derecho de reproducción (y también de la autorización del autor) las copias instrumentales respecto del acto principal de comunicación pública o puesta a disposición en Internet. Es decir, se excluyen aquellos actos de reproducción provisional que carecen por sí mismos de una significación económica independiente, bien sean transitorios o accesorios, pero que forman parte integrante y esencial de un proceso tecnológico y cuya única finalidad consiste en facilitar, bien una transmisión en red entre terceras partes por un intermediario, bien una utilización lícita, entendiendo por tal la autorizada por el autor o por la ley.

${ }^{147}$ Carbajo Cascón, F., Publicaciones electrónicas..., op. cit., p. 98. 
Sin embargo, la ubicación de este precepto dentro de aquellos que regulan los límites a los derechos de propiedad intelectual pone en duda la adecuada sistemática de la ley porque, realmente, más que un límite a los derechos de autor, el art. 31.1 del TRLPI lo que viene es a delimitar el contenido del derecho de reproducción. No obstante, aun cuando posiblemente hubiera sido preferible ubicar el precepto al regular el derecho de reproducción ${ }^{148}$, lo cierto es que la sistemática del texto legal no deja dudas sobre su configuración como una excepción a este derecho. Ello significa que debe ser objeto de interpretación restrictiva y que está, en todo caso, sujeto a la regla de los tres pasos, que opera en cuanto a los límites a los derechos de explotación en la propiedad intelectual.

\subsubsection{Requisitos legales del derecho de reproducción}

\subsubsection{Fijación y comunicación u obtención de copias}

Atendiendo al tenor del art. 18 del TRLPI existen dos elementos fundamentales que identifican y diferencian al derecho de reproducción respecto de otras modalidades de explotación de las creaciones intelectuales. Estos son la fijación y la comunicación o la obtención de $\operatorname{copias}^{149}$.

Consecuentemente, para que haya reproducción, en sentido técnico-jurídico, es imprescindible que la obra quede fijada en un medio, bien se trate de la primera forma de fijación que es la que realiza el autor al terminar su proceso creativo (cuando materializa un dibujo o escribe el poema que ha ideado y que hasta entones sólo estaba en su mente) o de fijaciones ulteriores (la introducción de ese dibujo o poema, por ejemplo, en un libro que va a ser lanzado en una tirada de varios ejemplares), si bien la

\footnotetext{
${ }^{148}$ En el mismo sentido, Rivero Hernández, F., “Artículo 17”, en BERCOVITZ Rodríguez-CANO, R. (Coord.), Comentarios a la Ley de Propiedad..., $3^{\mathrm{a}}$ ed., op. cit., p. 286 (nota 11); GARROTE FERNÁNDEZDíEz, I., "Artículo 31”, en BERCOVITZ RodRíGUEZ-CANO, R. (Coord.), Comentarios a la Ley de Propiedad..., $3^{\mathrm{a}}$ ed., op. cit., p. 539; RoDRÍGUEZ TAPIA, J. M., “Artículo 18”, en RoDRÍGUEZ TAPIA, J. M., Comentarios a la Ley de Propiedad Intelectual, 2a ed., Aranzadi, Madrid, 2009, p. 180; LóPEZ MAZA, S., Límites al derecho de reproducción en el entorno digital, COMARES, Granada 2009, p. 159.

${ }^{149}$ CAStelló Pastor, J. J., "Artículo 18. Reproducción (Comentario)", en PAlaU RAMíRez, F. y PALAO Moreno, G. (Dirs.), Comentarios a la Ley de Propiedad..., op. cit., p. 328.
} 
primera carece de significación como acto de explotación o, dicho de otro modo, "es un acto de explotación que siempre admite ser realizado"150.

A su vez, el medio en que la obra o prestación es fijada tiene que permitir la comunicación o la obtención de copias. Es importante en este punto enfatizar que el uso de la conjunción "o", que se introduce en el TRLPI mediante la Ley 23/2006, de 7 de julio, por la que se modifica el TRLPI, aprobado por el Real Decreto Legislativo 1/1996, de 12 de abril, amplía el ámbito de protección anteriormente contemplado, toda vez que no exige la concurrencia de ambos resultados copulativamente, sino de uno u otro. Así, basta que tenga lugar la comunicación o la obtención de copias, alternativamente, para que se configure el derecho de reproducción ${ }^{151}$.

\subsubsection{Formas de fijación de la obra}

Según dispone el propio art. 18 del TRLPI, la fijación puede ser directa o indirecta, provisional o permanente, por cualquier medio y en cualquier forma, de toda la obra o de parte de ella ${ }^{152}$.

\section{A) Fijación directa o indirecta}

La fijación directa alude a la reproducción de la obra en un medio sin que tenga lugar ninguna fase intermedia. Por el contrario, en la fijación indirecta, se produce una fase intermedia para que tenga lugar la reproducción ${ }^{153}$, es decir, la fijación se realiza a partir de un soporte tangible de la obra, en el cual, previamente, ésta ha quedado

\footnotetext{
${ }^{150}$ SÁNCHEZ ARISTI, R., “Artículo 18”, en BERCOVITZ RodRíGUEZ-CANO, R. (Coord.), Comentarios a la Ley de Propiedad Intelectual, $4^{\mathrm{a}}$ ed., Tecnos, Madrid, 2017, p. 310. Véase también, entre otros, DIETZ, A., El Derecho de Autor en España y Portugal, Ministerio de Cultura, Madrid, 1992, p. 88.

${ }^{151}$ CASTElló PASTOR, J. J., Motores de búsqueda y derechos de autor: infracción y responsabilidad, Aranzadi, Navarra, p. 93; y “Artículo 18. Reproducción” (Comentario), op. cit., p. 335.

${ }^{152}$ En este análisis se altera el orden que sigue el precepto a la hora de enumerar las formas en que puede realizarse la fijación porque el estudio de las reproducciones provisionales exige mayor detenimiento y teniendo en cuenta que, en definitiva, el orden en que se hacen los comentarios no afecta el resultado del análisis.

${ }^{153}$ Plaza PenadÉs, J., Propiedad Intelectual..., op. cit., p. 180.
} 
estampada. En el primer caso, la finalidad de la reproducción es fijar la obra; en el segundo, por el contrario, la fijación se produce a partir de ulteriores reproducciones ${ }^{154}$.

En cualquier caso, se trata de una clasificación que poco aporta a la regulación del derecho de reproducción, considerando que este derecho ha sido contemplado en el texto de la ley no sólo como fijación de la obra en sí misma (a partir de su manifestación incorporal o intangible), sino también como "la fijación de la obra en un medio que permita su comunicación y la obtención de copias de toda o parte de ella"155.

No obstante, el uso de ambos adjetivos evidencia la intención del legislador de dar a este derecho un amplio alcance. En efecto, la reproducción no se verá afectada por el hecho de que la copia no se produzca a partir del ejemplar original, siendo que tanto éste como los ejemplares derivados del mismo podrán igualmente dar lugar a actos de comunicación que podrán dar lugar a nuevas fijaciones ${ }^{156}$. Así, habrá reproducción, incluso cuando la copia no se produzca en los soportes técnicos del usuario u oferente ${ }^{157}$.

\section{B) Fijación por cualquier medio y en cualquier forma}

El titular tiene un derecho exclusivo sobre la fijación de su obra, sin importar el medio o la forma en que esta fijación se produzca. Consecuentemente, va a ser irrelevante que la obra o prestación intelectual se reproduzca en un medio tangible o intangible, lo cual va a dar cobertura jurídica a los actos de reproducción en el entorno virtual. Tampoco es importante si la reproducción deriva de un acto de comunicación

\footnotetext{
${ }^{154}$ Moscoso del Prado Hernández, A. (Coord.), Practicum Propiedad Intelectual 2016, Aranzadi, Pamplona, 2016, p. 241; SÁNCHEZ ARISTI, R., "Artículo 18", en BerCovitZ RodríGUEZ-CANO, R. (Coord.), Comentarios a la Ley de Propiedad ..., $4^{\text {a }}$ ed., op. cit., p. 317.

${ }^{155}$ La Ley 22/1987, de 11 de noviembre, ya refrendaba: "Se entiende por reproducción la fijación de la obra en un medio que permita su comunicación y la obtención de copias de toda o parte de ella", cuestión resaltada por RoDRIGO-BERCOVITZ RodRíGUEZ-CANO, R., GARROTE FERNÁNDEZ-DíEZ, I., GONZÁLEZ GonZalo, A. y SÁncheZ ARISTI, R., Las reformas de la Ley de Propiedad Intelectual, Tirant Lo Blanch, Valencia, 2006, pp. 31-32.

${ }^{156}$ SÁNCHEZ ARISTI, R., "Artículo 18”, en BERCOVITZ RodríGuEZ-CANO, R. (Coord.), Comentarios a la Ley de Propiedad..., $4^{\mathrm{a}}$ ed., op. cit., p. 317.

${ }^{157}$ ERDOZAIN, J. C., Derechos de autor y propiedad intelectual en Internet, Tecnos, Madrid, 2002, p. 124.
} 
pública, bien porque la obra sea recitada; expuesta al público en una galería o museo; o puesta a disposición del público mediante un acto de transmisión por hilo, cable, fibra óptica u otro procedimiento análogo, por ejemplo; o de la posesión física del soporte que contiene la obra o prestación intelectual adquirido por compraventa, alquiler o derivado de un préstamo, o incluso cuando éste no se posea de forma lícita. Asimismo, es irrelevante si la reproducción se obtiene partir de un original como de una copia, obtenida legítima o ilegítimamente, como tampoco es trascendente el destino que se le dé a la misma, salvo que concurra una finalidad que, junto con la presencia de otros factores, en su caso, constituya un criterio determinante para la aplicación de una excepción al derecho de reproducción ${ }^{158}$.

La amplitud de la expresión "por cualquier medio y en cualquier forma" es tal que resulta también indiferente el número de copias que se obtengan del original. En efecto, la mera fijación de la obra que permite su comunicación o la obtención de copias tan sólo una vez ya vulnera el derecho de reproducción si se hace sin el consentimiento del titular de derechos y sin amparo en una excepción legal. Lo mismo sucede si se realizan diversas reproducciones (salvo la posible aplicación de alguna excepción, como ya se ha mencionado).

\section{C) Fijación de toda la obra o de parte de ella}

El contenido del derecho de reproducción comprende también la facultad de autorizar o de prohibir la fijación tanto de una parte de la obra o prestación intelectual, como de su totalidad. Para el legislador resulta indiferente si la reproducción se realiza total o parcialmente, pues en cualquiera de los dos supuestos se requerirá el previo consentimiento del titular de los derechos.

\footnotetext{
158 Por ejemplo, en los casos en que la reproducción se produce para el correcto desarrollo de procedimientos administrativos, judiciales o parlamentarios (art. 31 bis del TRLPI), cuando se incluyen en una obra propia fragmentos de una obra ajena, así como la de obras aisladas de carácter plástico o fotográfico figurativo, a título de cita o para su análisis, comentario o juicio crítico, con fines docentes o de investigación (art. 32.1 del TRLPI), entre otros.
} 
En todo caso, queda a salvo la posibilidad de que se autorice legalmente la reproducción parcial o incluso total de la obra o prestación intelectual, al amparo de las excepciones o limitaciones que recaen sobre el derecho de reproducción ${ }^{159}$.

\section{D) Fijación provisional o permanente}

La provisionalidad o temporalidad de la fijación, o su carácter permanente, son también maneras en las que se puede realizar la reproducción de la obra o prestación intelectual, reservadas ambas al titular de derechos, las cuales se relacionan con el tiempo de permanencia de la copia en un soporte. Por tanto, bien si se trata de una copia permanente -como puede ser la obtención de un ejemplar de un libro-, como si se trata de una copia provisional o temporal -como las que se producen durante la transmisión de la obra en Internet-, ambas estarán supeditadas a la autorización del titular exclusivo de los derechos de propiedad intelectual, sin perjuicio de los límites que se establezcan legalmente.

Hoy en día ya no se discute que determinadas reproducciones de carácter permanente se incluyan dentro del contenido del derecho de reproducción del titular de derechos de propiedad intelectual y, por tanto, que queden sujetas a su control. Así, por ejemplo, en el entorno off line, no cabe duda de que la digitalización de una obra, es decir, que pasa de un formato analógico a uno digital, constituye un acto de reproducción; tampoco el hecho de que la obra se incorpore a una base de datos. Asimismo, en el entorno on line, es aceptado de forma general que tanto la carga (uploading) de una obra en servidores y ordenadores conectados a la Red, como la

\footnotetext{
${ }^{159}$ Así, por ejemplo, es lícita "la inclusión en una obra propia de fragmentos de otras ajenas de naturaleza escrita, sonora o audiovisual, así como la de obras aisladas de carácter plástico o fotográfico figurativo, siempre que se trate de obras ya divulgadas y su inclusión se realice a título de cita o para su análisis, comentario o juicio crítico. Tal utilización sólo podrá realizarse con fines docentes o de investigación, en la medida justificada por el fin de esa incorporación e indicando la fuente y el nombre del autor de la obra utilizada" (art. 32.1 del TRLPI), así como la copia privada (art. 31.2 del TRLPI).
} 
descarga (downloading) de ésta en un soporte material, integran la facultad de reproducción del titular de derechos de propiedad intelectual ${ }^{160}$.

Sin embargo, mayores problemas generan las fijaciones provisionales o temporales que se producen luego de que las obras y prestaciones intelectuales son introducidas en la Red. En lo referente a éstas se distinguen las reproducciones temporales en sentido estricto, las copias efímeras, las copias $R A M$ y las copias caché $^{161}$, a las que se hará referencia seguidamente.

En efecto, en la circulación de los contenidos en Internet se producen una serie de copias temporales que no dejan de estar implícitas en el derecho de reproducción -dado el amplio alcance de este derecho- y que sólo escapan del ius prohibendi del autor en la medida en que las limitaciones o excepciones a este derecho así lo permiten, de conformidad con el art. 31.1 del TRLPI o mediante la excepción de copia privada del art. 31.2 del TRLPI, en su caso. Por tanto, cobra gran relevancia la delimitación del concepto reproducción o fijación provisional para la configuración del derecho de reproducción, pues dicho límite sirve como un importante elemento delimitador de este derecho, mejor que como límite mismo ${ }^{162}$, de manera que conviene analizar aquellas actividades más trascendentes que se dan en el proceso de transmisión en línea y que pueden quedar dentro del ámbito de aplicación objetivo del art. 18 del TRLPI o, por el contrario, quedar excluidas al amparo del límite del mencionado art. 31.1 del TRLPI.

Pues bien, la excepción prevista para las reproducciones provisionales o temporales se contiene en el art. 31.1 del TRLPI, en concordancia con lo establecido en el art. 5.1 de la DDASI ${ }^{163}$. En su virtud, quedan exceptuados del derecho de reproducción contemplado en el art. 18 del TRLPI y en el art. 2 de la DDASI los actos

${ }^{160}$ Garrote FernándeZ-DíEZ, I., El Derecho de Autor..., op. cit., pp. 275-276; De Miguel AsEnSiO, P. A., Derechos de Propiedad Intelectual, Aranzadi, Madrid, 2015, p. 47.

${ }^{161}$ GARRote FERnÁNDEZ-DíEZ, I., El Derecho de Autor..., op. cit., pp. 280-283; LóPEZ MAZA, S., Límites al derecho de reproducción ..., op. cit., p. 136.

${ }^{162}$ En el mismo sentido Garrote FernÁndeZ-DíEZ, I., El Derecho de Autor..., op. cit., p. 324, quien, por tal razón, examina el art. 5.1 de la DDASI al analizar los diversos tipos de reproducciones temporales. ${ }^{163}$ Martín SalamancA, S., “Artículo 31”, en Rodríguez TAPIA, J. M., Comentarios a la Ley de Propiedad Intelectual, $2^{\text {a }}$ ed., Aranzadi, Navarra 2009, pp. 274-279; MARÍN RAIGAL, G., "La excepción obligatoria relativa a las reproducciones provisionales en el art. 31.1 LPI”, en MORENO MARTíNEZ, J. A. (Coord.), Limites a la propiedad intelectual y nuevas tecnologías, Dykinson, Madrid, 2008, pp. 358-386. 
de reproducción provisional, que sean transitorios o accesorios y formen parte integrante y esencial de un proceso tecnológico y cuya única finalidad consista en facilitar una transmisión en una Red entre terceras partes por un intermediario, o una utilización lícita de una obra o prestación protegidas, y que no tengan por sí mismos una significación económica independiente ${ }^{164}$. De esta forma, se intenta ofrecer una solución proporcionada a las exigencias del entorno digital.

Un primer examen se impone en relación con las reproducciones temporales que GARROTE FERNÁNDEZ-DíEZ califica como reproducciones temporales en sentido estricto $^{165}$. Estas vienen constituidas por aquellas reproducciones que pueden ocurrir tanto en el ordenador del usuario como en los ordenadores de los servidores web que albergan páginas ajenas, y que tienen un tiempo de duración más o menos variable, pero que, no obstante, permiten acceder a la obra y utilizarla posteriormente. Estas reproducciones [tratadas en el art. 4.a) de la Directiva 91/250/CEE del Consejo, de 14 de mayo de 1991, sobre la protección jurídica de programas de ordenador y en el art.7.a) de la Directiva 96/9/CE del Parlamento Europeo y del Consejo, de 11 de marzo de 1996, sobre la protección jurídica de las bases de datos con anterioridad a la DDASI] se incluyen dentro del derecho de reproducción del art. 2 de la DDASI y del art. 18 del TRLPI, que expresamente incluyen dentro de su ámbito, como ya se vio, a las reproducciones provisionales.

No puede decirse que estas reproducciones provisionales en sentido estricto estén exceptuadas de la autorización del autor, ni en el ordenamiento jurídico de la UE, de acuerdo a lo establecido en el art. 5.1 de la DDASI, ni en el ordenamiento jurídico español, a tenor del art. 31.1 del TRLPI. La razón radica, en primer lugar -y tomando como referente el Derecho de la UE-, en que la DDASI no altera lo dispuesto en las Directivas sobre programas de ordenador y bases de datos, donde ninguna excepción se

\footnotetext{
${ }^{164}$ Siguiendo lo expuesto por CARBAJO CASCÓN, F., Publicaciones electrónicas..., op. cit., pp. 111-112, puede entenderse por significación económica independiente "toda reproducción que sirva -siquiera potencialmente- para el uso económico (explotación) o puramente doméstico (utilización) de la obra o prestación y, por tanto, que pueda servir directa o indirectamente al titular de la propiedad intelectual para obtener un rendimiento económico de la obra o prestación reproducida".

${ }^{165}$ GARROTE FERnÁNDEZ-DíEZ, I., El Derecho de Autor ..., op. cit., p. 281.
} 
establece sobre estas reproducciones temporales, por cuanto el art. 1.2 deja a salvo lo dispuesto en las citadas Directivas ${ }^{166}$; y en segundo lugar, porque no puede decirse que estas copias no tengan relevancia económica alguna, requisito que es tomado en cuenta por el art. 5.1 de la DDASI y el art. 31.1 del TRLPI para el establecimiento de la excepción, pues, por el contrario, permiten la explotación y el disfrute de la obra ${ }^{167}$.

Cosa distinta sucede con las reproducciones efímeras, técnicas o intermedias que son aquellas que se efectúan en los puntos intermedios de la Red, en el proceso de transmisión digital de un punto a otro ${ }^{168}$. Éstas, si bien en principio deberían requerir la autorización del autor porque constituyen actos de reproducción ${ }^{169}$, quedan exceptuadas de la misma en virtud de los arts. 5.1 de la DDASI y 31.1 del TRLPI. Ello es así porque son reproducciones transitorias, dado su carácter efímero; accesorias al acto de comunicación pública que se realiza al transmitirse la obra por Internet; parte esencial del proceso tecnológico, que permite la transmisión en una red entre terceras partes por un intermediario; que hacen técnicamente posible la utilización lícita de la obra o prestación protegida por la propiedad intelectual; y que no tienen en sí mismas un significado económico independiente ${ }^{170}$. Se trata de copias que se producen automáticamente, de forma repetida en los ordenadores intermedios en el proceso de transmisión de las obras y prestaciones por Internet, siendo meramente incidentales al acto de comunicación pública, que es el que resulta realmente relevante, con lo cual, lo lógico sería que quedaran sujetas a una excepción adecuada ${ }^{171}$. En este sentido, bien podía el legislador de la UE -y el español, consecuentemente- haberlas excluido del derecho de reproducción, estableciendo un concepto más restringido de este derecho que no incluyera estas meras actividades técnicas, por el simple hecho de que no llevan

${ }^{166}$ El art. 1.2 de la DDASI establece: "Salvo en los casos mencionados en el artículo 11, la presente Directiva dejará intactas y no afectará en modo alguno las disposiciones comunitarias vigentes relacionadas con: a) la protección jurídica de los programas de ordenador; [...] e) la protección jurídica de las bases de datos".

${ }^{167}$ GARROTE FERnÁNDEZ-DíEZ, I., El Derecho de Autor..., op. cit., p. 328.

${ }^{168}$ Ibídem, p. 282.

169 Ibídem, p. 283.

${ }^{170}$ Ibídem, pp. 329-333.

${ }^{171}$ Ibídem, p. 285. 
aparejados actos de explotación ${ }^{172}$. En cambio, distinta ha sido la solución adoptada, al configurarse una noción amplia del derecho de reproducción, tanto en el art. 2 de la DDASI como en el art. 18 del TRLPI, aunque acotada por la vía de las excepciones mediante el art. 5.1 de la DDASI y traspuesta al ordenamiento jurídico español mediante el art. 31.1 del TRLPI.

Por otra parte, en la navegación por Internet, se producen reproducciones en la memoria RAM (Random Access Memory) del ordenador del usuario en el proceso de visualización de la obra en pantalla. Estas reproducciones no tienen un carácter permanente, sino que se borran una vez que el usuario elimina los contenidos en pantalla o apaga el ordenador, pero están sujetas, al menos en principio, a la autorización del titular de derechos porque, como ya se mencionó, el art. 18 del TRLPI utiliza un amplio concepto del derecho de reproducción, que da cabida a las fijaciones provisionales o temporales $^{173}$. Sin embargo, las reproducciones en la memoria $R A M$ son reproducciones transitorias y accesorias, que forman parte integrante y esencial del proceso tecnológico de browsing ${ }^{174}$, facilitan la utilización lícita de la obra y no puede

\footnotetext{
172 Ibídem, p. 323.

${ }^{173}$ En otros ordenamientos jurídicos, como el estadounidense, cobra especial relevancia que la fijación de la obra adquiera cierto grado de durabilidad o de permanencia que permita percibirla, reproducirla o comunicarla, para que pueda ser comprendida dentro del derecho de reproducción. En este sentido, señala la Sección 101 de la Copyright Act: "A work is 'fixed' in a tangible medium of expression when its embodiment in a copy or phonorecord, by or under the authority of the author, is sufficiently permanent or stable to permit it to be perceived, reproduced, or otherwise communicated for a period of more than transitory duration. A work consisting of sounds, images, or both, that are being transmitted, is 'fixed'for purposes of this title if a fixation of the work is being made simultaneously with its transmission". Como consecuencia, la doctrina se encuentra dividida, mostrándose algunos autores como J. LiTMAN, P. SAMUELSON y M. CHON contrarios a que las copias RAM queden sujetas a la autorización del titular de derechos de propiedad intelectual, considerando que a este nunca le ha sido conferida la posibilidad de controlar la lectura, visionado o audición de sus obras en privado. Al respecto, bajo la doctrina del fair use y bajo la doctrina de la licencia implícita - la introducción de la obra en la Red implica el consentimiento implícito de que los usuarios puedan visualizarla- se ha justificado que puedan tener lugar las copias RAM sin el consentimiento del titular de derechos. Por el contrario, autores como D. NIMMER y I. TROTTER HARDY entienden que deben ser autorizadas por el titular porque significan un acto de reproducción. Por otra parte, la doctrina alemana mayoritaria se ha inclinado por considerar que las copias $R A M$ son lo suficientemente permanentes como para quedar incluidas en el derecho de reproducción, aunque también hay opiniones en contra. Y sucede de forma similar en Francia, donde también la doctrina se encuentra dividida. Vid. GARrote FernándeZ-DíEZ, I., El Derecho de Autor..., op. cit., pp. 297 y ss.

${ }^{174}$ El browsing consiste en la actividad de "navegar" en la Red. Esta actividad genera la realización de reproducciones que, aun siendo incidentales, podrían afectar al derecho de reproducción si no se cuenta
} 
decirse que tengan una significación económica independiente, si se tiene en cuenta que los contenidos en Internet circulan de forma libre, con lo cual se acepta la presunción iuris tantum de que quien ha colocado estos contenidos autoriza su visionado, salvo que se oponga explícitamente a ello.

En este sentido, es ilustrativa la STJUE (Sala Cuarta), de 5 de junio de 2014 (asunto C360/13) $)^{175}$, que concluye:

“[...] el art. 5 de la Directiva 2001/29 debe interpretarse en el sentido de que las copias en pantalla y las copias en caché ${ }^{176}$, efectuadas por un usuario final durante la consulta de un sitio de Internet, cumplen los requisitos con arreglo a los cuales estas copias deben ser provisionales, tener carácter transitorio o accesorio y formar parte integrante y esencial de un proceso tecnológico, así como los requisitos establecidos en el artículo 5, apartado 5, de dicha Directiva, y, por lo tanto, pueden realizarse sin autorización de los titulares de derechos de autor" (párrafo 63) .

Por tanto, no tiene sentido demandar una vulneración del derecho de reproducción de la obra cuando para la explotación económica de la misma a través de la Red se requiere, inexorablemente, realizar reproducciones en la memoria $R A M$ de los ordenadores de los usuarios que navegan en ésta ${ }^{177}$. Incluso, en los casos en que los contenidos protegidos son colocados en la Red sin el consentimiento del titular de derechos, la apariencia de licitud -al no existir trabas de acceso a la página web-, así como la presunción de la buena fe del usuario, permitirían llegar a la misma conclusión $^{178}$.

En cambio, cuando existen restricciones para el acceso a los contenidos de una página web mediante clave de acceso, es presumible que la copia $R A M$ tenga en sí

con la autorización del titular de este derecho. Vid. CAstelló Pastor, J. J., Motores de búsqueda..., op. cit., p. 116.

175 ECLI:EU:C:2014:1195.

${ }^{176}$ La referencia está hecha a las copias caché del disco duro durante la navegación en Internet que, como luego se verá, son copias caché locales no persistentes, las cuales quedan amparadas en la excepción del art. 5.1 de la DDASI y del art. 31.1 del TRLPI y que son distintas de las copias caché locales persistentes o las copias caché del sistema, que siguen un régimen jurídico diferente.

${ }^{177}$ GarRote FernándeZ-Díez, I., El Derecho de Autor..., op. cit., pp. 338 y p. 356, solución también defendida con anterioridad por autores como RIBAS, X., "Usos permitidos en Internet", disponible en: http://www.onnet.es/01005006.htm (consultado 26.01.2017).

${ }^{178}$ GARROTE FernáNDEZ-DíEZ, I., El Derecho de Autor ..., op. cit., pp. 339 y 356. 
misma una significación económica ${ }^{179}$, ya que la finalidad perseguida por el titular de derechos será la explotación económica de la obra, que se llevará a cabo mediante la visualización y/o audición de la misma. De hecho, las copias $R A M$ son el soporte para la explotación de la obra mediante streaming ${ }^{180}$, pues facilitan su visionado o su audición sin necesidad de que se descargue en el disco duro del ordenador ${ }^{181}$. También son en muchas ocasiones el paso previo a la descarga de la obra o prestación intelectual ${ }^{182}$. Por tanto, en los casos en que la copia en la memoria $R A M$ del ordenador del usuario requiere autorización, no podrá sostenerse que opera el límite del art. 5.1 de la DDASI (art. 31.1 del TRLPI) ${ }^{183}$, sin perjuicio de que pueda prescindirse de la autorización del titular de derechos al amparo del límite de copia privada, cuando se cumplen los requisitos que esta excepción exige ${ }^{184}$.

En relación con las copias caché ${ }^{185}$, hay que distinguir entre las copias caché locales -que, a su vez, pueden ser persistentes y no persistentes-, y las copias caché del sistema. En efecto, al navegar por Internet se producen reproducciones de las páginas web visitadas, que se pueden utilizar en caso de que no esté disponible la versión más

${ }^{179}$ CARBAjo CASCón, F., "Delimitación de la responsabilidad de los servicios de intermediación de la sociedad de la información (I). (Primera Parte: Origen del problema y régimen jurídico general en EE.UU. y UE)", Iustitia, 2014, pp. 119-120.

${ }^{180}$ El streaming es la transmisión digital de contenidos multimedia a través de una red conectada a Internet, que facilita el visionado/escucha de los contenidos sin necesidad de que se produzca la descarga completa de estos al ordenador.

181 Garrote Fernández-DíEZ, I., “Artículo 9”, en BERCOVITZ RodríGUEZ-CANO, R. (Coord.), Comentarios al Convenio de Berna..., op. cit., p. 735.

${ }^{182}$ CARbajo CASCÓn, F., "Delimitación de la responsabilidad de los servicios...”, op. cit., p. 119.

${ }^{183}$ Castelló Pastor, J. J., Motores de búsqueda..., op. cit., p. 138; Garrote Fernández-DíEz, I., El Derecho de Autor..., op. cit., pp. 339-340; RIBERA BlANES, B., El derecho de reproducción..., op. cit., pp. 356-357; LÓPEZ MAZA, S., Límites al derecho de reproducción ..., op. cit., p. 155.

${ }^{184}$ Castelló Pastor, J. J., Motores de búsqueda..., op. cit., p. 138; Garrote Fernández-DíEZ, I., El Derecho de Autor..., op. cit., p. 340 y “Artículo 9", en BERCOVITZ RODRÍGUEZ-CANO, R. (Coord.), Comentarios al Convenio de Berna..., op. cit., p. 736; LóPEZ MAZA, S., Límites al derecho de reproducción..., op. cit., p. 163; GONZÁlEZ DE AlAIZA CARDONA, J. J., La copia privada. Sus fundamentos y tratamiento en el entorno digital, Comares, Granada, 2008, pp. 72 y 73 y CARBAJO CASCón, F., "Delimitación de la responsabilidad de los servicios...”, op. cit., pp. 121-124.

${ }^{185}$ Se trata de reproducciones temporales que se producen a nivel local o de sistema y que son indispensables para poder ejecutar correctamente el proceso tecnológico de transmisión de las obras en la Red. Estas copias tenían mayor virtualidad en el momento en el que no existía la banda ancha o tenía ésta menos potencia porque se mostraban mientras se cargaba la página web solicitada. CASTELLÓ PASTOR, J. J., Motores de búsqueda..., op. cit., pp. 67-70; GARrote FERnÁndEZ-DíEZ, I., El Derecho de Autor..., op. cit., p. 318. 
actualizada de una página; y estas copias, denominadas copias caché, se almacenan de forma automática por el navegador en el ordenador del usuario (copias caché locales) y en distintos ordenadores intermedios o servidores web (copias caché del sistema o proxy caching $)^{186}$. Las copias caché no son imprescindibles para la circulación de la obra o prestación en Internet, sino más bien su ventaja está en agilizar el proceso de acceso a las mimas ${ }^{187}$, haciendo más eficaz el proceso de consulta de los sitios de Internet frente al volumen actual de datos transmitidos en línea. Las copias caché locales no persistentes desaparecen cuando se cierra el navegador, mientras que las persistentes residen en la memoria $R A M$ del ordenador del usuario, en el disco duro, o en ambos, durante un cierto tiempo ${ }^{188}$.

Las copias caché locales no persistentes siguen el mismo régimen jurídico que las copias $R A M$, debido a su provisionalidad, aunque conceptualmente quepa distinguirlas desde un punto de vista técnico ${ }^{189}$. Por tanto, es posible afirmar que son reproducciones en el sentido del art. 18 del TRLPI, pero exceptuadas de la autorización del titular de derechos en virtud del art. 31.1 del TRLPI. Las copias caché locales persistentes, por el contrario, no pueden quedar exceptuadas en virtud de este art. 31.1 del TRLPI, sino sólo, en su caso, mediante la copia para uso privado $^{190}$; y es que estas copias -como las reproducciones temporales en sentido estricto- no son copias transitorias, e incluso pudiendo ser consideradas accesorias cuando la visualización es autorizada (téngase en cuenta que tanto el art. 5.1 de la DDASI como 31.1 del TRLPI se refieren a actos de reproducción transitorios $o$ accesorios) ${ }^{191}$, tienen una significación económica

\footnotetext{
${ }^{186}$ GARRote FernánDEZ-DíEZ, I., El Derecho de Autor..., op. cit., pp. 281-282.

${ }^{187}$ Castelló Pastor, J. J., Motores de búsqueda ..., op. cit., p. 138; CARbajo Cascón, F., "Delimitación de la responsabilidad de los servicios...", op. cit., p. 269.

${ }^{188}$ GARROTE FERNÁNDEZ-DíEZ, I., El Derecho de Autor ..., op. cit., pp. 281-282 y 310-311.

${ }^{189} \mathrm{Ibídem,} \mathrm{pp.} 282$ y 345 . Véase también LÓPEZ MAZA, S., Límites al derecho de reproducción..., op. cit., p. 166.

${ }^{190}$ Garrote Fernández-Díez, I., El Derecho de Autor..., op. cit., p. 357; Castelló Pastor, J. J., Motores de búsqueda..., op. cit., p. 138.

${ }^{191}$ Énfasis nuestro.
} 
independiente que excluye la posibilidad de que puedan quedar al amparo de las limitaciones previstas para las reproducciones provisionales ${ }^{192}$.

Por su parte, las copias caché del sistema son también reproducciones en el sentido del art. 2 de la DDASI y del art. 18 del TRLPI por lo que requerirían, igualmente, de la autorización del titular de derechos ${ }^{193}$. Sin embargo, en la práctica resulta inviable obtener la autorización del titular de derechos para cada una de las reproducciones que se hacen sistemáticamente en los discos duros de los ordenadores intermedios de la Red. Así pues, la mejor solución pasa por la posibilidad de que este tipo de copias queden amparas en alguna excepción o limitación a los derechos de propiedad intelectual. Sin embargo, el encaje de este tipo de copias en el límite previsto en el art. 5.1 de la DDASI y en el art. 31.1 del TRLPI no es posible si se tiene en cuenta que pueden llegar a tener un significado económico independiente ${ }^{194}$, aun cuando puedan ser consideradas accesorias a la transmisión en la Red y, si bien no son esenciales para hacer técnicamente posible la transmisión de los contenidos en la misma, sí para favorecer las transmisiones digitales al agilizar las mismas. Pero, en cualquier caso, el sólo hecho de tener una significación económica impide invocar la excepción mencionada.

192 GARROTE FernáNDEZ-DíEZ, I., El Derecho de Autor..., op. cit., p. 345. En particular, respecto de la significación económica independiente, este autor señala que éstas "pueden afectar los ingresos publicitarios o la exactitud de la información en tiempo real. Por tanto, deben ser objeto de autorización separada en principio, a salvo de la extensión del juego de la copia privada y de que en la práctica no parece que éste sea un mercado interesante para los derechohabientes".

${ }^{193}$ No pueden ser confundidas con las copias que se almacenan de manera temporal en los enrutadores cuando se produce el proceso de transferencia de información de una red a la siguiente. Los routers (enrutadores) tienen como función principal, además de interconectar varias redes de datos, direccionar los paquetes de datos hasta su destino del modo más eficaz (RIBERA BLANES, B., El derecho de reproducción..., op. cit., p. 351). Asimismo, para llevar a cabo este proceso de routing, la información es descompuesta en pequeños paquetes que son almacenados de forma temporal en los enrutadores y, en la medida en que no se trata de reproducciones de la información -y en lo que aquí interesa, de obras y prestaciones intelectuales que se transmiten a través de la Red-, sino de partes de ésta una vez descompuesta, que vuelven a unirse una vez que llegan al ordenador de destino, no estamos ante una reproducción en sentido técnico-jurídico (GARROTE FERNÁNDEZ-DíEZ, I., El Derecho de Autor ..., op. cit., p. 314).

${ }^{194}$ Garrote FernándeZ-DíEZ, I., El Derecho de Autor..., op. cit., pp. 341-342; CASTElló Pastor, J. J., Motores de búsqueda..., op. cit., p. 139. 
Por tanto, la necesidad de encontrar una solución para no tener que requerir autorización del titular en el supuesto de este tipo de copias y teniendo en cuenta que de no excluirlas de algún modo del derecho de reproducción se produciría un perjuicio al buen funcionamiento de la Red, la cuestión fue resuelta por el art. 13 de la Directiva 2000/31/CE del Parlamento Europeo y del Consejo de 8 de junio de 2000, relativa a determinados aspectos jurídicos de los servicios de la sociedad de la información, en particular, el comercio electrónico en el mercado interior ${ }^{195}$, y en el ordenamiento jurídico interno, mediante el art. 15 de la Ley 34/2002, de 11 de julio, de servicios de la sociedad de la información y de comercio electrónico (en adelante LSSI) ${ }^{196}$.

Al respecto, de conformidad con el art. 13 de la Directiva 2000/31/CE, se exonera de responsabilidad a los prestadores de servicios en línea por el almacenamiento automático, provisional y temporal de los datos que transmiten, facilitados por el destinatario del servicio, realizado con la única finalidad de hacer más eficaz la transmisión ulterior de la información a otros destinatarios del servicio, a petición de estos; aspectos que se ajustan al carácter de las copias caché del sistema ${ }^{197}$. Para que así sea y según el mencionado precepto, es imprescindible que el prestador de servicios no modifique la información; cumpla las condiciones de acceso a la información y las normas relativas a la actualización de la información, especificadas de manera ampliamente reconocida y utilizadas por el sector; no interfiera en la utilización lícita de tecnología ampliamente reconocida y utilizada por el sector con el fin de obtener datos sobre la utilización de la información; y actúe con prontitud para retirar la información que haya almacenado, o para hacer que el acceso a ella sea imposible, en cuanto tenga conocimiento efectivo del hecho de que la información ha sido retirada del lugar de la red en que se encontraba inicialmente, de que se ha imposibilitado el acceso a dicha información o de que un tribunal o una autoridad administrativa ha ordenado retirarla o impedir que se acceda a ella. De tal forma, de concurrir estas condiciones, se libera de responsabilidad al prestador de servicios en línea por el almacenamiento automático,

${ }^{195}$ D.O.U.E. núm. 178 , de 17 de julio de 2000.

${ }^{196}$ B.O.E. núm. 166, de 12 de julio de 2002.

${ }^{197}$ GARROTE FERnÁNDEZ-DíEZ, I., El Derecho de Autor ..., op. cit., p. 343. 
provisional y temporal de la información facilitada por el destinatario del servicio. Esta exoneración de responsabilidad se establece considerando que estas copias son reproducciones en el sentido legal, pero que merecen ser exceptuadas de la autorización del titular de derechos a efectos de realizar tal almacenamiento ${ }^{198}$, con el fin de hacer más eficaz la transmisión ulterior de la información a otros destinatarios del servicio, a petición de éstos.

Lo mismo cabe decir en virtud del art. 15 de la LSSI. A tenor de este precepto los prestadores de un servicio de intermediación que transmitan por una red de telecomunicaciones datos facilitados por un destinatario del servicio y, con la única finalidad de hacer más eficaz su transmisión interior a otros destinatarios que los soliciten, los almacenen en sus sistemas de forma automática, provisional y temporal, serán exonerados de responsabilidad por el contenido de esos datos, así como por la reproducción temporal de los mismos, siempre que se cumplan los requisitos enumerados dicho precepto ${ }^{199}$.

Ahora bien, no puede perderse de vista que las condiciones que deben cumplir los prestadores de servicios son muy estrictas, por lo que la excepción recogida en el art. 5.1.a) de la DDASI está condicionada al cumplimiento de los estrictos requisitos contemplados en la Directiva 2000/31/CE y, en el ámbito español, a lo dispuesto en el mencionado art. 15 de la $\operatorname{LSSI}^{200}$.

Por otra parte, relacionada con la actividad de caching hay que distinguir igualmente el proceso de mirroring, consistente en "la reproducción completa de un sitio web" 201 y la llamada práctica de archivo, consistente en "la reproducción total o parcial de un sitio web para archivarlo"202. Ambas prácticas constituyen reproducciones en el sentido del art. 18 del TRLPI, siendo imposible que quepan en la excepción del

\footnotetext{
${ }^{198}$ LÓPEZ MAZA, S., Límites al derecho de reproducción..., op. cit., pp. 165-166; CARBAJO CASCÓN, F., "Delimitación de la responsabilidad de los servicios...", op. cit., p. 270.

199 Así lo recoge expresamente la SAP Barcelona (Sección 15ª), de 17 de septiembre de 2008 [AC\2008\1773], F.J. $3^{\circ}$.

${ }^{200}$ CARbajo CASCÓN, F., "Delimitación de la responsabilidad de los servicios...”, op. cit., pp. 116-117.

${ }^{201}$ LÓPEZ MAZA, S., Límites al derecho de reproducción..., op. cit., p. 142; CARBAJO CASCÓN, F., Publicaciones electrónicas..., op. cit., p. 110.

${ }^{202}$ LÓPEZ MAZA, S., Límites al derecho de reproducción ..., op. cit., p. 142.
} 
art. 5.1 de la DDASI y del art. 31.1 del TRLPI. En el primer caso, porque el mirroring tiene significación económica por sí mismo ${ }^{203}$ y puede llegar a influir negativamente en los ingresos potenciales en publicidad y visitas al titular legítimo de la obra o prestación reproducida ${ }^{204}$, razón suficiente para que no pueda operar la excepción. En el segundo caso, porque mediante la técnica de archivo se realizan copias totales o parciales de un sitio web con el fin de almacenarlas y, por tanto, no puede hablarse de reproducciones en sentido provisional o temporal, con lo cual requerirán en todo caso de la autorización del autor. Así, sólo en la medida en que puedan quedar amparadas en la excepción de copia privada, podrá exonerarse de responsabilidad quien realiza la reproducción.

Finalmente, cabe mencionar que en la navegación en la Red es común -o mejor, pudiera decirse que es consustancial al funcionamiento de Internet actualmente- el uso de enlaces o links (también llamados hiperenlaces, hiperlinks o hipertextos) que conectan una página web con otra página web o contenido localizado en Internet, de tal forma que es posible que se creen copias en memoria $R A M$, lo cual hace que esta actividad de linking genere interrogantes sobre en qué medida se afecta el derecho de reproducción y en qué medida se requiere, por tanto, autorización del titular de derechos.

Técnicamente, lo que hace un enlace es designar un "comando escrito en un determinado código informático, normalmente HTML, que proporciona al navegador del usuario la instrucción de dirigirse hacia un determinado lugar de la red, donde se localiza el objeto al que el enlace se refiere" ${ }^{205}$. Ahora bien, todos los enlaces no son de igual tipo, ni provocan idénticas consecuencias. Como resultado, no todos afectarán al derecho de reproducción. En este sentido, la actividad de los enlaces voluntarios, simples o directos (los que a su vez pueden clasificarse en enlaces de superficie y

\footnotetext{
203 Ídem.

${ }^{204}$ CAStelló PAStor, J. J., Motores de búsqueda..., op. cit., p. 140.

205 SÁNCHEZ ARISTI, R., "Enlazadores y seudoenlazadores en Internet: del rol de intermediarios hacia el de proveedores de contenidos que explotan obras y prestaciones intelectuales", Revista Doctrinal Aranzadi Civil-Mercantil, núm. 5, 2012 [BIB 2012\1269], p. 1 (versión en línea). Disponible en: http://aranzadi.aranzadidigital.es/maf/app/document?docguid=I68cb5dd0d21511e18fb1010000000000\&s rguid=i0ad6adc500000159f429b4f47bb68585\&src=withinResuts\&spos=1\&epos=1\&displayid=\&publica cion $=\&$ clasificationMagazines $=\&$ fechacomun $=\&$ numeropub-tiponum $=($ consultado: 31.01 .2017$)$.
} 
enlaces de profundidad ${ }^{206}$ ) no afecta al derecho de reproducción, ya que el mero hecho de crear un enlace no genera una copia de la página original enlazada ni permite comunicar el contenido de ésta al público, siendo, en todo caso, necesario activar el enlace para que se pueda visualizar la página, y sólo en este momento se producirá la reproducción ${ }^{207}$. Sucede lo mismo en el caso de los enlaces involuntarios (subdivididos en enlaces ensamblados y enlaces "nueva ventana"208) debido a que tampoco en estos casos se produce una reproducción, al no crearse ninguna copia en el ordenador de la persona que crea el enlace ensamblado ${ }^{209}$.

Tampoco constituye un acto de reproducción la técnica del enmarcado (framing) $)^{210}$-técnica relacionada con los enlaces- que "consiste en fragmentar o dividir la página web en, al menos, dos marcos o ventanas, incluyendo en una de ellas todos los elementos distintivos de la propia web (como sería el logotipo, la marca o publicidad, entre otros), mientras que en la otra consta la información o contenidos de la propia web o bien de una ajena" ${ }^{211}$. El enmarcado no comprende un acto de reproducción debido a

\footnotetext{
${ }^{206}$ Los enlaces o links permiten a los usuarios de una página web el acceso fácil y rápido a otra página web o contenido localizado en cualquier lugar del ciberespacio. Los enlaces voluntarios, directos o simples (también conocidos como Hypertext Reference Link, HREF, por sus siglas en inglés) son aquellos que se activan voluntariamente por el usuario y son de dos tipos: de superficie, que son los que al activarse dirigen al usuario de una página web a la página de inicio (home page) de la otra página web; y los de profundidad, que son los que al activarse remiten al usuario al interior de otra página web, de modo que la página de inicio no es vista por el usuario. CASTElló PASTOR, J. J., Motores de búsqueda..., op. cit., pp. 70 y $72-73$.

${ }^{207}$ Ibídem, 119.

${ }^{208}$ Los enlaces involuntarios son aquellos que se activan por el propio navegador, sin que intervenga la actividad el usuario. Estos se clasifican en enlaces ensamblados (inlinking o embedded links), que permiten integrar en el contenido de una web contenidos de otra, sin que el usuario sea consciente de la existencia de este enlace; y los enlaces "nueva ventana", que hacen que cuando el usuario visita una página $w e b$, el navegador abra una nueva ventana que enlaza a una web distinta permaneciendo el usuario en la web que quería visitar. Ibídem, pp. 73 y 74.

${ }^{209}$ Ibídem, p. 121. En el mismo sentido, GARROTE FERnánDEZ-DíEZ, I., El Derecho de Autor ..., op. cit., p. 372, quien señala: "El problema no se plantea en términos de derecho de reproducción ya que, debido al proceso técnico que se utiliza, no se realiza ninguna copia $R A M$ en el ordenador de la persona que crea el enlace ensamblado. No obstante, tal como señala CASTELló PASTOR, J. J., Motores de búsqueda..., op. cit., p. 121, hay voces que defienden que el derecho de reproducción se ve implicado en estos casos, citando a ORTEGa Díaz, J. F., "Sitio web y enlaces en Internet. Una reflexión desde el ámbito de la propiedad intelectual", $R C E$, núm. 35, 2003, p. 76.

${ }^{210}$ CASTElló Pastor, J. J., Motores de búsqueda ..., op. cit., p. 122.

${ }^{211}$ Ibídem, p. 74; GARRote FernáNDEZ-DíEZ, I., El Derecho de Autor ..., op. cit., p. 375; ORTEGa Díaz, J. F., Los enlaces en Internet. Propiedad intelectual e industrial y responsabilidad de los prestadores, Aranzadi, Cizur Menor, Navarra, 2006, p. 132.
} 
que en el proceso técnico utilizado no existe reproducción en el ordenador del proveedor del servicio de enmarcado ${ }^{212}$.

Sin embargo, la técnica conocida como thumbnails o imágenes en versión reducida -también asociada a los enlaces- sí constituye un acto de reproducción, por cuanto supone una reproducción de las imágenes en versión miniatura en el servidor del usuario, mientras que la imagen original queda almacenada en ordenadores de terceros. Una vez que estas thumbnails se activan, el navegador web podrá localizar la versión original de la imagen almacenada y descargará la imagen original en la parte inferior de la ventana ${ }^{213}$. Estas imágenes reducidas no tienen amparo ni en el límite previsto para las reproducciones provisionales, porque no lo son, ni siquiera en otras excepciones de las que recoge el TRLPI en sus arts. 31 y siguientes. No obstante, la jurisprudencia ha buscado el modo de acomodar esta actividad dentro del límite de cita del art. 32 del TRLPI, e incluso, "creando en apariencia nuevos límites con la finalidad de garantizar la libertad de navegación y de comunicación de los usuarios" ${ }^{\text {214. }}$.

De modo similar sucede con la técnica conocida como snippets, consistente en un fragmento del texto de un sitio web que se muestra - a modo de resumen- en la página de resultados al realizar una búsqueda en Internet ${ }^{215}$. También esta técnica implica una reproducción en el sentido del art. 18 del TRLPI, pues parte del contenido de la obra es copiada y mostrada en la página de resultados ${ }^{216}$, que no tiene acomodo en el límite del art. 31.1 del TRLPI, debido a que no se trata de una reproducción provisional. Por el contrario, en principio podrá encontrar acomodo en el límite de la cita ${ }^{217}$.

Por último, no es posible dejar de mencionar la existencia de los enlaces conocidos como $\mathrm{P} 2 \mathrm{P}$ (peer to peer), que redirigen al usuario a una red $\mathrm{P} 2 \mathrm{P}$ que permite el intercambio de archivos entre usuarios mediante el establecimiento de conexiones

\footnotetext{
${ }^{212}$ GARRote FernándeZ-DíEZ, I., El Derecho de Autor..., op. cit., p. 375.

213 Castelló Pastor, J. J., Motores de búsqueda..., op. cit., p. 75.

${ }^{214}$ Ibídem, p. 141.

215 Para un estudio más detallado sobre los snippets, Vid. CASTElló PASTOR, J. J., "Los snippets (o fragmentos de texto) en la Reforma de la Ley de Propiedad Intelectual: ¿por qué tu sí y yo (Thumbnails) no?", Revista Doctrinal Aranzadi Civil-Mercantil (Parte Estudio), núm. 6, 2015, pp. 57 y ss.

${ }^{216}$ Castelló Pastor, J. J., Motores de búsqueda..., op. cit., pp. 76 y 122.

${ }^{217}$ Ibídem, p. 141.
} 
entre sus ordenadores. Sin embargo, lo relevante a efectos de una posible vulneración del derecho de reproducción no es el enlace en sí. En efecto, la posible descarga al ordenador del usuario no se produce desde el servidor del enlazador, sino desde el servidor donde se encuentra alojado el contenido enlazado y el derecho afectado sería el de comunicación pública en su modalidad de puesta a disposición ${ }^{218}$. Lo relevante es, pues, que mediante el uso de las redes $\mathrm{P} 2 \mathrm{P}$, los archivos (que pueden contener obras y prestaciones protegidas por los derechos de propiedad intelectual) se almacenan en los ordenadores de los usuarios, lo cual constituye un acto de reproducción que requiere, en todo caso, de la autorización del titular de derechos. Ahora bien, por las particulares implicaciones de este fenómeno sobre la explotación de los derechos de propiedad intelectual y su pretendida justificación al amparo del límite de copia privada, su estudio se realizará posteriormente, dentro del análisis de la copia privada como límite al derecho de propiedad intelectual.

${ }^{218}$ Vid. SÁNCHEZ ARISTI, R., “Enlazadores y seudoenlazadores...”, op. cit., p. 23. 



\title{
CAPÍTULO II: LOS LÍMITES A LOS DERECHOS DE PROPIEDAD INTELECTUAL: UNA VISIÓN GENERAL
}

\author{
SUMARIO: I. INTRODUCCIÓN. II. LOS LÍMITES A LOS DERECHOS DE
}

PROPIEDAD INTELECTUAL. 1. Apunte terminológico. 2. Los grupos de intereses en la regulación de la Propiedad Intelectual: la búsqueda de un punto de equilibrio. 3. El fundamento de las excepciones o limitaciones a los derechos de propiedad intelectual. 4. El régimen legal de las excepciones o limitaciones a los derechos de propiedad intelectual. 4.1. Marco legal: análisis en tres niveles. 4.1.1. El régimen legal de las excepciones en el Derecho internacional. 4.1.2. El régimen legal de las excepciones en la Unión Europea. 4.1.3. El régimen legal de las excepciones en el Derecho español. 4.2. Derecho continental versus copyright: panorámica general. 4.2.1. La doctrina del fair use. 4.2.1.1. Sus orígenes: una visión general. 4.2.1.2. Los factores de la doctrina del fair use. A) La finalidad y el carácter del uso. B) La naturaleza de la obra protegida. C) La cantidad y sustancialidad de la parte utilizada en relación con la obra en su conjunto. D) El efecto de la utilización de la obra en el mercado potencial o en el valor de la obra protegida. 4.3. La prueba de los tres pasos. 4.3.1. La decisión del Grupo Especial de la OMC en relación con el art. 13 del Acuerdo sobre los ADPIC en la interpretación de la prueba de los tres pasos. 4.3.1.1. Generalidades. 4.3.1.2. La interpretación de los pasos. 4.3.2. La prueba de los tres pasos y el fair use. 4.3.3. La prueba de los tres pasos en la DDASI y en el ordenamiento jurídico español. III. LA NECESIDAD DE REAJUSTAR EL SISTEMA DE LÍMITES A LOS DERECHOS DE PROPIEDAD INTELECTUAL EN LA UE. 1. Hacia una aplicación menos restrictiva de los límites a los derechos de propiedad intelectual. 2. Por un modelo renovado y más armonizado del sistema de límites a los derechos de propiedad intelectual. 



\section{INTRODUCCIÓN}

Al tratar los derechos de explotación, en general, y el derecho de reproducción, en particular, se ha venido advirtiendo de la existencia de limitaciones a los derechos de propiedad intelectual de contenido patrimonial. En efecto, estos no son derechos absolutos en la medida en que, precisamente, recaen sobre los mismos ciertos límites, teniendo en cuenta que en la regulación de la propiedad intelectual no sólo se involucran los intereses de los titulares de derechos, sino que cobran relevancia, también, otros intereses colectivos y sociales. Así, la protección equilibrada de ambos intereses se sustenta, en primer término, en la relación de interdependencia que existe entre la creación intelectual y los valores culturales y el acervo de conocimientos acumulados por la sociedad, que sirven de inspiración a la propia creación. En efecto, el autor se nutre de la cultura de la sociedad en que vive y ello sirve de fundamento para limitar su poder absoluto sobre el fruto de su ingenio, a favor de la colectividad. Ya lo reconocía la Declaración Universal de Derechos $\operatorname{Humanos}^{219}$ (art. 27) y el Pacto Internacional de Derechos Económicos, Sociales y Culturales ${ }^{220}$ (art. 15.1) que, al mismo tiempo que reconoce el derecho de toda persona a la protección de los intereses morales y materiales que le correspondan por razón de las producciones científicas, literarias o artísticas de que sea autora, reconoce igualmente el derecho de toda persona a tomar parte libremente en la vida cultural de la comunidad, a gozar de las artes y a participar en el progreso científico y en los beneficios que de él resulten.

De conformidad con lo anterior, las legislaciones que regulan los derechos de autor y conexos, al mismo tiempo que conceden a sus titulares un derecho exclusivo de explotación sobre su obra, establecen sistemas de excepciones o limitaciones a las facultades patrimoniales que integran dicho derecho. De este modo, se restringe el poder absoluto del autor -y demás titulares de derechos- sobre la creación. En consecuencia,

\footnotetext{
${ }^{219}$ Proclamada por la Asamblea General de las Naciones Unidas en París, en su Resolución 217 A (III), el 10 de diciembre de 1948.

${ }^{220}$ Adoptado y abierto a la firma, ratificación y adhesión por la Asamblea General de las Naciones Unidas, en su resolución 2200 A (XXI), de 16 de diciembre de 1966. Entrada en vigor: 3 de enero de 1976, de conformidad con el art. 27.
} 
el establecimiento de excepciones o limitaciones constituye un pilar fundamental para equilibrar los intereses entre los derechos exclusivos de los titulares sobre sus obras y prestaciones y los intereses de la sociedad para acceder a éstas.

En concreto, existen determinadas limitaciones al derecho de reproducción, unas veces impuestas exclusivamente al ejercicio de este derecho-como, por ejemplo, cuando se permite a la entidad radiodifusora registrar la obra por sus propios medios y para sus propias emisiones inalámbricas, al objeto de realizar, por una sola vez, la comunicación pública autorizada (art. 36.3 del TRLPI) o en el caso del límite de copia privada (art. 31.2 del TRLPI)-; otras veces compartidas con otras facultades exclusivas -como en el caso del límite previsto por cuestiones de seguridad pública o para el correcto desarrollo de procedimientos administrativos, judiciales o parlamentarios (art. 31 bis. 1 del TRLPI), el límite en beneficio de personas con discapacidad (art. 31 bis. 2 del TRLPI) o el límite establecido en relación con los trabajos sobre temas de actualidad (art. 33 del TRLPI), entre otros-.

En cualquier caso, para resguardar el equilibrio necesario en la regulación de los derechos de autor y conexos es fundamental comprender la importancia que juegan las excepciones o limitaciones a los derechos de propiedad intelectual, así como las condiciones que se tienen en cuenta para su establecimiento, en concreto, las delimitadas mediante la regla de los tres pasos contenida en el art. 9.2 del CB, que exige que las limitaciones establecidas legalmente no vayan en contra de la explotación normal de la obra, ni causen un perjuicio injustificado a los intereses legítimos del autor. De igual forma, debe quedar claro que las normas de propiedad intelectual -como el resto de las normas- tienen que adaptarse a la realidad que regulan, lo que implica reajustarlas, a veces flexibilizándolas, para enfrentar los cambios que acaecen en la sociedad y que, sobre todo, se han venido produciendo en las últimas décadas, debidos a las revolucionarias transformaciones en el área de las tecnologías digitales e Internet.

Sin pretender realizar un análisis exhaustivo de las limitaciones o excepciones, sí que resulta necesario poner de relieve algunas cuestiones generales, pues la copia privada sobre la que recae la compensación equitativa objeto de estudio es, precisamente, una limitación a los derechos de propiedad intelectual. De ahí que las reglas generales que operan en cuanto al resto de los límites funcionen también respecto 
a la copia privada, que ha de responder de igual forma al necesario equilibrio de intereses que se logra a través del binomio derechos exclusivos - límites a estos derechos y que, en su caso, es necesario flexibilizar y ajustar según cambien las circunstancias sociales que han dado lugar a su reconocimiento como tal.

\section{LOS LÍMITES A LOS DERECHOS DE PROPIEDAD INTELECTUAL}

\section{Apunte terminológico}

La alusión a los términos "excepciones o limitaciones" e, incluso, la apelación al término "límites" de forma genérica, tal y como resulta en el TRLPI, suelen utilizarse indistintamente.

No obstante, en la doctrina internacional, el término "excepciones" suele ser empleado para referirse a los supuestos en los que el titular de derechos queda totalmente desposeído del contenido de sus facultades patrimoniales, pues no tiene la posibilidad de autorizar o prohibir la utilización de su obra o prestación intelectual, ni percibe ninguna remuneración. Por su parte, con el término "limitaciones", se alude a aquellos casos en que no se puede ejercitar el ius prohibendi, pero se puede reclamar, en cambio, una remuneración como contrapartida del uso ${ }^{221}$. Siguiendo esta línea, las excepciones a los derechos patrimoniales de propiedad intelectual serían aquellas que comportan un uso libre y gratuito de la obra o prestación (licencias puras y simples) entre las que se encuentran, por ejemplo, la cita y la parodia. Por su parte, el término limitaciones quedaría reservado para los casos en que el uso es libre, pero está sujeto al pago de una remuneración, que coincide con lo que en la doctrina se conoce como licencias no voluntarias, y que, a su vez, se clasifican en licencias legales y obligatorias $^{222}$. La licencia legal es aquella en que la utilización es libre y la cuantía de

${ }^{221}$ Sobre la diferencia terminológica Vid. GARRote FERnÁNDEZ-DíEZ, I., “Artículo 9”, en BERCOVITZ Rodríguez-CANo, R. (Coord.), Comentarios al Convenio de Berna..., op. cit., pp. 748-750. En sentido similar Vid. GonzÁlez de AlaizA CARdonA, J. J., La copia privada. Sus fondamentos..., op. cit., pp. 103-104; Dusollier, S., Droit d'auteur..., op. cit., pp. 426-427.

${ }^{222}$ LIPSZYC, D., Derecho de Autor y Derechos Conexos, Félix Varela, Vol. 1, La Habana, 1998, p. 220. 
la remuneración es fijada por la ley, mientras que la licencia obligatoria, si bien comporta también una utilización libre, no excluye el poder de negociación del titular de derechos, que puede convenir las condiciones económicas de la utilización, generalmente, a través de las entidades de gestión colectiva de la categoría de derechos de que se trate (ej. visuales, musicales, reprográficos, etc.); pero, en caso de que las partes no alcancen un acuerdo, el monto de la remuneración será fijado por la autoridad competente (judicial o administrativa) ${ }^{223}$.

En otras ocasiones, el vocablo "excepciones" suele utilizarse en situaciones en las que es la ley la que restringe el derecho exclusivo del autor. Contrario sensu el término "limitaciones" (o "límites") se refiere a circunstancias en las cuales el autor -o derechohabiente- no ostenta derecho alguno porque no se dan los requisitos que le garantizan una protección legal, como puede suceder cuando la obra carece de originalidad o cuando ha expirado el plazo de protección ${ }^{224}$.

No obstante, en esta investigación los términos "limitaciones", "límites" y “excepciones” serán utilizados indistintamente, es decir, para hacer alusión a los supuestos que restringen legalmente la posibilidad de que el titular de derechos autorice o prohíba el ejercicio de sus facultades patrimoniales. Esta posición resulta más bien pragmática, al tiempo que toma en cuenta la posible indiferencia que parece alcanzar la cuestión en los textos legales supranacionales ${ }^{225}$.

\footnotetext{
${ }^{223}$ Ídem. Véase también OMPI, "Glosario de términos y expresiones sobre Derecho de Autor y Derechos Conexos", Guía sobre los Tratados de Derecho de Autor y Derechos Conexos administrados por la OMPI, Ginebra, 2003, Voz "Excepciones y limitaciones", p. 293, disponible en: http://www.wipo.int/edocs/pubdocs/es/copyright/891/wipo_pub_891.pdf (consultado: 20.12.2016).

${ }^{224}$ Garrote FernándeZ-DíEZ, I., "Artículo 9", en BerCovitZ RodrígueZ-CANo, R. (Coord.), Comentarios al Convenio de Berna..., op. cit., p. 750.

${ }^{225}$ En la DDASI, por ejemplo, se aprecia en sus Considerandos la alusión a "excepción o limitación" aun cuando se trata de supuestos de excepciones puras y simples (Considerandos $40^{\circ}, 41^{\circ}, 42^{\circ}$ ) como de limitaciones al derecho de autor a cambio de una compensación (Considerandos $38^{\circ}, 39^{\circ}, 52^{\circ}$ ). En el Acuerdo sobre los ADPIC, el Grupo Especial atribuye el mismo alcance a las nociones de "excepciones" y "limitaciones", en el sentido de que una "excepción" se refiere a una supresión del derecho exclusivo previsto en la legislación nacional, mientras que una "limitación" se refiere a cierto grado de reducción de ese derecho, Vid. OMC, Informe del Grupo Especial de la OMC, Estados Unidos - Artículo 110(5) de la Ley de Derecho de Autor de los Estados Unidos, de 15 junio de 2000 [2000 WT/DS160/R], p. 37.
} 


\section{Los grupos de intereses en la regulación de la Propiedad Intelectual: la búsqueda de un punto de equilibrio}

Sea cual sea el sistema desde el que se instituyan y protejan los derechos de propiedad intelectual, esto es, sea desde la perspectiva del Derecho continental o desde la del Derecho anglosajón, es apreciable la presencia de diversos intereses implicados.

Históricamente, para los países de tradición continental o civilista, el derecho de autor ha sido una construcción jurídica que ha puesto en su centro al autor, fundamentalmente a partir del siglo XX bajo el amparo de la "personalidad" unido a la protección de los derechos morales. Desde esta perspectiva, la propiedad literaria y artística ha mostrado un fuerte componente moral debido al estrecho vínculo existente entre la obra y el autor. Por su parte, la tradición anglosajona ha buscado equilibrar los intereses del autor con los de la sociedad en general. Ésta, con su postura utilitarista y de acentuación de los derechos patrimoniales, ha buscado instituir condiciones favorables para la producción de las obras y para la prohibición de aquellas conductas que puedan entorpecer el acceso del público a la creación.

Además, tanto en unos países como en otros, la presencia creciente y el papel ganado por los intermediarios económicos en la fabricación, financiación, gestión y explotación de las obras ha permitido la concesión de derechos a favor de los artistas intérpretes y ejecutantes, editores, productores de fonogramas y videogramas, y organismos de radiodifusión (es decir, para los titulares de derechos afines, conexos o vecinos).

Se conforman así tres grandes grupos de intereses, hoy comunes a una y otra tradición jurídica: los intereses de los autores, los de los intermediarios y los de los usuarios $^{226}$, los cuales alcanzan matices diferentes según se trate de uno u otro sistema de Derecho.

Como no puede ser de otro modo, el progreso técnico ha conllevado la diversificación de las partes interesadas en la creación, la aparición de intereses

${ }^{226}$ STROWEL, A., Droit d auteur..., op. cit., p. 271. 
colectivos y la evolución de la noción de "público". Por un lado, los avances tecnológicos han dado lugar a la desmitificación del autor como "genio" y como creador individual e independiente, cobrando relevancia el trabajo en equipo y bajo contrato, con la consecuencia añadida no sólo de la presencia de intereses colectivos sino también de una defensa colectiva de intereses a través de las sociedades de gestión ${ }^{227}$. Por otro, del lado de los intermediarios, proliferan las grandes industrias culturales que imponen de forma exorbitante los modelos de producción y consumo de los productos culturales, involucrando también intereses plurales ${ }^{228}$. En adición, el público es visto cada vez más como un consumidor, dadas las facilidades no sólo para acceder a las obras sino también a los medios de reproducción de éstas ${ }^{229}$.

Especialmente, en el curso de los últimos años ha emergido una reivindicación de los intereses del público por un acceso libre, amplio y poco costoso a la creación: la reivindicación de un "derecho de utilización"; ya no como interés garantizado por la estructura misma del derecho de autor, sino como un derecho propio, oponible frente a éste ${ }^{230}$. Las amplias posibilidades de acceso y reproducción de los contenidos protegidos por los derechos de autor y las facilidades de intercambio de estos en el entorno digital han enfrentado los intereses de autores e intermediarios a los del público que, en su deseo de consumo cultural, ve a la propiedad intelectual como obstáculo al acceso y a la circulación de las obras. La presencia de Internet consolida la idea de acceso ilimitado y gratuito a la información y, consecuentemente, los miembros del público exigen accesibilidad a las obras y libertad de utilización de estas.

Asimismo, otros actores aparecen en el ámbito de la propiedad intelectual a la luz de los debates asociados al desarrollo de la industria de equipos informáticos y electrónicos y la pertinencia del establecimiento de medidas tecnológicas de

\footnotetext{
${ }^{227}$ Ibídem, p. 279.

228 Ídem.

${ }^{229}$ Ibídem, pp. 281-282.

${ }^{230}$ Vid. DUSOLLIER, S. Droit d'auteur..., op. cit., pp. 292-293.
} 
protección $^{231}$. Se involucran así los intereses de quienes desarrollan estas medidas tecnológicas, a quienes les interesa la utilización de éstas por las industrias culturales a las que sirven como medio para restringir el acceso a la obra o su copiado ${ }^{232}$.

Dicho todo lo anterior, puede afirmarse que son diversos y variados los grupos de intereses inmersos en la propiedad intelectual, con lo cual, la búsqueda del equilibrio comentado se hace más compleja. Así pues, es difícil establecer un punto exacto de equilibrio, más aún cuando la evolución de esta disciplina jurídica, a la par del desarrollo tecnológico, obliga a realizar ajustes sistemáticos inevitables. El equilibrio de intereses se vuelve así -en palabras de DUSOLLIER - una "geometría variable"233 que se proyecta de modo diverso según las diferentes tradiciones jurídicas. La balanza del Derecho continental exige que el mayor peso sea puesto del lado del autor, sin que el interés público se desvanezca detrás del mismo; en tanto la balanza del common law se acomoda en el lado de los intereses de los usuarios, dando un carácter marcadamente utilitarista a la creación intelectual.

\section{El fundamento de las excepciones o limitaciones a los derechos de propiedad intelectual}

Aun cuando son diversas las razones que justifican el establecimiento de excepciones a los derechos de autor y conexos, todas ellas se dirigen al logro del equilibrio de intereses anteriormente señalado. Al respecto, abundan en la doctrina autores que se han preocupado por estudiar la justificación de estas excepciones ${ }^{234}$, que

\footnotetext{
231 "Las medidas tecnológicas son dispositivos informáticos que permiten a los derechohabientes controlar el acceso a las obras y/o su ulterior reproducción”. BERCOVITZ RODRÍGUEZ-CANO, R. (Coord.) et al., Manual de Propiedad Intelectual..., op. cit, p. 329.

${ }^{232}$ Ibídem, pp. 303-305.

${ }^{233}$ Dusollier, S., Droit d'auteur..., op. cit., p. 296.

${ }^{234}$ En la doctrina extranjera destacan, entre otros, Hugenholtz, P. B., "Fierce creatures. Copyright exemptions: Towards extinction?", en Rights, Limitations and Exceptions: Striking a Propert Balance, Amsterdam, 1997, pp. 10-12, disponible en: http://www.ivir.nl/publicaties/download/1082 (consultado: 21.12.2015); GuIBAULT, L., "Discussion paper on the question of Exceptions to and limitations on copyright and neighbouring rights in the digital era", Steering Committee on the Mass Media [MM-SPR(98)7], Estrasburgo, disponible en: http://www.ivir.nl/publicaties/download/336 (consultado: 21.12.2015), pp. 16 y ss.; SIRINELLI, P., Taller sobre cuestiones de aplicación del Tratado de la OMPI
} 
se sistematizan, normalmente, en razón de los diferentes intereses legítimos implicados: la protección de los derechos fundamentales e intereses públicos, los fallos del mercado o la ausencia de un perjuicio económico relevante.

En concreto, HugenHOLTZ, clasifica las limitaciones distinguiendo tres grupos diferentes de razones, de conformidad con intereses o circunstancias protegidos por el ordenamiento jurídico: el primero de ellos basado en la defensa de las libertades fundamentales; el segundo, en el interés público; y el tercero, en los fallos del mercado $^{235}$.

Respecto al primer grupo -el respeto a las libertades fundamentales- no es de extrañar que los derechos de propiedad intelectual se vean limitados en favor de derechos como la libertad de expresión, el derecho a la información y el derecho a la intimidad, todos ellos esenciales para el ejercicio de las libertades democráticas, el progreso social y el desarrollo del individuo. La libre expresión, la crítica, la educación, la transmisión del saber, entre otras razones, justifican el establecimiento de límites al derecho de autor, pues, de hecho, las excepciones no son una simple tolerancia del autor, sino un elemento esencial del sistema ${ }^{236}$.

Consecuentemente, el legislador ha establecido ciertas limitaciones tomando como base la importancia de estas libertades fundamentales, en función de las cuales se autorizan, por ejemplo, las citas y las reseñas de prensa (art. 32 del TRLPI), los trabajos sobre temas de actualidad (art. 33 del TRLPI) y la parodia (art. 39 del TRLPI) ${ }^{237}$.

sobre Derecho de Autor (WCT) y el Tratado de la OMPI sobre Interpretación o Ejecución y Fonogramas (WPPT). Excepciones y limitaciones al derecho de autor y los derechos conexos [WCT-WPPT/IMP/1], OMPI, Ginebra, 3 de diciembre de 1999. En la doctrina española, entre otros, LÓPEZ MAZA, S., Límites al derecho de reproducción..., op. cit., pp. 34 y ss.; RIBERA BLANES, B., El derecho de reproducción..., op. cit., pp. 60 y ss.

${ }^{235}$ HugenHOLTZ, P. B., "Fierce creatures...”, op cit., pp. 10-12.

${ }^{236}$ Para un análisis sobre la calificación de la excepción como tolerancia del autor Vid. DusOLLIER, S., Droit d'auteur..., op. cit, pp. 479-481.

237 Para más detalles sobre las limitaciones basadas en la defensa de los derechos fundamentales Vid. LÓPEZ MAZA, S., Límites al derecho de reproducción..., op. cit., pp. 35-39. 
Otras excepciones son motivadas, sobre todo, por la necesidad de preservar el interés público ${ }^{238}$. En esta categoría se inscriben, por ejemplo, los límites asociados a fines educativos, bibliotecas, archivos, museos y otras instituciones culturales, así como las limitaciones establecidas en beneficio de las personas con discapacidad. La idea de interés público -y no propiamente de interés del público ${ }^{239}$ - está en la base de las legislaciones de propiedad intelectual, bien se trate de los países del civil law como del common law, sin perjuicio de que en este último sistema su acentuación sea mayor. En efecto, la protección de estos intereses no sólo se evidencia bajo la concepción utilitarista del Derecho anglosajón, centrada en la instauración de condiciones favorables para la producción de obras, así como en la corrección de aquellos factores que impiden el acceso del público a las mismas. También, en la medida que el derecho de autor se instrumenta como un elemento esencial de la conservación del patrimonio cultural, el acceso a la información y a la cultura -objetivo implícito en la regulación continental- lleva sobrentendida la protección del interés general.

Siguiendo la clasificación realizada por HuGENHOLTZ, hay que referirse, finalmente, a aquellas limitaciones que encuentran su justificación en los fallos del mercado ${ }^{240}$. Los fallos del mercado se producen cuando las condiciones del mismo hacen imposible o prohibitivamente costosa la negociación entre los titulares de derechos de propiedad intelectual y los usuarios potenciales de las obras y prestaciones protegidas; también, en aquellos casos en que los titulares no pueden hacer valer sus derechos de forma efectiva en dicho mercado contra los usos no autorizados ${ }^{241}$. La ausencia de pérdidas económicas significativas o las dificultades del autor para explotar sus derechos en presencia de costos de transacción muy elevados son argumentos utilizados por parte de esta doctrina para explicar la existencia de limitaciones a los

\footnotetext{
${ }^{238}$ Hugenholtz, P. B., "Fierce creatures...”, op. cit., p. 11.

${ }^{239}$ A la distinción entre interés del público e interés público se refiere STROWEL, Droit d'auteur..., op. cit., p. 274. Destaca la contradicción existente entre uno y otro interés. El interés del público, en el sentido de consumidor, es el de poder comprar las obras al precio más bajo posible, lo cual se opone por principio al derecho de autor; el interés público, en cambio, puede requerir la instauración de un régimen de protección de las obras, en la medida en que las diversas finalidades (culturales, económicas, sociales) de interés general se cumplen por el derecho de autor.

${ }^{240}$ HugenHOLTZ, P. B., "Fierce creatures...", op. cit., p. 12.

${ }^{241}$ LÓPEZ MAZA, S., Límites al derecho de reproducción..., op. cit., p. 40.
} 
derechos de propiedad intelectual ${ }^{242}$. A su vez, la calificación legal de ciertos bienes como "bienes públicos" 243 es también expresión de los argumentos económicos que dan lugar a la presencia de determinados límites ${ }^{244}$. Estos bienes se caracterizan por la ausencia de rivalidad, que se deduce de la posibilidad de que una persona utilice un bien sin que su uso excluya la utilización por otra persona, y sin que dicho uso disminuya su valor, así como por la ausencia de exclusividad, que obedece, a que no se puede excluir fácilmente de su uso a quien no ha pagado por tener acceso al bien ${ }^{245}$.

Mencionados los anteriores fundamentos, resta por señalar que, puesto que las limitaciones a los derechos de propiedad intelectual persiguen equilibrar los grupos de intereses implicados, las razones que sirven al establecimiento de un límite no tienen por qué permanecer inmutables, toda vez que responden de forma general a este “equilibrio de intereses" que puede variar según se modifiquen los mismos, de acuerdo al nivel de desarrollo que va alcanzando la sociedad. Así, por ejemplo, la inocuidad de la copia para el titular de derechos de la obra reproducida, que justificaba inicialmente la excepción de copia privada, es actualmente insostenible, por lo que esta limitación encuentra su fundamento en otras razones, como se verá en el capítulo siguiente. Es necesario, en todo caso, que cualquier excepción supere la regla de los tres pasos establecida en el art. 9.2 del CB, aplicada con carácter mayoritario tanto en los países de tradición continental como anglosajona.

\footnotetext{
${ }^{242}$ Dusollier, S., Droit d'auteur..., op. cit., p. 467.

${ }^{243}$ La noción de bien público es relativa, pues varía en función de la evolución tecnológica. La multiplicación de las posibilidades de acceso a las obras ha provocado que bienes que tradicionalmente eran considerados como bienes privados puedan ser considerados como bienes públicos. Contrariamente, el control del acceso a las obras mediante técnicas informáticas, puede dar lugar a la exigencia de un pago por el acceso al contenido protegido, disminuyendo el carácter público del bien en cuestión. Vid. STROWEL, A., Droit d'auteur..., op. cit., pp. 204-205.

${ }^{244}$ DusOlLIER, S., Droit d'auteur..., op. cit., p. 469.

245 Ídem.
} 


\section{El régimen legal de las excepciones o limitaciones a los derechos de propiedad intelectual}

Las excepciones o limitaciones a los derechos de autor no han sido objeto de armonización en el plano internacional, más allá de la inclusión de la regla de los tres pasos que introduce el Acta de Estocolmo de 1967 del CB. Esta regla es adoptada también por la CR y seguida por otros instrumentos internacionales. En concreto, la regla de los tres pasos es también reconocida por el Acuerdo sobre los ADPIC (art. 13) y los llamados Tratados de la OMPI (art. 10.2 TDA y art. 16.2 TEIF) y, más recientemente, por el Tratado de Beijing (arts. 13 y 11, respectivamente) y el Tratado de Marrakech para facilitar el acceso a las obras publicadas a las personas ciegas, con discapacidad visual o con otras dificultades para acceder al texto impreso (art. 11). Tampoco puede hablarse de tal armonización en el ámbito regional de la UE puesto que la DDASI sólo prevé, con carácter obligatorio, el límite previsto para las reproducciones provisionales (art. 5.1) $)^{246}$, siendo facultativa la introducción o el mantenimiento del resto de las limitaciones que establece para los Estados miembros ${ }^{247}$.

Como resultado, los límites a los derechos de propiedad intelectual varían de un país a otro. Aun cuando pueda hablarse de cierta identidad entre los países insertos dentro de la tradición continental y de la anglosajona, aun así, existen diferencias entre ellos. Sin embargo, cierto es que el mayor contraste en la formulación, contenido y alcance de estos límites resulta de la existencia de sistemas cerrados y sistemas abiertos

\footnotetext{
246 Preceptúa el art. 5.1 de la DDASI: "Los actos de reproducción provisional a que se refiere el artículo 2, que sean transitorios o accesorios y formen parte integrante y esencial de un proceso tecnológico y cuya única finalidad consista en facilitar: a) una transmisión en una red entre terceras partes por un intermediario, o b) una utilización lícita de una obra o prestación protegidas, y que no tengan por sí mismos una significación económica independiente, estarán exentos del derecho de reproducción contemplado en el artículo 2".

247 No obstante, una vez que los países incorporan en sus ordenamientos jurídicos internos las limitaciones que la DDASI establece con carácter facultativo, deberán respetar el contenido que para dichas limitaciones les venga impuesto por la misma.
} 
de limitaciones, inscribiéndose en los primeros los países del droit d'auteur o sistema continental $^{248}$ y en los segundos, los del sistema angloamericano o del common law ${ }^{249}$.

Efectivamente, si de alguna uniformidad puede hablarse, ésta es, precisamente, la aplicación de la regla de los tres pasos, que sirve como instrumento a la hora de establecer limitaciones o excepciones a los derechos concedidos a los autores y demás titulares de derechos de propiedad intelectual.

\subsection{Marco legal: análisis en tres niveles}

\subsubsection{El régimen legal de las excepciones en el Derecho internacional}

No se puede hablar, propiamente, de un régimen internacional de excepciones al derecho de autor y a los derechos conexos, aun cuando existen referencias al respecto en diferentes convenios, convenciones y tratados internacionales.

Las dificultades por establecer un régimen uniforme de limitaciones a los derechos de autor y conexos se debe a la existencia de una gran diversidad legislativa entre los países, con lo cual, las fórmulas adoptadas son más bien acuerdos de minimis que permiten, al menos, un cierto grado de armonización. Si una regla general existe es la llamada regla o prueba de los tres pasos - test de las tres etapas, regla del criterio triple o triple test, como también se le conoce- que, como ya se mencionó, recoge el artículo 9.2 del $\mathrm{CB}^{250}$.

Desde su versión más antigua, este instrumento internacional regulaba límites al derecho de autor, permitiendo, por ejemplo, la reproducción de artículos de prensa y dejando al arbitrio de los Estados miembros de la Unión de Berna la decisión de incorporar el límite para la reproducción de textos en publicaciones para la educación,

\footnotetext{
${ }^{248}$ Ejemplo de estos son España, Francia, Alemania, Portugal, Italia, Bélgica y Holanda, así como los países iberoamericanos que recibieron la influencia de sus respectivas colonias europeas en sus leyes nacionales.

${ }^{249}$ Exponentes de esta tradición son Reino Unido, Estados Unidos de América, Canadá y Australia, entre otros.

${ }^{250}$ CASAS VAllÉs, R., “Artículo 40 bis”, en BerCOVITZ RodRíGueZ-CANO, R. (Coord.), Comentarios a la Ley de Propiedad..., $4^{\mathrm{a}}$ ed., op. cit., p. 808 reconoce que la prueba de los tres pasos se convierte en un elemento armonizador en sí mismo.
} 
las ciencias y la antología. Se buscaba, entonces, un criterio que garantizara que las limitaciones se establecieran con un alcance tal que no atentaran contra las facultades patrimoniales de los autores. Pero no es hasta el Acta de la Conferencia Diplomática sobre Propiedad Intelectual reunida en Estocolmo, de 14 de julio de 1967, cuando se adopta dicha regla. Su fórmula general fue incorporada al Convenio de Berna, Acta de París (1971) $)^{251}$, tras largos procesos de debate y revisión ${ }^{252}$, quedando dicha regla finalmente establecida en el art. 9.2 del CB como sigue:

"Se reserva a las legislaciones de los países de la Unión la facultad de permitir la reproducción de dichas obras en determinados casos especiales, con tal de que esa reproducción no atente contra la normal explotación de la obra ni cause un perjuicio injustificado a los intereses legítimos del autor" 253 .

Esta regla, que será objeto de un examen más detallado en un epígrafe posterior, ha sido un pilar esencial para estructurar el sistema de excepciones o limitaciones a los derechos de propiedad intelectual, pues, como se ha dicho, "ha sido una suerte de compromiso que huye tanto del establecimiento de una lista cerrada de excepciones a la que los Estados unionistas deben someterse rígidamente (el sistema propio de los países del derecho civil) como de una cláusula que autorice cualquier uso lícito u honrado de la obra como defensa o excepción frente a una reclamación indemnizatoria del autor (el sistema de los países de tradición del copyright)"254.

Por su parte, la $\mathrm{CR}$ es otro de los instrumentos internacionales que autoriza a los Estados parte a adoptar excepciones similares a las previstas en el CB para los autores, pero en este caso, referida a los derechos de los artistas intérpretes o ejecutantes, los productores de fonogramas y los organismos de radiodifusión. Este instrumento no logra -como no lo logró el CB-armonizar las limitaciones a nivel internacional, sino

251 Garrote Fernández-DíEz, I., “Artículo 9”, en Bercovitz RodríGuez-CANO, R. (Coord.), Comentarios al Convenio de Berna..., op. cit., p. 758; SouliÉ, Ch., "La protección de la obra audiovisual: El caso 'Que choisir' y la cuestión de la copia privada”, en CAMINAL BADÍA, F. de P. (Dir.), Cuadernos de Derecho Judicial, núm. 3 (Protección de la obra audiovisual), Madrid, 2007, p. 64.

${ }^{252}$ Vid. Garrote FernándeZ-DíEZ, I., "Artículo 9", en BERCOVITZ RodríGUEZ-CANO, R. (Coord.), Comentarios al Convenio de Berna..., op. cit., pp. 752-758. El autor se refiere en estas páginas a los antecedentes históricos del art. 9.2 del CB y al debate sobre el mismo en la Conferencia de Estocolmo.

${ }^{253}$ CB, Acta de París, de 24 de julio de 1971.

254 Garrote FernándeZ-DíEZ, I., “Artículo 9”, en BERCOVITZ RodríGuEZ-CANO, R. (Coord.), Comentarios al Convenio de Berna..., op. cit., p. 758. 
que más bien se encarga de establecer determinados mínimos. Al respecto, el art. 15 de la CR dispone la posibilidad de que los Estados miembros, de modo facultativo, incorporen en su legislación ciertas excepciones o limitaciones a los derechos de propiedad intelectual -como el uso privado o las grabaciones efímeras realizadas por los organismos de radiodifusión, por sus propios medios y para sus propias emisiones-, pero sin enumerar estas excepciones de modo exhaustivo.

El Acuerdo sobre los ADPIC, por otra parte, se refiere a las limitaciones y excepciones al derecho de autor en el art. 13, mediante una cláusula de excepción general aplicable a los derechos exclusivos de los titulares de los derechos de propiedad intelectual, que contiene la regla de los tres pasos del art. 9.2 del $\mathrm{CB}^{255}$. Este precepto puede examinarse en relación con los principios que recoge el Acuerdo sobre los ADPIC en su art. 8, que permite a los Estados firmantes adoptar medidas -siempre que sean compatibles con dicho instrumento- "para promover el interés público en sectores de importancia vital para su desarrollo socioeconómico y tecnológico", así como "para prevenir el abuso de los derechos de propiedad intelectual por sus titulares o el recurso a prácticas que limiten de manera injustificable el comercio", entre otros fines.

Asimismo, los denominados Tratados de la OMPI de 1996 (TODA y TOIEF) reconocen, bajo la rúbrica "limitaciones y excepciones", la posibilidad de que las partes contratantes prevean en sus legislaciones nacionales, limitaciones o excepciones impuestas a los derechos concedidos a los autores de obras literarias y artísticas estableciendo, como presupuesto, que se den las circunstancias previstas en el art. 9.2 del $\mathrm{CB}^{256}$. Por su parte, el Tratado de Beijing sobre Interpretaciones y Ejecuciones

\footnotetext{
${ }^{255}$ Para un estudio del alcance de las limitaciones y excepciones en el art. 13 del Acuerdo sobre los ADPIC vid. OMC, Informe del Grupo Especial de la OMC, Estados Unidos - Artículo 110(5) de la Ley de Derecho de Autor..., cit., pp. 29 y ss.

${ }^{256} \mathrm{El}$ art. 10.2 del TODA generaliza la regla de los tres pasos para todo tipo de obras y se refiere a la aplicación de las limitaciones al entorno digital. El art. 16.2 del TOIEF hace extensiva la regla de los tres pasos a los nuevos derechos previstos en el marco del Tratado. En las respectivas Declaraciones concertadas que acompañan tanto al TODA como al TOIEF se estipula que esas limitaciones y excepciones, establecidas en la legislación nacional, de conformidad con el Convenio de Berna, podrán hacerse extensivas al entorno digital. Los Estados contratantes podrán formular nuevas excepciones o limitaciones adecuadas al entorno digital y se permite la ampliación de las limitaciones y excepciones
} 
Audiovisuales faculta a las Partes Contratantes, en virtud de su art. 13, para que prevean en sus legislaciones nacionales, en relación con la protección de los artistas intérpretes o ejecutantes, los mismos tipos de limitaciones o excepciones que contenga su legislación nacional respecto de la protección del derecho de autor de las obras literarias y artísticas, a la misma vez que restringe al cumplimiento de las regla de los tres pasos toda limitación o excepción impuesta a los derechos de estos.

Finalmente, el Tratado de Marrakech para facilitar el acceso a las obras publicadas a las personas ciegas, con discapacidad visual o con otras dificultades para acceder al texto impreso contiene en su art. 11 una previsión general sobre las obligaciones en materia de excepciones o limitaciones, estableciendo al respecto el deber de cada Parte Contratante de cumplir con las obligaciones asumidas de conformidad con el CB, el Acuerdo sobre los ADPIC y el TODA, incluidos los acuerdos interpretativos de los mismos, de manera tal que también aquí el establecimiento de excepciones o limitaciones tendrá que pasar el filtro de la regla de los tres pasos. Puede decirse que la previsión en materia de excepciones o limitaciones a los derechos de propiedad intelectual que hace este Tratado es amplia y de formulación flexible. En efecto, llega a reconocer la posibilidad de que una Parte Contratante pueda disponer en su legislación nacional, en favor de los beneficiarios, otras limitaciones y excepciones al derecho de autor distintas de las que contempla dicho Tratado, teniendo en cuenta la situación económica y las necesidades sociales y culturales de la misma, de conformidad con sus derechos y obligaciones internacionales; y, en el caso de los países en vías de desarrollo, teniendo en cuenta sus necesidades especiales, sus derechos y obligaciones internacionales específicos y las flexibilidades derivadas de estos últimos. Todo ello sin perjuicio de cualesquiera otras limitaciones y excepciones que se contemplen en la legislación nacional en relación con las personas con discapacidad (art. 12).

existentes, o la creación de otras nuevas, siempre que se cumplan las condiciones de la regla de los tres pasos.

Para una explicación más detallada de los límites en virtud del TODA y el TOIEF: Vid. LÓPEZ MAZA, S., Límites..., op. cit., pp. 79-84. 


\subsubsection{El régimen legal de las excepciones en la Unión Europea}

La UE, desde hace ya algunas décadas, ha estado llevando a cabo un importante proceso de armonización en materia de derechos de autor ${ }^{257} \mathrm{y}$, como parte de este proceso, algunas Directivas se han referido a cuestiones asociadas a las limitaciones a estos derechos.

Ahora bien, la armonización lograda a través de estas Directivas fue inicialmente muy fragmentaria, referida a ciertas categorías de obras, como los programas de ordenador o las bases de datos. No es hasta que se dicta la DDASI, en el año 2001, cuando se aborda la regulación de la propiedad intelectual de manera transversal ${ }^{258}$, y con ello, las excepciones o limitaciones a los derechos de explotación sobre las creaciones intelectuales de forma general y no fragmentaria. De hecho, la preocupación por la armonización de los límites a los derechos de autor y conexos fue un punto de especial atención dentro de las cuestiones a abordar en la DDASI. Ello resulta lógico si se tienen en cuenta los nuevos retos que venía imponiendo el desarrollo de las tecnologías digitales, fundamentalmente en cuanto a las nuevas formas de explotación y utilización de las creaciones intelectuales y a la necesidad de alcanzar un adecuado equilibrio entre los intereses de los titulares de derechos de propiedad intelectual y los de la sociedad.

Así, la DDASI establece varias cuestiones importantes en relación con el régimen de las excepciones o limitaciones a los derechos de autor. Por un lado, el art. 5 de la

\footnotetext{
${ }^{257}$ Sirvan de ejemplos la Directiva 91/250/CEE del Consejo, de 14 de mayo de 1991, sobre la protección jurídica de programas de ordenador (D.O.C.E. núm. L 122, de 17 de mayo de 1991); la Directiva 92/100/CEE del Consejo, de 19 de noviembre de 1992 sobre derechos de alquiler y préstamo y otros derechos afines a los derechos de autor en el ámbito de la propiedad intelectual (D.O.C.E. núm. L 346, de 27 de noviembre de 1992); la Directiva 93/83/CEE del Consejo, de 27 de septiembre de 1993, sobre coordinación de determinadas disposiciones relativas a los derechos de autor y derechos afines a los derechos de autor en el ámbito de la radiodifusión vía satélite y de la distribución por cable (D.O.C.E. núm. L 248, de 6 de octubre de 1993); la Directiva 96/9/CE del Parlamento Europeo y del Consejo, de 11 de marzo de 1996, sobre la protección jurídica de las bases de datos (D.O.C.E. núm. L 077, de 27 de marzo de 1996); entre otras. Por otra parte, sobre la historia de la armonización europea en la materia vid. Hugenholtz, P.B. (Ed.), Harmonizing European Copyright Law. The Challenges of Better Lawmarking, Wolters Kluwer, Alphen aan den Rijn, 2009, pp. 2-11; y "Copyright in Europe: Twenty Years Ago, Today and What the Future Holds", Fordham Intellectual Property, Media and Entertainment Law Journal, núm. 2, Vol. 23, 2013, pp. 505-516.

${ }^{258}$ Colin, C., Droit..., op. cit., p. 111.
} 
DDASI regula el régimen general de las excepciones a los derechos de autor y a los derechos afines, conexos o vecinos, estableciendo una lista exhaustiva de límites a los mismos. Se trata de una lista cerrada que contiene un amplio catálogo de limitaciones. Sin embargo, no puede decirse que la armonización haya sido completa porque, salvo la excepción prevista en el art. 5.1 de la DDASI, relativa a los actos de reproducción provisional, el resto de las excepciones se establecen de modo facultativo para los Estados miembros ${ }^{259}$, lo que implica que estos podrán incorporarlas o no en sus legislaciones internas. Por otro lado, la DDASI contiene supuestos en los que exige que los titulares de derechos reciban una compensación equitativa asociada al establecimiento del límite ( $v$. gr. la excepción de reprografía ${ }^{260}$ y la copia privada ${ }^{261}$ ); ello sin perjuicio de la facultad de los Estados miembros de prever en sus legislaciones nacionales una compensación equitativa por otras excepciones, para las que la DDASI no establece, con carácter obligatorio, dicha compensación ${ }^{262}$.

Es importante señalar, igualmente, que la DDASI incluye en su art. 5.5 el criterio de la prueba de los tres pasos, con una formulación similar a la del $\mathrm{CB}^{263}$. Esta formulación es similar no sólo en su terminología, sino, también, en cuanto que no incluye ninguna pauta interpretativa del alcance de expresiones como "casos concretos" y "explotación normal de la obra", por ejemplo ${ }^{264}$. Además, la interpretación del precepto plantea dudas en la doctrina. En concreto, se cuestiona en qué medida la DDASI se dirige a los tribunales y no al legislador, lo cual daría la posibilidad de una reconfiguración de los límites en la solución de controversias judiciales, pues aun cuando el art. 5 de la DDASI encierre una formulación cerrada de las limitaciones, la aplicación de la regla de los tres pasos podría servir como instrumento útil, de poder ser

\footnotetext{
${ }^{259}$ Ibídem, pp. 430-431.

${ }^{260}$ Art. 5.2 a) de la DDASI.

${ }^{261}$ Art. 5.2 b) de la DDASI.

${ }^{262}$ Considerando $36^{\circ}$ de la DDASI.

263 Sobre la introducción de la prueba de los tres pasos en el Derecho de la Unión Europea vid. MaZziotti, G., EU Digital Copyright Law and the End-User, Springer, Berlín, 2008, p. 84 y 86.

${ }^{264}$ De Miguel Asensio, P. A., Derechos..., op. cit., p. 67.
} 
aplicado por el juez en la resolución de los conflictos que se le planteen, para adoptar soluciones particulares en el contexto de Internet ${ }^{265}$.

Además, debe mencionarse que el art. 6.4 de la DDASI relaciona las excepciones con las medidas tecnológicas de protección en un intento de buscar un punto de equilibrio entre los intereses de los usuarios, que legítimamente gozan de las prerrogativas concedidas por ley para el uso de las obras sin el consentimiento de los titulares de derechos, por un lado, y la aplicación de dichas medidas tecnológicas, por otro $^{266}$.

En conclusión, el régimen de excepciones previsto en la DDASI no facilita la armonización. No sólo dificulta dicha armonización el carácter facultativo con que se contemplan la gran mayoría de las limitaciones (a excepción del art. 5.1 de la DDASI como ya se mencionó), sino también la absoluta libertad que se otorga a los Estados miembros para tomar las medidas pertinentes que garanticen un equilibrio entre las medidas tecnológicas de protección y el uso legítimo de la obra en virtud de una excepción.

\subsubsection{El régimen legal de las excepciones en el Derecho español}

Las excepciones o limitaciones al derecho de autor están recogidas en el Capítulo II, Título III, Libro I, arts. 31 a 40 del TRLPI, aun cuando otras referencias a dichos límites se pueden encontrar en otros preceptos de la ley ${ }^{267}$. Ciertos actos de

\footnotetext{
265 Para ampliar al respecto vid. GARrote FERnÁndEZ-DíEZ, I., “Artículo 9”, en Bercovitz RodríGUEZCANo, R. (Coord.), Comentarios al Convenio de Berna..., op. cit., pp. 811-815; y LóPEz MAZA, S., "La posibilidad de la utilización directa por el juez de la regla de los tres pasos", en AA.VV., Estudios sobre la Ley de Propiedad Intelectual: últimas reformas y materias pendientes, Dykinson, Madrid, 2016, pp. 297-342.

${ }^{266}$ Sobre esta relación entre excepciones o limitaciones a los derechos de autor y medidas tecnológicas de protección se ahondará en el capítulo siguiente.

${ }^{267}$ Es el caso, por ejemplo, del art. 25 que se refiere a la compensación equitativa por copia privada y que, con motivo del establecimiento del régimen compensatorio, perfila los contornos de lo que constituye la copia privada: "La reproducción de obras divulgadas en forma de libros o publicaciones que a estos efectos se asimilen reglamentariamente, así como de fonogramas, videogramas o de otros soportes sonoros, visuales o audiovisuales, realizada mediante aparatos o instrumentos técnicos no tipográficos,
} 
reproducción provisional; la copia privada; la reproducción, la distribución y comunicación pública con fines de seguridad pública o para el correcto desarrollo de procedimientos administrativos, judiciales o parlamentarios; así como la reproducción, distribución y comunicación pública de obras ya divulgadas que se realicen en beneficio de personas con discapacidad; las citas y reseñas; y la ilustración con fines educativos o de investigación científica, entre otros, son algunas de las limitaciones que reconoce esta ley. En todo caso, para que dichas limitaciones operen habrán de cumplirse los requisitos específicos que en cada caso establecen los respectivos preceptos.

Junto a ellos, el art. 40.bis del TRLPI incorpora la mencionada regla de los tres pasos en el Derecho español, al trasponerse la DDASI al ordenamiento jurídico interno en virtud de la Ley 23/2006, de 7 de julio, por la que se modifica el TRLPI. No obstante, la primera aparición de esta regla en la legislación española se produjo en virtud del art. 6.3 de la Ley 16/1993, de 23 de diciembre, de incorporación al Derecho español de la Directiva 91/250/CEE, sobre la protección jurídica de programas de ordenador, pasando posteriormente a ser recogida en el art. 100.7 del TRLPI (1996) ${ }^{268}$, aunque sólo en referencia a estos programas.

\subsection{Derecho continental versus copyright: panorámica general}

Como regla general, en los países que siguen la tradición continental, para que la utilización de las creaciones intelectuales sea lícita sin el consentimiento del titular de los derechos de propiedad intelectual, ésta debe ampararse en alguna de las excepciones o limitaciones previstas expresamente en la ley. Se trata de sistemas cerrados de límites a los derechos de propiedad intelectual, es decir, sistemas numerus clausus. Si una conducta no está expresamente autorizada por el tenor literal de la norma queda dentro del ius prohibendi del autor, lo cual obliga, además, a hacer una interpretación restrictiva de los límites a su derecho. Así se deriva de los arts. 2 y 17 del TRLPI, en

exclusivamente para uso privado, no profesional ni empresarial, sin fines directa ni indirectamente comerciales, de conformidad con los apartados 2 y 3 del art. 31 [...]".

268 Garrote FERnÁndeZ-DíEZ, I., "Artículo 9", en BERCOVITZ RodrígueZ-CANo, R. (Coord.), Comentarios al Convenio de Berna..., op. cit., p. 821. 
una evidente expresión de la concepción del derecho de autor como derecho de propiedad, sin perjuicio de los matices propios que introduce el reconocimiento de facultades morales ${ }^{269}$. Es decir, se entiende que el derecho exclusivo es del autor y las limitaciones al mismo vienen a restringir su monopolio. Los usuarios de las obras y prestaciones intelectuales no tienen más que intereses y posibilidades de acceso a las mismas, pero no un legítimo derecho.

Estos sistemas cerrados presentan la ventaja de la previsibilidad ${ }^{270}$, ya que se puede conocer fácilmente cuáles son los usos autorizados. Así pues, el hecho de que las leyes contengan una lista exhaustiva de las limitaciones a los derechos exclusivos del autor tiene una gran relevancia práctica porque no habrá que esperar al criterio del juez en cada caso concreto, sino que, de antemano, se puede estimar, previsiblemente, la solución al problema.

Por otra parte, basados en un enunciado general y no en una lista exhaustiva de actos permitidos a los terceros, se presentan los sistemas abiertos de limitaciones, propios del copyright, es decir, de la tradición del common law. En su virtud, aquellos usos que cumplan con ciertas condiciones o requisitos, expresados en términos generales en la ley, no implicarán una violación de los derechos de propiedad intelectual y el titular de derechos no deberá ser compensado cuando un tercero realice una conducta que no tiene capacidad real o potencial suficiente para perjudicarle en la explotación económica de la obra ${ }^{271}$.

En estos sistemas, el análisis de la existencia de una infracción o no al derecho de autor en virtud de una limitación es casuístico. Por tanto, no existe un listado de usos exentos de la autorización del autor ${ }^{272}$, sino que, más bien, el uso lícito u honrado

\footnotetext{
${ }^{269}$ Ibídem, pp. 750-751.

${ }^{270}$ LÓPEZ MAZA, S., Límites al derecho de reproducción ..., op. cit., p. 32.

271 Garrote Fernández-DíEz, I., “Artículo 9”, en BErCovitz RodríGuez-CANo, R. (Coord.), Comentarios al Convenio de Berna..., op. cit., p. 751.

${ }^{272}$ Ello no quiere decir que, sin perjuicio de una excepción general, no puedan encontrarse en la ley ciertos usos excluidos de la autorización del autor bajo ciertas condiciones. Así, por ejemplo, en las secciones 108-112 del Título 17 del United States Code se establecen limitaciones puntuales a los derechos de propiedad intelectual para ciertas finalidades como la reproducción por bibliotecas y archivos, entre otras.
} 
funciona como defensa frente a una reclamación indemnizatoria por violación del derecho de autor ${ }^{273}$. De este modo, se consigue una mayor flexibilidad, sobre todo frente a los desafíos que impone la tecnología digital y el advenimiento de nuevos modelos de uso y explotación de las obras en el entorno on line. Se pierde, en cambio, la seguridad jurídica propia de los sistemas cerrados de límites.

Los exponentes de estos sistemas abiertos son el fair dealing anglosajón y el fair use norteamericano. La doctrina del fair dealing, de formación jurisprudencial, se consolida en Inglaterra en la Sección 2 (1) de la Copyright Act de 16 de diciembre de $1911^{274}$. En síntesis, esta doctrina viene a precisar que el derecho de autor se infringirá por cualquier persona que realice cualquier acto de los que la ley atribuye al titular de derechos, salvo en el caso de cualquier uso justo de una obra para fines de estudio privado, investigación, crítica, revisión o resumen periodístico ${ }^{275}$. De esta forma, el lenguaje utilizado, deja un amplio margen al juez para decidir si el uso que se ha hecho de la obra puede considerarse un uso lícito, aun sin el consentimiento del titular de derechos. Por su parte, el fair use se remonta a los fallos judiciales de los tribunales norteamericanos en el siglo XIX. Sin embargo, no es hasta la Copyright Act de 1976 cuando encontramos su expresión codificada. Se trata de una doctrina flexible, que permite evaluar de forma pormenorizada las circunstancias presentes en un caso específico a la hora de juzgar si se está autorizado a utilizar la creación sin el previo consentimiento del titular de los derechos.

\footnotetext{
273 Garrote Fernández-DíEz, I., “Artículo 9”, en Bercovitz RodríGuez-Cano, R. (Coord.), Comentarios al Convenio de Berna..., op. cit., p. 751.

274 Disponible en: http://www.legislation.gov.uk/ukpga/Geo5/1-2/46/contents/enacted (consultada: 07.02.2016).

275 "Copyright in a work shall be deemed to be infringed by any person who without the consent of the owner of the copyright does anything the sole right to do which is by this Act conferred on the owner of the copyright: provided that the following acts shall not constitute an infringement of copyright: (i)Any fair dealing with any work for the purposes of private study, research, criticism, review or newspaper summary”. Para un estudio más amplio sobre el fair dealing vid. SEYMOUR, A. Ch., Fair Dealing: ¿a quaint footnote to the British copyright regime?, Durham theses, Durham University, 2003, disponible en: http://etheses.dur.ac.uk/3735/ (consultada: 07.02.2017).
} 


\subsubsection{La doctrina del fair use}

\subsubsection{Sus orígenes: una visión general}

La doctrina del fair use -o uso justo o leal-constituye un pilar fundamental en la conformación del sistema de límites a los derechos de propiedad intelectual en Estados Unidos $^{276}$. De origen jurisprudencial ${ }^{277}$, esta doctrina se desarrolla mediante un amplio catálogo de decisiones judiciales, cuyos antecedentes más remotos se encuentran en los fallos de los tribunales ingleses posteriores a la promulgación del Estatuto de la Reina Ana de $1709^{278}$. Así pues, es posible encontrar diferentes resoluciones dictadas por los órganos judiciales en Inglaterra, a partir de 1740, que con "cierta cohesión y unidad de criterio" consienten la utilización de la obra de un autor por otro, sin previo consentimiento del creador de la obra primigenia, bajo la idea de que así se da por cumplido uno de los objetivos del mencionado Estatuto: "Animar a los [...] hombres instruidos a componer y escribir libros útiles" ${ }^{279}$. Estas decisiones constituyen los antecedentes de la formación del fair use en Estados Unidos ${ }^{280}$.

Desde los orígenes de la formación del copyright anglosajón, sus normas han estado especialmente dirigidas a la protección de la educación y del conocimiento como elementos del interés público. Haciéndose eco de ello, la Constitución de Estados Unidos de América de 1787 dio autoridad al Congreso para promover el progreso de la ciencia y de las artes útiles, garantizando a los autores e inventores derechos exclusivos

\footnotetext{
${ }^{276}$ El fair use es probablemente la limitación más importante que caracteriza al derecho de autor en Estados Unidos. No obstante, es importante saber que las limitaciones no quedan reducidas al fair use, sino que tales limitaciones se formulan con carácter más extenso entre la sección 107 (que desarrolla el fair use) y la sección 122 de la Copyright Act (1976).

${ }^{277}$ Vid. Report of the Register of Copyrights on the General Revision of the U.S. Copyright Law, U.S. Government Printing Office, Washington, 1961, p. 24, disponible en: https://www.copyright.gov/history/1961_registers_report.pdf (consultado: 14.02.2017).

${ }^{278}$ SAG, M., "The Prehistory of Fair Use”, Brooklyn Law Review, Vol. 76, núm. 4, 2011, p. 1373. El autor considera que la doctrina del fair use puede comprenderse mejor como continuación de la larga línea de decisiones de los casos ingleses, que data de los orígenes del Estatuto de la Reina Ana.

279 "Encourage [...] learned men to compose and write useful books". Véase también CóRDOBA MARENTES, J. F., "El fin no justifica la excepción. Propiedad Intelectual, educación y fair use estadounidense", Boletín Mexicano de Derecho Comparado, nueva serie, año XLV, núm. 134, 2012, p. 440.

${ }^{280}$ Para un análisis completo al respecto Vid. SAG, M., "The Prehistory of Fair Use”, op. cit., pp. 1379 y ss.
} 
limitados en el tiempo sobre sus escritos y descubrimientos ${ }^{281}$. Consecuentemente, es esta la perspectiva que inspira la primera ley dedicada a la protección del derecho de autor en Estados Unidos, mediante la Copyright Act de 1790, que se proclama como "An Act for the encouragement of learning, by securing the copies of maps, Charts, And books, to the authors and proprietors of such copies, during the times therein mentioned". Asimismo, sus modificaciones posteriores reflejan este propósito constitucional que requiere, necesariamente, de la ponderación de los intereses de los autores y los de la sociedad para el establecimiento de una protección ajustada a los intereses de ambos grupos.

Como puede apreciarse, la idea del monopolio temporal de derechos exclusivos a favor de autores e inventores es entendida como un medio para alcanzar dicho fin de promoción del saber y la cultura; un principio que inspirará no sólo el establecimiento de límites temporales a los derechos de autor en la ley de propiedad intelectual estadounidense, sino también la adopción de excepciones o limitaciones a estos derechos, dentro de las que destaca la doctrina del fair use. En esta línea, la importancia de este principio se hace evidente en el informe legislativo ${ }^{282}$ sobre la Copyright Act de $1909^{283}$ (una de las modificaciones más relevantes realizadas a esta ley) en el que se sostiene que la promulgación de la legislación de derechos de autor por el Congreso, bajo los términos que marca la Constitución, no se basa en un derecho natural reconocido al autor, sino en el hecho de que para la promoción del progreso de la ciencia y las artes útiles es necesario asegurar a los autores los derechos exclusivos sobre sus escritos por períodos limitados. En ese contexto, se hace notable cómo el interés público inspira el reconocimiento de derechos de propiedad intelectual, algo que también se reafirma cuando en el comentado informe se invita al Congreso a considerar -a efectos de la modificación a la Copyright Act en 1909- cuánto la legislación

\footnotetext{
${ }^{281}$ La Constitución (1787) establecía: The Congress shall have Power [...] to promote the Progress of Science and useful Arts, by securing for limited Times to Authors and Inventors the exclusive Right to their respective Writings and Discoveries" (art. 1, secc. 8), disponible en: https://www.archives.gov/espanol/constitucion.html (consultada: 16.02.2017).

${ }^{282}$ Legislative report (H. Rept. No. 2222, 60th Cong., 2d sess.) on the Copyright Act of 1909, cit. pos. Report of the Register of Copyrights..., op. cit., p. 5.

${ }^{283}$ Pub. L. 60-349, 35 Stat. 1075.
} 
beneficiará al creador y, como consecuencia, al público, así como en qué medida el monopolio concedido a aquél será perjudicial para este último ${ }^{284}$.

Pues bien, la necesidad de equilibrar los intereses implicados estará también en la base de la consolidación de la doctrina del fair use que, si bien -como se ha mencionado- deriva de las decisiones de los tribunales ingleses, se formula por primera vez en Estados Unidos en el año 1941 en el caso Folsom v. Marsh ${ }^{285}$, que incorpora los principios y reglas enunciados en las decisiones inglesas ${ }^{286}$. En aplicación de esta doctrina se admite que una parte razonable de la obra protegida por la ley de propiedad intelectual pueda reproducirse, aunque su titular no haya consentido su utilización, cuando ello sea necesario para su uso legítimo, no competitivo con el mercado de explotación de la obra por el autor ${ }^{287}$. Esta noción general del fair use -que escapa de una definición precisa-, se concreta, de algún modo en algunos ejemplos enunciados en el Report of the Register of Copyrights on the General Revision of the U.S. Copyright Law, U.S. (1961). Entre ellos, destacan la cita de extractos en una revisión o crítica con fines de ilustración o comentario; la cita de pasajes cortos en un trabajo académico o técnico, para la ilustración o aclaración de las observaciones del autor; o el uso en una parodia de parte del contenido de la obra parodiada ${ }^{288}$. Sin embargo, contrario a tal precisión, el Informe reconoce que la posibilidad de aplicar la doctrina del fair use en

\footnotetext{
284 "The enactment of copyright legislation by Congress under the terms of the Constitution is not based upon any natural right that the author has in his writings, for the Supreme Court has held that such rights as he has been purely statutory rights, but upon the ground that the welfare of the public will be served and progress of science and useful arts will be promoted by securing to authors for limited periods the exclusive rights to their writings. The Constitution does not establish copyrights, but provides that Congress shall have the power to grant such rights if it thinks best. Not primarily for the benefit of the author, but primarily for the benefit of the public, such rights are given. [...] In enacting a copyright law Congress must consider two questions: First, how much will the legislation stimulate the producer and so benefit the public, and, second, how much will the monopoly granted be detrimental to the public? The granting of such exclusive rights, under the proper terms and conditions, confers a benefit upon the public that outweighs the evils of the temporary monopoly". Report of the Register of Copyrights..., op. cit., p. 5.

${ }^{285}$ Folsom v. Marsh 9 F. Cas. 342 (C.C.D. Mass. 1841). Una ficha resumen del caso puede consultarse en línea: https://www.copyright.gov/fair-use/summaries/folsom-marsh-ccmass1841.pdf (consultada: 16.02.2017). Véase también LEval, P. N., “Toward a Fair Use Standard”, Harvard Law Review, Vol. 103, núm. 5, 1990, p. 1105.

${ }^{286}$ CóRdOBA MARENTES, J. F., “El fin no justifica la excepción...”, op. cit., p. 442.

${ }^{287}$ Report of the Register of Copyrights..., op. cit., p. 24.

288 Ídem.
} 
numerosas y variadas circunstancias hace difícil prescribir reglas precisas para todas las situaciones $^{289}$. Y en efecto, hasta hoy, una gran mayoría de los juristas desconfían de que alguna teoría general pueda justificar unitariamente el conjunto de los casos en que se ha venido invocando el fair $u s e^{290}$.

El Report of the Register of Copyrights on the General Revision of the U.S. Copyright Law fue muy importante puesto que puso de relieve que la consideración de un uso particular de la obra como legítimo -y no como una infracción de los derechos de autor- dependía de diferentes factores. De hecho, el propio Informe los enuncia, siendo los mismos que hasta hoy constituyen la base de la doctrina del fair use. En concreto, son el propósito del uso, la naturaleza de la obra protegida por derechos de autor, la cantidad y sustancialidad del material utilizado en relación con la obra protegida por derechos de autor en su conjunto y el efecto del uso en el mercado potencial del titular del copyright para su obra. De hecho, se trata de los enunciados en la sentencia del caso Folsom v. Marsh ${ }^{291}$. Es de destacar que esta sentencia refrendaba:

"In short, we must often, in deciding questions of this sort, look to the nature and objects of the selections made, the quantity and value of the materials used, and the degree in which the use may prejudice the sale, or diminish the profits, or supersede the objects, of the original work."

Finalmente, interesa señalar que el Report of the Register of Copyrights on the General Revision of the U.S. Copyright Law dio importancia a la necesidad de que la doctrina del fair use quedara recogida en la Copyright Act. Al respecto, subrayó la frecuencia con que surgía la ocasión de aplicar esta doctrina, así como su importancia creciente, con lo cual, era pertinente su mención y la indicación de su alcance general en la norma ${ }^{292}$.

\footnotetext{
${ }^{289}$ Ibídem, p. 25.

${ }^{290}$ LANDES, W. M. y PoSNER, R. A., La estructura económica del derecho de propiedad intelectual e industrial (traducción de SÁNCHEZ ÁlvareZ, V. M.), Fundación Cultural del Notariado, 2006, p. 155. 291 Cit.

292 "Nevertheless, the doctrine of fair use is such an important limitation on the rights of copyright owners, and occasions to apply that doctrine arise so frequently, that we believe the statute should mention it and indicate its general scope. It seems anomalous to have the statute specify the rights of copyright owners in absolute terms without indicating that those rights are subject to the limitation of fair use”. Report of the Register of Copyrights..., op. cit., p. 25.
} 
En consecuencia, la doctrina del fair use fue codificada en la Copyright Act de $1976^{293}$, enmarcada en la sección 107 del título 17 del United States Code. Esta sección precisa que el uso justo no constituye infracción de los derechos de propiedad intelectual, a la vez que menciona algunos ejemplos ilustrativos de los usos que pueden calificarse como tal -usos con finalidad de crítica, comentario, cobertura de noticias, docencia (incluyendo múltiples copias para uso en el aula), estudio o investigación ${ }^{294}$ - y enuncia los cuatro factores que permiten determinar si el fair use se aplica en un caso $\operatorname{particular}^{295}$.

Estos factores son, en línea con los establecidos en la sentencia del caso Folsom v. Marsh y de los mencionados en el Report of the Register of Copyrights on the General Revision of the U.S. Copyright Law, los siguientes:

1. la finalidad y el carácter del uso;

2. la naturaleza de la obra protegida;

3. la cantidad y sustancialidad de la parte utilizada en relación con la obra en su conjunto;

4. el efecto de la utilización de la obra en el mercado potencial o en el valor de la obra protegida 296 .

Años más tarde, la modificación realizada a la sección 107 del título 17 del United States Code, publicada el 24 de octubre de $1992^{297}$ añadió un párrafo final al precepto

\footnotetext{
${ }^{293}$ Pub. L. No. 94-553, 90 Stat. 2541.

${ }^{294}$ El hecho de tratarse de este tipo de usos no garantiza en sí mismo el uso justo, sino que tendrán que evaluarse los hechos de forma ponderada, de acuerdo con los factores enunciados en el propio precepto, de forma tal que se pueda determinar si el uso puede quedar amparado en el fair use.

295 "In determining whether the use made of a work in any particular case is a fair use the factors to be considered shall include: (1) the purpose and character of the use, including whether such use is of a commercial nature or is for nonprofit educational purposes; (2) the nature of the copyrighted work; (3) the amount and substantiality of the portion used in relation to the copyrighted work as a whole; and (4) the effect of the use upon the potential market for or value of the copyrighted work".

296 Vid. LANDES, W. M. y POSNER, R. A., La estructura económica ..., op. cit., p. 155.

${ }^{297}$ Pub. L. No. 102-492, 106 Stat. 3145.
} 
estableciendo que el hecho de que la obra sea inédita no impide la conclusión de un uso justo, si tal constatación se hace teniendo en cuenta todos los factores mencionados ${ }^{298}$.

En todo caso, la evaluación de la concurrencia de estos factores se hace en sede judicial. Determinar si estamos en presencia de un uso justo o leal es una labor que incumbe al juez y, en cada caso, la decisión habrá de razonarse de acuerdo a los hechos concretos enjuiciados. Por tanto, este sistema otorga a los jueces el margen de discrecionalidad necesario para adaptar ciertas limitaciones a los derechos exclusivos, caso por caso, con la obligación de respetar - a día de hoy ${ }^{299}$ - lo dispuesto en el CB respecto a la regla de los tres pasos. En definitiva, estos factores, aunque en ningún caso son definitivos o determinantes, constituyen guías de actuación que contribuyen a equilibrar los intereses implicados. Se trata, en fin, de requisitos orientativos que dejan un amplio margen a la discrecionalidad del juez ${ }^{300}$ y que, con independencia de su análisis individual, serán evaluados igualmente de forma global pues, según los casos, algunos factores pueden mostrarse más relevantes que otros $\mathrm{y}$, del mismo modo, también pueden algunos adquirir un carácter neutral en el análisis del supuesto en cuestión.

El fair use funciona, así, como una especie de privilegio legal para justificar un uso que, de otro modo, constituiría un uso infractor. Sin embargo, no estamos en presencia de un derecho sino de una excepción que tendrá que ser invocada y defendida por quien la sostiene, haciendo de esta doctrina una "affirmative defense" 301 frente a una demanda por infracción de los derechos de autor.

Finalmente, cabe agregar que aun cuando la doctrina del fair use fue contemplada en sus inicios como un límite exclusivo al derecho de reproducción, actualmente es

\footnotetext{
${ }^{298}$ Para ampliar sobre el fair use y el material inédito vid. LANDES, W. M. y PosNER, R. A., La estructura económica..., op. cit., pp. 167 y ss.

${ }^{299}$ Los Estados Unidos se adhieren al CB el 1 de marzo de 1989.

${ }^{300}$ LANDES, W. M. y PoSNer, R. A., La estructura económica ..., op. cit., p. 156.

${ }^{301}$ LIPINSKI, T. A., "Toward a Functional Understanding of Fair Use in U.S. Copyright Law", Annual Review of Information Science and Technology, Vol. 45, Sección 1, 2011, p. 533.
} 
aplicada también en relación con el resto de los derechos exclusivos contemplados en la 1 ley ${ }^{302}$.

\subsubsection{Los factores de la doctrina del fair use}

\section{A) La finalidad y el carácter del uso}

Como ha quedado expuesto, la Copyright Act estadounidense exige a los jueces evaluar la finalidad y el carácter del uso para determinar si la copia constituye fair use, atendiendo, en particular, a si el uso tiene propósitos comerciales o educativos, no lucrativos. En cuanto a los usos educativos, si bien han sido pocas las oportunidades para precisar qué ha de entenderse por tales en contrapartida a la distinción entre fines comerciales y no comerciales ${ }^{303}$, sí que es posible constatar en la jurisprudencia ejemplos que confirman que no en todo caso la finalidad educativa sirve como criterio para amparar un uso razonable, justo o leal ${ }^{304}$. En otros casos, la finalidad educativa (ponderada con el resto de los factores) ha permitido el reconocimiento del fair use ${ }^{305}$.

302 CASTelló Pastor, J. J., Motores de búsqueda..., op. cit., pp. 184-185.

${ }^{303}$ LIPINSKI, T. A., "Toward a Functional...", op. cit., p. 534.

${ }^{304}$ Por todos, Princeton Univ. Press v. Mich. Document Servs., Inc., 99 F.3d 1381 (6 ${ }^{\text {th }}$. Cir. 1996). Michigan Document Services, Inc., tienda dedicada a la reprografía, reunió diferentes materiales indicados a los estudiantes de la Universidad de Michigan para su lectura, ofreciéndolos a la venta para los estudiantes en "paquetes de cursos", violando así los derechos de los editores, titulares de los derechos sobre los materiales de lectura asignados a los estudiantes. La Corte de Apelación del Sexto Distrito de los Estados Unidos aclaró que, aunque el uso que hacían los estudiantes era un uso educativo, la demandada era una empresa que con fines lucrativos comercializaba dichos textos, careciendo de autorización para reproducir las obras de los demandantes. Resumen en línea, disponible en: https://www.copyright.gov/fair-use/summaries/princeton-michdocument-6thcir1996.pdf $\quad$ (consultado: 21.02.2017).

${ }^{305}$ Así, por ejemplo, en el caso Cambridge University Press v. Mark P. Becker No. 1:08-cv-01425-ODE (N.D. Ga. Mar. 31, 2016), amparado en el hecho de que los extractos utilizados de las obras fueron puestos a disposición de los estudiantes con fines de enseñanza en una institución educativa sin fines de lucro. Resumen en línea, disponible en: https://www.copyright.gov/fair-use/summaries/cambridgeunivbecker-11thcir2016.pdf (consultado: 21.02.2017). Otro ejemplo sería Cambridge Univ. Press v. Patton, 769 F.3d 1232 (11th Cir. 2014), asunto en el que no fue apreciado el fair use luego de analizar los cuatro factores de la doctrina, sí se reconoció que el primer factor (el propósito y el carácter del uso) era favorecedor al fair use al ser para fines educativos sin ánimo de lucro. Resumen en línea, disponible en: https://www.copyright.gov/fair-use/summaries/cambridgeuniv-patton-11thcir2014.pdf $\quad$ (consultado: 22.02.2017). 
Respecto al uso comercial, es bastante probable que la finalidad comercial del uso niegue su licitud amparada en el fair use $e^{306}$. En cambio, un análisis de la casuística judicial al respecto denota que sería erróneo ser categóricos en este sentido, pues se encuentran en la jurisprudencia norteamericana ejemplos que admiten como leales usos comerciales. Así, en Campbell v. Acuff-Rose Music, Inc. ${ }^{307}$, por ilustrar, la Corte Suprema de los Estados Unidos revocó la sentencia dictada por la Corte de Apelación, que revocaba a su vez la sentencia dictada por el Tribunal del Distrito de los Estados Unidos para el Distrito Medio de Tennessee que estimaba el fair use. La Corte Suprema entendió que el carácter comercial de la parodia no creaba una presunción contra el uso justo, afirmando, que al igual que otros usos, la parodia tenía que ser juzgada caso por caso, a la luz de los fines de la ley de derechos de autor y reconociendo la importancia que tiene para quien realiza una parodia evocar el trabajo previo para crear una nueva obra $^{308}$. La parodia suele ser, de hecho, una modalidad de crítica, muchas veces de corte humorístico o sarcástico y es precisamente esta finalidad la que hace que normalmente este tipo de obras puedan acogerse al fair $u s e^{309}$, sin que se requiera, por tanto, la autorización del autor para crear la parodia a partir de la obra parodiada.

En la misma línea, la sentencia recaída en el asunto Suntrust Bank v. Houghton Mifflin Co. ${ }^{310}$ muestra igualmente que la finalidad comercial no veda el fair use,

\footnotetext{
${ }^{306}$ En Associated Press v. Meltwater U.S. Holdings, Inc., 931 F. Supp. 2d 537 (S.D.N.Y. 2013), por ejemplo, se puede apreciar cómo el carácter comercial del uso es uno de los elementos que niegan la aplicación del fair use al caso. En efecto, se aprecia que el beneficio comercial no es una consecuencia fortuita del uso del material protegido por derechos de autor. Resumen en línea, disponible en: https://www.copyright.gov/fair-use/summaries/ap-meltwater-sdny2013.pdf (consultado 22.03.2017).

307 Campbell v. Acuff-Rose Music, Inc., 510 U.S. 569 (1994). La polémica en este caso radica en considerar uso justo la parodia realizada por el Grupo 2 Live Crew a la canción "Pretty Woman". Se trataba de una versión de rap, que conservaba la misma melodía de la canción original y se utilizaba un verso completo de la letra de aquella obra musical.

${ }^{308}$ Campbell v. Acuff-Rose Music, Inc. Resumen en línea, disponible en: https://www.copyright.gov/fairuse/summaries/campbell-acuff-1994.pdf (consultado: 21.02.2017).

${ }^{309}$ LANDES, W. M. y POSNER, R. A., La estructura económica ..., op. cit., p. 199.

${ }^{310}$ Suntrust Bank v. Houghton Mifflin Co., 268 F.3d 1257 (11th Cir. 2001). La controversia versaba sobre la presunta violación de los derechos de autor sobre la novela "Gone with the wind", de la autora Margaret Mitchell. El demandante, Suntrust Bank, fiduciario de los herederos de la autora y administrador de sus derechos de propiedad intelectual alegó que la demandada, Houghton Mifflin, titular de los derechos de autor sobre la novela "The wind done gone" había violado, con esta obra, los derechos correspondientes a los herederos de aquélla, al copiar personajes principales, rasgos y relaciones; copiar y resumir escenas famosas y copiar literalmente ciertos diálogos y descripciones de la novela.
} 
necesariamente. El tribunal fue determinante al reconocer que la novela "The wind done gone" constituía una nueva obra, diferente de la novela "Gone with the wind" de la autora Margaret Mitchell, a la cual parodiaba. La Corte encontró que, aunque la parodia claramente tenía un propósito comercial, su naturaleza significativamente transformadora superaba ese hecho y, junto con el análisis del resto de los factores, sostuvo que se trataba de un uso justo ${ }^{311}$.

Otro ejemplo lo constituye el caso Mattel Inc. v. Walking Mountain Prods ${ }^{312}$ en el que el Tribunal reconoce el uso transformativo de la muñeca Barbie realizado por el demandado en sus fotografías, siendo "la naturaleza extremadamente transformadora y la calidad paródica" de la obra resultante suficientes para restarle importancia a sus cualidades comerciales ${ }^{313}$. Cuanto más transformativa sea la nueva obra, menor importancia se les dará a otros factores (como el carácter comercial) que puedan ir en detrimento de la consideración del uso justo ${ }^{314}$.

De lo expuesto se deduce que el propósito comercial del uso puede no impedir el uso leal cuando se pueda invocar un uso transformativo (o productivo, como también se le suele llamar), que difiere del uso reproductivo (o sustitutivo) ${ }^{315}$. Es decir, será importante evaluar en qué medida el uso de la obra protegida opera como un sustitutivo

\footnotetext{
311 Suntrust Bank v. Houghton Mifflin Co. Resumen en línea, disponible en: https://www.copyright.gov/fair-use/summaries/suntrust-houghton-11thcir2001.pdf $\quad$ (consultado: 21.02.2017).

${ }^{312}$ Mattel Inc. v. Walking Mountain Prods., 353 F.3d 792 (9 ${ }^{\text {th }}$ Cir. 2003). Mattel, Inc., fabricante de juguetes, demandó a Walking Mountain Productions por las fotografías realizadas por Tom Forsythe, fotógrafo y propietario de la compañía, por infringir sus derechos sobre la muñeca Barbie al crear una serie de fotografías que representaban a una muñeca Barbie en posiciones absurdas y, en ocasiones, sexuales, normalmente junto a accesorios de cocina. El tribunal del distrito dio la razón al demandado, considerando que las fotografías constituían parodias de la muñeca Barbie, al ser un intento de criticar la visión de la mujer como objeto. La entidad demandante apeló la decisión del tribunal de distrito, que confirmó la conclusión del tribunal inferior de que el uso era un uso justo. Resumen en línea, disponible en: https://www.copyright.gov/fair-use/summaries/mattel-walkingmountain-9thcir2003.pdf (consultado: 21.02.2017).

313 Ídem. En palabras textuales: "The court based its holding on finding that defendant's use of the dolls for the purpose of parody was transformative and that 'the extremely transformative nature and parodic quality' of the defendant's work made its commercial qualities 'become less important'".

314 "The more transformative the new work, the less will be the significance of other factors such as the commercial aspect of the use that may weigh against a finding of fair use" (Campbell v. Acuff-Rose Music), cit. por LIPINSKI, T. A., "Toward a Functional...", op. cit., p. 535.

${ }^{315}$ LANDES, W. M. y PoSNer, R. A., La estructura económica ..., op. cit., p. 165.
} 
del original o, en cambio, aporta un nuevo significado o fin. Al respecto, el uso meramente reproductivo reduce los beneficios del autor por la explotación de la obra al aumentar el número de copias de ésta, a la vez que reduce los incentivos para la creación, contrariamente a lo que sucede con los usos transformativos. Por tanto, el fair use tendrá mayores posibilidades de prosperar en estos últimos casos ${ }^{316}$.

Existen en la jurisprudencia variadas sentencias que aprecian el carácter transformativo del uso y ya no sólo en el caso de la creación de obras derivadas, como la parodia -a la que antes se hacía referencia-, sino en supuestos diferentes. Los usos transformativos pueden incluir la crítica, el resumen y otros usos de índole variada ${ }^{317}$. En tal sentido puede traerse a colación el asunto resuelto por la Corte de Apelación del Noveno Circuito, asunto Kelly v. Arriba Soft Corp. ${ }^{318}$, en el que se consideró como un uso justo la reproducción por el demandado de fotografías del demandante como thumbnail o imágenes en miniatura. El tribunal apreció el uso transformador porque las imágenes en miniatura servían a una función completamente diferente a la de las imágenes originales, utilizadas no con propósitos estéticos, sino como herramienta para ayudar a indexar y mejorar el acceso a las imágenes en Internet y la consulta de los sitios web relacionados con éstas ${ }^{319}$.

Incluso el hecho de que no pueda sostenerse que el uso es transformativo, tampoco impide que el fair use pueda prosperar, pues los tribunales también han reconocido que un uso no necesita ser transformativo para ser considerado justo. Por el contrario, otros propósitos también pueden servir a tal reconocimiento. Así, en Swatch Grp. Mgmt. Servs. Ltd. v. Bloomberg L.P. ${ }^{320}$ el tribunal admitió que, aunque el demandado copió y distribuyó, sin autorización del demandante y sin modificación

\footnotetext{
316 Ídem.

${ }^{317}$ LEVAL, P. N., "Toward a fair use...”, op. cit., p. 1111.

${ }^{318}$ Kelly v. Arriba Soft Corp., 336 F.3d 811 (9 . Cir. 2003). La demandante Leslie Kelly, fotógrafo profesional, alegó que el motor de búsqueda del acusado Arriba Soft Corp. infringía sus derechos de autor sobre fotografías de su titularidad al copiar sus imágenes y mostrarlas como copias más pequeñas y de menor resolución en una página de resultados de búsqueda.

319 Kelly v. Arriba Soft Corp. Resumen en línea, disponible en: https://www.copyright.gov/fairuse/summaries/kelly-arriba-9thcir2003.pdf (consultado: 22.03.2017).

${ }^{320}$ Swatch Grp. Mgmt. Servs. Ltd. v. Bloomberg L.P., 742 F.3d 17 (2 ${ }^{\text {nd }}$. Cir. 2014).
} 
alguna una grabación de una conferencia telefónica convocada por este último con analistas financieros, el uso sirvió al importante propósito público de difundir información financiera significativa sobre una compañía que negocia sus valores en el mercado estadounidense $\mathrm{e}^{321}$.

Con todo, los anteriores fallos no son más que una ayuda en la comprensión del requisito. Por el contrario, es el análisis particular que haga el juez, en cada caso, el que determinará si el carácter y la finalidad concreta del uso en cuestión constituye o no una infracción de los derechos de propiedad intelectual. Como se ha visto, el propósito comercial o educativo, no lucrativo, es sólo un elemento en el análisis del primer factor, pues el mero hecho de que un uso sea educativo y no lucrativo no evita per se la infracción.

La conclusión a la que se llegue en el análisis de este primer factor resulta indispensable para una defensa del uso leal ${ }^{322}$, pero la fuerza de este criterio debe ponderarse en relación con los factores restantes ${ }^{323}$. No puede perderse de vista que este no es el único factor relevante, con lo cual, el resto de los factores también tendrán que ser examinados.

\section{B) La naturaleza de la obra protegida}

Este factor se centra en evaluar dos cuestiones fundamentales: la primera, el estado de la publicación de la obra protegida; y la segunda, su grado de creatividad $^{324}$, para saber si los hechos en que se funda son reales o de ficción ${ }^{325}$.

Respecto a la primera cuestión, cobra relevancia si la obra es inédita o si, por el contrario, ya ha sido publicada. En efecto, se trata de un elemento a considerar teniendo

321 Swatch Grp. Mgmt. Servs. Ltd. v. Bloomberg L.P. Resumen en línea, disponible en: https://www.copyright.gov/fair-use/summaries/swatchgrp-bloomberg-2dcir2014.pdf ） (consultado: 22.03.2017).

${ }^{322}$ LEVAL, P. N., “Toward a fair...”, op. cit., p. 1116: "Factor one is the soul of fair use”.

323 Ídem.

${ }^{324}$ LIPINSKI, T. A., “Toward a Functional...”, op. cit., pp. 537-538.

${ }^{325}$ LINK, B., "Drawing a line in alternate universes: exposing the inadequacies of the current four factor fair use test through chanslash", Thomas Jefferson Law Review, Vol. 33, núm. 139, 2010, p. 154. 
en cuenta que el autor posee, en virtud de la sección 106 (3) de la Copyright Act, el derecho a comunicar la obra al público, lo que incluye, la primera publicación o divulgación ${ }^{326}$. Sin embargo, ello no es un obstáculo para impedir la consideración de uso justo en el caso de las obras inéditas, tal y como se deriva de la modificación realizada a la Copyright Act en el año 1992 restando autoridad a la doctrina sentada por sentencias anteriores que negaban el fair use de obras no divulgadas ${ }^{327}$. En efecto, esta modificación incorporó un párrafo a la sección 107 de la Copyright Act facilitando el reconocimiento del fair use en las obras inéditas ${ }^{328}$.

A lo largo de los años, diversos casos han examinado esta cuestión a la luz de utilizaciones de cartas no divulgadas, memorias y escritos de personas famosas en la creación de nuevas obras ${ }^{329}$. En el asunto Salinger v. Random House, Inc. ${ }^{330}$, por ejemplo, no se reconoció el fair use, dándose un importante peso a este factor por la naturaleza inédita de las cartas de J. D. Salinger utilizadas por el demandado en la creación de la biografía de aquél ${ }^{331}$. La sentencia sigue la línea de la dictada en el asunto Harper \& Row Publishers, Inc. v. Nation Enterprises ${ }^{332}$, si bien ésta última reconoce que, aun cuando la naturaleza inédita de la obra resulta un factor clave, no es necesariamente determinante para negar la defensa del uso justo ${ }^{333}$.

En otros supuestos, sin embargo, se aprecia cómo la no divulgación de la obra citada no ha impedido el uso leal. Así lo demuestran los asuntos Wright v. Warner

${ }^{326}$ La sección 106 (3), Copyright Act concede al autor el derecho "to distribute copies or phonorecords of the copyrighted work to the public by sale or other transfer of ownership, or by rental, lease, or lending", entendiéndose por publicación, de acuerdo a la definición expuesta en la sección 101: "the distribution of copies or phonorecords of a work to the public by sale or other transfer of ownership, or by rental, lease, or lending. The offering to distribute copies or phonorecords to a group of persons for purposes of further distribution, public performance, or public display, constitutes publication".

${ }^{327}$ LANDES, W. M. y POSNER, R. A., La estructura económica ..., op. cit., p. 174.

328 "The fact that a work is unpublished shall not itself bar a finding of fair use if such finding is made upon consideration of all the above factors".

${ }^{329}$ LIPINSKI, T. A., "Toward a Functional...”, op. cit., p. 538.

${ }^{330}$ Salinger v. Random House, Inc., 811 F.2d 90 (2 $2^{\text {nd }}$. Cir. 1987). Resumen en línea, disponible en: https://www.copyright.gov/fair-use/summaries/salinger-random-2dcir1987.pdf (consultado: 27.02.2017).

331 Salinger $v$. Random House, Inc., cit.

${ }^{332}$ Harper \& Row Publishers, Inc. v. Nation Enterprises, 471 U.S. 539 (1985). Resumen en línea, disponible en: https://www.copyright.gov/fair-use/summaries/harperrow-nationmagazine-1985.pdf (consultado: 27.02.2017).

${ }^{333}$ Harper \& Row Publishers, Inc. v. Nation Enterprises, cit. 
Books, Inc. ${ }^{334}$, donde la reproducción de extractos y fragmentos parafraseados de la obra inédita fue considerada legítima toda vez que no constituían el "corazón" de la misma ${ }^{335}$, así como en Norse v. Henry Holt \& Co. ${ }^{336}$, con un razonamiento similar.

En definitiva, lo determinante para poder calificar como justa o leal la utilización de una obra inédita está vinculado con la propia finalidad que persigue el copyright en el sistema anglosajón y, en particular, en Estados Unidos, donde la finalidad del uso al servicio del interés púbico permite justificar utilizaciones no consentidas de las obras que, de otro modo, no serían aceptadas. El fundamento se encuentra en la respuesta a la cuestión de hasta qué punto es legítimo tener que solicitar el consentimiento del autor o de sus herederos para utilizar fragmentos de obras inéditas cuando ello sirve al interés general. Dicho de otro modo, prohibir el uso de una obra en la creación de una nueva obra por el hecho de no haber sido publicada no es algo que se pueda sustentar en el marco de la regulación de los derechos de autor en Estados Unidos. Más bien, en todo caso, el amparo podría encontrarse en las leyes que protegen la privacidad ${ }^{337}$. Ello no quiere decir, en cambio, que la publicación no sea un elemento importante ${ }^{338}$. Por el contrario, en la medida en que se pueda apreciar que el propósito del autor es publicar la obra inédita y la utilización secundaria de la obra no publicada pueda ir en contra de los incentivos del autor, debe garantizarse la protección de sus derechos sobre aquélla, a menos que el uso sea suficientemente transformativo como para no interferir en sus intereses $^{339}$.

La evaluación de la naturaleza del uso, en el sentido que se ha venido exponiendo, no puede apartarse de los propios fines utilitaristas que defiende la Copyright Act

\footnotetext{
${ }^{334}$ Wright v. Warner Books, Inc., 953 F.2d 731 (2 $2^{\text {nd }}$. Cir. 1991). Resumen en línea, disponible en: https://www.copyright.gov/fair-use/summaries/wright-warner-2dcir1991.pdf (consultado: 27.02.2017). La disputa versa sobre la publicación de una biografía sobre el escritor Richard Wright por parte de Warner Books, Inc., bajo la autoría de Margaret Walker, en la que, sin el consentimiento de la heredera del escritor, la autora parafraseó y citó trabajos inéditos de Wright, tales como entradas de diario y cartas.

${ }^{335}$ Wright v. Warner Books, Inc., cit.

${ }^{336}$ Norse v. Henry Holt \& Co., 847 F. Supp. 142 (N.D. Cal. 1994). Resumen en línea, disponible en: https://www.copyright.gov/fair-use/summaries/norse-henry-ndcal1994.pdf (consultado: 27.02.2017).

${ }^{337}$ LEVAL, P. N., "Toward a fair...", op. cit., p. 1119.

338 Ídem.

${ }^{339}$ Ibídem, p. 1122.
} 
estadounidense. En todo caso, hay que ponderar los intereses implicados, sin olvidar el interés del público.

El otro elemento a evaluar en el análisis de este factor es el grado de creatividad de la obra protegida. Para ilustrar este particular, sirva de ejemplo el caso Campbell $v$. Acuff-Rose Music, Inc. (1994) cuando señala al respecto:

"This factor calls for recognition that some works are closer to the core of intended copyright protection than others, with the consequence that fair use is more difficult to establish when the former works are copied".

La frase deja ver cómo hay obras cuyos usos derivados serán de más difícil encuadre en la doctrina del fair use porque, cuanto mayor sea la creatividad de la obra utilizada sin el consentimiento del titular de derechos, mayor será la justificación que requerirá su uso en la creación de una obra derivada para ser considerado un uso justo $^{340}$. Cobra así relevancia "el valor de los datos utilizados", tal como se puso de relieve en el asunto Folsom v. Marsh (1841) en los albores del reconocimiento de esta doctrina.

Los tribunales se centran en evaluar la naturaleza de los hechos para determinar en qué medida las obras gozan de mayor o menor creatividad. Así, por ejemplo, en Righthaven, L.L.C. v. Realty One Grp., Inc. ${ }^{341}$ el uso justo fue apreciado, entre otras cuestiones, teniendo en cuenta que las frases utilizadas por el demandado en su blog, tomadas del artículo periodístico publicado por Las Vegas Review-Journal, sólo se referían a cuestiones fácticas, recayendo la creatividad de la obra original en los comentarios que hacía y no en los hechos fácticos que sostenía, que eran los reproducidos por el demandado en su publicación ${ }^{342}$. Puede decirse que las creaciones científicas se basan en datos fácticos, pero ello no elimina la necesaria protección de este tipo de obras. No obstante, la utilización de datos predominante fácticos podrá

\footnotetext{
${ }^{340}$ CAStelló Pastor, J. J., Motores de búsqueda ..., op. cit., p. 190.

${ }^{341}$ Righthaven, L.L.C. v. Realty One Grp., Inc., No. 2:10-cv-1036-LRH-PAL. (D. Nev. Oct. 19, 2010). Resumen en línea, disponible en: https://www.copyright.gov/fair-use/summaries/righthaven-realtydnev2010.pdf (consultado: 27.02.2017).

${ }^{342}$ Righthaven, L.L.C. v. Realty One Grp., Inc., cit.
} 
conllevar una interpretación más favorable al fair $u s e^{343}$. Con todo, el uso de hechos fácticos no implica por sí mismo el uso justo.

Por otra parte, también debe destacarse que en la resolución de asuntos relativamente recientes los tribunales han dado menor importancia al segundo factor cuando el uso es transformativo ${ }^{344}$. El carácter transformativo del uso hace que la obra resultante pueda ampararse en el fair use, aun cuando la obra utilizada goce de suficiente carácter creativo, como sucedió en Blanch v. Koons ${ }^{345}$. En este asunto, la manera transformadora en que el demandado utilizó la obra de la fotógrafa A. Blanch (con el fin de comentar su significado social y estético, en lugar de explotar su creatividad) sirvió de justificación para que el uso secundario fuera admisible ${ }^{346}$.

En conclusión, una vez más se puede apreciar que no existe una interpretación general válida, sino que hay que atender a las circunstancias concretas de cada caso para determinar si el factor analizado facilita la calificación del uso como fair use, así como el mayor o menor peso asignado al mismo en el análisis global de esta doctrina.

\section{C) La cantidad y sustancialidad de la parte utilizada en relación con la obra en su conjunto}

Este factor impone al juez, nuevamente, analizar el caso de acuerdo a dos aspectos diferentes: un aspecto cuantitativo, atinente a la cantidad de la obra copiada; y un aspecto cualitativo, referente a la cualidad e importancia (sustancialidad) del fragmento utilizado en relación con la misma.

Tampoco en este factor existen reglas absolutas. Por el contrario, la jurisprudencia proporciona un amplio abanico de posibilidades. En todo caso, es oportuno advertir que el análisis suele llevarse más al terreno de lo cualitativo que al de lo cuantitativo ${ }^{347}$, lo

\footnotetext{
${ }^{343}$ Vid. American Geophysical Union v. Texaco Inc., 60 F.3d 913 (2 ${ }^{\text {nd }}$. Cir. 1994).

${ }^{344}$ LIPINSKI, T. A., "Toward a Functional...”, op. cit., p. 539.

${ }^{345}$ Blanch v. Koons, 467 F.3d 244 (2 $2^{\text {nd }}$. Cir. 2006).

346 Blanch v. Koons. Resumen en línea, disponible en: https://www.copyright.gov/fairuse/summaries/blanch-koons-2dcir2006.pdf (consultado: 27.02.2017).

${ }^{347}$ LIPINSKI, T. A., “Toward a Functional...”, op. cit., p. 542.
} 
que no quiere decir que este último no sea importante. Sin embargo, la cuestión cualitativa se hace más latente porque usualmente las obras no suelen ser copiadas en su totalidad o ampliamente, lo que iría, al menos en principio, en detrimento del uso justo.

Hay que significar, no obstante, que cuanto mayor sea la parte utilizada de la obra original, menor posibilidad habrá de que la utilización que se haga de ésta se considere justa $^{348}$, lo que no excluye que puedan darse supuestos en que la obra sea copiada en su totalidad y se aprecie, no obstante, el uso justo, a tenor de otras consideraciones, como puede ser la relevancia del uso transformativo ${ }^{349}$.

Asuntos como Compaq Computer Corp. v. Ergonome, Inc. ${ }^{350}$ y Warren Publ'g Co. v. Spurlock ${ }^{351}$ son ilustrativos respecto a cómo el uso de una porción mínima o un pequeño porcentaje de la obra reproducida puede inclinar la balanza a favor del fair use, siempre que no se involucre una parte esencial de la obra en cuestión. En otros casos, los tribunales suelen considerar irrelevante el impacto de este factor en la apreciación del uso justo y, en tal sentido, lo califican como "neutral" 352.

En contraste con lo anterior, la sustancialidad de la parte copiada, esto es, su relevancia como "esencia", comporta el reconocimiento de una violación de los derechos de autor, aun cuando la parte reproducida sea una porción cuantitativamente insustancial. Así fue declarado en el asunto Harper \& Row Publishers, Inc. v. Nation Enterprises (1985), que hasta hoy sigue siendo un precedente válido en la comprensión de este factor, tanto en su vertiente cuantitativa como cualitativa ${ }^{353}$.

\footnotetext{
${ }^{348}$ LEVAL, P. N., "Toward a fair...", op. cit., p. 1122.

${ }^{349}$ Así se aprecia en el asunto Bill Graham Archives v. Dorling Kindersley Ltd., 448 F.3d 605 (2 ${ }^{\text {nd. Cir. }}$ 2006), en el que, aun cuando las imágenes utilizadas eran reproducciones completas de las imágenes de carteles y entradas utilizadas para promocionar los conciertos de la banda "Grateful Dead", cuyos derechos ostentaba el demandante, el carácter transformativo del uso que perseguía fines históricos, era diferente del propósito expresivo que tenían estas obras protegidas, sin que pesara, en contra del uso justo, que las obras fueran copiadas en su totalidad porque el tamaño reducido de las imágenes estaba en correspondencia con el propósito del uso transformativo. Resumen en línea, disponible en: https://www.copyright.gov/fair-use/summaries/billgraham-dorling-2dcir2006.pdf $\quad$ (consultado: 27.02.2017).

${ }^{350}$ Compaq Computer Corp. v. Ergonome, Inc., 387 F.3d 403 (5th Cir. 2004).

${ }^{351}$ Warren Publ'g Co. v. Spurlock, 645 F. Supp. 2d 402 (E.D. Pa. 2009).

${ }^{352}$ L.A. News Serv. v. CBS Broad., Inc., 305 F.3d 924 (9th Cir. 2002).

${ }^{353}$ CAStelló PAStor, J. J., Motores de búsqueda..., op. cit., p. 192.
} 
Con todo, es comprensible que se califique como infracción aquella utilización secundaria que reproduzca la obra de manera amplia o relevante, de tal modo que constituya un sustituto de la original o impacte de forma trascendente en el mercado potencial o en el valor de la obra protegida. Por eso en la aplicación de la doctrina del fair use se ha destacado la importancia adicional de este factor en la evaluación del último de los factores, esto es, en el impacto que tiene la obra derivada $\multimap$ o que utiliza la obra original- en el mercado potencial de la obra original; al tiempo que también repercute en la consideración de la finalidad y el carácter del uso, bajo el primer factor analizado ${ }^{354}$.

Por último, es importante señalar que la evaluación de este factor no impide la consideración de uso justo en el caso de la parodia. Sin duda, si el parodista utiliza escasamente la obra parodiada, facilitará la apreciación del fair use. No obstante, si la parodia utiliza la "esencia", el "corazón" de la obra parodiada, tampoco hay que rechazar un uso justo ${ }^{355}$, tal como puso de relieve el citado caso Campbell v. Acuff-Rose Music, Inc.

\section{D) El efecto de la utilización de la obra en el mercado potencial o en el valor de la obra protegida}

La propia concepción utilitarista del copyright explica la presencia de este factor, pues la protección de los derechos de autor en el sistema anglosajón tiene como finalidad incentivar la creación. Por tanto, si se afecta el mercado potencial o el valor de las obras al facilitarse su explotación por personas distintas del autor y sin su consentimiento, se está atentando contra dicha finalidad. Por ello, cobra gran significado el análisis del efecto de la utilización de la obra en el mercado potencial o en el valor de la obra protegida ${ }^{356}$.

\footnotetext{
${ }^{354}$ LeVAL, P. N., “Toward a fair...”, op. cit., p. 1123.

${ }^{355}$ LIPINSKI, T. A., "Toward a Functional...", op. cit., p. 543.

${ }^{356}$ LeVAL, P. N., "Toward a fair...”, op. cit., p. 1124.
} 
Es posible partir de la premisa de que existe una gran resistencia al fair use cuando el uso de la obra interfiera significativamente en el mercado potencial de explotación de la misma generando un perjuicio al titular de derechos. Asimismo, hay que tener en cuenta no sólo el daño que se produce a la obra original, sino también al mercado de las obras derivadas ${ }^{357}$. En cambio, no puede afirmarse categóricamente lo contrario, esto es, que el fair use prospere cuando el uso no dañe tal mercado ${ }^{358}$, pues el resto de los factores podrán impedir la apreciación del fair use por el juez.

En todo caso, se exige que el daño al mercado sea significativo, es decir, relevante o sustancial, para no vaciar de contenido esta doctrina. De lo contrario, siempre cabría argumentar que toda explotación de una obra que reproduce otra preexistente genera una pérdida de ingresos para el autor o titular de derechos sobre aquélla, por lo que no existiría fair use a partir del examen del factor analizado.

Este deterioro se produce, normalmente, cuando el uso es reproductivo o sustitutivo de la obra original, pues en estos casos no es difícil advertir un perjuicio patrimonial relevante para el titular de los derechos de autor. Pero, lo más importante será evaluar el impacto que tiene la explotación de la copia de la obra original o de la nueva creación que incorpora elementos de la obra preexistente en la demanda de aquélla en el mercado. En efecto, también hay que tener presente que, aun siendo el uso meramente reproductivo, puede incidir de manera positiva sobre el mercado de la obra original $^{359}$.

Del mismo modo, el uso transformativo de la obra puede afectar el mercado de la misma, como, por ejemplo, las críticas literarias que vierten opiniones negativas sobre la obra original. Pero no es este tipo de impacto el que protege este factor de la doctrina del fair use, siempre que el daño esté asociado a la fuerza de la crítica ${ }^{360}$. En efecto, la

\footnotetext{
${ }^{357}$ Campbell v. Acuff-Rose Music, Inc., 510 U.S. 569 (1994).

358 Ídem.

${ }^{359}$ Un ejemplo emblemático al respecto es el asunto Universal City Studios, Inc. y Walt Disney Productions v. Sony Corp. of America [Sony Corp. of Am. v. Universal City Studios, Inc., 464 U.S. 417 (1984)], al que se hará una referencia más amplia en el siguiente capítulo, en el epígrafe referido a la copia privada y el fair use.

${ }^{360}$ LIPINSKI, T. A., “Toward a Functional...”, op. cit., p. 545.
} 
crítica literaria en sí constituye un complemento de la obra original, un "sustitutivo de la publicidad" que puede suponer un incremento de la demanda de libros ${ }^{361}$. De ser necesario el consentimiento del autor para realizar la crítica a su obra, el ejercicio de la crítica podría no conllevar un incremento de la demanda y, por consiguiente, ningún beneficio al sector editorial, puesto que se podría presumir que la autorización se condicionó precisamente a una crítica benévola, con lo cual, dejaría de ser un medio de publicidad fiable ${ }^{362} \mathrm{y}$, por tanto, un beneficio para la comercialización de la obra original.

La diversidad de casos que pretenden defender una utilización lícita de una obra al amparo del fair use hace que los jueces analicen supuestos muy distintos, también en lo relativo al examen de este factor. Algunas veces se ha concluido que no existe afectación al mercado potencial de la obra, como, por ejemplo, en el asunto Wright $v$. Warner Books, Inc. -ya citado-. En él se determinó que la biografía no explotaba el valor literario de las obras inéditas citadas de Richard Wright, a la vez que tampoco disminuiría su comercialización, de ser futuramente publicadas ${ }^{363}$, pues sólo se tomaban en la creación de la nueva obra algunas partes de aquéllas, del todo irrelevantes para dañar su posible explotación.

Por otra parte, este factor también puede mostrarse "neutral", como en Righthaven, L.L.C. v. Realty One Grp., Inc. -citado anteriormente-, donde el Tribunal de Distrito de los Estados Unidos para el Distrito de Nevada consideró que poco o ningún efecto sobre el mercado potencial o el valor de la obra protegida tenía el uso secundario por el demandado de la obra en cuestión. La parte reproducida se limitaba a hechos fácticos y no a los comentarios que hacía el autor de la obra originaria, con lo cual, no podía operar como un sustituto de la misma. Incluso el demandado dirigía a los lectores de su blog al texto completo de la obra.

\footnotetext{
${ }^{361}$ LANDES, W. M. y POSNER, R. A., La estructura económica..., op. cit., pp. 158-159.

362 Ibídem, p. 159

363 Disponible en: https://www.copyright.gov/fair-use/summaries/wright-warner-2dcir1991.pdf (consultado: 27.02.2017)
} 
Otras veces, por el contrario, este factor puede ser muy determinante en la exclusión del uso justo. En American Geophysical Union v. Texaco, Inc. ${ }^{364}$ esta fue la razón principal para determinar que la copia de ocho artículos publicados en el Journal of Catalysis no constituían fair use. En principio, la reproducción de estos artículos de forma individual podía no ser determinante para afectar al mercado tradicional de la revista, que se comercializaba bajo suscripciones. En la medida en que el demandante demostrara que las fotocopias perjudicaban la capacidad de comercialización de la revista, ello pesaría contra el fair use; pero, en caso contrario, la conducta de Texaco sería admisible. Sin embargo, a la hora de evaluar la afectación que producían estas reproducciones en el mercado potencial de la obra, el tribunal fue más allá, evaluando la posible pérdida de ingresos por licencias para American Geophysical Union. Analizada esta cuestión, el tribunal concluyó que, si bien el demandante no había establecido aun un mercado convencional para la venta directa y distribución de los artículos individuales, sí había creado un mercado viable para que los usuarios institucionales obtuvieran licencias para producir sus propias copias de artículos individuales a través de la fotocopia. Por tanto, la pérdida de ingresos por licencias era un elemento importante a la hora de evaluar este factor y, por tal razón, consideró que se producía una afectación de los derechos de autor, al evaluar no sólo la posible pérdida de potenciales suscripciones para el demandante, sino también de potenciales ingresos por licencias.

En definitiva, analizar en qué medida la utilización secundaria de una obra afecta a su explotación en el mercado potencial o a su valor tiene una gran relevancia para examinar si el uso secundario es ajustado a derecho sin la autorización del titular. Sin embargo, la fuerza de este factor varía en función del daño producido, así como de su necesaria ponderación con los restantes factores.

${ }^{364}$ American Geophysical Union v. Texaco Inc., 60 F.3d 913 (1994). 


\subsection{La prueba de los tres pasos}

El legislador español no es totalmente libre en el establecimiento de límites al derecho de reproducción del autor y demás titulares de derechos de propiedad intelectual. Por el contrario, como ya se apuntó ${ }^{365}$, está sometido a un marco legal de orden internacional y supranacional (normativa de la UE) que lo obliga a respetar el criterio de la regla o prueba de los tres pasos del art. 9.2 $\mathrm{CB}$, incorporada en el art. 40.bis del TRLPI.

Esta regla, que se refiere específicamente al derecho de reproducción y que fue incorporada al $\mathrm{CB}$ en la revisión efectuada al mismo durante la Conferencia de Estocolmo en el año $1967^{366}$, reserva a las legislaciones de los países de la Unión de Berna la facultad de permitir la reproducción de las obras literarias y artísticas en determinados casos especiales (aquellos contemplados específicamente en la ley), siempre que la reproducción no atente contra la explotación normal de la obra, ni cause un perjuicio injustificado a los intereses legítimos del autor.

Se trata de las tres etapas o fases del test que deben ser superadas en el establecimiento de límites al derecho de reproducción y que, siguiendo la doctrina mayoritaria, deben ser valoradas de forma independiente y cumulativa, esto es, todos los pasos deben superarse sucesivamente ${ }^{367}$. No obstante, existen autores que, frente a una valoración cumulativa de los pasos del test, entienden que debe efectuarse una interpretación global ${ }^{368}$. En este sentido, se ha señalado:

"La correcta aplicación de la Regla de los Tres Pasos exige una evaluación conjunta e integradora, en lugar de la aplicación paso a paso que su usual $-\mathrm{y}$ engañosa- denominación parece indicar. No debe darse prioridad a ningún 'paso'. De este modo, la Regla no altera el necesario equilibrio de intereses entre las

\footnotetext{
${ }^{365}$ Vid. supra Epígrafe 4.1 de este Capítulo.

${ }^{366}$ LÓPEZ MAZA, S., Límites al derecho de reproducción ..., op. cit., p. 46.

367 Garrote Fernández-DíEz, I., “Artículo 9”, en BERCOVITZ RodríGuez-CANo, R. (Coord.), Comentarios al Convenio de Berna..., op. cit., p. 762; CASAS VALlÉS, R., "Artículo. 40 bis", en Bercovitz Rodríguez-CANO, R. (Coord.), Comentarios a la Ley de Propiedad ..., $4^{\text {a }}$ ed., op. cit., p. 822. 368 Para ampliar Vid. CASAS VALlÉS, R., "Artículo 40 bis”, en BERCOVITZ RodRíGUEZ-CANO, R. (Coord.), Comentarios a la Ley de Propiedad..., $3^{\mathrm{a}}$ ed., op. cit., p. 695; GARrote FERnÁnDEZ-DíEz, I., “Artículo 9”, en Bercovitz Rodríguez-CAno, R. (Coord.), Comentarios al Convenio de Berna..., op. cit., pp. 763 y ss.
} 
distintas clases de titulares, ni entre los titulares y el público en general. Cualquier resultado contradictorio que se derive de la aplicación de los criterios individuales de la Regla a un caso concreto debe ser acomodado dentro de esta evaluación integradora y conjunta. De hecho, la presente formulación de la Regla de los Tres Pasos no impide esta lectura, aunque con frecuencia haya sido omitida en casos ya resueltos"369.

Siguiendo esta interpretación, sería posible admitir que una excepción o limitación concreta establecida en una legislación nacional no colisiona con la regla de los tres pasos, tras una evaluación conjunta del test, aunque no supere alguna de sus etapas $^{370}$. Sin embargo, esta forma de interpretar el test sólo parece tener sentido ante la posible valoración del mismo por el juez para alcanzar una solución equilibrada a un caso en concreto y no, por el contrario, en su aplicación por el legislador ${ }^{371}$.

La aplicación de la regla de los tres pasos se ha convertido en una pauta esencial para la fijación de excepciones o limitaciones al derecho de autor, a pesar de que en el sistema continental se limite su eficacia, toda vez que normalmente se suele considerar que es una regla dirigida al legislador y no al juez ${ }^{372}$, lo que dificulta la apreciación de un "uso justo" en el análisis de un caso concreto. Sin embargo, la posibilidad de que los tribunales apliquen esta regla ha encontrado apoyo doctrinal y jurisprudencial. La ventaja que de ello deriva se encuentra en la mayor flexibilidad en la aplicación de los límites al derecho de autor dentro de un sistema en el que las excepciones o limitaciones están expresamente previstas en la norma jurídica. Así pues, la regla sirve para evitar interpretaciones inadecuadas en la aplicación de un límite a un asunto determinado, toda vez que cuando el juez admite la aplicación de un límite debe hacerlo de forma tal que

\footnotetext{
369 XALABARDER Plantada, R., Declaración por una Interpretación Equilibrada de la Regla de los Tres Pasos en el Derecho de Autor, p. 2, traducción del texto original en inglés del Instituto Max Planck, disponible http://in3.uoc.edu/opencms_portalin3/export/sites/default/galleries/docs/INTERDRET/Xalabarder_2008_ trad_Decl_3ST_SPANISH.pdf (consultado: 29.08.2016).

370 Garrote Fernández-DíEz, I., "Artículo 9", en Bercovitz RodríGuez-Cano, R. (Coord.), Comentarios al Convenio de Berna..., op. cit., p. 764.

371 Ídem.

${ }^{372}$ Para una reflexión general sobre el destinatario de la prueba de los tres pasos vid. CASAS VALLÉs, R., “Artículo 40 bis", en BerCovitz RodríGUEZ-CANO, R. (Coord.), Comentarios a la Ley de Propiedad..., $4^{\mathrm{a}}$ ed., op. cit., pp. 813-818.
} 
su aplicación no vaya en detrimento de la explotación normal de la obra, ni cause un perjuicio injustificado a los legítimos intereses de los titulares de derechos ${ }^{373}$.

Son muchos los autores que han analizado la prueba de los tres pasos. Vale la pena llamar la atención sobre el estudio realizado por MASOUYE, en $1978^{374}$, por su carácter pionero tras la incorporación de la regla de los tres pasos al CB. En éste, el autor destaca que las etapas del test han de ser interpretadas en su conjunto, si bien son cumulativas ${ }^{375}$. Al respecto, se centra en dos de los requisitos del test: que la reproducción no atente contra la explotación normal de la obra y que no cause un perjuicio injustificado a los intereses del autor y señala:

"Es necesario ante todo que la explotación normal de una obra no sea dificultada ni padezca detrimento por el hecho de la reproducción que se haga de la misma; de no ser así, la reproducción no estaría permitida de ningún modo. [...] Si se cumple la primera condición (es decir, si la reproducción no atenta contra la explotación normal de la obra), procede examinar si la segunda se halla satisfecha. Cabe destacar que no se trata de averiguar si el autor sufre o no un perjuicio cualquiera: es evidente que, en último extremo, siempre hay algún perjuicio [...]. De lo que se trata, es de saber si el perjuicio es injustificado" 376 .

Además, MASOUYE reconoce que, en el caso de que se produzca una falta de ingresos para el titular de derechos, la ley debería atribuirle una compensación económica ${ }^{377}$ y enfatiza, "conviene conciliar estos intereses con las necesidades de los usuarios, correspondiendo a cada Estado adoptar con tal fin las medidas apropiadas que mejor convengan a su propio desarrollo educativo, cultural, social y económico"378.

\footnotetext{
${ }^{373}$ Ibídem, p. 51. Véase también LóPEZ MAZA, S. "La posibilidad de utilización directa por el Juez de la regla de los tres pasos “, en AA.VV., Estudios sobre la Ley de Propiedad Intelectual: últimas reformas y materias pendientes, Dykinson, Madrid, 2016, pp. 320-321; y GARROTE FERNÁNDEZ-DíEZ, I., "Artículo 9", en BerCovitz RodríGuez-CANo, R. (Coord.), Comentarios al Convenio de Berna..., op. cit., pp. 811-815.

${ }^{374}$ Masouye, C., Guía del Convenio de Berna para la protección de las obras literarias y artísticas (Acta de París, 1971), OMPI, Ginebra, 1978, pp. 62 y ss.

${ }^{375}$ Ibídem, p. 63.

376 Ídem.

377 Ídem.

${ }^{378}$ Ibídem, pp. 64 y 65.
} 
Otro estudio de interés es el realizado por FICSOR en el año $2002^{379}$, pues la regla de los tres pasos se analiza a la luz de los cambios provocados por el desarrollo tecnológico. El autor destaca que las reglas del test siguen siendo válidas con independencia de los avances tecnológicos y subraya que cualquier reproducción que entre en conflicto con la explotación normal de la obra debe prohibirse pues la finalidad de conciliar los intereses de los titulares de derechos y de los usuarios sigue siendo válida $^{380}$.

\subsubsection{La decisión del Grupo Especial de la OMC en relación con el art. 13 del Acuerdo sobre los ADPIC en la interpretación de la prueba de los tres pasos}

\subsubsection{Generalidades}

El art. 13 del Acuerdo sobre los ADPIC regula el test de las tres etapas o la prueba de los tres pasos, de manera similar al art. 9.2 del CB, si bien no puede obviarse su formulación novedosa, por cuanto las reglas o pasos del test, incorporados al art. 13 del Acuerdo sobre los ADPIC, dejan de estar circunscritos únicamente al derecho de reproducción, haciéndose extensivos al resto de los derechos patrimoniales ${ }^{381}$. Asimismo, dicho Acuerdo amplía el ámbito de aplicación del test, extendiéndolo a los derechos afines o $\operatorname{conexos}^{382}$, a las marcas (art. 17 del Acuerdo sobre los ADPIC), dibujos y modelos (art. 26.2 del Acuerdo sobre los ADPIC) y patentes (art. 30 del Acuerdo sobre los ADPIC), convirtiéndose así en una regla transversal ${ }^{383}$.

Concretamente, el art. 13 del Acuerdo sobre los ADPIC establece:

"Los Miembros circunscribirán las limitaciones o excepciones impuestas a los derechos exclusivos a determinados casos especiales que no atenten contra la

\footnotetext{
${ }^{379}$ FICSOR, M., The Law of Copyright and the Internet. The 1996 WIPO Treaties, their Interpretation and Implementation, University Press, Oxford, 2002, pp. 280 y ss.

${ }^{380}$ CAStelló Pastor, J. J., Motores de búsqueda..., op. cit., p. 153.

${ }^{381}$ CASAS VAllÉs, R., “Artículo 40 bis”, en BerCOVITZ RodRíGUEZ-CANO, R. (Coord.), Comentarios a la Ley de Propiedad..., $3^{\mathrm{a}}$ ed., op. cit., p. 674.

${ }^{382} \mathrm{El}$ art. 13 del Acuerdo sobre los ADPIC se refiere a "los intereses legítimos del titular de los derechos", ampliando así la referencia al "autor" hecha en el CB.

383 CASAS VALlÉs, R., “Artículo 40 bis”, en BerCOVITZ RodRÍGUEZ-CANO, R. (Coord.), Comentarios a la Ley de Propiedad..., $3^{\mathrm{a}}$ ed., op. cit., p. 676.
} 
explotación normal de la obra ni causen un perjuicio injustificado a los intereses legítimos del titular de los derechos".

Sin embargo, no siempre es fácil desentrañar el significado y alcance de cada uno de los pasos $^{384}$. En particular, así lo demuestra el caso WTO/DS160, de 15 de junio de $2000^{385}$, en cuya resolución intervino el Grupo Especial del Órgano de Solución de Diferencias de la Organización Mundial de Comercio (en adelante OMC). Esta decisión tuvo lugar en el contexto de las consultas solicitadas por las Comunidades Europeas con los Estados Unidos respecto a la sección 110 (5) de la Copyright Act estadounidense, modificada por la Ley sobre la lealtad en la concesión de licencias sobre obras musicales, promulgada el 27 de octubre de 1998. En especial, existían opiniones divergentes sobre la compatibilidad de dos exenciones previstas en la citada sección en relación con el art. 13 del Acuerdo sobre los ADPIC: la denominada exención “empresarial" prevista en la parte $(B)^{386}$; y la denominada exención “de uso doméstico", prevista en la parte $(\mathrm{A})^{387}$.

En su decisión, el Grupo Especial consideró que la excepción “empresarial” ni siquiera cumplía el primer paso del test (caso especial). Suerte distinta, sin embargo, corrió la excepción "de uso doméstico" que sí superó los tres pasos.

En general, esta decisión ha sido objeto de numerosas críticas por la perspectiva económica desde la que ha sido analizado el texto del art. 13 del Acuerdo sobre los ADPIC, que no ha tenido en cuenta el alcance de los intereses sociales y culturales

\footnotetext{
${ }^{384} \mathrm{El}$ test hace referencia a conceptos jurídicos indeterminados como "casos especiales", "explotación normal de la obra" y "legítimos intereses de los autores".

385 OMC, Informe del Grupo Especial (WT/DS160/R), 15 de junio de 2000, disponible en: https://docs.wto.org/dol2fe/Pages/FE_Search/FE_S_S006.aspx?Query=(\%40Symbol\%3d+wt\%2fds160\% $\left.2 \mathrm{f}^{*}\right) \&$ Language=SPANISH\&Context=FomerScriptedSearch\&languageUIChanged=true, $\quad$ (consultado: 26.06. 2016).

${ }^{386}$ En esencia, lo que hacía era permitir la amplificación de emisiones musicales, sin necesidad de autorización ni pago de tasas, por parte de establecimientos de comidas y bebidas y establecimientos de servicios minoristas, siempre que su tamaño no superara una determinada superficie, así como esa amplificación de emisiones musicales por parte de establecimientos con una superficie mayor siempre que se cumplieran determinadas limitaciones de equipamiento.

${ }^{387}$ Permitía que los pequeños restaurantes y los comercios minoristas amplificaran emisiones musicales sin autorización del titular del derecho, ni pago de tasas, siempre que emplearan equipos de uso doméstico.
} 
también implícitos en la regulación de la propiedad intelectual ${ }^{388}$. No obstante, tiene el mérito de ser un importante punto de apoyo en la interpretación internacional de los distintos pasos de la regla. Por ello, conviene detenerse en la interpretación que, de los pasos de la prueba de los tres pasos del art. 13 del Acuerdo sobre los ADPIC, hizo el Grupo Especial del Órgano de Solución de Diferencias de la OMC.

\subsubsection{La interpretación de los pasos}

En su informe, el Grupo Especial del Órgano de Solución de Diferencias de la OMC propuso una interpretación de cada una de los pasos o etapas del test ${ }^{389}$, analizados de manera cumulativa. Esto es, cada una de las etapas debía ser percibida como un requisito separado e independiente que, de no cumplirse, impediría concebir determinado acto como limitación a los derechos de propiedad intelectual ${ }^{390}$.

En cuanto al primer paso (determinados casos especiales), el Grupo Especial realizó el análisis partiendo del sentido corriente de los términos empleados. En primer lugar, atribuyó al término "determinados" la significación de "conocido y particularizado, pero no identificado explícitamente"; "fijo, no variable; definido, preciso, exacto". Por tanto, subrayó que no sería necesario identificar explícitamente todos los supuestos a los que podría aplicarse la excepción, aunque su alcance tendría que ser conocido y particularizado para garantizar suficiente seguridad jurídica ${ }^{391}$. En cuanto al vocablo "caso", se le atribuyó el significado común de "suceso", "circunstancia" o "acontecimiento" o "hecho"; y el término "especial", por su parte, se dijo que expresaba "una aplicación o propósito individual o limitado"; "que contiene

388 CASAS VAllÉs, R., “Artículo 40 bis”, en BERCOVITZ RodRÍGUEZ-CANO, R. (Coord.), Comentarios a la Ley de Propiedad..., $3^{\mathrm{a}}$ ed., op. cit., p. 678, señala: "Esta decisión o Informe [...] ha sido objeto de opiniones diversas. Sin duda, resulta del mayor interés y puede ser muy útil para la interpretación de la prueba de los tres pasos. Pero, dado su marco de referencia, hay que prevenir contra un uso mecánico del mismo". Sobre sus puntos críticos vid. Colin, C., Droit..., op. cit., pp. 408-409.

${ }^{389}$ Soulié, Ch., "La protección de la obra audiovisual...", op. cit., pp. 68-70.

${ }^{390}$ Vid., entre otros, SEnftLeben, M., Copyright, Limitations and the Three-Step Test, Wolters Kluwer, La Haya, 2004, pp. 126-127; y LIPSZYC, D., Nuevos temas de derechos de autor y derechos conexos, UNESCO-CERLAC-ZAVALIA, Buenos Aires, 2004, pp. 53 y ss.

${ }^{391} \mathrm{OMC}$, Informe..., cit., p. 37. 
detalles, precisos, específicos"; entre otros significados. En definitiva, sugería otorgar un ámbito reducido de aplicación a las limitaciones o excepciones o un carácter excepcional en su alcance" ${ }^{, 392}$.

Así pues, el Grupo Especial concluyó que la primera condición del art. 13 del Acuerdo sobre los ADPIC exige que "las limitaciones o excepciones prescritas en la legislación nacional estén claramente definidas y sean de aplicación y alcance estrictos" ${ }^{\text {393 }}$. No es preciso aquí entrar a juzgar la legitimidad de la excepción haciendo un juicio de valor sobre su justificación (algo que quedará reservado a los pasos posteriores ${ }^{394}$ ), pero sí puede ayudar a comprender el alcance y definición de la excepción o limitación ${ }^{395}$. Por tanto, es necesario que la imposición de un límite legal o el recorte a los derechos exclusivos del titular de derechos de autor esté justificada por un objetivo de política legislativa claro, esto es, que no sea un recorte $\operatorname{arbitrario}^{396}$. Podrá así convertirse un caso determinado en especial ${ }^{397}$, si lo inspira un propósito justo.

Puede decirse que este objetivo es más fácil de identificar en los países de tradición continental, al estar los límites explícitamente contenidos en la ley. Así, por ejemplo, el límite de la cita garantiza la libertad de crítica y la investigación científica, así como la reproducción provisional facilita la transmisión de contenidos en red. Por el contrario, es más difícil valorar este requisito en los países con un sistema abierto de límites. No obstante, ello no significa que estos no satisfagan las exigencias de la primera etapa de la prueba de los tres pasos (como se verá al analizar la compatibilidad del triple test con la doctrina del fair use $)^{398}$.

\footnotetext{
392 Ídem.

393 Ibídem, p. 38.

${ }^{394}$ En el mismo sentido, LÓPEZ MAZA, S., Limites al derecho de reproducción ..., op. cit., p. 54.

395 OMC, Informe..., cit., p. 38.

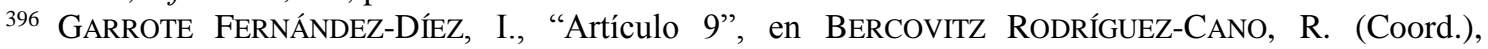
Comentarios al Convenio de Berna..., op. cit, p. 773.

${ }^{397}$ Ibídem, p. 772.

${ }^{398}$ Véanse al respecto los comentarios realizados en el epígrafe 4.3.2 de este mismo capítulo sobre la prueba de los tres pasos y el fair use.
} 
El segundo escalón del test consiste en examinar si la limitación o excepción "atenta contra la explotación normal de la obra". Aquí el Grupo Especial partió también del sentido común de las palabras, haciendo una exégesis gramatical. "Explotar" significa hacer uso de, o utilizar para los propios fines. Así, la explotación de la obra significa la actividad mediante la cual los titulares de derechos de autor utilizan las facultades exclusivas que les han sido conferidas sobre sus obras para obtener un valor económico a partir de éstas. Por otra parte, entre los significados que se atribuyen al término "normal" se encuentra "que constituye o se ajusta a un tipo o norma". También comprende acepciones como "regular", "usual", "típico", “ordinario" o "convencional".

Además, el Grupo Especial determinó que, aun cuando el art. 13 del Acuerdo sobre los ADPIC se refiere a "la obra", debía entenderse como tal todos los derechos exclusivos relativos a la misma, porque son estos derechos los medios jurídicos mediante los cuales puede llevarse a cabo su explotación patrimonial. Por tanto, la explotación normal debe juzgarse, caso por caso, en relación con cada derecho exclusivo $^{399}$.

En particular, respecto a la interpretación del vocablo "normal", debe tenerse en cuenta $-\mathrm{y}$ así lo pone de relieve el citado informe-, que una interpretación meramente empírica o cuantitativa de esta palabra en el contexto de la expresión induce a considerar el grado de pérdida económica que sufren los titulares de derechos a causa de la excepción, de tal modo que no serán parte de la explotación normal de la obra aquellas utilizaciones por las cuales el titular no esperaría normalmente ganar una remuneración ${ }^{400}$. Sin embargo, esta visión puede dar un resultado inadecuado porque esta visión empírica o cuantitativa, que se correspondería con la explotación habitual en un mercado determinado, otorga un marcado carácter "economicista" $" 401$ a este factor.

\footnotetext{
${ }^{399}$ OMC, Informe..., cit., p. 51.

${ }^{400}$ Ibídem, p. 53.

${ }^{401}$ Esta es la postura que, en definitiva, inspira el texto del Informe, aun cuando se haga referencia al enfoque normativo. Éste señala: "Consideramos que una excepción o limitación de un derecho exclusivo en la legislación nacional llega a atentar contra una explotación normal de la obra (es decir, el derecho de autor o más bien todo el conjunto de derechos exclusivos conferidos por el derecho de autor), si las utilizaciones, que en principio están comprendidas en ese derecho pero se hallan exentas en virtud de la excepción o a la limitación, entran en competencia económica con las formas en que los titulares de
} 
De ahí que también el Grupo Especial, en su interpretación de este paso, atienda al sentido normativo que aporta la acepción del vocablo normal de "ajustarse a un tipo o norma”. Al añadir este significado, es posible tomar en consideración la evolución tecnológica y del mercado, permitiendo examinar, además de las formas de explotación que generan actualmente ingresos importantes o apreciables, las formas de explotación que, con cierto grado de probabilidad y plausibilidad podrían adquirir considerable importancia económica o práctica.

En definitiva, el Grupo Especial consideró que para que se produzca un atentado a la explotación normal de la obra, las limitaciones o excepciones establecidas en la legislación nacional tienen que entrar en competencia económica con la forma en que los titulares de derechos consiguen normalmente un valor económico por la explotación de su obra, que los despoja de percibir utilidades comerciales importantes o apreciables $^{402}$.

Valga agregar que la interpretación normativa de este paso del test ha hecho que algún sector de la doctrina defienda que pueda atenderse en este punto del análisis a intereses diferentes de los intereses económicos de los autores, dando cobertura al interés general o a los intereses sociales y culturales ${ }^{403}$. En tal sentido, la normal explotación de la obra no estaría constreñida únicamente a los mandatos del mercado, si bien hay que advertir que esta interpretación se opone a la interpretación tradicional de la segunda etapa, normalmente volcada en el análisis económico ${ }^{404}$.

derechos consiguen normalmente un valor económico de su derecho de la obra (es decir, el derecho de autor) y por lo tanto los priva de percibir utilidades comerciales importantes o apreciables". Sobre esta interpretación vid. GARROTE FERNÁNDEZ-DíEZ, I., "Artículo 9", en BERCOVITZ RODRÍGUEZ-CANO, R. (Coord.), Comentarios al Convenio de Berna..., op. cit., p. 775; LUCAS, A. y CÁMARA ÁGUILA, Mª del $\mathrm{P}$., "Por una interpretación razonable de la regla de los tres pasos, o por qué hay que evitar la imprecisión: Un estudio sobre la 'Declaración por una interpretación equilibrada de la regla de los tres pasos en derecho de autor'”, Pe. I. Revista de Propiedad Intelectual, núm. 33, 2009, p. 28.

${ }^{402}$ LIPSZYC, D., Nuevos temas de derechos de autor..., op. cit., p. 96.

403 Garrote FernándeZ-DíEZ, I., "Artículo 9", en BERCOVITZ RodríGUEZ-CANO, R. (Coord.), Comentarios al Convenio de Berna..., op. cit., pp. 775-776.

${ }^{404}$ LuCAS, A. y CÁMARA ÁGUILA, M ${ }^{\mathrm{a}}$. del P., "Por una interpretación razonable...”, p. 28. Señalan además estos autores que incluso quienes se muestran favorables por conjugar los intereses económicos con otros intereses en el examen de la prueba de las tres etapas convienen en reservar el análisis de las consideraciones económicas para el tercer paso, Ibídem, p. 29. En cambio, en la doctrina también se 
Finalmente, el tercer paso del triple test radica en no causar un perjuicio injustificado a los intereses legítimos del autor. El análisis que hizo el Grupo Especial se centró, consecuentemente, en definir los "intereses" de los titulares de los derechos y determinar cuáles son las características que los hacen "legítimos", para luego realizar una interpretación del término "perjuicio" y en qué medida alcanza un nivel que pueda considerarse "injustificado"

Así, el término “intereses” en su sentido corriente ${ }^{406}$, a juicio del Grupo Especial, "no se limita necesariamente a una ventaja o un detrimento económico real o potencial". El vocablo "legítimo", por su parte, "se refiere al carácter lícito en una perspectiva jurídica positivista, pero también tiene una connotación de legitimidad en una perspectiva más normativa, en el contexto de exigir la protección de intereses que se justifican habida cuenta de los objetivos de protección de los derechos exclusivos”. El "perjuicio", finalmente, “connota daño, detrimento o lesión”. Y finalmente, el calificativo de "no injustificado" evoca un umbral ligeramente más estricto que "justificado", esto es, "proporcionado", "dentro de los límites de la razón, ni mucho menor ni mucho mayor de lo que podía considerarse probable o apropiado", o "de un monto o tamaño justo, promedio o considerable".

Según el Grupo Especial dichos intereses legítimos del autor podían relacionarse con el valor económico de sus derechos exclusivos, lo que podía calcularse en función de las licencias ${ }^{407}$, reconociendo, no obstante, que esta resultaba ser una visión sesgada. Finalmente concluyó que "el perjuicio de los intereses legítimos de los titulares de derechos llega a un nivel injustificado si una excepción o limitación causa o puede

apuesta por la apreciación del componente normativo en el segundo paso del test, lo que tiene como consecuencia que un límite no sea rechazado en esta fase por el sólo hecho de suponer "un recorte no sustancial al monopolio económico del autor si existe una motivación normativa suficiente para dicho recorte". GARRote FernándeZ-DíEz, I., “Artículo 9”, en BERCOVITZ RodRíGUEZ-CANO, R. (Coord.), Comentarios al Convenio de Berna..., op. cit., p. 781.

${ }^{405} \mathrm{OMC}$, Informe..., cit., p. 65.

${ }^{406}$ El Grupo Especial recoge en su informe que "El sentido corriente del término "intereses" puede abarcar un derecho o título legal a un bien o el uso o beneficio de un bien (inclusive la propiedad intelectual). También puede referirse a un posible detrimento o ventaja, y más generalmente a algo que es de cierta importancia para una persona física o jurídica”, Ibídem, p. 66.

407 Ídem. 
causar una pérdida de ingresos injustificada al titular del derecho de autor" ${ }^{208}$. En definitiva, parece ser que lo que se valora es la pérdida de rendimientos patrimoniales.

Desde la doctrina, en cambio, se ha defendido que los intereses legítimos no sólo incluyen los intereses patrimoniales, sino también los intereses morales ${ }^{409}$. Esta postura resulta más adecuada, pues debe considerarse que los intereses legítimos son aquellos que el propio $\mathrm{CB}$ protege y no debe perderse de vista que la protección del art. 6.bis del CB también alcanza a las facultades morales. Sin embargo, esta visión no es siempre compartida $^{410}$.

Además, la idea de proporcionalidad también está latente en el análisis de esta etapa del test, en el sentido de que tiene que haber un equilibrio entre la pérdida del monopolio que sufre el autor y la ventaja que representa el límite para los usuarios de las creaciones intelectuales protegidas. Aquí resultan relevantes los objetivos de política legislativa que persiga el legislador que, si bien son diferentes en cada país, tendrán que servir para justificar, suficientemente, la existencia de la excepción ${ }^{411}$.

Por otra parte, es importante considerar que es posible fijar una compensación equitativa a favor del autor que contribuya a mitigar los efectos causados sobre sus derechos exclusivos por los límites establecidos legalmente. La compensación constituye así un mecanismo para hacer que el perjuicio causado al titular de derechos sea "justificado o proporcionado" 412 . Se trata de una fórmula que ha sido contemplada por el legislador de la UE en diferentes preceptos de la DDASI. En efecto, los apartados a), b) y e) del art. 5.2 de la DDASI establecen una compensación obligatoria como requisito imprescindible en el caso de que la legislación nacional admita el límite

\footnotetext{
${ }^{408}$ Ibídem, p. 67.

409 GARrote FERnÁndez-DíEZ, I., “Artículo 9”, en BERCOVITZ RodríGUEZ-CANO, R. (Coord.), Comentarios al Convenio de Berna..., op. cit., p. 782; LuCAS, A. y CÁMARA ÁGuIlA, M". P., "Por una interpretación razonable...", op. cit., p. 20.

410 CASAS VAllÉs, R., “Artículo 40 bis”, en BerCOVITZ RodRÍGUEZ-CANO, R. (Coord.), Comentarios a la Ley de Propiedad..., $3^{\mathrm{a}}$ ed., op. cit., p. 706.

411 Garrote Fernández-DíEz, I., "Artículo 9", en Bercovitz RodríGuez-CANo, R. (Coord.), Comentarios al Convenio de Berna..., op. cit., p. 784.

${ }^{412}$ Ibídem, p. 786.
} 
asociado a las reproducciones reprográficas, la copia privada y la reproducción de radiodifusiones, respectivamente.

No obstante, la compensación no siempre salvará el establecimiento de un determinado límite. Los intereses del autor han de ser vistos más allá del aspecto patrimonial, pues de lo contrario se vaciarían de contenido sus facultades exclusivas, convirtiéndose el derecho exclusivo en un mero derecho compensatorio o remuneratorio, similar a un derecho de crédito, en contra del fundamento de la propiedad intelectual. Por ello, se afirma que la "remuneración es un recurso excepcional que permite 'salvar' un límite que, en otro caso, no superaría la tercera parte de la prueba por causar un perjuicio excesivo a los legítimos intereses de los titulares de derechos" ${ }^{\prime 13}$.

En todo caso, el Informe del Grupo Especial de la OMC adopta en su razonamiento una visión económica de la prueba de los tres pasos, probablemente como resultado del propio marco interpretativo de la norma (el Acuerdo sobre los ADPIC es un acuerdo comercial) y del contenido económico de las excepciones analizadas. Esta interpretación ha sido criticada fundamentalmente por no tener en cuenta las implicaciones socio-culturales de los derechos de propiedad intelectual, lo que permitiría un mayor margen de maniobra a los legisladores nacionales en la adaptación de las excepciones a las cambiantes circunstancias del desarrollo tecnológico ${ }^{414}$. Sin embargo, la interpretación dada a la regla de los tres pasos en dicho Informe ha proporcionado, sin duda, una guía para la comprensión de los pasos del test, esto es, para el establecimiento e interpretación de las de excepciones o limitaciones a los derechos de propiedad intelectual.

${ }^{413}$ Ibídem, p. 788.

${ }^{414}$ En este sentido, De Miguel Asensio, P. A., Derechos..., op. cit., p. 68. 


\subsubsection{La prueba de los tres pasos y el fair use}

La doctrina norteamericana del fair use parece que colisiona con la regla de los tres pasos, por cuanto, como sistema abierto de límites, resulta de difícil encaje en el primer escalón del test: “determinados casos especiales". En efecto, el carácter "leal" del uso no parece que sea, en principio, suficiente para ser considerado un caso especial, pues la determinación de tal lealtad tiene que realizarse en función de si el uso está ligado a un propósito determinado que responda a los criterios seguidos por las otras dos etapas de la prueba de los tres $\operatorname{pasos}^{415}$.

Por ello, para entender satisfecha la primera fase de esta prueba, el Grupo Especial estableció que no es necesario que queden identificadas explícitamente todas y cada una de las situaciones a las que podría aplicarse una excepción, siempre que su alcance sea conocido o particularizado ${ }^{416}$. En consecuencia, no hay por qué negar que el fair use sea acorde con la primera condición del test, pues esta doctrina la conforman unos criterios que permiten evaluar el uso justo y su aplicación por la jurisprudencia norteamericana permite conocer el alcance de esta excepción general a los derechos de autor.

Además, conforme al fair use, en el análisis de un determinado conflicto el juez tiene que evaluar el propósito y el carácter de la utilización que se hace de la obra o prestación intelectual por lo que, en definitiva, está valorando si el uso obedece a un "caso especial", en el sentido de estar justificado por un objetivo no arbitrario, es decir, un uso justo o leal, de acuerdo a los propios fines que la ley reconoce (crítica, comentario, reportaje informativo.... $)^{417}$. Téngase en cuenta que en la interpretación que hace el Grupo Especial no se exige más que un cierto grado de certidumbre jurídica ${ }^{418}$, que puede ser alcanzada aun faltando una mención expresa en la ley a límites puntuales.

\footnotetext{
415 OMPI (Comité Permanente de Derecho de Autor y Derechos Conexos), Estudio sobre las limitaciones y excepciones relativas al derecho de autor y a los derechos conexos en el entorno digital [SCCR/9/7], preparado por RICKETSON, S., Ginebra, 2003, p. 74, disponible en: http://www.wipo.int/edocs/mdocs/copyright/es/sccr_9/sccr_9 7.pdf (consultado: 15/08.2017).

${ }^{416} \mathrm{OMC}$, Informe ..., cit., p. 37.

${ }^{417}$ Sección 107 de la Digital Millennium Copyright Act (DMCA), Pub. L. No. 105-304, 112 Stat. 2860 (Oct. 28, 1998).

418 Ídem.
} 
En este sentido, como argumento para entender que la doctrina del fair use no se opone al primer paso del test se ha esgrimido que a Estados Unidos no se le exigió modificar su legislación de propiedad intelectual para adherirse al CB, lo que no quiere decir que se acepte unánimemente que esta doctrina satisface esta etapa de la mencionada prueba ${ }^{419}$.

Por el contrario, parece más acertada la opinión en la doctrina de que el fair use no contraviene la segunda y tercera etapas de la prueba de los tres pasos (no entrar en conflicto con la explotación normal de la obra y no causar un perjuicio injustificado a los intereses legítimos de los titulares de derechos de autor). De hecho, el fair use exige que se evalúe la finalidad y el carácter del uso, la naturaleza del contenido protegido, la cantidad o sustancialidad de la parte usada en relación con la obra protegida como conjunto, y el efecto sobre el mercado potencial y sobre el valor de la obra protegida, cuestiones éstas que, en definitiva, están presentes en el análisis de la segunda y la tercera etapas del test. Por ejemplo, cuando el juez valora si se trata de un uso comercial o no comercial, o si la explotación de la obra causa un daño al mercado potencial o a su valor, está evaluando las exigencias que impone el segundo paso del test. Asimismo, el "uso leal" conlleva excluir un uso que cause un perjuicio injustificado a los legítimos intereses del autor, si bien es cierto que en este análisis el fair use, a diferencia de la prueba de los tres pasos, no se preocupa por los intereses morales de los autores.

Con todo, puede decirse que la prueba de los tres pasos no es, pues, un obstáculo para la doctrina del fair use ${ }^{420}$ siendo el juez, más que el legislador, el que tiene a su disposición la misma como criterio de interpretación en el examen de la lealtad del uso hecho de la obra ajena, sin autorización de su titular.

\footnotetext{
${ }^{419}$ Así lo explica LóPEZ MAZA, S., Limites al derecho de reproducción ..., op. cit., pp. 65-66.

${ }^{420}$ SenftLeben, M., "The International Three-Step Test: A Model Provision for EC Fair Use Legislation”, JIPITEC, núm. 1, 2010, p. 76.
} 


\subsubsection{La prueba de los tres pasos en la DDASI y en el ordenamiento jurídico español}

La prueba de los tres pasos, como se ha expuesto, tiene su expresión en diferentes textos internacionales, así como en el art. 5.5 de la DDASI y en el art. 40.bis del TRLPI. No obstante, se discute si esta prueba es un instrumento dirigido únicamente al legislador nacional -que tendrá que tenerla en consideración a la hora de establecer los límites legales a los derechos de propiedad intelectual-, o si, por el contrario, es un instrumento de interpretación para los tribunales, que podrán recurrir a la misma para valorar si unos hechos concretos están amparados en el tenor de la excepción.

Esto es, sin lugar a dudas, de gran importancia. En efecto, admitir que los tribunales puedan hacer uso de esta regla en la resolución de un caso determinado facilitaría una interpretación más flexible de los límites a los derechos de propiedad intelectual. Ahora bien, tanto al amparo de la DDASI como del TRLPI, inclinarse por esta postura implica enfrentarse a la propia esencia de un sistema cerrado de excepciones o limitaciones que determina que éstas no sean otras que las taxativamente establecidas en la ley. Y es que, de hecho, bajo un sistema cerrado de límites como el de España, en el que su interpretación es restrictiva (ex. art. 2 en relación con el art. 17 del TRLPI), no parece, en principio, que haya cabida para que los tribunales realicen una interpretación analógica de las excepciones y limitaciones a los derechos de propiedad intelectual establecidas en la ley o para que creen nuevas excepciones al margen de las $\operatorname{tasadas}^{421}$. En efecto, tanto el orden constitucional español ${ }^{422}$ como el art. 1.1 del CC

\footnotetext{
${ }^{421}$ Entre otros, Garrote FernándeZ-Díez, I., "Artículo 9", en Bercovitz RodríGueZ-Cano, R. (Coord.), Comentarios al Convenio de Berna ..., op. cit., p. 770 y BERCovitZ RodríGUEZ-CANO, R., "La regulación legal de los límites en las legislaciones comunitarias y española", en O'CALLAGHAN, X. (Coord.), Los derechos de propiedad intelectual en la obra audiovisual, Dykinson, Madrid, 2011, p. 340. Asimismo, destaca CASAS VAllÉs, R., "Artículo 40 bis", en BERCovitz RodRíGuez-CANo, R. (Coord.), Comentarios a la Ley de Propiedad..., $4^{\mathrm{a}}$ ed., op. cit., p. 814: "sería un error pensar que la aplicación de la prueba permite reconfigurar el sistema de límites, más allá de la interpretación y aplicación de las normas concretas. La prueba no podrá usarse para eliminar límites que el legislador ha recogido ni para enmendar abiertamente la forma en que lo ha hecho".

${ }^{422} \mathrm{La}$ potestad legislativa corresponde a las Cortes Generales, según establece el art. 66.2 de la Constitución española.
} 
prohíben la creación judicial del Derecho. Sin embargo, como se verá, en el TRLPI la regla de los tres pasos parece formularse como una regla dirigida al juez, de carácter interpretativo $^{423}$.

Desde la perspectiva del Derecho de la UE no existen dudas acerca de que, estando codificada la regla de los tres pasos en el art. 5.5 de la DDASI, las legislaciones de los Estados miembros tienen que establecer sus excepciones a los derechos de propiedad intelectual siguiendo la misma, esto es, respetando el triple test, aun cuando la ley del Estado miembro en cuestión no lo incorpore expresamente ${ }^{424}$. Asimismo, la ausencia de trasposición no salva al juez nacional de la obligación de interpretar la ley interna de acuerdo con el art. 5.5 de la DDASI ${ }^{425}$. Tampoco existen dudas sobre la interpretación restrictiva de los límites a los derechos de propiedad intelectual, siendo la regla contenida en el art. 5.5 de la DDASI una medida para el control de las limitaciones contenidas en la misma ${ }^{426}$, sin que vaya en contra de una interpretación conforme al tenor y sentido de la norma que contenga la excepción que se analice en el caso enjuiciado, en concreto ${ }^{427}$.

\footnotetext{
${ }^{423}$ Sobre la naturaleza de la regla de los tres pasos como regla interpretativa vid. XIOL Ríos, J. A., "La regla de los tres pasos en la jurisprudencia española", en O'CALlaghan, X. (Coord.), Los derechos de propiedad intelectual en la obra audiovisual, Dykinson, Madrid, 2011, pp. 377 y ss.

${ }^{424}$ Alemania, Reino Unido, Bélgica y Holanda son ejemplos de la no incorporación de la regla de los tres pasos en su legislación interna.

${ }^{425}$ Entre otros, LuCAS, A. y CÁMARA ÁGUILA, Ma . P., "Por una interpretación razonable...", op. cit., p. 17; y CASAS VAllés, R., "Artículo 40 bis", en Bercovitz Rodríguez-CANo, R. (Coord.), Comentarios a la Ley de Propiedad..., $4^{\mathrm{a}}$ ed., op. cit., p. 813.

${ }^{426}$ Así se deduce de la STJUE (Sala Cuarta), de 16 de julio de 2009, Infopaq International A/S y Danske Dagblades Forening, en el asunto C-5/08 [ECLI:EU:C:2009:465], en el que el tribunal recuerda que, según consolidada jurisprudencia "las disposiciones de una directiva que constituyen una excepción a un principio general establecido por esa misma directiva se han de interpretar restrictivamente" (párrafo 56), y señala en el análisis de la aplicación del art. 5.1 de la DDASI al caso concreto "máxime habida cuenta que dicha excepción debe interpretarse a la luz del artículo 5, apartado 5, de la Directiva 2001/29, que establece que se aplicará únicamente en determinados casos concretos que no entren en conflicto con la explotación normal de la obra o prestación y no perjudiquen injustificadamente los intereses legítimos del titular del derecho" (apartado 58). Otros asuntos posteriores del TJUE confirman igualmente esta interpretación. Así, por ejemplo, los asuntos acumulados C-403/08 y C-429/08, STJUE (Gran Sala), de 4 de octubre de 2011, Football Association Premier League Ltd y otros contra QC Leisure y otros y Karen Murphy contra Media Protection Services Ltd [ECLI:EU:C:2011:631]; y el asunto C-145/10, STJUE (Sala Tercera), de 1 de diciembre de 2011, Eva-Maria Painer contra Standard VerlagsGmbH y otros [ECLI:EU:C:2011:798]. Vid. CASTELló PASTOR, J. J., Motores de búsqueda ..., op. cit., pp. 156-158.

${ }^{427}$ Garrote FernándeZ-DíEz, I., "Artículo 9", en Bercovitz Rodríguez-CANO, R. (Coord.), Comentarios al Convenio de Berna..., op. cit., p. 813.
} 
En España, en particular, la regla de los tres pasos difiere de la formulación expresa contenida en el $\mathrm{CB}$, por cuanto se elimina la referencia a "determinados casos especiales", si bien se remite a las limitaciones recogidas en los preceptos contenidos en el Capítulo II del Título III del TRLPI, por lo que precisa, en definitiva, los supuestos a los que se aplica esta regla. Asimismo, se invierte el orden de los otros dos pasos, esto es, se mencionan, en primer término, los intereses legítimos y seguidamente, la explotación normal de la obra. En efecto, el art. 40.bis del TRLPI está redactado como sigue:

"Los artículos del presente capítulo no podrán interpretarse de manera tal que permitan su aplicación de forma que causen un perjuicio injustificado a los intereses legítimos del autor o que vayan en detrimento de la explotación normal de las obras a que se refieran".

La doctrina se ha cuestionado si permite una interpretación global del test la inversión del segundo y tercer paso. No obstante, debe concluirse que dicha inversión no tiene como objetivo facilitar una interpretación global de la regla de los tres pasos, derogando la interpretación paso a paso ${ }^{428}$, pues la redacción del precepto obedece, más bien, a que dicha regla fue incorporada a la legislación nacional ${ }^{429}$, siguiendo la Directiva 91/250/CEE, de 14 de mayo de 1991, sobre la protección jurídica de programas de ordenador, más que el $\mathrm{CB}^{430}$.

Por otra parte, conforme al tenor literal del art. 40.bis del TRLPI, es de advertir que la expresión "no podrán interpretarse de manera tal" -refiriéndose a la regulación de los límites contenidos en la ley- permite considerar que el test se dirige al juez ${ }^{431}$. No se trata de que el juez tenga la posibilidad de derogar los límites establecidos en los arts. 31 a 39 del TRLPI o de que pueda excluir de estos límites conductas fácilmente

\footnotetext{
${ }^{428}$ CASAs Vallés, R., "Artículo 40 bis", en Bercovitz Rodríguez-CANO, R. (Coord.), Comentarios a la Ley de Propiedad..., $3^{\mathrm{a}}$ ed., op. cit., pp. 670-671.

${ }^{429}$ Vid. supra, epígrafe 4.1.3, in fine.

${ }^{430} \mathrm{El}$ art. 6.3 de la Directiva 91/250/CEE del Consejo, de 14 de mayo de 1991, sobre la protección jurídica de programas de ordenador señalaba: "De acuerdo con las disposiciones del Convenio de Berna para la protección de obras literarias y artísticas, las disposiciones del presente artículo no podrán interpretarse de manera que permitan que su aplicación perjudique de forma injustificada los legítimos intereses del titular de los derechos o sea contraria a una explotación normal del programa informático". 431 Garrote Fernández-DíEZ, I., "Artículo 9", en Bercovitz RodrígueZ-CANo, R. (Coord.), Comentarios al Convenio de Berna..., op. cit., p. 823.
} 
inscribibles en estos preceptos, sino de comprobar, en el análisis de la conducta concreta, si el límite enjuiciado no perjudica de forma injustificada los intereses de los titulares del derecho, ni causa un daño a la explotación normal de la obra ${ }^{432}$. La regla de los tres pasos se postula así, como una regla interpretativa de los preceptos contenidos en el Capítulo II del Título III del TRLPI que, a su vez, exige al juez no sólo tener en cuenta los requisitos concretos que la regla reivindica, sino también los principios, valores y derechos tomados en cuenta por el legislador para el establecimiento de los concretos límites a los derechos de propiedad intelectual que esta regla establece.

Ahora bien, en el examen de si el uso no perjudica los intereses del titular de derechos, ni la explotación normal de la obra, los tribunales han asumido dos posturas diferentes: una postura más tradicional, en la que utilizan esta regla para analizar la legitimidad de la conducta de acuerdo a los límites establecidos específicamente en la ley; y otra, más flexible, en la que entienden que el art. 40.bis del TRLPI permite acoger como lícita una actuación que no tiene un reconocimiento explícito como límite legal al derecho de propiedad intelectual, pero que se entiende que no va en contra de la explotación normal de la obra, ni perjudica los intereses legítimos de los titulares de derechos $^{433}$.

Dentro de esta última postura se inscriben, entre otras, la SAP Barcelona (Sección $15^{\mathrm{a}}$ ), de 17 de septiembre de $2008^{434}$, la SAP Barcelona (Sección $15^{\mathrm{a}}$ ), de 31 de octubre

\footnotetext{
432 Ídem.

${ }^{433}$ En uno u otro caso, sirvan como ejemplo las sentencias comentadas por GARROTE FERNÁNDEZ-DíEZ, I., “Artículo 9", en BerCovitz RodríGuEZ-CANO, R. (Coord.), Comentarios al Convenio de Berna..., op. cit., pp. 825-832, algunas de las cuales, son mencionadas explícitamente en el texto del trabajo como ejemplos de la adopción de una postura más flexible por los tribunales en la interpretación de los límites. ${ }^{434}$ ACl2008\1773. En este asunto, D. Blas interpone recurso de apelación contra la sentencia dictada por el Juzgado Mercantil núm. 5 de los de Barcelona, al ver desestimadas sus pretensiones frente a Google Spain, S.L., considerando, en lo esencial, que la demandada viola sus derechos cuando realiza una copia no autorizada de su obra, contenida en la página web que Google reproduce en la memoria "caché", sin requerir su autorización. Señala, además, la apelante en su recurso otras dos conductas infractoras: "una, consistente en las reproducciones parciales del texto de los sitios Web al presentar el resultado de la búsqueda formulada, que se lleva a cabo mostrando una pantalla con una relación de sitios Web, en que aparece el título de cada sitio, debajo del cual se reproduce un fragmento del texto del sitio en cuestión; y otra, las reproducciones de la copia caché que Google ofrece a sus usuarios y que es la misma que le ha servido para efectuar el proceso interno de selección" (F.J. $3^{\circ}$ ).
} 
de $2002^{435}$ y la SAP Madrid (Sección 14ª), de 23 de diciembre de $2003^{436}$, apreciándose en todas ellas una interpretación extensiva del alcance de las excepciones a los derechos de propiedad intelectual en aplicación del art. 40.bis del TRLPI, con la peculiaridad de que la primera de éstas, más que ampliar la interpretación del contenido de un límite concreto establecido en la ley, admite como límite una conducta que, como tal, no está prevista legalmente ${ }^{437}$.

Efectivamente, la SAP Barcelona (Sección 15 ), de 17 de septiembre de 2008 considera que no se han infringido los derechos de reproducción y comunicación púbica del demandante por el servicio caché $^{438}$ que presta la demandada, aun cuando su actuación no se pueda encuadrar explícitamente en alguno de los límites recogidos en el TRLPI. Para llegar a tal conclusión admite que el art. 40.bis del TRLPI "puede dar lugar a que, por vía interpretativa, nos cuestionemos los límites de estos derechos más allá de la literalidad de los preceptos que los regulan, positiva y negativamente, en este caso los derechos de reproducción y de puesta a disposición (comunicación)" (F.J. $4^{\text {o }}$ ). La sentencia invoca la doctrina del fair use, trayendo a colación sus pasos como guía para interpretar el alcance de la protección de los derechos de propiedad intelectual ${ }^{439}$, y declara:

"En última instancia, se trata de trasladar a la esfera de la propiedad intelectual lo que el ius usus inocui ha sido para la propiedad mobiliaria e inmobiliaria, un límite natural del derecho de propiedad, que opera sobre todo al interpretar el alcance de su protección para evitar extralimitaciones absurdas" (F.J. $\left.4^{\circ}\right)$.

\footnotetext{
435 JUR $2004 \backslash 54771$.

436 JUR\2004\90140.

${ }^{437}$ Pueden leerse algunas observaciones críticas en BERCOVITZ RODRÍGUEZ-CANO, R., "La regulación legal de los límites...", op. cit., pp. 342-343.

${ }^{438}$ La propia sentencia define al servicio caché como "complementario del servicio de motor de búsqueda de Google", que "pone a disposición del solicitante de la búsqueda, junto a los hipervínculos que remiten a los sitios Web originales, un vínculo en caché, esto es, el acceso a las copias caché realizadas en sus ordenadores por Google" (F.J. $3^{\circ}$ ).

${ }^{439}$ Vid. SÁNCHEZ ARISTI, R., “Artículo 18”, en BERCOVITZ RodRíGUEZ-CANO, R. (Coord.), Comentarios a la Ley de Propiedad..., $3^{\mathrm{a}}$ ed., op. cit., pp. 320-321; SALAS CARCELlER, A., "Los casos Google en las diferentes jurisprudencias", en O'CALLAGHAN, X. (Coord.), Los derechos de propiedad intelectual en la obra audiovisual, Dykinson, Madrid, 2011, pp. 400-401.
} 
Así, la sentencia trae al ámbito de la propiedad intelectual la doctrina del ius usus inocui (derecho al uso inocuo del derecho ajeno) ${ }^{440}$. De esta forma, es posible relativizar el carácter cerrado de la lista de excepciones a los derechos de propiedad intelectual contenida en el TRLPI. Un uso que no causa un perjuicio no debería, consecuentemente, dar lugar a una violación de los derechos de autor.

La STS (Sala de lo Civil, Sección $1^{\text {a }}$ ), de 3 abril de $2012^{441}$, que confirmó el fallo de apelación, abundó en esta doctrina. El TS considera que la referencia al fair use por la sentencia recurrida no altera el sistema de fuentes normativas, toda vez que esta doctrina es enlazada con la doctrina del uso inocuo. Reconoce que esta última doctrina no resulta ajena al ordenamiento jurídico español (F.J. $5^{\circ}$, apartado $1^{\circ}$ ) y, consecuentemente, aun partiendo de que, conforme al art. 31.1 del TRLPI, la puesta a disposición de la copia "caché" requeriría, en principio, la autorización del autor de la página web, llega a una conclusión contraria a partir del uso inocuo, contenido en el art. 40.bis del TRLPI. Señala la sentencia:

"Sin embargo no es menos cierto que el art. 40 bis LPI , como disposición común a todas las del capítulo primero del título III, en el que se encuadra el art. 31, tiene un valor interpretativo no solo y exclusivamente negativo ("Los artículos del presente capítulo no podrán interpretarse..."), sino también positivo, en cuanto enuncia los principios que justifican la propia excepcionalidad de los límites o, si se quiere, la necesidad de la licencia del autor como regla general ("perjuicio injustificado a los intereses legítimos" o "detrimento de la explotación normal de las obras" ). Esto permite que la denominada regla, prueba o test "de los tres pasos" contenida en el art. 40 bis pueda considerarse como manifestación especial en la LPI de la doctrina del ius usus inocui del principio general del ejercicio de los derechos conforme a las exigencias de la buena (art. 7.1 CC), del principio asimismo general de la prohibición del abuso del derecho o del ejercicio antisocial del mismo (art. 7.2 CC) y de la configuración constitucional del derecho de propiedad como derecho delimitado, lo que a su vez exige, en caso de litigio, que el tribunal analice la concreta pretensión del autor demandante para comprobar si en verdad la reproducción puede causar algún perjuicio a sus intereses

\footnotetext{
${ }^{440}$ La doctrina del "uso inocuo" es definida por GARROTE FERNÁNDEZ-DíEZ, I., “Artículo 9", en BerCovitz RodríGuez-CANo, R. (Coord.), Comentarios al Convenio de Berna..., op. cit., p. 829, como “imposibilidad para el autor de prohibir actos de explotación que no supongan ningún perjuicio en sus intereses patrimoniales o morales". Sobre la definición de uso inocuo, véase también, LóPEZ DE HARO, "El ius usus inocui", RDP, 1920, p. 18, cit. por GONZÁlEZ DE ALAIZA CARDONA, J. J., La copia privada. Sus fundamentos..., op. cit., p. 119.

${ }^{441}$ RJ $2012 \backslash 5272$.
} 
"legítimos", por remoto o indirecto que sea este perjuicio, o bien atentar contra la explotación "normal" de su obra, o, por el contrario, favorece esos mismos intereses y esa misma explotación "normal", pues de suceder esto último la pretensión formalmente amparada en la letra del art. 31 LPI y en el carácter cerrado de un sistema de excepciones carecerá de amparo en el ordenamiento jurídico por estar dirigida en realidad no a la protección del derecho de autor, finalidad del catálogo exhaustivo o cerrado de excepciones, sino a perjudicar al demandado no solo sin obtener el autor provecho alguno sino incluso sufriendo él mismo el perjuicio de una menor difusión de su página web" (F.J. $5^{\circ}$, apartado $5^{\circ}$ ).

Así pues, la Sala concluye que, sin perjuicio de una interpretación restrictiva de los límites al derecho de autor, ni el art. 31.1 del TRLPI ni el art. 40.bis del TRLP son excluyentes de la doctrina del ius usus inocui (F.J. $5^{\circ}$, apartado $6^{\circ}$ ). La sentencia subraya que la aplicación de esta doctrina no significa la creación de una nueva excepción, sino que emana de la consideración de que el derecho de autor no puede perjudicar a otros de manera arbitraria; una decisión que, en definitiva, tiende a una mayor flexibilización del derecho de autor ${ }^{442}$.

Por tanto, asoma una interpretación más flexible de los límites a los derechos de propiedad intelectual, no sin objeciones, al tratarse de un sistema cerrado de límites, pero que demuestra, en definitiva, la necesidad de una aplicación menos rigurosa de estos. Lo que se pretende es no impedir conductas no previstas expresamente como límites pero que no afectan la explotación normal de la obra, ni a los intereses legítimos del autor, sobre todo, dada la velocidad vertiginosa con la que el desarrollo tecnológico nos enfrenta a circunstancias no previstas en la ley.

No obstante, la prueba de los tres pasos no parece conjugar bien con un sistema cerrado de límites ${ }^{443}$, fundamentalmente cuando lo que persigue este sistema es brindar seguridad jurídica, sin que haya una "válvula de escape" que permita a los tribunales utilizar el triple test para validar como límites conductas no establecidas expresamente por el legislador. Con todo, la interpretación más flexible que deja abierta la vía del art. 40.bis del TRLPI es acertada en la medida en que da amparo a conductas que, de otro

\footnotetext{
${ }^{442}$ SÁnChez ARISTI, R., “Artículo 17”, en BerCovitz RodríGueZ-CANO, R. (Coord.), Comentarios a la Ley de Propiedad ..., $4^{\mathrm{a}}$ ed., op. cit., p. 307.

443 Garrote FernándeZ-DíEz, I., "Artículo 9", en Bercovitz Rodríguez-Cano, R. (Coord.), Comentarios al Convenio de Berna..., op. cit., p. 829.
} 
modo, no podrían considerarse lícitas aun cuando no fueran en detrimento del autor y demás titulares de derechos.

\section{LA NECESIDAD DE REAJUSTAR EL SISTEMA DE LÍMITES A LOS DERECHOS DE PROPIEDAD INTELECTUAL EN LA UE}

\section{Hacia una aplicación menos restrictiva de los límites a los derechos de propiedad intelectual}

Las excepciones o limitaciones al derecho de autor son parte de la ratio legis de las leyes de propiedad intelectual. En tal sentido, como se ha expresado, constituyen la contrapartida misma a los derechos de autor y expresión tanto de la protección de los intereses de los titulares de derechos de propiedad intelectual, como de los de la sociedad y/o grupos concretos de ésta. La existencia de diversos intereses implicados en la regulación de los derechos de autor, muchas veces enfrentados, hace de los límites a estos derechos un inexcusable punto de atención para reajustar el equilibrio entre unos y otros. No sólo hay que velar por los intereses de los autores, sino también por los de otros grupos implicados en la difusión, circulación, explotación y uso de los contenidos protegidos por las normas de propiedad intelectual.

Ahora bien, las reglas en que se funda este equilibrio no son siempre idénticas, pues mientras los países de tradición anglosajona dan una mayor flexibilidad al encuadre de ciertas conductas dentro de los límites a los derechos de autor, los países de tradición continental apuestan por un sistema de límites cerrado que restringe las posibilidades de considerar una conducta como excepción al derecho de autor cuando no está contemplada en la norma, pero que tiene, en cambio, la ventaja de la previsibilidad. Es decir, sólo aquellas conductas expresamente previstas en la ley pueden invocarse en defensa de un determinado uso no autorizado previamente por el titular de derechos. 
Como resultado, en el sistema continental sucede, normalmente, que el expreso tenor de la norma impide que usos nuevos de las obras y prestaciones intelectuales producidos fundamentalmente en el entorno de Internet y diferentes de los regulados como límites a los derechos de autor- encuentren respaldo como excepciones, convirtiéndose así en conductas infractoras ${ }^{444}$. Por tanto, sólo si se permitiese una interpretación flexible de estas excepciones en sede judicial, mediante una aplicación de la regla de los tres pasos no orientada únicamente a restringir el alcance de los límites ya regulados, sería posible admitir como lícitas determinadas conductas no previstas por el legislador y ampliar el alcance de aquellas ya establecidas. Sería, de hecho, una manera de "abrir" el sistema cerrado de límites a los derechos de propiedad intelectual en el ámbito de la UE para adaptarlo a las circunstancias del desarrollo tecnológico. Esta ha sido, en efecto, la postura que asoma en algunas sentencias españolas que abogan por una interpretación más flexible de los límites a los derechos de propiedad intelectual ${ }^{445}$.

Además, esto no sucede así exclusivamente en España. Como es de esperar, en otros países de la UE también se han dictado sentencias, incluso con anterioridad, que se inclinan hacia la consideración de un uso justo de las creaciones intelectuales a partir de una interpretación más flexible de la regla de los tres pasos, en defensa del interés social, cultural y económico general. Se citan así en la doctrina diversos ejemplos, entre ellos, la sentencia del Tribunal Supremo de los Países Bajos (Hoge Raad), de 20 de octubre de 1995, en el asunto Dior vs. Evora ${ }^{446}$. En este asunto, la necesidad de resguardar el equilibrio de intereses más allá de los estrictos límites de las excepciones fijadas en la norma y no siendo ninguna de las excepciones previstas aplicables al caso, hizo que el tribunal no considerara infracción a los derechos de propiedad intelectual la reproducción de la imagen de frascos de perfume en los anuncios de un minorista para

\footnotetext{
${ }^{444}$ Téngase en cuenta que, aun cuando la DDASI da un amplio margen a los Estados miembros para aplicar las excepciones que establece, se trata de una lista exhaustiva, con lo cual, el legislador nacional podrá ser más restrictivo que el europeo en la regulación del alcance de las excepciones, pero no podrá introducir o mantener excepciones que no figuren en la lista.

${ }^{445}$ Sirvan como ejemplo de lo anterior, en el ámbito nacional, la SAP Barcelona (Sección 15a), de 17 de septiembre de 2008 y la STS (Sala de lo Civil, Sección 1ª), de 3 abril de 2012, antes referenciadas.

${ }^{446}$ Dior v. Evora, Dutch Supreme Court (Hoge Raad) 20 October 1995, [1996] Nederlandse Jurisprudentie 682.
} 
la venta de productos importados ${ }^{447}$. Valga mencionar que la trascendencia de este caso fue tal que inspiró al Comité Holandés de Derecho de Autor (órgano consultivo del Ministerio de Justicia), a proponer la adopción de una disposición abierta en la ley que contemplara la posibilidad de admitir usos no autorizados expresamente con tal de que fueran compatibles con el art. 9.2 del CB.

Otro ejemplo de la flexibilización en la aplicación estricta de los límites -esta vez inspirado en la defensa de las libertades fundamentales- lo constituye la sentencia del Tribunal Federal Constitucional de Alemania, de 29 de junio de $2000^{448}$. En ésta, la aplicación estricta del límite de cita (invocado para permitir la utilización de extensas citas de obras de Berthold Brecht), vino mitigada por la libertad de expresión artística amparada en el art. 5.3 de la Constitución alemana. El tribunal admitió que las limitaciones debían reflejar el pertinente equilibrio de intereses y que, por tanto, los intereses económicos de los titulares de derechos de autor debían ceder frente a tal libertad de expresión artística ${ }^{449}$.

Es importante destacar, por otra parte, en el marco de la jurisprudencia de la UE, que el criterio de interpretación restrictiva de las excepciones que puso de relieve la STJUE (Sala Cuarta), de 16 de julio de $2009^{450}$ se ha ido atenuando para dar cobertura a otras consideraciones como la salvaguarda del efecto útil de la excepción establecida y el respeto a su finalidad ${ }^{451}$. En reconocimiento de lo anterior, la STJUE (Gran Sala), de 4 de octubre de 2011, refiriéndose al límite para las reproducciones provisionales contemplado en el art. 5.1 de la DDASI precisaba:

${ }^{447}$ Hugenholtz, P. B. y Senftleben, M., "Fair use in Europe. In search of flexibilities", Amsterdam Law School Research Paper No. 2012-39, p. 10, disponible en: https://papers.ssrn.com/sol3/papers.cfm?abstract_id=1959554 (consultado: 13.03.2017).

${ }_{448}$ Germania 3 Gespenster am toten Mann, Federal Constitutional Court 29 June 2000, Zeitschrift für Urheber- und Medienrecht (ZUM), 2000, p. 867.

${ }^{449}$ Hugenholtz, P. B. y Senftleben, M., "Fair use in Europe...", op. cit., p. 11. Estos autores mencionan, además, otros asuntos que podrían ser consultados como referencia (pp. 11-12).

${ }^{450}$ Infopaq International A/S y Danske Dagblades Forening, cit., párrafo 56.

${ }^{451}$ STJUE (Gran Sala), de 4 de octubre de 2011, Football Association Premier League Ltd y otros contra QC Leisure y otros y Karen Murphy contra Media Protection Services Ltd (asuntos acumulados C-403/08 y C-429/08), [ECLI:EU:C:2011:631], párrafo 163 y STJUE (Sala Tercera), de 1 de diciembre de 2011, Eva-Maria Painer contra Standard VerlagsGmbH y otros (asunto C-145/10), [ECLI:EU:C:2011:798], párrafo 133. 
“Así pues, con arreglo a su objetivo, esta excepción debe permitir y garantizar el desarrollo y el funcionamiento de nuevas tecnologías y mantener un justo equilibrio entre los derechos e intereses de los titulares de derechos, por una parte, $\mathrm{y}$ de los usuarios de obras protegidas, que desean disfrutar de esas nuevas tecnologías, por otra" (párrafo 164).

Consecuentemente, es posible apreciar cómo la interpretación estricta se abre a un enfoque teleológico que permite mitigar una aplicación demasiado limitada de las excepciones preceptuadas en la DDASI ${ }^{452}$.

Del mismo modo, la STJUE (Sala Cuarta), de 11 de septiembre de $2014^{453}$ cuestiona si el art. 5.3, letra n) de la DDASI permite que los Estados miembros concedan el derecho a digitalizar las obras que figuren en las colecciones de bibliotecas, centros de enseñanza o museos accesibles al público, o por archivos, que no tengan intención de obtener un beneficio económico o comercial directo o indirecto (la digitalización constituye un acto de reproducción), si este acto de reproducción es necesario para poner tales obras a disposición de los usuarios, a través de terminales especializados en los locales de esos establecimientos, aun cuando el art. 5.3, letra n) de la DDASI restringe el uso de la obra, a efectos de esta disposición, únicamente a los supuestos de comunicación de obras al público. En este caso el tribunal concluye, con una interpretación extensa de esta excepción en relación con el art. 5.2, letra c) de la DDASI, que tal digitalización es admisible ${ }^{454}$.

Con todo, esta necesidad de facilitar una aplicación menos restrictiva de los límites a los derechos de propiedad intelectual que paulatinamente se ha ido evidenciando en el panorama europeo ha provocado que, actualmente, se cuestione la pertinencia de un sistema cerrado de límites por la rigurosidad en su aplicación restrictiva, así como por su falta de flexibilidad para adaptarse a los rápidos cambios que generan la evolución tecnológica y el uso de Internet. La propia seguridad jurídica que se proclama a favor de este sistema resulta cuestionable a causa de las diferentes

\footnotetext{
452 Triaille, J. P. (Ed.), Study on the application of Directive 2001/29/EC on Copyright and Related Rights in the Information Society, European Commission, 2013, p. 252.

${ }^{453}$ Technische Universität Darmstadt vs. Eugen Ulmer KG, asunto C-117/13 [ECLI:EU:C:2014:2196].

${ }^{454}$ Ibídem, párrafo 49, en relación con los párrafos precedentes que justifican la aludida conclusión (párrafos del 36 al 48).
} 
posturas que han ido asumiendo algunos tribunales nacionales europeos, unas veces bajo criterios más inflexibles, otras veces más abiertos, como resultado de la aplicación más o menos restrictiva de la regla de los tres $\operatorname{pasos}^{455}$.

Así, no faltan voces en la doctrina que apuestan por una flexibilización del sistema cerrado de límites a los derechos de propiedad intelectual ${ }^{456}$ y no precisamente a partir del abandono de este sistema, sino a partir de la redefinición de estos límites mediante la combinación de la enumeración de las excepciones en la ley y la utilización de la regla de los tres pasos como instrumento para que el juez dé cobertura a excepciones que no atenten contra la normal explotación de la obra, ni causen un perjuicio injustificado a los legítimos intereses del autor. En tal sentido, el art. 5 de la DDASI se convertiría en una norma semi-abierta que conjugaría el catálogo de excepciones previstas expresamente, con la posibilidad de declarar, judicialmente, determinados usos como no infractores, siempre que respeten la segunda y tercera condiciones de la prueba de las tres etapas, antes analizadas ${ }^{457}$.

En otras palabras, no se trata de extrapolar la doctrina del fair use al Derecho de la UE, sino de ganar en flexibilidad dentro de las propias posibilidades que brinda el

\footnotetext{
${ }^{455}$ Para un análisis de distintos casos correspondientes a la jurisprudencia holandesa, francesa y alemana Vid. SenftLeben, M., "Bridging the differences between Copyright's Legal Traditions - The Emerging EC Fair Use Doctrine", Journal of the Copyright Society of the U.S.A., 2010, pp. 530-538, disponible en: https://www.researchgate.net/publication/228175162 Bridging the Differences between_Copyright\%27 s_Legal_Traditions_- The Emerging EC Fair Use Doctrine (consultado: 13.03.2017). En concreto, a través de diferentes asuntos pertenecientes a las jurisdicciones señaladas, el autor ilustra la insuficiente flexibilidad del marco europeo de las excepciones o limitaciones a los derechos de propiedad intelectual. En algunos casos, la interpretación de la regla de los tres pasos de forma demasiado restrictiva lleva a una solución inadecuada e incompatible con la realidad tecnológica actual (como en el caso de la sentencia de la Cour de Cassation francesa de 28 de febrero de 2006), mientras que otras veces es el propio catálogo cerrado de excepciones el que impide a los tribunales actuar de forma acorde al ritmo de la evolución tecnológica e Internet.

456 Vid. Hugenholtz, P. B. y Senftleben, M., "Fair use in Europe...”, op. cit., pp. 9-10. En la doctrina nacional, CARBAJO CASCÓN, F., "Desafíos de la propiedad intelectual en el «nuevo» ámbito digital. Ideas para una reforma de la LPI", Vasos Comunicantes, núm. 44, 2013, p. 69; y "Enlaces de prensa (press linking): entre la flexibilización y la regulación del derecho de autor en la era digital", Pe. $i$. Revista de Propiedad Intelectual, núm. 47, 2014, pp. 22-24; CASTEllón PAStor, J. J., Motores de búsqueda..., op. cit., p. 210.

457 SENFTLEBEN, M., "Bridging the differences...”, op. cit., p. 549.
} 
acervo comunitario ${ }^{458}$. Un acercamiento entre los sistemas abiertos y cerrados de límites no ha de verse como algo perjudicial. La prueba de las tres etapas tendría que ser percibida no sólo como un medio para reducir el alcance de ciertas excepciones establecidas legalmente a límites razonables, sino también para ampliar el alcance de las limitaciones existentes e introducir nuevos usos no reconocidos en la ley, siempre que no vayan en contra de la explotación normal de la obra, ni causen un perjuicio injustificado a los legítimos intereses del autor ${ }^{459}$. De esta manera, se garantizaría la observancia del art. 9.2 del CB y sus homólogos internacionales, al tiempo que se obtendría un marco más adecuado para garantizar el equilibrio entre los derechos de autor y los de los usuarios.

En esta línea, una propuesta muy interesante es la que acoge el Código Europeo de Derechos de Autor, elaborado por un grupo de académicos europeos en el marco del Proyecto Wittem y publicado en abril de $2010^{460}$. Este Código, cuyo objetivo es servir como referencia para la futura armonización o unificación de los derechos de propiedad intelectual a nivel europeo, aborda la regulación de las limitaciones y excepciones al derecho de autor en su Capítulo 5 integrando el sistema abierto de límites con el sistema cerrado. Para ello, enumera un conjunto de límites obligatorios en los arts. 5.1 a 5.4 y amplía, asimismo, el ámbito de usos permitidos mediante la incorporación del art. 5.5, consintiendo otros usos similares a cualquiera de los enumerados en los apartados precedentes, siempre que no sean incompatibles con la explotación normal de la obra y no causen un perjuicio injustificado a los intereses legítimos del autor o del titular de derechos, teniendo en cuenta los intereses legítimos de terceros ${ }^{461}$.

\footnotetext{
${ }^{458}$ Señalan al respecto Hugenholtz, P. B. y Senftleben, M., "Fair use in Europe...", op. cit., p. 12: "Flexibility should ideally be found inside the system of copyright proper". Véase también SENFTLEBEN, M., "Bridging the differences...", op. cit., pp. 550-551.

${ }^{459}$ SENFTLEBEN, M., "Bridging the differences...", op. cit., p. 551.

${ }^{460}$ Disponible en: http://www.copyrightcode.eu/ (consultado: 14.03.2017).

461 "Art. 5.5 - Further limitations: Any other use that is comparable to the uses enumerated in art. 5.1 to 5.4 (1) is permitted provided that the corresponding requirements of the relevant limitation are met and the use does not conflict with the normal exploitation of the work and does not unreasonably prejudice the legitimate interests of the author or rightholder, taking account of the legitimate interests of third parties".
} 
Con esta fórmula, la propuesta se decanta por un sistema mucho más flexible de límites, acorde con el reconocimiento que se hace en el propio Preámbulo al afirmar que el rápido desarrollo tecnológico hace imposible prever las futuras modalidades de explotación y utilización de las obras protegidas por el derecho de autor y, por lo tanto, reconociendo la necesidad de un sistema de derechos y limitaciones con cierta flexibilidad $^{462}$. Así, la posibilidad de ampliar las excepciones a otros usos similares proporciona al sistema la elasticidad indispensable para que estos puedan ser admitidos. Sin embargo, esta elasticidad está controlada, pues encuentra su frontera, precisamente, en que se exige que sean usos análogos a los expresamente mencionados en el Código, siempre que cumplan con las previsiones del segundo y del tercer criterio enunciados en el art. $9.2 \mathrm{CB}^{463}$.

En definitiva, más allá de las críticas y comentarios al respecto ${ }^{464}$, esta propuesta es una evidencia más de la percepción, por parte de ciertas voces autorizadas, de la necesidad de dotar al sistema actual de limitaciones y excepciones a los derechos de autor en la UE de mecanismos para su flexibilización. El proyectado Código Europeo es una clara muestra de la posibilidad de regular la materia sin recurrir a "importar" la doctrina del fair use. No persigue introducir esta doctrina, pues no permite todo tipo de usos, sino sólo los exclusivamente previstos y aquellos otros "análogos" a los estipulados en los arts. 5.1 a 5.4, sujetos a los criterios de la prueba de los tres pasos ${ }^{465}$.

\footnotetext{
462 "Recognizing: [...] that rapid technological development makes future modes of exploitation and use of copyright works unpredictable and therefore requires a system of rights and limitations with some flexibility".

${ }^{463}$ Vid. nota 48 del European Copyright Code.

${ }^{464}$ En relación con el art. 5.5 del Código Vid. GinsBurg, J. C., "European Copyright Code - Back to First Principles (with Some Additional Detail)", Columbia Public Law Research, paper núm. 11-261, 2011, pp. 26-27, disponible en: https://ssrn.com/abstract=1747148 (consultado 14.03.2017).

465 Hugenholtz, P. B., The Wittem Group's European Copyright Code, p. 351, disponible en: https://www.ivir.nl/publicaties/download/ILS_29_chapter17.pdf (consultado: 14.03.2017).
} 


\section{Por un modelo renovado y más armonizado del sistema de límites a los derechos de propiedad intelectual}

Al margen de la discusión sobre la admisión de posibles reformas para flexibilizar el sistema cerrado de límites en el Derecho de la UE para hacer frente a los continuos cambios que provocan el desarrollo de las tecnologías e Internet fundamentalmente, también es necesario reconsiderar la regulación de las limitaciones con el fin de lograr una mayor armonización, así como una actualización del modelo vigente.

En este sentido, es cierto que durante los últimos años el TJUE ha realizado una importante labor de armonización y ha servido para contribuir a una interpretación uniforme de las excepciones a los derechos de propiedad intelectual. Sin embargo, también es de resaltar que ya desde los propios orígenes de la DDASI se hacía evidente que su propuesto objetivo de armonización alcanzaba márgenes reducidos debido a la tolerancia del legislador europeo en consentir diferencias -seguramente necesariasentre las diversas regulaciones y políticas legislativas de los Estados miembros, pero que daban lugar a una parca aproximación de las legislaciones nacionales, a partir de un modelo mayoritariamente facultativo de límites. Por otra parte, los avances tecnológicos y la preocupación por la difusión del conocimiento, particularmente en el ámbito de los servicios en línea, también han exigido un examen de la normativa vigente sobre derechos de propiedad intelectual y, dentro de esta, de las excepciones aplicables a los derechos exclusivos, fundamentalmente las concernientes a bibliotecas y archivos, a la enseñanza y la investigación y a las personas con discapacidad ${ }^{466}$.

Como consecuencia, es lógico que durante los años de aplicación de la DDASI se hayan padecido los efectos de una armonización incompleta y que, a día de hoy, sea necesaria una reforma con la experiencia de casi dos décadas de vigencia de la DDASI y de la existencia un nuevo panorama tecnológico-digital.

${ }^{466}$ Este fue el objetivo del Libro Verde de la Comisión de las Comunidades Europeas sobre los Derechos de autor en la economía del conocimiento, de 16 de julio de 2008 [COM (2008) 466 final] y de las acciones anunciadas en la Comunicación de la Comisión de las Comunidades Europeas: "Los derechos de autor en la economía del conocimiento", de 19 de octubre de 2009 [COM (2009)532 final] que dio seguimiento al mismo. 
Ya la Comunicación de la Comisión al Parlamento Europeo, al Consejo, al Comité Económico y Social Europeo y al Comité de las Regiones: "Un mercado único de los derechos de propiedad intelectual. Estimular la creatividad y la innovación para generar crecimiento económico, empleos de calidad y productos y servicios de excelencia en Europa" ${ }^{467}$, de 24 de mayo de 2011, planteó la posibilidad de enfocar una reforma de los derechos de autor a nivel europeo mediante la creación de un Código Europeo de los Derechos de Autor, lo que ofrecería la oportunidad de examinar el marco legal de las excepciones y limitaciones en la DDASI para valorar si era precisa una actualización o armonización en la UE.

En esta línea, aunque no fue la Comisión Europea quien ha propuesto el Código Europeo de Derechos de Autor, sino especialistas en derecho de autor de la UE interesados en el desarrollo futuro de la legislación europea en la materia, sí que se ha preocupado por desarrollar diversas acciones con la finalidad de reexaminar la regulación de los derechos de autor en la "Sociedad de la Información". Entre otras, cobra relevancia la consulta pública sobre la revisión de las normas de derechos de autor de la UE, celebrada entre el 5 de diciembre de 2013 y el 5 de febrero de $2014^{468}$, que puso de relieve la existencia de diferentes puntos de vista según los intereses de los grupos examinados en los distintos temas abordados sobre la regulación de los derechos de propiedad intelectual ${ }^{469}$. Gran número de preguntas estuvieron, precisamente, dirigidas a explorar las opiniones sobre el régimen legal de las excepciones y limitaciones a los derechos de autor (de la 21 a la 71) y, en particular, las preguntas $24 \mathrm{y}$ 25 sobre la flexibilidad del marco legislativo de la UE para las excepciones a estos derechos.

${ }^{467}$ COM (2011) 287 final.

$468 \quad$ Disponible en: http://ec.europa.eu/internal_market/consultations/2013/copyrightrules/docs/consultation-document_en.pdf (consultado: 14.03.2017). La consulta abarcó una amplia gama de cuestiones, entre ellas, las limitaciones y excepciones al derecho de autor en la era digital con el objetivo de recabar la opinión de todas las partes interesadas sobre el tema.

${ }^{469}$ Para consultar las respuestas a las preguntas examinadas vid. Comisión Europea (Directorate General Internal Market and Services), Report on the responses to the Public Consultation on the Review of the EU Copyright Rules, julio 2014, disponible en: http://ec.europa.eu/internal_market/consultations/2013/copyright-rules/docs/contributions/consultationreport_en.pdf (consultado: 14.03.2017). 
Las opiniones de los grupos encuestados variaron según los intereses de los mismos ${ }^{470}$, siendo posible constatar, incluso, dentro de un mismo grupo, opiniones divergentes. Esencialmente, la consulta reveló dos grandes posiciones enfrentadas: mientras unos abogaron por la flexibilidad del sistema, otros consideraron que el actual marco jurídico otorgaba la flexibilidad suficiente.

A favor de la primera postura se subrayaron las ventajas de un modelo más abierto para adaptarse a los cambios tecnológicos, preservar las diferentes tradiciones culturales de los Estados miembros, no estar en desventaja en relación con otros países que utilizan sistemas abiertos como el fair use, poder añadir al catálogo fijo de excepciones otras no previstas en el momento en que se promulgue la ley, no sufrir el perjuicio que supone el largo proceso de adaptación de la legislación de la UE, así como por su impacto positivo en el mercado interior. Las soluciones propuestas fueron completar la lista con una norma abierta y extender la lista a usos "análogos", en ambos casos bajo el control de la prueba de las tres etapas; o incluso introducir nuevas excepciones en la ley, que se añadirían a las ya existentes. Este grupo estaba compuesto, fundamentalmente, por los usuarios finales y consumidores de contenidos protegidos por las normas de propiedad intelectual; los usuarios institucionales (bibliotecas, museos, archivos, etc.); una pequeña parte de autores y sociedades de gestión colectiva; algunos intermediarios, distribuidores y otros proveedores de servicios de Internet; así como parte de los representantes del mundo académico, de la sociedad civil y de otros grupos interesados.

En cambio, entre quienes consideraron que el marco actual ofrece la suficiente flexibilidad, se barajaron argumentos como la posibilidad que tienen los Estados miembros de aplicar las limitaciones según sus tradiciones y políticas culturales, que la regla de los tres pasos ya prevé un nivel suficiente de flexibilidad, que en caso de dudas sobre la aplicación de las excepciones, los tribunales han podido hacer las aclaraciones

\footnotetext{
${ }^{470}$ Respondieron a la consulta diferentes grupos interesados, a saber: usuarios finales/consumidores; usuarios institucionales (bibliotecas, museos, archivos, etc.); autores/artistas intérpretes o ejecutantes/editores/productores/organismos de radiodifusión/sociedades de gestión colectiva de derechos de propiedad intelectual; intermediarios/distribuidores y otros proveedores de servicios (proveedores de servicios de Internet, plataformas de Internet, compañías de telecomunicaciones, etc.); Estados miembros $\mathrm{y}$ otros interesados (académicos y expertos en derechos de autor y asociaciones que representaban a estos grupos de interesados, organizaciones no gubernamentales, etc.).
} 
necesarias, que ni la legislación ni las decisiones judiciales han impedido la aparición y sostenimiento de los servicios en línea y los nuevos modelos de negocio, y además, que la introducción de una norma abierta disminuiría la seguridad jurídica y daría lugar a interpretaciones divergentes del concepto de "uso leal". En este grupo se inscribían mayoritariamente los autores y los titulares de derechos conexos, las editoriales, un número significativo de proveedores y servicios en línea, así como la mayoría de Estados miembros que respondieron a la consulta, si bien algunos vieron factible considerar una extensión de los usos permitidos legalmente a usos análogos u otro tipo de norma abierta bajo el criterio de la prueba de las tres etapas. También, se encuentran en este grupo algunos académicos y otras organizaciones no gubernamentales.

Otras acciones demuestran la preocupación de la Comisión Europea por la actualización del marco normativo vigente de derechos de autor y de excepciones y limitaciones a los mismos, como la Comunicación de la Comisión al Parlamento Europeo, al Consejo, al Comité Económico y Social Europeo y al Comité de las Regiones: "Una Estrategia para el Mercado Único Digital de Europa" ${ }^{471}$, de 6 de mayo de 2015, en la que se anunció la necesidad de una modernización de la normativa sobre derechos de autor de la UE. Esta señalaba:

"Europa necesita un régimen de derechos de propiedad intelectual más armonizado que ofrezca incentivos para la creación y la inversión, permitiendo al mismo tiempo la transmisión y el consumo de contenidos a través de las fronteras, sobre la base de nuestra gran diversidad cultural" 472 .

En desarrollo de dicha estrategia del mercado único digital, la Comunicación de la Comisión "Hacia un marco moderno y más europeo de los derechos de autor", de 9 de diciembre de $2015^{473}$, explica el modo en que se propone alcanzar el objetivo de contar con un "marco europeo de los derechos de autor más moderno y más europeo". Al

\footnotetext{
${ }^{471}$ COM (2015) 192 final.

472 Ibídem, p. 8.

${ }^{473}$ Comisión Europea, Hacia un marco moderno y más europeo de los derechos de autor, Comunicación de la Comisión al Parlamento Europeo, al Consejo, al Comité Económico y Social Europeo y al Comité de las Regiones [COM (2015) 626 final], Bruselas, 9 de diciembre de 2015, disponible en: https://ec.europa.eu/transparency/regdoc/rep/1/2015/ES/1-2015-626-ES-F1-1.PDF (consultado: 20.10.2016).
} 
efecto, la Comunicación contiene un plan de acciones a desarrollar a corto plazo y con visión a largo plazo, basado en los trabajos preparatorios realizados durante los últimos años por la Comisión, incluyendo la comentada consulta pública efectuada durante los años 2013-2014, y teniendo en cuenta la opinión del Parlamento Europeo, expresada en su Resolución de 9 de julio de 2015, sobre la aplicación de la DDASI ${ }^{474}$.

En particular, es importante resaltar que en esta última Comunicación se constata el interés de la Comisión Europea por ir dando solución a la problemática que supone la fragmentación existente en materia de excepciones y limitaciones en la normativa sobre derechos de autor de la UE, especialmente debido al carácter facultativo de la mayoría de los límites establecidos en la DDASI; una situación que, como reconoce, "parece que [...] está planteando problemas en particular en el caso de las excepciones estrechamente relacionadas con la educación, la investigación y el acceso al conocimiento" ${ }^{475}$. Igualmente, la Comunicación incide en la "necesidad de reflejar mejor los avances tecnológicos y evitar las situaciones de desigualdad en el mercado único en relación con la minería de textos y datos, en virtud de la cual los ordenadores leen y analizan grandes volúmenes de contenidos digitales en el contexto de la ciencia y la investigación" 476 .

Pues bien, la Comisión Europea deja claro su objetivo de aumentar el nivel de armonización, de establecer las pertinentes excepciones obligatorias y de garantizar que se apliquen en la UE. Se persigue ofrecer, en definitiva, un sistema más seguro y previsible, tanto para los titulares de derechos como para los usuarios. Habrá que ver si la UE es capaz de lograr este objetivo, a la vez que facilita cierta apertura en la regulación de estos límites.

\footnotetext{
${ }^{474}$ P8_TA (2015)0273, disponible en: http://www.europarl.europa.eu/sides/getDoc.do?pubRef=-//EP//TEXT+TA+P8-TA-20150273+0+DOC+XML+V0//ES (consultada: 16.03.2017).

${ }^{475}$ Comunicación de la Comisión al Parlamento Europeo, al Consejo, al Comité Económico y Social Europeo y al Comité de las Regiones "Hacia un marco moderno y más europeo de los derechos de autor", cit. p. 8.

476 Ídem.
} 
Por otra parte, son particularmente importantes las observaciones que hace el Parlamento Europeo en su Resolución de 9 de julio de 2015. En términos generales destaca la necesidad de que las excepciones y limitaciones en el entorno digital se apliquen teniendo en cuenta la finalidad con la que fueron concebidas y las características propias de este entorno, así como del entorno analógico, velando por el equilibrio entre los intereses de los titulares de derechos y los del público ${ }^{477}$. Asimismo, considera acertado que algunas excepciones y limitaciones se beneficien de normas comunes, mientras que justifica que existan algunas diferencias "para permitir que los Estados miembros legislen con arreglo a sus intereses culturales y económicos específicos, en consonancia con los principios de proporcionalidad y subsidiariedad" ${ }^{478}$. Reconoce, igualmente, que la flexibilidad en la interpretación de las excepciones y limitaciones puede permitir la adaptación de las mismas a las distintas circunstancias nacionales y necesidades sociales ${ }^{479}$.

Asimismo, en cumplimiento de la Comunicación "Hacia un marco moderno y más europeo de los derechos de autor", la Comisión Europea elaboró la "Propuesta de Directiva del Parlamento Europeo y del Consejo sobre los Derechos de Autor en el Mercado Único Digital”, de 14 de septiembre de $2016^{480}$. En ésta, considerando que han ido surgiendo nuevos usos de las creaciones intelectuales y que las excepciones siguen siendo de ámbito nacional, sin que esté garantizada la seguridad jurídica en relación con los usos transfronterizos, la Comisión se cuestiona si las excepciones establecidas siguen siendo adecuadas para responder al justo equilibrio entre los derechos e intereses de los autores y otros titulares de derechos, por una parte, y de los usuarios, por otra. En particular, en este contexto, la Comisión se propone, entre otros objetivos, garantizar la legalidad de determinados tipos de usos en estos ámbitos, sobre todo a nivel transfronterizo; garantizar una justa remuneración a titulares de derechos de autor por la

\footnotetext{
${ }^{477}$ Resolución del Parlamento Europeo, de 9 de julio de 2015, cit., apartado 35.

${ }^{478}$ Ibídem, apartado 37.

${ }^{479}$ Ibídem, apartado 43.

${ }^{480}$ COM (2016) 593 final. Se trata hasta la fecha de una propuesta en estudio. Las últimas recomendaciones de enmienda a la misma han sido publicadas en el D.O.U.E C-207/80, de 30 de junio de 2017.
} 
utilización de sus obras y demás prestaciones; mejorar la posición de los titulares de derechos en la negociación de las licencias de explotación de sus contenidos por parte de servicios en línea; y facilitar el proceso de concesión de licencias y adquisición de derechos.

Pues bien, todas estas iniciativas, junto a otras producidas desde la promulgación de la DDASI, constituyen importantes pilares de reflexión y actuación para el enfoque futuro de la regulación de los derechos de autor y sus límites en la UE. Fijan las bases para la revisión de la legislación actual mediante el establecimiento de unas normas comunes de mayor alcance para los Estados miembros, con una correcta aplicación de las excepciones y limitaciones establecidas en la DDASI (o cualquier otra futura Directiva) y, al mismo tiempo, parten del respeto a la diversidad cultural dentro de una mayor armonización en el mercado interior.

Puede decirse que la preocupación por una regulación eficaz de las excepciones y limitaciones a los derechos de propiedad intelectual ha sido a lo largo de las últimas décadas un foco de atención constante tanto para la doctrina y la jurisprudencia, como para los órganos institucionales de la UE y los Estados miembros. Se trata, sin lugar a dudas, de un tema controvertido que lleva implícita la dicotomía entre la ampliación del marco legal establecido en la DDASI con la finalidad de facilitar el acceso y utilización de los contenidos protegidos por la propiedad intelectual a los consumidores y usuarios, de un lado; y, de otro, la protección más rigurosa de las facultades exclusivas de los titulares de derechos, quienes normalmente se oponen a la flexibilización de la regulación de los límites.

Tras varios años de aplicación de la DDASI, no sólo ha cambiado el panorama tecnológico con nuevos modelos de negocio (servicios en línea a la carta, cloud computer, etc.), sino que también se han podido constatar las disparidades entre las regulaciones de los diferentes Estados miembros de la UE, la necesidad de determinar nuevos límites y de adaptar el alcance de muchos de los previstos. La falta de armonización generada por el hecho de que veinte de las veintiuna excepciones previstas en la DDASI sean facultativas, atenta contra la creación del Mercado Único de derechos de autor en la UE y demuestra la necesidad de la intervención del legislador europeo. 
Por su parte, la jurisprudencia de la UE ha sido imprescindible para uniformizar y algunas veces completar el contenido y alcance del régimen jurídico de las limitaciones y excepciones establecidas en la DDASI. En este contexto se aprecia mayoritariamente una interpretación restrictiva de estas. El test de las tres etapas ha funcionado más bien como instrumento de control en la aplicación de las excepciones que de flexibilidad, aunque algún atisbo de apertura haya comenzado a ser perceptible por la necesidad de adaptar las limitaciones a un entorno tecnológico más desarrollado. La necesidad de preservar la seguridad jurídica y los principios del sistema continental de derechos de autor genera la reticencia por un modelo más abierto de excepciones, al estilo del fair use norteamericano. Pero, al mismo tiempo, la dinámica de las tecnologías, la economía y la sociedad exigen la búsqueda de nuevas alternativas para conseguir una regulación más actualizada y flexible de los límites a los derechos de propiedad intelectual. La prueba de los tres pasos, en definitiva, sirve como herramienta de reequilibrio.

Es preciso continuar con el proceso ya iniciado de revisión y actualización del vigente sistema europeo de limitaciones y excepciones a los derechos de propiedad intelectual y, consecuentemente, de los sistemas nacionales. Es preciso, igualmente, crear una legislación más flexible, que permita dar cobertura legal a las nuevas situaciones que no sólo se han ido creando a lo largo de estos últimos años, no previstas en la DDASI ${ }^{481}$, sino también a aquellas que se puedan producir en el futuro.

${ }^{481}$ Un ejemplo sería la "minería de datos" (text and data mining), consistente en el "proceso por el cual a través de una búsqueda automatizada de un conjunto de datos se tiene acceso a nuevos conocimientos e ideas", según el concepto ofrecido por Jean Martin en el informe realizado para el Consejo Superior de la Propiedad Literaria y Artística [cit. por Instituto Autor, Informe de la misión de la revisión de la Directiva 2001/29/CE sobre la armonización de ciertos aspectos del derecho de autor y los derechos afines en la sociedad de la información (resumen y traducción de Luis Riera Ramírez), 2015, p. 17], disponible en: http://www.institutoautor.org/uploads/website/docs/4283-1Informe\%20de\%20la\%20mision\%20de\%20la\%20revision\%20de\%20la\%20Directiva\%20200129CE\%20 -\%20Pierre\%20Sirinelli.pdf (consultado: 16.03.2017). Esta actividad incide sobre los derechos de autor y el derecho sui generis de las bases de datos, pues implica actos de reproducción y extracciones de obras protegidas no contemplados como limitaciones específicas en la DDASI y cuya recomendación de regulación pasa por desarrollarla como excepción sobre la base de una interpretación del derecho de cita (Ídem). 



\section{CAPÍTULO III: LA COPIA PRIVADA COMO LÍMITE AL DERECHO DE REPRODUCCIÓN}

SUMARIO: I. DE LA COPIA ANALÓGICA A LA COPIA DIGITAL: SU RECONOCIMIENTO COMO LÍMITE AL DERECHO DE REPRODUCCIÓN EN LA LPI. II. LOS FUNDAMENTOS DE LA COPIA PRIVADA. III. LA DELIMITACIÓN DE LA NOCIÓN DE COPIA PRIVADA Y SU CONFIGURACIÓN LEGAL. 1. Concepto. 2. Configuración legal. 2.1. La regulación de la copia privada en el Derecho de la Unión Europea. 2.2. La regulación de la copia privada en España. 2.2.1. Cuestiones generales sobre la evolución del marco normativo. 2.2.2. El objeto del límite de copia privada. 2.2.3. Los presupuestos del límite de copia privada. IV. LA SUJECIÓN DE LA COPIA PRIVADA A LA REGLA DE LOS TRES PASOS. V. EL FAIR USE Y LA COPIA PRIVADA. VI. LAS MEDIDAS TECNOLÓGICAS DE PROTECCIÓN Y LA COPIA PRIVADA. 1. Introducción. 2. Aspectos generales sobre las medidas tecnológicas de protección. 2.1. Definición y clasificación. 2.2. Marco general de protección de las medidas tecnológicas en la DDASI y en el ordenamiento jurídico español. 2.2.1. Antecedentes. 2.2.2. Esquema general de protección jurídica de las medidas tecnológicas en la DDASI. 2.2.3. Esquema general de protección jurídica de las medidas tecnológicas en el TRLPI. 3. Limitaciones al derecho de autor y medidas tecnológicas de protección. 3.1. Consideraciones generales. 3.2. Las limitaciones garantizadas. 3.3. Las limitaciones no garantizadas. 3.4. La desarticulación del régimen de garantía de las limitaciones frente a las medidas tecnológicas y su subordinación a lo dispuesto contractualmente. 4. El caso particular de la copia privada: la facultad de garantizar el disfrute del límite de copia privada en la DDASI y su expresión en el TRLPI. VII. LA INEXISTENCIA DE UN DERECHO DEL USUARIO A LA COPIA PRIVADA. VIII. EL INTERCAMBIO DE ARCHIVOS EN LAS REDES P2P Y LA COPIA PRIVADA. 



\section{DE LA COPIA ANALÓGICA A LA COPIA DIGITAL: SU RECONOCIMIENTO COMO LÍMITE AL DERECHO DE REPRODUCCIÓN EN LA LEY DE PROPIEDAD INTELECTUAL}

A lo largo de la segunda mitad del siglo XX, el desarrollo tecnológico trajo consigo la aparición de medios de reproducción reprográficos y mecánicos aptos para la obtención de copias en el ámbito doméstico o privado, como la fotocopiadora, el audiocassete, el video home system (VHS) o videocassete, así como los aparatos electrodomésticos de audio y vídeo diseñados para la grabación de sonidos y/o imágenes en soportes vírgenes ${ }^{482}$. Estos medios facilitaron a sus adquirentes la obtención de textos e imágenes impresos, así como de copias de obras musicales y videográficas, sin grandes esfuerzos y a un coste no muy elevado, en contraste con la situación anterior donde la copia se reducía a escasos tipos de obras, estando limitada, a escala doméstica, al uso de medios manuales y dactilográficos ${ }^{483}$.

Esta nueva situación repercutió en el modo de consumir las creaciones intelectuales. En efecto, comenzó a ser posible el disfrute de la obra o prestación protegida por derechos de autor sin necesidad de adquirir el soporte original. De facto, la facultad del autor de autorizar o prohibir la reproducción de su obra, conforme a su derecho exclusivo, se vio limitada frente a la reproducción realizada en el ámbito privado, pues esta copia escapaba de su control. Así, la "democratización” paulatina de los medios de reproducción para la obtención de copias en el ámbito privado comenzó a generar incertidumbres sobre la legalidad de esta práctica. Pese a que se advertía que esta copia representaba un perjuicio patrimonial para el autor ${ }^{484}$, el legislador era consciente de las dificultades asociadas a su control, no sólo por su coste, sino por cuanto implicaba una injerencia en la esfera privada de las personas, lo que más bien

\footnotetext{
482 ANTEQUera PARILli, R., “Del 'Entorno Analógico' a la Tecnología Digital”, Revista Jurídica Facultad de Jurisprudencia (379-417), Guayaquil, 2007, p. 385.

483 Vid. VAllés Rodríguez, M., "Artículo 25”, en Bercovitz RodríGuez-Cano, R. (Coord.), Comentarios a la Ley de Propiedad Intelectual, $1^{\text {a }}$ ed., Tecnos, Madrid, 1989, p. 461.

${ }^{484}$ PlaZA PENADÉs, J., El derecho de autor y su protección..., op. cit., p. 29.
} 
convertía dicho control en imposible. Así pues, la opción de prohibir la copia privada parecía ser una solución abocada al fracaso ${ }^{485}$.

En este contexto, el legislador español, siguiendo la estela de otros ordenamientos europeos como el alemán, optó por reconocer la copia privada como un límite al ejercicio exclusivo del derecho de reproducción del autor. Su regulación se estableció en el art. 31.2 de la Ley 22/1987, de 11 de noviembre, de Propiedad Intelectual (en adelante LPI), que admitió que las obras ya divulgadas pudieran reproducirse sin autorización del autor para uso privado del copista, siempre que la copia no fuera objeto de utilización colectiva ni lucrativa, si bien, disponiendo -según el art. 25 de la LPIque los titulares de derechos de las obras publicadas en forma de libro, fonograma o en cualquier otro soporte sonoro o visual, recibieran una remuneración compensatoria por dichas reproducciones efectuadas exclusivamente para uso personal, por medio de aparatos técnicos no tipográficos ${ }^{486}$.

De este modo, el art. 31.2 de la LPI $^{487}$ constituyó el primer reconocimiento legal del límite de copia privada en España, cuyo régimen apenas varió con la promulgación del Real Decreto Legislativo 1/1996, de 12 de abril, por el que se aprueba el texto refundido de la Ley de Propiedad Intelectual, regularizando, aclarando y armonizando las disposiciones legales vigentes sobre la materia (en adelante TRLPI).

No obstante, si bien la copia privada analógica supuso un replanteamiento de los límites al derecho de reproducción, la posterior y drástica transformación del escenario analógico al escenario digital, con la aparición de aparatos y soportes de reproducción digitales como el CD, el DVD o el escáner, entre otros, así como con el desarrollo de Internet, provocó toda una revolución en el panorama de los derechos de autor. En

${ }^{485}$ Vid. GonZÁlez de Alaiza Cardona, J. J., La copia privada. Sus fundamentos..., op. cit., p. 121; LÓPEZ RiCHART, J., "La copia privada ante los desafíos de la tecnología digital”, en MORENO MARTíNEZ, J. A. (Coord.), Límites a la propiedad intelectual y nuevas tecnologías, op. cit., p. 180; LÓPEZ MAZA, S., Limites al derecho de reproducción..., op. cit., p. 175.

${ }^{486}$ VATTIER FuenZALIDA, C., "La Propiedad Intelectual (Estudio sistemático...”, op. cit., p. 1074; LÓPEZ RICHART, J., "La copia privada ante los desafíos...”, op. cit., p. 180.

${ }^{487}$ Desde entonces, este precepto ha estado relacionado con el art. 25 de la LPI, relativo a la remuneración compensatoria según la denominación de aquel texto legal (hoy, compensación equitativa por copia privada), cuya regulación ha sufrido modificaciones significativas con el paso de los años, vid. infra Capítulo IV. 
efecto, el advenimiento de la copia privada digital, es decir, de la reproducción plasmada en un soporte digital ${ }^{488}$, incidió indiscutiblemente sobre la producción literaria, fonográfica y audiovisual, especialmente porque el uso de nuevos medios y formatos para la reproducción propiciaba una copia de alta calidad, fiel al original, altamente reproducible y susceptible de almacenarse y trasmitirse a mayor velocidad y menores costes.

Consecuentemente, estas nuevas posibilidades de reproducción, acceso y distribución de las obras y prestaciones intelectuales generaron la reflexión sobre el nuevo papel del Derecho de Propiedad Intelectual. En especial, fue necesario replantear las definiciones legales de los tradicionales derechos de explotación (reproducción, comunicación pública, distribución y transformación), precisar el alcance de los límites a estos derechos, evaluar la conveniencia a escala comunitaria de establecer mecanismos de compensación por copia privada y de conciliar dichos límites con las posibilidades del control de la copia a través del uso de medidas tecnológicas de protección y licencias de uso.

En efecto, si la copia analógica ya había traído consigo la necesidad de valorar la inclusión de la copia privada dentro de los límites a los derechos propiedad intelectual, la copia digital acentuaba esta necesidad que se había venido imponiendo por vía de hecho, dado el perjuicio provocado al autor frente al fenómeno masivo de la copia privada. Así pues, la digitalización de las obras y prestaciones motivó la reflexión sobre si debía plantearse un control riguroso sobre la copia privada, o si, por el contrario, ésta debía permitirse ${ }^{489}$.

En este escenario, la DDASI se convierte en el instrumento jurídico que sistematiza y armoniza en cierta medida las excepciones o limitaciones a los derechos

\footnotetext{
488 Vid. SÁnCHEZ ARISTI, R., "La copia privada digital”, Pe. i.: Revista de Propiedad Intelectual, núm. 14, 2003, p. 16.

${ }^{489} \mathrm{La}$ expresión de esta circunstancia queda reflejada en la Comisión de las Comunidades Europeas, Libro Verde sobre los derechos de autor y los derechos afines en la Sociedad de la Información, de 19 de julio de 1995 [COM (95) 382 final], p. 49: "Si el progreso y la difusión de los medios de reproducción analógicos habían hecho imposible el control de las copias, especialmente de las privadas, la digitalización de las obras y las prestaciones vuelve a permitir plantearse un control riguroso de la reproducción".
} 
de autor en la UE. Respecto a la copia privada, la DDASI regula, sin aparentes distinciones, la copia privada analógica y la copia privada digital. Sin embargo, algunas diferencias son constatables en un examen más profundo de algunos de sus Considerandos ${ }^{490}$. Por un lado, su regulación incide en la copia privada, no tanto en el establecimiento de la excepción, que queda reservada al legislador nacional, sino en la obligatoriedad de establecer, caso de admitirla, una compensación equitativa para los derechohabientes $^{491}$. Por otro lado, incide en la relación de la copia privada frente a las medidas tecnológicas de protección (art. 6.4. párrafo $2^{\circ}$ ).

La DDASI sirvió de base para dar una nueva redacción al art. 31.2 del TRLPI, mediante la Ley 23/2006, de 7 de julio, de trasposición de esta Directiva. Posteriormente, este precepto fue reformado con la promulgación de la Ley 21/2014, de 4 de noviembre, por la que se modifica el TRLPI y la Ley 1/2000, de 7 de enero, de Enjuiciamiento Civil ${ }^{492}$ y, más tarde, mediante el Real Decreto-ley 12/2017, de 3 de julio, por el que se modifica el TRLPI ${ }^{493}$, como se analizará infra.

\footnotetext{
${ }^{490}$ El Considerando $44^{\circ}$ de la DDASI sugiere a los Estados miembros tener en cuenta el impacto económico que, en particular, pueden tener las excepciones o limitaciones a los derechos de autor a la luz de los avances logrados en la electrónica, al momento de establecerlas. Y señala: “[...] puede resultar necesario limitar aún más el alcance de determinadas excepciones o limitaciones en lo tocante a ciertas nuevas utilizaciones de obras protegidas por derechos de autor y prestaciones protegidas por derechos afines a los derechos de autor". El Considerando $39^{\circ}$ de la DDASI, con motivo de la instrumentación de la copia privada, obliga a los Estados miembros a tener en cuenta el desarrollo económico y tecnológico, en particular, en lo relativo a la copia digital privada. Y lo mismo acontece cuando en el Considerando $38^{\circ}$, al referirse a la introducción o mantenimiento de los sistemas para compensar a los autores y titulares de derechos por los perjuicios sufridos, refrenda: "Aunque las diferencias existentes entre tales sistemas de retribución afecten al funcionamiento del mercado interior, en lo que respecta a la reproducción privada analógica, dichas diferencias no deben tener efectos significativos en el desarrollo de la sociedad de la información. La copia privada digital puede propagarse mucho más y tener mayor impacto económico. Por consiguiente, deben tenerse debidamente en cuenta las diferencias entre la copia privada digital y la analógica, y debe establecerse entre ellas una distinción en determinados aspectos" (la cursiva es nuestra). También, ya propiamente en el cuerpo de la DDASI, el art. 5.2 b) establece la necesidad de evaluar si se aplican o no a la obra las medidas tecnológicas contempladas en su art. 6.

${ }^{491}$ El término "derechohabiente" se utiliza como sinónimo de titular de derecho, es decir, el autor o cualquier otro titular derivado del derecho de autor. Con este sentido se emplea el término a lo largo de este trabajo.

${ }^{492}$ B.O.E. núm. 268, de 5 de noviembre de 2014.

${ }^{493}$ B.O.E. núm. 158, de 4 de julio de 2017.
} 


\section{LOS FUNDAMENTOS DE LA COPIA PRIVADA}

Como se ha expuesto, la copia privada -tanto analógica como digital- se impuso de facto ante el desarrollo tecnológico. Consecuentemente, el legislador se vio obligado a dar cobertura legal a esta realidad que atentaba contra el derecho de reproducción del autor y demás titulares de derechos de propiedad intelectual, pero que, en todo caso, parecía imposible de controlar. Quizás por ello, la imposibilidad de control de la copia privada ha sido la razón fundamental que ha justificado la existencia de este límite legal al derecho de reproducción, aunque no ha sido la única ${ }^{494}$.

En efecto, los costes transaccionales que supondría la gestión de los derechos de autor relativos a las reproducciones hechas por los usuarios privados serían demasiado elevados y la persecución de quienes realizan reproducciones no autorizadas sería imposible de afrontar. Es lo que, en términos económicos -tal como recuerda LÓPEZ RICHART ${ }^{495}$ - se conoce como "imperfección del mercado". Y frente a esta realidad, una Ley que prohibiese la copia privada sería, en todo caso, una norma ineficaz ${ }^{496}$.

Sin embargo, la irrupción de la tecnología digital hizo replantearse la validez del anterior argumento, pues la existencia y consiguiente posibilidad de aplicar medidas tecnológicas de protección para impedir la copia podía resultar una forma válida para controlar las reproducciones ${ }^{497}$. No obstante, lo cierto es que la aplicación de estas

${ }^{494}$ Vid. CABEDO SERNA, L. L., "Los consumidores y las medidas tecnológicas de protección incorporadas en soportes digitales", en MORENO MARTíNeZ, J. A. (Coord.), Límites a la propiedad intelectual y nuevas tecnologías, op. cit., pp. 74-79. En este sentido, señala XALABARDER PlANTADA, R. (Mod.); MARTínPRAT, M.; MALMIERCA, M. y RAMÍREZ, J., "La copia privada digital. Mesa redonda", op. cit., p. 36: "La justificación para esta exclusión varía según el contexto histórico y tecnológico en que nos encontremos". ${ }^{495}$ LÓPEZ RiCHART, J., “La copia privada ante los desafíos...”, op. cit., p. 184.

496 "La eficacia de una norma, según Kelsen, se concreta en una doble y disyunta condición: una norma es eficaz si, y sólo si, dadas las condiciones de aplicación de la misma, o bien es acatada por los sujetos sometidos al orden jurídico o bien los órganos jurídicos aplican la sanción que es parte de dicha norma". CAlvo Soler, R., "La ineficacia de las normas jurídicas en la Teoría Pura del Derecho", Isonomía, núm. 27, 2007, p. 174.

${ }^{497}$ LÓPEZ RICHART, J., "La copia privada ante los desafíos...”, op. cit., p. 184; LóPEZ MAZA, S., Límites al derecho de reproducción..., op. cit., p. 177, GARROTE FERNÁNDEZ-DÍEZ, I., La reforma de la copia privada en la Ley de Propiedad Intelectual, Comares, Granada, 2010, p. 65; GonZÁLEZ DE ALAIZA CARDonA, J. J., La copia privada. Sus fundamentos..., op. cit., p. 122. Este último autor afirma: "[...] parece que la posibilidad de control se constituya para el legislador en condición sine qua non del reconocimiento a los autores del derecho exclusivo a autorizar los actos privados de reproducción. Este 
medidas no ha resultado un mecanismo efectivo para impedir las reproducciones en el ámbito privado. Por un lado, debido a que las medidas tecnológicas son vulnerables ${ }^{498}$. Por otro, porque, más allá de la vulnerabilidad, el uso de las medidas tecnológicas de protección es también una amenaza para los postulados tradicionales de la propiedad intelectual, puesto que su utilización puede restringir el uso de las obras y prestaciones intelectuales al amparo de una excepción legal o limitar el uso de obras no protegidas por derechos de autor como resultado, por ejemplo, de la extinción del periodo de protección y, consecuentemente, lacerar el equilibrio de intereses, presupuesto esencial de esta disciplina. Por tanto, la imposibilidad de controlar la copia sigue siendo un argumento a favor de la existencia del límite de copia privada.

Junto al motivo anterior, una consecuencia no deseada del control de la copia privada es la irrupción en la vida privada de las personas; acto prohibido en tanto colisiona con la tutela al derecho a la intimidad. En efecto, averiguar si una persona realiza copias o no de una obra en su entorno personal y familiar, para uso privado, supone una injerencia en su intimidad ${ }^{499} \mathrm{y}$, por tanto, una vulneración de este derecho fundamental. Por tanto, la necesidad de proteger este derecho ${ }^{500}$ faculta a que haya una tolerancia legal a la admisión de la copia privada. Por ello, este tipo de reproducciones no son susceptibles de ser controladas, al menos mientras puedan conculcar el mencionado derecho ${ }^{501}$. En este sentido, el límite al derecho exclusivo de reproducción

control es, en principio, una de las novedades que presenta el entorno digital, por lo que la pervivencia del límite de copia privada requeriría de nuevas justificaciones".

${ }^{498} \mathrm{La}$ disponibilidad en la Red de contenidos de todo tipo ha impuesto en la sociedad una cultura de trasgresión que se concentra fundamentalmente en el fenómeno del intercambio de archivos en programas peer to peer. Vid. CARBAJO CASCÓN, F., "Creación, edición y lectura en la Sociedad de la Información: entre la Propiedad Intelectual y el acceso a la cultura", Pliegos de Yuste, núm. 11-12, 2010, p. 129.

${ }^{499}$ KARAPAPA, S., Private Copying, Routledge, Oxon, 2012, p. 105.

${ }^{500} \mathrm{El}$ art. 18 de la Constitución Española (B.O.E núm. 311, de 29 de diciembre de 1978) preceptúa: “1. Se garantiza el derecho al honor, a la intimidad personal y familiar y a la propia imagen. 2. El domicilio es inviolable. Ninguna entrada o registro podrá hacerse en él sin consentimiento del titular o resolución judicial, salvo en caso de flagrante delito. 3. Se garantiza el secreto de las comunicaciones y, en especial, de las postales, telegráficas y telefónicas, salvo resolución judicial. 4. La ley limitará el uso de la informática para garantizar el honor y la intimidad personal y familiar de los ciudadanos y el pleno ejercicio de sus derechos".

${ }^{501}$ El art.1.1 de la Ley Orgánica 1/1982, de 5 de mayo, sobre protección civil del derecho al honor, a la intimidad personal y familiar y a la propia imagen (B.O.E. núm. 115, de 14 de mayo de 1982) establece: "El derecho fundamental al honor, a la intimidad personal y familiar y a la propia imagen, garantizado en 
del autor que autoriza la copia privada obedece también, en mayor o menor medida, a la salvaguarda de un derecho de orden constitucional.

Por otra parte, es cierto que antes del desarrollo de las tecnologías analógicas de reproducción a escala privada, la copia era esporádica e imperfecta, con lo cual, no tenía sentido prohibir una reproducción que no dañaba al autor ${ }^{502}$. Ello justificó que durante muchos años la ausencia de un daño y el uso inocuo -entendido como "el derecho de aprovechar de una cosa ajena, usándola por razón de utilidad, sin que el dueño sufra perjuicio" 503 - fueran razones suficientes para considerar lícita la copia realizada en el ámbito privado. Sin embargo, el impacto de los medios de reproducción -primero analógicos, y posteriormente digitales- incidió sobre las posibilidades de copiado, al hacer accesibles a innumerables personas, equipos, aparatos y soportes de reproducción; expandiéndose así la actividad de copia y causando un perjuicio económico a los titulares de derechos de autor al limitar las posibilidades de explotación económica de su obra. En efecto, la copia dejaba de ser inocua por su masificación, pudiendo la obra ser reproducida cada vez más y con mejor calidad, lo que repercutía en la adquisición de ejemplares originales e imposibilitaba su control a escala individual, doméstica o privada. De ahí que el legislador tuviera que ponderar los intereses implicados, tanto de los autores y demás titulares de derechos, como de los usuarios de las obras y los fabricantes de los equipos y dispositivos de copiado, con la finalidad de dar una solución, lo más satisfactoria posible, a estos colectivos ${ }^{504}$.

el artículo 18 de la Constitución, será protegido civilmente frente a todo género de intromisiones ilegítimas $[\ldots] "$ ".

502 LÓPEZ RICHART, J., "La copia privada ante los desafíos...”, op. cit., p. 180.

503 Tomamos la definición de LóPEZ DE HARO, "El ius usus inocui", RDP, 1920, p. 18, cit. por GONZÁLEZ DE Alaiza CARDONA, J. J., La copia privada. Sus fundamentos..., op. cit., p. 119. El ius usus inocui es, por su propia definición, inocuo, benigno o inofensivo, esto es, que no hace daño, según señala ANTEQUERA PARILLI, R., "Los límites del derecho subjetivo y del derecho de autor (Los 'usos honrados', el 'fair use' y el 'ius usus innocui'. El supuesto de abuso de derecho a la no divulgación de la obra. Los límites al derecho de autor y la sociedad de la información)", en Rogel VIDE, C. (Coord.), Los límites del derecho de autor, Reus, Madrid, 2006, p. 30.

504 Tato PlazA, A., "La reforma de la ley de Propiedad Intelectual y los límites al derecho de autor: copia privada, canon digital y press clipping", en GARCíA PÉREZ, R. y LóPEZ SUÁrEZ, M. A. (Eds.), Nuevos retos para la propiedad intelectual..., op. cit., pp. 10-11. 
Es por ello que la aceptación de la copia privada como límite a los derechos de propiedad intelectual exige el cumplimiento de ciertos requisitos. Por una parte, la copia privada no puede ser una copia sustitutiva de la que puede adquirirse en el mercado, sino una copia de la adquirida con anterioridad, de manera legal ${ }^{505}$. Por otra parte, para paliar el perjuicio causado al autor se establecen mecanismos compensatorios en muchas legislaciones.

Así, no es que el legislador obvie que autorizar la copia privada genera un perjuicio patrimonial al autor, sino que, partiendo de su realidad y también de sus beneficios, la admite, considerando que no llega a afectar la explotación normal de la obra, aun cuando genere un perjuicio económico para el autor ${ }^{506}$. En este sentido, no puede perderse de vista que el límite de copia privada se autoriza para la reproducción a partir de ejemplares de adquisición lícita, que no de un mercado de copia ilegal que rompe con las expectativas de obtención de ganancias para el titular de derechos de propiedad intelectual. Ello, sin perjuicio de que el autor reciba una compensación para mitigar las consecuencias negativas que, desde el punto de vista económico, la copia privada le genera.

Finalmente, la copia privada también ha encontrado justificación doctrinal en la idea de que la misma supone un beneficio para la sociedad, pues permite acercar a los ciudadanos a la cultura ${ }^{507}$. En efecto, la copia privada puede también ser una manifestación del derecho al acceso a la información, la cultura, la investigación, la educación, etc. ${ }^{508}$. No puede olvidarse que la Propiedad Intelectual constituye un “instrumento de política cultural" y, en este sentido, "apoya y regula la difusión y circulación de las ideas y la cultura"509.

\footnotetext{
505 GARROTE FERnÁNDEZ-DíEZ, I., La reforma de la copia privada ..., op. cit., p. 70.

506 Garrote FERnÁndez-DíEz, I., "Artículo 31”, en BERCOVITZ Rodríguez-CANo, R. (Coord.), Comentarios a la Ley de Propiedad..., 3ª ed., op. cit., p. 554. 507 Ídem.

508 CARbajo Cascón, F., Publicaciones electrónicas..., op. cit., p. 81; y PÉrez de OnTIVERos BAQUero, C., "Artículo 31", en BerCovitz-RodríGuez-CANO, R. (Coord.), Comentarios a la Ley de Propiedad Intelectual, $2^{\mathrm{a}}$ ed., Tecnos, Madrid, 1997, p. 600.

${ }^{509}$ DusOlLIER, S., Pullet, Y. y BuYDENS, M., "Derecho de autor y acceso a la información en el entorno numérico", Boletín de Derecho de Autor, UNESCO, Vol. 34, núm. 4, 2000, p. 5.
} 
No obstante, debe tenerse en cuenta que la totalidad de la doctrina no ha apoyado que la finalidad social sea un fundamento válido para el establecimiento del límite de copia privada. Del mismo modo que se ha invocado ésta como interés subyacente en la excepción de copia privada ${ }^{510}$, también se ha negado que deba otorgarse a la copia privada un fundamento constitucional en atención a la promoción de la cultura como valor de interés general, aun cuando la copia privada suponga un beneficio para la colectividad y una mayor difusión de la cultura ${ }^{511}$.

Valga añadir que, siguiendo la doctrina ${ }^{512}$, los fundamentos expuestos han sido los cuatro apoyos dogmáticos principales que justifican el límite al derecho de reproducción de la copia privada. No obstante, este límite también ha encontrado apoyo doctrinal en razones como el derecho de propiedad y la teoría del abuso de derecho. En cuanto a la justificación basada en el derecho de propiedad se ha afirmado que los propietarios “deben poder ejercer su derecho de propiedad ordinaria en relación con los soportes

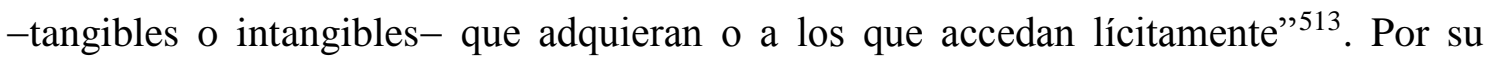
parte, respecto a la teoría del abuso de derecho, se ha sostenido que constituye un ejercicio antisocial del derecho de propiedad intelectual impedir la realización de una copia que el particular tiene interés en realizar y que no perjudica al titular de derechos de autor ${ }^{514}$.

En definitiva, son diferentes fundamentos de orden fáctico y jurídico los que han conducido a configurar legalmente la copia privada como excepción al derecho exclusivo de reproducción del autor, predominando la imposibilidad de controlar la copia efectuada en el ámbito privado; la vulneración del derecho fundamental a la intimidad; el carácter limitado del daño y el interés público de acceso a la cultura.

\footnotetext{
510 Ídem.

511 GARROTE FERNÁNDEZ-DíEZ, I., La reforma de la copia privada ..., op. cit., pp. 71-73.

512 Garrote FERnÁndeZ-DíEZ, I., "Artículo 31”, en BERCOVITZ-Rodríguez-CANo, R. (Coord.), Comentarios a la Ley de Propiedad..., $3^{\mathrm{a}}$ ed., pp. 553 y ss.

${ }^{513}$ SÁNCHEZ ARISTI, R., "La copia privada digital", op. cit., p. 15.

514 Ídem. Véase también Rogel VIDE, C., Estudios sobre Propiedad Intelectual, $1^{\mathrm{a}}$ ed., Bosch, Barcelona, 1995, p. 153, quien señala: "[...] si el derecho de uso que corresponde al tercero y limita al derecho de autor no es ejercitado "normalmente" -"lealmente", si se quiere- deja de ser tal derecho y se convierte en violación, en infracción del derecho de autor que éste puede perseguir, al margen de que sea perseguible de oficio".
} 
Incluso, cuando el surgimiento de las tecnologías digitales puso en duda la pervivencia de este límite en el nuevo entorno, la propia ineficacia de las medidas tecnológicas para llevar a cabo un control riguroso de la copia hizo que cobrase fuerza, nuevamente, el fundamento de la imposibilidad de control y, asociado a éste, la necesidad de salvaguarda del derecho a la intimidad. La copia privada digital quedó, de este modo, justificada como límite al derecho de reproducción y, como tal, encontró respaldo legal en el art. 31.2 del TRLPI.

\section{LA DELIMITACIÓN DE LA NOCIÓN DE COPIA PRIVADA Y SU CONFIGURACIÓN LEGAL}

\section{Concepto}

No es frecuente encontrar definiciones doctrinales de copia privada, sino que su concepto se obtiene a partir de un análisis de los requisitos que debe reunir la misma siguiendo la legislación. No obstante, entre las definiciones doctrinales, resulta ilustrativa la ofrecida por el profesor SÁNCHEZ ARISTI, quien conceptualiza la copia privada como un "límite al derecho de reproducción que ampara al legítimo tenedor o receptor de un soporte tangible o intangible de una obra a fin de que, sin necesidad de autorización del autor, pueda efectuar reproducciones para su uso privado, bien entendido que las mismas no podrán ser objeto de utilización colectiva ni lucrativa" 515 . Dicho concepto muestra los elementos característicos de la copia privada, entre ellos, su configuración como límite al derecho de reproducción del autor, la legítima posesión del soporte a partir del cual se obtiene la copia, y la imposibilidad de que se utilice colectivamente o con ánimo de lucro. Sin embargo, para mayor precisión, hay que acudir a cada legislación en concreto, ya que es la que define los requisitos legales que configuran esta figura jurídica.

Por ello, resulta necesario analizar los requisitos que contiene su definición legal siguiendo la DDASI y el TRLPI, que son las normas que delimitan legalmente los usos

\footnotetext{
${ }^{515}$ SÁNCHEZ ARISTI, R., "La copia privada digital”, op. cit., p. 11.
} 
que pueden tener cabida dentro de la excepción. En todo caso, debe resaltarse que estas normas no enuncian de manera detallada qué actos concretos son autorizados por esta excepción, sino que, más bien, mencionan una serie de criterios o requisitos que, de cumplirse, hacen de la reproducción una copia lícita, al encajar en el límite de copia privada y, por tanto, susceptible de realizarse sin la autorización previa del titular de derechos de autor y derechos conexos, en su caso.

\section{Configuración legal}

\subsection{La regulación de la copia privada en el Derecho de la Unión Europea}

La DDASI regula la excepción de copia privada en su art. 5.2.b), preceptuando:

"Los Estados miembros podrán establecer excepciones o limitaciones al derecho de reproducción contemplado en el artículo 2 en los siguientes casos: [...] b) en relación con reproducciones en cualquier soporte efectuadas por una persona física para uso privado y sin fines directa o indirectamente comerciales, siempre que los titulares de los derechos reciban una compensación equitativa, teniendo en cuenta si se aplican o no a la obra o prestación de que se trate las medidas tecnológicas contempladas en el artículo 6".

Del tenor del precepto se desprende, en primer término, que el límite de copia privada se configura con carácter facultativo para los Estados miembros de la UE, de tal modo que no tienen la obligación de acoger la excepción de copia privada en sus legislaciones internas ${ }^{516}$. En definitiva, el legislador nacional puede reconocer o no esta excepción, si bien cabe decir que así ha sucedido en la mayoría de Estados ${ }^{517}$.

\footnotetext{
${ }^{516}$ Países como Reino Unido e Irlanda, por ejemplo, no introdujeron este límite en sus legislaciones internas al momento de trasponer la DDASI. En cambio, otros como Alemania y España ya preveían mecanismos compensatorios por copia privada en sus legislaciones internas antes de trasponer esta Directiva. Alemania fue, de hecho, el país precursor, con la introducción de un sistema de remuneración por copia privada en el año 1965, previa recomendación judicial. Para ampliar al respecto vid. KARAPAPA, S., Private Copying, op. cit., pp. 120-121.

${ }^{517}$ Sólo Chipre, Irlanda, Luxemburgo y Malta no tienen establecida la excepción de copia privada. OMPI, International Survey on Private Copying: Law \& Practice 2015, p. 3, disponible en: http://www.wipo.int/edocs/pubdocs/en/wipo_pub_1037_2016.pdf (consultado: 24.03.2017). En el caso del Reino Unido, la excepción de copia privada se introdujo en la legislación en octubre de 2014. Sin embargo, no se introdujo un sistema compensatorio asociado al límite considerando que el daño causado por la copia privada resulta mínimo, pero la oposición que generó esta decisión por parte de la British
} 
En segundo lugar, la DDASI se refiere a reproducciones hechas "en cualquier soporte", por lo que es irrelevante si la copia queda estampada en un soporte analógico o digital, quedando así incluidas dentro del ámbito de la excepción las reproducciones sonoras, visuales, audiovisuales y reprográficas, en su caso, realizadas en soportes analógicos y digitales, siempre que se realicen cumpliendo con las exigencias legales marcadas por la DDASI y por la normativa nacional que corresponda ${ }^{518}$.

Asimismo, frente al silencio de la DDASI en cuanto al soporte a partir del cual se efectúa la copia, se ha entendido que ésta no sólo puede derivar de un soporte físico, sino también de un acto de comunicación pública o puesta a disposición ${ }^{519}$, lo cual implica que la copia privada no sólo resulta de la copia del ejemplar físico de un libro o un $\mathrm{CD}$, por ejemplo, sino que también puede considerarse copia privada aquélla que se obtiene a partir de la emisión de un programa de televisión o de radio, o de cualquier otra forma de comunicación realizada por procedimientos alámbricos o inalámbricos, siempre que se cumplan el resto de las exigencias legales. Además, tampoco parece que tenga relevancia alguna el método o procedimiento empleado para realizar la copia, pues ninguna limitación establece el art. 5.2.b) de la DDASI al respecto. Por tanto, la copia puede ser obtenida manualmente o como resultado de la utilización de aparatos o instrumentos de reproducción ${ }^{520}$.

Debe destacarse que la doctrina se ha cuestionado si lo trascendente para determinar el carácter analógico o digital de la copia es el tipo de soporte en el que se reproduce la obra, o si, por el contrario, es el soporte a partir del cual se realiza la copia o, incluso, la naturaleza de la transmisión ${ }^{521}$. En este sentido, el empleo de la preposición "en", como parte de la expresión "en cualquier soporte" contenida en el art.

Academy Of Songwriters, Composers And Authors, Musicians' Union y Uk Music 2009 Limited determinó que, en sede judicial, se resolviera que la decisión del gobierno no estaba justificada y se declarara ilegal la regulación de la excepción de copia privada (Ibídem, p. 7). Sobre esto último, consúltese la sentencia de 9 de junio de 2015, Royal Courts of Justice, caso CO/5444/2014, [2015] EWHC 1723 (Admin).

518 GARRote FERnÁndeZ-DíEZ, I., “Artículo 31”, en BERCOVITZ RodRÍGUEZ-CANO, R. (Coord.), Comentarios a la Ley de Propiedad..., $4^{\mathrm{a}}$ ed., op. cit., p. 591.

519 Ibídem, p. 78.

${ }^{520}$ GARROTE FERNÁNDEZ-DíEZ, I., La reforma de la copia privada ..., op. cit., p. 77.

${ }^{521}$ Por todos, SÁNChEZ ARISTI, R., "La copia privada digital", op. cit., p. 16; GonZÁleZ DE AlAIZA CARDONA, J. J., La copia privada. Sus fundamentos..., op. cit., p. 213. 
5.2.b) de la DDASI, en lugar de la preposición "de", ha conducido a la conclusión de que el legislador de la UE ha optado por el primer criterio, esto es, por tener en cuenta el soporte en el que se reproduce la obra y no aquel a partir del cual se efectúa la copia ${ }^{522}$. Esta cuestión es relevante más allá del debate teórico porque no tiene igual repercusión en el mercado la copia analógica que la copia digital. De hecho, la propia DDASI sugiere en el Considerando $38^{\circ}$ la necesidad de tener en cuenta las diferencias entre la copia privada digital y la analógica y sostiene, "debe establecerse entre ellas una distinción", aun cuando la única distinción práctica que efectúa es respecto a la regulación de las medidas tecnológicas de protección ${ }^{523}$, con lo cual, debe interpretarse que los Estados miembros tienen libertad para establecer en sus legislaciones internas la previsión de diferencias entre ambas formas de reproducción, analógica y digital.

Por otra parte, el art. 5.2.b) de la DDASI exige varios requisitos al límite de copia privada. Así pues, para que opere dicha excepción al derecho de reproducción, la copia tiene que ser realizada por una persona física, para uso privado, sin fines directa o indirectamente comerciales y los titulares de derechos han de recibir una compensación equitativa.

El primero de estos requisitos (que la reproducción se efectúe por una persona física) excluye del ámbito de la copia privada las reproducciones realizadas por personas jurídicas. En efecto, una persona jurídica no puede realizar copias de obras y prestaciones protegidas por la propiedad intelectual para su uso interno sin la autorización del titular de los derechos de autor, al menos bajo el amparo de la excepción de copia privada. Ni siquiera sería admisible una justificación basada en el hecho de que son las personas físicas las que realizan la reproducción en el seno de las personas jurídicas y que, por tanto, las reproducciones efectuadas por éstas pueden considerarse reproducciones lícitas en virtud del límite de copia privada. Admitirlo, supondría restar sentido a la previsión legal de que la copia privada debe ser realizada

522 GonZÁlez de Alaiza Cardona, J. J., La copia privada. Sus fundamentos..., op. cit., p. 214.

523 CADARSO PALAU, J., "Sobre algunos límites del derecho de reproducción: Reproducciones para constancia en un procedimiento. Reproducciones para uso privado. La remuneración compensatoria por copia privada. Reproducciones hechas por bibliotecas y entidades del género, en RoGEL VIDE, C. (Coord.), Los límites del derecho..., op. cit., pp. 118-119. 
por una persona física ${ }^{524}$, cuando está claro que la persona jurídica es una ficción legal que necesita de personas físicas para actuar ${ }^{525}$.

En segundo lugar, la DDASI exige que la copia privada sea para uso privado. Sin embargo, este requisito no significa que tenga que ser la misma persona quien realiza la copia privada y quien la utiliza. Ello ha hecho plantearse a la doctrina si sería admisible la copia por encargo, pues el tenor de la DDASI no excluye directamente esta posibilidad. Ante esta falta de prohibición legal expresa, los Estados miembros han adoptado diferentes soluciones en sus legislaciones internas. Así, por ejemplo, Alemania permite la copia por encargo sólo si se realiza gratuitamente, en papel o en soporte análogo por procedimientos fotomecánicos [art. 53 Abs.1, apart. 2, Gesetz über Urheberrecht und verwandte Schutzrechte (Urheberrechtsgesetz), 9 September 1965]; Francia acepta la copia por encargo siempre que la intervención del tercero no esté remunerada (L122-5.2 ${ }^{\circ}$, Code de la Propriété Intellectuelle, 1 juillet 1992) e Italia prohíbe que las reproducciones sean realizadas por un tercero (art. 71-sexies 2, Legge 22 aprile 1941, n. 633 sulla protezione del diritto d'autore e di altri diritti connessi al suo esercizio $)^{526}$. Con todo, la decisión de excluir o no la copia por encargo, es una decisión del legislador nacional ${ }^{527}$.

A su vez, el significado de uso privado es ambiguo, pues "privado" no es sinónimo de “individual”. Así, puede abarcar un mayor o menor conjunto de personas lo que ha generado dudas sobre el alcance de la excepción. De hecho, si se atiende a las acepciones del vocablo privado en el diccionario de la Real Academia Española, puede comprobarse cómo, efectivamente, lo privado no se relaciona exclusivamente con lo "particular y personal de cada individuo", sino también con aquello "que se ejecuta a vista de pocos, familiar y domésticamente, sin formalidad ni ceremonia alguna".

\footnotetext{
${ }^{524}$ Ibídem., p. 228.

${ }^{525}$ Cuestión distinta es que una persona física realice una reproducción para uso privado, sin ánimo de lucro y sin fines directa o indirectamente comerciales, utilizando equipos, aparatos y soportes de reproducción de personas jurídicas que no se dediquen a la realización de reproducciones para el público ni tengan a disposición del público los equipos, aparatos y materiales para su realización; dígase, por ejemplo, la copia que hace un profesor universitario valiéndose de la fotocopiadora de su oficina.

${ }^{526}$ LÓPEZ MAZA, S., Limites al derecho de reproducción ..., op. cit., pp. 211-212.

${ }^{527}$ GonZÁlez de Alaiza CARDONA, J. J., La copia privada. Sus fundamentos ..., op. cit., p. 168.
} 
Así pues, en el proceso de tramitación de la DDASI se contemplaron distintas posibilidades a la hora de formular este requisito, analizándose la trascendencia del empleo de expresiones que iban desde "por una persona física para su uso personal" hasta "para uso privado de una persona física" 528 . Finalmente se optó por el término "uso privado" en lugar de "uso personal", lo que ha permitido a la doctrina considerar que la norma se decanta por una configuración más extensa del ámbito de las personas que pueden disfrutar de la excepción, al mismo tiempo que ha excluido el uso por un número ilimitado de personas. Consecuentemente, el significado de "uso privado" debe interpretarse en un sentido amplio, esto es, incluyendo no sólo al individuo en sí mismo, sino también a otras personas próximas a él por vínculos familiares y de amistad ${ }^{529}$.

En este sentido, la doctrina española ha contrapuesto el concepto de "uso privado" al de "uso público" 530 . En concreto, se ha tenido en cuenta la referencia al concepto de “comunicación pública” que contiene el art. 20.1, párrafo $2^{\circ}$, del TRLPI. Este precepto, al prever que "no se considerará pública la comunicación cuando se celebre dentro de un ámbito estrictamente doméstico que no esté integrado o conectado a una red de difusión de cualquier tipo", ha permitido concluir que la expresión "uso privado" es equivalente a la expresión "estrictamente doméstico" empleada por el mismo y, por tanto, más amplia que uso personal.

La ausencia de "fines directa o indirectamente comerciales" es otro de los requisitos que caracterizan a la copia privada conforme al art. 5.2.b) de la DDASI y que también comporta dudas interpretativas ante su falta de precisión legal. Durante el trámite parlamentario esta locución sustituyó a la expresión "sin fines lucrativos". Sin embargo, se ha estimado que este cambio posee más bien un carácter aclaratorio que

${ }^{528}$ Para ampliar: GonZÁleZ de Alaiza CARDONA, J. J., La copia privada. Sus fundamentos..., op. cit., p. 225.

${ }^{229}$ Vid. por todos, GonZÁlez de Alaiza CARdona, J. J., La copia privada. Sus fundamentos..., op. cit., p. 172; y Rodrigo-Bercovitz Rodríguez-CANo, R., GarRote FernándeZ-Díez, I., GonZÁlez GonZALO, A. y SÁNCHEZ ARISTI, R., Las reformas de la Ley de Propiedad..., op. cit., p. 47.

${ }^{530}$ González de Alaiza Cardona, J. J., La copia privada. Sus fundamentos..., op. cit., p. 174. Véase también PÉREZ DE OnTIVERos BAQUero, C., "Aproximación al significado de la expresión ámbito estrictamente doméstico en la regulación legal de la facultad patrimonial de comunicación pública", Pe. $i$. Revista de Propiedad Intelectual, núm. 12, 2002, p. 34. 
modificador del precepto $^{531}$, de ahí que se concluya que este requisito apunta a la prohibición de ánimo de lucro, por lo que no será indiferente el propósito con el que se haga la reproducción pues, si implica la obtención de ganancias, no podrá quedar el acto amparado en la excepción legal.

No obstante, se cuestiona si el ánimo de lucro asociado a la finalidad comercial alcanza sólo a la ganancia económica obtenida como consecuencia de la explotación de la copia o también a los casos en que se obtiene una mera utilidad o beneficio. Aun cuando algunos autores han sostenido esta segunda tesis ${ }^{532}$, debe considerarse más acertada la primera alternativa ${ }^{533}$, esto es, entender el ánimo de lucro en el sentido de ventaja patrimonial, pues siempre cabrá esperar algún beneficio de la copia realizada, ya que, de lo contrario, no tendría sentido su realización.

En definitiva, la copia queda fuera del ámbito del límite cuando se intercambia por precio o se introduce en el seno de un proceso productivo ${ }^{534}$. Estos actos implican una explotación comercial, por lo que el mecanismo adecuado para poder realizar la copia sin vulnerar el derecho de autor sería la obtención de la correspondiente licencia. Escudarse en el límite a estos efectos sería contrario al fundamento mismo de la excepción.

Por último, la copia privada queda supeditada al establecimiento de un mecanismo de compensación. De este modo, surge una estricta dependencia entre la compensación equitativa y la excepción de copia privada, de manera tal que es la existencia de esta excepción la que justifica y explica la compensación; y al revés, sin compensación no se puede introducir en las legislaciones nacionales el límite de copia privada. Concretamente, el precepto exige que, frente a la copia privada, los titulares de derechos reciban una compensación equitativa teniendo en cuenta si se aplican o no a la obra o prestación de que se trate las medidas tecnológicas contempladas en el art. 6 de la

\footnotetext{
531 González de Alaiza Cardona, J. J., La copia privada. Sus fundamentos..., op. cit., p. 229.

532 Por ejemplo, es partidario de esta interpretación SERRANo GóMEZ, E., "Napster y la propiedad intelectual: ¿una relación imposible?”, Actualidad Civil, núm. 31, agosto-septiembre 2001, p. 1112.

${ }^{533}$ Para una explicación más detallada sobre los grados de lucro vid. GONZÁLEZZ DE AlAIZA CARDONA, J. J., La copia privada. Sus fundamentos..., op. cit., pp. 182 y ss. El autor distingue entre piratería, explotación comercial, uso profesional y copias de sustitución.

${ }^{534}$ LÓPEZ MAZA, S., Límites al derecho de reproducción..., op. cit., p. 226.
} 
DDASI. El estudio del régimen jurídico de la compensación equitativa por copia privada será analizado en un Capítulo posterior ${ }^{535}$.

\subsection{La regulación de la copia privada en España}

\subsubsection{Cuestiones generales sobre la evolución del marco normativo}

La regulación de la copia privada en la actualidad no sólo se encuentra contenida en el art. 31.2 y 3 del TRLPI, sino que se complementa con el art. 25 del TRLPI, relativo a la compensación equitativa asociada a la excepción, el art. 154.5, párrafo $1^{\circ}$. e ${ }^{536}$, y el art. 161 del TRLPI, que contiene la relación entre los límites a la propiedad intelectual y el establecimiento de medidas tecnológicas de protección, no menos importante.

La positivización del límite de copia privada en España data de la LPI de 1987, cuyo art. 31.2 se mantuvo prácticamente invariable con la promulgación del Real Decreto Legislativo 1/1996, de 12 de abril, por el que se aprueba el TRLPI. Este artículo admitía la reproducción sin autorización del autor de obras divulgadas para uso privado del copista, siempre que la copia no fuera objeto de utilización colectiva ni lucrativa.

Puede decirse que la única modificación que sufrió el art. 31.2 de la LPI con la promulgación del TRLPI en 1996 fue la incorporación de la cláusula "sin perjuicio de lo

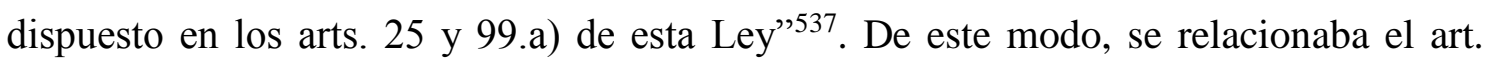
31.2 del TRLPI con el contenido de sus arts. 25 y 99.a), confirmando así la relación entre la copia privada y la entonces denominada "remuneración compensatoria", al mismo tiempo que excluía a los programas de ordenador del límite de la copia privada. Sin embargo, esta modificación no fue realmente relevante porque dichas disposiciones,

\footnotetext{
535 Vid. infra Capítulo V.

${ }^{536}$ Este precepto se refiere al destino de las cantidades recaudadas y no reclamadas por el titular de derechos de autor, que prevé que una parte de las mismas atiendan a la financiación de la persona jurídica encargada de la gestión de la compensación equitativa por copia privada, constituida conforme a lo previsto en el art. 25.10 del TRLPI, en representación de las entidades de gestión de derechos de propiedad intelectual.

${ }^{537}$ Estos artículos se refieren a la remuneración por copia privada y a la autorización para la reproducción total o parcial de un programa de ordenador, respectivamente.
} 
también existentes en la LPI, resultaban de aplicación en todo caso, pese a la ausencia de remisión expresa ${ }^{538}$. El mencionado art. 25 de la LPI, en cambio, sí sufrió modificaciones más significativas en el TRLPI, como se analizará en el capítulo siguiente.

Más apreciable fue la modificación que el art. 31.2 del TRLPI experimentó con la trasposición de la DDASI al ordenamiento jurídico interno mediante la Ley 23/2006, de 7 de julio. Esta reforma mejoró la terminología empleada, eliminando el uso del vocablo “copista" que resultaba ambiguo ${ }^{539}$, al mismo tiempo que adaptó el tenor del precepto al escenario digital, siguiendo las exigencias de la DDASI.

También fue significativa la reforma posterior del precepto con la promulgación de la Ley 21/2014, de 4 de noviembre, por la que se modifica el TRLPI y la Ley 1/2000, de 7 de enero, de Enjuiciamiento Civil. Cabe resaltar, como se sigue de su Exposición de Motivos, que esta Ley vino a reformar algunas cuestiones consideradas de mayor urgencia legislativa en relación con la protección de los derechos de propiedad intelectual y, dentro de ellas, la regulación del sistema de copia privada. En efecto, la Ley 21/2014 ofreció una nueva redacción al precedente art. 31.2 del TRLPI y, al mismo tiempo, añadió un tercer apartado al art. 31 del TRLPI con la finalidad de precisar los supuestos excluidos del límite de copia privada. Esta nueva reforma restringió los contornos de este límite al derecho de reproducción a la vez que introdujo algunas cuestiones no contempladas en las versiones anteriores de dicho precepto ${ }^{540}$.

Pero el régimen jurídico de la copia privada ha experimentado nuevos cambios recientemente. Los mismos responden en buena medida al hecho de que el TJUE haya

\footnotetext{
${ }^{538}$ MARÍn LÓPEZ, J. J., "La copia privada frente a las medidas tecnológicas de protección”, Pe. i.: Revista de propiedad intelectual, núm. 20, 2005, p. 16.

${ }^{539} \mathrm{La}$ interpretación del vocablo "copista" no era pacífica, lo que generaba problemas hermenéuticos respecto al alcance de la excepción de copia privada. Eran varias las alternativas o interpretaciones que, siguiendo la doctrina, podían derivarse de la noción de "copista". Así, copista podía ser tanto la persona que realiza directamente la copia, empleando sus propios medios; el establecimiento que ostenta la titularidad de los instrumentos necesarios para efectuar la reproducción y que se dedica a la realización por encargo de tales copias; como la persona que realiza la copia sirviéndose de equipos, aparatos y soportes de titularidad ajena. Vid. LóPEZ MAZA, S., Límites al derecho de reproducción ..., op. cit., p. 202. ${ }^{540}$ Vid. MARTíneZ EsPín, P., "El nuevo régimen de la compensación equitativa por copia privada en España”, en AA. VV., Estudios sobre la Ley de Propiedad Intelectual: Últimas Reformas y Materias Pendientes, Dykinson, Madrid, 2016, p. 455.
} 
considerado contraria al ordenamiento jurídico de la UE la compensación con cargo a los PGE. Como consecuencia, se ha promulgado el Real Decreto-ley 12/2017, de 3 de julio, por el que se modifica el TRLPI, que se encuentra en vigor desde el 1 de agosto de $2017^{541}$ y que, en particular, modifica la redacción de la letra b) del art. 31.2 del TRLPI, al mismo tiempo que incluye importantes reformas en el régimen jurídico de la compensación equitativa por copia privada ${ }^{542}$.

\subsubsection{El objeto del límite de copia privada}

Para determinar el objeto del límite de copia privada hay que acudir, en primer lugar, al art. 25 del TRLPI, pese a que es el art. 31 del TRLPI (apartados 2 y 3 ) el que regula esta excepción legal.

En efecto, es el art. 25.1 del TRLPI el que hace referencia a las diferentes categorías de obras y prestaciones intelectuales que son susceptibles de ser reproducidas bajo el límite de copia privada, al prever que originará una compensación equitativa y única la reproducción de "obras divulgadas en forma de libros o publicaciones que a estos efectos se asimilen mediante real decreto, así como de fonogramas, videogramas o de otros soportes sonoros, visuales o audiovisuales". Por tanto, son objeto de copia privada, por una parte, los libros y publicaciones asimiladas; por otra, los fonogramas y demás soportes sonoros; y, finalmente, los videogramas y demás soportes visuales y audiovisuales $^{543}$.

El concepto de libro se contiene en el art. 2.a) de la Ley 10/2007, de 22 de junio, de la lectura, del libro y de las bibliotecas ${ }^{544}$ en los términos siguientes:

\footnotetext{
${ }^{541}$ La Disposición final segunda del Real Decreto-ley 12/2017 refrenda: "El presente real decreto-ley entrará en vigor el día 1 del mes siguiente a su publicación en el «Boletín Oficial del Estado», sin perjuicio de que la primera determinación prevista en el apartado 4 del artículo 25 del texto refundido de la Ley de Propiedad Intelectual se fijará mediante el real decreto previsto en la disposición final primera". ${ }^{542}$ Vid. infra Capítulo V, donde se aborda el régimen jurídico de la compensación equitativa por copia privada a tenor de la última reforma al TRLPI (2017).

${ }^{543} \mathrm{La}$ referencia a las publicaciones asimiladas reglamentariamente a los libros y la mención a los soportes audiovisuales fueron introducidas en el ordenamiento jurídico con el TRLPI de 1996.

${ }^{544}$ B.O.E. núm. 150, de 23 de junio de 2007.
} 
"A los efectos de esta Ley se entiende por: a) Libro: obra científica, artística, literaria o de cualquier otra índole que constituye una publicación unitaria en uno o varios volúmenes y que puede aparecer impresa o en cualquier otro soporte susceptible de lectura. Se entienden incluidos en la definición de libro, a los efectos de esta Ley, los libros electrónicos y los libros que se publiquen o se difundan por Internet o en otro soporte que pueda aparecer en el futuro, los materiales complementarios de carácter impreso, visual, audiovisual o sonoro que sean editados conjuntamente con el libro y que participen del carácter unitario del mismo, así como cualquier otra manifestación editorial" 545 .

Ahora bien, en la práctica, un factor indicativo de que estamos ante un "libro" -a los efectos previstos en el art. 25.1 del TRLPI- es el código conocido como International Standard Book Number o ISBN, por sus siglas en inglés. Este código es creado internacionalmente con el propósito de dotar a cada libro de un código numérico que lo identifique. Tal y como establece el art. 8.1 de la Ley 10/2007, de 22 de junio, permite "coordinar y normalizar la identificación de cualquier libro para localizarlo y facilitar su circulación en el mercado" 546.

La definición de publicaciones asimiladas a los libros tiene su origen en el art. 9.3 del Real Decreto 1434/1992, de 27 de noviembre, de desarrollo de los artículos 24, 25 y 140 de la Ley 22/1987, de 11 de noviembre, de Propiedad Intelectual, en la versión dada a los mismos por la Ley 20/1992, de 7 de julio ${ }^{547}$. La misma ha permanecido invariable, quedando recogida en la actualidad en los mismos términos en la Disposición transitoria primera del Real Decreto-ley 12/2017, de 3 de julio, por el que se modifica el TRLPI ${ }^{548}$. En su virtud, se entienden asimiladas a los libros "las publicaciones de contenido cultural, científico o técnico siempre y cuando: a) Estén editadas en serie continua con un mismo título a intervalos regulares o irregulares, de forma que los ejemplares de la

\footnotetext{
${ }^{545}$ No obstante, la referencia hecha "a los efectos de esta Ley" en el TRLPI, a falta de una definición expresa de lo que es un libro en dicho texto legal, podría aplicarse a los supuestos que utiliza dicho término, por analogía, el concepto contenido en la Ley 10/2007, de 22 de junio. Vid. Garrote FERnÁNDEZ- DíEZ, I., "Artículo 25", en BerCovitz RodríGuez-CANO, R. (Coord.), Comentarios a la Ley de Propiedad..., $3^{\text {a }}$ ed., op. cit., p. 480.

${ }^{546}$ La disposición final primera de la Ley 21/2014 modifica el apartado segundo del art. 8 de la Ley 10/2007 y atribuye así a la Agencia Española del ISBN la competencia para desarrollar el sistema del ISBN en España; función que antes tenía asignada el Ministerio de Educación, Cultura y Deporte.

${ }^{547}$ B.O.E. núm. 301, de 16 de diciembre de 1992.

${ }^{548}$ Sin embargo, esta definición está prevista con carácter temporal, hasta que el Gobierno determine, mediante Real Decreto, las publicaciones que se entenderán asimiladas a los libros a los efectos del art. 25 del TRLPI.
} 
serie lleven una numeración consecutiva o estén fechados, con periodicidad mínima mensual y máxima semestral; b) Tengan al menos 48 páginas por ejemplar”.

Es posible que no exista una razón de peso para fundamentar la exclusión de las publicaciones de menos de 48 páginas del concepto de publicaciones asimiladas a los libros. En efecto, las obras literarias son protegibles al margen de su extensión, que sólo es necesario especificar para acceder al Registro de Propiedad Intelectual, de conformidad con lo establecido en el art. 17 del Real Decreto 1584/1991, de 18 de octubre, por el que se aprueba el Reglamento del Registro General de la Propiedad Intelectual $^{549}$. Cosa distinta es que -estadísticamente- sea infrecuente encontrar obras literarias impresas de volumen inferior a 48 páginas, razón que, quizás, haya sido la tenida en cuenta al redactar el art. 9.3.b) del Real Decreto 1434/1992 $2^{550}$, y que ha perdurado hasta el presente.

El TRLPI incluye dentro de la enumeración de las obras susceptibles de ser copiadas a los fonogramas. Su concepto se contiene en el art. 114 del TRLPI, a cuyo tenor, por fonograma se entiende "toda fijación exclusivamente sonora de la ejecución de una obra o de otros sonidos”, sin requerir ningún requisito adicional. Básicamente, esta definición coincide con la del artículo 3.b) de la Convención de Roma sobre la Protección de los Artistas, Intérpretes o Ejecutantes, los Productores de Fonogramas y los Organismos de Radiodifusión, de 26 de octubre de 1961; y con la del artículo 1.a) del Convenio para la protección de los productores de fonogramas contra la reproducción no autorizada de sus fonogramas, adoptado en Ginebra el 29 de octubre de 1971, conforme a los cuales, fonograma es toda fijación exclusivamente sonora de los sonidos de una ejecución o de otros sonidos.

Sin embargo, un concepto más elaborado ofrece el art. 2.b) del Tratado de la OMPI sobre Interpretación o Ejecución y Fonogramas (TOIEF), adoptado en Ginebra el 20 de diciembre de $1996^{551}$, que define al fonograma como: “toda fijación de los

\footnotetext{
${ }^{549}$ B.O.E. núm. 269, de 9 de noviembre de 1991.

${ }^{550}$ RoGel VIDE, C., Estudios completos..., op. cit., p. 250.

551 [En línea]: http://www.wipo.int/treaties/es/text.jsp?file id=295578\#P83 5515 (consultado 30 de noviembre de 2016).
} 
sonidos de una ejecución o interpretación o de otros sonidos, o de una representación de sonidos que no sea en forma de una fijación incluida en una obra cinematográfica o audiovisual".

Por consiguiente, el concepto de fonograma engloba tanto a la obra musical, como a otros sonidos que no constituyen una obra musical. Aunque lo más frecuente sea que los fonogramas contengan obras y/o prestaciones artísticas, no tiene por qué ser así necesariamente ${ }^{552}$, pudiendo tratarse, por ejemplo, de una secuencia de sonidos que por defecto de originalidad ni siquiera llegue a constituir una obra (sonidos de la naturaleza, ruidos ambientales, etc. $)^{553}$.

Por último, también se incluyen dentro del objeto de la copia privada los videogramas que, siguiendo a SERRANO GóMEZ, pueden definirse como "toda grabación o fijación de imágenes asociadas que den sensación de movimiento con o sin sonorización incorporada" ${ }^{, 54}$. Se trata de un concepto que históricamente se ha asociado a las grabaciones audiovisuales realizadas en vídeo, haciendo referencia al soporte ${ }^{555}$. Sin embargo, realmente, es mucho más amplio, pues según puede apreciarse de su definición, dicha grabación o fijación puede hacerse, a día de hoy, en soportes distintos a una cinta de vídeo.

El TRLPI no ofrece una definición del término videograma, aunque sí de grabaciones audiovisuales. El art. 120.1 del TRLPI entiende por tales "las fijaciones de un plano o secuencia de imágenes, con o sin sonido, sean o no creaciones susceptibles de ser calificadas como obras audiovisuales en el sentido del artículo 86 de esta Ley". A su vez el art. 86 del TRLPI conceptualiza a las obras audiovisuales -incluidas las cinematográficas- como "las creaciones expresadas mediante una serie de imágenes

\footnotetext{
552 Moscoso del Prado Hernández, A. (Coord.), Practicum ..., op. cit., p. 493.

${ }^{553}$ Ibídem, p. 495.

554 SERrano GómeZ, E., Los derechos de remuneración de la Propiedad Intelectual, Dykinson, Madrid, 2000, p. 180.

${ }^{555}$ OMPI, Los derechos de autor y los derechos conexos desde la perspectiva de su gestión colectiva, Séptimo Curso Académico Regional de la OMPI sobre derecho de autor y derechos conexos para países de América Latina [OMPI-SGAE/DA/COS/OO/16e], San José, 28 de agosto a 5 de septiembre de 2000, p. 4, disponible en: http://www.wipo.int/mdocsarchives/OMPI-SGAE_DA_COS_00/OMPISGAE_DA_COS 00_16e_S.pdf (consultado: 23.06.2017).
} 
asociadas, con o sin sonorización incorporada, que estén destinadas esencialmente a ser mostradas a través de aparatos de proyección o por cualquier otro medio de comunicación pública de la imagen y del sonido, con independencia de la naturaleza de los soportes materiales de dichas obras".

Puede decirse que el concepto de grabación audiovisual es más amplio que el de obra audiovisual. Mientras la grabación audiovisual es el género, la obra audiovisual es la especie, lo que significa que esta última presupone la existencia de aquélla, pero no viceversa, pues a la obra audiovisual se le exige el requisito de la originalidad que no requiere, en cambio, la grabación audiovisual ${ }^{556}$.

En cualquier caso, resulta claro que el TRLPI utiliza un concepto amplio de creaciones intelectuales que pueden ser objeto de copia privada, no limitadas únicamente al estricto concepto de lo que pueda entenderse por fonograma y videograma, junto a los libros y publicaciones asimiladas a estos. Por el contrario, se incluyen también a aquellas otras a las que de modo residual se refiere el art. 25.1 del TRLPI como "otros soportes sonoros, visuales o audiovisuales". De este modo, se superan las restricciones que comporta el término "videograma" 557.

Por otra parte, también delimitan el objeto del límite de copia privada ciertas reproducciones expresamente excluidas del ámbito de la excepción por mandato legal. Así se deriva del art. 25.5.c) del TRLPI, al establecer que determinadas reproducciones no tendrán la consideración de reproducciones para uso privado.

Al respecto, el primer grupo de reproducciones excluidas se contiene en el art. 25.5.c). $1^{\circ}$ del TRLPI, que no considera reproducciones para uso privado aquellas efectuadas en establecimientos dedicados a la realización de reproducciones para el

\footnotetext{
556 Vid. MARTín Villarejo, A., "Derechos de los productores de grabaciones audiovisuales", en EsteVE PARDO, Ma. A. (Coord.), Propiedad Intelectual. Doctrina, Jurisprudencia, Esquemas y Formularios, Tirant Lo Blanch, Valencia, 2009, p. 665; Moscoso Del Prado Hernández, A. (Coord.), Practicum..., op. cit., p. 501; BERCOVITZ RODRÍGUEZ-CANO, R., "Artículo 10.1”, en BERCOVITZ RODRÍGUEZ-CANO, R. (Coord.), Comentarios a la Ley de Propiedad..., $4^{a}$ ed., op. cit., p. 180; y SAIZ GarCía, C., Obras audiovisuales y derecho de autor, Aranzadi, 2002, pp. 3 y ss.

${ }^{557}$ Como sugiere Garrote Fernández- DíEz, I., "Artículo 25", en Bercovitz Rodríguez-CANo, R. (Coord.), Comentarios a la Ley de Propiedad..., $3^{\text {a }}$ ed., op. cit., p. 456 (nota 24), el TRLPI podría haberse referido en términos más amplios a los "soportes de grabaciones audiovisuales".
} 
público, o que tengan a disposición del público los equipos, aparatos y materiales para su realización [art. 25.5.c). $\left.1^{\circ}\right]^{558}$. Se trata, por ejemplo, de las copias que se realizan en una copistería o en un establecimiento cuya actividad consiste en servicios de reproducción mediante autoservicio. Sin embargo, sí incluye aquéllas realizadas mediante equipos, aparatos y soportes de reproducción puestos a disposición de usuarios privados, para una finalidad privada, como universidades y colegios para sus estudiantes, fundaciones para los beneficiarios de su actividad, o asociaciones para sus $\operatorname{socios}^{559}$.

El segundo grupo de reproducciones excluidas son "las realizadas mediante equipos, aparatos y soportes de reproducción digital que no se hayan puesto a disposición de derecho o de hecho de usuarios privados y que estén manifiestamente reservados a usos distintos a la realización de copias privadas" [art. 25.5.c). $2^{\circ}$ del TRLPI]. El precepto exige, ante todo, que los equipos, aparatos y soportes de reproducción no se destinen al uso efectivo de usuarios privados, lo que no queda excluido, prima facie, por el hecho de que sean adquiridos por empresas, empresarios y profesionales. La finalidad es "evitar el fraude que supondría que el equipos o soportes fuera adquirido formalmente por una empresa o profesional, pero para ser inmediatamente después dedicado al disfrute particular de un 'usuario privado', que es según la jurisprudencia del TJUE el único beneficiario del límite de copia privada" ${ }^{\$ 60}$. Además, tiene que ser presumible que su utilización será ajena a la realización de copias para uso privado de obras y prestaciones protegidas por la propiedad intelectual.

\footnotetext{
558 Ya en su día el art. 10.1.a) del Real Decreto 1434/1992, de 27 de noviembre, de desarrollo de los artículos 24, 25 y 140 de la Ley 22/1987, de 11 de noviembre, de Propiedad Intelectual, en la versión dada a los mismos por la Ley 20/1992, de 7 de julio, expresamente exceptuaba de la compensación equitativa por copia privada aquellas efectuadas en establecimientos dedicados a la realización de copias para el público o que tuvieran a disposición de éste los medios para realizarlas. La misma previsión contenía el art. 3.4.a) del Real Decreto 1657/2012, de 7 de diciembre, por el que se reguló el procedimiento de pago de la compensación equitativa por copia privada con cargo a los Presupuestos Generales del Estado, promulgado a tenor del mandato de la disposición adicional décima del Real Decreto-ley 20/2011, de 30 de diciembre, de medidas urgentes en materia presupuestaria, tributaria y financiera para la corrección del déficit público.

559 BERCOVITZ RODRÍGUEZ-CANO, R., "La copia privada", en BERCOVITZ RODRÍGUEZ-CANO, R. (Coord.), La reforma de la Ley de Propiedad Intelectual, Tirant Lo Blanch, Valencia, 2015, p. 85.

560 Garrote Fernández-Díez, I., "Artículo 25", en Bercovitz RodrígueZ-Cano, R. (Coord.), Comentarios a la Ley de Propiedad..., $4^{\mathrm{a}}$ ed., op. cit., p. 538.
} 
El tercer grupo de reproducciones excluidas del límite de copia privada está establecido en el art. 31.3.a), b) y c) del TRLPI. Comenzando por su letra a) ${ }^{561}$, se excluyen del límite de copia privada las reproducciones de obras "que se hayan puesto a disposición del público conforme al artículo 20.2.i) ${ }^{562}$, de tal forma que cualquier persona pueda acceder a ellas desde el lugar y momento que elija, autorizándose, con arreglo a lo convenido por contrato y, en su caso, mediante pago de precio, la reproducción de la obra". En consecuencia, quedan excluidas del límite de copia privada las reproducciones de las obras a las que el usuario accede como resultado de un acto de comunicación púbica (alámbrico o inalámbrico) convenido contractualmente, es decir, como resultado de servicios interactivos en línea, conocidos como servicios "a la carta" ${ }^{963}$. Dicho de otro modo, la previa concertación del contrato entre el ususario y el prestador de estos servicios a la carta excluye la aplicación del límite de copia privada, haciendo prevalecer el contrato por encima del propio límite legal, conforme a lo dispuesto en el precepto referido. Sin embargo, siguiendo a TATO Plaza y TORRES PÉREZ, esta solución sólo es viable si el titular de derechos ha implementado medidas tecnológicas de protección ${ }^{564}$, pues de lo contrario se estaría nuevamente frente al problema de no poder controlar la copia privada. Por todos es sabido que la responsabilidad que pueda generar la infracción de un deber contractual no excluye la comisión de la infracción legal (en este caso, la realización de copias privadas sin la previa autoización de titular en el caso de que el contrato las prohibiera). Por tanto, el uso de medidas tecnológicas de protección será el único modo de controlar, con cierto grado de eficacia, la realización de reproducciones para uso privado.

\footnotetext{
${ }^{561}$ Esta exclusión fue introducida en el TRLPI por la Ley 21/2014, de 4 de noviembre.

${ }^{562} \mathrm{El}$ art. 20.1.i) del TRLPI establece que constituye un acto de comunicación pública "la puesta a disposición del público de obras, por procedimientos alámbricos o inalámbricos, de tal forma que cualquier persona pueda acceder a ellas desde el lugar y en el momento que elija".

${ }^{563}$ Los servicios de "televisión a la carta" permiten a los usuarios la visualización de contenidos televisivos (documentales, series, películas, etc.) en el momento que ellos elijan, con la opción de visualizar el programa en más de una ocasión -si se quiere-, detener el programa o reanudarlo, adelantar o regresar en su visualización o ponerlo en pausa, como si de un sistema de video se tratara. Actualmente existen muchos operadores de televisión que ofrecen estos servicios. Los servicios de "audio a la carta" son equivalentes al "vídeo a la carta", pero en formato de audio.

564 TAto PlazA, A. y TORRes PÉREZ, F., "Artículo 31. Reproducciones provisionales y copia privada" (Comentario), en Palau Ramírez, F. y Palao Moreno, G. (Dirs.), Comentarios ..., op. cit., p. 506.
} 
Sea como fuere, lo cierto es que esta es una exclusión injustificada a tenor del Derecho de la UE, pues la posibilidad de instrumentar medidas tecnológicas en las creaciones intelectuales puestas a disposición del público en línea, bajo contrato, no descarta la aplicación del límite de copia privada a las reproducciones efectuadas a partir de dichos actos, ni tampoco de la compensación equitativa, tal y como como llama la atención al respecto CARBAJO CASCÓN ${ }^{565}$.

Por su parte, el art. 31.3.b) y el art. 31.3.c) del TRLPI excluyen del límite de copia privada las bases de datos electrónicas y los programas de ordenador, respectivamente. Se trata de exclusiones que han encontrado su justificación, fundamentalmente, en los elevados costes de creación de este tipo de obras y la facilidad con que se reproducen.

Éstas no constituyen una novedad en la norma, como sí lo es la establecida en virtud del art. 31.3.a) del TRLPI analizada anteriormente. De hecho, la exclusión de los programas de ordenador figuraba ya desde la redacción dada al art. 25.2 de la LPI de 1987 por la Ley 20/1992, de 7 de julio ${ }^{566}$. Por su parte, la exclusión de las bases de datos electrónicas, si bien no estaba expresamente contenida en el TRLPI, en su primera versión, sí indirectamente, toda vez que su art. 135.1.a) autorizaba únicamente la extracción y/o reutilización de una parte sustancial del contenido de una base de datos para fines privados sólo cuando se tratara de bases de datos no electrónicas, con lo cual, podía concluirse que el límite de copia privada no era de aplicación a las bases de datos electrónicas $^{567}$.

\subsubsection{Los presupuestos del límite de copia privada}

El art. 31.2 del TRLPI establece varios presupuestos para que una reproducción con fines privados pueda ser realizada sin el consentimiento del titular de derechos de

\footnotetext{
${ }^{565}$ CARbajo CASCón, F., "El retorno del canon digital. Consecuencias previsibles de la STJUE de 9 de junio de 2016", Ars Iuris Salmanticensis, Tribuna de Actualidad, Vol. 4, 2016, p. 18.

${ }_{566}$ En el TRLPI (1996) pasó a regularse en el art. 99.a).

${ }^{567}$ La redacción del art. 135 del TRLPI (1996) a la que se hace referencia fue la introducida por Ley 5/1998, de 6 de marzo, de incorporación al Derecho español de la Directiva 96/9/CE, del Parlamento Europeo y del Consejo, de 11 de marzo de 1996, sobre la protección jurídica de las bases de datos (B.O.E. núm. 57, de 7 de marzo de 1998).
} 
autor, a saber, que la reproducción se realice en cualquier soporte, sin asistencia de terceros, de obras ya divulgadas. Estos presupuestos, en su mayor parte, ya estaban incluidos en las versiones anteriores del precepto, en cambio, otros se introducen con la redacción dada al mismo por la Ley 21/2014, de 4 de noviembre, o se modifican (aunque no sustancialmente) mediante el Real Decreto-ley 12/2017, de 3 de julio.

Debe destacarse que el art. 31.2 del TRLPI parte del establecimiento del límite de copia privada sin perjuicio de la compensación equitativa prevista en el art. 25 del TRLPI, lo que resalta la relación existente entre la copia privada y la compensación equitativa asociada a la misma. Por tanto, son consideradas dentro de esta excepción aquellas reproducciones que cumplen los requisitos contenidos en el art. 31.2 del TRLPI (acotado por su art. 31.3 ${ }^{568}$ ), debiendo estar, a efectos de la compensación, a lo dispuesto en el mencionado art. 25 del TRLPI.

En primer lugar, siguiendo lo dispuesto en la DDASI ${ }^{569}$, el art. 31.2 del TRLPI permite que la copia privada puede ser realizada "en cualquier soporte", es decir, tanto analógico como digital. Así pues, tanto la copia analógica como digital pueden quedar al amparo del límite de copia privada, siempre que se cumplan los presupuestos que precisa el art. 31.2 del TRLPI.

En segundo lugar, exige el art. 31.2 del TRLPI que la reproducción sea "sin asistencia de terceros". Esta expresión, introducida por primera vez en el TRLPI por la Ley 21/2014, de 4 de noviembre, implica la exclusión del ámbito de la copia privada de las reproducciones realizadas con asistencia profesional o empresarial ${ }^{570}$. En cambio, no deben considerarse excluidas las reproducciones realizadas con el auxilio de un familiar o amigo ${ }^{571}$, pues carecería de sentido una interpretación tan estricta de la norma cuando, en definitiva, se trata de una copia efectuada para uso privado del beneficiario de la misma y sin ánimo de lucro que, además, el titular de derechos no puede controlar.

\footnotetext{
${ }^{568} \mathrm{El}$ art. 31.3 del TRLPI establece aquellos supuestos excluidos del límite de copia privada.

${ }^{569}$ Esta posibilidad venía contemplada desde la modificación del TRLPI por la Ley 23/2006, de 7 de julio, en concordancia con lo establecido en la DDASI.

570 Bercovitz Rodríguez-CANO, R., "La copia privada”, en BERCOVITZ RodríGUEZ-CANO, R. (Coord.), La reforma de la Ley de Propiedad Intelectual, op. cit., p. 73.

571 Ídem.
} 
Así, se excluyen del ámbito de la copia privada las reproducciones realizadas por quienes presten servicios de fotocopiado, grabación de audio o vídeo, u otros que lleven implícitos la reproducción de obras, prestaciones artísticas, fonogramas y videogramas para el público; en definitiva, aquellas reproducciones que quedan excluidas del límite de copia privada por efectuarse en establecimientos dedicados a la realización de reproducciones para el público o que tengan a disposición del público los equipos, aparatos y materiales para su realización (art. 25.5.c). $1^{\circ}$ del TRLPI). Pero se extiende, además, a cualquier supuesto en el que la obra o prestación intelectual sea reproducida mediante asistencia profesional o empresarial. De este modo, se excluyen las reproducciones realizadas mediante los servicios de videograbación remota y almacenamiento en la nube (que precisan para su realización de esta asistencia) ${ }^{572}$.

En consecuencia, la exigencia del TRLPI de que la reproducción se haga "sin asistencia de terceros" es contraria a la opinión del Parlamento Europeo en su "Informe sobre los cánones por copia privada" 573 , al declarar que "la excepción relativa a la copia privada debe aplicarse a determinados servicios en línea, incluidos algunos servicios de computación en nube".

Debe destacarse que la doctrina del TJUE no se opone a que la copia privada se haga con asistencia de terceros, como tampoco lo hace la DDASI ${ }^{574}$. Efectivamente, el TJUE ha declarado que la DDASI "no se opone a una normativa nacional que establece una compensación equitativa por las reproducciones de obras protegidas efectuadas por

572 CARBAJO CASCÓN, F., “Artículo 25. Compensación equitativa por copia privada” (Comentario), en Palau Ramírez, F. y Palao Moreno, G. (Dirs.), Comentarios..., op. cit., p. 437; SÁnchez Aristi, R., “Artículo 18”, en Bercovitz Rodríguez-CAno, R. (Coord.), Comentarios a la Ley de Propiedad..., 3 a ed., op. cit., p. 325.

En efecto, los servicios de videograbación remota son ofrecidos por empresas que gestionan sistemas que captan la señal de televisión utilizando sus antenas y graban en el espacio de almacenamiento en la nube indicado por el usuario y en la franja horaria de la emisión seleccionada por este último. El espacio de almacenamiento utilizado es suministrado por un proveedor.

573 Parlamento Europeo, Informe sobre los cánones por copia privada, ponente: Françoise Castex, aprobado por la Comisión de Asuntos Jurídicos el 17 de febrero de 2014 [A7-0114/2014], apartado 29.

${ }^{574}$ CARBAJO CASCÓN, F., “Artículo 25. Compensación equitativa por copia privada" (Comentario), en Palau Ramírez, F. y Palao Moreno, G. (Dirs.), Comentarios..., op. cit., p. 437; y "El retorno del canon digital. Consecuencias previsibles...”, op. cit., p. 17. 
una persona física a partir o mediante un dispositivo que pertenece a un tercero" 575 . Se reconoce así, al menos indirectamente, que la copia privada puede obtenerse valiéndose de un tercero que pone a disposición de la persona que realiza la copia un producto o servicio para la reproducción para uso privado. Cosa distinta es que, con independencia de que la copia se realice valiéndose de medios propios o ajenos, tenga una finalidad lucrativa o colectiva que la excluya del límite de copia privada.

Así lo expresa el Abogado General, Sr. Maciej SzPunAR, en sus Conclusiones presentadas ante el TJUE el 7 de septiembre de 2017, en el Asunto C-265/16 (VCAST Limited contra RTI S.p.A.) ${ }^{576}$ en el marco de un conflicto de servicios de almacenamiento en la nube o cloud computing:

“[...] en lo relativo a la intervención de terceros en el propio acto de reproducción, considero que una interpretación excesivamente rigurosa del artículo 5, apartado 2, letra b), de la Directiva 2001/29 no estaría justificada. Está claro que la reproducción de una obra al amparo de la excepción de copia privada y su grabación en la nube, esto es, en un espacio de almacenamiento de datos que no está directamente al alcance del usuario que efectúa dicha reproducción, requieren la intervención de un tercero, ya sea el proveedor de este espacio de almacenamiento u otra persona. En efecto, la realización de las operaciones previas a la reproducción por parte del usuario pone en marcha una serie de procesos, más o menos automatizados, que dan lugar a la creación de una copia de la obra en cuestión. No creo que esta forma de reproducción deba excluirse del ámbito de aplicación de la excepción de copia privada por el mero hecho de que la intervención de un tercero vaya más allá de una mera puesta a disposición de soportes o equipos. Mientras sea el usuario quien tome la iniciativa de la reproducción y quien determine el objeto y las modalidades de la misma, no veo una diferencia decisiva entre ese acto y la reproducción realizada por el mismo usuario mediante equipos manejados directamente por él" (apartado 25).

Distinta connotación debe tener, en cambio, la conducta de la empresa que ofrece a los particulares un servicio de videograbación remota en la nube de copias privadas de obras protegidas por derechos de autor, interviniendo activamente en la grabación de tales copias, sin solicitar previamente autorización de los titulares de derechos. En este

\footnotetext{
575 STJUE (Sala Cuarta), de 5 de marzo de 2015, Copydan Båndkopi vs. Nokia Danmark A/S, asunto C463/12 [ECLI:EU:C:2015:144], párrafo 91.

576 Conclusiones del Abogado General Maciej SZPUNAR, 7 de septiembre de 2017 [ECLI:EU:C:2017:649].
} 
caso, como pone de relieve la STJUE de 29 de noviembre de $2017^{577}$, "este servicio tiene una doble funcionalidad, consistente en garantizar a la vez la reproducción y la puesta a disposición de las obras y prestaciones a las que atañe" (párrafo 38). Por tanto, el prestador de servicios, al garantizar el acceso a las obras o prestaciones a las personas físicas que desean realizar copias privadas, realiza diferentes actos de comunicación al público que requieren de la autorización de los respectivos titulares de derechos, por lo que -concluye la sentencia- "tal servicio de grabación remota no puede acogerse al artículo 5, apartado 2, letra b), de la Directiva 2001/29"578.

En tercer lugar, otro presupuesto que hay que tener en cuenta, siguiendo el art. 31.2 TRLPI, es que el límite de copia privada opera respecto a "obras ya divulgadas". Al respecto, siguiendo al art. 4 del TRLPI, por divulgación de una obra se entiende "toda expresión de la misma que, con el consentimiento del autor, la haga accesible por primera vez al público en cualquier forma”. Esta exigencia deriva de la modificación del TRLPI llevada a cabo por la Ley 23/2006, de 7 de julio y, que no se encuentra contenida en la DDASI. Seguramente su inclusión pretende proteger el derecho moral de divulgación del autor e impedir que obras inéditas puedan ser reproducidas con fines privados, aun cuando estos fines no tengan una finalidad comercial.

Junto a los presupuestos mencionados, el legislador exige, además, la concurrencia simultánea de determinadas "circunstancias constitutivas del límite legal de copia privada". La excepción de copia de privada depende, así, de la concurrencia cumulativa de los tres requisitos que consigna el art. 31.2 del TRLPI, a saber:

1. Que la reproducción se lleve a cabo por una persona física exclusivamente para su uso privado, no profesional ni empresarial, y sin fines directa ni indirectamente comerciales.

2. Que la reproducción se realice a partir de una fuente lícita y que no se vulneren las condiciones de acceso a la obra o prestación.

\footnotetext{
577 STJUE (Sala Tercera), de 29 de noviembre de 2017, VCAST Limited vs. RTI, asunto C-265/16 [ECLI:EU:C:2017:913].

${ }^{578}$ Vid. párrafos 39, 40, 49 y 52.
} 
3. Que la copia obtenida no sea objeto de una utilización colectiva ni lucrativa, ni de distribución mediante precio.

En cuanto al primer requisito, contenido en el art. 31.2.a) del TRLPI, debe destacarse que, salvo el uso del adverbio "exclusivamente" y la mención "no profesional ni empresarial", el resto de su tenor ya figuraba prácticamente en idénticos términos en el TRLPI tras la Ley 23/2006, de 7 de julio; habiéndose incorporado los matices señalados mediante la Ley 21/2014, de 4 de noviembre. De este modo, no constituye ninguna novedad la exigencia de que la reproducción sea realizada por una persona física, para su uso privado y sin fines directa ni indirectamente comerciales; aunque tampoco cambia nada el empleo del adverbio "exclusivamente", que más bien viene a reafirmar el carácter privado del uso predicado de la persona física que realiza la $\operatorname{copia}^{579}$.

Sin embargo, el matiz introducido con la expresión "no profesional ni empresarial" restringe el alcance de la copia privada. Puede decirse que la exclusión del uso profesional o empresarial del ámbito del límite de copia privada refleja la influencia de la STJUE (Sala Tercera), de 21 de octubre de 2010, recaída en el caso conocido como Padawan ${ }^{580}$. En efecto, esta sentencia remarca la necesidad de distinguir, a efectos de la compensación equitativa por copia privada, entre las copias destinadas al uso profesional o empresarial y las que no tienen tal fin, respaldando la posibilidad de que las personas jurídicas no paguen una compensación económica cuando adquieran los dispositivos de reproducción digital para fines manifiestamente reservados a usos distintos a la realización de copias privadas ${ }^{581}$, esto es, para los fines empresariales o profesionales que demanda su actividad (v. gr. imprimir facturas, escanear recibos, etc.). Así pues, parece ser que el legislador español entiende que si estos usos están excluidos

\footnotetext{
${ }^{579}$ Desde la modificación del TRLPI, en su versión dada por la Ley 23/2006, el art. 31.2 se refiere a "su uso privado". La utilización del adjetivo posesivo "su" viene a reafirmar que el uso privado se predica de la persona física que hace la copia. Para un estudio amplio sobre el concepto de "uso privado" vid. GonzÁlez de Alaiza CARdonA, J. J., La copia privada. Sus fundamentos ..., op. cit., pp. 170-176.

${ }^{580}$ STJUE (Sala Tercera), de 21 de octubre de 2010, asunto C- 467/08, caso Padawan S.L. contra Sociedad General de Autores y Editores de España (SGAE) [TJCE\2010\312].

${ }^{581}$ PINA, C. y MUÑOZ VICO, A., "Comentario a la sentencia del Tribunal de Justicia de la Unión Europea de 21 de octubre de 2010 (Asunto C-467/08)", Actualidad Jurídica Aranzadi, núm. 809, 2010, pp. 12-13.
} 
de compensación es porque no deben formar parte de los usos permitidos en virtud de la excepción de copia privada.

El segundo requisito previsto en la letra b) del art. 31.2 del TRLPI es el acceso legal. Este requisito, no incluido expresamente en la DDASI ha sido introducido por el legislador español a tenor del amplio margen que otorga esta Directiva a los Estados miembros para disponer en el orden interno sobre los límites al derecho de autor, siempre que no se contravenga lo dispuesto en aquélla. Pese a ello, el TJUE, en su sentencia (Sala Cuarta), de 10 de abril de 2014, ACI Adam BV y otros contra Stichting de Thuiskopie y otros (asunto C-435/12) ${ }^{582}$ concluyó que era necesario distinguir entre fuentes lícitas e ilícitas respecto de la copia privada, aun cuando éste no fuera un requisito expresamente establecido en la DDASI. De hecho, reconoce la sentencia que una norma que no distingue en el sentido indicado, infringe el art. 5.5 de la DDASI ${ }^{583}$.

El requisito del acceso legal aparece en el art. 31.2. del TRLPI desde el año 2006, con la modificación realizada al precepto por la citada Ley 23/2006, al exigir que la reproducción con fines privados se realizara a partir de obras a las que se hubiera accedido legalmente. La Ley 21/2014, de modificación del TRLPI, añadió al mismo "desde una fuente lícita", delimitando, al mismo tiempo, los supuestos que podían ser considerados lícitos. Sin embargo, la formulación actual del art. 31.2.b) del TRLPI (que resulta del Real Decreto-ley 12/2017, de 3 de julio), si bien mantiene la exigencia de que la copia se realice "a partir de una fuente lícita", prescinde de mencionar los supuestos puntuales en los que dicho requisito se entenderá cumplido.

Ello ha de valorarse positivamente teniendo en cuenta las restricciones excesivas e injustificadas que supuso para la excepción de copia privada el establecimiento de aquellos supuestos $^{584}$. En efecto, el TRLPI, en su redacción por la Ley 21/2014, sólo

\footnotetext{
${ }^{582}$ ACI Adam BV y otros contra Stichting de Thuiskopie y otros, asunto C-435/12 [TJCEl2014\15].

${ }^{583}$ Ibídem, párrafos 38 a 40. El TJUE concluye que: “[...] el artículo 5, apartado 2, letra b), de la Directiva 2001/29 debe interpretarse en el sentido de que no incluye el supuesto en el que las copias privadas se realizan a partir de una fuente ilícita" (párrafo 41).

584 Vid. CARBAJO CASCÓN, F., "Artículo 25. Compensación equitativa por copia privada" (Comentario), en Palau Ramírez, F. y Palao Moreno, G. (Dirs.), Comentarios..., op. cit., p. 437; Tato Plaza, A. y TORRES PÉREZ, F., "Artículo 31. Reproducciones provisionales y copia privada" (Comentario), op. cit., pp. 504-505.
} 
consideró lícita la reproducción en dos supuestos. Por un lado, cuando fuera realizada una reproducción, directa o indirectamente, a partir de un soporte que contuviera una reproducción de la obra, autorizada por su titular, comercializado y adquirido en propiedad por compraventa mercantil; y por otro, cuando se fuera realizada una reproducción individual de obras a las que se hubiera accedido a través de un acto legítimo de comunicación pública, mediante la difusión de la imagen, del sonido o de ambos, y no habiéndose obtenido dicha reproducción mediante fijación en establecimiento o espacio público no autorizada.

Al respecto, debe señalarse que la primera de estas exigencias excluía los supuestos en los que la copia era obtenida de un soporte alquilado o prestado, así como los casos de compraventa efectuada con otro particular que careciera de carácter mercantil ${ }^{585}$. Por consiguiente, la Ley olvidaba que los titulares de derechos no tienen medios a su disposición para evitar estas reproducciones y que la solución de excluirlas de límite de copia privada sólo hacía que se convirtieran en prácticas prohibidas y sujetas a la autorización del autor, lo que, paradójicamente, aumentaría la circulación de reproducciones ilegales. Por demás, no podrían generar compensación alguna en favor de los titulares de derechos de propiedad intelectual ${ }^{586}$.

En este sentido se pronunció el CGPJ en sus observaciones sobre el proyecto de la Ley 21/2014:

"El problema de dibujar unos contornos como éstos es que dejan fuera del límite numerosas copias, que por lo mismo pasarían a caer bajo la órbita del derecho exclusivo de reproducción de los titulares, sin que en rigor éstos puedan ejercer un efectivo control sobre las mismas. Así, es fácil ver que los titulares no tendrán la posibilidad de comprobar si realmente el adquirente de un soporte lícito de la obra que no lo haya adquirido por compraventa (ejemplares alquilados o prestados), o que lo haya adquirido por compraventa no comercial (mercado de segunda mano), se abstiene de realizar una copia para uso privado. Del mismo modo, no se aprecia de qué manera podrían los titulares asegurarse de que los destinatarios de un acto de radiodifusión realizan una copia temporal, únicamente destinada a un visionado o audición en un momento más oportuno. La ostentación de un derecho

585 Ídem.

${ }^{586}$ CARBAJO CASCÓN, F., “Artículo 25. Compensación equitativa por copia privada” (Comentario), en Palau Ramírez, F. y Palao Moreno, G. (Dirs.), Comentarios..., op. cit., p. 437. 
de exclusiva en estas circunstancias resulta de escasa utilidad, y por ello el límite de copia privada ha cubierto tradicionalmente todos esos casos, paliándose el perjuicio que esas reproducciones ocasionan a los titulares mediante la compensación equitativa" ${ }^{387}$.

Siguiendo el art. 31.2.b) del TRLPI, en su redacción actual, el requisito de acceso legal se traduce no sólo en la exigencia de que la copia se realice desde una fuente lícita, sino que es necesario, además, que no se vulneren las condiciones de acceso a la obra o prestación. Ambas cuestiones son exigibles, quedando atrás las disquisiciones doctrinales que generaba la redacción del TRLPI a tenor de la Ley 23/2006, de 7 de julio, acerca de si lo importante era que la fuente de la reproducción fuese lícita o si, por el contrario, lícito debía ser el modo en que la persona que realizaba la copia accediese a la obra ${ }^{588}$.

Finalmente, el tercer requisito contenido en el art. 31.2.c) del TRLPI exige que la copia obtenida no sea objeto de una utilización colectiva ni lucrativa, ni de distribución

${ }^{587}$ Consejo General del Poder Judicial (Comisión de Estudios e Informes), Informe al Anteproyecto de Ley de Modificación de la Ley de Propiedad Intelectual aprobada por el RDL 1/1996, de 12 de abril y de la Ley 1/2000, de 7 de enero, de Enjuiciamiento Civil, 5 de julio de 2013, p. 21, disponible en: http://www.poderjudicial.es/cgpj/es/Poder_Judicial/Consejo_General_del_Poder_Judicial/Actividad_del_ CGPJ/Informes/Informe_al_Anteproyecto_de_Ley_de_modificacion_del_Texto_Refundido_de_la_Ley_ de_Propiedad_Intelectual_aprobado_por_Real_decreto_Legislativo_1_1996_de_12_de_abril_y_de_la ley_1_2000 de 7 de enero de Enjuiciamiento_Civil (consultado: 24.03.2017).

${ }^{588}$ A juicio de algunos autores aquella redacción parecía poner el acento en la forma de acceso a la obra, más que en la fuente de procedencia de la copia o en el modo en que había sido puesta la obra a disposición del público. En consecuencia, quien obtenía una copia ilícita (por ejemplo, una reproducción pirata adquirida en el "top manta") y posteriormente la reproducía con fines privados, no accedía lícita o ilícitamente a la obra, sino simplemente la adquiría, por lo que esta adquisición no podía tildarse de ilícita toda vez que se había pagado el precio correspondiente. Vid. LóPEZ RICHART, J., "La copia privada ante los desafíos...", op. cit., p. 188. Véase también GARROTE FERNÁNDEZ-DíEZ, I., La reforma de la copia privada..., op. cit., p. 93. Éste último autor destaca, refiriéndose al TRLPI (2006): "En el art. 31.2 LPI la ilicitud se predica literalmente del modo en que el usuario accede a la obra, no en si la obra ha sido puesta en el mercado con la previa autorización de los derechohabientes. [...] De manera que, al final, se ha dejado fuera de foco lo que se quería, que era declarar la ilicitud de una copia realizada a partir de un patrón o modelo puesto en el mercado sin la licencia o autorización de los derechohabientes".

Esta misma idea pretendía justificar el acceso legal a una obra en Internet en una red de intercambio de archivos P2P (peer to peer) puesto que, aun cuando la obra hubiera sido puesta a disposición del público sin la correspondiente autorización, quien la descargaba, lo hacía legalmente, toda vez que había pagado la correspondiente cuota de acceso a Internet. Sin embargo, en contra, se argumentaba que un acto que vulnera un derecho de autor es imposible que dé lugar a una copia lícita. También se argumentaba que las leyes de propiedad intelectual llevan implícitas la finalidad de luchar contra las prácticas ilegales de explotación no autorizadas. Se dio importancia, además, a la valoración de la buena fe del usuario de la copia. En este sentido se afirmaba que quien adquiere una copia en el "top manta" o a través de una red P2P, conoce que adquiere una copia ilegal, conforme al criterio de la diligencia media exigible. Vid. LóPEZ MAZA, S., Límites al derecho de reproducción..., op. cit., pp. 219-221. 
mediante precio. La ausencia de utilización colectiva y lucrativa ya venía contemplada en las versiones anteriores del texto legal. Sin embargo, la no distribución mediante precio fue incorporada al TRLPI por la Ley $21 / 2014$, de 4 de noviembre.

Puede decirse, no obstante, que esta última exigencia nada aporta a la regulación precedente pues más bien redunda en el carácter no lucrativo de la utilización. Y en lo que respecta a la utilización no colectiva, cabe añadir que este requisito se delimita como contrapartida al uso privado al que hace referencia el art. 31.2.a) del TRLPI, con lo cual, tampoco era preciso redundar en ello, aunque es cierto que la referencia hecha a la copia "obtenida" disipa las dudas en torno a si la "no utilización colectiva" se refiere al destino que pueda hacerse de la copia una vez efectuada o al acto mismo de reproducción $^{589}$, en favor de la primera postura.

\section{LA SUJECIÓN DE LA COPIA PRIVADA A LA REGLA DE LOS TRES PASOS}

De acuerdo con lo dispuesto en el art. 5.5 de la DDASI, en relación con el art. 9.2 $\mathrm{CB}$, cualquier excepción legal al derecho exclusivo del autor tiene que someterse al escrutinio de la regla de los tres pasos. De este modo, la copia privada tiene que cumplir necesariamente con las exigencias o pasos de esta regla y, por tanto, enmarcarse dentro de lo que se consideran determinados casos especiales, sin que pueda ir en contra de la explotación normal de la obra, ni causar un perjuicio injustificado a los intereses legítimos del autor ${ }^{590}$.

El primer paso - esto es, que la copia privada constituya un "caso especial" como excepción legal al derecho exclusivo del autor- no plantea problemas, pues la copia privada está claramente definida como una limitación en la ley de acuerdo a

${ }^{589}$ Esta cuestión fue objeto de debate en la doctrina con anterioridad a la modificación del TRLPI (2006). Sin embargo, la introducción en el texto del art. 31.2 del TRLPI (2006) del participio "obtenida", para referirse a la copia, elimina esta duda al confirmar la teoría del destino de la copia. Vid. GONZÁLEZ DE Alaiza CARdona, J. J., La copia privada. Sus fundamentos ..., op. cit., p. 181.

${ }^{590}$ Vid. supra, epígrafe 4.3 del Capítulo II. 
determinados objetivos de política legislativa. Su implementación no es arbitraria, sino que obedece a unos propósitos concretos que el legislador estatal considera oportunos para justificar la introducción en el Derecho interno de esta limitación, aun cuando no está obligado a ello conforme a la DDASI. Así, como ya se argumentó, la copia privada se fundamenta en la imposibilidad de controlar las reproducciones realizadas en el ámbito privado por el titular de derechos de propiedad intelectual, en la defensa del derecho a la intimidad y en razones de interés social.

Al mismo tiempo, la copia privada viene delimitada por unos contornos precisos, fijados por el art. 31 del TRLPI (apartados 2 y 3), en especial conexión con el art. 25 del mismo texto legal, todo ello en concordancia con lo dispuesto en el art. 5.2.b) de la DDASI, lo que hace a la copia privada una excepción delimitada legalmente. De ahí que puede decirse que cumple el primer escalón de la regla de los tres pasos.

El segundo paso de esta regla o test exige que la copia privada no atente contra la explotación normal de la obra. De conformidad con la interpretación de las reglas del test ${ }^{591}$, el cumplimiento de este requisito atiende fundamentalmente al grado de pérdida económica que sufren los titulares de derechos como consecuencia de la excepción. Bajo un enfoque empírico, habría que plantearse si los usos autorizados con la excepción se encuentran dentro de aquellos en los que normalmente el titular de derechos tiene unas expectativas de obtención de ganancias económicas, pero esta perspectiva supone concentrarse en los modos ordinarios, o quizás, razonables, en que tiene lugar la explotación de la obra, pasando por alto aquellos que puedan surgir en el futuro. En cambio, desde un enfoque normativo, es posible valorar si la excepción perjudica la comercialización la obra en el mercado actual o potencial, esto es, priva a los titulares de derechos de un mercado real o potencial de considerable importancia.

Pues bien, la copia privada superará el segundo escalón del test en la medida en que no perjudique las formas de explotación que generan ingresos de cierta importancia para el titular de derechos de autor, tanto en el mercado de explotación de la obra presente como futuro. Sin embargo, no siempre los tribunales son flexibles a la hora de

${ }^{591}$ Vid. supra, Capítulo II, epígrafe II, apartado 4.3. 
evaluar este criterio de la prueba de los tres pasos en un asunto concreto. Un ejemplo emblemático sobre la interpretación estricta del mismo, frecuentemente citado por la doctrina, es la sentencia dictada por la de la Cour de Cassation francesa, en fecha 29 de febrero de 2006, en el caso Mulholland Drive ${ }^{592}$. En este asunto, el adquirente de un DVD de la película Mulholland Drive advirtió la presencia de medidas tecnológicas de protección que le impedían la reproducción de la obra en un formato diferente (Video Home System, VHS) y solicitó del tribunal que le fuera reconocido su derecho a realizar una copia privada, con el fin de visionar la obra en la casa de su madre. La Corte de Apelación de París otorgó la razón al demandante, pero la decisión fue revocada en casación por el Tribunal Supremo considerando, como premisa, que no existe un derecho a la copia privada, sino que ésta constituye una excepción al derecho de autor y no puede impedirse el establecimiento de medidas tecnológicas de protección del copiado. El Tribunal afirmó que las copias privadas realizadas a partir de DVD pueden perjudicar la explotación normal de obra, en un contexto de mayor riesgo como es el digital, siendo muy importante para la industria del cine la explotación de las obras cinematográficas en DVD para recuperar los costos de estas producciones audiovisuales. Justificó así la preponderancia de la medida tecnológica de protección frente al límite de copia privada, en una interpretación realmente muy restrictiva del segundo paso del test ${ }^{593}$.

Esta etapa de la regla de los tres pasos explica por qué la copia privada sólo se autoriza si no existe ánimo de lucro, ya que, de esta forma, no se genera un mercado de comercialización de copias que compita con la explotación normal de la obra. Esta es también la razón por la cual no puede admitirse el límite más allá del uso privado, pues el uso colectivo de las copias también perjudica la comercialización del original.

Con todo, normalmente suelen admitirse al amparo de la excepción de copia privada conductas como el space-shifting (reproducción de una obra en un soporte

\footnotetext{
592 Studio Canal et al. V. S. Penguin and Union Federale des Consommateurs Que Choisir, Cour de Cassation, 19 June 2008, No. 07-142777 (France), comentado por SENFTLEBEN, M., "Bridging the differences...", op. cit., pp. 533-534. Véase también la reseña realizada por CASTELló PASTOR, J. J., Motores de búsqueda..., op. cit., pp. 160-161.

${ }^{593}$ MazziotTi, G., EU Digital Copyright Law..., op. cit., p. 304.
} 
idéntico al original para ser usado en un lugar distinto), el device-shifting (reproducción en un formato diferente para ser usado en otro equipo) y el time-shifting (reproducción que se realiza con la intención de disfrutar de la emisión en un momento posterior), justamente porque no privan a los titulares de derechos de una fuente de ingresos, ya que no perjudican los modos principales de explotación de la obra. Por el contrario, no puede decirse lo mismo de otras conductas como la descarga de obras en Internet en redes de intercambio de archivos peer to peer (P2P). En este caso, si bien no puede afirmarse con certeza que quien adquiere la obra gratuitamente desde una red de este tipo estaría dispuesto a comprar el original, lo cierto es que la masividad con que se intercambian los archivos en estas redes puede comportar un perjuicio sustancial para la comercialización de la obra ${ }^{594}$.

Finalmente, la tercera etapa de la prueba de los tres pasos requiere evaluar si la reproducción causa un perjuicio injustificado - $\mathrm{O}$ no- a los intereses legítimos del autor. En efecto, lo que persigue la regla en esta fase es que la excepción no perjudique injustificadamente los intereses legítimos de los titulares de derechos de autor, algo que, a priori, parecería imposible en el caso de la excepción de copia privada, toda vez que los titulares de derechos sufren siempre una desventaja patrimonial como consecuencia de la reproducción no autorizada de sus creaciones intelectuales, cuya prohibición escapa a su control.

Sin embargo, la clave de la cuestión radica en que, de causarse un perjuicio a los legítimos intereses de los titulares de derechos de autor, éste no sea justificado. En general, el perjuicio injustificado se produce cuando la excepción causa una pérdida actual o potencial de ingresos en una medida injustificada ${ }^{595}$, sin perjuicio de la afectación de otros intereses de orden moral del autor. Para valorar si es injustificado o no un determinado uso de la obra o prestación intelectual, hay que evaluar si está dentro de los límites de lo razonable de acuerdo a un criterio de proporcionalidad, para lo cual es necesario poner en la balanza, por un lado, la legitimidad de los intereses de los

\footnotetext{
${ }^{594}$ Vid. infra, epígrafe VIII de este Capítulo.

${ }^{595}$ KARAPAPA, S., Private Copying, op. cit., p. 116.
} 
titulares de derechos y, por otro, la de los beneficiarios del límite ${ }^{596}$. Pues bien, en este sentido, la compensación económica asociada al límite de copia privada viene a "salvar" dicho perjuicio ${ }^{597}$. Así lo entiende el legislador de la UE cuando obliga a que la introducción de la excepción en los Estados miembros se efectúe sometida a la condición del establecimiento de una compensación equitativa. En definitiva, la admisibilidad de la copia privada por el legislador permite afirmar que hay ciertos perjuicios soportables, precisamente, porque no son injustos ${ }^{598} \mathrm{y}$, dentro de ellos, se inscriben los causados por el límite de copia privada. Es decir, los potenciales perjuicios de la excepción sobre los legítimos intereses del autor permanecen así en un nivel tolerable.

\section{EL FAIR USE Y LA COPIA PRIVADA}

Habiendo analizado la copia privada a la luz del test de las tres etapas, conviene examinar también cómo esta regla se adapta a un sistema que, si bien no contraviene la regla de los tres pasos, sí que admite unos contornos más amplios de aplicación de las excepciones al derecho de autor, por asentarse sobre una doctrina jurisprudencial más flexible. Además, en cualquier caso, dicho análisis es conveniente, pues permite poner de relieve los conflictos inherentes al desarrollo de las tecnologías de reproducción en relación con los derechos de propiedad intelectual cuando, en la década de los 1980, comenzaron a comercializarse aparatos reproductores de vídeo en EE.UU.

Así pues, al amparo de la doctrina del fair use, la copia privada es admisible sin necesidad de solicitar el previo consentimiento del titular de derechos de autor para reproducir la obra, sin que por ello se cometa una infracción al copyright, siempre que la reproducción pueda circunscribirse en los contornos del "uso justo".

\footnotetext{
${ }^{596}$ LÓPEZ MAZA, S., Límites al derecho de reproducción ..., op. cit., p. 64.

${ }^{597}$ El establecimiento de un sistema compensatorio asociado a un límite al derecho de autor permite considerar justificado o proporcionado el perjuicio causado por dicho límite. Vid. GARROTE FERNÁNDEZDíEz, I., "Artículo 9", en Bercovitz RodríGuez-CANO, R. (Coord.), Comentarios al Convenio de Berna..., op. cit., pp. 786 y ss.

${ }^{598}$ Martín SalamanCA, S., "Límites a los derechos de explotación (II)”, en Esteve Pardo, Ma. A. (Coord.), Propiedad Intelectual..., op. cit., p. 249.
} 
Consecuentemente, está justificada la reproducción cuando el juez aprecie el fair use, caso de ser invocado como contrapartida a una reproducción no autorizada. Para ello, el juez debe valorar la finalidad y el carácter del uso, la naturaleza de la obra protegida, la cantidad y sustancialidad de la parte utilizada en relación con la obra en su conjunto y el efecto de la utilización de la obra en el mercado potencial o en el valor de la obra protegida, que son los factores que, con carácter general, se tienen en cuenta en la valoración del fair use ${ }^{599}$.

Como ya se ha expuesto ${ }^{600}$, no existe una regla general de aplicación que permita establecer una lista de los casos admitidos, por no injustos, conforme al fair use. Más bien, por el contrario, es necesario un análisis casuístico, con lo cual, no pueden adelantarse aquí criterios específicos bajo los cuales la copia privada sería consentida en virtud del fair use, a diferencia de lo que resulta en los países que contienen un sistema cerrado de límites y regulan, expresamente, los requisitos que requiere la reproducción con fines privados para encajar en el límite de la copia privada.

En todo caso, cabe destacar que, al margen de la aplicación de esta doctrina, no se consideran infracciones del derecho de autor las grabaciones musicales digitales y analógicas sin fines comerciales permitidas en virtud de la sección 1008 de la Audio Home Recording Act, promulgada el 28 de octubre de $1992^{601}$ (en adelante, AHRA). Así, siguiendo lo dispuesto en dicha norma, estas grabaciones no se consideran una infracción de los derechos de autor siempre que se realicen para un uso no comercial ${ }^{602}$. Sin embargo, esta excepción tiene un alcance más restringido que la excepción de copia privada establecida en virtud del art. 31.2 del TRLPI pues, en tanto el objeto de aquélla lo conforman únicamente las grabaciones musicales, el objeto de la copia privada se extiende no sólo a los fonogramas sino también a las obras divulgadas en forma de

${ }^{599}$ Vid. Supra, Capítulo 2, epígrafe II, apartado 4.2.1.B.

${ }^{600}$ Vid. Capítulo 2, epígrafe II, apartado 4.2.1.

${ }^{601}$ Pub. L. No. 102-563, 106 Stat. 4237. La Audio Home Recording Act conforma el Capítulo 10, del Título 17 (Copyright Law) del United States Code.

602 "§ 1008 Prohibition on certain infringement actions: No action may be brought under this title alleging infringement of copyright based on the manufacture, importation, or distribution of a digital audio recording device, a digital audio recording medium, an analog recording device, or an analog recording medium, or based on the noncommercial use by a consumer of such a device or medium for making digital musical recordings or analog musical recordings". 
libros o publicaciones que a estos efectos se asimilen reglamentariamente, los videogramas y otros soportes sonoros, visuales o audiovisuales. En consecuencia, las reproducciones que constituyen una infracción por quedar excluidas de la sección 1008 AHRA tendrán que ser defendidas bajo la doctrina del fair use.

En la jurisprudencia, probablemente el asunto más emblemático sobre el límite de copia privada resuelto en Estados Unidos sea el conocido caso Betamax que enfrentó a Universal City Studios, Inc. y Walt Disney Productions contra Sony Corp. y Sony Corp of America $^{603}$. La esencia del conflicto recayó sobre la posible vulneración de los derechos de las demandantes (productoras de películas cinematográficas y otras obras audiovisuales para la televisión), toda vez que la fabricación y distribución del vídeo Betamax producido por Sony Corp. permitía la reproducción casera de obras de titularidad de aquéllas sin su autorización, infringiendo así sus derechos de reproducción.

Se planteaba en el asunto si la grabación doméstica de un programa de televisión infringía el copyright y, de ser así, en qué medida Sony podía ser responsable de la actividad de reproducción que realizaban los terceros, quienes eran, en definitiva, los que realizaban la grabación.

El origen de la litis se remonta al año 1976, momento en que Universal City Studios, Inc. y Walt Disney Productions deciden interponer acciones legales contra Sony Corp. y Sony Corp. of America ante la Corte del Distrito Central de California. El reproductor de vídeo Betamax permitía grabar en una cinta de videocasete las emisiones de televisión para ser visionadas en un momento posterior (time-shifting), ya fuera por una sola vez o sucesivas veces y, de almacenarse las cintas grabadas, el uso de Betamax estaría facilitando la construcción de archivos audiovisuales. Las demandantes consideraban que la actividad de Sony podía perjudicar sus ingresos por licencias para la emisión de sus películas y programas, así como por la comercialización de estos por otras vías.

${ }^{603}$ Sony Corp. of Am. v. Universal City Studios, Inc., 464 U.S. 417 (1984). 
La Corte del Distrito consideró que la actividad de la demandada no infringía los derechos de autor de las actoras. Hizo hincapié en el hecho de que los programas que podían ser reproducidos eran difundidos gratuitamente al público en general. También evocó al carácter no comercial del uso y el carácter privado de la actividad de copia, remarcando, asimismo, que el propósito de este uso servía al interés público al aumentar el acceso a la programación de televisión ${ }^{604}$. Estimó que no había quedado probada la existencia de un perjuicio económico, actual o potencial, para el mercado de las obras audiovisuales y entendió que, incluso, de considerarse que la copia privada infringía los derechos de propiedad intelectual, las demandadas no podían considerarse responsables directas, indirectas o subsidiarias de tal infracción a tenor de la legislación vigente ${ }^{605}$.

Sin embargo, distinta fue la postura de la Corte de Apelación del Noveno Circuito, que revocó el fallo anterior considerando que el asunto no podía quedar amparado en la doctrina del fair use. Concluyó que el uso doméstico de un VHS no era un uso justo porque no era un "uso productivo". Por lo tanto, sostuvo que era innecesario que los demandantes probaran cualquier daño al mercado potencial de las obras protegidas por derechos de autor, si bien observó que parecía claro que el efecto acumulativo de la reproducción masiva que esta tecnología posibilitaba podría repercutir en una disminución del mercado potencial de las obras de las demandantes ${ }^{606}$.

Esta vez, la Corte de Apelación sí apreció la responsabilidad de Sony por contribuir a la realización de copias no autorizadas de materiales protegidos por derechos de autor. Sony era consciente de que la principal función del producto Betamax era la reproducción de estas creaciones, con lo cual, inducía y contribuía a la comisión de la conducta infractora, y ello la hacía responsable $e^{607}$.

Sin embargo, esta no fue la decisión definitiva. Posteriormente, la Corte Suprema entendió que sí existía un uso leal y revocó la sentencia dictada en apelación.

\footnotetext{
604464 U.S. 425 , p. 780.

605464 U.S. 426 , p. 780.

606464 U.S. 427, p. 781.

607464 U.S. 428 , p. 781.
} 
En lo que respecta a la doctrina del fair use, la Corte Suprema otorgó preponderancia en su análisis a los factores primero y cuarto de esta doctrina. En cuanto al primero (que atiende al carácter y la finalidad del uso), indicó que si el reproductor Betamax fuera utilizado para realizar reproducciones con fines lucrativos y comerciales, tal uso sería presumiblemente injusto. Sin embargo, -concluyó- que ésta no podía ser la interpretación apropiada al caso, toda vez que la reproducción en el ámbito doméstico con fines privados debía catalogarse como una actividad no comercial, sin fines lucrativos, tal como había razonado la Corte del Distrito. Además, no podía oponerse a un uso justo la reproducción realizada con el fin de disfrutar de una obra en un momento posterior, cuando el espectador hubiera podido acceder a la misma en el momento de su emisión sin cargo alguno ${ }^{608}$. Por otra parte, atendiendo al cuarto factor, esto es, al efecto de la utilización de la obra en el mercado potencial o en el valor de la obra protegida, el tribunal sostuvo que la demandante erró al no probar que el uso privado era perjudicial o que, de generalizarse, afectaría negativamente al mercado potencial de la obra protegida por derechos de autor ${ }^{609}$. Lo que se exigía como prueba no era la demostración del daño real presente, ni la certeza del daño ulterior, sino alguna probabilidad de la existencia de un daño futuro significativo ${ }^{610}$.

La Corte Suprema señaló que no era necesario un razonamiento amplio respecto al daño producido a las demandantes porque las mismas admitían que no se había ocasionado ningún daño real a sus derechos de autor hasta esa fecha ${ }^{611}$. También resaltó que habían quedado ampliamente rechazados los argumentos de la parte actora en la instancia sobre los posibles perjuicios que podía originarle la disminución de la audiencia de televisión y cine en vivo en la medida en que más personas apreciaran a

\footnotetext{
608464 U.S. 449,450 , p. 792.

609464 U.S. 451, p. 793.

${ }^{610}$ Señala la Corte Suprema, concretamente: “A challenge to a noncommercial use of a copyrighted work requires proof either that the particular use is harmful, or that if it should become widespread, it would adversely affect the potential market for the copyrighted work. Actual present harm need not be shown; such a requirement would leave the copyright holder with no defense against predictable damage. Nor is it necessary to show with certainty that future harm will result. What is necessary is a showing by a preponderance of the evidence that some meaningful likelihood of future harm exists. If the intended use is for commercial gain, that likelihood may be presumed. But if it is for a noncommercial purpose, the likelihood must be demonstrated" (Ídem).

611464 U.S. 452 , p. 793.
} 
Betamax como una alternativa, así como la disminución de la audiencia de las retransmisiones. Por el contrario, estimó que no había evidencias suficientes como para indicar que el reproductor Betamax produciría un daño (el daño alegado era especulativo y, como mucho, mínimo) y afirmó que la decisión de acoger el fair use se veía reforzada por los beneficios sociales que traía consigo esta nueva tecnología ${ }^{612}$.

En conclusión, una vez admitida que las reproducciones realizadas por los usuarios mediante la utilización del vídeo Betamax de Sony podían acogerse al fair use, la Corte Suprema no pudo sino precisar que no recaía sobre la parte recurrente, demandada en la instancia, responsabilidad alguna, puesto que no podía verse comprometida por la venta de un producto que era utilizado con carácter mayoritario para fines legítimos ${ }^{613}$.

\section{LAS MEDIDAS TECNOLÓGICAS DE PROTECCIÓN Y LA COPIA PRIVADA}

\section{Introducción}

El desarrollo tecnológico experimentado en las últimas décadas del siglo $\mathrm{XX}$ no sólo ha traído consigo nuevas formas de acceso y difusión de los contenidos protegidos por los derechos de propiedad intelectual, sino también posibilidades para "blindar la obra" frente a usos no consentidos por el titular de derechos de autor, en el entorno digital, a partir de la implementación de medidas tecnológicas de protección. Sin embargo, al mismo tiempo, el establecimiento de estas medidas tecnológicas se vuelve en contra del disfrute legítimo de las creaciones intelectuales al amparo de las

\footnotetext{
612464 U.S. 454, p. 795.

613464 U.S. 456, p. 796. La Corte Suprema en su sentencia advertía que el hecho de que la Copyright Act no estableciera un régimen expreso de responsabilidad frente a las infracciones cometidas por terceros no excluía la apreciación de alguna responsabilidad de estos. No obstante, añadía, la venta de los equipos de grabación, como la de cualquier otro objeto del comercio, no constituye una infracción ("contributory infringement") si el producto se utilizaba mayoritariamente con fines legítimos y no objetables: "Accordingly, the sale of copying equipment, like the sale of other articles of commerce, does not constitute contributory infringement if the product is widely used for legitimate, unobjectionable purposes. Indeed, it need merely be capable of substantial noninfringing uses" (464 U.S. 442, p. 789). Por tanto, a efectos del caso, señalaba la sentencia: "The question is thus whether the Betamax is capable of commercially significant noninfringing uses" (Ídem).
} 
excepciones al derecho del autor. De ahí la necesidad de establecer de forma adecuada la relación entre medidas tecnológicas y límites a los derechos de propiedad intelectual.

Y esta relación resulta compleja, pues implica la necesidad de conciliar el establecimiento de medidas tecnológicas de protección eficaces, que impidan el acceso y la utilización no autorizada de las obras y prestaciones, con la pervivencia de cierto espacio de garantía a quien pretende acceder o utilizar la obra en virtud de una excepción o limitación al derecho de autor. No se trata de una cuestión sencilla debido a la concurrencia, una vez más, de intereses contrapuestos en la regulación eficaz de la relación entre titulares de derechos y usuarios.

Esta relación ha sido especialmente complicada en el ámbito de la excepción de copia privada, de ahí que convenga analizar cuál ha sido la solución adoptada por el legislador de la UE y el nacional en su regulación, sin perjuicio de examinar, previamente, otras cuestiones generales sobre el tema.

\section{Aspectos generales sobre las medidas tecnológicas de protección}

\subsection{Definición y clasificación}

De acuerdo con la definición legal establecida por el art. 6.3 de la DDASI, por medidas tecnológicas de protección se entiende:

"Toda técnica, dispositivo o componente que, en su funcionamiento normal, esté destinado a impedir o restringir actos referidos a obras o prestaciones protegidas que no cuenten con la autorización del titular de los derechos de autor o de los derechos afines a los derechos de autor establecidos por ley o el derecho sui generis previsto en el Capítulo III de la Directiva 96/9/CE”.

Estas medidas pueden ser clasificadas en dos grupos: medidas tecnológicas de control de acceso y medidas tecnológicas de control de la utilización ${ }^{614}$.

${ }^{614}$ Vid. entre otros, CABEDO SERNA, L. L., “Los consumidores y las medidas tecnológicas...”, op. cit., pp. 68-69. Siguiendo a Colin, C., Droit..., op. cit., pp. 276-278, la clasificación aludida sería un subgrupo dentro de las medidas tecnológicas de protección, pudiendo hacerse una clasificación más amplia por medio de la cual las medidas tecnológicas comprenden las medidas calificadas como medidas tecnológicas de información sobre el régimen de derechos, por un lado, y las medidas tecnológicas de 
Fue el legislador estadounidense el primero en realizar tal distinción. Así lo hizo en la sección 1201, Capítulo 12, del Título 17 de la Digital Millennium Copyright Act (DMCA). Las primeras impiden el acceso a la obra, en tanto las segundas impiden actos reservados al titular de derechos, como la reproducción, comunicación pública, etc. Unas y otras medidas pretenden garantizar el control de la obra por el autor, aunque no siempre es fácil en la práctica distinguir unas de otras, toda vez que, en ocasiones, están muy relacionadas, pues, al impedir el acceso a la obra, indirectamente, se impide su copia.

En efecto, el uso de sistemas de encriptación o cifrado modulan el acceso a la obra. Consecuentemente, para acceder a ésta se requiere de una clave, que puede necesitarse tanto para el acceso inicial, como para accesos ulteriores ${ }^{615}$. En cuanto a la restricción de las utilizaciones de la obra, algunos sistemas impiden la realización de actos de explotación reservados a los titulares de derechos. Es el caso, por ejemplo, de los mecanismos anti-copia, como el Serial Copyright Management System (SCMS), que permite la realización de una única copia digital en los CDs en los que se incorpora; y el Content Scramblig System (CSS), utilizado para impedir la copia digital no autorizada de DVDs ${ }^{616}$.

protección, por otro. Las medidas tecnológicas de información no están dirigidas a impedir o controlar la utilización de la obra, sino que su objeto consiste en transmitir al utilizador potencial las indicaciones sobre el contenido del régimen de la obra o prestación: facilitan la identificación de la obra o prestación, el autor o cualquier otro derechohabiente, así como las condiciones de utilización de la obra o prestación. La autora, al referirse a éstas, hace alusión al art. 7.2 de la Directiva 29/2001/CE, precepto que se encarga de definir la "información para la gestión de derechos". Además, hace igualmente alusión a la gestión electrónica de derechos o Digital Rights Management (DRM, por sus siglas en inglés).

Cabe precisar, sin embargo, que los DRM no deben confundirse con lo que, en sentido estricto, se conoce como "información para la gestión de derechos", pues los DRM suponen más que una mera identificación de la obra, del autor, o de las condiciones de utilización, vid. GARROTE FERNÁNDEZ-DíEZ, I., "Artículo 162", en Bercovitz Rodríguez-CANo, R. (Coord.), Comentarios a la Ley de Propiedad..., $3^{\mathrm{a}}$ ed., op. cit., p. 2118.

Según LÓPEZ RichART, J., "La copia privada ante los desafíos...", op. cit., p. 192, se trata de sistemas avanzados que incorporan medidas tecnológicas de protección junto con otras que no van propiamente dirigidas a proteger la obra o el número de copias que de ellas se hace, sino más bien a facilitar la explotación de los derechos de autor.

${ }^{615}$ LÓPEZ RichART, J., "La copia privada ante los desafíos...", op. cit., p. 190.

${ }^{616}$ Garrote FernándeZ-DíEz, I., "Artículo 162", en BERCovitz RodríGuez-Cano, R. (Coord.), Comentarios a la Ley de Propiedad..., $3^{\text {a }}$ ed., op. cit., p. 2046. 


\subsection{Marco general de protección de las medidas tecnológicas en la DDASI y en ordenamiento jurídico español}

\subsubsection{Antecedentes}

En el ámbito internacional, los Tratados de la OMPI (TODA y TOIEF) fueron los primeros en proporcionar una protección a los titulares de derechos de autor mediante el establecimiento de medidas tecnológicas de protección. En concreto, tanto el art. 11 del TODA como el art. 18 del TOIEF, establecen la obligación de las Partes Contratantes de proporcionar una protección jurídica adecuada y unos recursos jurídicos efectivos contra la acción de eludir las medidas tecnológicas efectivas que sean utilizadas por los autores, por una parte, y los artistas intérpretes o ejecutantes o productores de fonogramas, por otra, en relación con el ejercicio de sus derechos y que, respecto de sus obras y sus interpretaciones o ejecuciones o fonogramas, respectivamente, impidan actos que no estén autorizados por dichos titulares de derechos o permitidos por la Ley.

Como puede apreciase, estos Tratados imponen al legislador nacional tres requisitos de obligatorio cumplimiento respecto a la tutela jurídica de las medidas tecnológicas de protección: su efectividad, su incorporación en la obra o prestación por el autor (o artista intérprete o ejecutante o productor de fonograma, en su caso) y su predisposición a impedir actos no autorizados por el titular de derechos o permitidos por la Ley. Nada mencionan, sin embargo, sobre el concepto de medida tecnológica "efectiva". Así pues, esta es una definición que queda en manos del legislador nacional, que podrá, por tanto, ser más o menos exigente en la determinación de la efectividad de la medida tecnológica y, consecuentemente, en su protección.

Por otra parte, en el ámbito de la UE, la Directiva 91/250/CEE del Consejo de 14 de mayo de 1991, sobre la protección jurídica de programas de ordenador ${ }^{617}$ y la Directiva 98/84/CE del Parlamento Europeo y del Consejo de 20 de noviembre de 1998, relativa a la protección jurídica de los servicios de acceso condicional o basados en

${ }^{617}$ D.O.C.E. núm. L 122/42, de 17 de mayo de 1991. 
dicho acceso ${ }^{618}$, fueron las primeras en establecer un régimen jurídico para las medidas tecnológicas de protección en este contexto. Cada una de estas Directivas estableció dicho régimen jurídico de acuerdo a su objeto respectivo: los programas de ordenador ${ }^{619}$ y los servicios de acceso condicional o basados en dicho acceso ${ }^{620}$.

En efecto, la Directiva 91/250/CEE, en su art. 7, requiere de los Estados miembros la adopción de medidas adecuadas contra las personas que cometan actos como: "a) la puesta en circulación de una copia de un programa de ordenador conociendo o pudiendo suponer su naturaleza ilegítima; b) la tenencia con fines comerciales de una copia de un programa de ordenador, conociendo o pudiendo suponer su naturaleza ilegítima; o c) la puesta en circulación o tenencia con fines comerciales de cualquier medio cuyo único propósito sea facilitar la supresión no autorizada o la neutralización de cualquier dispositivo técnico que se hubiere utilizado para proteger un programa de ordenador". El precepto protege, pues, los programas de ordenador frente a su explotación no autorizada; y extiende la protección, buscando que sean reprimidos los actos de elusión de las medidas tecnológicas que contengan.

Por su parte, la Directiva 98/84/CE, establece en su art. 4 la obligación de los Estados miembros de prohibir en su territorio “a) la fabricación, importación, distribución, venta, alquiler o posesión con fines comerciales de dispositivos ilícitos; b) la instalación, mantenimiento o sustitución con fines comerciales de un dispositivo ilícito; c) el uso de comunicaciones comerciales para la promoción de dispositivos ilícitos". Un dispositivo ilícito es "cualquier equipo o programa informático diseñado o

${ }^{618}$ D.O.C.E. núm. L 320/54, de 28 noviembre de 1998.

619 De conformidad con el Considerando $7^{\circ}$ de la Directiva 91/250/CEE el término «programa de ordenador» incluye programas en cualquier forma, incluso los que están incorporados en el «hardware», así como el trabajo preparatorio de concepción que conduce al desarrollo de un programa de ordenador, siempre que la naturaleza del trabajo preparatorio sea tal que más tarde pueda originar un programa de ordenador. Al definir el objeto de protección, el art. 1 de dicha Directiva refrenda que los programas de ordenador serán protegidos por los Estados miembros como obras literarias tal como se definen en el Convenio de Berna para la protección de las obras literarias y artísticas y comprenden su documentación preparatoria.

${ }^{620}$ A efectos de la Directiva 98/84/CE por «acceso condicional» se entiende: “cualquier medida o mecanismo técnico en virtud del cual se condicione el acceso al servicio protegido en forma inteligible a una autorización individual previa" [arts. 2 b)]. 
adaptado para hacer posible el acceso a un servicio protegido en forma inteligible sin autorización del proveedor del servicio".

\subsubsection{Esquema general de protección jurídica de las medidas tecnológicas en la DDASI}

El Considerando $47^{\circ}$ de la DDASI reconoce la necesidad de establecer, en el marco de la UE, una protección jurídica armonizada frente a la elusión de medidas tecnológicas efectivas y frente al suministro de dispositivos y productos o servicios para tal fin. Esta protección jurídica debe resguardar las medidas tecnológicas destinadas a impedir o restringir de manera efectiva los actos no autorizados por los titulares de cualesquiera derechos de autor, de derechos afines a los derechos de autor o del derecho sui generis en materia de bases de datos, sin que esta protección impida el funcionamiento normal de los equipos electrónicos y su desarrollo técnico; respetando el principio de proporcionalidad; no prohibiendo aquellos dispositivos o actividades cuyo empleo o finalidad comercial principal persiga objetivos distintos de la elusión de la protección técnica; no generando la obligación de que todo dispositivo, producto, componente o servicio esté integrado de dichas medidas tecnológicas y no creando obstáculos, especialmente, para la investigación sobre criptografía ${ }^{621}$.

Siguiendo lo expuesto, el art. 6 de la DDASI establece el régimen de protección de las medidas tecnológicas. El precepto contiene cuatro apartados. El primero, establece la obligación de los Estados miembros de establecer una protección jurídica adecuada frente a los actos de elusión de cualquier medida tecnológica efectiva; el segundo, establece una obligación similar respecto a los actos preparatorios de elusión; el tercero, define qué debe entenderse por "medidas tecnológicas" y cuándo estas han de considerarse que son "medidas tecnológicas eficaces"; y el cuarto, establece el ámbito de protección de las medidas tecnológicas en relación con las excepciones o limitaciones al derecho de autor.

${ }^{621}$ Vid. Considerando $48^{\circ}$ de la DDASI. 
A mayor abundamiento, el art. 6.1 de la DDASI es muy similar al art. 11 del TODA y al art. 18 del TOIEF. Tanto uno como los otros generan la obligación de establecer una "protección jurídica adecuada" contra la elusión de las medidas tecnológicas efectivas. La DDASI, no obstante, da un paso más al señalar como medidas para una protección adecuada, la acción de resarcimiento de daños y perjuicios y/o la posibilidad de solicitar medidas cautelares y, cuando proceda, la incautación del material ilícito (art. 8.2 de la DDASI) ${ }^{622}$.

En adición, la DDASI exige un requisito adicional respecto a los Tratados de la OMPI, puesto que la protección requerida de los Estados miembros contra la elusión de cualquier medida tecnológica efectiva se impone frente a quien "a sabiendas, o teniendo motivos razonables para saber" (art. 6.1) persigue el objetivo de eludir la medida. La introducción del componente volitivo, por tanto, excluye la elusión accidental ${ }^{623}$, pero no el desconocimiento negligente ${ }^{624}$.

Asimismo, siguiendo el art. 6.2 de la DDASI, los actos preparatorios de elusión de cualquier medida tecnológica efectiva comprenden la fabricación, importación, distribución, venta, alquiler, publicidad para la venta o el alquiler, o posesión con fines comerciales de cualquier dispositivo, producto o componente, así como la prestación de servicios que: “a) sea objeto de una promoción, de una publicidad o de una comercialización con la finalidad de eludir la protección, o b) sólo tenga una finalidad o uso comercial limitado al margen de la elusión de la protección, o c) esté principalmente concebido, producido, adaptado o realizado con la finalidad de permitir o facilitar la elusión de la protección de cualquier medida tecnológica eficaz”. Estos criterios son alternativos.

Respecto a qué debe entenderse por medida tecnológica eficaz, el art. 6.3 de la DDASI establece:

${ }^{622}$ El Considerando $58^{\circ}$ de la Directiva 29/2001/CE indica, además, que las sanciones aplicables han de ser "efectivas, proporcionadas y disuasorias".

${ }^{623}$ KARAPAPA, S., Private Copying, op. cit. p. 143.

${ }^{624}$ GonZÁlez de Alaiza CARDONA, J. J., La copia privada. Sus fundamentos..., op. cit., p. 256. 
“Las medidas tecnológicas se considerarán «eficaces» cuando el uso de la obra o prestación protegidas esté controlado por los titulares de los derechos mediante la aplicación de un control de acceso o un procedimiento de protección, por ejemplo, codificación, aleatorización u otra transformación de la obra o prestación o un mecanismo de control del copiado, que logre este objetivo de protección".

Así, la eficacia exigida a las medidas tecnológicas obliga a los titulares de derechos que las implementen en sus obras y prestaciones intelectuales a emplear medidas que cumplan con el objetivo de proteger la creación intelectual frente a usos no autorizados. No podrán, consecuentemente, emplear medidas tecnológicas poco adecuadas para contrarrestar dichos usos. Más bien, por el contrario, tendrán que ser medidas capaces de controlar, bien el acceso a la obra, bien el copiado, de una manera eficiente, es decir, según el efecto que se espera. Dicho de otro modo, no puede tratarse de medidas tecnológicas de protección fácilmente eludibles. Así, el legislador europeo contribuye a establecer una relación de proporcionalidad que, a la vez que impida la violación del derecho de autor, no haga de todo acto, un acto elusivo, por el sólo hecho del establecimiento de una medida tecnológica.

Finalmente, el art. 6.4 de la DDASI, ha sido muy criticado por la doctrina ${ }^{625}$ debido a su compleja formulación al establecer la relación entre las medidas tecnológicas de protección y las excepciones a los derechos de autor. La protección dispensada por este precepto resulta más o menos garantista de los usos exentos de la autorización del autor según de qué excepciones se trate y, si bien pudiera argumentarse que la razón del "privilegio" a favor de unas excepciones frente a otras radica en el fundamento mismo de cada una éstas, lo cierto es que la falta de aplicación de un criterio uniforme enturbia cualquier intento de comprensión de su ratio legis. En definitiva, este artículo establece un amplio margen de actuación a los Estados

${ }^{625}$ Ibídem, p. 261; GARROTE FERnÁNDEZ-Díez, I., "Artículo 162”, en BERCOVITZ RodRíGuEZ-CANO, R. (Coord.), Comentarios a la Ley de Propiedad..., $3^{a}$ ed., op. cit., p. 2079, pone de relieve la formulación "flexible, añadida a última hora por medio de una redacción compleja y, a ratos, incomprensible" y MARÍN LÓPEZ, J. J., "La copia privada frente a las medidas...", op. cit., p. 43, lo califica como "uno de los productos normativos más confusos de los últimos tiempos, si no el que más, entre las normas comunitarias sobre propiedad intelectual". 
miembros en la preservación del disfrute de las limitaciones a los derechos de propiedad intelectual frente al establecimiento de medidas tecnológicas de protección ${ }^{626}$.

\subsubsection{Esquema general de protección jurídica de las medidas tecnológicas en el TRLPI}

Las medidas tecnológicas de protección se encuentran reguladas en el Título V, denominado "Protección de las medidas tecnológicas y de la información para la gestión de derechos", inserto dentro del Libro Tercero "De la protección de los derechos reconocidos en esta Ley" del TRLPI. Dicho Título se encuentra integrado por tres artículos. El primero de ellos (art. 160 del TRLPI) regula las acciones frente a los actos de elusión y los actos preparatorios, delimitando las acciones que pueden ser ejercitadas por los titulares de derechos y frente a quiénes pueden ser ejercitadas. Asimismo, define qué se entiende por medida tecnológica y excluye de la aplicación del precepto a los programas de ordenador a los que la ley reserva un régimen particular, específicamente contemplado en el art. 102.c) del TRLPI.

El art. 161 del TRLPI, por su parte, articula la relación entre las medidas tecnológicas de protección y la eficacia de las excepciones a los derechos patrimoniales del autor. Este artículo se divide en cinco apartados que son, en buena medida, expresión de lo establecido en la DDASI respecto a este particular. Así pues, siguiendo dicha norma, el art. 161 del TRLPI, en su apartado primero, establece toda una serie de límites a los derechos de autor cuyo disfrute debe ser facilitado por los titulares de derechos sobre obras o prestaciones protegidas con medidas tecnológicas eficaces, a sus beneficiarios, siempre y cuando tales beneficiarios tengan legalmente acceso a la obra o prestación de que se trate. Asimismo, su apartado segundo contempla la posibilidad de que los beneficiarios de dichos límites acudan a la jurisdicción civil cuando los titulares de derechos de propiedad intelectual no adopten las medidas voluntarias para facilitarles el disfrute de dichos límites. Garantiza también el precepto, en su apartado tercero, que los titulares de derechos de propiedad intelectual puedan ejercitar las acciones legales

${ }^{626}$ Vid. infra epígrafe VI.3 de este Capítulo. 
previstas en el Título I del Libro III del TRLPI para la protección de las medidas tecnológicas eficaces, tanto en los casos de medidas tecnológicas adoptadas voluntariamente por los titulares de derechos, incluidas las derivadas de acuerdos con otros interesados, como, en su caso, las incluidas en la correspondiente resolución judicial. Finalmente, los apartados cuarto y quinto establecen, respectivamente, disposiciones particulares relacionadas con el límite de copia privada y con las obras que hayan sido puestas a disposición del público conforme a lo convenido por contrato.

Por último, el art. 162 del TRLPI contempla lo que se conoce como "información para la gestión", que comprende el uso de medidas tecnológicas como la "marca de agua" o "tatuado electrónico", muchas veces usadas en combinación con las medidas tecnológicas de protección, aunque con un fin diferente. Estas últimas van destinadas a dar "aviso" de que la obra está protegida por derechos de propiedad intelectual, identificar una obra original, y probar la titularidad de los derechos patrimoniales y la paternidad sobre una obra ${ }^{627}$.

\section{Limitaciones al derecho de autor y medidas tecnológicas de protección}

\subsection{Consideraciones generales}

El uso de medidas tecnológicas de protección genera el conflicto de hasta dónde proteger los intereses de los titulares de derechos de autor y hasta dónde los de los usuarios. La problemática radica en que el uso de las medidas tecnológicas de protección puede impedir el acceso y la utilización de las obras y prestaciones protegidas en virtud de una limitación legal a los derechos de autor.

El conflicto se manifiesta tanto en una vertiente práctica como jurídica. En efecto, quien pretenda utilizar de forma lícita - al amparo de una limitación legal al derecho de autor- una obra técnicamente protegida cuya barrera de protección no sea capaz de eliminar por falta de conocimientos y de herramientas tecnológicas a este fin, se verá

627 Garrote Fernández-DíEz, I., “Artículo 162”, en Bercovitz RodríGUEZ-CANO, R. (Coord.), Comentarios a la Ley de Propiedad..., $3^{\text {a }}$ ed., op. cit., p. 2107. 
impedido de poder utilizar la obra. Pero a su vez, si contara con los medios para quebrantar la medida tecnológica, se estaría exponiendo a una posible sanción por la elusión.

En consecuencia, la libre utilización de una obra o prestación intelectual, permitida al amparo de una excepción o limitación legal al derecho de autor, puede ser anulada por el uso de una medida tecnológica de protección. En efecto, el concepto mismo de medida tecnológica eficaz al que hace referencia el art. 6.3 de la DDASI excluye, prima facie, la oportunidad de invocar la ley para dar cobertura al uso de una obra, eludiendo una medida de protección, en virtud de un límite al derecho de autor. Si se observa, el precepto se refiere a "toda técnica, dispositivo o componente [...] destinado a impedir o restringir actos referidos a obras o prestaciones protegidas que no cuenten con la autorización del titular de los derechos de autor o de los derechos afines a los derechos de autor [...]"628. El precepto sólo hace referencia a la autorización de los titulares de derechos, no así a la autorización concedida por la ley, con lo cual, no quedará libre de sanción el acto de elusión de una medida tecnológica apoyado en la existencia de un límite ${ }^{629}$.

Así, la obligación de los Estados miembros de la UE de establecer una protección jurídica "adecuada" contra la elusión de cualquier medida tecnológica efectiva (art. 6.1 de la DDASI) se alcanza a partir de sancionar las conductas elusivas, tal y como prevé el art. 8 de la DDASI, lo que se consigue, generalmente, vía penal. De este modo, la actuación bajo una limitación al derecho de autor permitida por la ley, deviene punible por el efecto de otra norma de la propia ley ${ }^{630}$.

Ahora bien, el art. 6.4 de la DDASI establece la obligación de los Estados miembros de adoptar, al menos en ciertos casos, las medidas necesarias para facilitar que el beneficiario de las excepciones o limitaciones establecidas en el derecho nacional pueda disfrutar de las mismas cuando el titular de derechos no adopte medidas

\footnotetext{
${ }^{628}$ Énfasis nuestro.

${ }^{629}$ En este sentido, GARrote FernáNDEZ-DíEZ, I., “Artículo 161”, en BERCOVITZ RodríGUEZ-CANO, R. (Coord.), Comentarios a la Ley de Propiedad..., $3^{\mathrm{a}}$ ed., op. cit., p. 2079.

${ }^{630}$ DusOllier, S., Droit..., op. cit., p. 155.
} 
voluntarias. Otras veces, sin embargo, la salvaguarda de las excepciones frente a las medidas tecnológicas es una cuestión facultativa e incluso, hay supuestos sobre los que legislador comunitario nada señala, en cuyo caso, habrá que interpretar qué consecuencias derivan de este silencio.

Pues bien, antes de comentar las particularidades del art. 6.4 de la DDASI, conviene hacer una precisión preliminar. En el estudio de este precepto se subvierte la sistemática del mismo con la finalidad de posponer el análisis de lo dispuesto en su párrafo segundo, relativo a la excepción de copia privada, a un examen posterior. Se persigue así reservar un espacio particular al examen de la relación que se establece entre este límite y la protección de las obras y prestaciones intelectuales mediante medidas tecnológicas.

\subsection{Las limitaciones garantizadas}

Conforme a lo dispuesto en el párrafo $1^{\circ}$ del art. 6.4 de la DDASI, el legislador asigna una protección "privilegiada" ${ }^{31}$ a algunos de los límites al derecho de autor en relación con el uso de las medidas tecnológicas. De acuerdo a su tenor, el legislador nacional está obligado, en caso de que los titulares de los derechos no adopten medidas voluntarias, a tomar las medidas pertinentes para que los titulares de derechos faciliten al beneficiario de una excepción o limitación establecida por el Derecho nacional de conformidad con las letras a), c), d), y e) del apartado 2 del artículo 5 o con las letras a), b) y e) del apartado 3 del mismo artículo, los medios adecuados para disfrutar de dicha excepción o limitación, en la medida necesaria para ese disfrute, siempre y cuando dicho beneficiario tenga legalmente acceso a la obra o prestación protegidas.

De lo anterior se desprende que, colocar la obra en el mercado con o sin el establecimiento de alguna protección tecnológica es una prerrogativa del autor o titular de derechos patrimoniales. Ahora bien, de fijarse alguna medida tecnológica, será

${ }^{631}$ Así la califican GonzÁlez de Alaiza Cardona, J. J., La copia privada. Sus fundamentos ..., op. cit., p. 263; LÓPEZ RichART, J., "La copia privada ante los desafíos...”, op. cit., p. 201. 
preciso garantizar el disfrute de la excepción. En estos casos la intervención del Estado es subsidiaria y el disfrute de la excepción se subordina a la satisfacción de la condición de acceso lícito.

El legislador europeo garantiza así, por un lado, las excepciones de reprografía, reproducciones por bibliotecas y otras instituciones culturales, grabaciones efímeras y reproducción de radiodifusiones por instituciones sociales [art. 5.2.a), c), d) y e)]; y por otro, la ilustración con fines educativos o de investigación, las limitaciones establecidas en beneficio de personas con minusvalías, y los usos para fines de seguridad pública [art. 5.3.a), b) y e)].

La razón de este "privilegio" se apoya, según se desprende de la DDASI, en consideraciones de orden público y seguridad pública (Considerando $\left.51^{\circ}\right)^{632}$. Cabe preguntarse, no obstante, hasta qué punto la selección hecha por el legislador europeo al respecto es adecuada. Por un lado, puede defenderse que otras limitaciones a los derechos de autor como la parodia, la cita o la utilización con ocasión de informaciones de actualidad son también merecedoras de una tutela privilegiada al amparo de la libertad de expresión o la libertad de información o de prensa ${ }^{633}$. Por otro, llama la atención que, si bien la justificación de las excepciones "privilegiadas" se fundamenta en cuestiones de orden público, las mismas tengan carácter facultativo para los Estados miembros.

\subsection{Las limitaciones no garantizadas}

Más allá de la protección ofrecida por el art. 6.4, párrafo $1^{\circ}$ de la DDASI a las excepciones establecidas en los arts. 5.2, letras a), c), d), y e) y 5.3, letras a), b) y e) de la DDASI anteriormente analizada, esta Directiva sólo establece una regulación particular respecto al límite de copia privada en el art. 6.4, párrafo $2^{\mathrm{o} 634}$. En efecto, fuera

\footnotetext{
632 "La protección jurídica de las medidas tecnológicas se aplica sin perjuicio de las medidas de orden público, tal como contempla el artículo 5 , o de la seguridad pública [...]".

${ }^{633}$ En este sentido, DusOllier, S., Droit..., op. cit., p. 166; MARín LÓPEZ, J. J., "La copia privada frente a las medidas...", op. cit., p. 46.

${ }^{634}$ Vid. infra epígrafe VI.4 de este Capítulo.
} 
de estos casos, el legislador europeo nada establece respecto al resto de las excepciones contempladas en el art. 5 de la DDASI, en relación con las cuales no se dispone ningún régimen de protección frente a la existencia de medidas tecnológicas de protección. Así, en estas limitaciones no especialmente protegidas en virtud del art. 6.4 de la DDASI, son las medidas tecnológicas las que ostentan el protagonismo, subordinándose este grupo de excepciones a la implementación de aquéllas ${ }^{635}$. En consecuencia, se entiende que los Estados miembros no sólo no están obligados a intervenir en la salvaguarda de las excepciones frente al establecimiento de estos límites no establecidos expresamente por la ley, sino que ni siquiera tienen la posibilidad de garantizar su disfrute. Es ésta una conclusión que encuentra su fundamento en los fines armonizadores que persigue la DDASI ${ }^{636}$.

No obstante, también se ha propuesto una interpretación diferente, en el sentido de considerar que, a falta de previsión en la norma europea respecto a la suerte que han de correr las excepciones "no salvaguardadas", el legislador nacional tiene la facultad de intervenir en garantía del disfrute de estos límites, aunque no está obligado a ello, como sí resulta del art. 6.4, párrafo $1^{\circ}$ de la DDASI ${ }^{637}$. Apoya esta tesis el hecho de que, de conformidad con la Directiva, los Estados miembros tienen amplia libertad para trasponer las excepciones a los derechos de autor en sus legislaciones internas y esta libertad también puede predicarse de la relación entre medidas tecnológicas de protección y límites. De este modo, el hecho de que no se hayan incluido ciertas limitaciones por el legislador europeo en el catálogo de límites "privilegiados" no impide que el legislador nacional pueda introducir nuevas limitaciones de las no especialmente resguardadas, pues no existe prohibición legal alguna en este sentido ${ }^{638}$.

\footnotetext{
${ }^{635}$ De Miguel Asensio, P. A., Derechos..., op. cit., p. 84; MARÍn LÓPEZ, J. J., "La copia privada frente a las medidas...", op. cit., p. 45.

${ }^{636}$ En este sentido, MARÍN LÓPEZ, J. J., "La copia privada frente a las medidas...", op. cit., p. 45.

${ }^{637}$ GonzÁlez de Alaiza Cardona, J. J., La copia privada. Sus fundamentos..., op. cit., p. 275.

${ }^{638}$ Garrote Fernández-Díez, I., "Artículo 161”, en Bercovitz RodríGuez-Cano, R. (Coord.), Comentarios a la Ley de Propiedad..., $3^{\text {a }}$ ed., op. cit., p. 2089.
} 


\subsection{La desarticulación del régimen de garantía de las limitaciones frente a las medidas tecnológicas y su subordinación a lo dispuesto contractualmente}

El art. 6.4, párrafo $4^{\circ}$ de la DDASI libera a los Estados miembros de la UE de dispensar la protección prevista en sus párrafos $1^{\circ}$ y $2^{\circ}$, a favor de los beneficiarios de las limitaciones a los derechos de autor contempladas en los mismos, cuando las obras y prestaciones intelectuales "se hayan puesto a disposición del público con arreglo a lo convenido por contrato, de tal forma que personas concretas del público puedan acceder a ellas desde un lugar y en un momento que ella misma haya elegido".

El art. 6.4, párrafo $4^{\circ}$ abarca así, aquellos supuestos en que las obras y prestaciones intelectuales son objeto de servicios interactivos en línea, que es el modo por el cual dichas obras y prestaciones son puestas a disposición del público de forma tal que las personas puedan acceder a las mismas dónde y cuándo lo decidan. Por el contrario, quedan fuera de su alcance, las formas "no interactivas" de los servicios en línea ${ }^{639}$, es decir, aquellas en las que el usuario no puede disfrutar "a la carta" de estos servicios ${ }^{640}$, en cuyo caso, se estará a lo dispuesto en el art. 6.4, párrafos $1^{\circ}$ y $2^{\circ}$ de la $\operatorname{DDASI}^{641}$.

En efecto, en virtud del art. 6.4, párrafo $4^{\circ}$ de la DDASI, la "garantía" a favor del usuario de disfrutar de las obras y prestaciones intelectuales conforme a lo dispuesto en el art. 6.4, párrafos $1^{\circ}$ y $2^{\circ}$ de la DDASI, ante la existencia de ciertas medidas tecnológicas, cede frente a la voluntad del titular de derechos de autor, que tendrá la libertad de actuar de acuerdo con lo que mejor convenga a sus intereses. Dicho de otra

${ }^{639}$ GonzÁlez de Alaiza Cardona, J. J., La copia privada. Sus fundamentos..., op. cit., p. 279, menciona como ejemplos actos como el pago por visión (pay-per-view), el webcasting (uso de las redes para difundir información a los usuarios, principalmente de Internet) y el near-video-on-demand (oferta de un programa no interactivo que se emite varias veces paralelamente con breves intervalos).

${ }^{640}$ Conforme al Considerando $25^{\circ}$ de la DDASI, las "transmisiones interactivas a la carta se caracterizan por el hecho de que cualquier persona pueda acceder a ellas desde el lugar y en el momento que ella misma elija".

${ }^{641}$ Esta interpretación queda clara del contenido del Considerando $53^{\circ}$ de la DDASI, el cual precisa que "La protección de las medidas tecnológicas debe garantizar un entorno seguro para la prestación de servicios interactivos a la carta, de forma que el público pueda tener acceso a las obras u otras prestaciones desde el lugar y en el momento que prefiera. Cuando dichos servicios estén regulados por acuerdos contractuales, no deben aplicarse los párrafos primero y segundo del apartado 4 del artículo 6. Las formas no interactivas de servicios en línea deben seguir sometidas a dichas disposiciones”. 
manera, cuando el autor o demás titulares de derechos ponen las obras a disposición del público en Internet mediante la concertación de contratos-licencia que regulan las condiciones de utilización de dichas obras y prestaciones, el usuario está compelido a cumplir dichos términos, incluso si son restrictivos respecto a una utilización legítima amparada en una limitación legal, excluida por el uso de una medida tecnológica de protección $^{642}$.

Ciertamente, la libertad contractual permite que las partes sean libres en la concertación de los acuerdos que mejor convengan a sus intereses. El problema radica en que, con carácter general, los servicios interactivos en línea son concertados mediante contratos con condiciones generales de contratación, en los que los usuarios no tienen poder de negociación, con lo cual, no tienen más opción que respetar los términos impuestos unilateralmente, si quieren disfrutar de estos servicios.

En definitiva, tal y como se ha configurado la regulación de las medidas tecnológicas de protección frente a los límites a los derechos de propiedad intelectual, aquéllas ponen en peligro los intereses colectivos y sociales que se han tratado de proteger históricamente mediante los límites a la propiedad intelectual, sobre todo considerando que la tendencia es la contractualización del uso de las obras en línea, así como el predominio de las medidas tecnológicas de protección. De este modo, la realidad del "pago por uso" para las obras y prestaciones que circulan en línea impide la desarticulación de las medidas tecnológicas de protección sin el consentimiento del titular de los derechos, ni siquiera para hacer valer las excepciones que la propia ley establece $^{643}$.

Por otra parte, pese a que el art. 6.4, párrafo $4^{\circ}$ de la DDASI excluye claramente del régimen de protección de las limitaciones (establecido en sus párrafos $1^{\circ}$ y $2^{\circ}$ ) a las obras y prestaciones puestas a disposición del público mediante servicios en línea, cabría la alternativa de "atacar" esta prohibición, y en concreto la posibilidad de realizar copias para uso privado al amparo del límite de copia privada, invocando la nulidad de

${ }^{642}$ Mazziotti, G., EU Digital Copyright Law..., op. cit., p. 87.

${ }^{643}$ Carbajo Cascón, F., Publicaciones electrónicas..., op. cit., p. 140. 
la cláusula contractual que prohíba la utilización, siempre que el acceso a la obra o prestación se haya producido legalmente ${ }^{644}$. Esta alternativa lleva implícita la consideración de que las normas que regulan los límites a los derechos de autor son de carácter imperativo y, por tanto, no pueden ser excluidas por voluntad de las partes ${ }^{645}$; pero tampoco es ésta una cuestión pacífica. El hecho de que la DDASI no declare el carácter imperativo de las limitaciones que regula frente a la aplicación de medidas tecnológicas de protección o la imposición de cláusulas contractuales restrictivas genera, en definitiva, un clima de incertidumbre jurídica sobre la libertad de actuación del usuario en el entorno en línea al amparo de una limitación al derecho de autor.

\section{El caso particular de la copia privada: La facultad de garantizar el disfrute del límite de copia privada en la DDASI y su expresión en el TRLPI}

El art. 6.4, párrafo $2^{\circ}$ de la DDASI se refiere a la excepción de copia privada y establece igualmente un régimen de salvaguarda de ésta frente a la utilización de las medidas tecnológicas de protección. Sin embargo, su regulación contrasta con la del párrafo primero porque la obligación del Estado de intervenir para garantizar el ejercicio de la limitación al derecho de autor por copia privada, cuando no lo hace el autor o titular de derechos es, en este caso, facultativa.

En concreto, el precepto estipula que un Estado miembro podrá adoptar medidas tecnológicas de protección respecto del beneficiario de una excepción o limitación establecida en virtud del art. 5.2.b) de la DDASI (copia privada), a menos que los titulares de los derechos hayan hecho ya posible la reproducción para uso privado en la medida necesaria para el disfrute de esta excepción o limitación y de conformidad con lo dispuesto en el art. 5.5 de la DDASI, sin impedir a los titulares de los derechos la adopción de medidas adecuadas respecto del número de reproducciones de conformidad con tales disposiciones.

${ }^{644}$ Vid. GARRote FernáNDEZ-DíEZ, I., El Derecho de Autor..., op. cit., pp. 575-576.

${ }^{645}$ Ídem. 
En efecto, como se puede apreciar, la referencia en este caso no es imperativa sino facultativa, al establecer el precepto que "Un Estado miembro podrá adoptar [...]"646. De su tenor deriva, por tanto, que los Estados miembros deben fomentar el recurso a medidas voluntarias destinadas a posibilitar la consecución de los objetivos de la excepción ${ }^{647}$, pero el deber de fomentar el uso de estas medidas no garantiza su adopción. De tal circunstancia, si el autor o titular de derechos no decide voluntariamente garantizar el disfrute de la excepción, el Estado no tendrá la obligación de hacerlo ${ }^{648}$.

En adición, de la norma se colige que sobre el titular de derechos descansa la prerrogativa de decidir el número de copias permitidas que, en todo caso, habrá de ser suficiente para garantizar el disfrute de la excepción ${ }^{649}$. En este sentido, el titular de derechos que facilite un número de reproducciones estará garantizando a los beneficiarios el disfrute del límite y, por tanto, no podrá ser requerido por el Estado o por los beneficiarios para que adopte una medida diferente, pues ya ha cumplido con la exigencia legal de hacer posible la reproducción con fines privados ${ }^{650}$.

Sin perjuicio de lo anterior, es el legislador nacional quien tiene que decidir el alcance de la expresión "medidas adecuadas" y, consecuentemente, el número de reproducciones que permiten satisfacer este requisito ${ }^{651}$. En efecto, una vez más, el legislador de la UE guarda silencio, por lo que corresponde a los Estados su concreción, en todo caso respetando el texto de la DDASI y, en particular, la regla de los tres pasos invocada en el art. 5.5 de la DDASI.

Con todo, el Estado podrá adoptar las medidas necesarias para el disfrute de la excepción de copia privada -si así lo decide, a falta de intervención del autor o titular de

\footnotetext{
${ }^{646}$ Énfasis nuestro.

${ }^{647}$ Vid. Considerando $52^{\circ}$ de la DDASI.

${ }^{648}$ LÓPEZ RICHART, J., "La copia privada ante los desafíos...”, op. cit., p. 202

${ }^{649}$ Vid. MARÍn LÓPEZ, J. J., "La copia privada frente a las medidas...”, op. cit., p. 60; y CABEDO SERNA, L. L., "Los consumidores y las medidas tecnológicas de protección...”, op. cit., pp. 82-83.

${ }^{650}$ Por todos, MARín LÓPEZ, J. J., "La copia privada frente a las medidas...,", op. cit., p. 60.

${ }^{651}$ Para un análisis sobre el problema del número de reproducciones a tenor de la legislación española vid. CABEDO SERNA, L. L., “Los consumidores y las medidas tecnológicas de protección...”, op. cit., pp. 8893.
} 
derechos- $\mathrm{y}$, en cuanto al número de reproducciones, habrá que estar a lo que se entienda por "adecuado", requisito que se puede ver satisfecho por la autorización de una única reproducción consentida por el derechohabiente ${ }^{652}$.

Debe mencionarse, además, que el texto de la DDASI no hace ninguna referencia a si se debe garantizar que la copia privada tenga una calidad determinada ${ }^{653}$. En este punto la doctrina se encuentra dividida. Mientras un sector se centra en la omisión de la DDASI para argüir que no se exige a la copia una determinada calidad y, por tanto, la previsión del art. 6.4, párrafo $2^{\circ}$ de la DDASI debe entenderse cumplida si la copia autorizada es de calidad inferior al original, otros autores consideran que la copia ha de ser de la misma calidad para dar por satisfecha la condición de permitir la reproducción para uso privado "en la medida necesaria" para el disfrute de la excepción o limitación (art. 6.4, párrafo $2^{\circ}$ de la DDASI) ${ }^{654}$.

Siguiendo el art. 6.4, párrafo $2^{\circ}$ de la DDASI, el art. 161.1 del TRLPI establece que los titulares de derechos sobre obras o prestaciones protegidas con medidas tecnológicas eficaces deberán facilitar a los beneficiarios de los límites que cita dicho precepto, los medios adecuados para disfrutar de estos límites, conforme a su finalidad,

${ }^{652}$ En este sentido, GARrote FernándeZ-DíEZ, I., “Artículo 161”, en BERCOVITZ RodRíGUEZ-CANO, R. (Coord.), Comentarios a la Ley de Propiedad..., $3^{\mathrm{a}}$ ed., op. cit., p. 2095: "Basta por tanto con que los derechohabientes permitan una única reproducción por cada copia vendida para bloquear la intervención estatal". Esta solución es la que ha acogido el legislador italiano en el art. 71-sexies, párrafo cuarto, Legge 22 aprile 1941 n. 633 "Protezione del diritto d'autore e di altri diritti connessi al suo esercizio" (G.U. n.166 del 16 luglio 1941): "Fatto salvo quanto disposto dal comma 3, i titolari dei diritti sono tenuti a consentire che, nonostante l'applicazione delle misure tecnologiche di cui all'articolo 102-quater, la persona fisica che abbia acquisito il possesso legittimo di esemplari dell'opera o del materiale protetto, ovvero vi abbia avuto accesso legittimo, possa effettuare una copia privata, anche solo analogica, per uso personale, a condizione che tale possibilità non sia in contrasto con lo sfruttamento normale dell'opera o degli altri materiali e non arrechi ingiustificato pregiudizio ai titolari dei diritti".

En la misma línea, siguiendo a CARBAJO CASCÓn, F., Publicaciones electrónicas..., op. cit., p. 142., el autor destaca que "de una parte, la idéntica calidad de todas las copias digitales y, de otra, el riesgo que para la normal explotación de la obra y prestación, así como para los legítimos intereses de los titulares aparece asociado a esas copias digitales, constituyen argumentos más que suficientes para dar por buena una autorización unilateral por parte de los titulares de derechos para realizar única y exclusivamente dos copias de la misma obra o prestación (la adquirida legítimamente y otra adicional), sea en el mismo o diferentes formatos" (nota 222).

${ }^{653}$ En la doctrina, vid. GARRote FERnÁNDEZ-DíEZ, I., “Artículo 161”, en BERCOVITZ RodRÍGUEZ-CANO,

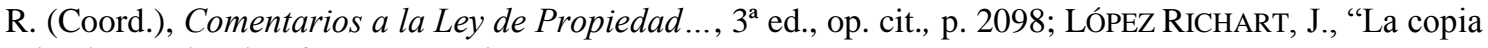
privada ante los desafíos...", op. cit., p. 213.

${ }^{654}$ Vid. LÓPEZ RICHART, J., "La copia privada ante los desafíos...”, op. cit., pp. 213-215. 
siempre y cuando tales beneficiarios tengan legalmente acceso a la obra o prestación de que se trate. Entre estos límites menciona la copia privada. El legislador español garantiza así que los titulares de derechos establezcan medidas que faciliten a los usuarios el ejercicio de la copia privada, en los términos establecidos por el art. 31.2 del TRLPI.

No obstante, el art. 161.4 del TRLPI otorga amplias facultades a los titulares de derechos para adoptar las soluciones que estimen adecuadas, incluyendo, entre otras, medidas tecnológicas respecto del número de reproducciones en concepto de copia privada, en cuyo caso, los beneficiarios del límite por copia privada no podrán exigir el levantamiento de las medidas tecnológicas que, en su caso, hayan adoptado. Consecuentemente, los titulares de derechos pueden conformar la obra o prestación con medidas tecnológicas de protección que no faciliten al usuario más que la realización de una copia para uso privado pues, en la medida en que la ley no prevé un número determinado de reproducciones, una sola reproducción podría considerarse adecuada en tanto no restringe absolutamente el ejercicio de dicho límite.

Nada dice el legislador español sobre la calidad de la copia ${ }^{655}$ y también en este punto la doctrina española se encuentra dividida. Así pues, mientas algunos autores sostienen que el titular de los derechos no está obligado a garantizar una calidad determinada de la copia digital, otros consideran que al menos debe poder obtenerse una copia de igual calidad que la original ${ }^{656}$.

En todo caso, en virtud del art. 161.2 del TRLPI los beneficiarios del límite de copia privada podrán acudir ante la jurisdicción civil para hacer valer su "derecho" cuando los titulares de derechos no hayan adoptado las medidas necesarias para

${ }^{655}$ SÁncheZ ARISTI, R., "La copia privada digital", op. cit., p. 32; CABEDO Serna, L. L., "Los consumidores y las medidas tecnológicas de protección...”, op. cit., p. 93.

${ }^{656} \mathrm{Vid}$. Como partidario de la primera postura GARROTE FERNÁNDEZ-DíeZ, I., “Artículo 161”, en Bercovitz RodríGuez-Cano, R. (Coord.), Comentarios a la Ley de Propiedad..., $3^{\text {a }}$ ed., op. cit., p. 2085. En favor de la segunda, LACRUZ MANTECÓN, M. L., "Copias privadas y calamidades públicas", en Rogel VIDE, C. (Dir.), Anuario de Propiedad Intelectual 2005, Reus, Madrid, 2006, p. 489. 
garantizarles el disfrute de la excepción ${ }^{657}$. Pero ésta es una solución totalmente ineficaz, pues la demora en la resolución de los conflictos por los tribunales hace que cuando quede resuelto el asunto, incluso si es en favor del beneficiario del límite, ya no tenga ningún sentido ${ }^{658}$.

Además, debe tenerse presente que la posibilidad de acudir a la jurisdicción civil, que se cumple tanto si las medidas tecnológicas han sido adoptadas voluntariamente por los titulares de derechos de propiedad intelectual (incluidas las derivadas de acuerdos con otros interesados), como si han sido dispuestas por resolución judicial (art. 161.3 del TRLPI), cede paso frente a aquellos casos en los que las obras o prestaciones se han puesto a disposición del público con arreglo a lo convenido por contrato, de tal forma que cualquier persona pueda acceder a ellas desde el lugar y momento que elija (art. 161.5 del TRLPI).

Así, en aquellos casos en que las creaciones intelectuales son objeto de servicios interactivos en línea, el beneficiario de una excepción no podrá oponerse al establecimiento de una medida tecnológica que restrinja el disfrute de la obra o prestación intelectual, aun cuando exista alguna limitación al derecho de autor que así lo permita. Ahora bien, respecto al límite de copia privada, la solución del TRLPI es aún más difícil de comprender. En este caso, ni siquiera opera el límite de copia privada, puesto que ha quedado excluido para las reproducciones de obras que hayan sido

${ }^{657}$ Cuando los beneficiarios de los límites sean consumidores o usuarios, de acuerdo con la definición legal que ofrece el art. 1.2 y 3 de la Ley 26/1984, de 19 de julio, General para la Defensa de los Consumidores y Usuarios, en su defensa podrán actuar las entidades legitimadas en el art. 11.2 y 3 de la Ley 1/2000, de 7 de enero, de Enjuiciamiento Civil (art. 161.2.2 ${ }^{\circ}$ del TRLPI). Vid. CABEDO SERNA, L. L., "Los consumidores y las medidas tecnológicas de protección...", op. cit., pp. 94-99, donde el autor comenta el recurso legal de acudir a la jurisdicción civil, con especial referencia a la defensa de intereses colectivos por parte de los consumidores.

658 Garrote Fernández-Díez, I., “Artículo 161”, en Bercovitz RodríGUEZ-CANO, R. (Coord.), Comentarios a la Ley de Propiedad..., $4^{\mathrm{a}}$ ed., op. cit., p. 2237; MARÍN LÓPEZ, J. J., "La copia privada frente a las medidas...", op. cit., p. 53; BUGANZA, C., "Las medidas de protección tecnológicas y la información para la gestión de derechos", en BugAnZA C. (Dir.), Novedades en la Ley de Propiedad Intelectual, J. M. Bosch, Barcelona, 2007, p. 137; GALLARDO PÉREZ, L., "El necesario ajuste entre los límites a los derechos de propiedad intelectual y la protección de las medidas tecnológicas", Opinión Jurídica, Vol. 6, núm. 12, Medellín, 2007, p. 101; y CARBAJO CASCóN, F., 'La 'larga marcha' de la compensación equitativa por copia privada. A propósito de la sentencia (Sala Primera) del Tribunal Supremo de 25 de octubre de 2005", Pe. I. Revista de Propiedad Intelectual, núm. 22, 2006, p. 37 (nota 42). 
puestas a disposición del público mediante estos servicios interactivos en línea, por mandato del art. 31.3.a) del TRLPI.

En definitiva, la implementación progresiva de medidas tecnológicas y la contractualización del uso de las obras en línea irá restando espacio a la copia privada, quedando los derechos que la copia privada protege desamparados, sin protección alguna, en perjuicio de los intereses individuales de los usuarios de las creaciones intelectuales y de la sociedad en su conjunto. Pero lo más triste será que el autor tampoco saldrá beneficiado con la imposición de tales medidas restrictivas de la copia pues, más bien, los beneficiados serán las grandes industrias culturales y tecnológicas. Más que la tutela de los legítimos derechos de los autores, primarán los intereses del mercado.

\section{LA INEXISTENCIA DE UN DERECHO DEL USUARIO A LA COPIA PRIVADA}

El hecho de que el art. 161.2 del TRLPI permita a los usuarios legítimos de una obra o prestación intelectual acudir a la jurisdicción civil para exigir a los titulares de derechos de autor el cumplimiento del deber de garantizar los medios adecuados para que puedan disfrutar de los límites mencionados en el art. 161.1 del TRLPI, ha puesto nuevamente de relieve la antigua cuestión de la defensa de la copia privada como un derecho subjetivo del usuario de las obras y prestaciones intelectuales. En efecto, se trata de una cuestión defendida inicialmente por quienes consideraban que la copia privada no entrañaba una mengua sustancial o intolerable del contenido económico del derecho de autor, a lo que se añade el propio fundamento de la imposibilidad de control $^{659}$, que vuelve a cobrar relevancia por el uso de las medidas tecnológicas de protección. El trasfondo de la cuestión radica, como señala GONZÁLEZ DE ALAIZA

${ }^{659}$ SERRANO CAÑAS, J. M., “La trasposición de la Directiva 2001/29/CE...”, op. cit., p. 58. 
CARDOna, en que si se considera que la copia privada es un derecho, entonces no sería posible utilizar medidas tecnológicas para restringirla ${ }^{660}$.

Desde el Derecho civil existe un derecho subjetivo cuando más allá de la existencia de un "interés jurídicamente protegido", se ponen a disposición del sujeto la protección y la tutela de ese interés ${ }^{661}$. Así pues, la idea de "poder" jurídico subyace en su definición ${ }^{662}$, otorgando al sujeto una serie de posibilidades de acción para la defensa del interés jurídico que la norma jurídica resguarda.

No puede negarse que, de conformidad con el art. 161.2 del TRLPI, el beneficiario de un límite al derecho de autor puede ejercitar la correspondiente acción civil para hacer efectivo su interés legítimo -la realización de la copia privada- y recabar la protección de los tribunales cuando el titular de derechos de propiedad intelectual le niega esta posibilidad.

Visto así, pudiera pensarse que el beneficiario del límite tiene un derecho a la copia privada ${ }^{663}$. Sin embargo, esta no es una posibilidad que la ley atribuya al beneficiario del límite en todo caso. El usuario no siempre puede enfrentarse al titular de derechos de propiedad intelectual para reclamarle su deber de garantizarle el disfrute del límite frente a la existencia de medidas tecnológicas de protección. En efecto, el usuario no tiene siempre la libertad de decidir y actuar (p. ej., no podrá decidir cuántas reproducciones efectúa para fines privados, ni tampoco si cede su goce a un tercero). Ello es así, puesto que la ley restringe la posibilidad de exigir el levantamiento de

\footnotetext{
${ }^{660}$ GonzÁlez de Alaiza Cardona, J. J., La copia privada. Sus fundamentos..., op. cit., p. 269.

${ }^{661}$ Díez PiCAZO, L. y Gullón, A., Sistema de Derecho Civil, Vol. I, 12a ed., Tecnos, Madrid, 2012, p. 404.

662 Ídem.

${ }^{663}$ En este sentido, TAto PlazA, A., "La reforma de la ley de propiedad intelectual y los límites al derecho de autor...", en GARCÍA PÉREZ, R. y LóPEZ SuÁREZ, M. A. (Coords.), Nuevos retos para la Propiedad Intelectual: II Jornadas sobre Propiedad Intelectual y el Derecho de Autor/a (9-30), Servicio de Publicaciones de la Universidad de A Coruña, 2008, p. 24, quien afirma: “[...] debe subrayarse que la Ley de Propiedad Intelectual no configura la copia privada únicamente como un límite al derecho de autor. Antes bien, configura también la copia privada como un auténtico derecho subjetivo susceptible de protección jurisdiccional". Y añade: "Nos encontramos, así pues, ante un auténtico derecho subjetivo a la copia privada del que es titular quien ha accedido legítimamente a la obra protegida. Un derecho subjetivo que, además, tiene su correlativo en la obligación que se impone a los titulares de los derechos de autor de adoptar las medidas precisas que faciliten el ejercicio de aquel derecho subjetivo. Y, para eliminar cualquier duda, el legislador ha decidido rodear también este derecho subjetivo a la copia privada de las debidas garantías jurisdiccionales".
} 
medidas tecnológicas cuando los titulares de derechos han implementado algún mecanismo que circunscribe el número de reproducciones en concepto de copia privada (art. 161.4 del TRLPI). Consecuentemente, no puede sostenerse que el usuario o beneficiario del límite ostente, en todo caso, un derecho que le garantiza la reproducción con fines privados ${ }^{664}$, puesto que no siempre podrá accionar -como sería propio de un derecho subjetivo- cuando sea perturbado en su interés de realizar una reproducción con fines privados.

Es cierto que la ley protege el interés del usuario, pero lo hace justamente porque la copia privada es un límite al derecho de autor. El hecho de que la copia privada sea una limitación al derecho de propiedad intelectual conlleva, necesariamente, tener en cuenta el interés del usuario. No puede obviarse que es consustancial a la propiedad intelectual el equilibrio de intereses contrapuestos entre titulares de derechos y usuarios, lo que exige establecer una proporción adecuada entre ambos.

La consideración de la copia privada como excepción o límite a los derechos de propiedad intelectual queda confirmada por la propia sistemática de la ley. El límite de copia privada se encuentra encabezando el articulado de los límites a los derechos de autor en el TRLPI (arts. 31 y ss.). Igualmente, la DDASI lo contempla como parte de las limitaciones establecidas en el art. 5 dedicado a las “excepciones y limitaciones".

En resumen, las limitaciones a los derechos de autor derogan el poder monopólico del autor sobre la explotación de la obra; delimitan un área sobre la que los titulares de los derechos no pueden interferir porque va más allá de su posible control ${ }^{665}$. Sin embargo, no por ello puede afirmarse la existencia de un derecho subjetivo en favor del

\footnotetext{
${ }^{664}$ En el mismo sentido, Garrote FernándeZ-DíEZ, I., "Artículo 31”, en BERCOVITZ RodríGuEZ-CANo, R. (Coord.), Comentarios a la Ley de Propiedad..., $3^{\text {a }}$ ed., op. cit., p. 556; Belloso MARTín, N., "Los derechos de autor en la sociedad tecnológica: contenido, tutela y límites", en MATA Y MARTín, R. M. (Dir.) y JaVAto Martín, A. M. (Coord.), La Propiedad Intelectual en la Era Digital. Límites e infracciones a los derechos de autor en Internet, La Ley, Madrid, 2011, p. 114; FERNÁNDEZ BALlesteros, C., "La remuneración por copia privada", Revista Jurídica de Propiedad Intelectual, Tomo III, Guayaquil, 2010, p. 25. Por otra parte, LÓPEZ MAZA, S., Límites al derecho de reproducción..., op. cit., p. 317, concluye que "[...] en teoría, la copia privada es un límite al derecho exclusivo de reproducción, establecido en la Ley, si bien en la práctica funciona como un derecho, al permitir a los usuarios reclamar judicialmente su ejercicio, como cualquier otro".

${ }^{665}$ KARAPAPA, S., Private Copying, op. cit., p. 166.
} 
usuario. Así lo ha reconocido la jurisprudencia en los asuntos Test Achast ${ }^{666}$, dirimido ante los órganos jurisdiccionales belgas; y Mulholland Drive ${ }^{667}$, resuelto en los tribunales franceses ${ }^{668}$.

En definitiva, puede afirmarse que la copia privada es una limitación o excepción a los derechos de autor y no un verdadero derecho subjetivo del usuario. Sin embargo, ello no impide que el usuario pueda accionar en defensa de su interés, siempre y cuando el titular de derechos no cumpla con su deber legal de garantizarle el disfrute de la copia poniendo a su disposición los medios adecuados para hacer frente a la implementación de medidas tecnológicas de protección sobre la obra o prestación intelectual, en los términos previstos legalmente.

\section{EL INTERCAMBIO DE ARCHIVOS EN LAS REDES P2P Y LA COPIA PRIVADA}

Se ha pretendido que la descarga de obras protegidas por la propiedad intelectual a través de las redes de intercambio de archivos P2P quede amparada en la excepción de copia privada. Es por ello que conviene en este apartado hacer un análisis -aunque sólo sea brevemente- del funcionamiento de estas redes y de los criterios que impiden tal consideración.

La locución P2P, que se corresponde con la abreviatura de la frase en inglés peer to peer (podría traducirse como "de igual a igual”), comporta el intercambio de archivos en Internet. Esta tecnología facilita que los usuarios puedan establecer conexiones en la Red para compartir archivos, bien sea a través de un servidor central, bien conectando sus ordenadores directamente, de forma tal que se convierten en potenciales emisores y

\footnotetext{
${ }^{666}$ L'ASBL Association Belge del Consomateurs Test Achast v. La SA EMI Recorded Music Belgium et al., Brussels Court of Appeal, 9 September 2005, case 2004/AR/1649 (Belgium).

${ }^{667}$ Studio Canal et al. V. S. Penguin and Union Federale des Consommateurs Que Choisir, Cour de Cassation, 19 June 2008, No. 07-142777 (France).

${ }^{668} \mathrm{La}$ referencia es tomada de KARAPAPA, S., Private Copying, op. cit., pp. 151-152, quien comenta ambos casos en apoyo de su argumentación sobre el hecho de que la copia privada no constituye un derecho del usuario.
} 
receptores de información ${ }^{669}$. Siguiendo a GARROTE FERNÁNDEZ-DíEZ estos programas “crean una red propia de usuarios capaz de conectarse entre sí con la ayuda de un ordenador personal y una conexión a Internet" y "normalmente funcionan utilizando un protocolo privado que permite que el programa funcione utilizando una serie de 'nodos' $\mathrm{u}$ ordenadores importantes que contienen la lista de peers (ordenadores que intercambian ficheros)" ${ }^{\prime 670}$.

Así, estas redes ponen a disposición de los usuarios contenidos protegidos por la propiedad intelectual sin el previo consentimiento de los titulares de derechos de autor. En efecto, los archivos informáticos intercambiados en formato de textos, imágenes y sonidos, generalmente contienen obras literarias, fotográficas, musicales y audiovisuales, entre otras, cuya explotación está reservada legalmente al titular de los derechos de autor. Naturalmente, el intercambio de estos archivos sin recabar el consentimiento del titular implica una violación de sus derechos, por lo que este comportamiento sólo estaría legitimado en la medida en que pueda quedar amparado en una excepción a los derechos de autor o conexos.

En la mayoría de los casos, estos programas alojan las obras descargadas por los usuarios en una carpeta compartida, de acceso, por tanto, al resto de los usuarios de la red P2P. Esto hace que la copia obtenida no pueda considerarse una copia para uso privado. Más bien al contrario, se trata de una reproducción de uso colectivo porque es puesta a disposición de un gran número de personas. En efecto, el carácter colectivo de las copias sólo podría negarse de aquellas almacenadas fuera de la carpeta compartida, en una carpeta diferente y de uso privado, creada por el usuario en su ordenador, aunque esto no suele ser lo común ${ }^{671}$.

Por otra parte, el límite de copia privada exige también el requisito del acceso legal a la obra divulgada, conforme a lo establecido en el art. 31.2.b) del TRLPI. Este

${ }^{669}$ CUADROS AÑAZCO, A., "Derechos patrimoniales de reproducción y comunicación pública del autor en Internet: Intercambio de archivos digitales a través de las redes P2P", Revista Jurídica de Propiedad Intelectual, Guayaquil, 2010, p. 23; LÓPEZ MAZA, S., Límites al derecho de reproducción..., op. cit., p. 324.

${ }^{670}$ GARRote FERNÁNDEZ-DíEZ, I., La reforma de la copia privada ..., op. cit., p. 197.

${ }^{671}$ Ibídem, p. 210. 
requisito influye, consecuentemente, en la valoración que pueda hacerse del intercambio de archivos mediante redes P2P al amparo de dicho límite.

Tradicionalmente, a falta de una definición legal sobre el significado y alcance de la expresión "acceso legal", la doctrina española mayoritaria ha excluido este intercambio de archivos del límite de copia privada, entendiendo que no cumple con la exigencia del acceso legal a la obra reproducida quien, de acuerdo con la diligencia media exigible, debe saber que está reproduciendo una copia ilegal ${ }^{672}$. Esto debe presuponerse en el caso de las redes P2P, pues en éstas, lo usual, es que las obras sean intercambiadas sin obtener la previa autorización del titular de derechos de autor a partir de obras obtenidas en el top manta, mediante la extracción de los archivos digitales fijados en CDs y DVDs con el uso de programas de ordenador especializados obtenidos desde distribuidores on line (muchas veces ilegales), así como fruto de intercambios en las propias redes $\mathrm{P} 2 \mathrm{P}^{673}$.

Más clara resultaba esta postura a tenor de la redacción dada al art. 31.2.b) del TRLPI por la Ley 21/2014, de 4 noviembre, en la que se especificaban las circunstancias en las que se entendía que se había accedido a la obra legalmente, desde una fuente lícita ${ }^{674}$. En efecto, pese a las críticas que puedan hacerse del contenido de este precepto, su redacción no daba cabida a considerar este tipo de intercambio de archivos dentro de los supuestos de acceso legal a la obra o prestación intelectual objeto de copia privada. En primer lugar, porque el propietario de un soporte adquirido por compraventa mercantil, autorizado para reproducir la obra contenida en el mismo por la

672 GonzÁlez de Alaiza Cardona, J. J., La copia privada. Sus fundamentos..., op. cit., p. 304; Rodrigo-BERCOVITZ RodríGUEZ-CANO, R., GARrote FERnÁNDEZ-DíEZ, I., GONZÁlEz GonZALO, A. y SÁNCHEZ ARISTI, R., Las reformas de la Ley..., op. cit., p. 48; LÓPEZ MAZA, S., Límites al derecho de reproducción..., op. cit., p. 221.

673 GARROTE FERNÁNDEZ-DíEZ, I., La reforma de la copia privada ..., op. cit., p. 205.

${ }^{674}$ A tenor de aquella redacción, el art. 31.2.b) del TRLPIestablecía: "Que la reproducción se realice a partir de obras a las que haya accedido legalmente desde una fuente lícita. A estos efectos, se entenderá que se ha accedido legalmente y desde una fuente lícita a la obra divulgada únicamente en los siguientes supuestos: 1. ${ }^{\circ}$ Cuando se realice la reproducción, directa o indirectamente, a partir de un soporte que contenga una reproducción de la obra, autorizada por su titular, comercializado y adquirido en propiedad por compraventa mercantil. $2{ }^{\circ}$ Cuando se realice una reproducción individual de obras a las que se haya accedido a través de un acto legítimo de comunicación pública, mediante la difusión de la imagen, del sonido o de ambos, y no habiéndose obtenido dicha reproducción mediante fijación en establecimiento o espacio público no autorizada". 
excepción de copia privada, únicamente estaría legitimado para reproducir dicha obra y no para ponerla a disposición de los usuarios en una red P2P. En segundo lugar, porque el acto de comunicación pública que se realiza al introducir la obra en una red P2P no es un acto legítimo de comunicación pública pues, para que dicho acto sea legítimo, tendría que solicitarse el permiso correspondiente al titular de derechos de autor ${ }^{675}$, algo que no sucede en el contexto de este tipo de intercambio de archivos.

No obstante, el hecho de haber eliminado de la redacción actual del art. 31.2.b) del TRLPI la precisión de acceso legal, no impide concluir que el intercambio de archivos en las redes P2P esté fuera del marco que ampara el límite de copia privada. En efecto, son válidos los mismos argumentos empleados por la doctrina con anterioridad a la promulgación de la Ley 21/2014, de 4 de noviembre, siendo por consiguiente, la falta de autorización del titular de derechos para que la obra sea puesta a disposición de los usuarios de una red P2P, por un lado, y el carácter colectivo de la utilización, por otro, razones suficientes para que este intercambio sea una práctica ilegal. A su vez, también hay que tener en cuenta que la actual redacción del art. 31.2 del TRLPI incluye dentro del límite de copia privada sólo aquellas reproducciones realizadas "sin asistencia de terceros", lo cual hace evidente que las copias obtenidas en estas redes no quedan amparadas en esta excepción.

A mayor abundamiento, se encuentran en la jurisprudencia española y comparada, fundamentalmente norteamericana, casos emblemáticos sobre la cuestión de la legalidad del intercambio de obras y prestaciones protegidas por la propiedad intelectual en estas redes $\mathrm{P} 2 \mathrm{P}^{676}$. El predecesor de todos fue el conocido caso Napster ${ }^{677}$, que enjuició por primera vez la legalidad de la práctica de intercambio de archivos en las redes P2P.

Napster es la denominación del primer sistema creado para intercambiar ficheros MP3 de música en línea entre usuarios conectados a una red. Se trataba de un sistema

\footnotetext{
${ }^{675}$ SÁNCHEZ ARISTI, R., El intercambio de obras protegidas a través de las plataformas peer-to-peer, Instituto de Derecho de Autor, Madrid, 2007, p. 172.

${ }^{676}$ La razón principal por la cual Estados Unidos ha sido precursor en el examen de estos temas se debe a que fue en este país donde surgieron los sistemas de intercambio de archivos P2P.

${ }^{677}$ A\&M Records, Inc. v. Napster, Inc., 239 F.3d 1004 (9 ${ }^{\text {th }}$. Cir. 2001).
} 
centralizado, debido a que existía un servidor central que contenía un directorio de usuarios e información acerca de los ficheros intercambiables, si bien no organizaba el tráfico de estos ficheros, ni almacenaba reproducciones temporales de los mismos ${ }^{678}$. Los usuarios adquirían, ante todo, el software diseñado por la compañía Napster y el uso de este software les permitía crear listas de archivos almacenados en sus ordenadores y "subirlas" a los servidores de Napster. Así, la empresa facilitaba mediante su programa informático la búsqueda y descarga de los mismos a otros usuarios del programa ${ }^{679}$. Básicamente, este software permitía a los usuarios poner a disposición de otros -para su reproducción por estos últimos-, archivos de música en formato MP3 almacenados en los discos duros de sus ordenadores. De igual modo, permitía buscar archivos de música MP3 almacenados en los ordenadores de otros usuarios y transferir copias exactas del contenido de dichos archivos MP3 de un ordenador a otro ${ }^{680}$.

Pero la introducción de esta tecnología entró en conflicto con el respeto a los derechos de autor, dando lugar a que, en diciembre de 1999, A\&M Records, Inc. (y otras entidades) interpusieran una demanda frente a Napster, Inc. en la Corte del Distrito Norte de California. Argumentaron, en términos generales, que los usuarios de los servicios de Napster infringían los derechos de propiedad intelectual, siendo la demandada responsable al contribuir de forma decisiva en la producción del daño. Napster se opuso argumentando que no había actividad infractora de sus usuarios y que tampoco sus propios actos vulneraban los derechos de autor, entre otras cuestiones, porque la actividad de aquellos estaba respaldada por la sección 1008 AHRA, que consentía ciertas actividades de reproducción de audio. La Corte del Distrito, sin

${ }^{678}$ GARROTE FERnÁNDEZ-DíEZ, I., La reforma de la copia privada ..., op. cit., p. 199.

${ }^{679}$ Vid. CORSARO, V., "From Betamax to YouTube: How Sony Corporation of America v. Universal City Studios, Inc. could still be a standard for new technology", Federeal Communications Law Journal, núm. 2, Vol. 64, Nebraska, 2012, p. 457.

${ }^{680}$ Así lo explica la sentencia dictada por la Corte de Apelación del Noveno Circuito A\&M Records, Inc. v. Napster, Inc., 239 F.3d 1004 (2001), p. 1011. 
embargo, dictó una medida cautelar contra Napster y decretó el cierre de su sitio web (la plataforma que servía para el intercambio de los archivos), el 26 de julio del $2000^{681}$.

En su razonamiento, la Corte afirmó que la sección 1008 AHRA no liberaba a la demandada de responsabilidad porque su contenido estaba dirigido a regular un fenómeno muy diferente ${ }^{682}$. En efecto, este precepto prohíbe el ejercicio de acciones por infracción de derechos de autor basados en la fabricación, importación o distribución de dispositivos o medios de grabación de audio (digitales y analógicos), así como contra los consumidores de tales dispositivos o medios, empleados para realizar grabaciones musicales digitales o analógicas, sin fines comerciales.

Entre otros argumentos, la Corte del Distrito razonó que esta red no basaba su funcionamiento en ninguno de los dispositivos o medios de grabación previstos en la sección 1008 AHRA, que son los que permitían liberar a los usuarios de responsabilidad. Tampoco los usuarios realizaban grabaciones musicales conforme a lo autorizado legalmente, pues la descarga de archivos MP3 no era una actividad cubierta por la sección 1008 AHRA. Además, los usuarios de Napster no sólo copiaban, sino que también distribuían estas grabaciones, a lo que añadía la Corte, que aun en el supuesto de que no fuera posible interponer acciones contra los usuarios en virtud de la sección 1008 AHRA, ello no significaba que no se pudiera actuar frente a Napster por "contributory and vicarious infringement" 683 .

${ }^{681}$ Para un análisis más amplio sobre el asunto Vid. SÁNCHEZ ARISTI, R., El intercambio de obras protegidas..., op. cit., pp. 97-110; ÁlvAREZ, H., "Aspectos jurídicos de las descargas de música en Internet”, en GARcía PÉREZ, R. y LóPEZ SuÁREZ, M. A. (Eds.), Nuevos retos para la propiedad intelectual..., op. cit., pp. 107-112.

682 Vid. U.S. Copyright Office: Brief in A\&M Records v. Napster, p. 4, disponible en: https://www.copyright.gov/docs/napsteramicus.html (consultado: 11.04.2017).

${ }^{683} \mathrm{Se}$ trata de dos figuras de responsabilidad extracontractual indirecta. La contributory liability "corresponde a quien, teniendo conocimiento de la conducta infractora, la induce, causa o contribuye materialmente a ella proveyendo medios o recursos al infractor" y la vicarious liability es "la responsabilidad que puede imponerse a aquel que tiene el derecho y la capacidad de supervisar la actividad del sujeto infractor y que obtiene un beneficio económico derivado de dicha actividad" (SÁNCHEZ ARISTI, R., El intercambio de obras protegidas..., op. cit., pp. 93-94). Se trata de categorías de creación jurisprudencial, cuyo nacimiento doctrinal y su aplicabilidad al ámbito de la propiedad intelectual se sitúa en el caso Sony Corp. of Am. v. Universal City Studios, Inc., 464 U.S. 417 (1984). Vid. LETAI, P., La infracción de derechos de propiedad intelectual sobre la obra musical en Internet, Comares, Granada, 2012, p. 130. 
Posteriormente, los argumentos sostenidos por la Corte del Distrito fueron confirmados por la sentencia de 12 de febrero de 2001 dictada por la Corte de Apelación del Noveno Circuito que puso fin al asunto ${ }^{684}$. En particular, interesa destacar aquí las consideraciones que fueron hechas en cuanto a la posibilidad de realizar reproducciones para uso privado al amparo de la sección 1008 AHRA y la doctrina del fair use, sin perjuicio de otros razonamientos, no menos importantes, sobre la responsabilidad indirecta de Napster por las infracciones cometidas por los usuarios.

Sobre la posibilidad de reproducir las obras mediante el uso del software de Napster, al amparo de la sección 1008 AHRA, el juez afirmó que no podía considerarse que los ordenadores (y sus discos duros) pudieran considerarse dispositivos de grabación de audio digital porque ésta no era su función principal; tampoco que los ordenadores realizaran grabaciones musicales digitales en el sentido de las disposiciones legales de dicha sección ${ }^{685}$. Por otra parte, respecto a la posibilidad de legitimar estas reproducciones bajo el fair use, la Corte de Apelación estuvo de acuerdo con la Corte del Distrito en que los usos que Napster defendía como justos eran contrarios a esta doctrina. Por un lado, la finalidad y el carácter de las utilizaciones de los usuarios no tenían un uso leal o justo. La descarga de archivos MP3 no podía considerarse un uso justo al excluirse el carácter trasformativo del mismo ${ }^{686} \mathrm{y}$ al apreciarse una finalidad comercial por el ahorro de los costes que suponía para el usuario la adquisición gratuita de la reproducción de la obra. Ello a pesar de que el usuario no obtuviese un beneficio económico directo, cuya apreciación era innecesaria, porque la obtención reiterada de copias no autorizadas de obras protegidas, incluso sin ofrecerse a la venta, podía constituir un uso comercial ${ }^{687}$. La naturaleza del uso contribuía también a descartar el uso justo. En efecto, las obras intercambiadas eran composiciones musicales de naturaleza creativa y estaban más cerca del núcleo de la protección de los derechos de autor, lo que contrarrestaba la posibilidad de defender un uso leal de acuerdo con el

\footnotetext{
${ }^{684}$ A\&M Records, Inc. v. Napster, Inc., 239 F.3d 1004 (2001).

685239 F.3d 1024-1025.

${ }^{686}$ Todo lo que se hacía era facilitar la transmisión en un medio diferente lo cual hacía que el uso fuera calificado de reproductivo.

${ }^{687}$ A\&M Records, Inc. v. Napster, Inc., 239 F.3d 1015; SÁNCHEZ ARISTI, R., El intercambio de obras protegidas..., op. cit., p. 104.
} 
segundo factor de esta doctrina ${ }^{688}$. A su vez, la obra era reproducida en su totalidad y, a pesar de que esto no era del todo óbice para apreciar el fair use, sí que era un elemento de peso a la hora de determinar si una conducta concreta podía considerarse "leal" 689 . Finalmente, la Corte de apelación coincidió con la Corte del Distrito en que la actividad de Napster perjudicaba al mercado potencial de la explotación de las obras musicales, reduciendo las ventas de $\mathrm{CD}$ de audios musicales y perjudicando el mercado de la descarga digital de música en línea de las demandantes ${ }^{690}$.

También se inaplicó el razonamiento de la defensa según el cual se pretendía justificar la licitud de la actividad de Napster basada en ciertos usos lícitos como el sampling o el space-shifting. En lo que respecta al sampling (muestreo), la actividad de la demandada, al contrario de la actividad promocional gratuita de las compañías discográficas, no era una actividad controlada en cuanto al tiempo y al alcance de la reproducción (las discográficas proporcionaban muestras de la obra de entre treinta y sesenta segundos de duración de la canción, almacenadas sólo por un tiempo en los ordenadores de los internautas), sino que facilitaba la descarga de ficheros íntegros y de duración permanente, afectando el mercado de venta de los CD de audio y el mercado de distribución en línea de la música ${ }^{691}$. Por su parte, el space-shifting quedaba igualmente descartado como argumento a favor de Napster porque el programa P2P, lejos de facilitar la reproducción de obras que habían sido adquiridas legalmente por los usuarios para disfrutarlas en otro lugar, hacía que las obras quedaran disponibles para el público de la red, para un uso general ${ }^{692}$.

688 239 F.3d 1016.

689 Ídem.

690 Ídem.

691239 F.3d 1018.

${ }^{692}$ La Corte de Apelación aprobó que la Corte del Distrito no hubiera aplicado los razonamientos expuestos en los asuntos Sony Corp. of Am. v. Universal City Studios, Inc., 464 U.S. 417 (1984) y Ass'n of Am. v. Diamond Multimedia Sys., Inc., 180 F.3d 1072. Al respecto, la sentencia de la Corte de Apelación del Noveno Circuito defiende: "We conclude that the district court did not err when it refused to apply the 'shifting' analyses of Sony and Diamond. Both Diamond and Sony are inapposite because the methods of shifting in these cases did not also simultaneously involve distribution of the copyrighted material to the general public; the time or space-shifting of copyrighted material exposed the material only to the original user. In Diamond, for example, the copyrighted music was transferred from the user's computer hard drive to the user's portable MP3 player. So too Sony, where 'the majority of VCR 
Con todo, el proceso contra Napster generó la primera respuesta judicial a las dudas sobre la licitud del intercambio de ficheros en las redes P2P. Las contestaciones contundentes, tanto de la Corte del Distrito Norte de California como de la Corte de Apelación del Noveno Circuito de Estados Unidos negaron la posibilidad de que un sistema de intercambio de archivos como Napster gozara de licitud, ni de acuerdo con lo dispuesto en la sección 1008 AHRA, ni con la doctrina del fair use. Napster marcó sin éxito legal el comienzo del intercambio de archivos P2P y aunque posteriormente han surgido otros sistemas basados en formas descentralizadas de intercambio de archivos, con la intención de que los operadores de estas redes puedan evadir su responsabilidad, tampoco estas nuevas fórmulas han sido consideradas legales (v. gr. Aimster ${ }^{693} \mathrm{y}$ Grokster $\left.^{694}\right)^{695}$.

En la jurisprudencia española también se encuentran diversas sentencias que han enjuiciado la conducta de algunas empresas creadoras y distribuidoras de software de intercambio de archivos $\mathrm{P} 2 \mathrm{P}^{696}$. Pero, a diferencia de lo acontecido en el caso Napster, en España no es posible la atribución de responsabilidad por infracción indirecta de los derechos de autor, esto es, la infracción cometida por quien, siendo consciente de ello, induce o contribuye a que un tercero realice una actividad infractora ${ }^{697}$. La razón fundamental que explica esta posición obedece a la inexistencia en el ordenamiento jurídico español de una regulación explícita sobre la infracción indirecta. La posibilidad de imputar responsabilidad por esta vía no prosperaría porque quien contribuye a la utilización ilegítima de la obra o prestación intelectual (en este caso la empresa que crea y comercializa el programa P2P) no incurre, como tal, en un comportamiento tipificado como infracción a los derechos de autor, y, por tanto, no puede quedar sometido a

purchasers... did not distribute taped television broadcasts, but merely enjoyed them at home'”, (239 F.3d 1019).

${ }^{693}$ In re Aimster Copyright Litigation, 334 F.3d 643 (2003).

${ }^{694}$ Metro-Goldwyn-Mayer Studios Inc. v. Grokster, Ltd., 545 U.S. 913 (2005).

${ }^{695}$ MILES, E., "In re Aimster \& MGM, Inc. v. Grokster, Ltd.: Peer-to-Peer and the Sony Doctrine", Berkeley Technology Law Journal, núm. 1, Vol. 19, 2004, pp. 29-34; GIBLIN, R., "The P2P Wars: How Code Beat Law", IEEE Internet Computing, núm. 3, Vol. 16, 2012, pp. 92-93.

${ }^{696}$ Por todas, SAP Barcelona (Sección 15a), de 24 febrero de 2011 (AC 2011186); SAP Barcelona (Sección 15a), de 7 julio de 2011 (AC 2011\1505) y SAP Madrid (Sección 28a), de 31 marzo de 2014 (AC 2014l652). Véase también, SÁNCHEZ ARISTI, R., "Enlazadores y seudoenlazadores...”, op. cit., pp. 22-23. ${ }^{697}$ SAP Madrid (Sección $28^{\text {a }}$ ), de 31 marzo de 2014, op. cit., F.J. $8^{\circ}$. 
responsabilidad alguna ${ }^{698}$. Tampoco serviría la imputación de responsabilidad al amparo del art. 1903 CC (responsabilidad por hecho ajeno), pues este tipo de responsabilidad vincula únicamente la conducta de un sujeto a la de otro por lazos de jerarquía, subordinación o dependencia, por lo que no cabe inspirarse en ella en estos supuestos, ya que estas empresas no tienen posibilidades de injerencia, vigilancia o control sobre la conducta de los usuarios de los programas ${ }^{699}$.

Ahora bien, ello no significa que el usuario del programa no transgreda con su conducta el derecho exclusivo de propiedad intelectual. Una cosa es el enjuiciamiento de la responsabilidad de quien crea y opera los programas de intercambio de archivos; y otra, la de los usuarios de estos programas, que son directamente responsables. Así pues, en la medida en que el intercambio de archivos no afecte derechos exclusivos de propiedad intelectual, la conducta de los usuarios será lícita. En cambio, cuando el objeto de las transferencias sean creaciones intelectuales y el intercambio se realice sin el consentimiento del titular de derechos de autor, su conducta será ilícita, ya que no podrá ampararse en el límite legal de copia privada. Cosa distinta es que, ciertamente, existan dificultades prácticas para la articulación de demandas frente a los usuarios individuales de estas redes, sobre todo por la dificultad legal para la identificación de los mismos ${ }^{700}$.

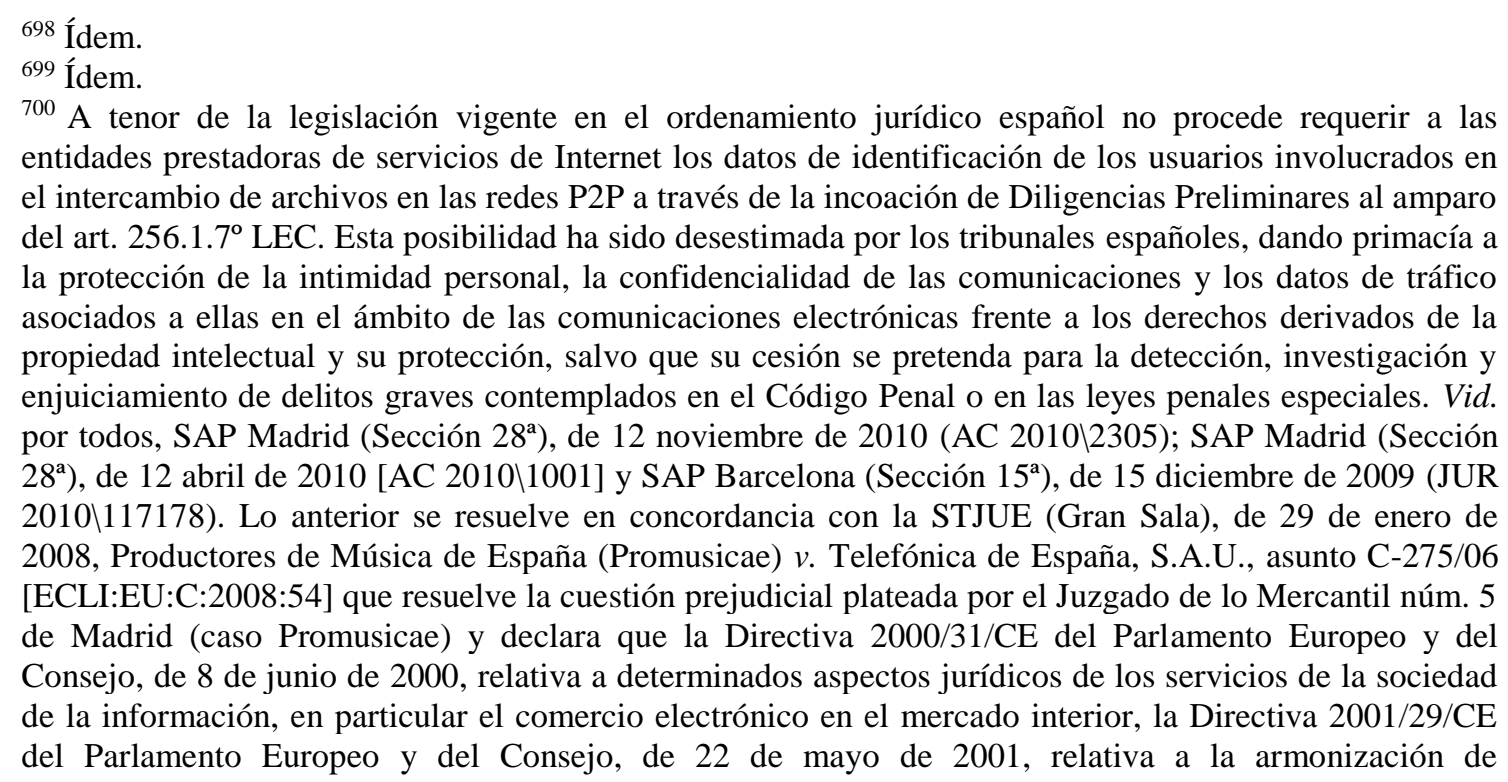


En definitiva, el límite de copia privada difícilmente puede operar para justificar el comportamiento de los usuarios de las redes de intercambio de archivos $\mathrm{P} 2 \mathrm{P}$, salvo que los archivos intercambiados no estén sujetos a la protección de las leyes de propiedad intelectual. En primer lugar, debido a que, aun cuando las descargas no almacenadas en la carpeta compartida pudieran considerarse legítimas al amparo de la copia privada, el carácter ilícito de las copias obtenidas sería irrefutable, teniendo en cuenta que no se trata de un acceso legal a la obra reproducida. En segundo lugar, porque la puesta a disposición de otros usuarios de los archivos en estas redes va en contra del carácter privado que se exige del uso a efectos de dicha excepción.

determinados aspectos de los derechos de autor y derechos afines a los derechos de autor en la sociedad de la información, la Directiva 2004/48/CE del Parlamento Europeo y del Consejo, de 29 de abril de 2004, relativa al respeto de los derechos de propiedad intelectual, y la Directiva 2002/58/CE del Parlamento Europeo y del Consejo, de 12 de julio de 2002, relativa al tratamiento de los datos personales y a la protección de la intimidad en el sector de las comunicaciones electrónicas, "no obligan a los Estados miembros a imponer, en una situación como la del asunto principal, el deber de comunicar datos personales con objeto de garantizar la protección efectiva de los derechos de autor en el marco de un procedimiento civil". 


\section{CAPÍTULO IV: EVOLUCIÓN LEGISLATIVA DE LA COMPENSACIÓN EQUITATIVA POR COPIA PRIVADA EN ESPAÑA: ESPECIAL REFERENCIA A LA COMPENSACIÓN CON CARGO A LOS PRESUPUESTOS GENERALES DEL ESTADO}

I. INTRODUCCIÓN. II. EVOLUCIÓN DEL MARCO LEGISLATIVO. 1. La compensación equitativa por copia privada: origen y evolución en Derecho interno. 1.1. Origen legal del sistema de compensación equitativa por copia privada en España: la Ley 22/1987, de 11 de noviembre, de Propiedad Intelectual. 1.2. En busca de una regulación más eficiente: la Ley 20/1992, de 7 de julio, de modificación de la Ley 22/1987, de 11 de noviembre, de Propiedad Intelectual. 1.3. Nuevas reformas al sistema compensatorio: la Ley 43/1994, de 30 de diciembre y su incidencia en el art. 25 LPI. 1.4. La aprobación del TRLPI: meros ajustes sistemáticos e insuficiencia regulatoria frente al escenario digital. 2. La compensación equitativa por copia privada en el Derecho de la Unión Europea: su influencia en el Derecho interno. 2.1. La DDASI como respuesta a los retos de la "Sociedad de la Información" en la Propiedad Intelectual. 2.2. La Ley 23/2006, de 7 de julio: norma de transposición de la DDASI al Derecho interno. 2.3. La Orden PRE 1743/2008, de 18 de junio. 3. La financiación de la compensación con cargo a los Presupuestos Generales del Estado. 3.1. Instrumentación legal. 3.2. La consolidación del modelo mediante la Ley 21/2014, de 4 de noviembre. 3.3. Crisis del modelo. 3.3.1. Observaciones generales. 3.3.2. La resolución por el TJUE de la cuestión prejudicial planteada por el ATS (Sala de lo ContenciosoAdministrativo), de 10 de septiembre de 2014 y su repercusión en el Derecho interno. 3.3.2.1. Las conclusiones del Abogado General: el intento de legitimación del modelo de compensación con cargo a los Presupuestos Generales del Estado. 3.3.2.2. La posición del TJUE. 3.3.2.3. La repercusión del pronunciamiento del TJUE en el ordenamiento jurídico interno. 



\section{INTRODUCCIÓN}

A partir de la promulgación de la DDASI en el año 2001, la excepción legal de copia privada quedó supeditada al establecimiento con carácter obligatorio en las legislaciones de los Estados miembros de la UE de un mecanismo compensatorio, introducido con la finalidad de compensar a los titulares de derechos de propiedad intelectual por los perjuicios provocados por las reproducciones realizadas en el ámbito privado. Sin embargo, esta compensación no era una figura jurídica nueva. Por el contrario, los Estados miembros que reconocían en sus legislaciones la limitación de copia privada, entre ellos, España, que la había introducido en su legislación mediante la Ley 22/1987, de 11 de noviembre, de Propiedad Intelectual, ya tenían establecido un sistema compensatorio ${ }^{701}$.

En particular, la introducción de la compensación por copia privada en el ordenamiento jurídico español ha atravesado por diferentes reformas legislativas, que no han sido sino expresión de la falta de una regulación acabada y pacífica sobre el tema. La razón fundamental de las sucesivas modificaciones ha sido la necesidad de encontrar un sistema eficaz y eficiente de determinación y recaudación de la compensación frente a la involuntariedad y la oposición de los deudores a su pago. A lo anterior, se suman las dificultades por establecer una regulación que satisfaga los intereses de los acreedores y los deudores de dicha compensación, el auge de las tecnologías digitales y su incidencia sobre la reglamentación precedente, la confrontación de opiniones sobre el modelo más idóneo para satisfacer esta obligación legal y la necesidad de adecuar las normas establecidas a las sentencias dictadas por el TJUE.

En este panorama de cambios, la legislación española ha transitado desde un modelo que pudiéramos llamar, tradicional, vigente en la mayoría en los países de la UE, basado en una cantidad fijada sobre el precio de los equipos, aparatos y soportes de

\footnotetext{
${ }^{701}$ El país precursor en el establecimiento legal de un sistema compensatorio por copia privada fue Alemania, mediante la Urheberrechtsgesetz, de 9 de septiembre de 1965. Posteriormente esta iniciativa se incorporaría en otros países del entorno europeo, como Francia, que la introdujo en su ordenamiento jurídico con la Loi $n^{\circ} 85-660$ du 3 juillet 1985 relative aux droits d'auteur et aux droits des artistesinterpretes, des producteurs de phonogrammes et de videogrammes et des entreprises de communication audiovisuelle.
} 
reproducción (más conocido como canon compensatorio ${ }^{702}$ ) $^{703}$, hacia un modelo que se apartaba del resto de las regulaciones en el ámbito de la UE (a excepción de Finlandia), consistente en satisfacer la compensación por copia privada con cargo a los PGE. Este último modelo ha regido sólo de forma temporal, produciéndose -como se analizarámuy recientemente la vuelta de la legislación española al sistema de canon.

Frente a tantas reformas legislativas, el examen de la evolución del marco legal de la compensación por copia privada se hace imprescindible para comprender el régimen jurídico vigente en la legislación española.

\section{EVOLUCIÓN DEL MARCO LEGISLATIVO}

\section{La compensación equitativa por copia privada: origen y evolución en}

\section{Derecho interno}

\subsection{Origen legal del sistema de compensación equitativa por copia privada en} España: la Ley 22/1987, de 11 de noviembre, de Propiedad Intelectual

La remuneración compensatoria por copia privada (término empleado entonces) se introdujo en el Derecho español con la Ley 22/1987, de 11 de noviembre, de Propiedad Intelectual (en adelante LPI), regulando su art. 25, apenas en tres apartados, dicha obligación legal.

En efecto, el precepto incorporó, por primera vez en la LPI, el derecho de los autores de obras publicadas en forma de libro, fonograma o en cualquier otro soporte sonoro o visual, conjuntamente con los editores o productores de dichas obras y con los artistas, intérpretes o ejecutantes, cuyas actuaciones se hallasen fijadas en dichos fonogramas y videogramas, a participar en una remuneración compensatoria por las

\footnotetext{
702 El término "canon" o "canon compensatorio" ha sido acuñado para referirse a la compensación equitativa, entendido como "gravamen afecto a determinados aparatos y soportes sujetos al límite de copia privada". AVILÉS GARCÍA, J., El derecho de compensación equitativa por copia privada, un debate abierto en la jurisprudencia, Reus, Madrid, 2015, p. 103. Si bien el empleo del término no es del todo satisfactorio porque puede dar lugar a equívocos sobre la naturaleza jurídica de la compensación, su uso se ha generalizado para referirse a esta figura jurídica, como sinónimo de la expresión "compensación equitativa".

${ }^{703}$ Vid. Anexo 1.
} 
reproducciones de tales obras, efectuadas exclusivamente para uso personal, por medio de aparatos técnicos no tipográficos. Dicha remuneración se exigía a los fabricantes e importadores de equipos y materiales aptos para realizar tales reproducciones destinados a su distribución comercial en España y, siguiendo los arts. 25.7 y 152.4 de la LPI, la misma se hacía efectiva a través de las correspondientes entidades de gestión colectiva de los derechos de propiedad intelectual.

La introducción de esta compensación en el ordenamiento jurídico, en conexión con el art. 31.2 de la LPI referido al límite de copia privada, fue vista por un sector de la doctrina como un medio para facilitar al autor y demás titulares de derechos la participación en la rentabilidad económica de los negocios sobre reproducción de sus obras. Sin embargo, para otro sector significó un debilitamiento del derecho de explotación y del derecho moral de los autores y demás titulares de derechos de autor ${ }^{704}$.

En cualquier caso, lo cierto es que resultó ser una opción acorde con la realidad social de aquel momento, en el que la evolución tecnológica incrementaba los medios de reproducción puestos a disposición del público en el mercado, haciéndolos accesibles a una amplia pluralidad de personas. El legislador se adaptaba así al "signo de los tiempos" y al sentir popular, que aceptaba como lícito el copiado doméstico sin necesidad de previa autorización del autor ${ }^{705}$, aunque sujeto a una compensación económica -entonces denominada remuneración- de carácter obligatorio ${ }^{706}$. En este contexto, adoptar una postura o regulación diferente hubiera generado una norma ineficaz ante la imposibilidad de realizar un control efectivo de la copia privada y, a su

\footnotetext{
${ }^{704}$ Así lo explica DE Fuentes, J., "Un enfoque jurídico. Razón de ser de la remuneración por copia privada. Un septenio legislando sobre la materia", en MINISTERIO DE CULTURA, La copia privada a examen: el derecho de remuneración compensatoria en el ámbito de la Propiedad Intelectual, Colección de Análisis y Documentos, núm. 6, Madrid, 1995, pp. 67 y 68.

${ }^{705}$ De Palacios CARO, E., "La negociación como necesidad. Sujetos del derecho y de la obligación. Nacimiento de la remuneración. Responsabilidad solidaria", en MINISTERIO DE CULTURA, La copia privada a examen: el derecho de remuneración compensatoria en el ámbito de la Propiedad Intelectual, Colección de Análisis y Documentos, núm. 6, Madrid, 1995, p. 81.

${ }^{706}$ El reconocimiento del límite de copia privada en la Ley estaba directamente relacionado con el pago de una compensación al titular de los derechos de propiedad intelectual. Sin tal compensación, la copia privada estaba prohibida, como lo sigue estando hasta el presente.
} 
vez, hubiera influido negativamente en el desarrollo tecnológico y en la industria de los aparatos y soportes de reproducción.

Ahora bien, indudablemente fue una regulación muy parca ${ }^{707}$. El art. 25 de la LPI apenas configuró esta obligación de remuneración. No precisó los equipos y materiales que la generaban y tampoco estableció la cuantía de la remuneración, ni el procedimiento a través del cual se haría efectiva, al remitir estas cuestiones a ulterior desarrollo reglamentario (art. 25.3 LPI). Ello se llevó a cabo mediante el Real Decreto 287/1989, de 21 de marzo ${ }^{708}$, cuyo objeto fue, precisamente, regular el procedimiento para determinar los equipos y materiales sujetos al canon, el importe, el sistema de recaudación y la distribución de la remuneración compensatoria a que se referían los arts. 25 y 31 de la LPI. En concreto, este Real Decreto estableció la creación de una Comisión Mixta en la que estarían representados paritariamente los titulares de derechos de autor y los fabricantes o importadores a quienes se exigía el pago de dicha remuneración. La misma era la encargada de precisar los equipos y materiales afectados, la fijación del importe del canon y el procedimiento de cobro de la remuneración (arts. 1.1 y 1.2).

Sin embargo, fue imposible alcanzar un acuerdo entre las partes implicadas para la fijación de la cuantía de la remuneración, es decir, entre los titulares del derecho y los fabricantes e importadores, acreedores y deudores del canon, respectivamente. En efecto, la solución de dejar completamente al arbitrio de la Comisión Mixta la determinación de los equipos y materiales sujetos al canon, su importe y su sistema de distribución y recaudación, a sabiendas de la inevitable confrontación de intereses entre las partes y sin prever la intervención de un tercero en caso de desacuerdo, no podía, sino ser una solución ingenua, abocada al fracaso ${ }^{709}$. Tal y como señala VALLÉS

\footnotetext{
707 VALlÉs Rodríguez, M., “Artículo 25”, en BERCOVITZ-RodRÍGUEZ-CANO, R. (Coord.), Comentarios a la Ley..., $1^{\mathrm{a}}$ ed., op. cit., p. 520.

${ }^{708}$ B.O.E. núm. 72 , de 25 de marzo de 1989.

${ }^{709}$ De PAlacios CARO, E., "La negociación...”, op. cit., p. 70. El autor señala la previsibilidad de que el sistema para la determinación de la deuda relativa a la remuneración compensatoria fracasara al quedar sometida al acuerdo de acreedores y deudores, y añade que esta opción no merece más que ser calificada de ingenua. Además, el sistema de quórum previsto impedía alcanzar la representación necesaria para la
} 
RODRÍGUEZ, la parquedad de la regulación legal, que utilizó desmesuradamente la técnica de remisión legislativa, así como los mecanismos estructurados para adoptar las decisiones en la citada Comisión, llevaron al fracaso la aplicabilidad y la operatividad de la norma ${ }^{710}$. Ello provocó la reforma del sistema, de tal forma que se determinase legalmente el importe total de la remuneración compensatoria en función de los distintos tipos de aparatos y soportes de reproducción (libros, fonogramas, videogramas), así como los procedimientos de fijación anual de la cuantía.

\subsection{En busca de una regulación más eficiente: la Ley 20/1992, de 7 de julio, de modificación de la Ley 22/1987, de 11 de noviembre de Propiedad Intelectual}

La necesaria reforma del art. 25 de la LPI tuvo lugar mediante la promulgación de la Ley 20/1992, de 7 de julio ${ }^{711}$, desarrollada por el Real Decreto 1434/1992, de 27 de noviembre, de desarrollo de los artículos 24, 25 y 140 de la Ley 22/1987, de 11 de noviembre, de Propiedad Intelectual, en la versión dada a los mismos por la Ley 20/1992, de 7 de julio $^{712}$.

La Ley 20/1992 introdujo cambios en el articulado del texto de la LPI, si bien las modificaciones realizadas no afectaron sustancialmente su regulación. Por el contrario, la nueva normativa persiguió, más bien, precisar o delimitar aspectos puntuales, con el fin de corregir las imperfecciones aparecidas tras cuatro años de aplicación práctica de la $\mathrm{LPI}^{713}$.

adopción de acuerdos. En el mismo sentido, De FuENTES, J., "Un enfoque jurídico. Razón de ser de la compensación...”, op. cit., pp. 69-70.

710 Vid. Vallés Rodríguez, M., "Artículo 25”, en Bercovitz-Rodríguez-Cano, R. (Coord.), Comentarios a la Ley..., $1^{\text {a }}$ ed., op. cit., p. 521.

${ }^{711}$ B.O.E. núm. 168, de 14 de julio de 1992.

${ }^{712}$ B.O.E. núm. 301, de 16 de diciembre de 1992.

${ }^{713}$ De la Puente García, E., "Notas sobre la Ley 20/1992, de 7 de julio, de modificación de la Ley 22/87, de 11 de noviembre, de Propiedad Intelectual", en Boletín de Información del Ministerio de Justicia, núm. $1655, \quad 1992, \quad$ p. $73 . \quad$ [En línea]: http://www.mjusticia.gob.es/cs/Satellite/Portal/1292344070105?blobheader=application\%2Fpdf\&blobhea dername $1=$ Content-

Disposition\&blobheadername2=EstudioDoctrinal\&blobheadervalue $1=$ attachment $\% 3 B+f i l e n a m e \% 3 D 199$ 2_1655.pdf\&blobheadervalue2=1288777614307 (consultado: 15 octubre 2016). 
De hecho, la nueva redacción dada al art. 25 de la LPI vino originada por la necesidad de regular con mayor detalle en la propia LPI la remuneración compensatoria por copia privada, previendo unas cantidades para la determinación del importe de la compensación, así como precisando un mecanismo legal para la fijación anual de dichas cantidades. Como se deriva de la propia Exposición de Motivos de la Ley 20/1992, el legislador de 1987 había optado por "efectuar una amplia llamada a la colaboración de la norma reglamentaria para la ultimación del diseño de su régimen jurídico" y el Real Decreto 287/1989, de 21 de marzo -norma de desarrollo de aquélla-, cumplió con dicha habilitación legal, "fiando por entero la efectividad de la remuneración compensatoria a una solución construida sobre el principio de autoadministración por los agentes sociales implicados", lo que dio lugar a una experiencia negativa en la aplicación práctica de estas normas.

En general, los cambios introducidos constituyeron una mejora sistemática respecto a lo previsto inicialmente en la LPI. Quedaron fijados en su art. 25.4 las cantidades para determinar el importe total de la remuneración compensatoria a satisfacer por sus deudores y el procedimiento a seguir para la determinación anual de estas cantidades, precisándose, además, un mecanismo de mediación de carácter forzoso a falta de acuerdo. En efecto, el art. 25.6 de la LPI estableció la intervención de un mediador nombrado por el Ministerio de Cultura para determinar las cantidades a pagar en concepto de remuneración compensatoria por copia privada. Así, para la fase de convenio entre deudores y acreedores de la remuneración compensatoria se estableció la obligación de intentar alcanzar un acuerdo en el plazo de los dos primeros meses de cada año [art. 25.5 a) de la LPI]. Sin embargo, de transcurrir dicho plazo legalmente establecido para la celebración del convenio sin que éste se hubiere concluido, el mediador sería el encargado de fijar la remuneración compensatoria [art. 25.5. b) LPI], garantizando, de este modo, la eficacia del sistema a falta de acuerdo inter partes.

También, el Reglamento de desarrollo de la Ley 20/1992, esto es, el Real Decreto 1434/1992, de 27 de noviembre, estableció una regulación más detallada de la remuneración compensatoria por copia privada precisando determinados aspectos como las reproducciones que no tenían la consideración de reproducciones para uso privado a efectos de la compensación (art. 10); los sujetos acreedores y deudores y los representantes de éstos (arts. 11-14); los conceptos de "equipos o aparatos" y 
"materiales" que determinaban la remuneración y la determinación de aquellos excluidos de la obligación de remuneración compensatoria (art. 15); el momento en el que nacía y era exigible la obligación de pago (art. 17), entre otros, en su mayor parte omitidos en el Real Decreto 287/1989, y, sin lugar a dudas, con una mejor sistemática. Además, el art. 21.1 del Real Decreto 1434/1992 estableció claramente el objeto principal del convenio entre los deudores y las correspondientes entidades de gestión colectiva de los derechos de los acreedores, salvando así las sombras que recaían sobre la cuestión con anterioridad ${ }^{714}$.

Pero, más allá de las mejoras alcanzadas en la regulación de la remuneración compensatoria por las normas de 1992, el sistema evidenció su crisis al no ser del agrado de los sujetos implicados. Por un lado, desde el sector de los deudores, se plantearon recursos contra el Real Decreto $1434 / 1992^{715}$. Por otro, también se alzaron las críticas de los acreedores, quienes advertían, sobre todo, de la aparición de importadores "de ocasión" que, luego de importar los equipos, desaparecían del tráfico mercantil, por lo que resultaba imposible que cumpliesen con la obligación legal de remuneración ${ }^{716}$. Además, se puso de relieve que el sistema de convenios, cuya aprobación debía adoptarse por unanimidad (art. 20.3 del Real Decreto 1434/1992) resultaba inoperativo, lo que traía como consecuencia la necesaria intervención mediadora y resolutoria del experto designado por el Ministerio de Cultura. Y, por último, tampoco quedó claramente establecido si los distribuidores, mayoristas y minoristas que habían adquirido los equipos y aparatos de reproducción de fabricantes españoles o a través de importación, debían responder solidariamente con los

\footnotetext{
${ }^{714}$ Este objeto fue "la determinación global e imputación individual entre los deudores del montante de la remuneración compensatoria devengada en el curso del año natural precedente al de negociación del convenio".

715 Por todos, el Recurso núm. 199/1993, interpuesto por la Asociación Nacional de Grandes Empresas de Distribución contra el R.D. 1434/1992, de 27 noviembre, de desarrollo de los artículos 24, 25 y 140 de la Ley 22/1987, de 11 noviembre, reguladora de la Propiedad Intelectual, en la versión dada a los mismos por la Ley 20/1992, de 7 julio. Este recurso quedó resuelto por la STS (Sala de lo ContenciosoAdministrativo, Sección Tercera), de 10 de febrero de 1997 (Roj: STS 820/1997) siendo desestimado, toda vez que el Alto Tribunal consideró que la norma impugnada era conforme a Derecho en los aspectos sometidos a revisión jurisdiccional en dicho proceso.

${ }^{716}$ Vid. DE FUENTES, J., “Un enfoque jurídico...”, op. cit., pp. 76-78, quien aborda estas cuestiones al tratar las críticas y crisis del sistema implantado mediante la Ley 20/1992.
} 
fabricantes e importadores del pago de la remuneración ${ }^{717}$. Todas estas cuestiones debían, por tanto, quedar resueltas en los futuros cambios legislativos.

En este contexto debe resaltarse la promulgación, dos años más tarde, del Real Decreto 325/1994, de 25 de febrero, por el que se modifica el artículo 15.2 del Real Decreto 1434/1992, de 27 de noviembre, de desarrollo de los artículos 24, 25 y 140 de la Ley 22/1987, de 11 de noviembre, de Propiedad Intelectual, en la versión dada a los mismos por la Ley 20/1992, de 7 de julio ${ }^{718}$. Esta norma se dictó con el único propósito de restringir los supuestos exentos del pago de la remuneración compensatoria previstos en el art. 15.2.c). $1^{\circ}$ y 15.2.d). $1^{\circ}$ del Real Decreto 1434/1992, para adecuarlos a las peculiaridades de uso o explotación que, para disfrutar de la exención de copia privada, exigía la Ley 20/1992, toda vez que la experiencia práctica había demostrado que determinados equipos o aparatos eran utilizados para realizar reproducciones para uso privado de obras y grabaciones audiovisuales. Así, en virtud del Real Decreto 325/1994, de 25 de febrero, se incluyeron en la obligación de pago de la compensación equitativa por copia privada las cintas de vídeo y los equipos y aparatos con paso igual a $12.7 \mathrm{~mm}$, rectificando el criterio antes empleado ${ }^{719}$.

\subsection{Nuevas reformas al sistema compensatorio: la Ley 43/1994, de 30 de diciembre y su incidencia en el art. 25 LPI}

La Ley 43/1994, de 30 de diciembre, de incorporación al Derecho español de la Directiva 92/100/CEE, de 19 de noviembre de 1992, sobre derechos de alquiler y préstamo y otros derechos afines a los derechos de autor en el ámbito de la propiedad intelectual $^{720}$, también incidió en la redacción del art. 25 de la LPI, en su versión tras la Ley 20/1992. En efecto, su Disposición adicional segunda modificó el art. 25 de la LPI, mejorando su sistemática, haciendo más viable la satisfacción de la remuneración por

717 Vid. Vallés Rodríguez, M., "Artículo 25”, en Bercovitz-Rodríguez-CANo, R. (Coord.), Comentarios a la Ley..., $1^{\mathrm{a}}$ ed., op. cit., p. 522.

${ }^{718}$ B.O.E. núm. 63, de 15 de marzo de 1994.

${ }^{719}$ CARBAJO CASCÓN, F., "La 'larga marcha' de la compensación...", op. cit. p. 57.

${ }^{720}$ B.O.E. núm. 313, de 31 de diciembre de 1994. 
copia privada e incorporando algunas novedades que contribuían, asimismo, a dilucidar cuestiones que no quedaban del todo claras bajo la redacción anterior del precepto ${ }^{721}$.

Pese a la similitud de la nueva redacción del art. 25.1 LPI (en la versión introducida por la Ley 43/1994) con la anterior, esta reforma supuso un cambio trascendente en la forma de determinación de la compensación equitativa por copia privada, así como en la regulación del procedimiento para recaudar dicha remuneración. Así, en cuanto al modo de determinación de la compensación equitativa se derogó el sistema de convenio y la mediación sustitutiva en el caso de que, transcurrido el plazo para la celebración del mismo, no se hubiere concluido con acuerdo ${ }^{722}$. Por lo que respecta al procedimiento, se configuró un sistema recaudatorio que constituiría la base del sistema de recaudación que se consolidará posteriormente en el TRLPI al establecer la competencia exclusiva de las entidades de gestión como receptoras de las declaraciones de los deudores y como fiscalizadoras de éstas. Asimismo, se estableció un sistema de autoliquidación de la compensación, obligando a los deudores y, en su caso, a sus responsables solidarios, a la presentación de la declaración-liquidación a las entidades de gestión según lo dispuesto en el art. 25. 12 y el art. 25.13 de la LPI, en su nueva redacción.

Debe señalarse que la inoperatividad del sistema de convenio ya había quedado constatada tras los intentos frustrados de alcanzar un acuerdo sobre la determinación de la cuantía entre todas las partes implicadas, esto es, por una parte, las entidades de gestión colectiva en representación de los acreedores de la remuneración y, por otra, los fabricantes e importadores de los equipos, aparatos y soportes materiales sujetos

\footnotetext{
${ }^{721}$ La reforma dio respuesta, por ejemplo, a la cuestión de si los distribuidores, mayoristas y minoristas adquirentes de los equipos y materiales de reproducción debían responder solidariamente del pago del canon con los fabricantes e importadores. Esta cuestión quedó resuelta en sentido positivo al precisarse el carácter solidario de la obligación, a menos que los fabricantes e importadores acreditasen haber satisfecho el canon a los deudores [art. 25.4.a), $2^{\circ}$ párrafo de la Ley 43/1994].

${ }^{722}$ Vid. Disposición Derogatoria Única de la Ley 43/1994, de 30 de diciembre que, entre otros preceptos, derogó los comprendidos en los capítulos II y III del Título II del Real Decreto 1434/1992, de 27 de noviembre, referidos a estas cuestiones.
} 
legalmente al pago de la misma ${ }^{723}$. Las Mesas de Negociación celebradas durante los años 1993, 1994 y 1995 así lo evidencian, pues lo más que pudo alcanzarse fueron acuerdos parciales ${ }^{724}$. En efecto, en la Mesa de Negociación de 1993, que debía ocuparse de la remuneración devengada en 1992, de conformidad con lo dispuesto en el art. 21.1 del Real Decreto 1434/1992, de 27 de noviembre ${ }^{725}$, y, más concretamente, de la remuneración devengada durante el segundo semestre, ya que la entrada en vigor de la Ley 20/1992 tuvo lugar el 15 de julio de ese año, sólo consiguió alcanzar dos acuerdos parciales, uno para los llamados bloques de fonogramas y demás soportes sonoros y videogramas y demás soportes visuales o audiovisuales, y otro para el llamado bloque de publicaciones en forma de libro o asimiladas ${ }^{726}$. De manera similar se comportó la Mesa de Negociaciones del año 1994, donde únicamente se logró acordar la vigencia de los acuerdos obtenidos en el año precedente y determinar la cuantía de la deuda global de la remuneración compensatoria en el bloque de publicaciones en forma de libro o asimiladas ${ }^{727}$. Y de igual modo sucedió con la Mesa de Negociación del año 1995, en la que únicamente se obtuvo un acuerdo parcial, suscrito por los deudores y acreedores de los bloques de fonogramas y demás soportes sonoros y videogramas y demás soportes visuales o audiovisuales ${ }^{728}$.

Asimismo, deben destacarse otras dos reformas de importancia. En primer lugar, la Ley 43/1994 otorgó por primera vez un carácter equitativo y único a la remuneración (la Ley se expresó entonces en términos de "remuneración equitativa y única"); y, por otro, se estableció, también por primera vez, el carácter irrenunciable de la

\footnotetext{
${ }^{723}$ Vid. MARTíNEZ LAGE, S., "El acuerdo ente las partes como instrumento primordial para hacer efectiva la remuneración por copia privada", en MINISTERIO DE CULTURA, La copia privada a examen ..., op. cit., pp. 107-108.

${ }^{724}$ En virtud del art. 34.2 en relación con el art. 20.3 del Real Decreto 1434/1992, de 27 de noviembre, los acuerdos parciales alcanzados por los presentes en las sesiones de negociación del convenio debían ser tenidos en especial consideración por el mediador a los efectos de dictar la resolución sustitutiva del convenio previsto en el art. 25.5 de la LPI, tras su modificación por la Ley 20/1992, de 7 de julio.

${ }^{725}$ El art. 21.1 del Real Decreto 1434/1992, de 27 de noviembre prevé: "Constituye objeto del convenio la determinación global e imputación individual entre los deudores del montante de la remuneración compensatoria devengada en el curso del año natural precedente al de negociación del convenio".

${ }^{726}$ Estos acuerdos fueron publicados, respectivamente, en el B.O.E. núm. 53, de 3 de marzo de 1993 y en el B.O.E. núm. 61, de 12 de marzo de 1993.

${ }^{727}$ Vid. B.O.E. núm. 77, de 31 de marzo de 1994.

${ }^{728}$ Vid. B.O.E. núm. 86, de 11 de abril de 1995.
} 
remuneración para autores y artistas intérpretes y ejecutantes. Ambas características de la remuneración subsisten en la actualidad.

El carácter equitativo de la remuneración resultó un elemento fundamental del sistema para evitar una desproporción o arbitrariedad en el establecimiento de la cuantía de dicha remuneración. La característica de única, por su parte, contribuyó a evitar conflictos en la gestión colectiva de la remuneración porque significó que sólo se establecía un importe y un pago por cada modalidad de reproducción (libros y publicaciones asimiladas, fonogramas y videogramas). Por el contrario, la irrenunciabilidad de la remuneración no fue acogida por la doctrina como un aspecto positivo, puesto que se entendía que la voluntad de ser compensado debía recaer en la esfera de decisión personal del titular de derechos de propiedad intelectual, pues sólo él se veía afectado por la copia privada. Sin embargo, parece ser que, hasta hoy, ha cobrado peso la voluntad del legislador de blindar la institución y su eficacia recaudatoria ${ }^{729}$.

Al mismo tiempo debe destacarse que es a partir de esta modificación legislativa cuando quedaron incorporadas en la propia LPI diferentes cuestiones relacionadas con el pago de la remuneración, antes establecidas reglamentariamente, entre ellas, el momento de pago (art. 25.11); su forma de liquidación (art. 25.12); los plazos para efectuar el mismo (art. 25.14) y la obligación de los fabricantes y distribuidores comerciales de hacer constar separadamente en las facturas el importe de la remuneración que sería repercutido a sus clientes y retendrían para su entrega (art. 25.16). Además, se añadió la medida cautelar de embargo ante el impago de la remuneración a los acreedores (art. 25.20) y se otorgó a las entidades de gestión colectiva el control de las operaciones sometidas a la remuneración (art. 25.21).

\footnotetext{
${ }^{729}$ PÉREZ GARCÍA, J., La industria electrónica ante el canon y la copia privada digital: solidaridad entre empresas, internautas y consumidores, Dykinson, Madrid, 2015, p. 63.
} 


\subsection{La aprobación del TRLPI: meros ajustes sistemáticos e insuficiencia regulatoria frente al escenario digital}

La Ley 27/1995, de 11 de octubre, de incorporación al Derecho español de la Directiva 93/98/CEE, del Consejo, de 29 de octubre, relativa a la armonización del plazo de protección del derecho de autor y de determinados derechos afines ${ }^{730}$ autorizó al Gobierno, mediante su Disposición Final segunda, para que, antes del 30 de junio de 1996, aprobara un texto que refundiese las disposiciones legales vigentes en materia de Propiedad Intelectual, regularizando, aclarando y armonizando los textos que hubieran de ser refundidos. Como consecuencia, se promulgó el Real Decreto Legislativo 1/1996, de 12 de abril, por el que se aprueba el texto refundido de la Ley de Propiedad Intelectual, regularizando, aclarando y armonizando las disposiciones legales vigentes sobre la materia (TRLPI) ${ }^{731}$.

En lo que a la regulación de la remuneración equitativa respecta, el TRLPI acogió el sistema compensatorio configurado por las normas anteriores de propiedad intelectual, esto es, la Ley 22/1987, la Ley 20/1992, el Real Decreto 1434/92 y la Ley 43/1994, incorporando una parte importante de sus disposiciones. De esta forma, pocas son las reformas que el nuevo texto introdujo. De hecho, el art. 25 de la LPI, permaneció prácticamente invariable, al ser el cambio sólo sistemático consistiendo en una mera alteración del número de apartados.

En consecuencia, el TRLPI -como texto refundido que es-, resultó ser-como las normas que refunde-, una regulación diseñada, sobre todo, para operar en un entorno analógico, a pesar de los avances tecnológicos experimentados ya entonces y de la aparición de nuevos medios y soportes de reproducción digitales disponibles en el mercado, que resultaban del todo propicios para la reproducción con fines privados de creaciones protegidas por la propiedad intelectual.

Esta situación hizo emerger la inevitable confrontación entre las sociedades de gestión, recaudadoras del canon, por un lado; y los deudores del mismo, por otro,

\footnotetext{
${ }^{730}$ B.O.E. núm. 245 , de 13 de octubre de 1995.

${ }^{731}$ B.O.E. núm. 97 , de 22 de abril de 1996.
} 
quienes se negaban a liquidarlo en soportes digitales como, por ejemplo, discos compactos. La razón que se esgrimía por los deudores del canon era que la regulación vigente resultaba inaplicable a dichos soportes. Esta cuestión fue resuelta, transitoriamente, mediante la adopción de un acuerdo, firmado el 30 de julio de $2003^{732}$, entre algunas de las entidades de gestión de derechos de propiedad intelectual españolas (AIE, AISGE, EGEDA, SGAE) y la Asociación Multisectorial de Empresas de Tecnologías de la Información, Comunicaciones y Electrónica (ASIMELEC) ${ }^{733}$, al que posteriormente se adhirieron otras entidades de gestión (AGEDI y DAMA) y prácticamente la totalidad del sector de empresas fabricantes o importadoras de materiales aptos para realizar copias privadas digitales. Se trató de un acuerdo privado, abierto a la adhesión de terceros, cuyo objeto principal fue establecer las tarifas a pagar por los soportes digitales de audio y vídeo (CD, DVD, etc.), incluidos los polivalentes (CD-Data y DVD-Data) ${ }^{734}$, idóneos para reproducir digitalmente obras y/o grabaciones audiovisuales y/o musicales, con una vigencia inicial de tres años prorrogables.

Lo anterior puso de manifiesto la necesidad de adecuar la regulación del TRLPI a los avances tecnológicos y, con ello, al entorno digital. Esta necesidad se vio acentuada, si cabe aún más, tras la promulgación de la DDASI en el año 2001, toda vez que esta Directiva venía a destacar la necesidad de diferenciar entre el entorno analógico y el entorno digital en la regulación de la compensación equitativa por copia privada.

Por ello, finalmente, la Ley 23/2006, de 7 de julio, modificó el TRLPI, con la finalidad, entre otras, de regular la realidad de la copia privada digital.

\footnotetext{
732 Moscoso del Prado Hernández, A. (Coord.), Practicum ..., op. cit., p. 290.

${ }^{733}$ Esta asociación estaba integrada por el $80 \%$ de los fabricantes de equipos, materiales y soportes digitales en ese momento.

${ }^{734}$ Cuando se habla de soportes DATA, se alude a soportes híbridos, es decir, que permiten la reproducción tanto de textos, como de imágenes y sonidos. La Ley 23/2006, de 7 de julio, por la que se modifica el texto refundido de la Ley de Propiedad Intelectual, aprobado por el Real Decreto Legislativo 1/1996, de 12 de abril (B.O.E. núm. 162, de 8 de julio de 2006), en su Disposición Transitoria única les llama "soportes de reproducción mixtos".
} 
2. La compensación equitativa por copia privada en el Derecho de la Unión Europea: su influencia en el Derecho interno

\subsection{La DDASI como respuesta a los retos de la "Sociedad de la Información" en la Propiedad Intelectual}

Hacia finales de la década de los años ochenta se hizo evidente la preocupación en el ámbito de la UE por dar respuesta a los desafíos que venía imponiendo la "sociedad de la información" en materia de propiedad intelectual $\mathrm{y}$, en particular, sobre el fenómeno incontrolado de la copia para uso privado. Al respecto, el Libro Verde de la Comisión Europea "Libro Verde sobre los derechos de autor y el desafío tecnológico: problemas de derechos de autor que requieren una acción inmediata", de 7 de junio de $1988^{735}$, reflejó las diferentes medidas prioritarias a adoptar en aquél contexto con respecto a la protección de los derechos de autor ante los nuevos medios de reproducción y, en especial, frente a las nuevas posibilidades de realización de copias de obras audiovisuales para uso personal. A su vez, destacó, entre otras cuestiones, las posiciones de los Estados miembros en relación con la legitimidad o ilegitimidad de tales copias.

Posteriormente, en el año 1995, el Libro Verde titulado "Los derechos de autor y los derechos afines en la Sociedad de la Información", presentado por la Comisión de las Comunidades Europeas en fecha 19 de julio de $1995^{736}$, señaló la necesidad de procurar la creación de un marco normativo coherente en el ámbito nacional, comunitario e internacional en relación con los derechos de autor y derechos afines, que diera respuesta a los retos de las nuevas tecnologías informáticas y de la comunicación; así como de valorar las oportunidades que ofrecía la tecnología digital para controlar las copias digitales -a diferencia de lo que sucedía en el entorno analógico-, lo cual

\footnotetext{
735 Comisión de las Comunidades Europeas, Libro Verde sobre los derechos de autor y el desafío tecnológico. Problemas de derechos de autor que requieren una acción inmediata [COM (88) 172 final], Bruselas, 7 junio 1988, pp. 99 y ss., versión en inglés disponible en: http://aei.pitt.edu/1209/1/COM_(88)_172 final.pdf (consultado: 17 de octubre de 2016).

${ }^{736}$ Comisión de las Comunidades Europeas, Libro Verde. Los derechos de autor y los derechos afines en la Sociedad de la Información [COM (95) 382 final], 1995, pp. 49-52.
} 
resultaba trascendente para determinar el marco legal de protección de las creaciones intelectuales ante este nuevo panorama.

En aquel contexto era evidente que debían reevaluarse las excepciones y limitaciones a los derechos de propiedad intelectual en el escenario europeo, pues, ya se preveía que la implementación desigual de excepciones y limitaciones a los derechos de autor y afines en los distintos Estados miembros incidiría en el funcionamiento del mercado interior y en la circulación de los bienes culturales; diferencias que podían acentuarse en la medida que avanzara la explotación transfronteriza de las obras. A su vez, dentro de la armonización de estas limitaciones, se vislumbraba la importancia de alcanzar un determinado grado de uniformidad respecto de la copia para uso privado.

Estos antecedentes sirvieron de base para que, en fecha de 22 de mayo de 2001, el Parlamento Europeo y el Consejo dictaran la Directiva 2001/29/CE, relativa a la armonización de determinados aspectos de los derechos de autor y derechos afines a los derechos de autor en la sociedad de la información (DDASI). La DDASI constituyó una respuesta fundamental a los retos impuestos por la sociedad de la información para los derechos de autor y derechos conexos en el escenario europeo. Sin embargo, lamentablemente, no consiguió la armonización pretendida, pues las dificultades de conciliación de las diferentes tradiciones jurídicas y posiciones de los Estados miembros imposibilitaron un mayor grado de armonización ${ }^{737}$.

No obstante, al menos en forma de mínimos, se lograron imponer ciertas obligaciones a los Estados miembros, entre ellas, la obligación de compensar a los titulares de derechos por la copia privada, aunque sólo en el supuesto de que el Estado miembro optase por incluir en su legislación el límite de copia privada.

En concreto, el art. 5.2 de la DDASI señala:

"Los Estados miembros podrán establecer excepciones o limitaciones al derecho de reproducción contemplado en el artículo 2 en los siguientes casos: [...] b) en

\footnotetext{
${ }^{737}$ Pierre SIRINELLI pone de relieve las dudas sobre el alcance armonizador que alcanzaría la Directiva en materia de excepciones y limitaciones a los derechos de autor y los derechos conexos. Vid. SIRINELLI, P., Taller sobre cuestiones de aplicación del Tratado de la OMPI..., op. cit., p. 29. Véase también, epígrafe 4.1.2 del Capítulo 2 de esta tesis.
} 
relación con reproducciones en cualquier soporte efectuadas por una persona física para uso privado y sin fines directa o indirectamente comerciales, siempre que los titulares de los derechos reciban una compensación equitativa, teniendo en cuenta si se aplican o no a la obra o prestación de que se trate las medidas tecnológicas contempladas en el artículo 6".

Por tanto, aun cuando de la lectura de los Considerandos $35^{\circ}, 36^{\circ}$ y $38^{\circ}$ de la DDASI $^{738}$ pareciera -en una primera aproximación- que el legislador nacional tendría la oportunidad de decidir sobre la introducción o no de sistemas compensatorios en los ordenamientos internos respecto de los límites al derecho de reproducción, el art. 5.2.b) de la DDASI no dejó lugar a dudas de que la facultad de los Estados miembros de autorizar la copia privada quedaba supeditada al hecho de que los titulares de derechos de autor y derechos afines recibieran una compensación equitativa. Consecuentemente, esta compensación se forjó en el ámbito de la UE como una obligación legal y un presupuesto necesario para autorizar la copia privada, salvo en el caso de aquellas situaciones en las que el perjuicio causado al titular del derecho resulte mínimo, en cuyo caso no existe obligación de pago ${ }^{739}$.

738 “(35) En determinados casos de excepciones o limitaciones, los titulares de los derechos deberían recibir una compensación equitativa para recompensarles adecuadamente por el uso que se haya hecho de sus obras o prestaciones protegidas. A la hora de determinar la forma, las modalidades y la posible cuantía de esa compensación equitativa, deben tenerse en cuenta las circunstancias de cada caso concreto. Un criterio útil para evaluar estas circunstancias sería el posible daño que el acto en cuestión haya causado a los titulares de los derechos. Cuando los titulares de los derechos ya hayan recibido una retribución de algún tipo, por ejemplo, como parte de un canon de licencia, puede ocurrir que no haya que efectuar un pago específico o por separado. El nivel de compensación equitativa deberá determinarse teniendo debidamente en cuenta el grado de utilización de las medidas tecnológicas de protección contempladas en la presente Directiva. Determinadas situaciones en las que el perjuicio causado al titular del derecho haya sido mínimo no pueden dar origen a una obligación de pago".

“(36) Los Estados miembros pueden prever una compensación equitativa a los titulares de los derechos también cuando apliquen las disposiciones facultativas relativas a las excepciones o limitaciones que no requieren dicha compensación".

“(38) Debe facultarse a los Estados miembros para que establezcan una excepción o limitación al derecho de reproducción en relación con determinados tipos de reproducción de material sonoro, visual y audiovisual para uso privado, mediante una compensación equitativa. Ello puede suponer la introducción o el mantenimiento de los sistemas de retribución para compensar a los titulares de los derechos por los perjuicios sufridos. Aunque las diferencias existentes entre tales sistemas de retribución afecten al funcionamiento del mercado interior, en lo que respecta a la reproducción privada analógica, dichas diferencias no deben tener efectos significativos en el desarrollo de la sociedad de la información. La copia privada digital puede propagarse mucho más y tener mayor impacto económico. Por consiguiente, deben tenerse debidamente en cuenta las diferencias entre la copia privada digital y la analógica, y debe establecerse entre ellas una distinción en determinados aspectos".

${ }^{739}$ Vid. Considerando $35^{\circ}$ de la DDASI. 
Pues bien, con la introducción de la compensación equitativa por copia privada en la DDASI, esta figura pasó a integrar el acquis comunitario. Se echa en falta, eso sí, su definición legal, ya que la norma no proporcionó un concepto de ésta, siendo la doctrina y la jurisprudencia, especialmente del TJUE, las que han perfilado sus contornos, como se analizará posteriormente ${ }^{740}$.

Como consecuencia de la parquedad de la regulación y de la falta de imposición de unos criterios uniformes en la determinación de la compensación equitativa por copia privada por la UE, tanto las modalidades de financiación y de percepción, como la cuantía de la compensación equitativa varían de un Estado miembro a otro. Apenas asoman en el Considerando $35^{\circ}$ de la DDASI algunos criterios orientativos a fin de regular la materia, a saber: la vinculación de la compensación a las circunstancias de cada caso concreto; la vinculación de la compensación con el posible daño causado a los titulares; la no conveniencia de acumular compensaciones; y la necesaria adaptación del nivel de compensación equitativa al grado de utilización de las medidas tecnológicas de protección $^{741}$.

El primero de los criterios, esto es, la vinculación de la compensación a las circunstancias de cada caso concreto, parece referirse a las condiciones imperantes en un mercado determinado de equipos, aparatos y soportes de reproducción, diferenciando los ámbitos de actuación (reprografía, copia analógica de audio o vídeo, copia digital). El criterio del daño o perjuicio causado a los derechohabientes implica tomar en consideración la vinculación entre el daño sufrido y la compensación equitativa. Por su parte, el hecho de valorar la procedencia del pago de una compensación cuando los titulares de derechos de autor ya hayan recibido una retribución de algún tipo, evita el pago de una doble compensación resultante de acumular la compensación por copia privada con la retribución derivada de contratos de licencia. Por último, la necesaria adaptación del nivel de compensación equitativa al grado de utilización de las medidas tecnológicas de protección es un modo de conciliar el uso de estas medidas con la

\footnotetext{
${ }^{740}$ Vid. infra Capítulo 5, epígrafe II, apartado 1.

741 Garrote FERnÁnDEZ-DíEZ, I., "Artículo 25”, en BERCOVITZ RodríGuez-CANO, R. (Coord.), Comentarios a la Ley..., $3^{\mathrm{a}}$ ed., p. 460.
} 
determinación de la forma, las modalidades y la cuantía de la compensación equitativa $^{742}$.

\subsection{La Ley 23/2006, de 7 de julio: norma de transposición de la DDASI al Derecho interno}

Con la promulgación de la Ley 23/2006, de 7 de julio, por la que se modifica el texto refundido de la Ley de Propiedad Intelectual, aprobado por el Real Decreto Legislativo 1/1996, de 12 de abril, se produjo la transposición de la DDASI al Derecho interno. No obstante, el régimen anterior no varió significativamente con su entrada en vigor, manteniéndose el principio fundamental del sistema compensatorio, basado en un canon sobre los equipos, aparatos y soportes materiales idóneos para la copia privada.

En todo caso, la Ley 23/2006 no sólo armonizó la legislación española con el Derecho de la UE sino que, al mismo tiempo, introdujo algunos cambios necesarios, dada la urgencia de adecuar el TRLPI al escenario digital.

En primer lugar, debe destacarse que la Ley 23/2006 sustituyó la expresión anterior de "remuneración equitativa" por "compensación equitativa"; una modificación que, puede decirse, buscaba resaltar la idea de que las cantidades percibidas por los beneficiarios de la compensación se dirigían a "sustituir los ingresos realmente dejados de percibir por la confección de copias privadas" ${ }^{743}$. Este cambio de terminología posiblemente obedeció a la intención del legislador español de transponer lo más fielmente posible el tenor de la DDASI, pues esta norma se refiere a "compensación equitativa" y no utiliza el término "remuneración". En este sentido, el Consejo de Estado se pronunció a favor de la sustitución de la expresión ${ }^{744}$, en su Dictamen de 10

\footnotetext{
742 Para ampliar. Ibídem, pp. 460-465. Véase también en esta tesis, Capítulo 3, epígrafe VI, apartado 4.

743 Bercovitz Rodríguez-CANo, R.; Garrote FernándeZ-Díez, I., GonzÁlez Gonzalo, A. y SÁNCHEZ ARISTI, R., Las reformas de la Ley de Propiedad..., op. cit., p. 138.

${ }^{744}$ GonZÁlez de Alaiza CARdonA, J. J., La copia privada. Sus fundamentos ..., op. cit., p. 325.
} 
de marzo de 2005 al Anteproyecto de la Ley 23/2006 ${ }^{745}$ al señalar el significado diferente de ambas expresiones:

"Ciertamente, desde el punto de vista jurídico, la noción de 'compensación' es distinta del concepto de 'remuneración'. En efecto, la remuneración es el pago por una contraprestación o adquisición de un derecho, mientras que la compensación es el restablecimiento de un desequilibrio patrimonial objetivamente causado por la conducta de un tercero" $" 746$.

También, como novedad, se reconoció por primera vez de forma expresa en el TRLPI, con la modificación introducida por la Ley 23/2006, la existencia del límite de copia privada en equipos, aparatos y soportes materiales digitales. Ello representó un claro avance en la regulación, puesto que permitió eliminar por completo las dudas existentes sobre la legalidad del cobro del canon más allá de los dispositivos analógicos de reproducción ${ }^{747}$.

Además, con la modificación, se actualizaron los importes de la compensación aplicable a los equipos y soportes de reproducción analógica previstos en el art. 25.5 del

\footnotetext{
${ }^{745}$ Consejo de Estado, Dictamen núm. 187/2005: Expediente de Anteproyecto de Ley por la que se modifica el texto refundido de la Ley de Propiedad Intelectual, aprobado por Real Decreto Legislativo 1/1996 de 12 de abril, 10 de marzo de 2005, disponible en: https://www.boe.es/buscar/doc.php?id=CE-D2005-187 (consultado: 17.11.2016).

${ }^{746}$ Ha señalado igualmente que el término "compensación" exige la comprobación real del daño causado, MARÍN LÓPEZ, J. J., "La copia privada frente a las medidas...,", op. cit., p. 35.

${ }^{747}$ Si bien la Ley 23/2006 eliminó las dudas sobre este particular, hay que decir que los tribunales ya admitieron la procedencia del cobro del canon compensatorio sobre soportes digitales en reclamaciones referidas a momentos previos a su entrada en vigor. Un ejemplo es la sentencia recaída en el conocido caso "Traxdata", en el que se declaró que los CDs regrabables estaban sujetos al pago de una remuneración compensatoria por copia privada (Sentencia del Juzgado de Primera Instancia núm. 22 de Barcelona, de 2 de enero de 2002, F.J. 2º, (Roj: SJPI 2/2002). En sentido similar, la SAP Alicante (Sección 8a), de 17 de julio de 2008 (Roj: SAP A 3307/2008), declara: “[...] entendemos que el sistema anterior es de aplicación a los soportes digitales comercializados con anterioridad a la reforma ya que la disposición final segunda de la Ley 23/2006 viene a establecer que es a partir de la entrada en vigor de la reforma, que el apartado 5 del artículo 25 sólo es de aplicación a materiales analógicos lo que implica que con anterioridad a la reforma, era de aplicación, sin distinción, tanto a los medios analógicos como a los digitales" (F.J. $8^{\circ}$ ). Incluso, otro argumento a tomar en consideración es que, siendo la Directiva del año 2001, al no haberse practicado su incorporación efectiva al ordenamiento interno hasta el año 2006, los órganos jurisdiccionales españoles -como del resto de los Estados miembros- tenían la obligación de promover un resultado lo más cercano posible al pretendido por la norma comunitaria como resultado de la doctrina de la "interpretación conforme" establecida por el Tribunal de Justicia de las Comunidades Europeas. De hecho, el órgano jurisdiccional nacional debe proteger con preferencia las facultades que el Derecho de la Unión Europea conceda a los particulares, así como abstenerse de aplicar, en su caso, cualquier disposición que en su aplicación conduzca, en las circunstancias del litigio, a un resultado contrario al Derecho de la Unión".
} 
TRLPI. En cambio, respecto de la copia privada digital, se introdujo en el art. 25.6 del TRLPI un procedimiento a fin de determinar periódicamente los equipos, materiales y soportes gravados, así como el importe de la compensación a satisfacer por cada deudor, aprobado conjuntamente por los Ministerios de Cultura y de Industria, Turismo y Comercio.

En concreto, con carácter bienal, los citados Ministerios tenían que publicar en el Boletín Oficial del Estado y comunicar a las entidades de gestión de derechos de propiedad intelectual y a las asociaciones sectoriales identificadas por el Ministerio de Industria, Turismo y Comercio, que representaran mayoritariamente a los deudores, el inicio del procedimiento para la determinación de los equipos, aparatos y soportes materiales sujetos al pago de la compensación equitativa por copia privada, así como para la determinación, en su caso, de las cantidades que los deudores debían abonar por este concepto a los acreedores. Transcurrido el plazo de cuatro meses desde la citada publicación, las partes interesadas referidas en ella, tenían que comunicar a los mencionados Ministerios los acuerdos adoptados, o en su defecto, la falta de tales acuerdos. Posteriormente, los Ministerios de Cultura y de Industria, Turismo y Comercio, en el plazo de tres meses, contado desde la comunicación o el agotamiento del plazo dado a las partes para negociar, debían establecer, mediante Orden conjunta, la relación de equipos, aparatos y soportes materiales, las cantidades aplicables a cada uno de ellos y, en su caso, la distribución entre las diferentes modalidades de reproducción (libros y publicaciones asimiladas, fonogramas y demás soportes sonoros y videogramas y demás soportes visuales o audiovisuales), previa consulta al Consejo de Consumidores y Usuarios y previo informe del Ministerio de Economía y Hacienda.

Asimismo, se adoptó la solución transitoria de elaborar, con carácter provisional, un listado de equipos, aparatos y soportes materiales digitales sujetos a la compensación equitativa $^{748}$, que estaría vigente hasta el momento en que tuviera lugar la aprobación de la mencionada Orden ministerial (Disposición Transitoria Única de la Ley 23/2006). En

\footnotetext{
${ }^{748}$ En el mencionado listado se recogían, entre otros, soportes materiales digitales específicamente destinados a la reproducción sonora y a la reproducción visual o audiovisual: discos o minidiscos compactos para audio y video, discos compactos de reproducción mixta, sonora y visual, entre otros.
} 
su elaboración se debían tener en cuenta, lógicamente, los criterios establecidos en el art. 25.6.4 $4^{\circ}$ del modificado TRLPI.

La Ley 23/2006 también incidió en el concepto de deudor de la compensación equitativa por copia privada. En este sentido, al referirse el art. 25.4.a) del TRLPI modificado a los fabricantes en España como deudores del canon, introdujo la cláusula "en tanto actúen como distribuidores comerciales". Ello constituyó un aspecto positivo de la reforma, por cuanto, bajo la vigencia del texto anterior, todo fabricante en España de equipos, aparatos y soportes aptos para la reproducción de libros o publicaciones asimiladas, fonogramas, videogramas u otros soportes sonoros, visuales y audiovisuales debía abonar el canon, mientras que, a partir de la reforma, sólo lo pagaría aquel que actuara como distribuidor comercial, evitando así que los fabricantes españoles que no actuaran como tales se constituyeran en deudores de la compensación y, por tanto, que tuvieran que acudir al mercado internacional con precios menos competitivos que los de otros fabricantes, a los cuales, probablemente, sus legislaciones no les exigieran el desembolso de un canon.

A su vez, la nueva redacción del TRLPI también limitó la posibilidad del Gobierno de establecer excepciones al pago de la compensación equitativa por copia privada. Ello se explica dado que, la antigua redacción del art. 25.23 del TRLPI había habilitado al Gobierno para establecer reglamentariamente los equipos, aparatos y materiales exceptuados del pago de la compensación, atendiendo a la peculiaridad del uso o explotación a la que se destinaran, así como a las exigencias que pudieran derivarse de la evolución tecnológica y el correspondiente sector de mercado. Sin embargo, al amparo del art. 25.7.d) del TRLPI, modificado por la Ley 23/2006, el Gobierno únicamente estaba facultado para establecer excepciones al pago de la compensación equitativa en los casos en que quedara suficientemente acreditado que el destino o uso final de los equipos, aparatos o soportes materiales no fuera la reproducción para uso privado.

Otra cuestión de obligada referencia resulta la introducción en el TRLPI de la regulación de las medidas tecnológicas de protección como límite al alcance de la compensación equitativa (art. 161), con la finalidad de que los titulares de derechos 
sobre obras o prestaciones protegidas con medidas tecnológicas eficaces facilitaran a los beneficiarios de ciertos límites los medios adecuados para disfrutar de ellos.

Además, con la reforma, el art. 25.24 del TRLPI contempló la obligación de las entidades de gestión de "comunicar al Ministerio de Cultura los criterios detallados de distribución entre sus miembros de las cantidades recaudadas en concepto de compensación por copia privada".

\subsection{La Orden PRE/1743/2008, de 18 de junio}

Como resultado del procedimiento previsto en el art. 25.6 del TRLPI, tras la reforma introducida por la Ley 23/2006, a falta de acuerdo entre las entidades de gestión colectiva de derechos de propiedad intelectual y las asociaciones sectoriales representantes de los deudores del canon, fue promulgada la Orden PRE/1743/2008, de 18 de junio, por la que se estableció la relación de equipos, aparatos y soportes materiales sujetos al pago de la compensación equitativa por copia privada, las cantidades aplicables a cada uno de ellos y la distribución entre las diferentes modalidades de reproducción ${ }^{749}$. Esta Orden entró en vigor el 20 de junio de 2008 (un día después de su publicación).

Con su aprobación, el régimen compensatorio previsto en la Disposición Transitoria única de la Ley 23/2006 quedó sustituido por el régimen establecido en la mencionada Orden, que disponía, con mayor claridad, los equipos, aparatos y soportes de reproducción digitales sujetos a la compensación equitativa por copia privada, las cuantías o tarifas aplicables, así como los criterios de reparto o distribución de lo recaudado entre los titulares de derechos de propiedad intelectual.

En cuanto al momento en que la Orden produciría sus efectos jurídicos, el apartado tercero de la Disposición Transitoria única de la Ley 23/2006 señalaba que la primera Orden ministerial que se dictase en aplicación de lo previsto en el art. 25.6 del TRLPI tendría efectos a contar desde la fecha de entrada en vigor de la Ley 23/2006.

${ }^{749}$ B.O.E. núm. 148 , de 19 de junio de 2008. 
Ello suponía, por tanto, la aplicación retroactiva de las disposiciones contenidas en la Orden.

Las consecuencias de esta disposición podían ser muy perjudiciales. En primer lugar, se podían generar reclamaciones judiciales en el caso de que las tarifas establecidas en la Orden fueran inferiores a las que se hubieran estado cobrando a tenor del régimen transitorio establecido en la Ley 23/2006, obligando a las entidades de gestión colectiva de los derechos de propiedad intelectual a devolver lo cobrado en exceso. En segundo lugar, podían surgir conflictos por el hecho de introducir en la lista de dispositivos gravados, equipos, aparatos o soportes de reproducción digitales distintos a los previstos en la referida Disposición Transitoria única de la Ley 23/2006, pues ello podía conllevar la devolución o la exigencia del pago, según el caso, de las cantidades cobradas o impagadas, según los dispositivos de reproducción que contuviera la misma ${ }^{750}$.

Ello explica que la Disposición Final única de la Orden ministerial se redactase en los términos siguientes:

"Se aplicará para la relación de equipos, aparatos y soportes materiales de reproducción digitales establecidos en la disposición transitoria única de la Ley 23/2006, de 7 de julio, en el período comprendido entre la entrada en vigor de la citada ley y el 30 de junio de 2008 las cuantías previstas en esa misma Ley. A partir del 1 de julio de 2008 se aplicará la relación de equipos, aparatos y soportes materiales de reproducción digitales, así como las cuantías de compensación establecidas en el apartado primero de esta Orden y la distribución de las mismas previstas en el apartado segundo, hasta, en su caso, la publicación de la Orden de revisión a la que se refiere el punto segundo del apartado tercero, que tendrá una vigencia de un año".

Con ello, las nuevas tarifas a aplicar, de acuerdo con la relación de equipos, materiales y soportes de reproducción digitales contenidos en la Orden PRE/1743/2008, de 18 de junio, así como la distribución de lo recaudado entre los derechohabientes, en función de las distintas modalidades de reproducción, comenzaron a regir a partir del 1

\footnotetext{
${ }^{750}$ En este sentido, CARBAJO CASCÓn, F., “Consideraciones sobre la nulidad de la Orden PRE/1743/2008, de 18 de junio, de reglamentación del canon digital (Sentencias de la Audiencia Nacional, Sala Tercera de lo Contencioso-Administrativo, de 22 de marzo de 2011)", Pe. I., Revista de Propiedad Intelectual, núm. 39, 2011, pp. 120-121.
} 
de julio de 2008 y estarían vigentes (a tenor de lo dispuesto en el punto segundo del apartado tercero de la propia Orden) hasta que se produjera su revisión o modificación. Sin embargo, a falta de ésta, la Orden PRE/1743/2008 prorrogó automáticamente su vigencia, siguiendo lo dispuesto en el párrafo tercero de su Disposición Final única.

Así pues, la Orden estuvo vigente hasta que fue declarada nula de pleno derecho el 22 de marzo de 2011 por la Sala de lo Contencioso-Administrativo de la Audiencia Nacional mediante sentencias, dictadas en respuesta a los recursos promovidos por MOTOROLA ESPAÑA, S.A. ${ }^{751}$, NOKIA SPAIN SAU ${ }^{752}$, SONY ERICSSON MOBILE COMMUNICATIONS IBERIA, S.L. ${ }^{753}$, AETIC $^{754}$, ASIMELEC ${ }^{755}$ y AI $^{756}$.

Con idénticos argumentos, estas sentencias fundamentaron la nulidad de la Orden basándose en defectos de forma no convalidables ${ }^{757}$. Al respecto, partiendo de la consideración de la Orden como Reglamento, la misma debía satisfacer las exigencias de forma previstas para la elaboración de las disposiciones reglamentarias, lo que implicaba respetar el procedimiento establecido en los arts. 22 a 26 de la Ley 50/1997, de 27 de noviembre, del Gobierno ${ }^{758}$. Así pues, en concreto, la Sala apreció la omisión del Dictamen del Consejo de Estado (art. 24.2 de la Ley 50/1997 y art. 22.3 de la Ley Orgánica 3/1980, de 22 de abril, del Consejo de Estado ${ }^{759}$ ) y de las memorias justificativa y económica inherentes a todo reglamento [art. 24.1.a) Ley 50/1997], que -según declaró- no podían ser exceptuadas del procedimiento de elaboración de la Orden. Ello, aunque el art. 25.6, regla $3^{\text {a }}$ del TRLPI contemplara únicamente los

\footnotetext{
${ }^{751}$ SAN (Sala de lo Contencioso-Administrativo, Sección Tercera), de 22 de marzo de 2011, Recurso contencioso-administrativo 755/2008 (JUR\2011194695).

${ }^{752}$ SAN (Sala de lo Contencioso-Administrativo, Sección Tercera), de 22 de marzo de 2011, Recurso contencioso-administrativo 731/2008 (JUR\2011\94694).

${ }^{753}$ SAN (Sala de lo Contencioso-Administrativo, Sección Tercera), de 22 de marzo de 2011, Recurso contencioso-administrativo 766/2008 (JUR\2011194696).

${ }^{754}$ SAN (Sala de lo Contencioso-Administrativo, Sección Tercera), de 22 de marzo de 2011, Recurso contencioso-administrativo 769/2008 (JUR\2011\94692).

755 SAN (Sala de lo Contencioso-Administrativo, Sección Tercera), de 22 de marzo de 2011, Recurso contencioso-administrativo 774/2008 (JUR\2011\94693).

756 SAN (Sala de lo Contencioso-Administrativo, Sección Tercera), de 22 de marzo de 2011, Recurso contencioso-administrativo 704/2008 (JT\2011\202).

${ }^{757}$ Para ampliar sobre los pronunciamientos de estas sentencias y sus consecuencias vid. CARBAJO CASCÓN, F., "Consideraciones sobre la nulidad...”, op. cit., pp. 122 y ss.

${ }^{758}$ B.O.E. núm. 285 , de 28 de noviembre de 1997.

${ }^{759}$ B.O.E. núm. 100, de 25 de abril de 1980.
} 
trámites relativos a la previa consulta del Consejo de Consumidores y Usuarios y al previo informe del Ministerio de Economía y Hacienda. La Sala también dispuso que, debiendo ser congruente con el petitum de la demanda de conformidad con el principio de congruencia procesal, no podía acceder a aquellas peticiones que fueran más allá de declarar la nulidad de la Orden. En concreto, no podía pronunciarse sobre las pretensiones planteadas por ASIMELC y AI, respecto del alcance retroactivo de la nulidad de la Orden impugnada a toda recaudación realizada abusivamente y al cese del cobro indiscriminado de la compensación equitativa, toda vez que ello desbordaba el ámbito de la jurisdicción contencioso-administrativa, dada la naturaleza jurídico-privada de la compensación equitativa por copia privada ${ }^{760}$.

La nulidad de la Orden PRE/1743/2008 hizo necesario analizar cuál debía ser el régimen aplicable a partir de ese momento a la compensación equitativa por copia privada digital ${ }^{761}$. Así pues, a pesar de las diferentes posturas existentes en función de

\footnotetext{
${ }^{760}$ Vid. CARBAJO CASCÓn, F., “Consideraciones sobre la nulidad...”, op. cit., p. 131.

${ }^{761}$ Cuestión distinta sería la incidencia de la declaración de nulidad de la Orden PRE/1743/2008 sobre las cantidades satisfechas de acuerdo con sus disposiciones, análisis que excede el objeto de este epígrafe, sin perjuicio de lo cual no puede menos que decirse que se encuentran en la jurisprudencia pronunciamientos que desestiman la pretensión de dejar sin efecto las compensaciones abonadas en aplicación de la Orden PRE/1743/2008. El fundamento radica en que, en virtud de lo previsto en el art. 73 de la Ley 29/1998, de 13 de julio, reguladora de la Jurisdicción Contencioso Administrativa (B.O.E. núm. 167, de 14 de julio de 1998), las sentencias firmes que anulen un precepto de una disposición general -como es el caso de la Orden- no afectarán por sí mismas a la eficacia de las sentencias o actos administrativos firmes que lo hayan aplicado antes de que la anulación alcanzara efectos generales, salvo en el caso de que la anulación del precepto supusiera la exclusión o la reducción de las sanciones aún no ejecutadas completamente. Consecuentemente, se ha sostenido que, del mismo modo que el art. 73 de la Ley 29/1998 impide la revisión de actos que han adquirido firmeza, no es posible dejar sin efecto las compensaciones abonadas en aplicación de la Orden. Así lo ha entendido el Tribunal Supremo en las sentencias en que ha declarado la pérdida sobrevenida de objeto del recurso de casación contra las sentencias de la Audiencia Nacional, Sala de lo Contencioso-Administrativo, de 22 de marzo de 2011, que declaraban la nulidad de la Orden PRE 1743/2008. En los recursos de casación interpuestos frente a estas últimas resoluciones, las partes se opusieron al sobreseimiento, tras la entrada en vigor de la disposición adicional décima del Real Decreto Ley 20/2011, de 30 de diciembre, defendiendo la pervivencia del interés del recurso por su incidencia en las reclamaciones "interpuestas o pendientes de interponer". Sin embargo, el Tribunal Supremo concluyó que, de confirmarse la nulidad de la Orden, lejos de tener efectos retroactivos, no afectaría por sí misma a la eficacia de las sentencias o actos administrativos firmes que hubieran aplicado la misma antes de su derogación por la Disposición Adicional Décima del Real Decreto Ley 20/2011, ya que la Orden se elaboró en desarrollo del art. 25.6 del TRLPI (2006) y reguló las cantidades aplicables a los equipos, aparatos y soportes sujetos a compensación equitativa por copia privada, disciplinando, con ello, relaciones entre personas físicas y entidades de gestión de derechos -no Administraciones Públicas-. Todo ello ha llevado a interpretar, en definitiva, que la ausencia de efectos retroactivos de la sentencia de nulidad de la Orden alcanza a las liquidaciones practicadas en su aplicación [Vid. SAP Barcelona
} 
los distintos intereses afectados, esto es, de las asociaciones de consumidores, de las asociaciones de fabricantes y distribuidores de dispositivos de reproducción, o de las entidades de gestión, en su caso, respecto a la procedencia del cobro del canon y las tarifas a aplicar, lo cierto es que la nulidad de la Orden debía tener efectos ex tunc, con lo cual, habría que retrotraer sus efectos al momento de su entrada en vigor, esto es, a 1 de julio de 2008 .

En consecuencia, cobró nuevamente vigencia el régimen provisional previsto en la Disposición Transitoria única de la Ley 23/2006 y, con éste, la sujeción de los equipos, aparatos y soportes de reproducción a lo dispuesto en aquélla ${ }^{762}$, hasta tanto fuera dictada una nueva Orden ministerial o hasta que se modificara el TRLPI, como de hecho, aconteció, con la promulgación del Real Decreto-Ley 20/2011, de 30 de diciembre, de medidas urgentes en materia presupuestaria, tributaria y financiera para la corrección del déficit público ${ }^{763}$. Éste último estableció, en su Disposición Adicional décima, la supresión del sistema de pago de la compensación equitativa por copia privada mediante el sistema de canon compensatorio, siendo sustituido por un nuevo régimen, con cargo a los PGE, como se analizará seguidamente.

Es importante señalar, no obstante, que, frente a las sentencias dictadas por la Sala de lo Contencioso-Administrativo de la Audiencia Nacional, que dieron lugar a la nulidad de la Orden PRE 1743/2008, de 18 de junio, se alzaron las entidades que habían comparecido como codemandadas en los recursos contencioso-administrativos interpuestos frente a aquélla (AIE, SGAE, AISGE, EGEDA y AGEDI), así como la Abogacía del Estado. Sin embargo, ningunos efectos sobre la nulidad ya decretada de la Orden tuvieron las respectivas sentencias dictadas por el Tribunal Supremo (Sala de lo Contencioso-Administrativo, Sección 4a). En efecto, el Alto Tribunal declaró la pérdida sobrevenida del objeto del recurso, puesto que la compensación equitativa por copia

(Sección 15ª) núm. 178/2014, de 21 mayo (JUR\2014\179317), F.J. 6º y SAP Guadalajara (Sección 1ª), de 4 enero de 2016 (JUR\2016132147), F.J. $3^{\circ}$, que se hace eco de la anterior sentencia mencionada].

${ }^{762}$ Criterio compartido por CARBAJO CASCÓN, F., “Consideraciones sobre la nulidad...”, op. cit., p. 132.

${ }^{763}$ B.O.E. núm. 315 , de 31 de diciembre de 2011. 
privada que la Orden ministerial desarrollaba ya había sido suprimida por la Disposición Adicional Décima del Real Decreto-Ley 20/2011, de 30 de diciembre ${ }^{764}$.

\section{La financiación de la compensación con cargo a los Presupuestos Generales del Estado}

\subsection{Instrumentación legal}

Son distintas las circunstancias que impulsaron la creación de un nuevo diseño para la financiación de la compensación equitativa por copia privada.

En primer lugar, cobran especial relevancia la sentencia del TJUE (Sala Tercera) de 21 de octubre de 2010 (caso Padawam) ${ }^{765}$ y la SAP Barcelona (Sección 15 ), de 2 marzo de $2011^{766}$, dictada en relación con la anterior resolviendo el recurso que dio lugar a las cuestiones prejudiciales formuladas al TJUE en dicho asunto. Los pronunciamientos de aquella revelaron la contrariedad con el Derecho de la UE de un sistema de compensación por copia privada como el español en el cual la compensación se cobraba indiscriminadamente, es decir, sin distinguir aquellos casos en que presumiblemente pudiera inferirse que los equipos, aparatos y soportes de reproducción iban a ser destinados a la copia privada, de aquellos otros casos en que se usaban para

\footnotetext{
${ }^{764}$ STS (Sala de lo Contencioso-Administrativo, Sección 4a ), de 27 de noviembre de 2012 (RJ/2013\431), en relación con la sentencia del recurso contencioso-administrativo núm. 755/2008; STS (Sala de lo Contencioso-Administrativo, Sección 4a), de 10 de enero de 2014 (RJ/2014/568), en relación con la sentencia del recurso contencioso-administrativo núm. 731/2008; STS (Sala de lo ContenciosoAdministrativo, Sección 4a), de 13 de noviembre de 2012 (RJ/2013\152), en relación con el recurso contencioso-administrativo núm. 766/2008; STS (Sala de lo Contencioso-Administrativo, Sección 4a), de 13 de noviembre de 2012 (RJ\2013\153), en relación con el recurso contencioso-administrativo núm. 769/2008; STS (Sala de lo Contencioso-Administrativo, Sección 4ª), de 22 de marzo de 2013 (RJ/201313014), en relación con el recurso contencioso-administrativo núm. 774/2008; y STS (Sala de lo Contencioso-Administrativo, Sección 4a), de 22 de marzo de 2013 (RJ/2013/2812), en relación con el recurso contencioso-administrativo núm. 704/2008.

${ }^{765}$ Padawan SL contra Sociedad General de Autores y Editores de España (SGAE), en el que participan: Entidad de Gestión de Derechos de los Productores Audiovisuales (EGEDA), Asociación de Artistas Intérpretes o Ejecutantes - Sociedad de Gestión de España (AIE), Asociación de Gestión de Derechos Intelectuales (AGEDI) y Centro Español de Derechos Reprográficos (CEDRO), asunto C-467/08, ECLI:EU:C:2010:620.

${ }^{766}$ Roj: SAP B 2/2011.
} 
fines manifiestamente ajenos a aquélla. Por tanto, la legislación debía perfilar los distintos supuestos en que el cobro del canon no era exigible.

Otro elemento determinante fue la nulidad de la Orden PRE/1743/2008, de 18 de junio, que dejó a la regulación española sobre compensación equitativa por copia privada sin un listado de referencia de los equipos y soportes digitales sujetos al pago del canon, más allá de los previstos con carácter temporal en la Disposición Transitoria única de la Ley 23/2006. Consecuentemente, acuciaba la necesidad de una nueva regulación al respecto.

Junto a ello, y aunque de modo indirecto, las SSTC 196/2009, de 28 de septiembre $^{767}$ y 123/2010, de 29 de noviembre ${ }^{768}$ propiciaron también la reflexión sobre la naturaleza, contenido y alcance del derecho de compensación equitativa por copia privada en el escenario nacional ${ }^{769}$. Estas sentencias se centraron en analizar la posible vulneración del derecho fundamental de la SGAE a obtener la tutela efectiva de jueces y tribunales (art. 24.1 CE), pues esta entidad consideraba que no había podido acceder a los procedimientos judiciales respectivos en los que se había debatido sobre el contenido y alcance de la obligación legal de compensación equitativa por copia privada de la cual resultaba legítima acreedora, y consecuentemente, sobre los cuales tenía especial interés ${ }^{770}$. Pero estas sentencias también incidieron en el análisis de las relaciones jurídico-materiales originadas entre las entidades de gestión de los derechos de propiedad intelectual y los vendedores de los equipos, aparatos o soportes materiales de reproducción (deudores del canon), así como entre estos vendedores y los clientesconsumidores que los adquirían, poniendo de relieve las dificultades propias del sistema, no sólo en cuanto a la legitimación de las entidades de gestión, sino también

\footnotetext{
${ }^{767}$ B.O.E. núm. 254, de 21 de octubre de 2009.

${ }^{768}$ B.O.E. núm. 4, de 5 de enero de 2011.

${ }^{769}$ Para ampliar sobre los fundamentos de estas sentencias y el papel que desempeñan en el análisis crítico del sistema de compensación equitativa por copia privada, AVILÉS GARCíA, J., El derecho de compensación..., op. cit., pp. 23 y ss.

${ }^{770}$ Se trata de los recursos de amparo núm. 10063-2006 y 7402/2005, ambos promovidos por la SGAE; el primero, frente al AAP Málaga (Sección $5^{\text {a }}$ ), de 17 de octubre de 2006 y, el segundo, frente a la Sentencia del Juzgado de Primera Instancia núm. 7 de Alcalá de Henares, de 15 de junio de 2005 [Roj: SJPI 2/2005]. En ambos casos, los procesos judiciales de instancia fueron promovidos por los respectivos adquirentes de un CD-Rom virgen, quienes reclamaban el importe cobrado en concepto de canon por copia privada a sus respectivos vendedores.
} 
respecto a la posibilidad de oponerse al pago del canon sobre cualquier soporte idóneo para la copia privada que, en cambio, no fuera utilizado para realizar reproducciones de creaciones intelectuales.

Además, incidió en esta modificación la promulgación de la Ley 2/2011, de 4 de marzo, de Economía Sostenible (LES) ${ }^{771}$. Esta Ley introdujo algunas reformas al régimen de protección de los derechos de autor establecido en el TRLPI ${ }^{772}$ mediante su Disposición Final cuadragésima tercera, que popularmente se conoce como "Ley Sinde" 773 y, a su vez, otorgó al Gobierno el plazo de los tres meses siguientes a su entrada en vigor para que, mediante Real Decreto y de plena conformidad con el marco normativo y jurisprudencial de la UE, procediera a modificar la regulación de la copia privada (Disposición Adicional duodécima).

En consecuencia, unos meses más tarde y muy poco después de asumir el Gobierno español el Partido Popular, se aprobó el Real Decreto-Ley 20/2011, de 30 de diciembre, de medidas urgentes en materia presupuestaria, tributaria y financiera para la corrección del déficit público ${ }^{774}$, cuya Disposición Adicional Décima estableció la supresión del sistema de pago de la compensación equitativa por copia privada, o mejor, la supresión del procedimiento de pago de esta compensación en base al denominado canon compensatorio. De hecho, pese a que en el apartado primero de la citada

${ }^{771}$ B.O.E. núm. 55, de 5 de marzo de 2011.

${ }^{772}$ Añadió una disposición adicional quinta con la finalidad de que el Ministerio de Cultura, en el ámbito de sus competencias, velara por la salvaguarda de los derechos de propiedad intelectual frente a su vulneración por los responsables de servicios de la sociedad de información y modificó el art. 158 TRLPI. ${ }^{773}$ Este nombre obedece a que fue la ex Ministra de Cultura, Ángeles González-Sinde, del Partido Socialista, quien impulsó la aprobación de la norma en un escenario político marcado por la campaña electoral de 2011 para la celebración de las elecciones generales de 20 de noviembre de ese año, en las que la copia privada y el canon digital estuvieron muy presentes, existiendo una fuerte presión por parte de los internautas y sus asociaciones para suprimir dicho canon. Se trata de una Ley de contenido polémico, aprobada finalmente tras varias negociaciones y una enmienda pactada por el Partido Popular con el Partido Socialista y con Convergencia y Unión para comprometer al Gobierno a modificar el canon digital en un plazo de tres meses posteriores a su aprobación. Téngase en cuenta que el Partido Popular había prometido con anterioridad, desde la campaña electoral para las elecciones generales celebradas el 9 de marzo de 2008, la supresión del canon digital.

Para unos breves comentarios críticos sobre esta Ley Vid. BERCOVITZ RoDRíGUEZ-CANO, R., "La Ley Sinde", Revista Doctrinal Aranzadi Civil-Mercantil, Vol. 1, núm. 1/2011 (Parte Tribuna), 2011, pp. 11 y ss.; y Alemán EzCARAY, C., "Los huecos de la Ley Sinde y el miedo a la tecnología", Actualidad Jurídica Aranzadi, núm. 813/2011 (Parte Tribuna), 2011, pp. 4 y ss.

${ }^{774}$ B.O.E. núm. 315, de 31 de diciembre de 2011. 
Disposición Adicional Décima puede leerse "se suprime la compensación equitativa por copia privada, prevista en el artículo 25 [...]", el apartado segundo evidencia sólo un cambio de modelo en cuanto a la satisfacción de esta compensación, al señalar: "El Gobierno establecerá reglamentariamente el procedimiento de pago a los perceptores de la compensación equitativa por copia privada con cargo a los Presupuestos Generales del Estado".

Debe señalarse que el Partido Popular había prometido con anterioridad, desde la campaña electoral para las elecciones generales celebradas el 9 de marzo de 2008, la supresión del canon digital, de manera que, en dicho año y encontrándose en tramitación la Ley Sinde, votó a favor de la última de sus versiones, a cambio, entre otras cuestiones, de una modificación del modelo de satisfacción de esta compensación por copia privada, que pasaría a estar a cargo de los PGE.

Así pues, con la aprobación definitiva de la Ley Sinde en 2011, la legislación española se decantó por un nuevo modelo compensatorio en el cual el Estado y, por tanto, indirectamente todos los contribuyentes, se convirtieron en deudores de la compensación, remitiendo el procedimiento de pago de la misma a ulterior desarrollo reglamentario.

Al hilo de lo anterior, se promulgó el Real Decreto 1657/2012, de 7 de diciembre ${ }^{775}$, que sistematizó el procedimiento y los criterios objetivos para la determinación de la cuantía anual de la compensación equitativa por copia privada con cargo a los PGE, así como el procedimiento de liquidación y pago a sus perceptores en las tres modalidades de reproducción objeto del límite copia privada (libros y publicaciones asimiladas; fonogramas y demás soportes sonoros; y videogramas y demás soportes audiovisuales).

Las críticas a este modelo no se hicieron esperar ${ }^{776}$. Se trataba de un modelo compensatorio que parecía alejarse de las directrices marcadas por el TJUE, aun cuando

\footnotetext{
${ }^{775}$ B.O.E. núm. 295, de 8 de diciembre de 2012.

${ }^{776}$ Vid. entre otros, BERCOVITZ RODRÍGUEZ-CANO, R., "Cambio de rumbo en el canon de copia privada", Revista Aranzadi Civil-Mercantil, Vol. 1, núm. 10, 2012, p. 18; BERCOVITZ RodRÍGUEZ-CANO, R., "El nuevo procedimiento de pago de la compensación equitativa por copia privada", Revista Aranzadi Civil-
} 
algunas de sus sentencias fueran invocadas en la propia Exposición de Motivos de la norma como fundamento a su contenido ${ }^{777}$. De hecho, el TJUE había cuestionado que la compensación equitativa por copia privada se exigiera en aquellos casos en que no fuera previsible que los equipos, aparatos y soportes materiales fueran utilizados para la obtención de copias privadas de obras protegidas por la propiedad intelectual y, sin embargo, con la regulación de la compensación equitativa por copia privada con cargo a los PGE todos pasábamos a ser, de algún modo, deudores del canon ${ }^{778}$. Perdía, así, esta figura su propia esencia, que había operado hasta entonces con carácter compensatorio respecto de los perjuicios económicos causados a los autores y demás titulares de derechos de propiedad intelectual por la reproducción para uso privado de sus obras y prestaciones.

No obstante, no puede negarse que el Real Decreto 1657/2012 mantuvo la vigencia de muchas de las disposiciones contenidas en el art. 25 del TRLPI y en el Real Decreto 1434/1992. De hecho, varias cuestiones quedaron reguladas de manera análoga a la anterior: los titulares beneficiarios de la compensación equitativa (art. 2.1 del Real Decreto 1657/2012); el carácter irrenunciable para los autores y los artistas intérpretes o ejecutantes del derecho de remuneración equitativa por copia privada (art. 2.2 del Real Decreto 1657/2012); el criterio para considerar asimiladas a los libros, las publicaciones de contenido cultural, científico o técnico (art. 2.3 del Real Decreto 1657/2012); los criterios objetivos enumerados para la estimación del daño causado por la copia privada,

Mercantil, Vol. 1, núm. 10, 2013, pp. 27 y ss.; SoTO PINO, A. y RAMíREZ SILVA, P., "La reclamación del canon por copia privada", Actualidad Jurídica Aranzadi, núm. 859, 2013, p. 10.

777 Así, en la Exposición de Motivos se acude a la doctrina expuesta por el TJUE en las sentencias de 16 de junio de 2011 (asunto C-462/09) y de 21 de octubre de 2010 (asunto C-467/08), con el fin de ilustrar que la normativa europea ofrece un amplio margen de apreciación a los Estados miembros para determinar quién está obligado al pago de la compensación equitativa y para establecer, dentro de los límites impuestos por la DDASI, la forma, las modalidades de financiación y de percepción y la cuantía de dicha compensación. Sin embargo, no parece, que el sistema previsto permita alcanzar el "justo equilibrio", porque es preciso que el deudor, de no ser quien utilice directamente los aparatos, soportes y equipos de reproducción para realizar copias privadas, pueda repercutir lo pagado en el precio que abonará el consumidor final de estos medios de reproducción, quien resulta, en última instancia, el beneficiario del límite de copia privada. Es decir, se persigue buscar ese "justo equilibrio" a partir de la posibilidad de que el perjuicio causado por la copia privada sea compensado por quien efectivamente reproduce creaciones intelectuales protegidas.

778 BerCOVITZ RodRÍGUEZ-CANO, R., “Cambio de rumbo...”, op. cit., p. 18. 


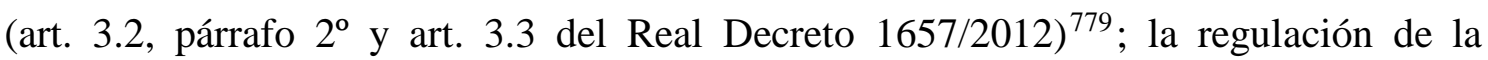
distribución de la compensación para cada modalidad de reproducción (art. 5 del Real Decreto 1657/2012) ${ }^{780}$; la ejecución del pago a través de las entidades de gestión (art. 6.1 del Real Decreto 1657/2012); la remisión a un reparto equitativo y proporcional dentro de cada entidad [art. 154 del TRLPI (2006) y art. 7.1 del Real Decreto 1657/2012]; la atribución del veinte por ciento del importe de la compensación a actividades de asistencia y fomento (Disposición Adicional primera 1 y 2 del Real Decreto 1657/2012); y la exigencia a las entidades de gestión de información en relación con la aplicación de la compensación a dichas actividades y con el número de titulares beneficiarios en el ejercicio anterior (Disposición Adicional primera 3 del Real Decreto $1657 / 2012)^{781}$.

\subsection{La consolidación del modelo mediante la Ley 21/2014, de 4 de noviembre}

La Ley 21/2014, de 4 de noviembre, por la que se modifica el texto refundido de la Ley de Propiedad Intelectual, aprobado por Real Decreto Legislativo 1/1996, de 12 de abril, y la Ley 1/2000, de 7 de enero, de Enjuiciamiento Civil, apareció en el panorama jurídico con el objetivo de modificar ciertos aspectos considerados de mayor urgencia en la regulación de la protección de los derechos de propiedad intelectual. Uno de sus propósitos

\footnotetext{
${ }^{779}$ En este caso se introducen algunas variaciones respecto de la regulación contenida en el art. 25.6.4 del TRLPI 2006. En cambio, se mantienen criterios como que la cuantía de la remuneración se calculará sobre la base del perjuicio efectivamente causado a los titulares de los derechos de propiedad intelectual, que se atenderá para el cálculo a la calidad y al tiempo de conservación de las reproducciones, así como que la disponibilidad y aplicación de medidas tecnológicas efectivas no darán origen a una obligación de compensación en aquellas situaciones en las que el perjuicio causado al titular del derecho de reproducción haya sido mínimo. En todo caso, llama la atención cómo el artículo se refiere al "perjuicio efectivamente causado a los titulares de los derechos de propiedad intelectual como consecuencia de la reproducción por personas físicas" (la cursiva es nuestra), cuando al final, tanto las personas físicas como las personas jurídicas contribuyen a la obtención de los ingresos públicos.

${ }^{780}$ Se mantiene en los mismos términos en que estaba prevista en el art. 36 del Real Decreto 1434/1992 (en la modalidad de fonogramas y demás soportes sonoros, el 50 por ciento para los autores, el 25 por ciento para los artistas intérpretes o ejecutantes y el 25 por ciento para los productores; en la modalidad de videogramas y demás soportes visuales o audiovisuales, un tercio para los autores, un tercio para los artistas intérpretes o ejecutantes y un tercio para los productores; y en la modalidad de libros y publicaciones asimiladas, el 55 por ciento para los autores y el 45 por ciento para los editores).

${ }^{781}$ Sobre estas similitudes vid. BERCOVITZ RODRÍGUEZ-CANO, R., "El nuevo procedimiento de pago...", op. cit., pp. 27 y 28.
} 
más relevantes fue, precisamente, la regulación del sistema de copia privada. De hecho, las reformas de la Ley se agruparon en tres bloques, tal y como enunció su propia Exposición de Motivos: "la profunda revisión del sistema de copia privada, el diseño de mecanismos eficaces de supervisión de las entidades de gestión de los derechos de propiedad intelectual y el fortalecimiento de los instrumentos de reacción frente a las vulneraciones de derechos que permita el impulso de la oferta legal en el entorno digital”.

Esta Ley fue fuertemente criticada desde su Anteproyecto, tanto por el Consejo General del Poder Judicial ${ }^{782}$, como por el Consejo de Estado ${ }^{783}$.

Respecto del sistema de copia privada se modificaron, en concreto, los artículos 31.2 y 25 del TRLPI, esto es, el régimen de la copia privada y de la compensación equitativa, respectivamente. En concreto, el art. 25 del TRLPI redujo significativamente su contenido, pasando a tener sólo seis apartados frente a los veinticinco anteriores. Los apartados primero y segundo contenían el nacimiento de la obligación de compensar y los beneficiarios de la compensación, mientras que el resto de los apartados regulaba su cuantificación. Fue un modelo no exento de polémica, además de incompatible con el Derecho de la UE, como seguidamente se analiza.

\subsection{Crisis del modelo}

\subsubsection{Observaciones generales}

Desde su introducción en el ordenamiento jurídico español, el modelo de satisfacción de la compensación equitativa con cargo a los PGE recibió fuertes críticas tanto políticas como doctrinales. Asimismo, se opusieron a este modelo las entidades de gestión de derechos de propiedad intelectual, dando voz al sentir de los titulares de derechos por ellas representados.

\footnotetext{
${ }^{782}$ Consejo General del Poder Judicial (Comisión de Estudios e Informes), Informe al Anteproyecto de Ley de Modificación de la Ley..., cit.

${ }^{783}$ Consejo de Estado, Dictamen del Anteproyecto de Ley de Modificación del Texto Refundido de la Ley de Propiedad Intelectual, aprobado por Real Decreto Legislativo 1/1996, de 12 de abril, y de la Ley 1/2000, de 7 de enero, de Enjuiciamiento Civil, 28 de noviembre de 2013 [Documento CE-D-2013-1064], disponible en: http://www.boe.es/buscar/doc.php?id=CE-D-2013-1064 (consultado: 03.09.2016).
} 
Era evidente su contrariedad con el Derecho de la UE, pues en la medida en que la compensación equitativa por copia privada dependía de una partida presupuestaria, se hacía depender la misma de la capacidad económica del Estado, restando virtualidad al verdadero alcance del daño provocado a los titulares de derechos de propiedad intelectual por la excepción de copia privada ${ }^{784}$. Asimismo, comportaba una ausencia de vinculación entre quien debía ser beneficiario del límite de copia privada y quien debía satisfacer dicha compensación, que, según el TJUE, era el usuario privado a cuya disposición hubieran sido puestos los equipos, aparatos y soportes de reproducción digital o que utilizara un servicio de reproducción ${ }^{785}$.

Por ello, el Tribunal Supremo (Sala de lo Contencioso-Administrativo) se planteó si el art. 5.2.b) de la DDASI permitía oponerse a un sistema de compensación equitativa por copia privada con cargo a los PGE, como el establecido en la Disposición Adicional Décima del Real Decreto-Ley 20/2011, de 30 de diciembre.

Concretamente, el Tribunal Supremo formuló su cuestión prejudicial al TJUE mediante Auto de 10 de septiembre de $2014^{786}$, en el marco del Recurso contenciosoadministrativo núm. 34/2013, presentado por EGEDA, DAMA y VEGAP contra el Real Decreto 1657/2012, de 7 de diciembre, en desarrollo de la Disposición Adicional Décima del Real Decreto-Ley 20/2011. Las recurrentes habían solicitado al Tribunal que dictase sentencia declarando la nulidad de pleno derecho de dicha Disposición Adicional y, consecuentemente, del Real Decreto 1657/2012 origen de aquélla. Consideraban que éste vulneraba lo previsto en el art. 5.2.b) de la DDASI, conforme a la interpretación dada a este precepto por las sentencias del TJUE de 21 de octubre de 2010 (asunto C-467/08) y de 16 de junio de 2011 (asunto C-462/09).

Las cuestiones planteadas por el Tribunal Supremo fueron las siguientes:

1. Si es conforme al art. 5.2.b) de la DDASI un sistema de compensación equitativa por copia privada que, tomando como base de estimación el perjuicio

\footnotetext{
${ }^{784}$ BERCOVITZ RODRÍGUEZ-CANO, R., La reforma de la Ley... ”, op. cit., p. 69.

785 STJUE (Sala Tercera), de 21 de octubre de 2010, asunto C-467/08, cit., párrafo 48.

786 ATS (Sala de lo Contencioso-Administrativo, Sección $4^{\mathrm{a}}$ ), de 10 de septiembre de 2014 (ATS 6659/2014).
} 
efectivamente causado, se sufraga con cargo a los PGE, sin que resulte por ello posible asegurar que el coste de dicha compensación sea soportado por los usuarios de copias privadas;

2. Caso de recibir la anterior cuestión una respuesta afirmativa, si es conforme al art. 5.2.b) de la DDASI que la cantidad total destinada por los PGE a la compensación equitativa por copia privada, aun siendo calculada con base en el perjuicio efectivamente causado, deba fijarse dentro de los límites presupuestarios establecidos para cada ejercicio.

Por otra parte, ante las dudas acerca de la constitucionalidad de la Ley 21/2014, ochenta y nueve diputados del Grupo Parlamentario Socialista presentaron ante el Tribunal Constitucional un recurso contra la misma y contra diversos preceptos de la Ley 36/2014, de 26 de diciembre, de PGE para el año 2015. Este recurso (núm. 6812015) fue admitido por el Pleno del Tribunal Constitucional, mediante providencia de 3 de marzo de $2015^{787}$ y ha sido resuelto mediante sentencia de fecha 22 de febrero de $2018^{788}$.

En particular, el recurso de inconstitucionalidad fue presentado contra el art. 25.1, párrafo segundo y art. 25.3 del TRLPI, conforme a su modificación por la Ley 21/2014, en cuanto a la consignación anual de la compensación equitativa por copia privada en la Ley de PGE. El recurso se centró, en lo esencial, en tres líneas argumentativas

\footnotetext{
${ }^{787}$ B.O.E. núm. 58 , de 9 de marzo de 2015.

${ }^{788}$ Disponible en: https://www.tribunalconstitucional.es/NotasDePrensaDocumentos/NP 2018 020/2015681STC.pdf (consultada: 24.02.2018). En su sentencia, el Tribunal Constitucional declara la pérdida sobrevenida del recurso y señala: "Examinado cómo el Real Decreto-ley 12/2017 ha instaurado un nuevo sistema de compensación por copia privada que sustituye enteramente al anterior, cabe igualmente señalar que el sistema de compensación de copia privada, con cargo a los Presupuestos Generales del Estado, regulado en los preceptos impugnados en el presente proceso, no era aplicable antes de su sustitución por el Real Decreto-ley 12/2107, en tanto en cuanto había sido considerado por la Sentencia del Tribunal de Justicia de la Unión Europea de 9 de junio de 2016, asunto C-470/14, como contrario al artículo 5, apartado 2, letra b), de la Directiva 2001/29/CE del Parlamento Europeo y del Consejo, relativa a la armonización de determinados aspectos de los derechos de autor y derechos afines a los derechos de autor en la sociedad de la información, lo que ha determinado, como consecuencia, que los preceptos impugnados de la Ley 21/2014 no hayan podido ser aplicados y, por ello, que la norma legal de referencia carezca de ultraactividad, por lo que las quejas imputadas a aquellos deben decaer".
} 
fundamentales: la vulneración del contenido esencial del derecho de propiedad intelectual; la salvaguarda de los intereses protegidos en la compensación equitativa por copia privada y la competencia legislativa; y la injerencia estatal en la equitativa determinación y asignación de la compensación equitativa ${ }^{789}$.

En definitiva, eran evidentes las discrepancias frente a este nuevo modelo de satisfacción de la compensación equitativa por copia privada con cargo a los PGE, que, además, parecía del todo contrario al derecho de la UE, lo que presagiaba su fracaso.

\subsubsection{La resolución por el TJUE de la cuestión prejudicial planteada por el} ATS (Sala de lo Contencioso-Administrativo), de 10 de septiembre de 2014 y su repercusión en el Derecho interno

\subsubsection{Las conclusiones del Abogado General: el intento de legitimación del modelo de compensación con cargo a los Presupuestos Generales del Estado}

Paradójicamente, las Conclusiones presentadas el 19 de enero de 2016 por el Abogado General, Sr. Maciej SzPUNAR ${ }^{790}$, en el asunto C-470/14 ${ }^{791}$, con motivo de la petición de decisión prejudicial de la Sala de lo Contencioso-Administrativo del Tribunal Supremo, justificaron la compatibilidad entre un sistema de compensación sufragado con cargo a los PGE y el artículo 5.2.b) de la DDASI.

El Sr. SZPUNAR parte del presupuesto de que la DDASI no se pronuncia sobre la forma y los métodos de cálculo y financiación de la compensación equitativa por copia privada, como tampoco se encarga de establecer quiénes han de ser los deudores de ésta,

\footnotetext{
${ }^{789}$ Para ampliar vid. AvILÉS GARCÍA, J., El derecho de compensación ..., op. cit., pp. 116 y ss., quien hace un detallado análisis de las líneas de argumentación jurídica del recurso de inconstitucionalidad.

790 Conclusiones del Abogado General Sr. Maciej Szpunar, de 19 de enero de 2016 [ECLI:EU:C:2016:24].

${ }^{791}$ Entidad de Gestión de Derechos de los Productores Audiovisuales (EGEDA), Derechos de Autor de Medios Audiovisuales (DAMA), Visual Entidad de Gestión de Artistas Plásticos (VEGAP) contra Administración del Estado y Asociación Multisectorial de Empresas de la Electrónica, las Tecnologías de la Información y la Comunicación, de las Telecomunicaciones y de los Contenidos Digitales (AMETIC), con intervención de: Artistas Intérpretes, Sociedad de Gestión (AISGE), Centro Español de Derechos Reprográficos (CEDRO), Asociación de Gestión de Derechos Intelectuales (AGEDI), Entidad de Gestión, Artistas, Intérpretes o Ejecutantes, Sociedad de Gestión de España (AIE), Sociedad General de Autores y Editores (SGAE), (Asunto C-470/14), ECLI:EU:C:2016:418.
} 
sino más bien sólo quiénes son los beneficiarios de la misma. Atendiendo a estas razones, sostiene que "la Directiva 2001/29 no contiene normas jurídicamente vinculantes según las cuales el justo equilibrio [...] suponga necesariamente la financiación de la compensación equitativa en concepto de excepción de copia privada por parte de los usuarios que realizan o pueden realizar tales copias" ${ }^{\text {792 }}$. Así pues, considera que no existe una vinculación directa entre los actos de copia privada y la compensación del perjuicio causado a los titulares de derechos concretos, toda vez que dicho perjuicio se aprecia globalmente sobre la base de los ingresos dejados de percibir por estos con motivo de la copia privada ${ }^{793}$.

Al respecto, emplea como punto fundamental de su línea expositiva la figura del "usuario-pagador", entendiendo por tal la persona que soporta la carga de la compensación que le repercute vía precio el fabricante o vendedor de equipos electrónicos. En este sentido, se cuestiona si éste debe existir de manera general en todo modelo de satisfacción de la compensación equitativa, o bien sólo en el modelo del canon $^{794}$, cuestión que basa en el hecho de que, si bien el TJUE ha declarado la conformidad del canon con el art. 5.2.b) de la DDASI siempre que la carga económica del mismo pueda repercutirse sobre el comprador del equipo, esta afirmación sólo ha sido expuesta en relación con el sistema de canon y no en relación con otro modelo alternativo $^{795}$.

A mayor abundamiento, el Abogado General sostiene que esta interpretación se corrobora por el propio tenor de la regla «usuario-pagador». Conforme a esta regla, de acuerdo con la doctrina del TJUE en asuntos como Padawan (C-467/08) y Stichting de Thuiskopie (C-462/09), puede decirse que, "en principio", el usuario es el deudor de la compensación. Sin embargo, la reserva "en principio" a la que se refieren estas sentencias, demuestra que se trata de un principio teórico que, "en la práctica", siempre se aplica en el marco de un sistema de canon percibido sobre los equipos

\footnotetext{
792 Ibídem, párrafo 26.

793 Ibídem, párrafo 23.

${ }^{794}$ Ibídem, párrafo 32.

${ }^{795}$ Ibídem, párrafo 37.
} 
electrónicos 796 . Asimismo, añade que "este principio no aparece siempre como una constatación jurídica independiente, sino como un elemento de un razonamiento que lleva a la confirmación del sistema del canon"797.

Basado en la fundamentación anterior, el Sr. SZPUNAR concluye que no parece que pueda deducirse legítimamente de la jurisprudencia del TJUE, que la compensación equitativa por copia privada deba ser financiada necesariamente por los usuarios que se benefician del límite de copia privada ${ }^{798}$.

En particular, en lo que atañe a la legitimidad del pago de la compensación con cargo a los PGE, el Abogado General reflexiona en sus Conclusiones sobre el modo en que los contribuyentes participan en la financiación de los gastos del Estado y sobre el poder soberano del Estado para decidir cómo asignar los fondos recaudados. Señala: “[...] no existe un vínculo directo entre el impuesto abonado por un contribuyente determinado y una u otra partida de gastos de los Presupuestos, ya que la intermediación de los Presupuestos rompe precisamente este vínculo"799.

Así pues, alega que no tiene que existir un vínculo entre los tributos que abonan los contribuyentes (incluidas las personas jurídicas) y la financiación de la compensación por copia privada con cargo a los PGE, al no existir un tributo específico para esta compensación ${ }^{800}$. En consecuencia, no tiene por qué entenderse contraria al Derecho de la UE una compensación con cargo a los PGE, pues "no se trata de ampliar el ámbito del canon a todos los contribuyentes, sino de un sistema de financiación basado en una lógica diferente" 801 .

Sin perjuicio de lo anterior, el Abogado General, Sr. SzPUNAR, no aprueba en sus Conclusiones el diseño particular del sistema de satisfacción de la compensación equitativa por copa privada con cargo a los PGE establecido en España. Más bien al contrario. El fallo del modelo español estaba, a su juicio, en que el modelo instaurado

\footnotetext{
796 Ibídem, párrafo 38.

${ }^{797}$ Ibídem, párrafo 40.

${ }^{798}$ Ibídem, párrafo 41.

${ }^{799}$ Ibídem, párrafo 50.

${ }^{800}$ Ibídem, párrafo 51.

${ }^{801}$ Ibídem, párrafo 52.
} 
no era equitativo; la equidad no existe cuando la cuantía asignada presupuestariamente no es reflejo del perjuicio soportado por los titulares de derechos. En este sentido, destaca que desde la implementación de la copia privada en España con cargo a los PGE, esta partida presupuestaria había permanecido invariablemente fijada en la cantidad de cinco millones de euros. Además, sostiene que la imposibilidad de prever con exactitud ex ante el gasto asociado a una obligación legal que se sufraga por medio del erario público, no excluye la posibilidad de realizar estimaciones sobre la base de datos precisos y fiables que repercutan en el establecimiento de una partida ajustada al perjuicio soportado por los titulares de los derechos de propiedad intelectual ${ }^{802}$.

Con todo, el Abogado General concluye:

“[...] es perfectamente posible garantizar una compensación equitativa, en el sentido del artículo 5, apartado 2, letra b), de la Directiva 2001/29, tal como lo interpreta el Tribunal de Justicia, en el marco de la financiación de esta compensación con cargo a los Presupuestos Generales del Estado. No obstante, esta compensación no puede establecerse a priori y de manera rígida en un límite que no tenga suficientemente en cuenta el importe del perjuicio sufrido por los titulares de los derechos, tal y como se estima según las reglas aplicables en la materia en Derecho interno del Estado miembro de que se trate" $" 803$.

\subsubsection{La posición del TJUE}

La postura del TJUE quedó recogida en la STJUE (Sala Cuarta), de 9 de junio de $2016^{804}$, especialmente trascendente toda vez que declara la incompatibilidad del art. 5.2.b) de la DDASI con un sistema de compensación equitativa por copia privada que, como el español implantado en 2011, se sufragaba con cargo a los PGE. Un sistema así diseñado no asegura que el coste de dicha compensación equitativa sea soportado por

\footnotetext{
${ }^{802}$ Ibídem, párrafo 67.

${ }^{803}$ Ibídem, párrafo 69.

804 EGEDA, DAMA y VEGAP vs. Administración del Estado y AMETIC, asunto C-470/2014 [ECLI:EU:C:2016:418].
} 
los usuarios de copias privadas, por lo que se rompe el vínculo entre la compensación y el perjuicio causado a los titulares de derechos de propiedad intelectual ${ }^{805}$.

De este modo, la sentencia dio respuesta únicamente a la primera de las cuestiones prejudiciales planteadas, esto es, la relativa a si el art. 5.2.b) de la DDASI debe interpretarse en el sentido de que se opone a un sistema de compensación equitativa por copia privada que se sufraga con cargo a los PGE, ya que no permite asegurar que el coste de dicha compensación equitativa sea soportado por los usuarios de copias privadas. La segunda de las cuestiones prejudiciales formuladas [sobre la conformidad del art. 5.2.b) de la DDASI con una compensación equitativa por copia privada cuya cuantía se fija dentro de los límites presupuestarios] quedó sin responder, toda vez que se supeditaba a la respuesta afirmativa de la primera, lo que no sucedió.

En efecto, el TJUE no compartió el criterio del Abogado General de que fuera posible sufragar la compensación equitativa por copia privada con cargo a los PGE, al menos si el sistema no garantizaba que el coste de dicha compensación sólo fuera sufragado, en último término, por los usuarios de copias privadas. Así, partiendo de un análisis de su doctrina anterior sobre la materia, recogida en la STJUE (Sala Tercera) de 21 de octubre de 2010, la STJUE (Sala Tercera) de 16 de junio de 2011, la STJUE (Sala Segunda), de 11 de julio de 2013 y la STJUE (Sala Cuarta) de 5 de marzo de 2015, destacó dos cuestiones esenciales que, tomadas como premisas, explican claramente su posición.

En primer lugar, el TJUE afirmó que el art. 5.2 de la DDASI no se opone, en principio, a que los Estados miembros que han optado por introducir la excepción de copia privada decidan establecer un sistema de compensación equitativa que no esté financiado por un canon, sino por sus PGE, siempre que ese sistema alternativo garantice, por un lado, el pago de una compensación equitativa a favor de los titulares de los derechos y, por otro, su percepción efectiva por estos (párrafos 24 y 25).

\footnotetext{
${ }^{805}$ En este sentido: GonZÁlez NAVARro, B. A., "Copia privada y canon digital: conclusiones del abogado general del TJUE”, Revista Aranzadi Doctrinal, núm.3/2016 (Parte Comentario), 2016, p. 91.
} 
En segundo lugar, el TJUE destacó que, con independencia de cuál sea el sistema elegido para sufragar la compensación equitativa (bien sea mediante canon compensatorio o PGE), las personas jurídicas no pueden ser, en ningún caso, deudoras efectivas de dicha compensación (párrafo 36).

En consecuencia, el TJUE consideró que, al no haber afectación de ingresos concretos a gastos determinados, la partida presupuestaria destinada al pago de la compensación equitativa se alimenta de la totalidad de los recursos de los PGE, con lo cual, todos los contribuyentes participan en la satisfacción de la compensación por copia privada, tanto personas físicas como jurídicas (párrafo 39). Además, añadió que no se desprendía de los autos que existiera algún mecanismo que permitiera a las personas jurídicas solicitar la exención de la obligación de contribuir a financiar esta compensación, o, al menos, solicitar la devolución de esta contribución (párrafo 40). Por tanto, el sistema de financiación con cargo a los PGE no podía garantizar que el coste de dicha compensación sólo fuera sufragado, en último término, por los usuarios de copias privadas (párrafo 41).

En definitiva, la sentencia declaró que el art. 5.2.b) de la DDASI debe interpretarse en el sentido de que se opone a un sistema de compensación equitativa por copia privada sufragado con cargo a los PGE, cuando no resulte posible asegurar que el coste de dicha compensación equitativa sea soportado por los usuarios de copias privadas (párrafo 42 ).

\subsubsection{La repercusión del pronunciamiento del TJUE en el ordenamiento jurídico interno}

La incompatibilidad entre el modelo de financiación de la compensación equitativa por copia privada con cargo a los PGE y el art. 5.2.b) de la DDASI, declarada por la STJUE (Sala Cuarta), de 9 de junio de 2016, tuvo -como no podía ser de otro modo- consecuencias en el orden interno.

En primer lugar, con carácter inmediato, sobre el procedimiento judicial que dio origen a la cuestión prejudicial que dicha sentencia resolvió, es decir, sobre la resolución del Recurso contencioso-administrativo núm. 34/2013, dirimido ante el Tribunal Supremo (Sección Cuarta, Sala de lo Contencioso-Administrativo). Aclarada la 
cuestión por el TJUE, el Tribunal Supremo tenía que decidir el recurso siguiendo la interpretación contenida en la sentencia ${ }^{806}$.

Así, la STS (Sección Cuarta, Sala de lo Contencioso-Administrativo), de 10 de noviembre de $2016^{807}$, declaró la falta de fundamento legal del Real Decreto 1657/2012, de 7 de diciembre y, con ello, su nulidad, toda vez que desarrollaba unas normas (Disposición adicional 10 a del Real Decreto-Ley 20/2011 y art. Primero. Dos de la Ley 21/2014 por el que se modifica el art. 25 TRLPI) que resultaban inaplicables por ser incompatibles con la DDASI. Esta conclusión, a su vez, llevó a la Sala a desestimar la solicitud del Abogado del Estado de suspender el proceso hasta que el Tribunal Constitucional resolviese el recurso de inconstitucionalidad relativo al artículo Primero. Dos de la Ley 21/2014. Y es que, con independencia de la decisión del Tribunal Constitucional, las normas que el Real Decreto 1657/2012 desarrolla debían ser inaplicadas.

A mayor abundamiento, no comparte el Tribunal Supremo el criterio del Abogado del Estado relativo a que el sistema español de compensación equitativa por copia privada con cargo a los PGE sea sólo incompleto "en la medida en que no contiene ningún medio para evitar que las personas jurídicas soporten también el coste económico de la compensación”. A juicio de este, bastaría con añadir una norma que exonerase a las personas jurídicas de soportar el coste de la compensación equitativa para que el sistema fuese compatible con la Directiva 2001/29/CE. Sin embargo, en contra de tal opinión, el Tribunal Supremo sostuvo:

\footnotetext{
${ }^{806}$ De lo contrario, el órgano jurisdiccional nacional hubiera incumplido el deber de obediencia que tiene en relación con las resoluciones dictadas por el TJUE pues, como es sabido, toda sentencia pronunciada con carácter prejudicial sobre la interpretación o validez de un acto adoptado por las instituciones de la UE vincula al juez nacional para la resolución del litigio principal [Vid. PÉrEz GonZÁlEZ, C., "La cuestión prejudicial", en Grandes Tratados: Practicum Proceso Contencioso - Administrativo 2015, Aranzadi, Madrid, 2014, p. 28 (versión en línea), disponible en: http://aranzadi.aranzadidigital.es/maf/app/document?docguid=Ie531be505f1211e49d43010000000000\&s rguid=i0ad82d9a00000160ac4acc96d3452c06\&src=withinResuts\&spos=6\&epos=6\&displayid=\&publica cion $=\&$ clasificationMagazines $=\&$ fechacomun $=\&$ numeropub-tiponum $=\# \quad($ consultado: 18.10.2017)]. De hecho, debe recordarse que el mecanismo prejudicial no sólo evita divergencias en la interpretación del Derecho de la UE, sino que también garantiza que el juez nacional no tenga dificultades a la hora de otorgar plenos efectos al mismo (vid. Alonso GaRCía, R., Sistema Jurídico de la Unión Europea, $3^{\mathrm{a}}$ ed., Aranzadi, Madrid, 2012, p. 191).

${ }^{807}$ Roj: STS 4832/2016.
} 
"Es verdad que el TJUE comienza su razonamiento diciendo que un sistema de compensación equitativa con cargo a los Presupuestos Generales del Estado no es necesariamente contrario a la Directiva 2001/29/CE, pero inmediatamente impone una condición: que el coste efectivo pese exclusivamente sobre los usuarios de la copia privada, que en ningún caso pueden ser, por definición, las personas jurídicas. Dado que la regulación española de la compensación equitativa no prevé medio alguno de que se cumpla dicha condición, la sentencia del TJUE 9 de junio de 2016 concluye que no es compatible con la Directiva 2001/29/CE. Más aún, su parte dispositiva [...] no introduce matización alguna, sino que declara tajantemente la incompatibilidad de la regulación española con el derecho de la Unión Europea. Un sistema de compensación equitativa que contuviese el elemento que el Abogado del Estado estima ausente sería un sistema sustancialmente diferente $\mathrm{y}$, desde luego, no es el diseñado en los preceptos legales que el Real Decreto 1657/2012 -objeto directo de este proceso- está llamado a desarrollar" (F.J. $\left.9^{\circ}\right)$.

En segundo lugar, otra de las consecuencias del fallo del TJUE fue la inaplicación del art. Primero, apartado Dos, de la Ley 21/2014, por el que se modifica el art. 25 TRLPI, derivada del principio de primacía del Derecho de la UE que supone, esencialmente, que dicho ordenamiento prevalece frente al nacional, al que sustituye, en caso de confrontación entre sus normas, resultando inaplicable la norma interna incompatible ${ }^{808}$. Consecuentemente, el juez no puede aplicar la norma nacional contraria al Derecho de la UE ${ }^{809}$.

\footnotetext{
${ }^{808}$ AÑón CALVETE, J., "Primacía del Derecho de la Unión Europea (a propósito de la STC 232/2015, de 5 de noviembre)", en Noticias Jurídicas (Artículos Doctrinales), publicado el 23 de febrero de 2016, disponible en: http://noticias.juridicas.com/conocimiento/articulos-doctrinales/10895-primacia-delderecho-de-la-union-europea-a-proposito-de-la-stc-232-2015-de-5-de-noviembre/ 25.06.2017).

${ }^{809}$ Conviene recordar, en este sentido, que el Derecho comunitario constituye un ordenamiento jurídico autónomo respecto a la legislación de los Estados miembros. Este Derecho, al igual que crea obligaciones a cargo de los particulares, también genera derechos que nacen no sólo cuando se reconocen de forma explícita, sino también en razón de las obligaciones que impone el Tratado Constitutivo de la Comunidad Económica Europea (Tratado CEE) -así como el Tratado de la UE y el Tratado de Funcionamiento de la UE, a día de hoy-, tanto a los particulares como a los Estados miembros y a las Instituciones comunitarias. Así lo afirmó en su día la STJCE (TJUE en la actualidad), de 5 de febrero de 1963 [NV (Sociedad Anónima) Algemene Transport- en Expeditie Onderneming van Gend \& Loos vs. Nederlandse Administratie der Belastingen (Administración Tributaria neerlandesa)], asunto 26/62, disponible en http://curia.europa.eu/juris/showPdf.jsf?text=\&docid=87120\&pageIndex=0\&doclang=ES\&mode=req\&di

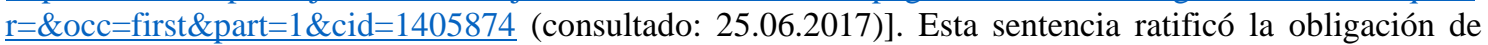
los Estados miembros de cumplir con el Derecho originario, formado por los Tratados constitutivos y de adhesión, así como con el Derecho derivado, es decir, aquel que emana de las distintas instituciones comunitarias. A su vez, esta sentencia sirvió de premisa para que la STJCE, de 15 de julio de 1964 [Flaminio Costa vs. ENEL (Ente Nazionale Energía Elettrica, empresa que pertenecía anteriormente a la
} 
En definitiva, siguiendo el principio de primacía del Derecho de la UE, la solución adoptada por el Tribunal Supremo no podía ser otra que la de declarar inaplicable el art. 25 TRLPI, en su redacción dada por el art. Primero, apartado Dos, de la Ley 21/2014, una vez dictada la STJUE (Sala Cuarta), de 9 de junio de 2016 declarando la incompatibilidad del sistema español de compensación por copia privada con el art. 5.2.b) de la DDASI.

\begin{tabular}{lcccc}
$\begin{array}{l}\text { Edison } \\
\text { http://curia.europa.eu/juris/showPdf.jsf?text=\&docid=87399\&pageIndex=0 \&doclang=ES\&mode=req\&di }\end{array}$ \\
\hline
\end{tabular} $\underline{\mathrm{r}=\& o c c=\text { first\&part=1\&cid=843016 }}$ (consultado: 25.06.2017)] comenzara a aproximarse a los fundamentos del principio de primacía del Derecho de la UE (Vid. Alonso GARCíA, R., Sistema Jurídico..., op. cit., p. 304).

En particular, la STJCE, de 15 de julio de 1964 reafirmó, por un lado, el carácter propio del sistema jurídico comunitario, integrado desde su entrada en vigor en el sistema jurídico de los Estados miembros creando un cuerpo normativo aplicable a sus nacionales y a sí mismos y, por otro, la primacía del Derecho comunitario, sustentada en la imposibilidad de que los Estados hagan prevalecer medidas unilaterales que vayan en contra del ordenamiento comunitario; la necesaria fuerza vinculante del Derecho comunitario, que no puede variar de un Estado a otro a causa de legislaciones internas ulteriores, sin que peligren los objetivos del Tratado CEE; el carácter eventual que tendrían las obligaciones contraídas por los Estados miembros, si pudieran quedar cuestionadas por los actos legislativos posteriores de sus signatarios; la limitación de la soberanía de los Estados, cuya facultad de actuación unilateral se les reconoce mediante una cláusula especial expresa y cuyas peticiones para obtener una excepción están sometidas a autorización, las cuales no tendrían sentido si pudieran sustraerse de sus obligaciones mediante la promulgación de una ley; así como la fuerza obligatoria y directa de los Reglamentos (art. 189 del Tratado CEE). Otra resolución importante, al efecto, fue la STJCE de 9 de marzo de 1978 [Amministrazione delle Finanze dello Stato vs. SpA Simmenthal, asunto 106/77, disponible

http://curia.europa.eu/juris/showPdf.jsf?text=\&docid=89693\&pageIndex=0\&doclang=ES\&mode=doc\&di r=\&occ=first\&part=1\&cid=5051311 (consultado: 27.06.2017)], que se pronunció sobre los efectos del principio comentado, dejando claro que no sólo la norma nacional posterior deviene inaplicable si contraviene una norma comunitaria, sino también que la inaplicación opera sin necesidad de esperar a su expresa derogación por el órgano legislativo. Señala al respecto el TJCE: “[...] el Juez nacional encargado de aplicar, en el marco de su competencia, las disposiciones del Derecho comunitario, está obligado a garantizar la plena eficacia de dichas normas dejando, si procede, inaplicadas, por su propia iniciativa, cualesquiera disposiciones contrarias de la legislación nacional, aunque sean posteriores, sin que esté obligado a solicitar o a esperar la derogación previa de éstas por vía legislativa o por cualquier otro procedimiento constitucional" (F.J. 24'). También la jurisprudencia española ha sido receptiva a este principio (Vid. MARTín AlONSO, N., "Contradicción entre los ordenamientos jurídicos nacional y comunitario. El papel del juez nacional y la cuestión prejudicial", Noticias Jurídicas, publicado el 2 de septiembre de 2014, disponible en: http://noticias.juridicas.com/conocimiento/articulos-doctrinales/4926contradiccion-entre-los-ordenamientos-juridicos-nacional-y-comunitario-el-papel-del-juez-nacional-y-lacuestion-prejudicial/ (consultado: 27.06.2017). Así, por ejemplo, se pone de manifiesto en la STS (Sala de lo Contencioso-Administrativo), de 3 de noviembre de 2008 (Roj: STS 6061/2008) que, citando otras sentencias previas, enfatiza su posición de que los jueces nacionales, en su condición de jueces comunitarios, están obligados a salvaguardar la efectividad del Derecho comunitario y su supraordenación al Derecho interno conforme a la jurisprudencia del TJCE (F.J. $6^{\circ}$ ).

Al hilo de lo anterior, es importante mencionar que el art. 4.bis, apartado primero, de la Ley Orgánica 6/1985, de 1 de julio, del Poder Judicial, establece que los Jueces y Tribunales aplicarán el Derecho de la UE de conformidad con la jurisprudencia del TJUE. En consecuencia, el Juez nacional puede excluir la norma nacional incompatible con el Derecho de la UE. 
Ello generó una situación compleja debido a que la inaplicabilidad de una norma interna por su falta de concordancia con el Derecho de la UE no significa su derogación. En consecuencia, el art. 25 del TRLPI continuó estando vigente conforme a la redacción dada al mismo por la Ley 21/2014, de 4 de noviembre, aunque inaplicable, lo que impedía rescatar la regulación anterior, esto es, lo establecido en el art. 25 del TRLPI en su versión dada al mismo por la Ley 23/2006 de 7 de julio.

Debía, por tanto, procederse a la aprobación de una nueva normativa que regulase un sistema de compensación equitativa por copia privada acorde con la jurisprudencia europea y nacional, lo que se lleva a cabo mediante el Real Decreto-ley 12/2017, de 3 de julio, por el que se modifica el TRLPI, aprobado por el Real Decreto Legislativo 1/1996, de 12 de abril. El mismo instrumenta la compensación equitativa, nuevamente, mediante un sistema o modelo basado en el pago de una cantidad sobre los equipos, aparatos y soportes materiales de reproducción, también conocido como canon compensatorio, que conforma el ordenamiento jurídico actualmente vigente, como se analizará en el capítulo siguiente. 



\title{
CAPÍTULO V: EL RÉGIMEN JURÍDICO DE LA COMPENSACIÓN EQUITATIVA POR COPIA PRIVADA EN EL ORDENAMIENTO JURÍDICO ESPAÑOL
}

\author{
I. INTRODUCCIÓN. II. LA COMPENSACIÓN EQUITATIVA POR COPIA
} PRIVADA: GENERALIDADES. 1. Concepto. 2. Características. 3. Naturaleza jurídica. III. LOS SUJETOS DE LA COMPENSACIÓN EQUITATIVA. 1. Acreedores. 2. Deudores. IV. EL NACIMIENTO DE LA OBLIGACIÓN DE COMPENSAR. V. EL SISTEMA DE EXCEPTUACIONES Y REEMBOLSOS. 1. Las excepciones ex ante del pago de la compensación. 2. Los supuestos de reembolso ex post de la compensación. VI. LOS EQUIPOS, APARATOS Y SOPORTES MATERIALES IDÓNEOS A EFECTOS DEL PAGO DE LA COMPENSACIÓN. 1. El criterio de idoneidad. 2. El criterio de idoneidad objetiva en relación con la presunción de utilización de los equipos, aparatos y soportes materiales para la copia privada. 3. Los equipos, aparatos y soportes materiales de reproducción sujetos a la compensación: el tránsito de lo analógico a lo digital. 3.1. Los equipos, aparatos y soportes materiales de reproducción analógica. 3.2. Los equipos, aparatos y soportes materiales de reproducción digital. 3.2.1. El régimen provisional de la Disposición Transitoria única de la Ley 23/2006, de 7 de julio. 3.2.2. La Orden PRE/1743/2008, de 18 de junio. 3.2.3. La Disposición Transitoria segunda del Real Decreto-ley 12/2017, de 3 de julio. 3.2.4. El establecimiento de un nuevo régimen definitivo tras la etapa de transitoriedad. VII. LA CUANTÍA DE LA COMPENSACIÓN EQUITATIVA. 1. El perjuicio como elemento base del cálculo de la compensación. 2. Criterios objetivos para la determinación de la cuantía de la compensación. 2.1. Apuntes introductorios. 2.2. Los criterios objetivos del art. 25.5.a) del TRLPI. 2.2.1. La intensidad de uso de los equipos, aparatos y soportes materiales. 2.2.2. La capacidad de almacenamiento de los equipos, aparatos y soportes materiales y la importancia de la función de reproducción. 2.2.3. El impacto del límite legal de copia privada sobre la venta de ejemplares de las obras y el precio de la unidad de cada modalidad reproducida. 2.2.4. El carácter digital o analógico o la calidad y el tiempo de conservación de las reproducciones. 2.2.5. La disponibilidad, grado de aplicación y efectividad de las medidas tecnológicas y su impacto en las reproducciones realizadas al amparo del límite legal de copia privada. 2.2.6. La consideración de las cuantías aplicadas en otros Estados miembros de la UE como referencia. 3. El procedimiento para la determinación de la cuantía de la compensación. 4. La cuantía de la compensación en el régimen transitorio. VIII. LA GESTIÓN DE LA COMPENSACIÓN EQUITATIVA POR COPIA PRIVADA. 1. Las entidades encargadas de la gestión. 2. El procedimiento de gestión. 3. La distribución y posterior reparto de la compensación entre los acreedores. 



\section{INTRODUCCIÓN}

El presente capítulo analiza el régimen jurídico de la compensación equitativa por copia privada en España, de acuerdo con los últimos cambios legislativos acaecidos con la promulgación del Real Decreto-ley 12/2017, de 3 de julio, cuya entrada en vigor se ha producido el 1 de agosto de 2017. No obstante, debe tenerse en cuenta que durante el primer año de su vigencia es de aplicación el régimen establecido en su Disposición Transitoria segunda, que rige, con carácter temporal, hasta la aprobación del Reglamento que establecerá, de forma definitiva, el procedimiento de pago, liquidación y reembolso de la compensación equitativa por copia privada.

Así pues, si bien este capítulo pretende ser una referencia actualizada de esta temática, lo cierto es que no puede perderse de vista que muchos de los comentarios que aquí se realizan se hacen partiendo del régimen transitorio vigente. No obstante, lo anterior no hace perder virtualidad a las cuestiones aquí tratadas, pues, en definitiva, el régimen jurídico de la compensación equitativa no se verá alterado por las especificaciones reglamentarias que se establezcan. Antes bien, estas disposiciones se referirán a los equipos, aparatos y soportes materiales sujetos al pago de la compensación equitativa, las cantidades que los deudores deberán abonar por este concepto a los acreedores y la distribución de dicha compensación entre las distintas modalidades de reproducción, pero aplicando el procedimiento y los criterios contenidos en los apartados del art. 25 del TRLPI y sin afectar, en modo alguno, a la definición legal y naturaleza jurídica de esta compensación y a los sujetos obligados al pago de la misma que son, en definitiva, los pilares básicos de ésta.

\section{LA COMPENSACIÓN EQUITATIVA POR COPIA PRIVADA: GENERALIDADES}

\section{Concepto}

La compensación equitativa por copia privada es un concepto introducido en el acquis comunitario con la DDASI. Sin embargo, esta norma no ofrece una definición al respecto, como tampoco hace remisión alguna al Derecho de los Estados miembros a efectos de determinar el sentido y alcance de esta compensación. 
En estas circunstancias, según jurisprudencia consolidada del TJUE, el tenor de una disposición de Derecho de la UE, que no contenga una remisión expresa al Derecho de los Estados miembros, debe ser objeto de una interpretación autónoma y uniforme en todo su territorio. En concreto, así lo declara el TJUE (Sala Tercera), en su sentencia de 21 de octubre de 2010 (caso Padawan) ${ }^{810}$ que, entre otras cuestiones, se pronuncia sobre el alcance del concepto de compensación equitativa por copia privada.

En efecto, el TJUE sostiene que el concepto de compensación equitativa por copia privada constituye un concepto autónomo de Derecho de la UE, que debe interpretarse de manera uniforme en todos los Estados miembros que hayan establecido la excepción de copia privada, con independencia de la facultad que éstos tienen reconocida para determinar -dentro de los límites impuestos por el Derecho de la Unión y, en particular, por la propia DDASI-, la forma, las modalidades de financiación y de percepción y la cuantía de dicha compensación equitativa ${ }^{811}$.

La propia finalidad armonizadora de la DDASI corrobora dicho carácter autónomo y la interpretación uniforme de este concepto por los Estados miembros. No tendría sentido una postura diferente -conclusión que también alcanza el TJUE-, pues sería contrario al objetivo de la DDASI una interpretación según la cual los Estados miembros que han establecido la excepción de copia privada tengan libertad para precisar los parámetros de la compensación equitativa de forma incoherente y no armonizada, susceptible de variar de un Estado a otro ${ }^{812}$. Por tanto, el sentido y alcance del concepto de compensación equitativa corresponde al ordenamiento europeo y, con ello, queda prohibido al legislador y a los jueces nacionales interpretar esta figura jurídica desde una perspectiva nacional ${ }^{813}$.

${ }^{810}$ STJUE (Sala Tercera), de 21 de octubre de 2010, Padawan S.L. contra Sociedad General de Autores y Editores de España (SGAE), asunto C- 467/08 [(JCE\2010\312), párrafo 32, que cita, por todas, las sentencias de 18 de enero de 1984, Ekro, C-327/82, apartado 11; de 19 de septiembre de 2000, Linster, C287/98, apartado 43, y de 2 de abril de 2009, A, C-523/07, apartado 34.

${ }^{811}$ Ibídem, párrafos 33 y 37.

812 Ibídem, párrafos 34-36.

${ }^{813}$ López MAZA, S. y Minero AlejAndRE, G., "El carácter equitativo de la compensación por copia privada. Comentario a la sentencia de TJUE de 11 de octubre de 2010 (caso Padawan)", Pe. I. Revista de Propiedad Intelectual, núm. 36, 2010, p. 97. 
En todo caso, el concepto de "compensación equitativa" no es equivalente al concepto de "remuneración equitativa" regulado en los arts. 4.4 y 8.2 de la Directiva 2006/115, 12 de diciembre, sobre derechos de alquiler y préstamo y otros derechos afines a los derechos de autor en el ámbito de la propiedad intelectual ${ }^{814}$. La diferencia radica, en términos generales, en que la remuneración equitativa parte de la idea de que los autores tienen derecho a una retribución por cada acto de utilización de sus obras protegidas, mientras que la compensación equitativa por copia privada conecta con el posible daño derivado de estos $\operatorname{actos}^{815}$. En efecto, los derechos de mera remuneración sustituyen el ius prohibendi del titular de derechos de propiedad intelectual -dado el establecimiento de licencias obligatorias- por el derecho a percibir una remuneración. Sin embargo, la compensación equitativa es consecuencia del ejercicio legal del límite de copia privada y concede a su titular la facultad de percibir una cantidad de dinero, a modo de compensación, con motivo de la autorización, ex lege, de dicho límite ${ }^{816}$.

Esta finalidad queda expuesta en el Considerando $35^{\circ}$ de la DDASI, que declara que, en determinados casos de excepciones y limitaciones, los titulares de derechos deberían recibir una compensación equitativa para recompensarles adecuadamente por el uso que se haya hecho de sus obras o prestaciones protegidas; compensación que, conforme al Considerando $38^{\circ}$ y al art. 5.2.b) de la DDASI, se establece para el límite de copia privada. Esta compensación, en consecuencia, permite mitigar los efectos causados por el reconocimiento legal de esta excepción.

${ }^{814}$ D.O.U.E. núm. 376, de 27 de diciembre de 2006.

${ }^{815}$ Comisión Europea, Fair compensation for acts of private copying (Background Document), Bruselas, 14 de febrero de 2008, disponible en:

http://ec.europa.eu/internal_market/copyright/docs/levy_reform/background_en.pdf (consultado: 29.10.2016): "While the notion of 'equitable remuneration' is based on the assumption that authors are entitled to remuneration for every act of usage of their protected works, fair compensation is, inter alia, linked to the possible harm that derives from acts of private copying (cf. recital 35 of the Directive). Article 5(2)(b) therefore requires that any payment to rightholders must be compensatory in nature". Así, por ejemplo, el art. 8.2 de la Directiva 2006/115, 12 de diciembre, sobre derechos de alquiler y préstamo y otros derechos afines a los derechos de autor en el ámbito de la propiedad intelectual, reconoce un derecho de remuneración equitativa y única a favor de los artistas intérpretes o ejecutantes y productores de fonogramas, derivado de la obligación del usuario de un fonograma publicado con fines comerciales, o de una reproducción de dicho fonograma, que se utilice para la radiodifusión inalámbrica o para cualquier tipo de comunicación al público de pagar una remuneración equitativa y única a los artistas intérpretes o ejecutantes y productores de fonogramas, entre los cuales se efectuará el reparto de la misma.

${ }^{816}$ CARBAJO CASCón, F., "La 'larga marcha' de la compensación...”, op. cit., p. 35. 
De tal suerte, el término "compensación equitativa" introducido por la DDASI, a diferencia del de "remuneración equitativa", se aviene mejor a la naturaleza misma de la figura. $\mathrm{Y}$ es que, se insiste, no se trata de remunerar al titular de derechos como contrapartida por la cesión de su derecho de explotación, sino más bien de compensarle, de restablecer un desequilibrio patrimonial objetivamente causado por la conducta de quien realiza reproducciones con fines privados, lo que redunda en un perjuicio patrimonial para el titular de los derechos de propiedad intelectual.

Esta lógica compensatoria es además confirmada cuando la norma europea regula la conciliación entre las medidas tecnológicas de protección y la copia privada ${ }^{817}$. En efecto, la DDASI prevé la modulación de la compensación teniendo debidamente en cuenta el grado de utilización de las medidas tecnológicas de protección (Considerando $\left.35^{\circ}\right)$.

Con todo, es posible conceptualizar la compensación equitativa por copia privada como una obligación legal, de contenido económico, establecida en favor de los titulares de derechos sobre las obras y prestaciones intelectuales reproducidas al amparo del límite legal de copia privada, que se dirige a compensarles por el perjuicio causado como consecuencia de dichas reproducciones. A lo anterior hay que agregar, como se ha expuesto, que se trata de un concepto autónomo del Derecho de la UE y que ha de interpretarse de manera uniforme en el territorio de ésta, como ha dejado establecido la citada sentencia del TJUE de 21 de octubre de 2010 (caso Padawan).

\section{Características}

Siguiendo la DDASI y el TRLPI son varios los elementos que caracterizan la compensación equitativa por copia privada ${ }^{818}$. Conforme al tenor de la DDASI, cabe

\footnotetext{
${ }^{817}$ Colin, C., Droit d 'utilisation..., op. cit., p. 442.

${ }^{818}$ Garrote FernándeZ- DíEz, I., "Artículo 25", en Bercovitz RodríGuez-Cano, R. (Coord.), Comentarios a la Ley de Propiedad..., $3^{\text {a }}$ ed., op. cit., p. 454, señala diversas características de la compensación equitativa por copia privada a tenor de la regulación contenida en el art. 25 (y arts. relacionados) del TRLPI, tras su modificación por la Ley 23/2006, de 7 de julio, muchas de las cuales persisten hasta hoy en nuestro ordenamiento. Por tal razón, este apartado es, en gran medida, reflejo de los comentarios hechos por el autor.
} 
mencionar su carácter legal, por cuanto se instrumenta en la misma, así como su carácter compensatorio y equitativo, como su propio nombre indica. Estas características también se hacen evidentes en el ordenamiento jurídico interno, donde, igualmente, la compensación equitativa por copia privada se establece y regula por la ley y de la cual también se predica su carácter compensatorio y equitativo.

En efecto, el carácter compensatorio lo indica expresamente el art. 25.1 del TRLPI cuando dispone que la compensación por copia privada se dirige a "compensar adecuadamente el perjuicio causado a los sujetos acreedores como consecuencia de las reproducciones realizadas al amparo del límite legal de copia privada". Lo mismo sucede con el carácter equitativo, pues el precepto califica expresamente a la compensación como “equitativa y única" para cada una de las modalidades de reproducción autorizadas, sin obviar que la propia rúbrica del art. 25 del TRLPI ya utiliza este calificativo ("Compensación equitativa por copia privada"819).

La característica de "equitativa" se asocia al hecho de que la compensación debe ser proporcional al posible daño causado a los titulares de derechos de autor, teniendo en cuenta el mercado de explotación de la obra de que se trate y la afectación que produce la copia privada en éste. Ello implica que la cuantía de la compensación no puede ser arbitraria, sino que tiene que obedecer a unos criterios o parámetros legalmente predeterminados, de forma tal que pueda ser expresión de los ingresos dejados de percibir por la afectación que produce la copia privada ${ }^{820}$. En consecuencia,

\footnotetext{
819 Énfasis añadido.

${ }^{820}$ El modelo de satisfacción de la compensación por copia privada con cargo a los PGE puso en duda el carácter equitativo de esta compensación. En efecto, la compensación podía verse afectada por el hecho de que la cantidad global destinada a la compensación equitativa quedara sujeta a los límites presupuestarios establecidos para cada ejercicio, conforme establecía el art. 25.3 del TRLPI, en la versión dada al mismo por la mencionada Ley 21/2014. Así lo puso de relieve el ATS (Sala de lo ContenciosoAdministrativo, Sección 4 ${ }^{\text {a }}$ ), de 10 de septiembre de 2014 (ATS 6659/2014). Vid. Supra, Capítulo IV.

El carácter equitativo de la compensación también era puesto en duda bajo la vigencia de las versiones precedentes del TRLPI debido al establecimiento de cuantías a tanto alzado en relación con los equipos y soportes de grabación, sin que quedara claro que la cantidad a compensar obedeciera realmente al daño causado a los titulares de derechos de autor. También se cuestionaba el hecho de que los discos duros de ordenador, por ejemplo, aun siendo idóneos para la copia privada, no fueran incluidos como parte de los dispositivos gravados con el canon. Vid. GARROTE FERnÁNDEZ- DíEZ, I., "Artículo 25”, en BERCOVITZ RodrígueZ-CANO, R. (Coord.), Comentarios a la Ley de Propiedad..., $3^{\mathrm{a}}$ ed., op. cit., p. 459 y, en el mismo sentido, CARBAJO CASCÓN, F., "La 'larga marcha' de la compensación...”, op. cit., p. 42.
} 
la cantidad establecida en concepto de compensación equitativa por copia privada debe estar vinculada con el daño sufrido por los titulares de derechos de propiedad intelectual $^{821}$.

A lo anterior hay que agregar que el carácter equitativo de la compensación por copia privada conecta, ineludiblemente, con la idea esencial del "justo equilibrio" entre los derechos e intereses de los autores y demás titulares de derechos de propiedad intelectual, beneficiarios de la compensación equitativa, por un lado, y los de los usuarios de obras y prestaciones protegidas, por otro, al que se refiere el Considerando $31^{\circ}$ de la DDASI. Téngase en cuenta que la compensación equitativa viene a resarcir un perjuicio "necesario", en la medida en que no puede ser evitado porque deben salvaguardarse otros intereses implícitos en la actividad de copia privada. Precisamente esto legitima la compensación. Pero, de otro lado, la compensación tiene que ser proporcional al daño sufrido, pues tampoco sería justo establecer una compensación demasiado gravosa para los obligados al pago. En este sentido debe expresarse en una cantidad adecuada, no arbitraria, que puede llegar incluso a ser inexistente -por mandato legal- en aquellas situaciones en las que pueda considerarse que el daño causado al titular de derechos es mínimo [art. 25.5.b) del TRLPI] ${ }^{822}$.

Ahora bien, también destacan otras características de la compensación equitativa por copia privada. Siguiendo el art. 25.1 del TRLPI, la compensación equitativa debe ser, además de equitativa, única, para cada una de las tres modalidades de reproducción

${ }^{821}$ Vid. Garrote Fernández-Díez, I., "Artículo 9", en Bercovitz RodrígueZ-Cano, R. (Coord.), Comentarios al Convenio de Berna..., op. cit., p. 459.

${ }^{822} \mathrm{El}$ art. 25.5.b) del TRLPI es expresión de lo dispuesto en el Considerando $35^{\circ}$ in fine de la DDASI, que reconoce que cuando se causa un perjuicio mínimo al titular de derechos, éste no tiene que ser compensado. Consigna expresamente dicho Considerando: "Determinadas situaciones en las que el perjuicio causado al titular del derecho haya sido mínimo no pueden dar origen a una obligación de pago". Nótese que se dice que el perjuicio mínimo no debe generar la obligación de compensar. En la doctrina, sin embargo, se defiende que todo perjuicio causado al titular de derechos de propiedad intelectual debe ser resarcido, con lo cual, para que haya equidad, la solución no sería no compensar, sino compensar en menor medida. Al respecto señala LóPEZ MAZA, S., "Estudio de los criterios del art. 25.6.4 LPI y su aplicación a la Orden ministerial PRE/1743/2008, de 18 de junio", Pe. I. Revista de Propiedad Intelectual, núm. 32, 2009, p. 60: "Para que existiera un tratamiento equitativo, debería decirse que si el perjuicio causado al titular de los derechos es mínimo, la compensación será también mínima, en lugar de inexistente". En el mismo sentido Vid. LóPEZ MAZA, S. y Minero Alejandre, G., "El carácter equitativo...”, op. cit., p. 99. La referencia al perjuicio mínimo viene establecida en el TRLPI desde su modificación por la Ley 23/2006, de 7 de julio. 
que este precepto menciona. Por tanto, la reproducción mediante aparatos o instrumentos técnicos no tipográficos de libros y publicaciones asimiladas da lugar a una única cantidad compensatoria; lo mismo que la reproducción de fonogramas y demás soportes sonoros; y la reproducción de videogramas y demás soportes visuales o audiovisuales.

Asimismo, la compensación equitativa por copia privada es de gestión colectiva obligatoria, es decir, se hace efectiva a través de las entidades de gestión de derechos de propiedad intelectual. Así lo recoge actualmente el art. 25.9 del TRLPI, si bien esta característica no constituye una novedad, ni es exclusiva del ordenamiento jurídico español, sino que está presente en todos los ordenamientos jurídicos del ámbito europeo $^{823}$.

Destaca, además, su carácter irrenunciable para los autores y para los artistas intérpretes o ejecutantes. Así lo establece el art. 25.2 in fine del TRLPI en su versión actual al igual que en sus anteriores versiones. En consecuencia, los titulares de derechos de propiedad intelectual no pueden renunciar a la compensación y, aun si deciden no obtener los rendimientos económicos derivados de la compensación por copia privada, se procederá igualmente a su recaudación ${ }^{824}$. Según parece, lo que se pretende es proteger a los acreedores considerados más débiles, como de hecho, ha puesto de relieve la doctrina ${ }^{825}$.

Otro rasgo propio de la compensación equitativa es su configuración a partir de las tres modalidades de reproducción consignadas en el art. 25 del TRLPI, a saber, libros o publicaciones que a estos efectos se asimilen reglamentariamente, fonogramas y demás soportes sonoros y videogramas y demás soportes visuales y audiovisuales.

\footnotetext{
${ }^{823}$ Marín LóPez, J. J., “Artículo 153”, en BerCovitz RodríGueZ-CANO, R. (Dir.), Comentarios a la Ley de Propiedad..., $3^{\mathrm{a}}$ ed., op. cit., p. 1907.

${ }^{824}$ LÓPEZ MAZA, S. y MiNERO AlEJANDRE, G., "El carácter equitativo....", op. cit., p. 93.

${ }^{825}$ DELgado PorRas, A., "La gestión colectiva de los Derechos de Autor", en Estudios sobre Derecho Industrial. Homenaje a $\mathrm{H}$. Baylos (Colección de trabajos sobre propiedad industrial e intelectual y derecho de la competencia), Grupo español de la AIPPI, Barcelona, 1992, p. 210.
} 
Puede decirse, además, que la compensación equitativa por copia privada ha estado marcada por las diferencias entre el entorno analógico y digital. Así lo evidencia, por ejemplo, lo dispuesto en el Considerando $35^{\circ}$ de la DDASI cuando vincula el nivel de compensación con el grado de utilización de las medidas tecnológicas de protección; o el contenido del art. 25.5.a) del TRLPI, en su apartado $6^{\circ}$, cuando dispone que, a los efectos de la determinación de la cuantía de la compensación, se tendrá en cuenta "la disponibilidad, grado de aplicación y efectividad de las medidas tecnológicas a las que se refiere el artículo 160.3 del TRLPI y su impacto en las reproducciones realizadas al amparo del límite legal de copia privada".

Por otra parte, es importante dejar claro que la compensación equitativa por copia privada no está dirigida a resarcir las pérdidas que puedan sufrir los derechohabientes como resultado de reproducciones ilícitas derivadas de actos de piratería, sino a compensar los daños producidos por las copias autorizadas legalmente al amparo del límite de copia privada. Sólo las copias que cumplen los requisitos del art. 31.2 y 3 del TRLPI pueden dar lugar a la compensación por copia privada, no así las realizadas a partir de fuentes ilícitas, toda vez que el acceso legal constituye una condición sine qua non de dicho límite al derecho de reproducción ${ }^{826}$.

Finalmente, cabe mencionar que la DDASI no establece un modelo único para hacer efectiva la compensación equitativa por copia privada, sin perjuicio de que el modelo implementado por la mayoría de los Estados miembros de la UE, hasta el momento, se haya basado en el establecimiento de un canon o gravamen sobre los equipos, aparatos y soportes de reproducción aptos para la copia para uso privado. No obstante, no puede perderse de vista que se opone al art. 5.2.b) de la DDASI, como se expuso en el capítulo precedente, un modelo basado en la satisfacción de la compensación con cargo a los PGE, en el que no sea posible asegurar que la compensación sea soportada por los beneficiarios de la excepción de copia privada.

${ }^{826}$ Vid. Art. 31.2.b) del TRLPI. 


\section{Naturaleza jurídica}

La compensación equitativa por copia privada ha sido considerada por algún sector doctrinal como una suerte de licencia legal ${ }^{827}$, teniendo en cuenta que este tipo de licencia permite la utilización de la obra sin autorización del autor a cambio de una remuneración legalmente establecida. Sin embargo, esta perspectiva no está exenta de inconvenientes. El problema fundamental que enfrenta es que la licencia legal opera sobre un acto de explotación normal de la obra (reproducción, comunicación pública...), mientras que la compensación equitativa recae sobre una excepción o limitación al derecho de autor: la copia $\operatorname{privada}^{828}$. Partiendo de este presupuesto, no parece correcto admitir que la compensación equitativa por copia privada se equipare a una licencia legal ${ }^{829}$.

No obstante, desde la doctrina, también se ha intentado reconciliar esta diferencia. $\mathrm{Al}$ respecto, COLIN nos ilustra sobre la propuesta del profesor GAUDRAT, para quien el corazón del debate no es la copia privada, sino su explotación, es decir, la circulación de la copia libre fuera del círculo de familia ${ }^{830}$. Para GAUDRAT, el perjuicio surge cuando la copia privada sale del círculo de familia y puede disuadir a terceros de comprar un ejemplar, no cuando la copia circula en su interior. La sutileza de su razonamiento consiste en considerar de un modo diferente el acto que da origen a la compensación;

\footnotetext{
${ }^{827}$ Por todos, Bondía Román, F., Propiedad Intelectual: Su significado..., op. cit., p. 268: “[...] el derecho de remuneración por la copia privada supone una licencia legal, o sea, una autorización concedida por la legislación de propiedad intelectual para utilizar una obra protegida de una manera determinada y en ciertas condiciones (copiarla por los modernos equipos de reproducción para un uso privado), a cambio del pago de unos derechos de autor (regalías o remuneración compensatoria) que se hacen efectivos al comprar los aparatos reproductores".

${ }^{828}$ Existen, no obstante, semejanzas entre la compensación equitativa por copia privada y la licencia legal, pues ambas impiden al titular de derechos prohibir el uso de la obra o prestación intelectual y, en ambos casos, la compensación viene fijada por la ley.

${ }^{829}$ Colin, C., Droit d'utilisation..., op. cit., p. 437. Señala la autora: «En effet, dans la mesure où la licence légale est une alternative au droit exclusif, comment accepter qu'une rémunération puisse être octroyée aux auteurs pur des usages qui sont étrangers à leur sphère patrimoniale? Comment expliquer qu'une licence légale rémunère une pratique étrangère au droit exclusif de l'auteur ? Dès l'instant où il est admis que le droit d'auteur n'exerce son emprise qu'en présence d'une communication des ouvres au public, il n'est pas concevable de définir la rémunération pour copie privée sonore et audiovisuelle comme une licence légale ».

${ }^{830}$ GAUDRAT, Ph., "Le droit d'auteur au lendemain de la transposition: Titre $1^{\text {er }}$ de la loi $\mathrm{n}^{\mathrm{o}} 2006-961 \mathrm{du}$ 1er août 2006", RTD com., janv. - mars. 2007, pp. 107-137, spéc. № 79, p. 129, cit. por Colin, C., Droit d'utilisation..., op. cit., p. 438.
} 
ésta no procede de la copia privada sino de la explotación de la copia privada $^{831}$; y es esto lo que lleva a concluir al autor que el sistema de compensación por copia privada se corresponde con una verdadera licencia legal, fundada no en la compensación de una excepción, sino en la compensación de un modo de explotación independiente de la excepción ${ }^{832}$, esto es, de la copia que circula fuera del círculo familiar.

Sin embargo, tampoco este planteamiento convence al efecto de considerar la compensación equitativa como una licencia legal, pues significaría admitir que toda puesta a disposición de una copia privada fuera del círculo de familia estaría implícitamente autorizada al recaer sobre la misma la compensación ${ }^{833}$, algo que contraviene la naturaleza del límite de copia privada que se autoriza, únicamente, para uso privado, es decir, restringido a dicho círculo de familia, que también comprende a las amistadas más allegadas.

A mayor abundamiento, la idea de la compensación como licencia legal no se avendría al sentido tradicional del término, ni siquiera en el caso de otorgar una naturaleza particular a esta licencia admitiendo que pudiera recaer sobre una limitación o excepción al derecho de autor y no sobre un derecho patrimonial exclusivo. Y es que la finalidad de la licencia legal difiere de la que persigue la compensación equitativa pues, mientras que la licencia legal satisface los intereses económicos de terceros utilizadores, la compensación equitativa compensa a los titulares de derechos de autor y satisface, consecuentemente, los intereses patrimoniales de estos ${ }^{834}$. Asimismo, la licencia legal no retribuye un modo de explotación privado de las obras y prestaciones intelectuales, sino, por el contrario, un modo de explotación público de las mismas ${ }^{835}$.

Por otra parte, también se ha acudido a la tesis de la responsabilidad civil objetiva para explicar la naturaleza jurídica de la compensación equitativa por copia privada ${ }^{836}$,

\footnotetext{
${ }^{831}$ Colin, C., Droit d'utilisation..., op. cit., p. 438.

${ }^{832}$ Ibídem, p. 439.

833 Ídem.

${ }^{834}$ Ibídem, p. 437.

835 Ídem.

${ }^{836}$ En lo que atañe al sistema español de compensación equitativa, se ha afirmado que esta tesis fue la que se tomó en consideración en los proyectos legislativos que dieron lugar a la LPI de 1987, ROGEL VIDE, C., Estudios completos..., op. cit., p. 205.
} 
seguramente porque las teorías objetivas de la responsabilidad civil se preocupan por las consecuencias de los daños provocados por quien pone en riesgo a los demás con su actuación ${ }^{837}$. Téngase en cuenta que en la responsabilidad civil objetiva la obligación de reparar el daño no va ligada a la culpa característica de la responsabilidad extracontractual, sino que se vincula al nexo causal ${ }^{838}$.

Sin embargo, esta tesis tampoco es satisfactoria para determinar la naturaleza jurídica de la compensación equitativa por copia privada. En efecto, la razón fundamental se sustenta en la inexistencia de un ilícito civil, pues el límite de copia privada está autorizado legalmente, con lo cual, goza de licitud y no puede dar lugar a responsabilidad, sino, en todo caso, a una compensación por las pérdidas que sufren los titulares de derechos de autor por la implementación legal de dicho límite. Es cierto que se produce un daño para los titulares de derechos de propiedad intelectual derivado de la copia privada, pero procedente del propio acto de copia que la legislación autoriza; un daño que, aunque justo, merece reparación ${ }^{839}$.

Tampoco se aviene a la naturaleza de la responsabilidad civil objetiva el procedimiento de pago de la compensación, que sólo se puede garantizar a través de la actividad de las entidades de gestión colectiva de los derechos de propiedad intelectual $^{840}$. Contrariamente, la indemnización derivada de la responsabilidad civil objetiva depende de la gestión del afectado, quien no se ve compelido a recurrir a ningún ente colectivo para la satisfacción de su derecho. De igual modo, tampoco se ajustan los criterios de distribución de la compensación equitativa por copia privada a la

\footnotetext{
${ }^{837}$ Las teorías objetivas de la responsabilidad civil dan sustento a "la necesidad de indemnizar a quien haya sido víctima del riesgo creado por el causante del daño con su actuar, pues si se beneficia con ello también ha de pechar con las consecuencias dañosas", DíEZ PiCAZO, L. y Gullón, A., Sistema de Derecho Civil, Vol. II, Tomo 2, $10^{\mathrm{a}}$ ed., Tecnos, Madrid, 2012, p. 315.

${ }^{838}$ O`Callaghan Muñoz, X., Compendio de Derecho Civil, Tomo 2 (Derecho de Obligaciones), Editorial Universitaria Ramón Areces, Madrid, 2012, p. 685.

${ }^{839}$ RoGEL VIDE, C., Estudios completos..., op. cit., p. 208. Señala el autor: "Ello sabido, la justificación de la remuneración [recuérdese que las primeras leyes de propiedad intelectual hacían uso del término remuneración] no es, nunca, el ilícito civil, sino, y si cabe, la constatación de un daño -para los autoresderivado del legítimo ejercicio de un derecho - por los copistas- [era el término empleado en la LPI hasta la Ley 23/2006, de 7 de julio], daño que, aunque justo, es merecedor de reparación”. Y agregaba: “[...] el daño es justo, la antijuricidad no se puede afirmar, pero tampoco que el daño no sea, en modo alguno resarcible".

${ }^{840}$ Ibídem, p. 206.
} 
responsabilidad civil objetiva pues, mientras estos reservan, normalmente, un porcentaje de la recaudación para fines sociales y culturales ${ }^{841}$, en el caso de la responsabilidad civil objetiva no es necesario deducir ninguna cantidad a estos fines. En contra de esta asimilación destaca también que la compensación equitativa no se satisface -al menos directamente- por quienes utilizan los equipos, aparatos y soportes materiales de reproducción para efectuar copias para uso privado ${ }^{842}$, es decir, por los usuarios de estos dispositivos de reproducción, pues los deudores legalmente establecidos son los fabricantes en España, en tanto actúen como distribuidores comerciales, así como los adquirentes fuera del territorio español, para su distribución comercial o utilización dentro de éste y, en su caso, los distribuidores, mayoristas y minoristas, que sean sucesivos adquirentes de los mencionados equipos, aparatos y soportes, los cuales responderán de esta obligación solidariamente, con respecto a los deudores que se los hubieran suministrado, salvo que acrediten haber satisfecho efectivamente a estos la compensación (art. 25.3, párrafo 2, del TRLPI).

Por otra parte, hay autores que han considerado que la figura de la compensación equitativa por copia privada posee un carácter impositivo o tributario. Al respecto, la doctrina ha debatido sobre la naturaleza fiscal del canon compensatorio, calificándola bien como impuesto, bien como tasa. Igualmente se ha propuesto su calificación como prestación patrimonial de carácter público, en concreto, como exacción parafiscal ${ }^{843}$.

Es cierto que la compensación equitativa comparte con los tributos la nota común de la coactividad en cuanto obligación de pagar una suma de dinero ex lege, pero se

\footnotetext{
841 Ídem.

${ }^{842}$ Ibídem, p. 210.

${ }^{843}$ Al respecto: RuIZ Hidalgo, C., "Aproximación tributaria a la naturaleza del canon analógico y digital", Crónica Tributaria, núm. 135, 2010, pp. 215-229; FALCóN Y TELLA, R., "La compensación equitativa por copia privada. (Copyright Levy) tras la Ley 23/2006 (RCL 2006, 1386): una exacción parafiscal de dudosa constitucionalidad", Revista española de Derecho Tributario y Financiero, núm. 137, 2008; RuIZ ZAPATERO, G. G., "Naturaleza y límites constitucionales de la compensación equitativa por copia digital privada establecida en la Ley 23/2006 (RCL 2006, 1386) de modificación del Texto Refundido de la Ley de Propiedad Intelectual", Repertorio de jurisprudencia Aranzadi, núm. 7, 2007, pp. 185 y ss., disponible en: http://noticias.juridicas.com/conocimiento/articulos-doctrinales/4277-naturalezay-limites-constitucionales-de-la-compensacion-equitativa-por-copia-digital-privada-establecida-en-la-ley23-2006-de-modificacion-del-texto-refundido-de-la-ley-de-propiedad-intelectual/) (consultado: 18.10.2016).
} 
diferencia de estos porque no es un ingreso público, ni se destina a gastos públicos en sentido estricto.

Así, se ha negado la calificación de la compensación equitativa por copia privada como impuesto o tasa ${ }^{844}$. Considerarla como un impuesto [art. 2.2.c) de la Ley 58/2003, de 17 de diciembre, General Tributaria ${ }^{845}$ ] supondría determinar que su hecho imponible es "la reproducción realizada exclusivamente para uso privado, mediante aparatos o instrumentos técnicos no tipográficos, de obras divulgadas en forma de libros o publicaciones que a estos efectos se asimilen reglamentariamente, así como fonogramas, videogramas o de otros soportes sonoros, visuales o audiovisuales" (art. $25.1 \mathrm{del}$ TRLPI). Sin embargo, la entrega onerosa de estos equipos, aparatos y soportes queda gravada mediante el impuesto sobre el valor añadido (IVA), con lo cual, puede resultar confuso que la compensación por copia privada vuelva a gravar la adquisición de estos a través de la repercusión que del mismo se hace a sus adquirentes ${ }^{846}$. Además, no siempre la adquisición de dichos equipos, aparatos y soportes se hace para reproducir obras protegidas por la propiedad intelectual ${ }^{847}$. Estos argumentos descartan su consideración como impuesto.

A su vez, para considerar a la compensación equitativa como una tasa, tendría la Administración que realizar una actividad o prestar un servicio en régimen de derecho público que se refiera, afecte o beneficie de modo particular al obligado tributario, cuando los servicios o actividades no sean de solicitud o recepción voluntaria para los obligados tributarios o no se presten o realicen por el sector privado [art. 2.2.a) de la Ley 58/2003]. En este sentido, lo cierto es que la compensación equitativa no supone actividad administrativa alguna dirigida a los deudores del canon y, aun cuando pudiera argumentarse que existe una autorización legal para permitir la copia privada como

\footnotetext{
${ }^{844}$ RUIZ HIDALGO, C., “Aproximación tributaria a la naturaleza...”, op. cit., pp. 221-222.

${ }^{845}$ B.O.E. núm. 302, de 18 de diciembre de 2003.

${ }^{846}$ RUIZ HidAlgO, C., “Aproximación tributaria a la naturaleza...”, op. cit., p. 221.

${ }^{847}$ Ibídem, pp. 221-222.
} 
resultado de la cual la compensación es exigible, realmente se trata de un límite legal al derecho de reproducción, autorizado por el TRLPI en virtud de su art. $31.2^{848}$.

Tampoco resulta acertado considerar que se trata de una prestación patrimonial de carácter público como sostienen algunos autores ${ }^{849}$. En efecto, aun justificado su carácter de prestación pecuniaria impuesta por la ley independientemente de la voluntad de los sujetos implicados, elemento que evidencia la coactividad (propia de cualquier prestación patrimonial de carácter público), no concurre el mencionado carácter público. Para que así fuera, tendría que haber un desplazamiento por parte del Estado de la carga económica que le correspondería soportar, derivada del ejercicio de una función pública que la Constitución le encomienda, característica que no se cumple en este caso ${ }^{850}$.

Resulta esencial señalar que, pese al uso común del término canon compensatorio como sinónimo de la expresión compensación equitativa, así como su uso indistinto (como también se hace en este trabajo para facilitar la redacción, teniendo en cuenta el uso del vocablo, tanto por la doctrina, como por la propia jurisprudencia nacional y europea), ello no implica, en modo alguno, atribuir una naturaleza fiscal a la compensación equitativa por copia privada. Respecto a esta cuestión semántica, hay que decir que, simplemente, se fue acuñando en el vocabulario popular y jurídico el uso del vocablo "canon" para referirse a esta compensación, porque el mecanismo diseñado por el legislador para compensar a los titulares de derechos de propiedad intelectual frente a la copia privada fue establecer un importe o gravamen sobre el precio de comercialización de los soportes idóneos para realizar copias privadas.

En cambio, estos términos no son equiparables en sentido jurídico. En un uso ordinario, la palabra canon es sinónimo de tasa, renta, gravamen, contribución, etc. En

\footnotetext{
${ }^{848}$ Ibídem, p. 222.

${ }^{849}$ FALCÓN Y TELlA, R., "La compensación equitativa..., op. cit., pp. 10 y ss.; RUIZ ZAPATERO, G. G., "Naturaleza y límites constitucionales...", op. cit., pp.198 y ss.; GÓMEZ JIMÉNEZ, C., "La responsabilidad patrimonial del Estado legislador y el canon", Revista de Contabilidad y Tributación, núm. 338, 2011, pp. 92 y ss.

${ }^{850}$ PIÑA GARRIDO, L., "El canon digital español y el derecho comunitario: Conclusiones de la abogada general en el asunto C-467/08, Sociedad General de Autores y Editores (SGAE) contra Padawan S.L., pendientes de la sentencia del TJUE”, Crónica Tributaria: Boletín de Actualidad, núm. 7, 2010, pp. 3031 .
} 
el Derecho Tributario lo normal es que el vocablo canon o regalía se emplee en los “Convenios para Evitar la Doble Imposición sobre la Renta y el Capital”, aplicándose desde inicios del siglo XX a "los pagos por el uso o derecho a usar diferentes intangibles o bienes tangibles", especialmente en los países de tradición continental ${ }^{851}$. En España, al margen de otros significados otorgados a este término en el ámbito civil y mercantil ${ }^{852}$, en materia fiscal ha estado asociado a diferentes significados como "el impuesto o título que los concesionarios de minas satisfacen al Estado" o como sinónimo de precio o tasa ${ }^{853}$. En cambio, la compensación equitativa, como ya se apuntó, tiene una naturaleza diferente; una naturaleza compensatoria, que se asocia a otros fines.

La tesis de la compensación equitativa o del canon como tributo o exacción parafiscal ha sido descartada por la jurisprudencia, que ha reiterado que la compensación equitativa por copia privada es una obligación civil de naturaleza privada. Al respecto son ilustrativas, ente otras muchas, la STS (Sala de lo Civil, Sección Primera) núm. 764/2005, de 25 de octubre de 2005 ${ }^{854}$; la SAP Murcia (Sección $4^{\text {a })}$ núm. 52/2007, de 22 de febrero de $2007^{855}$, así como la STS (Sala de lo Contencioso-Administrativo), de 10 de febrero de $1997^{856}$, precursora en declarar la

${ }^{851}$ BuITRAGo DíAZ, E., El concepto de cánones y/o regalías en los convenios para evitar la doble Tributación sobre la Renta, CISS (Wolters Kluwer), Valencia, 2007, p. 12.

${ }^{852}$ Ibídem, pp. 19-20.

853 Ídem.

${ }^{854}$ Roj: STS 7953/2005.

855 Roj: SAP MU 411/2007.

${ }^{856}$ Roj: STS 820/1997. Señala la sentencia: "Se trata, como se preocupa de resaltar el artículo 25 de la Ley 22/1987, de 11 de noviembre, de Propiedad Intelectual, en la redacción dada al mismo por la Ley 20/1992, de una obligación de naturaleza jurídico-civil, dirigida a compensar, anualmente, los derechos de propiedad intelectual, de naturaleza jurídico-privada por tanto, dejados de percibir por razón de la reproducción para uso privado del copista que la Ley permite sin autorización del autor (artículo $31,2^{\circ}$ ), es decir, a compensar una ganancia dejada de obtener; de la que son acreedores los autores de obras publicadas en forma de libros o publicaciones asimiladas a éstos, de fonogramas, videogramas o en cualquier otro soporte sonoro, visual o audiovisual, y, en sus respectivos casos, los editores, los productores de fonogramas y videogramas y los artistas intérpretes o ejecutantes cuyas actuaciones hayan sido fijadas en dichos fonogramas y videogramas; cuyo importe puede incluso fijarse mediante convenio pactado, dentro de los dos primeros meses de cada año, por los deudores, o, en su caso, a través de las asociaciones constituidas por ellos para la defensa de sus derechos o intereses, y las correspondientes Entidades de gestión de los acreedores o la persona jurídica en la que éstas se hayan podido agrupar para negociar el convenio y realizar el cobro y distribución de la remuneración; es más, en ausencia de pago voluntario, su importe, tanto si es fijado mediante convenio o, en su defecto, mediante la resolución del 
naturaleza no parafiscal de la remuneración compensatoria, al faltar en ella el carácter contributivo y su destino a la financiación de gastos públicos o necesidades colectivas y reconocer, al mismo tiempo, su naturaleza civil ${ }^{857}$.

Aún dicho lo anterior, cabría plantearse si la compensación por copia privada conservaba esta naturaleza civil bajo el modelo de financiación de la compensación equitativa por copia privada con cargo a los PGE. Al respecto, debe considerarse que el hecho de que la compensación equitativa se financiara con cargo a los PGE no contravenía su naturaleza jurídico-privada. En efecto, con independencia de que este fuera el mecanismo de financiación adoptado, la compensación equitativa seguía estando dirigida a compensar unos perjuicios de naturaleza jurídico-privada por razón de la reproducción para uso privado; a compensar una ganancia dejada de obtener, de la que resultaban acreedores los titulares de derechos de propiedad intelectual legalmente establecidos. Por tanto, incluso dependiendo la compensación del erario público, ésta no era consecuencia ni efecto de una norma fiscal ${ }^{858}$.

Insiste en la naturaleza civil de la obligación la SAN (Sala de lo ContenciosoAdministrativo, Sección Tercera), de 29 de mayo de $2013^{859}$, dictada con posterioridad a la entrada en vigor de la compensación con cargo a los PGE, al negar que la compensación equitativa tuviera la naturaleza de una exacción parafiscal.

Con todo, pese a la controvertida naturaleza jurídica de la compensación equitativa por copia privada, en la doctrina se ha alcanzado un consenso, bastante generalizado, sobre su naturaleza civil y su carácter compensatorio ${ }^{860}$. Se trata, en

mediador, no se hace efectivo a través de vía de apremio alguna, sino en sede jurisdiccional civil, otorgando la consideración de título ejecutivo al convenio, y a la sustitutiva resolución del mediador, una vez formalizados, aquél o ésta, en escritura pública" (F.J. $3^{\circ}$ ).

${ }^{857}$ En la argumentación de este criterio Vid. PIÑA GARRIDO, L., "El canon digital...", op. cit., pp. 30-34.

${ }^{858}$ AvILÉS GARCÍA, J., "La socialización de la compensación equitativa por copia privada: ¿un desatino inconstitucional?", Pe. I. Revista de Propiedad Intelectual, núm. 41, 2015, p. 36.

${ }^{859}$ Roj: SAN 2538/2013.

860 Garrote Fernández-Díez, I., “Artículo 9”, en Bercovitz Rodríguez-CANo, R. (Coord.), Comentarios al Convenio de Berna ..., op. cit., p. 452. 
definitiva, de una obligación pecuniaria de origen legal (art. 1089 CC), predeterminada en cuanto a sus aspectos subjetivos y objetivos por la propia Ley ${ }^{861}$.

\section{LOS SUJETOS DE LA COMPENSACIÓN EQUITATIVA}

\section{Acreedores}

A tenor del art. 25.2 del TRLPI, serán acreedores de la compensación equitativa por copia privada los autores de las obras divulgadas en forma de libros o publicaciones que a estos efectos se asimilen reglamentariamente, así como de fonogramas y videogramas o de otros soportes sonoros, visuales o audiovisuales, explotadas públicamente en alguna de estas formas, conjuntamente y, en los casos y modalidades de reproducción en que corresponda, con los editores, los productores de fonogramas y videogramas y los artistas intérpretes o ejecutantes cuyas actuaciones hayan sido fijadas en dichos fonogramas y videogramas. De ahí que los acreedores de la compensación haya que colocarlos en relación con las tres modalidades de reproducción susceptibles de copia privada; de forma tal que serán acreedores los autores y editores, en la modalidad de libros y publicaciones asimiladas; los autores, artistas intérpretes y ejecutantes y productores de fonogramas, en la modalidad de fonogramas; y los autores, artistas intérpretes y ejecutantes y productores de grabaciones audiovisuales, para la modalidad de videogramas ${ }^{862}$.

Consecuentemente, quedan excluidos de la condición de acreedores de la compensación otros sujetos a los que, sin embargo, la ley les confiere derechos de propiedad intelectual. Es el caso de las entidades de radiodifusión, cuyos derechos reconoce el art. 126.1 del TRLPI ${ }^{863}$; de los editores de publicaciones protegidas por el

\footnotetext{
861 Ídem.

862 Garrote Fernández- DíEz, I., “Artículo 25”, en Bercovitz RodríGuez,-CANo, R. (Coord), Comentarios a la Ley de Propiedad..., op. cit., $4^{\text {a }}$ ed., p. 522.

${ }^{863}$ RODRÍGUEZ TAPIA ha planteado la cuestión de por qué las entidades de radiodifusión no han sido consideradas acreedoras de la compensación, cuando éstas ostentan un derecho exclusivo de fijación y de reproducción que, al menos teóricamente, son afectados por las copias privadas de las emisiones de televisión. RoDRÍGUEZ TAPIA, J. M., La Ley de Propiedad Intelectual tras las reformas efectuadas por la Ley 19/2006, de 5 de junio y 23/2006, de 7 de julio, Aranzadi, Navarra, 2006, p. 28. En cambio, a día de
} 
derecho conexo del art. 129.2 del TRLPI ${ }^{864}$; así como de los productores de meras fotografías del art. 128 del TRLPI.

Tampoco ostentan la condición de acreedores de esta compensación los autores de bases de datos electrónicas y de programas de ordenador. La razón de esta exclusión obedece al hecho de que esta categoría de obras no está amparada en el límite legal de copia privada, de acuerdo con lo dispuesto en el art. 31.3 b) y c), respectivamente, del TRLPI. En consecuencia, no se da el presupuesto necesario para la compensación, esto es, la reproducción para uso privado.

Lo mismo cabe decir del director de escena y el director de orquesta ${ }^{865}$. La exclusión de estos sujetos, comprendidos dentro de la categoría de artistas intérpretes o ejecutantes, como acreedores de la compensación equitativa por copia privada obedece a que el art. 105 del TRLPI sólo les reserva los derechos reconocidos en el Título I del Libro Segundo del TRLPI ${ }^{866}$. En sus preceptos, que van del art. 105 al art. 113 del TRLPI, los derechos reconocidos a los artistas comprenden únicamente los derechos de reproducción, de comunicación pública y de distribución, lo que excluye el derecho de compensación que origina la copia privada que está regulado en el art. 25 del TRLPI

hoy, la discusión en torno al tema pierde relevancia, al menos en el contexto español, porque cada vez más la práctica de reproducir las emisiones para su visionado posterior disminuye frente a la puesta a disposición del público de emisiones mediante servicios TV a la carta, tanto gratuitos como de pago.

${ }^{864} \mathrm{El}$ art. 129.2 del TRLPI concede un derecho de explotación en exclusiva con respecto a determinadas producciones editoriales individualizadas por sus características. El derecho de exclusiva es, en este caso, sobre la edición de la obra, concediéndole el TRLPI al editor, el derecho exclusivo de autorizar la reproducción, distribución y comunicación pública de dichas ediciones siempre que puedan ser individualizadas por su composición tipográfica, presentación y demás características editoriales. Vid. BERCOVITZ Rodríguez-CANO. R., “Artículo 129”, en BERCOVITZ RODRÍGUEZ-CANO, R., (Coord.), Comentarios a la Ley de Propiedad..., $3^{\mathrm{a}}$ ed., op. cit., p. 1632. Señala el autor: "En este precepto no existe problema alguno en relación con la inclusión o no del derecho de remuneración por copia privada (art. 25 LPI). [...] la clave viene dada por el objeto de la protección: la edición y no la obra. No existe fundamento para conceder al editor una participación sobre esa compensación equitativa por copia privada distinta de la que ya le corresponde en cualquier caso como editor de cualquier obra, esto es, como editor a secas”. Ibídem, p. 1635.

865 Garrote FernándeZ-DíEZ, I., “Artículo 9", en Bercovitz RodríGUeZ-CANO, R. (Coord.), Comentarios al Convenio de Berna..., op. cit., p. 475; LóPEZ MAZA, S. y Minero AlEJANDRE, G., "El carácter equitativo...", op. cit., p. 93.

${ }^{866}$ En particular, el art. 105 del TRLPI establece: "Se entiende por artista intérprete o ejecutante a la persona que represente, cante, lea, recite, interprete o ejecute en cualquier forma una obra. El director de escena y el director de orquesta tendrán los derechos reconocidos a los artistas en este Título". 
fuera del ámbito de los derechos reconocidos a favor de aquéllos ${ }^{867}$.

Ahora bien, entre los sujetos reconocidos legalmente como acreedores del canon, destaca, en primer lugar, el autor. Este es, conforme al art. 5.1 del TRLPI, la persona natural que crea una obra literaria, artística o científica, sin perjuicio de que la protección que se concede al autor en virtud de la ley pueda extenderse a las personas jurídicas en los casos expresamente previstos en la misma (art. 5.2 del TRLPI). En cualquier caso, la eventual excepción a favor de la persona jurídica no altera el principio de que autor es sólo la persona física que crea la obra ${ }^{868}$.

Pues bien, no puede sino el autor ser el primero de los sujetos que menciona el art. 25.2 del TRLPI como acreedor de la compensación equitativa por copia privada, porque es el titular originario y pleno de la propiedad intelectual, es decir, el titular de los derechos morales y patrimoniales ${ }^{869} \mathrm{y}$, consecuentemente, el primero en ver afectado su derecho de autorizar o prohibir la reproducción como consecuencia de la copia privada. El acto de creación es el que atribuye al autor tal condición (art. 1 del TRLPI) y es, en efecto, el que hace nacer sobre éste derechos exclusivos ${ }^{870}$. No obstante, el derecho del autor a ser compensado por la copia privada no deriva del propio acto de creación sino, en todo caso, de que su obra sea explotada en alguna de las tres modalidades de reproducción referidas en el art. 25.1 del TRLPI y bajo las condiciones que el precepto señala ${ }^{871}$. En el caso de las obras audiovisuales habrá que tener en cuenta que la condición de autor puede recaer sobre una pluralidad de sujetos (el director-realizador; los autores del argumento, de la adaptación y del guión o los diálogos; así como los autores de las composiciones musicales, con o sin letra, creadas especialmente para la

867 Garrote Fernández-DíEz, I., “Artículo 9”, en BerCOVitz Rodríguez-CANo, R. (Coord.), Comentarios al Convenio de Berna..., op. cit., p. 475.

${ }^{868}$ SAIZ García, C., "Artículo 5. Autores y otros beneficiarios" (Comentario), en Palau Ramírez, F. y Palao Moreno, G. (Dirs.), Comentarios..., op. cit., p. 124.

${ }^{869}$ Bercovitz Rodríguez-CANo, R. (Coord.), Manual de Propiedad Intelectual, op. cit., pp. 9-10; Rogel Vide, C. y Serrano Gómez, E., Manual de Derecho de Autor, Reus, Madrid, 2008, pp. 25 y ss.

${ }^{870}$ PlAZA PENADÉS, J., El derecho de autor y su protección..., op. cit., pp. 284 y ss.

871 Garrote FernándeZ- DíEZ, I., “Artículo 25”, en BERCOVITZ RodríGUEZ,-CANo, R. (Coord), Comentarios a la Ley de Propiedad..., $4^{\mathrm{a}}$ ed., op. cit., p. 522. 
obra), según dispone el art. 87 del TRLPI ${ }^{872}$.

Por su parte, el editor también es considerado acreedor de la compensación equitativa por copia privada, con lo cual, podrá participar en el reparto de la misma. El editor es, conforme al art. 2.c) de la Ley 10/2007, de 22 de junio, de la lectura, del libro y de las bibliotecas ${ }^{873}$, la "persona natural o jurídica que, por cuenta propia, elige o concibe obras literarias, científicas y en general de cualquier temática y realiza o encarga los procesos industriales para su transformación en libro, cualquiera que sea su soporte, con la finalidad de su publicación y difusión o comunicación”.

La condición de acreedor de la compensación le viene atribuida ex lege y no en virtud del contrato de edición que suscribe con el autor (art. 58 del TRLPI), del que derivan el resto de los derechos que el editor ostenta. No puede perderse de vista que la STJUE (Sala Cuarta), de 12 de noviembre de $2015^{874}$ ha confirmado la participación legítima de los editores en la compensación equitativa por copia privada, aun cuando los mismos no sean titulares del derecho exclusivo de reproducción en el sentido del art. 2 de la DDASI. Ahora bien, su derecho a participar de la compensación no puede excluir, total o parcialmente, aquél que ostentan -en el mismo sentido- los autores como titulares originarios del derecho de reproducción en virtud de la copia privada ${ }^{875}$.

Finalmente, también son sujetos acreedores de la compensación el artista intérprete o ejecutante, el productor de fonogramas y el productor de videogramas. Se trata de sujetos que, a diferencia del editor, son titulares per se del derecho de reproducción, como titulares de derechos conexos que son, porque la ley establece a favor de estos sujetos el derecho exclusivo de autorizar la reproducción de la fijación de

\footnotetext{
872 Ídem.

${ }^{873}$ B.O.E. núm. 150 , de 23 de junio de 2007.

${ }^{874}$ Hewlett-Packard Belgium SPRL y Reprobel SCRL, con intervención de Epson Europe BV, asunto C572/13 [ECLI:EU:C:2015:750].

${ }^{875}$ Vid. párrafos 48 y 49 de la STJUE (Sala Cuarta), de 12 de noviembre de 2015. En concreto, el párrafo 49 concluye: "el artículo 5, apartado 2, letra a), de la Directiva 2001/29 y el artículo 5, apartado 2, letra b), de ésta se oponen a una normativa nacional, como la controvertida en el litigio principal, que autoriza al Estado miembro a atribuir una parte de la compensación equitativa que corresponde a los titulares de derechos a los editores de las obras creadas por los autores, sin que estos editores estén en ningún modo obligados a hacer partícipes, siquiera indirectamente, a los autores de la parte de la compensación de la que éstos se ven privados".
} 
sus actuaciones en el caso de los artistas intérpretes o ejecutantes, así como la reproducción de sus fonogramas y grabaciones audiovisuales, en el caso de los productores de fonogramas y de los productores de grabaciones audiovisuales, respectivamente.

Así pues, conforme al art. 105 del TRLPI, el artista intérprete o ejecutante es la persona que representa, canta, lee, recita, interpreta o ejecuta en cualquier forma una obra. Por su parte, el productor de fonogramas es aquella persona natural o jurídica bajo cuya iniciativa y responsabilidad se realiza por primera vez una fijación exclusivamente sonora de la ejecución de una obra o de otros sonidos; y que de efectuase dicha fijación en el seno de una empresa, el titular de ésta será considerado productor del fonograma (art. 114.2 del TRLPI). Por último, el productor de videogramas -o como refiere el TRLPI, el productor de una grabación audiovisual- es la persona natural o jurídica que toma la iniciativa y asume la responsabilidad de realizar una grabación audiovisual, es decir, las fijaciones de un plano o secuencia de imágenes, con o sin sonido, sean o no creaciones susceptibles de ser calificadas como obras audiovisuales en el sentido del art. 86 del TRLPI (art. 120.2 TRLPI).

\section{Deudores}

El art. 25.3 del TRLPI establece quiénes son los deudores de la compensación equitativa por copia privada. Según señala el precepto, en su párrafo primero, serán deudores del pago de la citada compensación los fabricantes en España, en tanto actúen como distribuidores comerciales, así como los adquirentes fuera del territorio español, para su distribución comercial o utilización dentro de éste, de equipos, aparatos y soportes materiales idóneos para realizar las reproducciones amparadas en el límite de copia privada. Asimismo, serán responsables solidarios del pago de la compensación, conforme al párrafo segundo del mismo precepto, los distribuidores, mayoristas y minoristas, que sean sucesivos adquirentes de los mencionados equipos, aparatos y soportes materiales, con respecto de los deudores que se los hubieran suministrado, salvo que acrediten haber satisfecho efectivamente a éstos la compensación.

De lo anterior se deduce que no se considera deudores de la compensación equitativa a los exportadores de equipos, aparatos y soportes materiales idóneos para la 
copia privada, toda vez que la comercialización de estos productos se realiza fuera del territorio español. Se evita así la duplicación indebida de los pagos (considérese que, de lo contrario, el canon se cobraría en España y en el lugar de destino de estos productos, a menos que allí no se regulase la compensación por copia privada), y se garantiza que la compensación se pague en el lugar donde, efectivamente, se realizan las reproducciones.

El precepto refleja la peculiaridad del sistema de compensación equitativa por copia privada. En efecto, siendo la finalidad de este sistema la compensación del perjuicio que irroga la copia privada a los titulares de derechos de autor, la compensación debería ser satisfecha por quienes la realicen. Pese a ello, los obligados a cumplir con esta obligación legal son los sujetos mencionados en el art. 25.3 del TRLPI, encargados de la puesta a disposición del público de los equipos, aparatos y soportes reproductores mediante su fabricación y comercialización, ajenos, por tanto, a la actividad de copia. En efecto, lo lógico sería que fueran los consumidores finales de los referidos equipos, aparatos y soportes los obligados a satisfacer la compensación. Pero, como no es posible compeler a cada uno de ellos a realizar su pago directamente, se ha articulado un mecanismo que instituye como deudores directos, en su lugar, a los citados sujetos del art. 25.3 del TRLPI, quienes repercuten a dichos consumidores, vía precio, el importe de la compensación.

En consecuencia, puede hablarse de dos tipos de deudores del canon: los deudores directos, contemplados en el art. 25.3 del TRLPI; y los deudores indirectos, es decir, los consumidores finales, usuarios privados, cuyo calificativo obedece a la STJUE de 21 de octubre de 2010, recaída en el caso Padawan, bajo el razonamiento siguiente:

"[...] habida cuenta de las dificultades prácticas para identificar a los usuarios privados y obligarles a indemnizar a los titulares de los derechos por el perjuicio que les causan y atendiendo al hecho de que el perjuicio que puede derivarse de cada utilización privada, considerada individualmente, puede resultar mínimo y, por lo tanto, no dar origen a una obligación de pago, como indica la última frase del trigésimo quinto considerando de la Directiva 2001/29, los Estados miembros tienen la facultad de establecer, al objeto de financiar la compensación equitativa, un «canon por copia privada» que no grava a las personas privadas afectadas, sino a quienes disponen de equipos, aparatos y soportes de reproducción digital y, a este título, de derecho o de hecho, ponen dichos equipos a disposición de personas privadas o les prestan un servicio de reproducción. En el marco de dicho sistema, son las personas que disponen de dichos equipos quienes han de abonar el canon por copia privada. 
Ciertamente, en un sistema de este tipo, no son los usuarios de prestaciones protegidas quienes figuran como deudores a efectos de la financiación de la compensación equitativa $[\ldots]$.

No obstante, ha de señalarse que, por un lado, la actividad de los deudores de dicha financiación, a saber, la puesta a disposición de equipos, aparatos y soportes de reproducción a favor de usuarios privados o la prestación a éstos de un servicio de reproducción, constituye la premisa fáctica necesaria para que las personas físicas puedan obtener copias privadas. Por otro lado, nada impide que dichos deudores repercutan el importe del canon por copia privada en el precio de puesta a disposición de los equipos, aparatos y soportes de reproducción o en el precio del servicio de reproducción prestado. De este modo, el usuario privado que abona dicho precio es quien soportará, en definitiva, la carga del canon. Dadas las circunstancias, el usuario privado a cuya disposición se ponen los equipos, aparatos y soportes de reproducción digital o que utiliza un servicio de reproducción ha de considerarse, en realidad, como el «deudor indirecto» de la compensación equitativa" 876 .

Efectivamente, de los párrafos transcritos se entiende que el usuario privado, que es quien realiza la copia privada, tiene la consideración de deudor del canon, aunque sólo sea de modo indirecto, con independencia de que la obligación de pagar el canon recaiga sobre los deudores contemplados en el art. 25.3 del TRLPI, esto es, los deudores directos, que lo son más por una cuestión fáctica que jurídica.

También resulta de especial interés la STJUE (Sala Tercera), de 16 de junio de $2011^{877}$, que trae a colación la conclusión anterior para explicar por qué, pese a que los deudores indirectos del canon son los consumidores neerlandeses (en el caso), ello no impide que los importadores de los equipos, aparatos y soportes de reproducción puedan ser considerados deudores del canon, aun cuando estén establecidos en un Estado miembro distinto de aquel en el cual residen los compradores y, por consiguiente, queden obligados al pago de la compensación. En dicho asunto, Stichting de Thuiskopie, demandante en el litigio principal, entendía que la demandada Opus Supplies Deutschland GmbH, debía ser considerada “importador" y, en consecuencia, deudora del canon por copia privada. Por su parte, Opus Supplies Deutschland GmbH sostenía que quienes debían ser calificados como importadores debían ser los compradores

\footnotetext{
${ }^{876}$ Párrafos 46 y 47 y 48, respectivamente.

877 Stichting de Thuiskopie contra Opus Supplies Deutschland GmbH y otros, asunto C-462/09 [ECLI:EU:C:2011:397].
} 
neerlandeses, es decir, los consumidores individuales ${ }^{878}$. Esta alegación sirvió de base para que los tribunales neerlandeses de primera instancia y de apelación desestimaran la demanda incoada por Stichting de Thuiskopie, que acudió en casación al tribunal remitente, el cual decidió plantear la cuestión prejudicial al TJUE para resolver las dudas acerca de si la solución dada al litigio era conforme a la DDASI ${ }^{879}$.

En el análisis de las cuestiones prejudiciales planteadas en el asunto ${ }^{880}$, el TJUE insiste en que, en principio, es el usuario final que realiza a título privado la reproducción de una obra protegida quien debe considerarse deudor de la compensación equitativa prevista en el art. 5.2.b) de la DDASI. No obstante, señala que los Estados miembros tienen la facultad de establecer un canon por copia privada que grave a quienes ponen a disposición del usuario final equipos, aparatos o soportes de reproducción, siempre que estas personas tengan la posibilidad de repercutir el importe de dicho canon en el precio de puesta a disposición abonado por el usuario final ${ }^{881}$. Precisa, además, que la DDASI no contiene ninguna indicación específica a los efectos de realizar una interpretación concreta de quién debe ser el deudor del canon en el marco de un contrato celebrado a distancia ${ }^{882}$. Sin embargo, reconoce que sobre el Estado miembro que ha introducido la excepción de copia privada en su Derecho nacional pesa una obligación de resultado, en el sentido de que está obligado a

\footnotetext{
${ }^{878}$ Ibídem, apartado 14.

${ }^{879}$ El órgano jurisdiccional remitente temía que, al considerar al comprador -consumidor individual-, importador, y consecuentemente, deudor del canon por copia privada, dicho gravamen fuera irrecuperable, dado que el comprador individual es difícilmente identificable en la práctica. Por consiguiente, planteaba si el concepto de "importador" debería definirse de una manera más amplia que la que se desprende de la acepción meramente lingüística del término, teniendo también en cuenta el destino final de los soportes de información que, en el caso, claramente, también se dirigían al vendedor profesional. Ibídem, párrafo 16.

880 “1.- ¿Ofrece la Directiva 2001/29/CE, en particular su artículo 5, apartados 2, letra b), y 5, criterios para responder a la cuestión de quién ha de ser considerado, en la legislación nacional, deudor de la "compensación equitativa" establecida en el artículo 5, apartado 2, letra b)? En caso de respuesta afirmativa, ¿cuáles?

2.- En caso de un contrato negociado a distancia, si el comprador tiene su domicilio en un Estado miembro distinto del Estado miembro del vendedor, ¿obliga el artículo 5, apartado 5, de la referida Directiva a una interpretación de la normativa nacional tan amplia que permita que, cuando menos en uno de los países a los que afecte al contrato negociado a distancia se adeude la "compensación equitativa" mencionada en el artículo 5, apartado 2, letra b), por un deudor que actúe en el ejercicio de una actividad mercantil?".

${ }^{881}$ STJUE (Sala Tercera) de 16 de junio de 2011 (asunto C-462/09), párrafo 29.

${ }^{882}$ Ibídem, párrafo 31.
} 
garantizar, en el marco de sus competencias, la percepción efectiva de la compensación equitativa, en particular, si el perjuicio se ha producido en el territorio de dicho Estado miembro ${ }^{883}$, toda vez que son los usuarios finales residentes en dicho territorio los que realizan la reproducción.

De este modo, puesto que, por un lado, el perjuicio se produce en el Estado miembro donde residen los compradores (usuarios finales a título privado de las obras protegidas), y que es en dicho territorio donde corresponde exigir la compensación por la copia privada; y, por otro, dado que es imposible en la práctica percibir tal compensación de los usuarios finales (importadores) en dicho territorio, corresponde a las autoridades de ese Estado miembro y, en particular, a las judiciales, realizar una interpretación del Derecho nacional que permita garantizar la percepción de la compensación del vendedor que importa los equipos, aparatos y soportes de reproducción y los pone a disposición de los usuarios finales. Se entiende, por tanto, que el Estado miembro no puede sustraerse de la obligación de resultado que impone el ordenamiento jurídico de la $\mathrm{UE}^{884}$.

En definitiva, la STJUE (Sala Tercera) de 16 de junio de 2011 deja claro que es obligación de los Estados miembros de la UE garantizar a los autores y demás titulares de derechos afectados por la copia privada el cobro efectivo de una compensación equitativa, como indemnización por el perjuicio producido en su territorio; y que no tiene incidencia alguna en el caso de contratos negociados a distancia, que el vendedor profesional que pone a disposición de los usuarios finales los equipos, aparatos y soportes de reproducción esté establecido en otro Estado miembro ${ }^{885}$.

Valga destacar que el uso del término "importadores", empleado por la antigua Ley 22/1987, de 11 de noviembre (LPI), es sustituido en el TRLPI por "adquirentes fuera del territorio español". En definitiva, su significado es el mismo, sólo que se emplea esta terminología para expresar mejor la realidad de los intercambios de

\footnotetext{
${ }^{883}$ Ibídem, párrafo 34.

${ }^{884}$ Ibídem, párrafos 37, 38 y 39.

${ }^{885}$ Ibídem, párrafo 40.
} 
productos en el ámbito de la UE, donde la existencia de una unión aduanera justifica la desaparición del uso del término de importador ${ }^{886}$. En cualquier caso, con la expresión actual se incluyen tanto los adquirentes intracomunitarios, como los extracomunitarios, siendo estos últimos los verdaderos importadores, en el sentido de que son quienes realmente introducen en el mercado europeo los productos, esto es, los importan desde otro país no perteneciente a la $\mathrm{UE}^{887}$.

Por otra parte, debe señalarse que los deudores directos del canon se clasifican en deudores principales y deudores secundarios ${ }^{888}$. Los deudores principales son los fabricantes en España, en tanto actúen como distribuidores comerciales, así como los adquirentes fuera del territorio español, para su distribución comercial o utilización dentro de éste, de equipos, aparatos y soportes materiales idóneos para la copia privada. Los deudores secundarios son los distribuidores, mayoristas y minoristas, que sean sucesivos adquirentes de los mencionados equipos, aparatos y soportes materiales, con respecto de los deudores que se los hubieran suministrado, salvo que acrediten haber satisfecho efectivamente a estos la compensación. El art. 25.3 del TRLPI se refiere a estos últimos como deudores solidarios, si bien la expresión no es correcta porque, más que un supuesto de solidaridad, se trata de un supuesto de pago subsidiario, esto es, de obligación de abonar la compensación equitativa por copia privada en el caso de que no hayan satisfecho a aquéllos dicha compensación en el momento en que adquirieron de ellos los productos sujetos al canon.

Por ello, no se puede hablar de un verdadero supuesto de solidaridad, como acertadamente ha reconocido la doctrina ${ }^{889}$. En efecto, los deudores secundarios deberán satisfacer la compensación sólo en el caso de que los deudores principales no les hayan repercutido y hecho constar en la factura la correspondiente compensación (como precisa el apartado segundo, párrafo cuarto, de la Disposición Transitoria segunda del

\footnotetext{
886 VALlÉs RodríGUEZ, M., “Artículo 25”, en BERCOVITZ RodRÍGUEZ-CANO, R. (Coord.), Comentarios a la Ley de Propiedad..., $1^{\mathrm{a}}$ ed., op. cit., p. 545.

887 Garrote Fernández-DíEZ, I., “Artículo 9”, en BErCovitz RodríGuez-CANo, R. (Coord.), Comentarios al Convenio de Berna ..., op. cit., p. 467.

${ }^{888}$ Ibídem, pp. 466-467.

${ }^{889}$ Ibídem, pp. 467-468.
} 
Real Decreto-Ley 12/2017, de 3 de julio). Por tanto, la ley no autoriza al acreedor -o, mejor dicho, en este caso, a la entidad de gestión colectiva correspondiente- a dirigirse contra cualquiera de los deudores directos de la compensación equitativa para reclamar su pago, como correspondería a un supuesto de solidaridad ex art. 1144 del CC. Por el contrario, sólo puede dirigirse contra los deudores principales y, subsidiariamente, contra los deudores secundarios, cuando no hayan pagado a aquellos la cantidad correspondiente a la compensación en el momento de la adquisición de estos productos, dada su omisión en la correspondiente factura.

\section{EL NACIMIENTO DE LA OBLIGACIÓN DE COMPENSAR}

Según establece el art. 25.6 del TRLPI, el nacimiento de la obligación de pago de la compensación equitativa por copia privada nace para los deudores contemplados en el art. 25.3 del TRLPI en dos momentos diferentes.

Así, conforme al art. 25.6.a) del TRLPI, la obligación nace para los fabricantes en tanto actúen como distribuidores, y para los adquirentes de equipos, aparatos y soportes materiales fuera del territorio español con destino a su distribución comercial en éste (adquirentes intracomunitarios e importadores), en el momento en que dichos sujetos transmiten la propiedad o, en su caso, la cesión del uso o disfrute de cualquiera de aquellos. Por consiguiente, la transmisión de estos bienes, sea mediante compraventa, arrendamiento, préstamo o cualquier otro título jurídico, hace nacer sobre dichos sujetos la obligación de pago de la compensación equitativa por copia privada.

Por su parte, siguiendo el art. 25.6.b) del TRLPI, la obligación nace para los adquirentes de equipos, aparatos y soportes materiales fuera del territorio español con destino a su utilización dentro de dicho territorio, desde el momento de la adquisición. En efecto, el adquirente va a utilizar estos bienes para su propio consumo, no así para su posterior venta o distribución comercial, lo que explica que el nacimiento de la obligación se fije en el momento en el que adquiere la titularidad, uso o disfrute el bien.

Nada dice la ley, en cambio, sobre el momento en el que nace la obligación para los responsables subsidiarios del pago (erróneamente llamados "responsables solidarios" ex art. 25.3, párrafo $2^{\circ}$ del TRLPI), esto es, los distribuidores, mayoristas y 
minoristas, que sean sucesivos adquirentes de los mencionados equipos, aparatos y soportes materiales, con respecto a los deudores que se los hubieran suministrado. No obstante, se entiende que serán responsables del pago de la compensación desde el momento en que adquieran los mencionados equipos, aparatos y soportes de reproducción, pues es entonces cuando podrán disponer de los mismos para ponerlos a disposición de los usuarios finales o de otros distribuidores comerciales, salvo que acrediten haber satisfecho efectivamente la compensación a los deudores principales mediante la correspondiente factura.

\section{EL SISTEMA DE EXCEPTUACIONES Y REEMBOLSOS}

\section{Las excepciones ex ante del pago de la compensación}

El art. 25.7 del TRLPI contiene una lista de supuestos exceptuados del pago de la compensación equitativa por copia privada. Estos supuestos se establecen en función de las condiciones de utilización de los equipos, aparatos y soportes materiales de reproducción por los sujetos que el precepto relaciona.

Así, en primer lugar, el art. 25.7.a) del TRLPI excluye del pago de la compensación equitativa por copia privada las adquisiciones de equipos, aparatos y soportes de reproducción realizadas por las entidades que integran el sector público siguiendo el texto refundido de la Ley de Contratos del Sector Público, aprobado por Real Decreto Legislativo 3/2011, de 14 de noviembre ${ }^{890}$, así como aquellas adquisiciones realizadas por el Congreso de los Diputados, el Senado, el Consejo General del Poder Judicial, el Tribunal de Cuentas, el Defensor del Pueblo, las Asambleas legislativas de las Comunidades Autónomas y las instituciones autonómicas análogas al Tribunal de Cuentas y al Defensor del Pueblo.

\footnotetext{
${ }^{890}$ Pese a la referencia explícita que hace el art. 25.7.a) del TRLPI al texto refundido de la Ley de Contratos del Sector Público aprobado por Real Decreto Legislativo 3/2011, de 14 de noviembre, debe tenerse en cuenta que, desde el 9 de marzo de 2018, ha entrado en vigor la Ley 9/2017, de 8 de noviembre, de Contratos del Sector Público, por la que se transponen al ordenamiento jurídico español las Directivas del Parlamento Europeo y del Consejo 2014/23/UE y 2014/24/UE, de 26 de febrero de 2014 (B.O.E. núm. 272, de 9 de noviembre de 2017). Esta ley deroga dicho Real Decreto Legislativo y su art. 3 establece las entidades que integran el sector público.
} 
Dicha disposición constituye una novedad en el texto de la ley, que había venido siendo reclamada por parte de la doctrina y por los órganos y entidades afectados por el canon, ya durante la vigencia de las versiones anteriores del texto legal. En efecto, una de las críticas tradicionales al sistema de compensación equitativa por copia privada articulado sobre el modelo de un canon compensatorio ha sido precisamente aquella que entendía que gravaba indiscriminadamente los equipos, aparatos y soportes materiales idóneos para la copia privada, sin exceptuar determinados supuestos de los que pudiera preverse una utilización diferente de la realización de reproducciones para uso privado $^{891}$, como es el caso de los entes y organismos públicos.

En este sentido se pronunciaba MC. CREEVY (Comisario de Mercado Interior de la UE) en nombre de la Comisión Europea, el 19 de septiembre de 2007:

"De acuerdo con el análisis preliminar de la Comisión, sólo deben gravarse con cánones los soportes y equipos que puedan utilizarse, y que efectivamente se utilicen en medida apreciable, para hacer copias realmente destinadas a uso privado. La Comisión considera asimismo que los equipos utilizados con fines comerciales (p. ej., en empresas o en Administraciones Públicas) no deberían gravarse con cánones, pues ello supone ir claramente más allá de la necesaria compensación por actos autorizados (es decir, la copia privada), con arreglo a lo dispuesto en la Directiva" ${ }^{892}$.

Asimismo, es una excepción acorde con los pronunciamientos de la sentencia del caso Padawan (asunto C- 467/08) 893 $^{393}$ en lo referente a la imposibilidad de sujetar a la compensación a los equipos, aparatos y soportes materiales de reproducción que estén manifiestamente destinados a usos distintos de la copia privada. Se presume así, legalmente, que estas copias no serán realizadas para uso privado y, por tanto, deben

\footnotetext{
${ }^{891}$ No se trata de que la ley no estableciera algunas excepciones subjetivas al pago del canon (v. $g r$. art. 25.6.a) y b) del TRLPI en su versión original; art. 25.7.a) y c) del TRLPI, tras su modificación por la Ley 23/2006, de 7 de julio; y art. 25.4 del TRLPI, tras su modificación por la Ley 21/2014, de 4 de noviembre). Sin embargo, se entendía que otros supuestos podían también quedar excluidos por tratarse de adquisiciones hechas por sujetos cuya actividad justificaba un uso de los equipos, aparatos y soportes de reproducción distintos a la copia privada de creaciones intelectuales protegidas.

${ }^{892}$ Respuesta formulada en nombre de la Comisión Europea, frente a la pregunta escrita del parlamentario europeo D. Raúl RoMEVA I RUEDA, sobre la aplicación del canon digital en España, disponible en: http://www.europarl.europa.eu/sides/getAllAnswers.do?reference=E-2007-2864\&language=ES (consultado: 02.10.2016). 893 Cit.
} 
quedar excluidas de la compensación. De hecho, el art. 25.7.a) del TRLPI no hace referencia alguna al destino que deba dársele a estos equipos, aparatos y soportes de reproducción a diferencia del resto de los supuestos del art. $25.7^{894}$.

Puede decirse que la exclusión del pago de la compensación de las adquisiciones hechas por los sujetos previstos en el art. 25.7.a) del TRLPI es una decisión acertada. En definitiva, se trata de excluir del pago a entes y organismos cuya actividad necesita el uso de medios de reproducción, pero que son adquiridos para fines ajenos a la copia privada de obras protegidas, por lo que carece de sentido sujetarlos al pago de la compensación. Ahora bien, la adquisición de estos equipos, aparatos y soportes por parte de la Administración Pública no excluye la posibilidad de que se utilicen para realizar copias de obras y prestaciones protegidas, en cuyo caso, la Administración habrá de adquirir las correspondientes licencias de reproducción que le autorice para realizarlas.

La segunda excepción está contenida en el art. 25.7.b) del TRLPI. Siguiendo el mismo, quedan exceptuadas de la compensación las adquisiciones realizadas por personas jurídicas o físicas que actúen como consumidores finales, que justifiquen el destino exclusivamente profesional de los equipos, aparatos o soportes materiales adquiridos. Se impone como condiciones adicionales que estos equipos, aparatos y soportes no se hayan puesto, de derecho o de hecho, a disposición de usuarios privados y que estén manifiestamente reservados a usos distintos a la realización de copias privadas.

También esta excepción es fruto de las críticas a la regulación anterior del sistema de canon por copia privada y a los intentos por excluir de la obligación de pago de la compensación equitativa por copia privada a las personas jurídicas, empresarios y profesionales que presumiblemente utilizaran los equipos, aparatos y soportes de reproducción para fines ajenos a la copia privada. De hecho, ya durante el trámite de enmiendas presentadas al Congreso de los Diputados en relación con el Proyecto de Ley

${ }^{894}$ Garrote Fernández- DíEz, I., “Artículo 25”, en Bercovitz RodríGuez,-CANo, R. (Coord), Comentarios a la Ley de Propiedad..., $4^{\mathrm{a}}$ ed., op. cit., p. 541. 
modificativo del TRLPI de 1996, precisamente el artículo 25.7 fue objeto de varias propuestas de modificación. Entre ellas, la enmienda núm. 44 presentada por GIU-IV$\mathrm{ICV}^{895}$, en la que se sugería exceptuar del pago de la compensación equitativa por copia privada "a todas las personas jurídicas al estar excluidas de la posibilidad de ejercitar el derecho de copia privada, así como todas las empresas y profesionales de software y demás actividades relacionadas con la Sociedad de la Información [...]”. Pese a que su contenido no era del todo acertado (lo correcto no sería excluir absolutamente del pago de la compensación a toda persona jurídica o empresario sin más precisiones ${ }^{896}$ ), y aunque tampoco llegó a materializarse, esta propuesta es un reflejo de la preocupación que generaba el pago del canon para las empresas, instituciones, administraciones y trabajadores autónomos que, más bien, utilizaban los equipos, aparatos y soportes de reproducción para satisfacer sus necesidades empresariales.

Esta excepción es acorde con la conclusión de la citada sentencia Padawan sobre la disconformidad de un sistema de canon aplicado de manera indiscriminada, sin tener en cuenta el destino y la finalidad del uso de los equipos, aparatos y soportes de reproducción, con el Derecho de la UE y, en particular, con el art. 5.2.b) de la DDASI. Resulta, por ello, lógico que no estén dentro del concepto de copia privada aquellas reproducciones realizadas con un fin profesional o empresarial (art. 25.1 del TRLPI), así como la exclusión de este límite de las reproducciones realizadas mediante equipos, aparatos y soportes de reproducción digital "que no se hayan puesto a disposición de derecho o de hecho de usuarios privados y que estén manifiestamente reservados a usos

${ }^{895}$ B.O.C.G. núm. 44-10, de 30 de noviembre de 2005.

${ }^{896}$ En un sistema de canon no puede descartarse por completo que las personas jurídicas, los empresarios y los profesionales puedan resultar deudores del mismo, pues pueden adquirir los dispositivos de reproducción para ceder su uso a personas físicas sin garantía alguna de que sólo se reserven a fines manifiestamente ajenos o distintos a la copia privada. Por ejemplo, una empresa puede adquirir memorias USB para obsequiárselas a sus empleados o a otras personas físicas (usuarios privados), como las que asisten a un evento donde son entregadas a los asistentes con fines promocionales. En esta línea Vid. CARBAJo CASCÓn, F., "El retorno del canon digital. Consecuencias previsibles...", op. cit., pp 18-19, quien destaca que excluir de antemano la aplicación del límite de copia privada y la compensación equitativa a los dispositivos de reproducción adquiridos por personas jurídicas, empresarios individuales o profesionales no se ajusta al Derecho de la Unión Europea, por cuanto dicha exclusión sólo es posible si los dispositivos o servicios de reproducción adquiridos por estos estuvieran manifiestamente reservados a usos distintos de la realización de copias privadas. 
distintos a la realización de copias privadas", conforme establece el art. 25.5.c). $2^{\circ}$ del TRLPI.

Por otra parte, es correcta la precisión que hace el artículo de que se trate de adquisiciones hechas tanto por personas físicas, como jurídicas, pues no sólo las personas jurídicas adquieren estos equipos, aparatos y soportes de reproducción para fines profesionales. También los utilizan los particulares en el ejercicio de su actividad profesional, como es el caso de los trabajadores autónomos. De esta forma, la ley amplía el ámbito subjetivo de la exceptuación, con mejor criterio que el contenido en el art. 25.4.a) del TRLPI tras su modificación por la Ley 21/2014, de 4 de noviembre. En efecto, el precepto sólo excluía de la consideración de copia privada, a los efectos de la determinación de la cuantía de la compensación equitativa, las reproducciones realizadas mediante equipos, aparatos y soportes de reproducción digital adquiridos por personas jurídicas (presuponiendo que los destinarían al uso de su actividad), sin incluir en la excepción las efectuadas por personas físicas para uso profesional, quienes también podían haber quedado exceptuadas cuando los equipos, aparatos y soportes de reproducción no se hubieran puesto, de derecho ni de hecho, a disposición de usuarios privados y estuvieran manifiestamente reservados a usos distintos a la realización de copias privadas, como ahora recoge el art. 25.5.c). $2^{\circ}$ del TRLPI.

La tercera excepción, está contenida en la letra c) del art. 25.7 del TRLPI y se refiere a las adquisiciones de equipos, aparatos y soportes materiales de reproducción por quienes cuenten con la preceptiva autorización para llevar a efecto la correspondiente reproducción de obras, prestaciones artísticas, fonogramas o videogramas, según proceda, en el ejercicio de su actividad. Esta excepción ya figuraba en el TRLPI desde su promulgación ${ }^{897}$, aunque con un ámbito más restringido, luego

\footnotetext{
${ }^{897}$ El art. 25.6.a) del TRLPI, aprobado por el Real Decreto Legislativo 1/1996 de 12 de abril y antes de que fuera modificado por la Ley 23/2006, de 7 de julio señalaba: "Los productores de fonogramas o de videogramas y las entidades de radiodifusión, por los equipos aparatos o materiales destinados al uso de su actividad siempre que cuenten con la preceptiva autorización para llevar a efecto la correspondiente reproducción de obras, prestaciones artísticas, fonogramas o videogramas, según proceda, en el ejercicio de tal actividad, lo que deberán acreditar a los deudores y, en su caso, a sus responsables solidarios, mediante certificación de la entidad o entidades de gestión correspondientes, en el supuesto de adquirir los equipos, aparatos o materiales dentro del territorio español”.
} 
ampliado por la Ley 23/2006, de 7 de julio, cuyo tenor recoge el actual art. 25.7.c) del TRLPI.

Siguiendo la versión original del precepto sólo se beneficiaban de la excepción los productores de fonogramas o videogramas y las entidades de radiodifusión, pues eran los sujetos específicamente contemplados en la norma. Sin embargo, con posterioridad, han pasado a beneficiarse todos aquellos sujetos que cuenten con una licencia o autorización al efecto. Se incluyen aquí las empresas dedicadas profesionalmente a la reproducción de libros o publicaciones asimiladas, así como de fonogramas y de videogramas y las entidades de radiodifusión. En definitiva, todo aquel que desempeñe una actividad de reproducción autorizada y profesional ${ }^{898}$.

Por último, el TRLPI recoge otra excepción, aunque no constituye una novedad, pues también ha estado presente en los textos anteriores ${ }^{899}$. Se excluyen del pago de la compensación las adquisiciones realizadas por personas físicas para uso privado fuera de territorio español en régimen de viajeros, según dispone el art. 25.7.d) del TRLPI. Es decir, esta excepción opera para los adquirentes de equipos, aparatos y soportes de reproducción en el extranjero que destinen los mismos a su uso, también en el extranjero. Se trata de una excepción que, tradicionalmente, ha encontrado su fundamento en la escasa repercusión económica que tiene para los titulares de derechos el uso privado en régimen de viajeros de estos equipos, aparatos y soportes de reproducción, así como en la dificultad de controlar su adquisición; y finalmente, en la necesidad de evitar que se produzca una doble compensación (en el país de adquisición y en el de destino $)^{900}$.

El matiz diferente del actual tenor respecto de los textos precedentes está en el hecho de que el legislador ahora omite una condición que venía repitiéndose en los

\footnotetext{
898 Garrote Fernández-DíEz, I., “Artículo 9", en Bercovitz RodríGuez-CANO, R. (Coord.), Comentarios al Convenio de Berna..., op. cit., p. 469.

${ }^{899}$ Esta excepción reitera lo dispuesto en las versiones precedentes del TRLPI, haciéndose eco de una regulación más antigua, contenida en el art. 13.b), párrafo segundo, del Real Decreto 1434/1992, de 27 de noviembre, de desarrollo de los artículos 24, 25 y 140 de la Ley 22/1987, de 11 de noviembre, de Propiedad Intelectual, en la versión dada a los mismos por la Ley 20/1992, de 7 de julio.

${ }^{900}$ LÓPEZ MAZA, S., Límites..., op. cit., p. 277.
} 
preceptos anteriores, que exigía que los equipos, aparatos y soportes materiales de reproducción se adquirieran en una cantidad tal que permitiera presumir razonablemente que serían destinados a su uso privado fuera del territorio español ${ }^{901}$. Parece que el legislador ha considerado que es innecesario incluir dicha condición porque las circunstancias mismas de la adquisición de estos equipos, aparatos y soportes de reproducción (en régimen de viajeros) excluyen la posibilidad de que sea de grandes cantidades.

En todo caso, el legislador prevé que los sujetos cuyas adquisiciones estén exceptuadas del pago de la compensación equitativa, ex art. 25.7 del TRLPI, puedan acreditar tal condición ante los deudores de la compensación y, en su caso, ante los responsables solidarios que menciona el art. 25.3, párrafo segundo, del TRLPI.

Para ello, estos sujetos tendrán que obtener la correspondiente certificación. La misma es expedida por diferentes órganos, en el caso de los sujetos exceptuados en la letra a) del art. 25.7 del TRLPI ${ }^{902}$. Para los sujetos de las letras b) y c), la entidad autorizada para emitirla es la persona jurídica prevista en el art. 25.10 del TRLPI, constituida por las entidades de gestión de derechos de propiedad intelectual. De producirse algún conflicto respecto a la denegación de estas certificaciones es el Ministerio de Educación, Cultura y Deporte el encargado de su resolución, conforme establece el art. 25.12 del TRLPI.

Cabe agregar que la ley no establece cuál es el plazo de validez de estas

\footnotetext{
${ }^{901}$ Así, si la cantidad adquirida no superaba las necesidades personales de los viajeros, no habría por qué generar el pago de compensación alguna, pues los equipos, aparatos y soportes de reproducción no estarían destinados a su distribución comercial, sino a su uso privado.

902 Señala el art. 25.7.a) del TRLPI: “[...] Esta exceptuación se podrá acreditar a los deudores y, en su caso, a los responsables solidarios:

$1 .^{\circ}$ Mediante una certificación emitida por el órgano competente de la Administración General del Estado, de las Administraciones de las Comunidades Autónomas, de las Entidades que integran la Administración Local, de las entidades gestoras y los servicios comunes de la Seguridad Social, de las Universidades Públicas así como del Congreso de los Diputados, el Senado, el Consejo General del Poder Judicial, el Consejo de Estado, el Tribunal de Cuentas, el Defensor del Pueblo, las Asambleas legislativas de las Comunidades Autónomas y las instituciones autonómicas análogas al Consejo de Estado, Tribunal de Cuentas y al Defensor del Pueblo.

$2 .^{\circ}$ Mediante una certificación emitida por el órgano de dirección y tutela respecto de las mutuas colaboradoras con la Seguridad Social.

$3 .^{\circ}$ Mediante una certificación emitida por la administración territorial de la que dependan o a la que estén vinculados el resto de entes que conforman el sector público".
} 
certificaciones. No obstante, al menos garantiza que la persona jurídica encargada, entre otras cuestiones, de la gestión de las exceptuaciones del pago y de los reembolsos, pueda comprobar que los sujetos exceptuados mantienen los requisitos para ser beneficiarios de la exceptuación (art. 25.11 del TRLPI).

Asimismo, la presentación de la correspondiente certificación por los adquirentes contemplados en el art. 25.7 del TRLPI frente a los obligados al pago deberá ser suficiente para que estos no les repercutan el importe de la compensación equitativa por copia privada. Dicho de otro modo, los deudores del canon, que distribuyen equipos, aparatos y soportes de reproducción en el territorio español, no tendrán que repercutir el importe de la compensación en la factura que entregan a sus respectivos clientes cuando estos sean los sujetos exceptuados ex art. 25.7.a), b) y c) del TRLPI, siempre que hayan acreditado que tienen tal condición de sujetos excluidos. Ello explica que la Disposición Transitoria segunda, apartado 2, del Real Decreto-ley 12/2017, de 3 de julio, permita a los deudores principales y, en su caso, a los responsables solidarios, deducirse las cantidades correspondientes a las entregas exceptuadas por el art. 25.7.a) del TRLPI, de la cantidad total a abonar correspondiente a los bienes que comercializan, idóneos para la reproducción con fines privados. Debe destacarse que esta Disposición no prevé expresamente la posibilidad de deducir las cantidades por los sujetos del art. 25.7.b) y c) del TRLPI. Sin embargo, hay que entender que estas cantidades también podrán ser deducidas conforme al procedimiento que se determine mediante Real Decreto ${ }^{903}$.

En definitiva, opera en todos estos casos una excepción ex ante al pago de la compensación, evitando engrosar los supuestos de reembolso ex post, que también prevé la ley y que añaden costos y tiempo a la gestión de la misma.

\section{Los supuestos de reembolso ex post de la compensación}

Los supuestos de reembolso de la compensación por copia privada son más bien

\footnotetext{
${ }^{903}$ El art. 25.9 del TRLPI, tras su modificación por el Real Decreto-ley 12/2017, de 3 de julio, establece que la compensación equitativa se hará efectiva a través de las entidades de gestión de derechos de propiedad intelectual conforme al procedimiento que se determine a tal efecto por Real Decreto.
} 
excepcionales. En efecto, la regla general es que las cantidades recaudadas en concepto de compensación sean abonadas a las entidades de gestión colectiva para su posterior reparto y distribución entre los titulares de derechos. Ahora bien, en aquellos supuestos en que la compensación ha sido recaudada, pero existe una justificación legal para su devolución, deberá procederse a su reembolso. Sólo así se garantiza que el sistema de recaudación de la compensación equitativa por copia privada se ajusta a las exigencias del art. 5.2.b) de la DDASI, tal y como ha establecido el TJUE ${ }^{904}$.

Conforme al art. 25.8 del TRLPI, aquellas personas jurídicas o físicas no exceptuadas del pago de la compensación podrán solicitar su reembolso en dos supuestos diferentes. Por un lado, es posible cuando actúan como consumidores finales, justificando el destino exclusivamente profesional del equipo, aparato o soporte material de reproducción adquirido, y siempre que estos no se hayan puesto, de derecho o de hecho, a disposición de usuarios privados y estén manifiestamente reservados a usos distintos a la realización de copias privadas. En este supuesto se incluye el importador o adquirente intracomunitario que demuestre que adquiere los equipos, aparatos y soportes de reproducción para su propio uso, bajo las condiciones y la finalidad que señala el precepto. Por otro lado, opera el reembolso cuando los equipos, aparatos o soportes materiales de reproducción adquiridos se hayan destinado a la exportación o entrega intracomunitaria. En este caso la razón de la norma se explica por sí sola: estos bienes no son utilizados en el territorio español y, por consiguiente, las reproducciones amparadas en el límite de copia privada tienen que ser compensadas en el lugar donde dichos bienes son utilizados. Así pues, habiéndose satisfecho la compensación en España en el momento de su adquisición, lo correcto es poder solicitar su reembolso, tal y como prevé la norma.

En ambos casos, conforme a lo previsto en la Disposición Transitoria segunda del Real Decreto-ley 12/2017, de 3 de julio (apartado siete), las personas jurídicas o físicas que, habiendo abonado la compensación, tuvieran derecho a su rembolso en virtud del

\footnotetext{
${ }^{904}$ Véanse las sentencias de 11 de julio de 2013, Amazon.com International Sales y otros, C-521/11, EU:C:2013:515 (apartado 31) y de 5 de marzo de 2015, Copydan Båndkopi, C-463/12, EU:C:2015:144 (apartado 45).
} 
art. 25.8 del TRLPI, podrán hacerlo ante la persona jurídica creada al efecto, esto es, la Asociación Ventanilla Única Digital, a partir del día siguiente a la entrada en vigor del Real Decreto que reglamente el procedimiento de satisfacción de la compensación equitativa por copia privada. Asimismo, el art. 25.8 del TRLPI establece la inadmisibilidad de las solicitudes de reembolso por importe inferior a veinticinco euros, salvo que en la solicitud de reembolso se acumule la compensación equitativa abonada por la adquisición de equipos, aparatos y soportes materiales realizada en un ejercicio anual.

Lógicamente, el reembolso no se justifica cuando la compensación ha sido abonada a las entidades de gestión colectiva por los deudores principales de ésta (fabricantes españoles para su distribución en territorio español, o adquirentes fuera del territorio español para su comercialización o utilización en éste); en los casos en que estos deudores han repercutido el importe de la compensación en la factura a sus clientes $^{905}$; o cuando han adquirido los equipos, aparatos y soportes para su propia utilización sin que puedan demostrar un destino exclusivamente profesional. En dichos supuestos, el abono de la compensación por parte de estos deudores está del todo justificado.

Sin embargo, no puede decirse lo mismo en aquellos casos en que la compensación ha sido pagada por el distribuidor, mayorista y minorista, sucesivo adquirente de los mencionados equipos, aparatos y soportes de reproducción, a su proveedor (deudor principal), sin haber podido discriminar, en el momento de su adquisición, cuáles y cuántos iban a parar a manos de usuarios exceptuados del pago de la compensación según el art. 25.7 del TRLPI. En efecto, la realidad es que este distribuidor o participante en la cadena de venta al público de estos bienes también puede tener como clientes a sujetos exceptuados del pago de la compensación, en cuyo caso, no se justifica que tenga que hacerse cargo del pago de la compensación que ha efectuado a su proveedor. Por consiguiente, el legislador, consciente de esta situación,

\footnotetext{
${ }^{905}$ Lo mismo resulta si son clientes finales o adquirentes mayoristas y minoristas para su distribución comercial.
} 
legitima a los distribuidores, mayoristas y minoristas, que sean sucesivos adquirentes de los mencionados equipos, aparatos y soportes materiales, para solicitar a las entidades de gestión la devolución de las cantidades que se correspondan con las mencionadas ventas a los sujetos exceptuados del pago de la compensación, conforme a lo preceptuado en el art. 25.3, párrafo $3^{\circ}$ del TRLPI.

Otro supuesto de reembolso se contiene en el art. 25.7 in fine del TRLPI. En virtud del mismo, los sujetos cuyas adquisiciones estén exceptuadas del pago de la compensación equitativa por copia privada que no hayan podido demostrar oportunamente que se encuentran en tal situación mediante la certificación correspondiente, podrán solicitar su reembolso. Al respecto, se exige que hayan liquidado el importe de la compensación al deudor al adquirir los equipos, aparatos y soportes materiales de reproducción sujetos al canon para que -posteriormente- puedan recuperar las cantidades indebidamente satisfechas, por estar exceptuados de su pago. Nada dice la ley sobre el procedimiento para hacer efectiva esta devolución, ni tampoco de los plazos al efecto, lo que se espera que quede determinado en el Real Decreto que desarrolle reglamentariamente las disposiciones del art. 25 del TRLPI, conforme a lo previsto en la Disposición Final primera del Real Decreto-ley 12/2017, de 3 de julio.

Cabe añadir que el art. 25.12 del TRLPI prevé que los conflictos que se planteen respecto a las solicitudes de reembolso del pago de la compensación equitativa previstas en el art. 25.8 del TRLPI serán resueltos por el Ministerio de Educación, Cultura y Deporte. Ahora bien, aún está por reglamentar cuál será el procedimiento a este fin, pues la ley sólo se limita a establecer la legitimación del Ministerio.

\section{LOS EQUIPOS, APARATOS Y SOPORTES MATERIALES IDÓNEOS A EFECTOS DEL PAGO DE LA COMPENSACIÓN}

\section{El criterio de idoneidad}

Según el art. 25.1 del TRLPI, la compensación por copia privada se determina para cada modalidad de reproducción (obras divulgadas en forma de libros o publicaciones que a estos efectos se asimilen reglamentariamente, así como fonogramas, videogramas $\mathrm{u}$ otros soportes sonoros, visuales o audiovisuales) en función de los equipos, aparatos y soportes materiales idóneos para realizar dicha reproducción, 
fabricados en territorio español o adquiridos fuera de éste para su distribución comercial o utilización dentro de dicho territorio. El mecanismo compensatorio depende, pues, de los "equipos, aparatos y soportes materiales idóneos"906. De este modo, la idoneidad es un factor determinante en el régimen jurídico de la compensación equitativa por copia privada, que se materializa, como se analizará, por medio de la concreción que se hace en la norma de los equipos, aparatos y soportes materiales de reproducción sujetos a la compensación equitativa.

La idoneidad es un criterio introducido en la Ley 22/1987, de 11 de noviembre, de Propiedad Intelectual, tras su modificación por la Ley 20/1992, de 7 de julio. Sin embargo, ni entonces, ni actualmente en el TRLPI, existe un concepto al respecto. No obstante, toda vez que la ley se refiere a "equipos, aparatos y soportes idóneos", se entiende que utiliza este calificativo en el sentido de aptitud, competencia, capacidad o suficiencia para realizar reproducciones para uso privado, lo que permite concluir que todo equipo, aparato o soporte susceptible de generar una reproducción podrá servir como medio para garantizar que los titulares de derechos de propiedad intelectual sean compensados por la copia privada. Así lo ha venido entendiendo la doctrina, que ha definido la idoneidad como "la aptitud objetiva para hacer una reproducción para uso privado, para almacenarla, o para llevar a cabo ambas funciones simultáneamente"907. Lo determinante es, por tanto, que los equipos, aparatos y soportes materiales de reproducción tengan aptitud para ser utilizados para realizar copias privadas, sin necesidad de constatar si efectivamente se han efectuado ${ }^{908}$. Incluso en aquellos casos en que la función principal de estos bienes no sea la de elaborar o almacenar reproducciones para uso privado, tampoco quedarán excluidos de la compensación, al menos en principio ${ }^{909}$, pues siempre que tengan aptitud para realizar reproducciones,

\footnotetext{
906 Énfasis añadido.

907 Garrote Fernández-DíEz, I., “Artículo 9", en Bercovitz RodríGuEZ-CANO, R. (Coord.), Comentarios al Convenio de Berna..., op. cit., p. 478.

${ }^{908}$ LÓPEZ MAZA, S. y Minero AlejANDRE, G., "El carácter equitativo...”, op. cit., p. 105.

909 Podría quedar excluido de valorarse, por ejemplo, que causa un daño inocuo, debido a su uso mayoritario para fines diferentes de la copia privada. En efecto, el art. 25.5.b) del TRLPI establece que "no darán origen a una obligación de compensación aquellas situaciones en las que el perjuicio causado al titular del derecho de reproducción haya sido mínimo [...]". Vid. infra, epígrafe VII, apartado 1.
} 
podrán ser considerados idóneos y ello permitirá su inclusión dentro de los dispositivos gravados.

El criterio de la idoneidad ha sido un aspecto neurálgico del sistema compensatorio, aunque durante el período en que la compensación equitativa por copia privada pasó a depender de los PGE, perdió virtualidad. En efecto, bajo el sistema de los Presupuestos, la compensación no dependía de una cantidad a pagar sobre los equipos, aparatos y soportes idóneos para la reproducción, sino de una cantidad consignada presupuestariamente al efecto ${ }^{910}$.

En la jurisprudencia se encuentran numerosas sentencias que ayudan a esclarecer la aplicación de este criterio de idoneidad objetiva. En efecto, los jueces y tribunales han contribuido a perfilar los contornos de la obligación de pago de la compensación en función de este criterio, sobre todo en asuntos relacionados con la reclamación del canon en soportes digitales $^{911}$. Sirva de ejemplo la SAP Málaga (Sección 6 ${ }^{\text {a }}$ ) núm. 115, de 20 de febrero de $2007^{912}$ que, resolviendo un recurso de apelación interpuesto por las demandadas en instancia frente a su condena a abonar el canon compensatorio en soportes DVD, resaltó lo siguiente:

“[...] el artículo $25^{[913]}$, en definitiva, establece con carácter imperativo, el canon compensatorio que se determinará en función de los equipos, aparatos y materiales que en cada momento, y atendiendo a la evolución de la técnica, resulten idóneos para la reproducción, idoneidad para la reproducción privada, que es el criterio determinante para la sujeción al canon, no especificando dicho precepto materiales concretos, por lo que es claro que cualesquiera que resulten idóneos para la reproducción para uso privado, incluidos los DVDs, son los que están sujetos".

Con todo, el criterio de idoneidad supone que las entidades de gestión, que actúan en representación de los acreedores del canon, no tengan que demostrar el empleo de

\footnotetext{
910 Vid. supra Capítulo IV, epígrafe II, apartado 3.

911 Antes de la modificación del TRLPI por la Ley 23/2006, los soportes digitales no quedaban gravados expresamente, lo que dio lugar a un sinnúmero de reclamaciones judiciales en contra de la satisfacción del canon respecto a estos.

912 Roj: SAP MA 111/2007.

${ }^{913}$ Se refiere a la versión del TRLPI de 1996, pero sin consecuencia alguna al efecto de lo que aquí se comenta, porque tanto el TRLPI aprobado en 1996, como la versión actual del mismo establecen (con igual formulación) que "la compensación se determinará para cada modalidad en función de los equipos, aparatos y soportes materiales idóneos para realizar dicha reproducción”.
} 
estos equipos, materiales y soportes para la reproducción con fines privados de obras y prestaciones amparadas por los derechos de propiedad intelectual. Lo contrario supondría una probatio diabólica, como así se ha declarado ${ }^{914}$.

En todo caso, así lo ha venido declarando el TJUE, desde la sentencia Padawan ${ }^{915}$, al señalar en su apartado 56 que:

"[...] la mera capacidad de dichos equipos o aparatos para realizar copias basta para justificar la aplicación del canon por copia privada, siempre y cuando dichos equipos o aparatos se hayan puesto a disposición de personas físicas en condición de usuarios privados".

Por tanto, basta el presumible uso de estos aparatos o equipos para realizar copias privadas, no siendo necesaria la realización efectiva de la copia.

\section{El criterio de idoneidad objetiva en relación con la presunción de utilización de los equipos, aparatos y soportes materiales para la copia privada}

Antes de la sentencia Padawan no se tenía en cuenta el destino dado al equipo, aparato o soporte de reproducción en función de la condición de persona física o jurídica del adquirente. Tanto particulares, como empresarios o administraciones públicas debían pagar el canon por la mera aptitud de los productos que adquirían para realizar copias privadas de obras y prestaciones protegidas. Así lo declara la sentencia núm. 134/2007 del Juzgado de lo Mercantil núm. 1 de Bilbao, de 16 de marzo de $2007^{916}$ :

"Cierto es que podría el legislador haber evitado esa generalización, de manera que cada vez que se vendiera un soporte digital los autores habrían de perseguir al adquirente para comprobar si se utilizaba para obtener una copia privada. En ese

\footnotetext{
${ }^{914}$ En este sentido, la SAP Zaragoza (Sección $2^{\text {a }}$ ) núm. 112/2005, de 8 marzo (JUR\2005\100643), FJ $2^{\text {o }}$ señala: “[...] la Sentencia recurrida no es contraria a lo dispuesto en el art. 25 de la Ley de Propiedad Intelectual por cuanto este artículo al igual que lo hiciera la anterior legislación de 1987 establece un sistema de remuneración compensatoria por copia privada como vía complementaria de explotación de la obra audiovisual estando basada en la legislación Europea en el criterio de la idoneidad o aptitud de los soportes para la reproducción con independencia de su destino final, bastando pues que la gestora acredite su idoneidad y no sometiéndola a la «probatio diabolica» de acreditar su destino final [...]".

${ }^{915} \mathrm{Cit}$.

916 Roj: SJM BI 9/2007.
} 
caso se reclamaría la compensación correspondiente y se satisfaría el derecho reconocido por la ley. De esa manera sólo aquellos que hacen una copia privada tendrían que atender la compensación legal, evitando que otros que utilizan el soporte para almacenar datos privados hubieran de verificarlo.

De haberse optado por esa posibilidad legal, cualquier ciudadano o empresa $^{917}$ se vería compelido a dar explicaciones, cooperando con los autores protegidos por la ley, sobre el uso de sus soportes digitales. Ello supondría algún coste para los adquirentes, que tendrían que explicar y justificar el destino de los soportes que compran, los autores y sus entidades de gestión, que habrían de hacer un seguimiento de cada una de las transacciones, y para la propia sociedad, que seguramente tendría que destinar recursos superiores a la administración de justicia, para atender el probable incremento de litigios que se plantearían en este ámbito.

Pero no es ese el sistema escogido por el legislador. Deliberada y expresamente han optado el legislador europeo y el español por una fórmula genérica, que grava cualquier soporte susceptible de registrar datos protegidos o no, evaluando el uso medio que suele hacerse de los mismos para concluir una determinada cantidad, mediante una ponderación media" $\left(\mathrm{FJ} 5^{\circ}\right)$.

En contraste con anterior, la sentencia Padawan vino a destacar lo siguiente:

"La Directiva 2001/29 debe interpretarse en el sentido de que es necesaria una vinculación entre la aplicación del canon destinado a financiar la compensación equitativa en relación con los equipos, aparatos y soportes de reproducción digital y el presumible uso de éstos para realizar reproducciones privadas. En consecuencia, la aplicación indiscriminada del canon por copia privada, en particular en relación con equipos, aparatos y soportes de reproducción digital que no se hayan puesto a disposición de usuarios privados y que estén manifiestamente reservados a usos distintos a la realización de copias privadas, no resulta conforme con la Directiva 2001/29" (apartado 59).

Esta doctrina supuso, en consecuencia, un punto de inflexión en la aplicación del canon por copia privada en el ámbito nacional. En efecto, si bien el criterio de idoneidad objetiva siguió siendo clave para exigir el canon compensatorio de adquirirse los equipos, aparatos y soportes de reproducción por personas jurídicas, comenzó a operar en la práctica de nuestros tribunales, la presunción de su utilización para un uso ajeno al de la copia privada y, por tanto, la no procedencia del cobro del canon compensatorio, como seguidamente se verá.

\footnotetext{
917 Énfasis nuestro: tanto particulares como empresarios estaban obligados a abonar el canon sin necesidad de que quedara demostrado el uso final de los aparatos, equipos y soportes adquiridos.
} 
En efecto, tras este fallo, comenzó a cobrar relevancia el destino dado a los equipos, aparatos y soportes de reproducción, al efecto de distinguir cuáles de ellos habían sido puestos a disposición de usuarios privados y cuáles a disposición de empresarios y profesionales. Así lo manifestó, en primer lugar, la SAP Barcelona (Sección $15^{\mathrm{a}}$ ), de 2 marzo de $2011^{918}$, que fue precisamente la que resolvió el recurso que dio lugar a las cuestiones prejudiciales formuladas al TJUE en el asunto Padawan. La Audiencia Provincial de Barcelona, como no podía ser de otro modo, de conformidad con la doctrina del TJUE, reafirmó que la aplicación indiscriminada del canon por copia privada en relación con todo tipo de equipos, aparatos y soportes de reproducción digital no resultaba conforme con el art. 5.2.b) de la DDASI, señalando:

"Basta la mera acreditación de que algunos de los adquirientes de aquellos productos que se quieren gravar fueron empresas públicas o privadas, para advertir que se pretendió aplicar indiscriminadamente [el canon], incluso a supuestos en que claramente no iban a ser destinados a copia privada. [...] No tiene sentido repercutir sobre una empresa o un profesional la financiación de la "compensación equitativa" por copia privada, al adquirir soportes digitales para su actividad empresarial o profesional" 919 .

De acuerdo con lo anterior, la Audiencia determinó que, aun existiendo el derecho de la SGAE - demandante en la instancia y apelada- a aplicar un canon sobre los soportes digitales comercializados a particulares por la demandada, Padawan, S.L., esta última no debía abonar el canon, al no poder distinguir cuántos CD-Rs, CD-RWs, DVD-Rs y aparatos de MP3 habían sido adquiridos por particulares y cuántos por empresas y profesionales ${ }^{920}$. Así, estimó el recurso y revocó la sentencia dictada en fecha 14 de junio de 2007 por el Juzgado Mercantil núm. 4 de Barcelona. Posteriormente a esta sentencia siguieron otras dictadas por la misma Audiencia en idéntico sentido. Sirvan de ejemplo las sentencias núm. 471/2011, de 30 noviembre ${ }^{921}$ y núm. 516/2011, de 22 diciembre ${ }^{922}$.

\footnotetext{
918 Roj: SAP B 2/2011.

919 Ídem, FJ $16^{\circ}$.

920 Ídem, FJ $17^{\circ}$.

${ }^{921}$ Roj: SAP B 13125/2011.

922 Roj: SAP B 11458/2011.
} 
En similares términos se pronunció la SAP Madrid (Sección 28 $8^{\text {a }) ~ n u ́ m . ~ 123 / 2013, ~}$ de 22 abril $^{923}$. Esta resolución, trayendo a colación la sentencia Padawan, precisó que, aun cuando los términos empleados en la misma resultaban muy variados ${ }^{924}$, podía considerarse que la expresión "usuario privado" se empleaba de forma equivalente a "persona física". Bajo esta perspectiva, se reafirmaba la idea de que debían excluirse del canon los equipos, aparatos y soportes de reproducción digital que no hubieran sido puestos a disposición de personas físicas y que estuvieran manifiestamente reservados a usos distintos de la realización de copias privadas. Consecuentemente, en el caso de los equipos, aparatos y soportes puestos a disposición de personas jurídicas debía acreditarse que éstas los habían empleado para la realización de copias privadas de obras y prestaciones protegidas por la propiedad intelectual (FJ $4^{\circ}$ ). La carga probatoria al respecto correspondía al deudor de la compensación, quien debía demostrar que los equipos y soportes materiales idóneos para la copia privada no se habían puesto a disposición de los sujetos comprendidos en el ámbito de aplicación de la norma, esto es, los usuarios privados, conforme al principio de facilidad probatoria ${ }^{925}$.

Asimismo, la SAP Murcia (Sección 4ª ) núm. 388/2011, de 21 julio ${ }^{926}$ desestimó el recurso presentado por la Entidad de Gestión de Derechos de los Productores Audiovisuales (EGEDA) contra el fallo dictado por el Juzgado de instancia en el que se desestimaba, igualmente, su reclamación contra la mercantil MICROX INFORMÁTICA 2000, S.L. por el impago de la compensación equitativa por copia privada. En este asunto, el fallo se fundó en que no quedó acreditado que, durante el período a que se refería la reclamación, los soportes DVD y DVD-Data comercializados por la demandada hubiesen sido puestos a disposición de personas físicas en calidad de usuarios privados, para la realización de copias privadas en el sentido del artículo 31.2

\footnotetext{
923 Roj: SAP M 7677/2013.

924 "Usuario privado" (apdos. 50 y 59), "persona física" (apdo. 57), "persona privada" (apdo. 46), "persona física en condición de usuario privado" (apdo. 56), "persona física a título particular" (apdo. 44)], todos de la STJUE de 21 de octubre de 2010 (caso Padawan).

925 “[...] la demandada tiene la condición de deudor de la compensación y tiene en su mano acreditar, conforme al principio de facilidad probatoria, a quien ha vendido y que los materiales se destinen a usos distintos de la copia privada. Por otra parte, no puede la demandada repercutir la compensación a los adquirentes y negar la aplicación de la compensación", Ibídem, FJ $4^{\circ}$.

926 Roj: SAP MU 1812/2011.
} 
del TRLPI (2006), aun cuando la demandada se dedicaba a la comercialización de soportes informáticos aptos para la obtención de este tipo de reproducciones (FJ $2^{\circ}$ ).

En el mismo sentido se pronunció la SAP Oviedo (Sección $1^{\text {a }}$ ) núm. 304/2011, de 8 de julio ${ }^{927}$. En cambio, esta vez, el fundamento del fallo no fue, propiamente, la imposibilidad de discriminar entre los soportes cuáles de ellos habían sido vendidos para fines manifiestamente ajenos a la copia privada, sino que se centró en analizar si la apelante comercializaba, efectivamente, estos soportes como parte de su actividad empresarial. En este caso, la sentencia reconoció que, dentro de las actividades incluidas en el objeto social de la apelante, esta tenía la posibilidad de vender a terceros soportes aptos para la copia privada. Sin embargo, a partir de su facturación estimó que la cantidad vendida a particulares representaba sólo una ínfima parte. Por tanto, concluyó:

"[...] la actividad de la empresa demandada, y en estos momentos apelante, es la de un consumidor de soportes, frente a los minoristas que son quienes los venden a los particulares para copias de dicha naturaleza [...]. Puesto que resulta que aquellos soportes son utilizados por la demandada en forma distinta a la realización de copias privadas desde el momento en que es la propia empresa la que los utiliza en su actividad de software, resulta que la pretensión de la demanda es la aplicación totalmente indiscriminada del canon a la empresa demandada" (FJ $\left.3^{\circ}\right)$.

Una cuestión similar fue abordada por la SAP Santa Cruz de Tenerife (Sección 4a ) núm. 331/2012, de 7 septiembre ${ }^{928}$. En este asunto la recurrente negó que se hubiese acreditado por la demandante el hecho generador de la obligación de pago del canon, esto es, que el destino de los soportes adquiridos fuera su venta a particulares. A diferencia del caso anterior, aquí entre las actividades incluidas en el objeto social de la apelante no se encontraba la venta, alquiler u otra que permitiera poner a disposición de otros usuarios los soportes en cuestión. No existía prueba directa de que la demandadaapelante se dedicara a tal comercio, aunque fue inferido en la instancia por el alto número de soportes adquiridos. La Audiencia estimó que se estaba ante una prueba por presunciones (art. 386 LEC), habiendo quedado acreditada únicamente la compra de los

\footnotetext{
${ }^{927}$ Roj: SAP O 1179/2011.

${ }^{928}$ Roj: SAP TF 2591/2012.
} 
soportes, no así su puesta a disposición de usuarios particulares, por cuanto las actividades de la mercantil podían justificar su consumo interno ${ }^{929}$. Por tanto, otorgó la razón a la recurrente en este punto y la liberó del pago del canon.

Todos estos ejemplo demuestran cómo a partir del pronunciamiento del TJUE en el asunto Padawan y la consiguiente sentencia de la AP Barcelona (Sección 15 a), de 2 marzo de 2011, comenzó a ser relevante no sólo la aptitud o capacidad de los equipos, materiales y soportes para la reproducción de obras y prestaciones objeto de propiedad intelectual, sino también la necesidad de evaluar, en función de la condición del adquirente de los mismos, los casos en que, manifiestamente, podía inferirse que serían utilizados para fines distintos a la copia privada. En concreto, se trataba de aquellos supuestos en que los dispositivos eran adquiridos por empresarios y profesionales, personas jurídicas y administraciones públicas, tal y como ya había resaltado el Auto de 15 de septiembre de $2008^{930}$ de la Audiencia Provincial de Barcelona, mediante el cual se formularon las cuestiones prejudiciales planteadas al TJUE.

No obstante, hay que decir que la interpretación dada por la SAP Barcelona (Sección 15 ), de 2 marzo de 2011 no fue del todo acorde con la sentencia Padawan. En efecto, la misma no establecía que estuvieran excluidos del pago de la compensación los adquirentes de equipos, aparatos y soportes materiales que tuvieran la condición de empresas públicas o privadas, o profesionales. Por el contrario, la condición exigida era que dichos equipos, aparatos o soportes materiales no se hubieran puesto a disposición

\footnotetext{
929 Ídem, FJ $4^{\circ}$.

${ }^{930}$ Roj: AAP B 5301/2008. Según la Audiencia Provincial, son situaciones diferentes las que se producen mediante la venta directa al consumidor de equipos y soportes idóneos para la realización de copias privadas de contenidos protegidos por la propiedad intelectual, y las que derivan de la adquisición de estos equipos y soportes por entidades públicas, empresas o despachos profesionales. En el primer caso, sería más común pensar que la adquisición podrá tener lugar para reproducir contenidos protegidos por la propiedad intelectual, no así, en el segundo, donde se supone que lo habitual será la utilización de estos con fines ajenos a la copia privada, como puede ser el almacenamiento de información generada por ellas mismas o que no es objeto de propiedad intelectual de terceros. Con estas premisas, la Audiencia concluye que cabría discriminar en función del adquirente y, como consecuencia, gravar sólo las ventas realizadas a consumidores particulares y no a las entidades públicas, empresas o despachos profesionales, lo que puede fácilmente observarse del análisis de la contabilidad (F.J. $2^{\circ}$ ).
} 
de usuarios privados y la mera adquisición de los mismos por empresas o profesionales, no debía constituir una presunción de esta falta de puesta a disposición ${ }^{931}$.

En efecto, es evidente que muchas personas jurídicas sólo reproducen materiales propios o generados por su actividad, que nada tienen que ver con contenidos protegidos por la propiedad intelectual y ello justifica que queden exceptuadas del pago del canon. Más cuestionable es afirmar, con carácter general, que cuando los equipos, aparatos y soportes de reproducción son adquiridos por personas jurídicas, su finalidad es siempre ajena a la copia privada ${ }^{932}$. Por el contrario, estos equipos también pueden ser destinados a la reproducción para uso privado de contenidos protegidos por derechos de autor, pues su adquisición por personas jurídicas no excluye su puesta a disposición de personas físicas, ni la realización por éstas de copias para uso privado ${ }^{933}$. En efecto, también las personas jurídicas pueden adquirir estos equipos con la finalidad de ponerlos a disposición de usuarios privados quienes, a su vez, al amparo del límite de copia privada, podrán realizar lícitamente reproducciones de obras protegidas. Así pues, en estos supuestos, debería ser exigible la compensación, de ahí que sea necesario no dar por hecho que toda adquisición por una persona jurídica de equipos, aparatos y soportes de reproducción deba quedar excluida del pago del canon.

Por tanto, a tenor de la doctrina del TJUE, la mejor solución no debía ser excluir de la compensación a todos los equipos y soportes adquiridos por personas distintas de los usuarios privados, sino sólo aquellos en los que, además, su uso estuviera reservado de forma manifiesta, clara y evidente, a fines distintos de la realización de copias

\footnotetext{
${ }^{931}$ En este sentido Vid. LóPEZ SÁNCHEZ, C., "Consecuencias jurídicas de la sentencia del TJUE en el caso Padawan”, en EsteVe PARDo, M. A. (Coord.), Cuestiones de actualidad sobre propiedad intelectual. Iniciativas legales frente a las descargas ilegales en Internet y consecuencias del "caso Padawan" sobre la compensación equitativa por copia privada, Tirant lo Blanch, Valencia, 2013, p. 117.

932 Esteve PARDO, M. A., "Comentario a la sentencia de la Audiencia Provincia de Barcelona (Sección $15^{\mathrm{a}}$ ) de 2 de marzo de 2011, 'Caso Padawan'. La compensación equitativa por copia privada a examen", en ESTEVE PARDO, M. A. (Coord.), Cuestiones de actualidad sobre propiedad intelectual. Iniciativas legales frente a las descargas ilegales en Internet y consecuencias del "caso Padawan" sobre la compensación equitativa por copia privada, Tirant lo Blanch, Valencia, 2013, p. 133.

${ }^{933}$ En este sentido, BERCOVITZ RODRÍGUEZ-CANO, R., destaca que podría ser el caso de universidades y colegios, en relación con sus estudiantes; una fundación, con respecto a los beneficiarios de su actividad; o una asociación, con respecto a sus socios. BERCOVITZ RODRÍGUEZ-CANO, R., "La copia...", op. cit., pp. 84-85. Véase también, CARBAJO CASCÓN, F., "El retorno del canon digital. Consecuencias previsibles...", op. cit., pp. 18-19.
} 
privadas ${ }^{934}$. Y esta parece ser la perspectiva que prima actualmente en la redacción del art. 25.7 del TRLPI que, en lo que respecta a la adquisición de equipos, aparatos y soportes materiales de reproducción por personas físicas y jurídicas para uso profesional, exige, expresamente, que no se hayan puesto, de hecho o de derecho, a disposición de usuarios privados y que estén manifiestamente ${ }^{935}$ reservados a usos distintos de la realización de copias privadas.

En todo caso, también se encuentran en la jurisprudencia menor (si bien anterior a la actual redacción del TRLPI), criterios interpretativos distintos, admitiendo que cabe prueba en contrario respecto de la presunción legal de que los soportes comprados por personas físicas van a ser destinados a la copia privada de obras protegidas por la propiedad intelectual. Así, por ejemplo, la SAP Málaga (Sección 5a), de 19 de septiembre de $2006^{936}$ declaró que cabía justificar que el soporte se había usado para otro fin concreto, distinto de la reproducción privada de obras protegidas de autores. No obstante, la SAP Madrid (Sección $28^{\text {a }}$ ) núm. 37/2007, de 8 de febrero ${ }^{937}$ se manifestó en contra.

\footnotetext{
${ }^{934}$ LÓPEZ SÁNCheZ, C., "Consecuencias jurídicas de la sentencia del TJU en el 'caso Padawan'”, en ESTEVE PARDO, M. A. (Coord.), Cuestiones de actualidad sobre propiedad intelectual..., op. cit., pp. $118-119$.

${ }^{935}$ Énfasis añadido.

${ }^{936}$ Roj: SAP MA 952/2006. Esta sentencia resolvió el recurso interpuesto por don E.S.M. contra la sentencia desestimatoria de su pretensión en el juicio verbal por razón de la cuantía, promovido por éste, frente a la mercantil Naylo Hardware, SL, de Málaga, para la reclamación de diecinueve céntimos $(0,19$ euros), desglosados en la factura de compra de un CDRom en blanco o virgen por un importe total de sesenta céntimos ( 0,60 euros), en concepto de cobro del canon por reproducción por copia privada del art. 25.1 TRLPI. Cabe señalar que contra esta sentencia la SGAE presentó demanda de amparo ante el Tribunal Constitucional, basada en la infracción de su derecho fundamental a la tutela judicial efectiva (art. 24.1 CE), aduciendo que se había debatido en el proceso sobre el contenido y alcance de una obligación legal de la que es legítima acreedora sin que se le hubiese dado la más mínima posibilidad de acceder al procedimiento judicial a fin de poder defender su interés legítimo en la cuestión. El Tribunal Constitucional otorgó el amparo solicitado, mediante la STC 196/2009, de 28 de septiembre (B.O.E. núm. 254, de 21 de octubre de 2009), anulando todo lo actuado tanto en el rollo de apelación núm. 267-2006, como en el juicio verbal núm. 1362-2004 seguido ante el Juzgado de Primera Instancia núm. 14 de Málaga, desde el momento en que se produjo la admisión a trámite de la demanda.

${ }^{937}$ Roj: SAP M 3944/2007.
} 
En particular, la referida SAP Málaga (Sección 5ª), de 19 de septiembre de 2006

(a la que siguió, por ejemplo, la sentencia del Juzgado de lo Mercantil núm. 1 de Sevilla, 2 septiembre de $2009^{938}$ ) señaló:

“[...] el artículo 25 de la mencionada L.P.I. se articula bajo el epígrafe 'Derecho de remuneración por copia privada', y es evidente de su literalidad que excluye del canon aquellas copias destinadas a uso industrial, pero también entiende la Sala que al establecer que 'la reproducción', realizada exclusivamente para uso privado, de obras divulgadas en forma de libros o publicaciones, así como de fonogramas, videogramas o de otros soportes sonoros, visuales o audiovisuales, es la que 'originará' una remuneración [...] dirigida a compensar los derechos de propiedad intelectual que se dejaren de percibir por razón de la expresada reproducción, permite acreditar el destino final de los soportes adquiridos, y demostrar que no se han usado para la definida reproducción. Aparece pues un problema meramente probatorio en el sentido antedicho que ha de resolverse sobre la presunción legal de que, en principio, la compra de los soportes es para la reproducción de obras acogidas al amparo de la Legislación Especial, pero cabe, dado el tenor legal, justificar que el soporte se ha usado para otro concreto fin distinto de la reproducción de obras de autores, que es la causa de la tributación $\left(\mathrm{FJ} \mathrm{3}{ }^{\circ}\right.$ ).

[...] a juicio de esta Sala, la presunción de existencia de la 'reproducción de obra de autor' que se deduce de la compra del soporte adecuado para ello, es presunción 'iuris tantum' que es posible destruir si se declara probado que la compra obedeció a otra causa que excluiría en sí misma la aplicación del canon. La conclusión no puede ser otra que la alcanzada por la sentencia del Juzgado número 1 de Alcalá de Henares, fechada el 15 de junio de 2005 y a la que en esta resolución se ha hecho referencia: en el caso de autos, el material adquirido, o sea, un 'CD-ROM' en blanco, tiene un campo de posibilidades que, no solo no viene necesariamente circunscrito a servir de soporte a obras literarias, artísticas o científicas de ajena pertenencia, aunque sea lo que el legislador presume, sino que en el presente caso ha servido de soporte a un documento visual y sonoro que no goza de la protección otorgada por la Ley Especial que comentamos" (FJ 4º.

\footnotetext{
938 AC 2009\1970. En este caso, el Juzgado de lo Mercantil núm. 1 de Sevilla, conforme con el criterio enunciado en la SAP Málaga (Sección 5a), de 19 de septiembre de 2006 referenciada, reconoce la posibilidad de que pueda destruirse judicialmente la presunción de que la compra de soportes aptos para la reproducción con fines privados es la realización de copias privadas en el sentido del art. 31.2 TRLPI. Así, da la razón al demandante, puesto que de las pruebas documentales aportadas se desprendía que los CDs adquiridos por el fueron utilizados en los procedimientos judiciales en los que intervino como Letrado para obtener una copia de las vistas celebradas en los mismos, con lo cual, el objeto de estos no fue la reproducción de obras protegidas por derechos de propiedad intelectual, por lo que no se cumplían los requisitos establecidos en la ley para la aplicación de la compensación equitativa.
} 
Admitía la Sala, de este modo, que era posible acreditar que el uso dado a un CDRom no tenía por qué ser la realización de copias privadas en el sentido del art. 31.2 del TRLPI (2006) y, de acreditarse, resultaba improcedente el pago del canon ${ }^{939}$.

Sin embargo, contraria a esta postura, la SAP Madrid (Sección 28 $8^{\text {a }}$ núm. 37/2007, de 8 de febrero, expuso:

"Lo que en opinión de la Sala excede de una mera interpretación de la ley, y entra de lleno en el campo de la creación legislativa, ajeno a la función de los tribunales, es permitir que en cada caso el adquirente del equipo, aparato o soporte acredite que el destino del mismo no es el de realizar una copia privada para obtener la devolución de dicho canon, y menos aún para obtenerlo del vendedor del equipo, aparato o soporte, que viene obligado por el juego de los apartados 4a-II y 13 del art. 25 de la Ley de Propiedad Intelectual a abonar el canon al fabricante o distribuidor o a realizar ellos mismos la declaración-liquidación y pago del mismo a las entidades de gestión colectiva de derechos de autor" (FJ $3^{\circ}$ ).

Esta segunda postura parece más coherente con la articulación del sistema de compensación equitativa por copia privada, donde el ejercicio de una acción del adquirente final (persona física) contra el vendedor, con la finalidad de obtener el importe de la compensación que le ha sido repercutida al hacer la compra del soporte, puede incidir negativamente en la dinámica de recaudación del canon, de prosperar la misma. Téngase en cuenta que quien pone el soporte de reproducción a disposición del usuario final, que no ha sido exceptuado del pago de la compensación ex art. 25.7 del TRLPI, tiene la obligación de repercutirle el importe de esta en la factura, bien sea para recuperar lo pagado a su suministrador en el momento de adquirir dicho soporte, bien para liquidarlo a la entidad de gestión colectiva, de no haberlo abonado oportunamente al distribuidor, fabricante o mayorista. Por tanto, la eventual condena al vendedor, para

\footnotetext{
${ }^{939}$ En contra, AVILÉs GARCÍA, J., El derecho de compensación ..., op. cit., pp. 50 y ss. Este autor destaca que, con esta sentencia, "se pone en tela de juicio la operatividad y eficacia del sistema legislativo vigente entonces en torno a la compensación equitativa por copia privada". La sentencia - refiere el autor"justifica exclusivamente la solución dada como si se tratase de «un problema meramente probatorio [...] que ha de resolver sobre la presunción legal de que, en principio, la compra de los soportes es para la reproducción de obras acogidas al amparo de la legislación especial, pero cabe, dado el tenor legal, justificar que el soporte se ha usado para otro concreto fin distinto de la reproducción de obras de autores, que es la causa de la tributación». [...] También todo ello implica una considerable inseguridad y muchos riesgos para que el mecanismo de una presunción legal, ideada un tanto al margen de la realidad económica y jurídica de la propiedad intelectual, opere sin ningún contrapeso o equilibrio [...]”.
} 
que devuelva lo repercutido al cliente final en concepto de canon, lo pondría en una situación injusta, pues asumiría el pago de la compensación dos veces.

Valga señalar que tampoco justifica una postura contraria a la anterior el hecho de que el TJUE haya admitido una presunción iuris tantum del uso privado de soportes digitales de reproducción en caso de que éstos se vendan a personas físicas ${ }^{940}$. Conforme a dicha doctrina, se trata de poder demostrar un uso para fines manifiestamente ajenos a la copia privada, frente a la presunción general de que, una vez puestos los equipos, aparatos y soportes de reproducción a disposición de usuarios privados, estos los utilizarán para esta finalidad. Por tanto, no se trata de demostrar que un uso cualquiera de un soporte es para fines ajenos a la copia privada, sino de demostrar que la finalidad de la adquisición no es el uso privado, sino distinta, como es el caso de los usos profesionales o empresariales.

El razonamiento que sigue el TJUE a efecto es el siguiente:

"Habida cuenta de las dificultades prácticas vinculadas a la determinación de la finalidad privada del uso de un soporte de grabación que puede utilizarse para la reproducción, el establecimiento de una presunción iuris tantum de dicho uso al poner dicho soporte a disposición de una persona física está, en principio, justificado y responde al 'justo equilibrio' que debe alcanzarse entre los intereses de los titulares del derecho de reproducción exclusivo y los de los usuarios de prestaciones protegidas.

Corresponde al juez nacional comprobar, atendiendo a las circunstancias particulares de cada sistema nacional y a los límites impuestos por la Directiva 2001/29, si hay dificultades prácticas vinculadas a la determinación de la finalidad privada del uso de los mencionados soportes que justifiquen el establecimiento de dicha presunción $\mathrm{y}$, en cualquier caso, si la presunción prevista no supone la imposición del canon por copia privada en casos en que el uso final de los citados soportes queda manifiestamente fuera del supuesto contemplado en el artículo 5, apartado 2, letra b), de la Directiva 2001/29.

En estas circunstancias, [...] el artículo 5, apartado 2, letra b), de la Directiva 2001/29 debe interpretarse en el sentido de que, en el marco de un sistema de financiación de la compensación equitativa a la que se refiere dicha disposición

\footnotetext{
${ }^{940}$ Vid. STJUE (Sala Segunda), de 11 de julio de 2013. Amazon.com International Sales Inc., Amazon EU Sàrl, Amazon.de GmbH, Amazon.com GmbH, en liquidación, y Amazon Logistik GmbH contra AustroMechana Gesellschaft zur Wahrnehmung mechanisch-musikalischer Urheberrechte Gesellschaft mbH, asunto C-521/11 [ECLI:EU:C:2013:515], párrafos 43 al 45.
} 
por medio de un canon por copia privada pagado por las personas que ponen por primera vez en circulación en el territorio del Estado miembro de que se trata, a título oneroso y con fines comerciales, soportes de grabación que pueden utilizarse para la reproducción, la citada disposición no se opone al establecimiento por dicho Estado miembro de una presunción iuris tantum del uso privado de dichos soportes en caso de que éstos se vendan a personas físicas, cuando haya dificultades prácticas vinculadas a la determinación de la finalidad privada del uso de los mencionados soportes que justifiquen el establecimiento de dicha presunción y siempre que la presunción prevista no suponga la imposición del canon por copia privada en casos en que el uso final de esos soportes quede manifiestamente fuera del supuesto contemplado en la citada disposición"941.

Puede decirse que el sentido de la citada presunción ha sido recogido por el legislador español en el art. 25.8 del TRLPI, al admitir que la persona física, no exceptuada del pago de la compensación, pueda solicitar el reembolso de la cantidad pagada por tal concepto. Por tanto, no se está estableciendo una presunción iuris et de iure de que la adquisición de soportes de reproducción por personas físicas es necesariamente la realización de copias privadas, sino que cabe prueba en contrario, para demostrar que su finalidad es exclusivamente profesional o para la exportación o entrega intracomunitaria.

\section{Los equipos, aparatos y soportes materiales de reproducción sujetos a la compensación: el tránsito de lo analógico a lo digital}

\subsection{Los equipos, aparatos y soportes materiales de reproducción analógica}

Tradicionalmente, la compensación equitativa por copia privada se ha determinado para cada modalidad de reproducción (libros o publicaciones asimiladas a los libros reglamentariamente ${ }^{942}$, fonogramas, videogramas u otros soportes sonoros, visuales o audiovisuales) en función de los equipos, aparatos y soportes materiales idóneos para realizar dicha reproducción, fabricados en territorio español o adquiridos fuera de éste para su distribución comercial o utilización dentro de dicho territorio.

941 Ídem, párrafos 43-45.

${ }^{942}$ Estas se incorporaron mediante el Real Decreto 1434/1992, de 27 de noviembre. 
Las primeras regulaciones al respecto, esto es, la Ley 22/1987, de 11 de noviembre y el TRLPI (en su versión original de 1996), sólo sujetaron al canon por copia privada a equipos y aparatos de reproducción analógicos ${ }^{943}$. El listado de estos quedó fijado, inicialmente, en el art. 25.4 de la Ley 22/1987, de 11 de noviembre, tras su modificación por la Ley 20/1992, de 7 de julio; que posteriormente pasó al art. 25.5 del TRLPI (1996), donde se mantuvo una vez promulgada la Ley 23/2006, de 7 de julio.

En virtud de dicho precepto quedaron sujetos al canon por copia privada los equipos o aparatos de reproducción de libros y publicaciones asimiladas; los equipos o aparatos de reproducción de fonogramas; los equipos o aparatos de reproducción de videogramas; los soportes materiales de reproducción sonora; y los soportes materiales de reproducción visual o audiovisual. Se trataba de equipos o aparatos de reproducción analógicos, pues la redacción de la norma provenía de la regulación de la Ley 20/1992, momento en el que esta era la tecnología imperante, sin perjuicio de que, como se verá, la Ley 23/2006 introdujera en el TRLPI un canon por copia privada para los equipos, aparatos y soportes materiales de reproducción digital.

Valga mencionar que respecto a los equipos o aparatos de reproducción analógicos de libros o publicaciones asimiladas, la ley no sólo hizo una mención genérica a los mismos como al resto de equipos, sino que fue más exhaustiva en su tratamiento, clasificándolos en función de su capacidad de copia (de hasta 9 copias, desde 10 hasta 29 copias, desde 30 hasta 49 y de 50 copias en adelante, por minuto). Ello sirvió, a su vez, para atribuir a cada uno, en función de su respectiva capacidad, una cuantía al efecto de calcular el importe de la compensación equitativa.

Hay que añadir que el TRLPI no consideró al papel como soporte material idóneo para la reproducción de libros y publicaciones asimiladas a efectos compensatorios, a pesar de ser el papel el soporte por excelencia empleado en la reproducción

\footnotetext{
943 Entonces la ley se refería a "equipos y aparatos", introduciéndose la expresión "equipos, aparatos y materiales" con el Real Decreto 1434/1992, de 27 de noviembre, de desarrollo de los artículos 24, 25 y 140 de la Ley 22/1987, de 11 de noviembre, de Propiedad Intelectual, en la versión dada a los mismos por la Ley 20/1992, de 7 de julio. Esta última expresión se mantuvo en la versión original del TRLPI y en 2006, pasó a hablarse de "equipos, aparatos y soportes materiales".
} 
reprográfica. Tampoco lo hizo pese a que la expresión "en cualquier soporte", empleada por el art. 31.2 del TRLPI, afectaba también a las reproducciones realizadas sobre papel u otro soporte similar. No obstante, esta exclusión era y sigue siendo acertada, teniendo en cuenta los múltiples usos del papel, más allá de la fotocopia o impresión de obras con derechos de autor ${ }^{944}$.

Pues bien, en la redacción actual del TRLPI, el legislador suprime la tradicional mención a los equipos, aparatos y soportes de reproducción analógicos sujetos a la compensación equitativa por copia privada, contenida en el art. 25.5 del TRLPI. Quizás la intención del legislador sea referirse a todos los equipos, aparatos y soportes materiales de reproducción sujetos al canon (tanto analógicos como digitales) en el Real Decreto que se dicte siguiendo la Disposición Final primera del Real Decreto-ley 12/2017, de 3 de julio. Llama la atención, sin embargo, que la Disposición Transitoria segunda de este Real Decreto-ley (que establece el listado provisional de los equipos, aparatos y soportes sujetos al canon), se refiera a equipos, aparatos y soportes de reproducción digital, e incluso, en su apartado 1, letra a), se insista en el carácter digital de los equipos o aparatos de reproducción de libros y publicaciones asimiladas reglamentariamente a los libros, cuando las impresoras y fotocopiadoras que quedarían incluidas en dicho apartado, son normalmente consideradas como equipos o aparatos analógicos ${ }^{945}$.

\footnotetext{
${ }^{944}$ Vid. Rogel VIDE, C., Estudios completos..., op. cit., pp. 268-270, quien critica la no inclusión del papel como soporte grabado y señala: "Que sea difícil distinguir el papel de fotocopias del normal, es problema que se zanja fijando un papel especial para fotocopias sobre el que se establezca la remuneración compensatoria". Sin embargo, dado los extensos usos del papel y considerando que el papel de uso ordinario sirve también como soporte para fotocopias de obras no protegidas, considero que no gravar el papel con el canon fue una solución más acertada.

945 En el mismo sentido, Garrote FernáNDEZ- DíEz, I., "Artículo 25”, en Bercovitz RodríGueZCANO, R. (Coord), Comentarios a la Ley de Propiedad..., 4a ed., op. cit., p. 543.
} 


\subsection{Los equipos, aparatos y soportes materiales de reproducción digital}

\subsubsection{El régimen provisional de la Disposición Transitoria única de la Ley}

\section{3/2006, de 7 de julio}

La primera referencia a los equipos, aparatos y soportes materiales de reproducción digital sujetos a la compensación equitativa por copia privada apareció en la Disposición Transitoria única de la Ley 23/2006, de 7 de julio ${ }^{946}$.

Esta disposición estableció, en su apartado primero, letra a), los equipos o aparatos digitales aptos para la reproducción de libros y publicaciones asimiladas: escáneres o equipos monofunción para la digitalización de documentos; equipos multifuncionales de sobremesa con pantalla de exposición cuyo peso no superara los 17 kilos y capacidad de copia no superior a 29 copias por minuto, capaces de realizar al menos dos de las siguientes funciones: copia, impresión, fax o escáner; y equipos o aparatos con capacidad de copia de hasta 9 , de 10 a 29, de 30 a 49 y de más de 50 copias por minuto.

También contempló los equipos o aparatos digitales de reproducción de fonogramas y de reproducción de videogramas, aunque en este caso, la norma no estableció una relación específica de estos, sino que se refirió a los mismos de forma genérica ["equipos o aparatos digitales de reproducción de fonogramas", apartado primero, letra b) y "equipos o aparatos digitales de reproducción de videogramas", apartado primero, letra c)]. Lo hizo con la misma generalidad con la que el TRLPI trataba a los equipos o aparatos de reproducción de fonogramas y videogramas analógicos. Debe destacarse que el uso de la expresión "equipos o aparatos de reproducción", era confuso, pues podía dar lugar a una interpretación errónea que condujera a considerar dentro de los sujetos al canon a los meros reproductores de CD o DVD, sin funciones asociadas de copiado o almacenamiento digital de obras y prestaciones intelectuales. Consecuentemente, hubiera sido más adecuado excluir

\footnotetext{
${ }^{946}$ No obstante, ya algún paso hacia la compensación en soportes digitales se había dado con el Acuerdo concertado entre ASIMELEC y las entidades de gestión colectiva de los derechos de propiedad intelectual en el año 2003, que facilitó la recaudación de la compensación sobre los CD-R/RW Audio y Data y DVD-R/RW Vídeo y Data. Vid. supra Capítulo 4, epígrafe II, apartado 1.4.
} 
claramente a los equipos o soportes digitales destinados únicamente a la visualización o audición, no aptos, por tanto, para la realización de copias privadas; y, del mismo modo, a los que tuvieran una capacidad potencial de almacenamiento, pero sin incidencia real en la confección de copias privadas (como cámaras de foto y vídeo digitales) ${ }^{947}$.

Por otra parte, la Disposición Transitoria única de la Ley 23/2006, de 7 de julio también hizo referencia a los soportes materiales digitales [apartado primero, letras d), e) y f)]. Estos podían ser soportes materiales de reproducción sonora; de reproducción visual o audiovisual y de reproducción mixta (sonora y visual o audiovisual). Entre los primeros mencionaba a los discos o minidiscos compactos para audio o similares; entre los segundos, a los discos versátiles para vídeo o similares; y, por último, entre los terceros, los discos compactos y los discos versátiles. En todos los casos podía tratarse de soportes regrabables o no regrabables.

Llama la atención que los soportes materiales de reproducción mixta fueran excluidos como soportes idóneos para la reproducción de libros y publicaciones asimiladas, pese a su capacidad para almacenar todo tipo de contenidos en formato digital. Puede decirse que fue una exclusión injustificada, sobre todo considerando que la definición de "libro" contenida en la Ley 10/2007, de 22 de junio, de la lectura, del libro y de las bibliotecas no se limitaba a los libros impresos, sino que incluía los libros electrónicos editados en soportes materiales como los discos compactos y los discos versátiles $^{948}$.

\subsubsection{La Orden PRE/1743/2008, de 18 de junio}

La relación de equipos, aparatos y soportes materiales digitales sujetos a la compensación equitativa por copia privada dispuesta en la Disposición Transitoria única de la Ley 23/2006, de 7 de julio, tuvo sólo carácter provisional. De hecho, de acuerdo con esta Disposición, en su apartado 2, los Ministerios de Cultura y de Industria, Turismo y Comercio tenían la obligación de elaborar una Orden conjunta que

\footnotetext{
${ }^{947}$ LÓPEZ MAZA, S., "Estudio de los criterios del art. 25.6.4 LPI...”, op. cit., p. 38.

${ }^{948}$ LÓPEZ MAZA, S., "Estudio de los criterios del art. 25.6.4 LPI...", op. cit., p. 37.
} 
determinara los equipos, aparatos y soportes materiales sujetos al pago de la compensación equitativa por copia privada, así como las cantidades que los deudores debían abonar por este concepto a los acreedores, de conformidad con la regla $1^{\mathrm{a}}$ del art. 25.6 del TRLPI (tras su modificación por dicha ley).

Como resultado, se aprobó la Orden PRE/1743/2008, de 18 de junio, de los Ministerios de Cultura y de Industria, Turismo y Comercio, que puso fin al régimen provisional establecido en la citada Disposición Transitoria única. La norma agrupó los equipos y aparatos de reproducción sujetos al canon en dos conjuntos, establecidos en su apartado Primero, punto 1. En la letra a) del mismo contempló los equipos o aparatos de reproducción de libros y publicaciones asimiladas; mientras que en su letra b), estableció los equipos o aparatos de reproducción de fonogramas y de videogramas, sin perjuicio de que esta disposición también hiciera referencia a los equipos o aparatos de reproducción de libros y publicaciones asimiladas, considerando el carácter polivalente de ciertos equipos o aparatos de reproducción digitales, tanto para la copia de textos, como de imágenes y sonidos.

En concreto, los equipos o aparatos destinados específicamente a la reproducción de libros y publicaciones asimiladas reglamentariamente a los libros que quedaron sujetos a la compensación equitativa fueron los siguientes:

1. Equipos multifuncionales de sobremesa, con pantalla de exposición cuyo peso no superara los 17 kilos, bien fueran de inyección de tinta o de láser, capaces de realizar al menos dos de las siguientes funciones: copia, impresión, fax o escáner;

2. Escáneres monofunción que permitan la digitalización de documentos;

3. Equipos o aparatos con capacidad de copia estándar de hasta 9 copias por minuto;

4. Equipos o aparatos con capacidad de copia estándar desde 10 hasta 29 copias por minuto;

5. Equipos o aparatos con capacidad de copia estándar desde 30 hasta 49 copias por minuto;

6. Equipos o aparatos con capacidad de copia estándar desde 50 hasta 69 copias por minuto; $\mathrm{y}$ 
7. Equipos o aparatos con capacidad de copia estándar de 70 o más copias por minuto.

La Orden conjunta atribuyó la condición de "equipos o aparatos con capacidad de copia" a aquellos equipos o aparatos digitales de reproducción de libros y publicaciones asimiladas mencionados en el punto 1 anterior que alcanzaran un peso superior a 17 kilos. El objetivo era diferenciar aquellos que tenían una capacidad menor de reproducción de aquellos que tenían una superior, pasando a ser relevante esta diferenciación a efectos de cuantificar la compensación.

También quedaron sujetas al canon las grabadoras de discos compactos (CD) y de discos versátiles (DVD), tanto mixtos como específicos ${ }^{949}$. Acertadamente, esta vez se previó en la norma que estos aparatos reproductores podían servir tanto para la reproducción de libros y publicaciones asimiladas, como para la reproducción de fonogramas y videogramas. Lo desacertado fue que se utilizara el término "grabadora", ya que no eliminaba el problema de la posibilidad de someter a compensación a equipos no aptos para realizar o almacenar copias privadas, toda vez que, por "grabadora", también puede entenderse el mero aparato que permite la reproducción para la escucha o visualización ${ }^{950}$.

Asimismo, la Orden conjunta estableció una compensación sobre diferentes tipos de soportes. La lista incluyó los discos compactos y los discos versátiles, regrabables y no regrabables [apartado Primero, punto 1, letras de la c) a la f)]; las memorias USB y otras tarjetas de memoria no integradas en otros dispositivos [apartado Primero, punto 1, letra g)]; los discos duros integrados o no en un equipo, idóneos para la reproducción de videogramas y fonogramas siempre que no se tratase de un disco duro de

\footnotetext{
${ }^{949}$ Los CD y DVD mixtos permiten grabar tanto datos como audio y vídeo, a diferencia de los específicos que sólo están diseñados para una sola de estas finalidades.

${ }^{950}$ En sentido similar, LÓPEZ MAZA, S., "Estudio de los criterios del art. 25.6.4 LPI...", op. cit., pp. $42-$ 43 quien afirma: "[...] se mantiene el problema que ya señalé: la Orden grava no sólo los dispositivos aptos para realizar copias privadas, sino también cualquier tipo de dispositivo que permita disfrutar de las mismas, siendo lo correcto aplicar el canon sólo respecto de dispositivos que permitan realizar o almacenar copia privadas".
} 
ordenador $^{951}$, así como los discos duros integrados en equipos descodificadores de señales de televisión digital, una vez transcurrido el primer año de vigencia de la Orden [apartado Primero, punto 1, letra h)]; los dispositivos reproductores de fonogramas, videogramas o de otros contenidos sonoros, visuales o audiovisuales en formato comprimido regrabables [apartado Primero, punto 1, letra i)]; y, finalmente, los teléfonos móviles con funcionalidad de reproducción de fonogramas en formato comprimido regrabables [apartado Primero, punto 1, letra j)].

En conclusión, la Orden estableció una relación más detallada de los equipos, aparatos y soportes digitales sujetos a la compensación equitativa que la contenida en la Disposición Transitoria única de la Ley 23/2006, de 7 de julio. Sus disposiciones estuvieron vigentes hasta que, en fecha 22 de marzo de 2011, fue declarada nula por la Sala de lo Contencioso-Administrativo de la Audiencia Nacional por defectos de forma en su elaboración ${ }^{952}$. En ese momento, volvió a ser aplicable el régimen previsto en la citada Disposición Transitoria única, aunque tuvo escasa aplicación, teniendo en cuenta que el cambio radical al modelo de PGE se produjo a finales de ese mismo año, con la promulgación del Real Decreto-Ley 20/2011, de 30 de diciembre, de medidas urgentes en materia presupuestaria, tributaria y financiera para la corrección del déficit público.

\subsubsection{La Disposición Transitoria segunda del Real Decreto-ley 12/2017, de 3 de julio}

La Disposición Transitoria segunda del Real Decreto-ley 12/2017, de 3 de julio, contiene los equipos, aparatos y soportes digitales de reproducción sujetos a la compensación equitativa por copia privada. Está previsto que esta norma rija desde la entrada en vigor de este Real Decreto-ley, esto es, desde el 1 de agosto de 2017, hasta la entrada en vigor del Real Decreto previsto en su Disposición Final primera, que deberá dictarse dentro del plazo de un año desde la entrada en vigor de aquél.

\footnotetext{
${ }^{951}$ La definición de "disco duro de ordenador" estaba contenida en el Apartado Primero, punto 2, de la Orden PRE/1743/2008, de 18 de junio.

952 Vid. Supra Capítulo 4, epígrafe II, apartado 2.3.
} 
Hay que tener en cuenta, por consiguiente, que la lista que contempla el Real Decreto-ley 12/2017, de 3 de julio, no tiene carácter definitivo, pues podrá confirmarse o modificarse, una vez transcurrido el régimen transitorio. No obstante, es conveniente hacer algunos comentarios al respecto.

A primera vista, parece que existe, frente al Derecho anterior contenido en la Orden PRE/1743/2008, de 18 de junio, una restricción de los equipos o aparatos digitales de reproducción de libros y publicaciones asimiladas. En cambio, si se observa con más detenimiento, se puede apreciar que más que una restricción, lo que sucede es que el apartado 1.a).1 $1^{\circ}$ de la Disposición Transitoria segunda del Real Decreto-ley 12/2017, de 3 de julio, modifica su redacción respecto al apartado Primero, punto 1, letra a) de la Orden PRE/1743/2008, de 18 de junio. En efecto, ahora el legislador agrupa en un mismo apartado los equipos multifuncionales de inyección de tinta o laser y con capacidad de copia, impresión o escaneado, que antes figuraban en apartados diferentes, sin tener en cuenta su peso a efectos de considerarlos con capacidad de copia, ni distinguir en función de que puedan proporcionar más o menos copias por minuto. En cuanto a los equipos monofuncionales aptos para la copia de libros y publicaciones asimiladas, el apartado 1.a). $2^{\circ}$ de la Disposición Transitoria segunda incluye nuevos supuestos, pues si bien antes sólo se mencionaban los escáneres monofunción, ahora se refiere a "equipos monofuncionales con capacidad de copia, impresión o escaneado" $" 953$.

El Real Decreto-ley también incluye -como sucedía anteriormente- las grabadoras de discos compactos y de discos versátiles (específicos o mixtos). La diferencia está en que no las cataloga, a efectos compensatorios, como "equipos o aparatos digitales de reproducción de videogramas, fonogramas y libros y publicaciones asimiladas reglamentariamente a libros", aunque esto no supone ninguna dificultad porque es sabido que estas grabadoras son aptas para la reproducción de todas estas tipologías de obras y prestaciones intelectuales. Por otra parte, se mantienen igualmente sujetos al canon los discos compactos y versátiles, regrabables y no regrabables; las

${ }^{953}$ Se gravan aquellos cuya capacidad de copia no supere las 39 copias por minuto. 
memorias USB y otras tarjetas de memoria no integradas en otros dispositivos; y los discos integrados o no integrados en un equipo, idóneos para la reproducción de videogramas y fonogramas, aunque en este último caso, la sujeción al canon no se limita a aquellos aptos únicamente para la reproducción de audio o vídeo, sino que se extiende a los que son aptos para la reproducción de textos [Disposición Transitoria segunda, punto 1, letras e) y f) del Real Decreto-ley 12/2017]. Asimismo, se mantiene la previsión respecto a los dispositivos reproductores de fonogramas, videogramas o de otros contenidos sonoros, visuales o audiovisuales en formato comprimido, aunque ahora la norma agrega aquellos que tienen capacidad para reproducir textos [Disposición Transitoria segunda, punto 1, letra g) del Real Decreto-ley 12/2017].

Respecto a los teléfonos móviles, la Orden PRE/1743/2008 sólo incluía aquellos que tenían capacidad de reproducción de fonogramas. Ahora la norma es más amplia, pues comprende también los que tienen entre sus funciones la reproducción de videogramas y textos u otros contenidos sonoros, visuales o audiovisuales, es decir, la gran mayoría de los que se comercializan actualmente.

También quedan sujetos al canon los dispositivos electrónicos portátiles con pantalla táctil [Disposición Transitoria segunda, punto 1, letra g) del Real Decreto-ley 12/2017], que no estaban incluidos en la regulación precedente.

Es necesario puntualizar que la Disposición Transitoria segunda del Real Decretoley 12/2017, de 3 de julio, no excluye del canon a los discos duros de ordenador, en tanto son subsumibles en su apartado 1, letra f). Estos dispositivos eran excluidos bajo el régimen anterior, de conformidad con lo dispuesto en el art. 25.7.b) del TRLPI, tras su modificación por la Ley 23/2006 y a tenor de lo dispuesto en el apartado Primero, punto 1 , letra h) de la Orden PRE/1743/2008 ${ }^{954}$. La introducción de dicha excepción fue realmente polémica, por cuanto no había razón alguna para excluir los discos duros del

\footnotetext{
${ }^{954}$ El apartado Primero, punto 2, de la Orden PRE/1743/2008, de 18 de junio, consideró como disco duro de ordenador, a los efectos previstos en el art. 25.7.b) del TRLPI: "el dispositivo de almacenamiento magnético de un ordenador en el que se aloja el sistema operativo de dicho ordenador, al cual está conectado con carácter permanente, de forma que éste solo y exclusivamente pueda servir de disco maestro o del sistema en el sentido de que su conexión sólo le permite adoptar esa funcionalidad y no la de disco esclavo".
} 
pago de la compensación equitativa, dada la aptitud de estos para el almacenamiento de datos en forma de textos, imágenes, sonidos, entre otros ${ }^{955}$. De hecho, no podía decirse que no fueran idóneos para la copia privada de obras y prestaciones protegidas. Sin embargo, la voluntad del legislador fue exceptuarlos de la compensación de modo acorde con la situación existente en la mayoría de los Estados miembros de la UE ${ }^{956}$.

Por el contrario, sí excluye los discos que estén integrados en equipos descodificadores de señales de televisión digital, que únicamente fueron excluidos del pago, bajo el régimen anterior, durante el primer año de vigencia de la Orden, conforme al tenor de su apartado Primero, letra d). Excluye también, como es lógico, a los discos integrados en videoconsolas que no permitan realizar reproducciones amparadas por el límite de copia privada [Disposición Transitoria segunda, punto 1, letra f) del Real Decreto-ley 12/2017], lo cual supone una novedad.

También merece ser destacado que, bajo el régimen anterior, resultaba polémico si las conexiones ADSL debían o no quedar sujetas al canon, pues no fueron excluidas expresamente por el TRLPI. La cuestión quedó zanjada al considerarse que estas no son, por su propia naturaleza, ni equipos, ni aparatos, ni soportes materiales susceptibles de utilizarse para realizar reproducciones con fines privados, sino que son meras conexiones $^{957}$. Valga decir que se trata de un argumento válido también a día de hoy, que se reafirma por el propio hecho de que, pese a que la ley apela al criterio de idoneidad, el mismo tiene reflejo en el listado de equipos, aparatos y soportes materiales de reproducción concretos sobre los que el legislador establece la compensación equitativa y este listado no incluye a las conexiones ADSL, como puede apreciarse en la Disposición Transitoria segunda en vigor.

En definitiva, puede decirse que los equipos, aparatos y soportes sujetos al canon

955 Garrote Fernández-DíEz, I., “Artículo 9”, en BERCOVITZ RodríGuez-CANo, R. (Coord.), Comentarios al Convenio de Berna..., op. cit., p. 494.

956 GONZÁLEZ, A., "La compensación equitativa por copia privada digital en la Ley 23/2006, de 7 de julio", Actualidad Jurídica Uría Menéndez, núm. 15, 2016, p. 43, disponible en: http://www.uria.com/documentos/publicaciones/1611/documento/art02.pdf?id=2121 $\quad$ (consultado: 29.10.2016).

957 Vid. Plaza Penadés, J., “Artículo 25”, en RodríGuez TAPIA, J. M. (Dir.), Comentarios a la Ley de Propiedad Intelectual, $2^{\mathrm{a}}$ ed., Aranzadi, Pamplona, 2009, p. 253. 
en virtud del actual régimen transitorio son, básicamente, los que contemplaba la anulada Orden PRE/1743/2008, con algunas pequeñas variaciones.

\subsubsection{El establecimiento de un nuevo régimen definitivo tras la etapa de transitoriedad}

Los equipos, aparatos y soportes materiales sujetos al pago de la compensación que regirán en un futuro próximo serán establecidos por el Gobierno mediante Real Decreto, en virtud de lo previsto en la Disposición Final primera del Real Decreto-ley 12/2017, de 3 de julio. De acuerdo con esta norma, estos equipos, aparatos y soportes serán determinados aplicando el procedimiento y los criterios contenidos, respectivamente, en los aparatados 4 y 5 del art. 25 del TRLPI.

La aparente claridad de esta Disposición Final primera choca con el procedimiento establecido en el art. 25.4 del TRLPI, al que se remite, pues conforme a este precepto, la determinación de los equipos, aparatos y soportes materiales sujetos al pago de la compensación equitativa se fijarán por Orden del Ministerio de la Presidencia y para las Administraciones Territoriales. Al respecto, el Preámbulo del Decreto-ley 12/2017, de 3 de julio, también reconoce que "el instrumento jurídico donde se concretarán los equipos, aparatos y soportes de reproducción sujetos al pago de la compensación equitativa, así como la cuantía de la misma, será una Orden del Ministerio de la Presidencia y para las Administraciones Territoriales [...]". Se produce así una evidente contradicción entre lo dispuesto en el art. 25.4 del TRLPI y lo estipulado en la citada Disposición Final primera, que exige que la norma que se promulgue sea un Real Decreto.

Debe entenderse que es más adecuado que la determinación de estos equipos, aparatos y soportes se apruebe mediante Orden, que puede ser revisada en cualquier momento, como así prevé el propio TRLPI, en función de la evolución tecnológica y de las condiciones del mercado y, en todo caso, cada tres años (art. 25.4, párrafo 5, del 
TRLPI) ${ }^{958}$. El Real Decreto quedaría, de este modo, reservado al desarrollo de otras cuestiones del art. 25 del TRLPI, como la determinación de las publicaciones asimiladas a los libros y el procedimiento de gestión de la compensación, actualmente establecidas con carácter temporal en las Disposiciones Transitorias primera y segunda, respectivamente, del Real Decreto-ley 12/2017, de 3 de julio.

Sin embargo, siguiendo lo dispuesto en la Disposición Final primera del Real Decreto-ley 12/2017, de 3 de julio, parece que, inicialmente, el instrumento para determinar estas cuestiones deberá ser un Real Decreto y, sólo después, serán reguladas mediante Orden del Ministerio de la Presidencia y para las Administraciones Territoriales, cuando sea necesario actualizar o modificar los equipos, aparatos y soportes de reproducción sujetos a la compensación, el establecimiento de las cuantías compensatorias y su distribución entre los acreedores ${ }^{959}$.

\section{LA CUANTÍA DE LA COMPENSACIÓN EQUITATIVA}

\section{El perjuicio como elemento base del cálculo de la compensación}

La cuantía de la compensación equitativa por copia privada se calcula en función del perjuicio causado a los sujetos acreedores como consecuencia de las reproducciones realizadas al amparo del límite de copia privada. Así lo recoge el art. 25.5.a) del TRLPI, siendo coherente el legislador con el carácter compensatorio de dicha figura. En efecto, la relación intrínseca entre "perjuicio" y "compensación equitativa" ha quedado expuesta por el TJUE en la sentencia Padawan al señalar: "la compensación equitativa debe considerarse la contrapartida del perjuicio sufrido por el autor" (párrafo 40). Del mismo modo, el Considerando $38^{\circ}$ de la DDASI contempla esta relación cuando expone

\footnotetext{
${ }^{958} \mathrm{El}$ art. 25.6 del TRLPI, en la versión dada al mismo por la Ley 23/2006, de 7 de julio, no daba lugar a duda de que el procedimiento que establecía para la promulgación de la Orden Conjunta de los Ministerios de Cultura y de Industria, Turismo y Comercio, que determinaba los equipos, aparatos y soportes materiales sujetos al pago de la compensación equitativa por copia privada y las cantidades que los deudores debían pagar a los acreedores, era el mismo procedimiento que debía seguirse para la revisión del contenido de dicha Orden.

959 Garrote Fernández- Díez, I., "Artículo 25”, en Bercovitz RodríGuez,-Cano, R. (Coord), Comentarios a la Ley de Propiedad..., $4^{\text {a }}$ ed., op. cit., pp. 531 y 543.
} 
que la introducción del límite de copia privada en las legislaciones "puede suponer la introducción o el mantenimiento de sistemas de retribución para compensar a los titulares de los derechos por los perjuicios sufridos" 960 .

Con la misma finalidad, es decir, con el propósito de determinar la cuantía de la compensación, el art. 25.6, regla $4^{\circ}$, letra a) del TRLPI, en su versión anterior tras la reforma de la Ley 23/2006, tenía también en consideración este criterio. De hecho, el mismo encabezaba la lista de aquellos que debían considerarse por los Ministerios de Cultura y de Industria, Turismo y Comercio para dictar la Orden conjunta mediante la cual se determinarían los equipos, aparatos y soportes materiales de reproducción sujetos a la compensación, las cantidades a abonar por los deudores por este concepto a sus acreedores y la distribución entre las diferentes modalidades de reproducción.

Con mejor sistemática, el TRLPI -en su versión actual- señala, en primer lugar, que "la determinación de la cuantía de la compensación se calculará sobre la base del perjuicio causado [...]" y a continuación enumera una serie de criterios objetivos a tener en cuenta. De esta forma, queda claro que lo que determina la cuantía de la compensación no son, propiamente, los criterios que luego el legislador enuncia en los diferentes numerales del art. 25.5.a) del TRLPI, sino que la compensación la determina el perjuicio que la copia privada provoca y que ese perjuicio se calcula, de acuerdo con criterios como la intensidad del uso de los equipos, aparatos y sopores materiales; la capacidad de almacenamiento de estos; entre otros contenidos en el propio precepto.

Esta vez el legislador es también más cauto, pues a diferencia de la regulación anterior no se refiere al "perjuicio efectivamente causado" sino que simplemente considera "el perjuicio causado". Puede decirse que el uso del adverbio "efectivamente"

\footnotetext{
${ }^{960}$ La relación intrínseca entre "perjuicio" y “compensación equitativa” ha quedado expuesta por el TJUE en la sentencia Padawan: "[...] el concepto y la cuantía de la compensación equitativa están vinculados al perjuicio causado al autor mediante la reproducción para uso privado, no autorizada, de su obra protegida. Desde esta perspectiva, la compensación equitativa debe considerarse la contrapartida del perjuicio sufrido por el autor" (párrafo 40).

También deriva del Considerando $38^{\circ}$ DDASI, al señalar que la introducción por los Estados miembros de una excepción o limitación al derecho de reproducción en relación con determinados tipos de reproducción de material sonoro, visual y audiovisual para uso privado, mediante una compensación equitativa, puede suponer la introducción o el mantenimiento de sistemas de retribución para compensar a los titulares de los derechos por los perjuicios sufridos.
} 
no era correcto porque el perjuicio no puede más que ser estimado. En efecto, el análisis del daño efectivo y real que exigía el precepto resultaba imposible en la práctica, en la medida en que las reproducciones realizadas por los usuarios en el ámbito privado escapan de cualquier posibilidad de control $^{961}$. Así pues, ante la dificultad práctica de determinar el perjuicio exacto, había que acudir a estimaciones o aproximaciones que, difícilmente, eran expresión real de ese perjuicio.

Una evidencia de lo anterior es la parte preliminar de la Orden PRE/1743/2008 (apartado II), que se refería a la necesidad de estimar ${ }^{962}$ el daño que la copia privada origina a los titulares derechos de propiedad intelectual. Es decir, se trataba de estimar, lo que resultaba, por su propia naturaleza, diferente de la determinación del perjuicio real y efectivo causado a los titulares de derechos. A la misma conclusión se llega si se observa que esta Orden (en el mismo apartado II) fijaba unas cuantías máximas y mínimas, resultado de la estimación del perjuicio anual ${ }^{963}$. Estas cuantías, si bien pretendían garantizar que la recaudación de la compensación equitativa por copia privada se ajustara a la cuantificación del perjuicio estimado, resultaron quedar muy por encima de las cantidades realmente recaudadas por las entidades de gestión de derechos de propiedad intelectual en concepto de copia privada ${ }^{964}$. Ello demuestra que ni siquiera las estimaciones realizadas eran una expresión aproximada de las cantidades que efectivamente las entidades de gestión podían recaudar por este concepto.

Hay que tener en cuenta, además, que si las ventas de equipos, aparatos y soportes materiales digitales de reproducción quedaban por debajo del importe mínimo fijado en

\footnotetext{
${ }^{961}$ LÓPEZ MAZA, S. y Minero AlejANDre, G., "El carácter equitativo...”, op. cit., p. 100; y LóPEZ MAZA, S., "Estudio de los criterios del art. 25.6.4 LPI...", op. cit., p. 53.

962 Énfasis nuestro.

${ }^{963}$ Dispone el Apartado II de la parte preliminar de la Orden PRE/1743/2008, de 18 de junio: “Analizada la repercusión que el límite de copia privada tiene en nuestro país mediante el uso que del mismo hacen los ciudadanos en sus modos de consumo de las creaciones protegidas y la influencia que sobre estos modos ha tenido la aparición y desarrollo de las nuevas tecnologías, se ha estimado que el perjuicio anual correspondiente a la modalidad de reproducción de obras divulgadas en forma de libros y publicaciones asimiladas reglamentariamente a libros está comprendido entre 34.800.000€ y 37.200.000€, y el correspondiente a la modalidad de reproducción de fonogramas u otros soportes sonoros y de reproducción visual o audiovisual está comprendido entre 75.400.000€ y 80.600.000€. Dentro de esta horquilla se sitúa la compensación equitativa que las entidades de gestión deben recaudar efectivamente". 964 Así lo pone de relieve LóPEZ MAZA, S., "Estudio de los criterios del art. 25.6.4 LPI...”, op. cit., pp. 57 y ss.
} 
la Orden o llegaban a sobrepasar el importe máximo consignado en ésta, ya no se estaría pagando por el perjuicio, ya no digamos efectivo, sino ni siquiera estimado ${ }^{965}$. De hecho, tampoco puede decirse que existiera una relación directamente proporcional entre las ventas de estos equipos, aparatos y soportes sobre los que se recaudaba el canon y las copias privadas que mediante estos se realizaban; podían venderse muchos de estos dispositivos y apenas emplearse los mismos por sus adquirentes para la reproducción con fines privados de obras y prestaciones protegidas por la propiedad intelectual $^{966}$. A su vez, la propia Orden reconocía que el cálculo de la compensación equitativa aplicable a cada uno de los equipos de reproducción se hacía mediante una estimación de sus ventas, que podía diferir, en la práctica, de las ventas efectivas que se produjeran.

En definitiva, resulta más apropiado referirse a "perjuicio" que a "perjuicio efectivo" cuando de estimaciones se trata. De cualquier manera, lo que se busca es que el cálculo para establecer la cuantía de la compensación sea lo más cercano posible a los patrones de copiado de los usuarios y, consecuentemente, del perjuicio causado a los titulares de derechos, acreedores de la compensación.

Por otra parte, la regla $4^{\circ}$, letra a) del art. 25.6 del TRLPI (en su versión de 2006) establecía que el perjuicio mínimo no daría lugar a compensación alguna, como también lo dispuso el art. 25.5 del TRLPI, tras su modificación por la Ley 21/2014, de 4 de noviembre. Esta regla se repite ahora en el art. 25.5.b) del TRLPI, en su versión actual, dejando a ulterior desarrollo reglamentario la precisión de las situaciones en que se considere al perjuicio como tal. Habrá que esperar pues a la promulgación del correspondiente Real Decreto, siendo posible anticipar que se repita la única situación de perjuicio mínimo que previó la Ley 21/2014. A su tenor, el perjuicio mínimo tenía lugar cuando se producía "la reproducción individual y temporal por una persona física para su uso privado de obras a las que se haya accedido mediante actos legítimos de difusión de la imagen, del sonido o de ambos, para permitir su visionado o audición en

\footnotetext{
965 Ibídem, p. 56

966 Ídem.
} 
otro momento temporal más oportuno". El legislador se refería al fenómeno del time shifting, que se produce cuando se realiza una reproducción de contenidos emitidos mediante actos de comunicación pública por radiodifusión, de forma tal que el usuario de estos servicios pueda acceder a la escucha o visualización de estos contenidos en un momento posterior, según su conveniencia ${ }^{967}$. La razón está en que los nuevos modelos de negocio de puesta a disposición de contenidos "a la carta", hace que, cada vez más, el usuario prescinda de hacer reproducciones de obras protegidas para su visionado o escucha posterior. De hecho, según encuesta del Ministerio de Educación Cultura y Deporte sobre hábitos y prácticas culturales, las personas que han adquirido música o vídeo por medio de la grabación desde la radio o la televisión ha disminuido en los últimos años, representando un $0,2 \%$ y un $0,8 \%$ de la población, respectivamente, en el período 2014-2015

En conclusión, la compensación equitativa se produce bajo la premisa del impacto económico negativo que tiene la copia privada sobre la explotación de la obra o prestación intelectual y, en particular, sobre el derecho exclusivo de reproducción. Por tanto, resultará necesario valorar el perjuicio que represente la copia privada a efectos del cálculo de la cuantía de esta compensación, para lo cual el legislador establece unos criterios objetivos que serán analizados a continuación y que, en todo caso, le vinculan para la determinación reglamentaria del primer listado definitivo de equipos, aparatos y soportes de reproducción sujetos a la compensación y, en su caso, para las modificaciones que se lleven a cabo mediante Orden Ministerial ${ }^{969}$.

\footnotetext{
967 Moscoso del Prado Hernández, A. (Coord.), Practicum..., op. cit., p. 299; Martínez Espín, P., "El nuevo régimen de compensación...", op. cit., p. 487.

${ }^{968}$ Encuesta de hábitos y prácticas culturales en España 2014-2015, elaborada por la Subdirección General de Estadística y Estudios, Secretaría General Técnica del Ministerio de Educación, Cultura y Deporte, Madrid, 2015, p. 63, disponible en: https://www.mecd.gob.es/mecd/dms/mecd/servicios-alciudadano-mecd/estadisticas/cultura/mc/ehc/20142015/Encuesta_de_Habitos_y_Practicas_Culturales_2014-2015.pdf (consultada: 26.10.2017).

969 Vid. infra, epígrafe VII, apartado 3.
} 


\section{Criterios objetivos para la determinación de la cuantía de la compensación}

\subsection{Apuntes introductorios}

Hace ya algunas décadas, en los inicios de la regulación de la compensación equitativa por copia privada en la legislación española de propiedad intelectual se contenían algunos criterios que podían ser tomados en consideración a efectos de determinar la cuantía de la compensación. Pero la aplicación de estos criterios, contenida en el art. 14 del Real Decreto 287/1989, de 21 de marzo (por el que se desarrollaba el art. 25 de la LPI), era facultativa, en el sentido de que la norma no obligaba directamente a su observancia ${ }^{970}$. En efecto, este precepto sólo establecía que para la determinación del importe de la remuneración compensatoria por copia privada se podían tener en cuenta la calidad, las características, la duración, la capacidad de reproducción de los equipos y materiales, así como cualquier otro criterio que se considerara necesario. Se trataba entonces de copias analógicas.

Sin embargo, no hubo una referencia similar en las normas posteriores hasta la modificación del TRLPI por Ley 23/2006, de 7 de julio, que esta vez estableció unos criterios objetivos de obligatoria observancia para los Ministerios de Cultura y de Industria, Turismo y Comercio al momento de aprobar la Orden conjunta que fijaría la cuantía de la compensación sobre los equipos, aparatos y soportes de reproducción digital $^{971}$. En aquel momento, sobre el TRLPI pesaba ya la influencia de la DDASI, cuyo Considerando $35^{\circ}$ menciona algunos criterios útiles para precisar la cuantía de la compensación equitativa por copia privada. En concreto, dispone que para la determinación de la forma, las modalidades y la posible cuantía de la compensación equitativa deben tenerse en cuenta las circunstancias de cada caso concreto, para lo cual considera útil evaluar el posible daño que la copia privada causa a los titulares de

\footnotetext{
${ }^{970}$ LÓPEZ MAZA, S., "Estudio de los criterios del art. 25.6.4 LPI...”, op. cit., p. 46.

${ }^{971}$ No obstante, aspectos como las características o la capacidad de los equipos, aparatos y soportes de reproducción eran tomados en cuenta en el momento de establecer la cuantía de la compensación. Así, el art. 16 del Real Decreto 1434/1992, de 27 de noviembre, de desarrollo de los artículos 24, 25 y 140 de la LPI, en la versión dada a los mismos por la Ley 20/1992, de 7 de julio, evidencia que se atribuía una cantidad diferente por remuneración compensatoria por copia privada, dependiendo del mayor o menor número de copias que efectuase un equipo o aparato de reproducción. Lo mismo puede decirse respecto a la fijación de las cantidades establecidas en el art. 25.5 del TRLPI, en su versión original.
} 
derechos; la posible obtención por los titulares de derechos de alguna retribución como la resultante de la concertación de una licencia; el grado de utilización de las medidas tecnológicas de protección; y la mayor o menor relevancia del perjuicio ocasionado por la copia privada.

Pues bien, los criterios fueron establecidos en el art. 25.6, regla $4^{\circ}$, del TRLPI de 2006, siendo una enumeración abierta (téngase en cuenta que el precepto citado utilizaba la expresión "entre otros"). Entre ellos figuraban el criterio del perjuicio; el grado de uso de los equipos, aparatos y soportes materiales para la realización de dichas reproducciones; la capacidad de almacenamiento de los equipos, aparatos y soportes materiales de reproducción; la calidad de las reproducciones; y la disponibilidad, grado de aplicación y efectividad de las medidas tecnológicas previstas en el art. 161 del TRLPI. La mayoría de esos criterios se mantienen en la redacción actual del art. 25.5.a) TRLPI, sin perjuicio de alguna supresión o incorporación.

\subsection{Los criterios objetivos del art. 25.5.a) del TRLPI}

\subsubsection{La intensidad de uso de los equipos, aparatos y soportes materiales}

El primer criterio para la determinación de la cuantía de la compensación equitativa por copia privada que contiene el art. 25.5.a) del TRLPI actualmente vigente es el de la intensidad de uso de los equipos, aparatos y soportes materiales de reproducción. Este criterio es similar al establecido en la regla $4^{\mathrm{a}}$.b) del art. 25.6 del TRLPI de 2006, si bien éste se refería a "grado de uso". En efecto, ambas expresiones ("grado de uso" e "intensidad de uso") tienen parecido significado. En definitiva, no se trata de evaluar la intensidad del uso no a la luz del uso general que pueda hacerse de estos equipos, aparatos y soportes de reproducción, sino de su uso potencial para realizar reproducciones al amparo del límite de copia privada. Por ello, el propio precepto menciona que se tendrá en cuenta la estimación del número de copias realizadas al amparo de dicho límite.

Éste no es un criterio que sirva para calcular el número de reproducciones realizadas de forma absoluta. En efecto, es imposible determinar, con precisión, el uso real que se hace de cada uno de los equipos, aparatos y soportes materiales de reproducción adquiridos por los usuarios, o de la medida en que se utilizan para la 
reproducción de obras y otras creaciones intelectuales protegidas. En otras palabras, la venta de los equipos no es un referente apropiado para evaluar la magnitud de la copia privada, ya que no es posible justificar que exista una relación directa entre la compraventa de estos equipos, aparatos y soportes de reproducción y su uso para la copia de obras protegidas. En, cambio, el número de reproducciones es estimable. En este sentido, hay equipos, aparatos y soportes de reproducción de los que puede esperarse un uso más frecuente que el de otros, pues mientras algunos sólo sirven a efectos del almacenamiento de datos -un CD, DVD o escáner-, otros combinan distintas funcionalidades (impresión, fotocopia, escáner, etc.). Además, la propia evolución tecnológica hace que muchos de estos equipos caigan en desuso o se utilicen en menor medida, con lo cual, su repercusión a efectos de la copia privada también puede disminuir o incluso, llegar a desaparecer.

Al respecto, un estudio reciente elaborado por la Asociación de Empresas de Electrónica, Tecnologías de la Información, Telecomunicaciones y Contenidos Digitales (AMETIC) refleja una disminución de la comercialización de equipamiento físico informático, entre cuyas causas destaca el movimiento hacia soluciones basadas en la computación en la nube, así como las crecientes funcionalidades y capacidades de otros dispositivos como los smartphones ${ }^{972}$. En consecuencia, si bien esto no significa la correlativa disminución del uso de ordenadores e impresoras, sí que es una muestra de cómo el uso de una tecnología puede incidir en la sustitución o en la disminución del consumo de otra, y de cómo puede variar, en consecuencia, la intensidad del uso de un equipo o soporte para la realización de reproducciones autorizadas por el límite de copia privada.

A su vez, a la hora de tener en consideración el número de copias realizadas al amparo del límite de copia privada de acuerdo a un equipo o aparato concreto de reproducción es importante no perder de vista que no todos los adquirentes o usuarios explotan la capacidad técnica de estos equipos o aparatos en la misma medida, sino que

972 AMETIC, Las tecnologías de la información en España, Madrid, 2016, disponible en: http://ametic.es/sites/default/files//TI2016 Vf.pdf (consultado 36.10.2017). 
difiere según las necesidades de cada persona. Por ello, es preciso considerar estas diferencias cuando la cuantía de la compensación se fije a tanto alzado, tal y como sucede en España y en otros países del entorno. Al respecto, la STJUE (Sala Cuarta), de 12 de noviembre de 2015 ha declarado que el art. 5.2.b) y el art. 5 de la DDASI se oponen a una compensación que se fija a tanto alzado y que es pagada por el fabricante, el importador o el adquirente intracomunitario en el momento de la comercialización de un aparato en el territorio nacional antes de la realización de la operación de reproducción, cuando el importe de esta compensación esté fijado únicamente en función de la velocidad a la que, desde un punto de vista técnico, este aparato puede realizar reproducciones ${ }^{973}$.

\subsubsection{La capacidad de almacenamiento de los equipos, aparatos y soportes materiales y la importancia de la función de reproducción}

El segundo de los criterios recogidos en el art. 25.5.a) del TRLPI implica tener en consideración dos cuestiones diferentes. Por un lado, la capacidad de almacenamiento de los equipos, aparatos y soportes materiales; y, por otro, la importancia de la función de reproducción respecto del resto de sus funciones.

Pues bien, la capacidad de almacenamiento es una exigencia que también figuraba en la redacción anterior del TRLPI, concretamente, en la regla $4^{\mathrm{a}}$.c) del art. 25.6 del TRLPI, tras su modificación en 2006, por cuanto puede incidir en la posibilidad de acumular mayor o menor número de reproducciones. A mayor capacidad de almacenamiento, mayor capacidad para la reproducción, por lo que la capacidad de almacenamiento de los dispositivos de reproducción puede generar un impacto económico real en la realización de copias al amparo del límite de copia privada.

Sin embargo, lo cierto es que no estamos ante una ecuación exacta. Por ejemplo, una memoria USB, a la que puede atribuirse una cuantía por compensación superior a un $\mathrm{CD}$ regrabable, no garantiza que la memoria no vaya a ser usada por su comprador

${ }^{973}$ Cit. Vid. párrafos 73-77. 
para almacenar documentos generados por el mismo, no sujetos a la protección de la propiedad intelectual y que el $\mathrm{CD}$, en cambio, no se utilice en reiteradas ocasiones para almacenar contenidos protegidos, en cuyo caso, la capacidad de almacenamiento no debe repercutir en un mayor o menor importe de la compensación. Además, la capacidad de almacenamiento parece estar imperfectamente relacionada con la capacidad de copia, toda vez que para una capacidad de memoria determinada, la cantidad de copias varía significativamente según el tipo de contenidos (audio, vídeo, entre otros $)^{974}$.

Ahora bien, ante la imposibilidad de anticipar el uso que se le dará a un equipo, aparato o soporte concreto de reproducción, este criterio puede ser útil, al menos, como una referencia más para prever su mayor o menor aptitud para la realización de copias de creaciones intelectuales. En este sentido es evidente que si se emplean para esta finalidad, tendrán un mayor impacto sobre la copia privada aquellos que tengan mayor capacidad de almacenamiento y, consecuentemente, ello deberá verse reflejado de algún modo en la compensación al titular de los derechos de propiedad intelectual.

A diferencia de la capacidad de almacenamiento, sí que constituye una novedad del TRLPI (en su redacción actual) la exigencia de tener en cuenta la importancia de la función de reproducción respecto del resto de funciones de los equipos, aparatos y soportes materiales.

Su incorporación en el TRLPI seguramente obedezca a la influencia de la STJUE (Sala Cuarta), de 5 de marzo de $2015^{975}$. Esta sentencia reconoce que la multifuncionalidad del soporte y el carácter secundario de la función relacionada con la reproducción pueden afectar a la cuantía de la compensación equitativa (párrafo 27) ${ }^{976}$.

\footnotetext{
974 DG MARKT AND EUROPEAN COMMISSION, Assessing the economic impacts of adapting certain limitations and exceptions to copyright and related rights in the EU. Analysis of specific policy options, 2014, pp. 92-93, disponible en: http://ec.europa.eu/internal_market/copyright/docs/studies/140623limitations-economic-impacts-study_en.pdf (consultado: 11.12.2016).

${ }_{975}$ Copydan Båndkopi contra Nokia Danmark A/S (Asunto C-463/12), ECLI:EU:C:2015:144.

976 "Sin perjuicio de ello, la multifuncionalidad y el carácter secundario de la función relacionada con la reproducción pueden afectar a la cuantía de la compensación equitativa. En particular, habida cuenta de las consideraciones expuestas en el apartado 21 de la presente sentencia, tal cuantía debe fijarse por las
} 
Será necesario evaluar, consecuentemente, el papel principal o secundario que juegue la función de reproducción en los equipos, aparatos y soportes de reproducción y determinar, al efecto, la mayor o menor repercusión que tiene esta función en la reproducción de contenidos sujetos a la propiedad intelectual.

\subsubsection{El impacto del límite legal de copia privada sobre la venta de ejemplares} de las obras y el precio de la unidad de cada modalidad reproducida

El impacto del límite legal de copia privada sobre la venta de ejemplares de las obras es el tercer criterio que señala el art. 25.5.a) del TRLPI, mientras que el precio de la unidad de cada modalidad reproducida aparece en cuarto lugar. Ambos criterios habían sido recogidos ya en el art. 3.2.b) del Real Decreto 1657/2012, de 7 de diciembre, por el que se regula el procedimiento de pago de la compensación equitativa por copia privada con cargo a los PGE, sin que tuvieran un precedente similar en el TRLPI.

Para valorar el impacto del límite legal de copia privada sobre la venta de ejemplares, el propio precepto menciona que se tienen que tener en cuenta dos factores: por una parte, el grado de sustitución real de ejemplares por las copias privadas realizadas; y, por otro, el efecto que supone que el adquirente de un ejemplar o copia original tenga la posibilidad de realizar copias privadas. Por tanto, será imprescindible realizar estudios de mercado y encuestas que permitan conocer los índices de consumo, tanto de ejemplares originales como de reproducciones.

Y es que, en efecto, si bien los estudios económicos del Derecho de Propiedad Intelectual revelan que puede ser provechoso para el autor que se realicen copias de su obra a partir de ejemplares adquiridos por compraventa (para el comprador supone un valor añadido poder realizar copias para algún miembro de su familia, por ejemplo, y ello influye en su determinación de comprar el original, lo cual beneficia al autor); también se afirma que, cuanto más barata sea la obtención de copias, más generalizada

autoridades competentes, en principio, a la luz de la importancia relativa de la capacidad del soporte para realizar reproducciones de obras para uso privado". 
será esta práctica, con lo que es más probable que el autor reciba menos ingresos que si ha vendido los ejemplares directamente a los destinatarios de las copias de su comprador/cliente ${ }^{977}$.

Por otra parte, el legislador también estima necesario atender al precio de la unidad de cada modalidad reproducida. Pese a que la redacción puede resultar un tanto confusa, el legislador se refiere al precio de venta de cada ejemplar original, bien se trate de un libro o publicación asimilada, un fonograma o un videograma, o de cualquier otro soporte sonoro, visual o audiovisual.

Parece ser que la idea que inspira al legislador, en este caso, es que cuanto mayor sea el precio de venta de los originales, mayor inclinación habrá a obtenerlo por la vía de la reproducción y no por su compra. No obstante, tampoco en este caso existe una ecuación exacta, pues habrá quien apueste igualmente por conseguir el original aunque su precio sea elevado.

\subsubsection{El carácter digital o analógico o la calidad y el tiempo de conservación de las reproducciones}

El legislador se refiere con este criterio a dos cuestiones: por un lado, al carácter analógico o digital de las reproducciones efectuadas al amparo del límite legal de copia privada; y por otro, a la calidad y el tiempo de conservación de las reproducciones [art. 25.5.a). $5^{\circ}$ del TRLPI].

Se trata del quinto de los criterios objetivos de obligada observancia a efectos de determinar la cuantía de la compensación. El mismo es formulado de forma alternativa, por lo que parece que podrá tenerse en cuenta una u otra de las opciones que establece, aunque de algún modo parecen relacionarse porque normalmente a la copia digital se le atribuye una mayor calidad y mayor durabilidad.

${ }^{977}$ LANDES, W. M. y PoSner, R. A., La estructura económica ..., op. cit., p. 67. 
Este criterio ya aparecía formulado en términos muy parecidos en el art. 3.2.d) del Real Decreto 1657/2012, de 7 de diciembre, atendiendo también, alternativamente, al carácter analógico o digital de las reproducciones o a la calidad y el tiempo de conservación de aquéllas. También se referían a estos dos últimos parámetros (calidad y tiempo) las letras d) y f), respectivamente, del art. 25.6, regla $4^{\circ}$, del TRLPI en su versión tras la aprobación de la Ley 23/2006.

No cabe duda de que la tecnología digital ha facilitado la realización de copias de altísima calidad, a veces ni siquiera diferenciables del original. Ello puede determinar que se opte por la obtención de una copia, más que por la adquisición del original. En consecuencia, parece que el legislador ha querido que la diferencia entre la calidad de la copia analógica respecto a la digital, o incluso, la calidad que puede llegar a alcanzar una copia dependiendo de si se usa un equipo, aparato o soporte de reproducción u otro, se vea reflejada en la cuantía de la compensación que se fija sobre estos. Por tanto, se espera que aquéllos que faciliten la obtención de copias con una alta calidad de la imagen, del sonido o de ambos, generen una compensación mayor que aquellos otros que tengan menor capacidad para elaborar copias de alta calidad ${ }^{978}$.

Por otro lado, el tiempo de conservación de las reproducciones sólo puede ser apreciable respecto de los soportes materiales de reproducción, pues son las reproducciones, contenidas en los soportes, las que alcanzarán mayor o menor durabilidad. No obstante, habría que tener en cuenta -y ello constituye una dificultadque no siempre resulta previsible el tiempo de conservación de una copia, que depende de factores de tan difícil concreción legal como las condiciones de almacenamiento o las condiciones ambientales. Por tanto, habrá que atender, más bien, al tiempo medio de vida útil de los diferentes soportes informáticos.

${ }^{978}$ LÓPEZ MAZA, S., “Estudio de los criterios del art. 25.6.4 LPI...”, op. cit., p. 69. 


\subsubsection{La disponibilidad, grado de aplicación y efectividad de las medidas} tecnológicas y su impacto en las reproducciones realizadas al amparo del límite legal de copia privada

Puede decirse que este criterio es un reflejo de los Considerandos $35^{\circ}$ y $39^{\circ}$ de la DDASI. En efecto, el Considerando $35^{\circ}$ se refiere expresamente como criterio útil para evaluar la posible cuantía de la compensación equitativa a la correlación existente entre el uso de medidas tecnológicas de protección y el nivel de compensación equitativa en aquellos supuestos en los que el establecimiento de una limitación o excepción lleva aparejada una compensación, como es el caso de la copia privada. En concreto, la DDASI indica que el nivel de compensación tiene que determinarse teniendo debidamente en cuenta el grado de utilización de las medidas tecnológicas de protección contempladas en la misma. Por su parte, el Considerando $39^{\circ}$ de la DDASI insta a que los Estados miembros tengan en cuenta, en la aplicación de la excepción o limitación relativa a la copia privada, el desarrollo económico y tecnológico, en particular, en lo relativo a la copia privada digital y a los sistemas de retribución, siempre que existan medidas tecnológicas de protección eficaces. También nos advierte de esta relación el art. 5.2.b) de la DDASI cuando, al reconocer el derecho de los titulares a ser compensados por la copia privada, obliga a tener en cuenta "si se aplican o no a la obra o prestación de que se trate las medidas tecnológicas contempladas en el artículo 6".

Así pues, el art. 25.5.a). $6^{\circ}$ del TRLPI, haciéndose eco de lo establecido en el art. 25.6, regla $4^{\mathrm{a}}$.e) del TRLPI, en la redacción dada al mismo por la Ley 23/2006, así como de lo dispuesto en el art. 3.2.e) del Real Decreto 1657/2012, de 7 de diciembre, exige que el establecimiento de medidas tecnológicas repercuta en la determinación de la cuantía de la compensación equitativa. Parece ser que la razón fundamental que ha llevado al legislador a considerar esta repercusión ha sido prever una tendencia al alza en la implementación de estas medidas tecnológicas y, por tanto, una propensión a la 
disminución de la copia privada ${ }^{979}$. En efecto, era de esperar que la utilización de medidas tecnológicas eficaces frente a la copia privada fuera dando paso al licenciamiento de las obras y prestaciones intelectuales, pues es el único modo de acceder legalmente (sin quebrantar la medida tecnológica) a las obras y prestaciones intelectuales y, con ello, al abandono paulatino del sistema de compensación por copia privada $^{980}$. Sin embargo, este abandono no se ha producido, entre otras razones porque las medidas tecnológicas siguen siendo vulnerables; porque el titular de derechos no tiene por qué implementar mecanismos de protección en su obra para controlar el acceso a la misma o impedir la reproducción (como se deriva del Considerando $52^{\circ}$ y del art. 6.4 DDASI que evidencian la voluntariedad por parte de los titulares de derechos en el uso de estas medidas) ${ }^{981}$; y porque no siempre es posible la implementación de estas medidas (v. gr. sobre ciertos actos de comunicación pública de la obra).

Debe tenerse en cuenta que el art. 25.5.a). $6^{\circ}$ del TRLPI prevé tres elementos distintos para determinar la cuantía de la compensación equitativa por copia privada, a saber: la disponibilidad de las medidas tecnológicas, su grado de aplicación y, finalmente, su efectividad. Resulta criticable que el legislador apele a la disponibilidad de estas medidas. En efecto, la disponibilidad de las mismas no obliga a su uso, como tampoco garantiza que las medidas disponibles impidan, efectivamente, la realización de actos de reproducción no autorizados por el titular de derechos de propiedad intelectual. Más importantes resultan su grado de aplicación y su efectividad. El primero, porque a mayor uso de estas tecnologías, menor necesidad de compensar $^{982}$; y

\footnotetext{
979 Bercovitz Rodríguez-CANO, R.; Garrote Fernández-DíEz, I.; GonZÁlez GonZalo, A. y SÁNCHEZ ARISTI, R., Las reformas..., op. cit., p. 151; CARBAJO CASCÓN, F., "La 'larga marcha' de la compensación...", op. cit., p. 43.

${ }^{980}$ LÓPEZ MAZA, S., "Estudio de los criterios del art. 25.6.4 LPI...”, op. cit., p. 70.

${ }^{981}$ Vid. supra Capítulo 3, epígrafe VI, apartado 3.

$982 \mathrm{Al}$ respecto señala LÓPEZ MAZA, S., "Estudio de los criterios del art. 25.6.4 $4^{\circ}$ LPI...", op. cit., p. 75, "Podría distinguirse varios escalones, de mayor a menor recepción de la compensación, en función de las medidas tecnológicas que se usen: el titular de derechos que no utiliza ninguna medida tecnológica, el titular de derechos que las utiliza pero que permite un número determinado de copias privadas, el titular de derechos que las utiliza con el fin de impedir este tipo de copias pero que pueden resultar ineficaces y el titular que utiliza medidas $100 \%$ eficaces. Sólo en este último caso, no se debería percibir la compensación".
} 
el segundo, porque sólo en la medida en que el uso de técnicas, dispositivos o componentes tecnológicos dirigidos a restringir o impedir la copia privada sean efectivos, se evitará el perjuicio patrimonial que representa la copia privada para los titulares de derechos de autor y derechos conexos.

Consecuentemente, el uso de medidas tecnológicas de protección eficaces es un criterio útil para establecer o modular la cuantía de la compensación equitativa por copia privada. No obstante, habrá que tener en cuenta que no todas las medidas tecnológicas producen idénticos efectos. Al respecto, recuérdese que las medidas que controlan el acceso a la obra no impiden que, obtenida la autorización, se reproduzca la misma al amparo del límite de copia privada, con lo cual no se está controlando el copiado, que es lo que verdaderamente genera un perjuicio al autor y se busca compensar. Por el contrario, las medidas que controlan el copiado sí impiden la obtención de reproducciones, sólo que en algunos casos lo impedirán totalmente y, en otros, sólo lo harán parcialmente (autorizándose por el titular de derechos cierto número de copias). Por consiguiente, de impedirse absolutamente la realización de copias, no tiene sentido la compensación ${ }^{983}$, pero sí cuando se permite realizar un número determinado, en cuyo caso la compensación deberá ser modulada ${ }^{984}$.

Sobre la relación entre medidas tecnológicas de protección y compensación equitativa por copia privada se pronunció la STJUE (Sala Cuarta), de 27 de junio de $2013^{985}$, en el marco de una cuestión prejudicial instada por el Bundesgerichtshof. En este caso, el Tribunal Supremo alemán planteaba, entre otros interrogantes, si la posibilidad de aplicar las medidas tecnológicas mencionadas en el art. 6 de la DDASI

\footnotetext{
983 Ahora bien, frente a la vulnerabilidad de las medidas tecnológicas, la solución de no compensar en ninguna medida tampoco parece ser la solución más acertada, pues no podrá afirmarse, categóricamente, que estas medidas tecnológicas no han sido vulneradas. LÓPEZ MAZA, S., "Estudio de los criterios del art. 25.6.4 ${ }^{\circ}$ LPI...", op. cit., p. 73.

${ }^{984}$ Ibídem, p. 72. En el mismo sentido, MARTínEZ EsPín, P., "El nuevo régimen de la compensación equitativa...,", op. cit., p. 488.

985 Verwertungsgesellschaft Wort (VG Wort) contra Kyocera, anteriormente Kyocera Mita Deutschland $\mathrm{GmbH}$, Epson Deutschland GmbH y Xerox GmbH en el asunto C-457/11, contra Canon Deutschland GmbH en el asunto C-458/11, y Fujitsu Technology Solutions contra VG Wort en el asunto C-459/11 y Hewlett Packard GmbH contra VG Wort en el asunto C-460/11 (Asuntos acumulados C-457/11 a C460/11), ECLI:EU:C:2013:426.
} 
eliminaba la condición del pago de una compensación equitativa por copia privada ${ }^{986}$.

En el análisis de la cuestión, los divergentes criterios de diferentes empresas y países de la UE sobre el particular quedaron expuestos por la Abogada General, al señalar:

"Hewlett Packard, Kyocera, Lituania, los Países Bajos y el Reino Unido sostienen que la mera posibilidad de aplicar 'medidas tecnológicas' para proteger una obra

${ }^{986} \mathrm{El}$ art. 6 de la DDASI se pronuncia en los términos siguientes:

“1. Los Estados miembros establecerán una protección jurídica adecuada contra la elusión de cualquier medida tecnológica efectiva, cometida por una persona a sabiendas, o teniendo motivos razonables para saber que persigue ese objetivo.

2. Los Estados miembros establecerán una protección jurídica adecuada frente a la fabricación, importación, distribución, venta, alquiler, publicidad para la venta o el alquiler, o posesión con fines comerciales, de cualquier dispositivo, producto o componente o la prestación de servicios que: a) sea objeto de una promoción, de una publicidad o de una comercialización con la finalidad de eludir la protección, o b) sólo tenga una finalidad o uso comercial limitado al margen de la elusión de la protección, o c) esté principalmente concebido, producido, adaptado o realizado con la finalidad de permitir o facilitar la elusión de la protección de cualquier medida tecnológica eficaz.

3. A efectos de la presente Directiva, se entenderá por «medidas tecnológicas» toda técnica, dispositivo o componente que, en su funcionamiento normal, esté destinado a impedir o restringir actos referidos a obras o prestaciones protegidas que no cuenten con la autorización del titular de los derechos de autor o de los derechos afines a los derechos de autor establecidos por ley o el derecho sui generis previsto en el Capítulo III de la Directiva 96/9/CE. Las medidas tecnológicas se considerarán «eficaces» cuando el uso de la obra o prestación protegidas esté controlado por los titulares de los derechos mediante la aplicación de un control de acceso o un procedimiento de protección, por ejemplo, codificación, aleatorización u otra transformación de la obra o prestación o un mecanismo de control del copiado, que logre este objetivo de protección.

4. No obstante la protección jurídica prevista en el apartado 1, en caso de que los titulares de los derechos no adopten medidas voluntarias, incluidos los acuerdos con otros interesados, los Estados miembros tomarán las medidas pertinentes para que los titulares de los derechos faciliten al beneficiario de una excepción o limitación establecida por el Derecho nacional de conformidad con las letras a), c), d), y e) del apartado 2 del artículo 5 o con las letras a), b) y e) del apartado 3 del mismo artículo, los medios adecuados para disfrutar de dicha excepción o limitación, en la medida necesaria para ese disfrute, siempre y cuando dicho beneficiario tenga legalmente acceso a la obra o prestación protegidas.

Un Estado miembro podrá adoptar asimismo tales medidas respecto del beneficiario de una excepción o limitación establecida en virtud de la letra b) del apartado 2 del artículo 5, a menos que los titulares de los derechos hayan hecho ya posible la reproducción para uso privado en la medida necesaria para el disfrute de la excepción o limitación contemplada y de conformidad con lo dispuesto en la letra b) del apartado 2 del artículo 5 y en el apartado 5 del mismo artículo, sin impedir a los titulares de los derechos la adopción de medidas adecuadas respecto del número de reproducciones de conformidad con tales disposiciones. Tanto las medidas tecnológicas adoptadas voluntariamente por los titulares de los derechos, incluidas las derivadas de acuerdos voluntarios, como las adoptadas en aplicación de medidas adoptadas por los Estados miembros, disfrutarán de la protección jurídica prevista en el apartado 1.

Lo dispuesto en los párrafos primero y segundo no será de aplicación a obras o prestaciones que se hayan puesto a disposición del público con arreglo a lo convenido por contrato, de tal forma que personas concretas del público puedan acceder a ellas desde un lugar y en un momento que ella misma haya elegido.

Cuando el presente artículo se aplique en el contexto de las Directivas 92/100/CEE y 96/9/CE, el presente apartado se aplicará mutatis mutandis". 
basta para anular cualquier exigencia de abono de una compensación equitativa por las reproducciones de la obra; Irlanda tiene básicamente la misma opinión aunque aboga por un enfoque casuístico. Por el contrario, VG Wort, Alemania, Polonia y la Comisión consideran que únicamente el uso efectivo de dichas medidas debe tener dicho efecto. España y Finlandia, por otro lado, consideran que la Directiva no es suficientemente explícita y que incumbe a los Estados decidir al respecto" 987.

Sin embargo, el TJUE concluye que la DDASI, al otorgar la posibilidad a los titulares de derechos de aplicar voluntariamente medidas tecnológicas (Considerando $52^{\circ}$ ), lo hace en tanto este mecanismo sea compatible con la excepción de copia privada y contribuya a alcanzar el objetivo de la excepción, es decir, en tanto estas medidas permitan limitar o impedir la realización de copias no autorizadas por los Estados miembros en virtud de dicha excepción ${ }^{988}$. De hecho, las medidas tecnológicas de protección constituyen un mecanismo de salvaguarda frente a actos de explotación de las obras no autorizados, pero no pueden convertirse, en modo alguno, en un instrumento que impida a los usuarios disfrutar de las creaciones intelectuales al amparo de las limitaciones al derecho de autor y a los derechos conexos establecidas legalmente ni, en particular, la obtención de copias lícitas para uso privado, del mismo modo que no puede imponerse al titular de los derechos la carga de aplicarlas. Así, el carácter voluntario de las medidas tecnológicas hace que su implementación no suponga eliminar la compensación ${ }^{989}$. Ahora bien, “el Estado miembro afectado puede hacer depender de la aplicación o no de tales medidas tecnológicas el nivel concreto de la compensación debida a los titulares de los derechos"990, por lo que la STJUE afirma: "la posibilidad de aplicar las medidas tecnológicas mencionadas en el artículo 6 de la

\footnotetext{
987 Conclusiones de la Abogada General, Sra. Eleanor SHARPSTON, presentadas al TJUE el 24 de enero de 2013 (Asuntos acumulados C-457/11, C-458/11, C-459/11 y C-460/11), ECLI:EU:C:2013:34, párrafo 98. Aun cuando se aprecien las diferentes posiciones comentadas, la Abogada General señala en el propio apartado como, no obstante, "las partes parecen coincidir en que no existe un derecho a recibir una compensación equitativa cuando de hecho se aplican medidas tecnológicas efectivas".

${ }^{988}$ Vid. Sentencia del TJUE (Sala Cuarta), de 27 de junio de 2013, cit., apartado 56.

${ }^{989}$ Ibídem, apartado 57.

990 Ibídem, apartado 58.
} 
DDASI no elimina la condición de la compensación equitativa establecida en el artículo 5, apartado 2, letra b), de dicha Directiva"991.

\subsubsection{La consideración de las cuantías aplicadas en otros Estados miembros de la UE como referencia}

El último de los criterios objetivos contemplados en el art. 25.5.a) del TRLPI precisa atender a las cuantías de la compensación equitativa por copia privada que resulten de aplicación en otros Estados miembros de la UE, siempre que existan bases homogéneas de comparación ${ }^{992}$. En este caso, el legislador no especifica en qué medida estas cuantías influirán en la determinación de las que se establezcan en el ordenamiento jurídico español. Dicho de otro modo, el texto legal sólo menciona que estas cuantías deberán ser consideradas, pero sin imponer ninguna otra exigencia adicional en cuanto a cuáles podrían ser los márgenes admisibles de diferenciación respecto de aquéllas.

Todo indica, sin embargo, que lo que se persigue es que España no se desmarque con la aplicación de unas cuantías muy diferentes de las vigentes en otros Estados miembros de la UE, a la vez que una apuesta por lograr una aplicación más armónica de la compensación por copia privada en este ámbito. En efecto, la existencia de grandes disparidades entre los sistemas nacionales de compensación puede originar distorsiones en la competencia dentro del mercado interior europeo, así como la búsqueda del fuero más favorable dentro de este mercado ${ }^{993}$.

\footnotetext{
991 Ibídem, apartado 59.

992 Un ejemplo comparativo de estas cuantías en algunos Estados miembros de la UE puede consultarse en el Anexo 2.

993 PARLAMENTO EUROPEO, Informe sobre los cánones..., cit., apartado 7. La preocupación sobre la incidencia de la falta de armonización a este respecto no es una cuestión novedosa. Desde el proceso de consulta realizado como parte del programa de trabajo de la Comisión Europea en el año 2006 quedó patente la intención de examinar el criterio de las partes interesadas respecto de la diversidad de soportes, aparatos y equipos gravados, así como respecto a la variación de las tarifas establecidas en unos y otros Estados miembros y su repercusión en la libre circulación de estos productos en el mercado interior. Comisión Europea, Stakeholder Consultation on Copyright Levies in a Converging World, 2006, disponible en:
} http://ec.europa.eu/internal_market/copyright/docs/levy_reform/stakeholder_consultation_en.pdf (consultado: 18.11. 2016). 
De cualquier forma, no puede olvidarse que las cuantías de la compensación equitativa en los Estados Miembros de la UE son dispares, lo que dificultará la aplicación de este criterio, pues pese a que el precepto señala "siempre que existan bases homogéneas de comparación", lo cierto es que sobre un mismo producto, equipo o soporte material de reproducción las cuantías pueden ser muy variables de un país a otro. Habrá que esperar, pues, al desarrollo reglamentario que concrete las mismas, siguiendo el mandato de la Disposición Final primera del Real Decreto-ley 12/2017, de 3 de julio, para saber en qué medida se aproximan a lo establecido en otros Estados miembros.

\section{El procedimiento para la determinación de la cuantía de la compensación}

El Real Decreto que se dicte en cumplimiento de lo dispuesto en la Disposición Final primera del Real Decreto-ley 12/2017, de 3 de julio, será el que determine, entre otras cuestiones ${ }^{994}$, las cantidades que los deudores deberán abonar en concepto de compensación equitativa por copia privada a los acreedores, esto es, la cuantía de la compensación equitativa por copia privada. De este modo, se fijará la primera lista de equipos, aparatos y soportes de reproducción sujetos a la compensación y su correspondiente cuantía con carácter no transitorio, sin perjuicio de que puedan ser modificadas mediante Orden del Ministerio de la Presidencia y para las Administraciones Territoriales, que deberá dictarse en el marco del procedimiento establecido por el art. 25.4 del TRLPI.

Este procedimiento se inicia a propuesta de los Ministerios de Educación, Cultura y Deporte y de Energía, Turismo y Agenda Digital, previo informe a la Comisión Delegada del Gobierno para Asuntos Económicos.

Durante el procedimiento de elaboración tanto de la Orden como del Real-Decreto (a este también le son aplicables las normas contenidas en el art. 25.4 y 25.5 del TRLPI

\footnotetext{
${ }^{994}$ Se recuerda que también contendrá la lista de equipos, aparatos y soportes de reproducción sujetos al pago de la compensación y la distribución de la compensación entre las distintas modalidades de reproducción.
} 
por mandato de la Disposición Final primera del Real Decreto-ley 12/2017), se dará audiencia a las entidades de gestión de derechos de propiedad intelectual, a los interesados y a las asociaciones mayoritarias que representen a los sujetos deudores. Se puede entender que cuando la ley se refiere a las entidades de gestión de derechos de propiedad intelectual hace alusión a todas aquellas que gestionan los derechos de aquellos sujetos acreedores de la compensación, según la modalidad de reproducción de que se trate (libros, fonogramas, etc. $)^{995}$. Sin embargo, no queda claro quiénes habrán de ser considerados "interesados", como tampoco se especifica cuáles serán las "asociaciones mayoritarias que representen a los sujetos deudores", aunque se espera que esta omisión sea salvada por lo que determine el Ministerio de Energía Turismo y Agenda Digital, de acuerdo con lo dispuesto en el propio art. 25.4, párrafo 3, del TRLPI ${ }^{996}$.

Valga señalar que una referencia similar a estas asociaciones se contenía en el art. 25.6 (regla $1^{\text {a }}$ ) del mismo texto legal, en su versión anterior tras la Ley 23/2006, entonces llamadas "asociaciones sectoriales", identificadas por el Ministerio de Industria y Comercio, y representantes mayoritarias de los deudores. Tampoco entonces la ley dejó claro a qué entidades se refería, pero la Resolución conjunta de 7 de agosto de 2006, de la Secretaría General Técnica del Ministerio de Cultura y de la Dirección General para el Desarrollo de la Sociedad de la Información del Ministerio de Industria ${ }^{997}$, que dio inicio al procedimiento para la elaboración de la Orden PRE/1743/2008, señaló que se trataba de la Asociación de Empresas Electrónicas, Tecnologías de la Información y Telecomunicaciones de España (AETIC) y de la Asociación Multisectorial de Empresas Españolas de Electrónica y Comunicaciones (ASIMELEC).

Conforme al procedimiento comentado, tanto las entidades de gestión de derechos

\footnotetext{
${ }^{995}$ SGAE, CEDRO, AGEDI, AIE, VEGAP, EGEDA, AISGE y DAMA.

${ }^{996}$ Durante el procedimiento de elaboración de dicha Orden se dará audiencia a las entidades de gestión de derechos de propiedad intelectual, a los interesados y a las asociaciones mayoritarias que representen a los sujetos deudores, de acuerdo con lo que determine el Ministerio de Energía, Turismo y Agenda Digital, debiendo aportar, todos estos, una propuesta motivada respecto a su ámbito de interés, que irá acompañada de un informe justificativo.

${ }^{997}$ B.O.E. núm. 202, de 24 de agosto de 2006.
} 
de propiedad intelectual, como los interesados y las asociaciones mayoritarias que representen a los sujetos deudores deberán aportar una propuesta motivada respecto a su ámbito de interés, que irá acompañada de un informe justificativo. Sus alegaciones serán relevantes a efectos de la aprobación tanto de la Orden como del Real Decreto, pues deberán ser objeto de primordial atención por parte del Centro directivo promotor de la misma, por mandato del propio art. 25.4, párrafo 4, del TRLPI.

Asimismo, según el art. 25.4, párrafo 2, del TRLPI, con carácter previo a la aprobación de dicha Orden (y del Real Decreto) será consultado el Consejo de Consumidores y Usuarios; consulta a la que antes también obligaba el TRLPI, en su versión tras la Ley 23/2006 ${ }^{998}$. Asimismo, emitirá informe preceptivo la Sección Primera de la Comisión de Propiedad Intelectual ${ }^{999}$, que sustituiría la actuación que antes desempeñaba, en este punto, el Ministerio de Economía y Hacienda.

Cabe remarcar, finalmente, que si se contrasta el art. 25.4 del TRLPI actual con el art. 25.6 del TRLPI en la versión dada al mismo por la Ley 23/2006, el procedimiento de aprobación de la Orden del Ministerio de la Presidencia y para las Administraciones Territoriales, si bien difiere del que se seguía para la aprobación de la Orden Conjunta de los Ministerios de Cultura y de Industria, Turismo y Comercio, conserva algunos puntos comunes (la previsión de trámites de consulta e informes, por ejemplo). Pero hay

\footnotetext{
${ }^{998}$ Los consumidores y usuarios agrupados en las asociaciones de internautas mostraron su férrea oposición al canon por copia privada bajo la vigencia del TRLPI en la versión dada al mismo por la Ley 23/2006 y, en particular, en el momento de aprobación de la Orden PRE/1743/2008; una oposición que cobra fuerza nuevamente tras la aprobación del Real Decreto-ley 12/2017. En efecto, la Asociación de Internautas y la Asociación de Usuarios de Internet, unidas junto a otras organizaciones en la plataforma "Todos contra el canon", presentaron un escrito de rechazo al "nuevo canon digital", según publicación de Cinco Días (El País) de 5 de julio de 2017, disponible en: https://cincodias.elpais.com/cincodias/2017/07/05/companias/1499258446_926075.html (consultado: 10/12/2017).

${ }^{999}$ Se trata de un órgano de carácter colegiado, adscrito al Ministerio de Educación, Cultura y Deporte, con funciones de arbitraje, mediación, fijación de cantidades sustitutorias de tarifas y resolución de conflictos en los que sean parte las entidades de gestión de derechos de propiedad intelectual entre sí o entre alguna o algunas de ellas y una o varias asociaciones de usuarios o entidades de radiodifusión. Vid. Bello JANeIRO, D., "La Sección Primera de la Comisión de Propiedad Intelectual; mediación, arbitraje, tarifas y control", en Anguita Villanueva, L. A. (Coord.), En torno a la reforma de la Ley de Propiedad Intelectual, Reus, Madrid, 2013, pp. 99 y ss.; y CASAS VALLÉS, R., "La Comisión de Propiedad Intelectual", en BERCOVITZ RODRÍGUEZ-CANO, R. (Coord.), La reforma de la Ley de Propiedad Intelectual, Tirant lo Blanch, Valencia, 2015, pp. 284-310.
} 
que decir que se echa en falta en la ley la determinación de los plazos que tienen los sujetos implicados en el procedimiento para llevar a cabo cada una de las acciones que éste prevé, que, en cambio, sí quedaban expuestos en la versión del texto legal de $2006^{1000}$. En efecto, el art. 25.4, párrafo final del TRLPI, únicamente alude a la periodicidad con que tendrá que ser revisada la Orden, autorizando a que se haga en cualquier momento, en función de la evolución tecnológica y de las condiciones de mercado o, en cualquier caso, al menos, con una periodicidad de tres años. Sin embargo, no establece ningún otro plazo a efectos de la tramitación de la mencionada Orden.

\section{La cuantía de la compensación en el régimen transitorio}

Hasta que se aprueben las nuevas cuantías de la compensación equitativa por copia privada, son aplicables las previstas en la Disposición Transitoria segunda del Real Decreto-ley 12/2017, de 3 de julio ${ }^{1001}$. En la mayoría de los supuestos estas cuantías suponen una cantidad menor a la consignada para los mismos equipos, aparatos y soportes de reproducción en la Orden PRE/1743/2008, de 18 de junio, a excepción de la prevista para los dispositivos reproductores de fonogramas, videogramas o de otros contenidos sonoros, visuales o audiovisuales en formato comprimido y para los teléfonos móviles con funcionalidad de reproducción de fonogramas ${ }^{1002}$.

Conforme al apartado 1, in fine, de la Disposición Transitoria segunda del Real Decreto-ley 12/2017 no podrá aplicarse más de una cantidad de las previstas en dicho apartado a los ordenadores, portátiles o de sobremesa; a los dispositivos portátiles reproductores de fonogramas, videogramas, textos o de otros contenidos sonoros,

\footnotetext{
${ }^{1000}$ El art. 25.6 del TRLPI en su versión dada por la Ley 23/2006 (reglas $2^{\mathrm{a}}$ y $3^{\mathrm{a}}$ ) establecía que las partes interesadas disponían de cuatro meses, siguientes a la publicación en el B.O.E. del inicio del procedimiento para la determinación de los equipos, aparatos y soportes sujetos al pago de la compensación equitativa por copia privada, para comunicar a los Ministerios de Cultura y de Industria, Turismo y Comercio los acuerdos a los que hubieran llegado como consecuencia de sus negociaciones o, en su defecto, la falta de tal acuerdo. Establecía, asimismo, que los Ministerios de Cultura y de Industria, Turismo y Comercio, en el plazo de tres meses, contado desde la comunicación o desde el agotamiento del mencionado plazo, establecerían, mediante orden conjunta, la relación de equipos, aparatos y soportes materiales, las cantidades aplicables a cada uno de ellos y, en su caso, la distribución entre las diferentes modalidades de reproducción de libros, de sonido y visual o audiovisual.

${ }^{1001}$ Vid. Anexo 3.

1002 Estos se mantienen en las cantidades de 3,15 euros y 1,10 euros por unidad, respectivamente.
} 
visuales o audiovisuales en formato comprimido; a los dispositivos electrónicos portátiles con pantalla táctil; y a los teléfonos móviles con funcionalidad de reproducción de fonogramas, videogramas y textos o de otros contenidos sonoros, visuales o audiovisuales. No obstante, la aplicación práctica de este criterio puede resultar controvertida, toda vez que la norma no especifica si deberá aplicarse la cantidad mayor o menor de las que puedan corresponder en estos casos. A falta de previsión legal, quizás lo más aconsejable para los deudores, sea liquidar la cantidad mayor, para evitar así ser requeridos y tener que hacer frente a cantidades no satisfechas, al menos mientras esta cuestión no quede aclarada.

También es necesario tener presente que la determinación temporal de estas cuantías no es, de acuerdo con lo dispuesto en la Disposición Transitoria segunda, un precedente vinculante para el establecimiento de las cuantías definitivas, dado el carácter transitorio de las mismas.

\section{LA GESTIÓN DE LA COMPENSACIÓN EQUITATIVA POR COPIA PRIVADA}

\section{Las entidades encargadas de la gestión}

Desde que fuera reconocida la excepción o límite de copia privada en el ordenamiento jurídico español (1987) hasta la actualidad, la gestión de la compensación equitativa asociada a esta excepción ha sido encargada, por mandato legal, a las entidades de gestión de derechos de propiedad intelectual ${ }^{1003}$. Las entidades de gestión

\footnotetext{
${ }^{1003}$ Según el art. 3.a) de la Directiva 2014/26/UE del Parlamento Europeo y del Consejo, de 26 de febrero de 2014, relativa a la gestión colectiva de los derechos de autor y derechos afines y a la concesión de licencias multiterritoriales de derechos sobre obras musicales para su utilización en línea en el mercado interior (D.O.U.E. L 84/72, de 20 de marzo de 2014), por entidad de gestión colectiva se entiende: "toda organización autorizada, por ley o mediante cesión, licencia o cualquier otro acuerdo contractual para gestionar los derechos de autor o los derechos afines a los derechos de autor en nombre de varios titulares de derechos, en beneficio colectivo de esos titulares de derechos, como único o principal objeto, y que cumple al menos uno de los siguientes criterios: i) ser propiedad o estar sometida al control de sus miembros, o ii) carecer de ánimo de lucro".

Asimismo, siguiendo el art. 147 del TRLPI, estas entidades no tienen una naturaleza lucrativa y son autorizadas por el Ministerio de Cultura (actualmente Ministerio de Educación, Cultura y Deporte) para poder dedicarse, en nombre propio o ajeno, a la gestión de derechos de explotación u otros de carácter
} 
colectiva han sido pues las que se han ocupado de la recaudación, distribución y reparto de esta compensación entre los acreedores, así como del ejercicio de las funciones de fiscalización y control de su obligación de pago por los deudores, a excepción del período en que la compensación fue satisfecha con cargo a los PGE, en el cual las entidades de gestión pasaron a ser meras perceptoras de la compensación, con las funciones adicionales de distribución y reparto ${ }^{1004}$. Es por ello que se dice que la compensación equitativa por copia privada es un derecho de gestión colectiva obligatoria, pues la ley ha determinado que sean estas entidades las encargadas de su gestión que, por el contrario, no puede ser ejercida de manera individual por el titular de derechos de propiedad intelectual.

En efecto, el vínculo que se establece entre las entidades de gestión colectiva y los titulares de derechos de propiedad intelectual viene determinado ex lege. Así lo dispone el art. 25.9 del TRLPI en su redacción actual, que señala expresamente: "la compensación equitativa se hará efectiva a través de las entidades de gestión de derechos de propiedad intelectual [...]". Es cierto que en una gran mayoría de los casos estas entidades actúan en representación de los titulares de derechos previa concertación de un contrato "cuya duración no podrá ser superior a tres años renovables por períodos de un año, ni podrá imponer como obligatoria la gestión de todas las modalidades de explotación ni la de la totalidad de la obra o producción futura" (art. 153 del TRLPI). En cambio, otras veces, es el propio TRLPI el que exige que la gestión de los derechos se ejerza, exclusivamente, a través de las entidades de gestión. Así lo prevé el art. 153 del TRLPI y es lo que sucede en el caso de la compensación equitativa por copia privada.

Estas entidades han de participar en la constitución, gestión y financiación de una persona jurídica, que ejercerá, en representación de todas ellas, diferentes funciones, como parte del procedimiento para hacer efectiva la compensación (art. 25.10 del TRLPI).

patrimonial, por cuenta y en interés de varios autores u otros titulares de derechos de propiedad intelectual.

${ }^{1004}$ AviLÉs GarCíA, J., El derecho de compensación..., op. cit., p. 20. 
Así, tienen la obligación de comunicar a la Secretaría de Estado de Cultura el nombre o denominación y el domicilio de la persona jurídica que hayan constituido, debiendo presentar, además, la documentación acreditativa de su constitución, con una relación individualizada de sus entidades miembros en la que se indique su nombre y domicilio (apartado 4, Disposición Adicional única del Real Decreto-ley 12/2017, de 3 de julio). Para ello, la ley no hace mención a ningún término legal, pero se entiende que sea con la mayor prontitud, una vez constituida la referida persona jurídica.

Adicionalmente, la citada Disposición Adicional única exige, en su apartado 3, que la persona jurídica constituida cuente con una sede electrónica y con los recursos económicos suficientes para la realización de sus funciones y para el abono en tiempo de los reembolsos que se le soliciten. En concreto, a la financiación de esta persona jurídica se destinarán las cantidades recaudadas y no reclamadas por los titulares de los derechos de propiedad intelectual que cada asamblea general de cada entidad de gestión destine a la financiación de esta persona jurídica, según dispone el art. 154.5, párrafo primero, letra e) del TRLPI, en relación con el párrafo segundo del mismo precepto.

Por otro lado, esta persona jurídica no estará subordinada en su actuación a ninguna de las entidades de gestión que, en concreto, intervengan en su constitución, pues, conforme establece la Disposición Adicional única del Real Decreto-ley 12/2017, de 3 de julio, en su apartado 2, "ninguna de las entidades de gestión ostentará, por sí misma, capacidad para controlar la toma de decisiones de la referida persona jurídica".

Con todo, no se puede perder de vista que la constitución de esta persona jurídica es una novedad en el ordenamiento jurídico español, si bien su creación siempre fue un reclamo de los deudores y responsable solidarios del pago de la compensación equitativa por copia privada, con el fin de simplificar el proceso de declaraciónliquidación de esta compensación. Así pues, su creación, viene a garantizar a dichos sujetos una comunicación unificada de la facturación que les corresponda abonar, tal y como señala el art. 25.9 del TRLPI en su versión actual.

Pues bien, en cumplimiento del TRLPI las entidades de gestión de derechos de propiedad intelectual AGEDI, AIE, AISGE, CEDRO, DAMA, EGEDA, SGAE y VEGAP han constituido la Asociación Ventanilla Única Digital, de ámbito estatal, con 
CIF G-87301404 e inscrita en el Registro Nacional de Asociaciones con el número $608.378^{1005}$.

Se espera que esta tenga un papel relevante, tal y como lo evidencian las funciones que le han sido atribuidas por el art. 25.10 del TRLPI. En efecto, siguiendo dicho precepto, esta persona jurídica ejercerá la gestión de las exceptuaciones del pago y de los reembolsos; la recepción y posterior remisión a las entidades de gestión de las relaciones periódicas de equipos, aparatos y soportes de reproducción respecto de los que haya nacido la obligación de pago de la compensación, elaboradas por los sujetos deudores y, en su caso, por los responsables solidarios; así como la comunicación unificada de la facturación. Por tanto, esta entidad no se encargará directamente de la recaudación de la compensación de los deudores, ni del reparto a los acreedores. Funcionará, más bien, como una especie de "ventanilla única" para los sujetos deudores de la compensación y, en su caso, los responsables solidarios y, al mismo tiempo, como ente colaborador de las entidades de gestión colectiva en la tramitación de las exceptuaciones el pago y de los rembolsos, así como en el cumplimiento de la obligación de éstas de garantizar que los deudores y los responsables solidarios reciban una comunicación unificada de la facturación que les corresponda abonar ${ }^{1006}$.

Asimismo, como se desprende del art. 25.11 del TRLPI, esta persona jurídica tendrá facultades de control e inspección. Así, podrá realizar el control de las adquisiciones y de las ventas sujetas al pago de la compensación equitativa y de aquellas afectadas por las exceptuaciones establecidas en el art. 25.7 del TRLPI. Podrá comprobar, igualmente, que los sujetos que hayan obtenido la certificación de exceptuación se mantienen en el efectivo cumplimiento de los requisitos para ser beneficiarios de la misma.

Al respecto, los deudores y sus responsables solidarios deberán favorecer el ejercicio de dichos controles, facilitando los datos necesarios que les sean requeridos,

\footnotetext{
1005 Vid. Nota informativa de la ADEPI, disponible en http://adepi.net/2017/11/13/sede-electronicaventanilla-unica-fabricantes-distribuidores-importadores-copia-privada-canon-digital/ (consultada: $20 \mathrm{de}$ noviembre de 2017).

${ }^{1006}$ GaRrote FernáNDEZ- DíEZ, I., “Artículo 25 (Comentario)”, en Bercovitz RodríGueZ,-CANo, R. (Coord), Comentarios a la Ley de Propiedad..., $4^{\text {a }}$ ed., op. cit., p. 547.
} 
pues, de lo contrario, podrán quedar compelidos a hacerlo por decisión judicial, si esta persona jurídica así lo insta, toda vez que es la propia ley la que impone a aquellos la obligación de permitir su fiscalización. Ahora bien, esta labor de fiscalización no podrá ir más allá de las acciones estrictamente relacionadas con la obligación de pago de la compensación. Por consiguiente, la persona jurídica podrá solicitar a los deudores o, en su caso, a los responsables solidarios, información sobre el número de unidades vendidas, sus características técnicas y destino, así como las facturas o albaranes de entrega y cualquier otra documentación que permita contrastar si las facturas se corresponden con las ventas efectivamente realizadas, pero en ningún caso información empresarial ajena al control de las actividades sometidas a la compensación equitativa.

Por otra parte, como señala el art. 25.12 del TRLPI, también corresponde a esta persona jurídica la obligación de comunicar a la Secretaría de Estado de Cultura del Ministerio de Educación, Cultura y Deporte, el día 1 de abril de cada año, un listado pormenorizado de las relaciones periódicas de equipos, aparatos y soportes de reproducción respecto de los que haya nacido la obligación de pago de la compensación, elaboradas por los sujetos deudores y por los responsables solidarios; un listado pormenorizado de las compensaciones pagadas por los sujetos deudores y por los responsables solidarios; la relación de certificaciones de exceptuación y de reembolsos tramitadas; y cuanta información adicional considere necesaria dicho Ministerio para ejercer sus funciones de inspección, vigilancia y control sobre las entidades de gestión de derechos de propiedad intelectual.

\section{El procedimiento de gestión}

El TRLPI, en su versión actual, no contiene normas que regulen el procedimiento de gestión de la compensación equitativa por copia privada, a diferencia de sus versiones anteriores (tanto de 1996 como de la Ley 23/2006), que contaban con una prolija regulación al respecto. Por el contrario, el TRLPI ahora en su art. 25.9, se limita a establecer que esta gestión se realizará conforme al procedimiento que se determine mediante Real Decreto, que -como se ha expuesto- no ha sido aprobado todavía, pero que, siguiendo la Disposición Final primera del Real Decreto-ley 12/2017, de 3 de julio, 
se espera que se apruebe en el plazo máximo de un año desde la entrada en vigor de dicho Real Decreto-ley, esto es, a más tardar el 1 de agosto de 2018.

En cualquier caso, se espera que el Real Decreto contenga normas reglamentarias que ordenen el procedimiento de recaudación, distribución y reparto entre los acreedores de esta compensación, conservando -en lo sustancial- el mecanismo de declaración y pago que contenían los textos precedentes del TRLPI de 1996 y 2006. En efecto, éste es el procedimiento que ahora también establece la Disposición Transitoria segunda del Real Decreto-ley 12/2017, de 3 de julio. Con todo, debe destacarse la novedad que supone en la gestión de la compensación equitativa la creación de la persona jurídica prevista por el art. 25.10 del TRLPI.

De conformidad con la Disposición Transitoria segunda del Real Decreto-ley 12/2017, a falta de una norma definitiva, el procedimiento de recaudación de la compensación equitativa por parte de las entidades de gestión colectiva es actualmente el siguiente:

1) Se inicia por medio de las declaraciones que los deudores y, en su caso, que los responsables solidarios, presentan ante la citada persona jurídica dentro de los treinta días siguientes a la finalización de cada trimestre natural. En el caso de los deudores principales, estas declaraciones deben contener una relación de las unidades, capacidad y características técnicas de los equipos, aparatos y soportes materiales de reproducción respecto de los cuales haya nacido la obligación de pago, una deducción de las cantidades correspondientes a los equipos, aparatos y soportes materiales destinados fuera del territorio español, así como de las entregas exceptuadas en virtud de lo establecido en el art. 25.7.a) del TRLPI (apartado 2, párrafos 1 y 2). Por su parte, los responsables solidarios (distribuidores, mayoristas y minoristas sucesivos adquirentes) deben detallar los equipos, aparatos y soportes materiales por ellos adquiridos en territorio español de deudores que no les hayan repercutido y hecho constar en la factura la correspondiente compensación, así como también deducirse las cantidades correspondientes a las entregas exceptuadas en virtud de lo establecido en el art. 25.7.a) del TRLPI (apartado 2, párrafo 4). Debe detallarse de cada entrega exceptuada: la fecha y número de la factura, y la denominación de la entidad adquirente exceptuada (apartado 2, párrafo 2). 
Llama la atención que las deducciones por entregas exceptuadas previstas por el Real Decreto-ley 12/2017, de 3 de julio, sean, siguiendo el apartado 2, párrafos 2 y 4, sólo las del art. 25.7.a) del TRLPI, esto es, las derivadas de adquisiciones de equipos, aparatos y soportes materiales de reproducción realizadas por las entidades del sector público y demás órganos contemplados en el precepto. No obstante, seguramente se deba a que estas entidades obtienen la certificación que las exceptúa del pago de la compensación equitativa de órganos diferentes a la persona jurídica que deberá emitirlas en los casos de las letras b) y c) del precepto. Se espera, por tanto, que el Real Decreto que regule el procedimiento definitivo de gestión de esta compensación establezca la posibilidad de deducirse las cantidades correspondientes a las entregas exceptuadas en virtud de lo establecido en el art. 25.7.b) y c) del TRLPI, esto es, por las adquisiciones de equipos, aparatos y soportes materiales de reproducción realizadas por personas jurídicas o físicas que actúen como consumidores finales, que justifiquen el destino exclusivamente profesional de los equipos, aparatos o soportes materiales adquiridos; y por las adquisiciones realizadas por quienes cuenten con la preceptiva autorización para llevar a efecto la correspondiente reproducción de obras, prestaciones artísticas, fonogramas o videogramas, según proceda, en el ejercicio de su actividad. Por el contrario, la deducción de la excepción del art. 25.7.d) del TRLPI, no resulta procedente, ya que se trata de la exceptuación del pago de la compensación de equipos, aparatos y soportes materiales de reproducción adquiridos por personas físicas para uso privado fuera del territorio español en régimen de viajeros.

2) Las declaraciones deben ser presentadas por los deudores dentro de los plazos establecidos por el Real Decreto-ley 12/2017. Dichos plazos difieren según se trate de fabricantes (en tanto actúen como distribuidores en España) y de adquirentes de equipos, aparatos y soportes materiales fuera del territorio español con destino a su distribución comercial en éste [art. 25.6.a) del TRLPI]; o de adquirentes de equipos, aparatos y soportes materiales fuera del territorio español con destino a su utilización dentro de dicho territorio [art.25.6.b) del TRLPI]. Los primeros deben presentar la declaración dentro de los treinta días siguientes a la finalización de cada trimestre natural (apartado 2, párrafo 1), respecto de los equipos, aparatos y soportes materiales para los cuales haya nacido la obligación de pago de la compensación; en tanto los 
segundos dentro de los cinco días siguientes al nacimiento de la obligación (apartado 2, párrafo 3).

Debe señalarse que la obligación de pago de la compensación equitativa por copia privada surge para el primer grupo de sujetos mencionados (fabricantes en el territorio Español que actúan como distribuidores en éste y adquirentes de equipos, aparatos y soportes materiales fuera del territorio español con destino a su distribución comercial en dicho territorio) en el momento en que transmiten la propiedad o, en su caso, ceden el uso o disfrute de los referidos equipos, aparatos y soportes de reproducción [art. 25.6.a) del TRLPI] ${ }^{1007}$. Por el contrario, para los adquirentes de equipos, aparatos y soportes materiales fuera del territorio español con destino a su utilización dentro de dicho territorio, dicha obligación surge desde el momento de la adquisición de los mencionados equipos, aparatos y soportes materiales de reproducción [art. 25.6.b) del TRLPI]. Consecuentemente, aunque el nacimiento de la obligación de pago de la compensación equitativa se produzca con anterioridad, la obligación de presentar la declaración-liquidación no se produce hasta los treinta días siguientes a la finalización de cada trimestre natural, o los cinco siguientes al momento de adquisición. De este modo, los fabricantes en tanto actúen como distribuidores en España, y los adquirentes de equipos, aparatos y soportes materiales fuera del territorio español con destino a su distribución comercial en éste tienen atribuido un plazo más largo para efectuar la correspondiente declaración que los sujetos pertenecientes al segundo grupo (adquirentes de equipos, aparatos y soportes materiales fuera del territorio español con destino a su utilización dentro de dicho territorio), que sólo cuentan con el breve plazo de los cinco días posteriores a la adquisición de estos bienes ${ }^{1008}$.

\footnotetext{
${ }^{1007}$ Lo importante no es el título de transmisión que dé lugar a la facultad de disfrute, sino que el adquirente tenga la posibilidad de disfrutar del equipo, aparato o soporte material de reproducción. GARrote FERnÁndeZ- DíEZ, I., “Artículo 25”, en BERCOVITZ RodríGueZ-CANO, R. (Coord), Comentarios a la Ley de Propiedad..., $4^{\mathrm{a}}$ ed., op. cit., p. 530.

${ }^{1008}$ Este mecanismo no es diferente al establecido en el TRLPI en sus versiones anteriores (salvo la versión del art. 25 del TRLPI a tenor de la Ley 21/2014). Estos textos también diferenciaban entre el momento de surgimiento de la obligación de pago de la compensación y el momento de presentación de la declaración-liquidación, según se tratase de uno u otro grupo de sujetos. De hecho, tanto en uno como en otro caso, la obligación surgía en los mismos plazos ahora contenidos en la D.T. $2^{\circ}$ del Real Decretoley 12/2017, de 3 de julio, lo que indica que ésta se ha inspirado en aquél, a dichos efectos.
} 
Nada especifica la Disposición Transitoria segunda del Real Decreto-ley 12/2017, de 3 de julio, sobre el momento en que los distribuidores, mayoristas y minoristas, sucesivos adquirentes de los equipos, aparatos y soportes materiales deben presentar la declaración. Sin embargo, siendo estos sujetos deudores subsidiarios de los fabricantes españoles que comercializan sus productos en España y de los adquirentes fuera del territorio español para su distribución comercial en dicho territorio, debe entenderse que tendrán que realizar la declaración en el mismo plazo que aquéllos. Este parece ser el sentido del apartado 2, párrafo 4, al establecer que estos sujetos estarán obligados a la presentación de la "referida relación trimestral".

3) Tras la presentación a la persona jurídica, dentro del plazo previsto, de la relación de las unidades, capacidad y características técnicas de los equipos, aparatos y soportes materiales de reproducción respecto de los cuales haya nacido la obligación de pago de la compensación, continúa la fase de recaudación de la compensación equitativa por copia privada con la apertura de un período de facturación por las entidades de gestión colectiva de los derechos de propiedad intelectual. En efecto, siguiendo el párrafo 3 , una vez recibida la relación trimestral de unidades, la persona jurídica debe remitirla a las entidades de gestión correspondientes. Es decir, debe remitirla a las distintas entidades implicadas en función de la modalidad de reproducción de que se trate -obras divulgadas en forma de libros y publicaciones asimiladas, fonogramas y otros soportes sonoros, y videogramas y otros soportes visuales o audiovisuales-.

Hay que tener en cuenta que hay entidades de gestión colectiva que concurren en la gestión de una misma modalidad de reproducción ${ }^{1009}$. Al respecto, la norma no establece si la persona jurídica debe remitir la relación trimestral de unidades a una o a todas las entidades concurrentes. En todo caso, siendo única la compensación equitativa para cada modalidad de reproducción, el pago realizado por el deudor a una de estas

\footnotetext{
${ }^{1009}$ Así, por ejemplo, para el caso de la reproducción sonora, concurren las entidades de gestión colectiva representativas de los autores (SGAE), de artistas intérpretes y ejecutantes (AIE), y de productores (AGEDI).
} 
entidades tendrá efectos liberatorios frente a las demás que concurran en la misma modalidad de reproducción.

Se trata de una cuestión relevante porque, según se deriva del apartado 4 de la Disposición Transitoria segunda del Real Decreto-ley 12/2017, la remisión de la relación trimestral de unidades a las entidades de gestión correspondientes por la persona jurídica tiene por finalidad que éstas, a la vista de tal relación, emitan una factura a nombre del deudor o, en su caso, del responsable solidario, con el importe de la compensación a pagar.

No obstante, a falta de previsión legal sobre la actuación conjunta y bajo una sola representación de las entidades en la gestión de una misma modalidad de reproducción, éstas deberían tener en cuenta dicha concurrencia en el momento de emitir las facturas correspondientes a nombre del deudor. Es decir, deberían emitir sus respectivas facturas por el valor proporcional que les correspondiese, atendiendo al número de acreedores representados por cada una de ellas ${ }^{1010}$. Sin embargo, esta no parece ser la solución prevista, puesto que el TRLPI prevé la posibilidad de supuestos de reembolso, en cuyo caso, respecto a un deudor concreto que tenga derecho al mismo, no podrá determinarse qué entidad de gestión específica actuó en la recaudación de la cantidad a reembolsar. Otra solución sería que la persona jurídica en cuestión remitiese la comunicación a una única entidad de las concurrentes, designada por acuerdo entre las distintas entidades encargadas $\mathrm{o}$, a falta de acuerdo, por decisión de quien se determine legalmente, en cuyo caso, dicha entidad actuaría en representación de todas, convirtiéndose en deudora de la compensación en la proporción que corresponda, en función del número de acreedores representados por cada una de ellas.

\footnotetext{
${ }^{1010}$ Esta solución sería similar a la que se daba, en la práctica, a la hora de presentar la declaraciónliquidación y realizar el pago de la compensación por los deudores, a tenor del procedimiento regulado en el art. 25 del TRLPI conforme a su redacción por la Ley 23/2006 e incluso en su versión de 1996, teniendo en cuenta que el procedimiento de gestión de la compensación era muy similar en uno u otro texto. Sucedía, igualmente, que, a falta de acuerdos bilaterales para la gestión entre determinadas entidades, los deudores se veían compelidos a presentar tantas declaraciones-liquidaciones como entidades concurrieran en una misma modalidad de reproducción. Ello implicaba que cada entidad de gestión concurrente en una misma modalidad de reproducción recibiera una declaración-liquidación por la parte proporcional que le correspondía y emitiera una factura por esa misma parte. Vid. GARROTE FERNÁNDEZ- DíEZ, I., “Artículo 25”, en BERCOVITZ RODRÍGUEZ-CANO, R.. (Coord.), Comentarios a la Ley de Propiedad..., $3^{\text {a }}$ ed., op. cit., p. 503.
} 
De acuerdo con el apartado 4 de la Disposición Transitoria segunda del Real Decreto-ley 12/2017, "en el caso de que deba efectuarse una devolución del importe de la compensación abonada por el deudor o su responsable solidario, la entidad de gestión, previas las comprobaciones que procedan, se lo comunicará a estos en un plazo no superior a dos meses desde la finalización del plazo de presentación de la relación trimestral de unidades, a los efectos de que emitan una factura, a nombre de la entidad de gestión en cuestión, con el importe de la compensación a pagar por ésta, que será abonado dentro del mes siguiente a su fecha de emisión".

4) Los deudores o los responsables solidarios deben realizar el pago dentro del mes siguiente a la fecha de finalización del plazo de presentación de la relación trimestral de unidades y, entre tanto no realicen efectivamente el pago, se consideran depositarios de la compensación devengada. Las entidades de gestión que reciban estos pagos deberán provisionar al menos el 30 por ciento de las cantidades percibidas hasta el momento en que se realicen los reembolsos a los que se hace referencia en el apartado 7 de esta disposición (apartado 5).

Debe destacarse que los deudores y los responsables solidarios están obligados a repercutir el importe de la compensación de forma separada en la factura que entreguen a su cliente e indicar, en el caso de que el cliente sea consumidor final, su derecho a obtener el reembolso de dicho importe, si cumple los requisitos previstos en el artículo 25.8 del TRLPI. Así lo dispone el apartado 6, párrafo 1 de la Disposición Transitoria segunda del Real Decreto-ley 12/2017, que tiene por finalidad lograr una transparencia en la gestión de la compensación, de tal modo que el cliente pueda conocer la cuantía que se le repercute en concepto de canon, así como, en su caso, la posibilidad de recuperar lo pagado si concurre alguno de los supuestos de reembolso previstos por el art. 25.8 TRLPI. Pero también facilita el control de los pagos por parte de las entidades de gestión colectiva. De hecho, se establece la presunción legal de que cuando el importe de la compensación no aparece de forma separada en factura, salvo prueba en contrario, la compensación devengada por los equipos, aparatos y soportes materiales transmitidos no ha sido satisfecha (apartado 6, párrafo 1). En consecuencia, a menos que se acredite su pago, éste podrá ser exigido nuevamente. 
5) En caso de impago de la compensación por los sujetos obligados, habrá que acudir al ejercicio de las acciones civiles correspondientes. Las mismas no están reguladas en el actual TRLPI, como tampoco en sus versiones anteriores. No obstante, el art. $25.21 \mathrm{del}$ TRLPI, tras la Ley 23/2006, de 7 de julio, confirió a las entidades de gestión la posibilidad de solicitar del tribunal la adopción de medidas cautelares, siguiendo la Ley de Enjuiciamiento Civil y, en concreto, el embargo de los correspondientes equipos, aparatos y soportes materiales ${ }^{1011}$. La versión vigente del TRLPI, tras la modificación por el Real Decreto-ley 12/2017, de 3 de julio, no se pronuncia al respecto. Con todo, esta es una posibilidad que persiste, considerando que el art. 141.5 del TRLPI admite que la autoridad judicial pueda decretar, a instancia de los titulares de los derechos, las medidas cautelares que, según las circunstancias, fuesen necesarias para la protección urgente de los mismos y, en especial, en lo que al pago de la compensación respecta, el embargo de los equipos, aparatos y soportes materiales a los que se refiere el art. 25 del TRLPI, que quedarán afectos al pago de la compensación reclamada y a la oportuna indemnización de daños y perjuicios.

\section{La distribución y posterior reparto de la compensación entre los acreedores}

El procedimiento para la distribución de las cantidades recaudadas en concepto de compensación equitativa por copia privada se ha reservado a ulterior desarrollo reglamentario, según dispone la Disposición Final primera del Real Decreto-ley 12/2017, de 3 de julio. Dicho procedimiento deberá establecer los porcentajes a aplicar sobre la cuantía recaudada por cada modalidad de reproducción en concepto de compensación equitativa, de forma tal que se pueda obtener la cantidad correspondiente a los distintos grupos de titulares de derechos (autores, artistas intérpretes y ejecutantes, productores y editores), según la modalidad de reproducción que corresponda en cada

\footnotetext{
${ }^{1011}$ La versión original del TRLPI, promulgada mediante el Real Decreto Legislativo 1/1996, de 12 de abril, también previó que, en caso de impago de la compensación, la entidad o entidades de gestión, o, en su caso, la representación o asociación gestora, solicitaran del Juez el embargo de los correspondientes equipos, aparatos y materiales de reproducción. Los bienes así embargados quedaban afectos al pago de la compensación reclamada y de la oportuna indemnización de daños y perjuicios, según su art. 25.20.
} 
caso ${ }^{1012}$. En concreto, en la modalidad de libros y publicaciones asimiladas, las cantidades recaudadas son para los autores y los editores, mientras que las modalidades de reproducción de fonogramas y de videogramas corresponden a los autores, a los artistas intérpretes y ejecutantes y a los productores.

Estos porcentajes fueron establecidos por el art. 36 del Real Decreto 1434/1992, de 27 de noviembre, y continuaron vigentes tras la aprobación del TRLPI en $1996^{1013}$. De hecho, fueron los mismos que recogía la Orden PRE 1743/2008, de 18 de junio y que, años más tarde, contemplara el Real Decreto 1657/2012, de 7 de diciembre. A día de hoy, el art. 36 del Real Decreto 1434/1992 sigue en vigor, con lo cual, en tanto se apruebe el Real Decreto previsto en la Disposición Final primera del Real Decreto-ley 12/2017 y, a resultas de lo que en el mismo se disponga, la distribución por categorías de creedores es la dispuesta en dicho precepto.

En consecuencia, la distribución opera del modo siguiente: en la modalidad de fonogramas y demás soportes sonoros, el $50 \%$ para los autores, el $25 \%$ para los artistas intérpretes o ejecutantes y el $25 \%$ para los productores; en la modalidad de videogramas y demás soportes visuales o audiovisuales, un tercio para los autores, un tercio para los artistas intérpretes o ejecutantes y un tercio para los productores; y en la modalidad de libros y publicaciones asimiladas, el $55 \%$ para los autores y el $45 \%$ para los editores.

\footnotetext{
${ }^{1012}$ De concurrir varias entidades de gestión de derechos de propiedad intelectual en la administración de la compensación equitativa de una misma categoría de titulares de derechos, respecto a una misma modalidad de reproducción, habrá que dividir la cantidad obtenida entre las distintas entidades de gestión concurrentes. Así, por ejemplo, tanto la SGAE como DAMA representan a autores audiovisuales. Por tanto, aplicando el porcentaje de distribución reservado para los autores sobre el total recaudado en la modalidad de videogramas, se obtendrá una cantidad resultante que será la que corresponda a los autores en dicha modalidad. A su vez, siendo dos las entidades concurrentes en la gestión de los derechos de autor en esta modalidad de reproducción, habrá que dividir la cantidad obtenida entre dos. El resultado será la cantidad que corresponda a cada una de estas entidades, en concepto de compensación equitativa por copia privada, por la reproducción de videogramas.

${ }^{1013}$ Tras la aprobación del TRLPI mediante el Real Decreto Legislativo 1/1996, de 12 de abril, quedaron vigentes varios preceptos del Real Decreto 1434/1992, de 27 de noviembre, de desarrollo de los artículos 24, 25 y 140 de la Ley 22/1987, de 11 de noviembre, de Propiedad Intelectual, en la versión dada a los mismos por la Ley 20/1992, de 7 de julio, entre ellos, el art. 36 de dicho Real Decreto 1434/1992.
} 
Una vez distribuidas las cantidades recaudadas entre los distintos grupos de acreedores, según cada modalidad de reproducción, debe realizarse su reparto entre los titulares de derechos de propiedad intelectual, individualmente considerados, representados por cada entidad de gestión colectiva. Al respecto, resulta de aplicación el art. 154 del TRLPI, que establece las normas que rigen el procedimiento de reparto y pago de los derechos recaudados por las entidades de gestión, bien sean estos derechos de gestión colectiva voluntaria, o bien de gestión colectiva obligatoria como es el caso de la compensación equitativa.

Siguiendo el mismo, el reparto de la compensación equitativa recaudada entre los titulares de derechos de autor debe efectuarse con arreglo al sistema de reparto propio que cada entidad de gestión de derechos de propiedad intelectual contiene en sus estatutos. Así pues, cada entidad goza de un amplio margen de determinación. No obstante, siguiendo el art. 154.1 de TRLPI se exige que dicho reparto sea equitativo y no arbitrario, así como que se realice de manera diligente.

El art. 154.2 del TRLPI, como modo de cumplir con la obligación legal de un reparto equitativo y no arbitrario, prevé que debe ser proporcional a la utilización de las obras o prestaciones de los titulares de derechos. Existe, por tanto, la necesidad de adquirir datos sobre el grado de utilización de las obras y prestaciones intelectuales por parte de los usuarios, a cuyo efecto, las entidades de gestión establecerán los métodos y medios adecuados para obtener información pormenorizada al respecto. En este sentido, puede ser de utilidad el número de ejemplares vendidos o la realización de encuestas.

Finalmente, es importante señalar que el reparto de las cantidades recaudadas está limitado por la obligación de las entidades de gestión de dedicar, por partes iguales, un porcentaje de la compensación equitativa a la promoción de actividades o servicios de carácter asistencial en beneficio de sus miembros y a la realización de actividades de formación y promoción de autores y artistas, intérpretes y ejecutantes, según dispone el art. 155.2 en relación con el art. 155.1.a) y b) del TRLPI. 
Esta obligación no es exclusiva del ordenamiento jurídico español, sino que, por el contrario, está prevista con en otros muchos países ${ }^{1014}$. En su virtud, el legislador reserva un $20 \%$ de la remuneración compensatoria recaudada a estos fines asistenciales, de formación y promoción, según dispone el art. 39 del Real Decreto 1434/1992, de 27 de noviembre; precepto que también ha mantenido su vigencia, pese a las tantas modificaciones que ha experimentado el art. 25 del TRLPI, tras la aprobación de aquél ${ }^{1015}$.

Finalmente, debe señalarse que la STJUE (Sala Segunda), de 11 de julio de $2013^{1016}$, refrenda la posibilidad de destinar parte de las cantidades recaudadas a estos fines. El Tribunal, considerando que la DDASI no impone a los Estados miembros que han introducido en su Derecho nacional la excepción de copia privada la obligación de garantizar a los titulares de dicha compensación equitativa el abono de la totalidad de ésta en efectivo, no les impide establecer, dentro del amplio margen de apreciación del que gozan, que una parte de dicha compensación se perciba en forma de compensación indirecta.

\footnotetext{
1014 Vid. Anexo 4.

${ }^{1015}$ Vid. Capítulo 4, epígrafe II, apartados 1.3 y ss.

1016 Amazon.com International Sales Inc., Amazon EU Sàrl, Amazon.de GmbH, Amazon.com GmbH, in Liquidation y Amazon Logistik GmbH, y Mechana Gesellschaft zur Wahrnehmung mechanischmusikalischer Urheberrechte Gesellschaft mbH (Asunto C-521/11), ECLI:EU:C:2013:515, párrafos 46 a 55.
} 



\section{CAPÍTULO VI: LA COPIA PRIVADA Y LA COMPENSACIÓN POR COPIA PRIVADA EN AMÉRICA LATINA Y EL CARIBE}

I. INTRODUCCIÓN II. EL MARCO LEGAL DE LA PROPIEDAD INTELECTUAL EN AMÉRICA LATINA Y EL CARIBE. 1. El origen de las leyes de propiedad intelectual en los países de la región. 2. Primeros pasos en la implementación de la protección internacional. 3. El marco regulatorio actual de los derechos de autor en el contexto latinoamericano y caribeño. III. PANORAMA GENERAL DE LAS EXCEPCIONES Y LIMITACIONES A LOS DERECHOS DE AUTOR EN AMÉRICA LATINA Y EL CARIBE. IV. LA COPIA PRIVADA. V. LA COMPENSACIÓN POR COPIA PRIVADA. 1. Introducción. 2. Examen comparativo de las legislaciones. VI. BREVE EXAMEN DE LA SITUACIÓN ACTUAL DE ALGUNOS PAÍSES EN LOS QUE NO ESTÁ AUTORIZADA LA COPIA PRIVADA. 1. Argentina. 2. Chile. 3. Uruguay. VII. CUBA. LA PROTECCIÓN DEL DERECHO DE AUTOR Y SU SUBORDINACIÓN A LOS INTERESES SOCIALES Y CULTURALES 



\section{INTRODUCCIÓN}

El presente capítulo analiza el régimen legal de la copia privada y la compensación por copia privada de América Latina y el Caribe, especialmente de algunas de las legislaciones de los principales países de la región. Se han tenido en cuenta, en particular, las leyes sobre derechos de autor y derechos conexos o afines a los derechos de autor, así como otras normas reglamentarias de diecinueve países de la región: Argentina, Bolivia, Brasil, Chile, Colombia, Costa Rica, Cuba, Ecuador, El Salvador, Guatemala, Honduras, México, Nicaragua, Panamá, Paraguay, Perú, República Dominicana, Uruguay y Venezuela, lo que permite obtener una panorámica general sobre el estado de la regulación de esta limitación al derecho de autor en dicho ámbito. No obstante, cabe precisar que los comentarios que aquí se vierten se centran, fundamentalmente, en las disposiciones de aquellos países que contemplan la copia privada como límite al derecho de autor, así como de aquellos que establecen una compensación asociada a dicho límite.

Previa referencia al marco normativo nacional e internacional que regula los derechos de autor en este contexto, por un lado, y de algunos comentarios generales sobre las excepciones a los derechos de propiedad intelectual, por otro, se hace un examen de las disposiciones específicas que instrumentan la regulación de la copia privada en los países seleccionados. De esta forma, se contrastan estas regulaciones identificando sus puntos comunes y divergentes y, a su vez, diferenciándolas de la legislación española. Por último, se analiza el grado de implicación de los países latinoamericanos y caribeños en el establecimiento de sistemas compensatorios frente a la excepción de copia privada, así como, en su caso, el modelo adoptado para satisfacer dicha obligación.

\section{MARCO LEGAL DE LA PROPIEDAD INTELECTUAL EN AMÉRICA LATINA Y EL CARIBE}

\section{El origen de las leyes de propiedad intelectual en los países de la región}

La historia legislativa en materia de derechos de autor y derechos afines a los derechos de autor en América Latina y el Caribe es relativamente reciente si se compara con la amplia tradición jurídica en materia de Propiedad Intelectual existente en el 
continente europeo. En efecto, las primeras regulaciones en dar cobertura legal a los derechos de propiedad intelectual en los países de la región se sitúan en la primera mitad del siglo XIX. En este período se enmarcan la ley colombiana de 10 de mayo y la ley chilena de 24 de julio, ambas de 1834; la ley venezolana de 19 de abril de 1839; y la ley peruana de 3 de noviembre de $1849^{1017}$. También el Decreto sobre Propiedad Literaria de México de 1846, aunque éste, a diferencia de las anteriores normas, no provenía del poder legislativo sino del ejecutivo ${ }^{1018}$. Todas estas leyes fueron el desarrollo del reconocimiento de los derechos de autor que, de forma más o menos expresa, contenían entonces los textos constitucionales latinoamericanos y que conferían cierta protección a los creadores ${ }^{1019}$.

La protección a los derechos de autor también encontró respaldo en los Códigos Civiles promulgados en la segunda mitad del siglo XIX y principios del XX en esta área geográfica. Así, por ejemplo, los Códigos Civiles de Argentina (1869), de México (1871), de Nicaragua (1904) y de Brasil (1916) contenían disposiciones relativas a los derechos de propiedad intelectual ${ }^{1020}$, al igual que el Código Civil de Chile (1855), obra de Andrés Bello ${ }^{1021}$, aun en vigor, y que sirvió de inspiración a los códigos civiles de los

1017 Vid. CERDA SILVA, A. J., "Evolución histórica del Derecho de Autor en América Latina”, Revista Ius et Praxis, año 22, núm. 1, 2016, p. 25; PAVÓN CADAVID, J. A., "Aproximación a la historia del derecho de autor: antecedentes normativos", La propiedad inmaterial, Revista del Departamento de la Propiedad Intelectual de la Universidad Externado de Colombia, núm. 13, 2009, pp. 83, 85 y 88.

1018 PAVÓN CADAVID, J. A., “Aproximación a la historia del derecho de autor...”, op. cit.

1019 Vid. CERDA SILVA, A. J., "Evolución histórica del Derecho de Autor...”, op. cit., pp. 23-25.

${ }^{1020}$ HARVEY, E. R., "Derecho de autor y derecho a la cultura en los países iberoamericanos", I Congreso Iberoamericano de Derecho de la Cultura, Madrid, 29 de noviembre - 2 de diciembre, 1999, p. 6, disponible en: https://cdn.educ.ar/repositorio/Download/file?file id=a2ed19e1-7a09-11e1-8123ed15e3c494af (consultado: 19.07.2017); AugsburGER, A. E., "La Convención Universal sobre Derecho de Autor en el ámbito de los países de América Latina y el Caribe", Boletín de Derecho de Autor, Vol. XXI, núm. 3, UNESCO, 1987, p. 9.

${ }^{1021}$ Sobre la historia del Código Civil de Chile, sus reformas e importancia, vid. GuZMÁn BRITO, A., "El Código Civil de Chile en sus ciento cincuenta años y crónica de un congreso internacional de conmemoración celebrado en Santiago de Chile", en Anuario de Derecho Civil (B.O.E.), 2006, pp. 12831301, disponible en: https://www.boe.es/publicaciones/anuarios derecho/abrir_pdf.php?id=ANU-C2006-

30128301302_ANUARIO_DE_DERECHO_CIVIL_El_C\%F3digo_Civil_de_Chile_en_su_ciento_cincu enta_a\%F1os_y_cr\%F3nica_de un_congreso_internacional_de conmemoraci\%F3n_celebrado_en_Santi ago_de_Chile (consultado 19.07/2017). 
países del área ${ }^{1022}$. Igualmente, existían normas sobre la materia en otras regulaciones como el Código Administrativo de Panamá, aprobado por la Ley 1 de 22 de agosto de 1916 o la Ley de Patentes de Inversión de Honduras, aprobada por el Decreto Presidencial 123 de 15 de abril de $1919^{1023}$.

Así pues, hacia finales del siglo XIX, existía ya un amplio catálogo de leyes especiales que otorgaban protección al autor sobre su obra, conformado por las legislaciones de Chile, Colombia, Venezuela, Perú, Guatemala, Ecuador, Costa Rica, entre otras. A Cuba y a Puerto Rico, por otra parte, les resultaba aplicable la Ley de Propiedad Intelectual española, de 10 de enero de $1879^{1024}$. El número de normas se fue ampliando con otras disposiciones relativas a la propiedad intelectual dictadas a principios del siglo XX. Es el caso, entre otros países latinoamericanos, de El Salvador (1900) o Argentina (1910). Con todo, también se llevó a cabo la actualización de algunos de los textos legales vigentes de fechas anteriores ${ }^{1025}$.

Es decir, los países de América Latina y el Caribe cuentan con más de un siglo de tradición en la protección de la propiedad intelectual y, a día de hoy, poseen regulaciones que son fruto del desarrollo legislativo y de la adaptación de sus normas a los compromisos internacionales y a las exigencias de los avances tecnológicos, aunque en menor medida que Europa, donde los países cuentan con una mayor tradición jurídica al respecto.

\section{Primeros pasos en la implementación de la protección internacional}

La protección bilateral y multilateral de los derechos de autor en el siglo XIX también tuvo influencia en la región de Latinoamérica y el Caribe. En efecto, la

${ }^{1022}$ El Código Civil de Chile reconocía expresamente que: "las producciones del talento o del ingenio son una propiedad de sus autores". Asimismo, reservaba la regulación de esta propiedad autoral a las leyes especiales (art. 584).

${ }^{1023}$ HARVEY, E. R., "Derecho de autor y derecho a la cultura...”, op. cit., p. 6.

${ }^{1024}$ B.O.E. núm. 12, de 12 de enero de 1879. Su art. 56 refrendaba: "Esta ley regirá en las islas de Cuba y Puerto Rico a los tres meses de su promulgación en Madrid, y a los seis meses, contados desde la misma promulgación, en el Archipiélago Filipino".

1025 Vid. HARVEY, E. R., "Derecho de autor y derecho a la cultura...”, op. cit. pp. 6-7. 
abolición de los privilegios en Europa y la flexibilidad de la imprenta para impulsar el mercado editorial dio paso a la necesidad de otorgar una protección adecuada a los autores y editores fuera de las fronteras nacionales. Así pues, hacia la segunda mitad del siglo XIX, algunas leyes nacionales europeas comenzaron a dar cobertura jurídica a las obras extranjeras (tal fue el caso de la ley francesa, belga, alemana, sueca, entre otras), propiciándose la concertación de acuerdos bilaterales de propiedad literaria entre algunos Estados ${ }^{1026}$. España y Francia, por ejemplo, concertaron un Tratado para la protección de las obras literarias, en 1853, que intentaba controlar el mercado de ediciones piratas, de gran auge en Francia, donde se imprimían numerosas obras literarias de autores hispanos sin autorización, con destino al mercado latinoamericano $^{1027}$.

Esta necesidad de salvaguarda internacional de los derechos de propiedad intelectual también tuvo eco en el continente americano. Así, en la década de los ochenta del siglo XIX se suscribieron acuerdos bilaterales entre algunos países latinoamericanos y europeos. España, por ejemplo, firmó acuerdos con El Salvador (1884) y Colombia $(1855)^{1028}$. Asimismo, sólo tres años después de la firma del Convenio de Berna para la Protección de las Obras Literarias y Artísticas, de 9 de septiembre de 1886 (en adelante, CB), se celebró en Montevideo el Primer Congreso Sudamericano de Derecho Internacional Privado, en cuyo marco se adoptó el Tratado sobre Propiedad Literaria y Artística, de 1 de noviembre de 1889, firmado por Argentina, Bolivia, Paraguay, Perú, Uruguay, Brasil y Chile, que fue ratificado por

${ }^{1026}$ PAVÓN CADAVID, J. A., “Aproximación a la historia del derecho de autor...”, op. cit.

1027 Ídem.

${ }^{1028}$ HARVEY, E. R., "Derecho de autor y derecho a la cultura...", op. cit., p. 10; OMPI, Obligaciones internacionales en materia de propiedad intelectual: espacios para diseños de políticas nacionales [OMPI/JPI/BUE/06/5], documento preparado por el Sr. Juan José Marín López, Reunión Regional de Directores de Oficinas de Propiedad Industrial y de Oficinas de Derecho de Autor de América Latina, Buenos Aires, 30 de mayo - 2 de junio de 2006, p. 6. 
todos, a excepción de los dos últimos ${ }^{1029}$. Al mismo se adherirían países como Alemania Oriental, Austria, Bélgica, España, Francia, Hungría e Italia ${ }^{1030}$.

Por otra parte, las Conferencias Internacionales Americanas (conocidas como Conferencias Panamericanas ${ }^{1031}$ ) que se celebraron de forma periódica entre los años 1889 y $1948^{1032}$ en diferentes Estados americanos, contribuyeron al desarrollo de una normativa más uniforme para la protección de los derechos de propiedad intelectual en la región. Al efecto, fueron especialmente relevantes la segunda de estas Conferencias (México, 1901-1902), en la que se adoptó la Convención para la protección de las obras literarias y artísticas; la tercera (Río de Janeiro, 1906), en la que los países representados adoptaron los Tratados suscritos en la Segunda Conferencia Internacional Americana de México sobre patentes de invención, dibujos y modelos industriales, marcas de fábrica y comercio, y propiedad literaria y artística, con algunas modificaciones; la cuarta (Buenos Aires, 1910), que dio lugar a una nueva Convención sobre Propiedad Literaria y Artística; así como la sexta (La Habana, 1928), que revisó la citada Convención de 1910.

A su vez -sin ánimo de exhaustividad- son reseñables los esfuerzos e interés mostrados por algunos países centroamericanos y sudamericanos por la protección de los derechos de autor más allá de las aludidas Conferencias Internacionales Americanas. Como expresión de lo anterior, es importante mencionar la Conferencia

1029 El listado de países signatarios y fechas de adhesión y ratificación está disponible en: http://www.oas.org/juridico/spanish/firmas/f-5.html (consultado: 21.07.2017).

${ }^{1030}$ El Tratado sobre Propiedad Literaria y Artística de Montevideo, de 1889, fue sustituido por el Tratado sobre Propiedad Intelectual, adoptado el 4 de agosto de 1939, durante la celebración del Segundo Congreso Sudamericano de Derecho Internacional Privado de Montevideo (1939-1940), suscrito por Argentina, Bolivia, Paraguay, Perú, Uruguay y ratificado únicamente por Paraguay y Uruguay, Vid. FERNÁNDEZ SHAW, F., "Derecho de autor y derechos conexos en la radiodifusión española", Anuario de Derecho Civil, 1975, p. 355.

1031 Así se les conoce popularmente a estas Conferencias, desde que se empleara el vocablo "Panamericano" en la primera, celebrada en Washington de 1889-1990. Vid. MANGER, W., El Panamericanismo y las Conferencias Panamericanas, Serie sobre Congresos y Conferencias núm. 22, Unión de Repúblicas Americanas, 1930, p. 7, disponible en: https://www.bcn.cl/estanteriadigital/resultados?terminos=El+Panamericanismo+y+las+conferencias + Pan americanas (consultado: 21.07.2017).

1032 Con posterioridad a la IX Conferencia Internacional Americana, celebrada en Bogotá en 1948, estas Conferencias pasaron a denominarse Conferencias Interamericanas, pese a lo cual mantuvieron la numeración correlativa. 
Centroamericana de Paz (Washington, 1907), en la que participaron Guatemala, El Salvador, Honduras, Nicaragua y Costa Rica, así como el Congreso Bolivariano (Caracas, 1911), celebrado por Bolivia, Colombia, Ecuador, Perú y Venezuela ${ }^{1033}$. En el marco de la mencionada Conferencia se celebró la Convención para el establecimiento de una Oficina Internacional Centroamericana con el fin de fomentar los intereses comunes de la zona, entre ellos, la uniformidad de la legislación civil, reconociendo el respeto a la propiedad y la consagración más absoluta de los derechos de la personalidad humana (art. 1.5). El Congreso Bolivariano, por su parte, dio origen al Acuerdo sobre Propiedad Literaria y Artística, de 17 de julio de 1911, por el cual los Estados intervinientes se comprometían a reconocer y proteger los derechos de propiedad literaria y artística de los ciudadanos de los cinco países firmantes (art. 1).

Asimismo, esta vez fuera de las anteriores iniciativas legislativas centro y sudamericanas adoptadas en las Conferencias Panamericanas, fue aprobada en Washington, el 22 de junio de 1946, la Convención Interamericana sobre el Derecho de Autor en Obras Literarias, Científicas y Artísticas ${ }^{1034}$, como resultado de la Conferencia Interamericana de Expertos para la protección de los derechos de autor celebrada en esa ciudad. Esta Convención contó con la firma de veintiún Estados ${ }^{1035}$, y tenían por objetivos comunes, según se desprende del preámbulo, "perfeccionar la protección recíproca interamericana del derecho de autor en obras literarias, científicas y artísticas" y "fomentar y facilitar el intercambio cultural interamericano".

La Convención de Washington, como se le conoce, reemplazó entre los Estados contratantes a la Convención sobre Propiedad Literaria y Artística suscrita en Buenos Aires, el 11 de agosto de 1910 y su Revisión, efectuada en La Habana, el 18 de febrero de 1928, así como a todas las convenciones interamericanas suscritas con anterioridad

\footnotetext{
${ }^{1033}$ FERNÁNDEZ SHAW, F., "Derecho de autor y derechos conexos...”, op. cit., p. 356.

${ }^{1034}$ Disponible en: http://www.wipo.int/wipolex/es/other_treaties/details.jsp?group_id=21\&treaty_id=378 (consultada: 21.07/2017).

${ }^{1035}$ Nicaragua, Ecuador, República Dominicana, Guatemala, México, Venezuela, Perú, Haití, Panamá, Colombia, Chile, Brasil, Costa Rica, Honduras, Argentina, Estados Unidos de América, Uruguay, Paraguay, El Salvador, Cuba y Bolivia. De los veintiún Estados contratantes, la ratificaron dieciséis (todos a excepción de El Salvador, Estados Unidos, Perú, Uruguay y Venezuela. Vid. http://www.oas.org/juridico/spanish/firmas/b-28.html (consultado: 21.07.2017).
} 
sobre la materia, sin afectar, eso sí, a los derechos adquiridos de acuerdo con las mismas (art. XVII). Dicha Convención fue muy significativa porque no sólo reconoció derechos patrimoniales a los autores, sino también porque veló por el respeto de ciertos derechos morales, como el derecho de integridad [art. II (f)], divulgación (art. IV) y paternidad (art. XI). Además, reconoció la protección respecto a un gran conjunto de obras, tanto literarias, como dramático-musicales, coreográficas y pantomímicas, musicales, de las artes plásticas, etc.; en definitiva, a "toda producción literaria, científica o artística apta para ser publicada y reproducida" (art. III). Se trató de una regulación caracterizada por la flexibilidad. En efecto, la protección del derecho de autor se determinaba de acuerdo con lo dispuesto por la ley del Estado contratante en el que se hubiera obtenido originariamente la protección, pero sin que excediera el plazo fijado por la ley del Estado contratante en el que se reclamara la misma (art. VIII). Además, obtenido el derecho de autor en un Estado contratante, los demás Estados debían otorgar protección sin necesidad de registro, depósito u otra formalidad (art. IX).

Con todo, esta Convención supuso la consolidación del sistema de derechos de autor interamericano ${ }^{1036}$, cuyos países no se habían inscrito hasta la fecha en el sistema jurídico de la Unión de Berna, a excepción de Brasil, que se había adherido al Convenio de Berna el 6 de febrero de $1922^{1037}$. De hecho, la mayoría de los Estados latinoamericanos firmaron la Convención ${ }^{1038}$.

En el desarrollo legislativo del Derecho de Autor ${ }^{1039}$ en América Latina, fue muy importante, también, la Convención Universal sobre Derecho de Autor, adoptada el 6 de

\footnotetext{
1036 Cerda Silva, A. J., “Evolución histórica del Derecho de Autor...”, op. cit., p. 33. 1037 Vid. Información $\quad$ suministrada $\quad$ por la http://www.wipo.int/treaties/es/remarks.jsp?cnty_id=922C (consultado: 22.07.2017).

${ }^{1038}$ Fue firmada por veintiún Estados, de los cuales dieciséis la ratificaron, a excepción de El Salvador, Estados Unidos de América, Perú, Uruguay y Venezuela. Información suministrada por la OMPI, disponible en: http://www.wipo.int/wipolex/es/other_treaties/parties.jsp?treaty_id=378\&group_id=21 (consultada: 22.07.2017).

${ }^{1039}$ El término "Derecho de Autor" ha ido sustituyendo al término tradicional de "Propiedad Intelectual" en el contexto latinoamericano, siendo la expresión utilizada con carácter general para referirse a esta materia por las legislaciones y la doctrina latinoamericanas.
} 
septiembre de 1952 en Ginebra y posteriormente revisada en París en $1971^{1040}$. Ésta fue una iniciativa impulsada por la Organización de las Naciones Unidas para la Educación, la Ciencia y la Cultura (UNESCO), con el objetivo de establecer un nivel de protección inferior al establecido en la Convención de Berna, pero buscando que fuera también un estándar de protección aceptable por aquellos países que no pudieran alcanzar la protección exigida por dicho Convenio. De esta forma, se aseguraba una protección universal de los derechos de autor, superando la fragmentación provocada por los diferentes niveles de protección que ofrecían los instrumentos multilaterales suscritos por los países americanos en relación con los niveles de protección alcanzados por los países europeos mediante el $\mathrm{CB}^{1041}$. Así pues, se acordó un nivel de protección más bajo que el establecido en ésta, pero sin afectar el nivel de protección alcanzado por los Estados que ya eran parte o que se adhirieran al $\mathrm{CB}$, puesto que la Convención Universal expresamente dispone: "La presente Convención no afectará en nada a las disposiciones de la convención de Berna para la protección de las obras literarias y artísticas, ni al hecho de pertenecer a la Unión creada por esta Convención" (art. XVII.I). En efecto, su Declaración Anexa, en la su letra b) precisa: "La Convención Universal sobre Derecho de Autor no será aplicable en las relaciones entre los Estados ligados por la Convención de Berna, en lo que se refiera a la protección de las obras que, de acuerdo con esta Convención de Berna, tengan como país de origen uno de los países de la Unión Internacional creada por dicha Convención”, lo que explica que, a día de hoy, la Convención haya perdido virtualidad, puesto que actualmente los países miembros de ésta lo son también del $\mathrm{CB}$, aplicándose este último.

1040 Los datos bibliográficos y el texto de la Convención están disponibles en: http://www.wipo.int/wipolex/es/other_treaties/text.jsp?file_id=172838 (consultada: 24.07.2017).

${ }^{1041}$ LEWINSKI, S., "El papel de la Convención Universal sobre Derecho de Autor y su futuro", e.Boletín de derecho de autor, UNESCO, octubre-diciembre 2006, p. 1, disponible en: http://unesdoc.unesco.org/images/0015/001578/157846s.pdf (consultado: 14.05.2017); y BERCOVITZ RoDRíGUEZ-CANO, R. et al., Manual de Propiedad..., op. cit., p. 36. 


\section{El marco regulatorio actual de los derechos de autor en el contexto latinoamericano y caribeño}

La mayoría de las leyes sobre propiedad intelectual vigentes en América Latina y en el Caribe provienen de la década de los años noventa ${ }^{1042}$. Es el caso de la ley de Bolivia, que data de 1992; las leyes de El Salvador y Venezuela, que son de 1993; las de México y Perú, de 1996; las de Brasil, Ecuador, Guatemala y Paraguay, de 1998 y las de Honduras y Nicaragua, ambas de 1999. En otros casos, continúan vigentes (con modificaciones) normas de mayor antigüedad, como la Ley chilena $\mathrm{N}^{\circ} .17 .336$, de 28 de agosto de 1970 sobre la Propiedad Intelectual; la Ley cubana No. 14, de 28 de diciembre de 1977 de Derecho de Autor; la Ley colombiana $N^{\circ}$. 23, de 28 de enero de 1982 sobre Derechos de Autor; la Ley costarricense $N^{\circ}$. 6683, de 14 de octubre de 1982 sobre el Derecho de Autor y Derechos Conexos; y, especialmente, la Ley argentina $\mathrm{N}^{\circ}$. 11.723, de 28 de septiembre de 1933 sobre el Régimen Legal de la Propiedad Intelectual, así como la Ley uruguaya $N^{\circ}$. 9.739, de 17 de diciembre de 1937 sobre Derechos de Autor. Finalmente, los textos legislativos en vigor en República Dominicana (Ley Nº. 65-00 de Derecho de Autor, de 26 de julio de 2000) y Panamá (Ley N. ${ }^{\circ}$ 64, de 10 de octubre de 2012 sobre el Derecho de Autor y Derechos Conexos) son de fechas más recientes, sin perjuicio de que con anterioridad hayan existido otras regulaciones sobre la materia ${ }^{1043}$.

De la valoración conjunta de las leyes de propiedad intelectual de los países latinoamericanos puede destacarse su modernidad -en el sentido de que son normas relativamente recientes-, su adecuada sistemática y su correcta técnica legislativa. Así lo pone de manifiesto el Documento de la Reunión Regional de Directores de Oficinas de Propiedad Industrial y de Oficinas de Derecho de Autor de América Latina, que fue organizada por la OMPI en cooperación con el Instituto Nacional de la Propiedad Industrial (INPI) y la Dirección Nacional de Derecho de Autor del Ministerio de Justicia y Derechos Humanos de Argentina, celebrada en la ciudad de Buenos Aires, del 30 de

\footnotetext{
${ }^{1042}$ Ello no significa que permanezcan en su redacción inicial. Por el contrario, en su mayoría han sido modificadas por leyes posteriores con el fin de adaptarlas al entorno digital y a los compromisos bilaterales e internacionales adoptados por estos países.

${ }^{1043} \mathrm{Vid}$. Anexo 5, que contiene una tabla resumen sobre las leyes de propiedad intelectual vigentes en los países de América Latina y el Caribe estudiados y sus respectivas modificaciones, en su caso.
} 
mayo al 2 de junio de $2006^{1044}$. Siguiendo el mismo, estas leyes deben su modernidad, fundamentalmente, a dos factores. En primer lugar, a la "muy visible influencia de la legislación española en la materia, concretamente de la Ley 22/1987, de 11 de noviembre, de Propiedad Intelectual"; y, en segundo lugar, a "la necesidad de adaptar la legislación nacional a los compromisos internacionales derivados de la adhesión a los Tratados y Convenios en materia de derecho de autor y derechos conexos" ${ }^{1045}$. En efecto, debe destacarse que la mayoría de países de América Latina y el Caribe han firmado o ratificado, según los casos, los principales instrumentos internacionales en la materia. Así pues, un gran número de Estados forma parte del Convenio de Berna y de la Convención de Roma, del Convenio de Ginebra para la protección de los productores de fonogramas contra la reproducción no autorizada de sus fonogramas ${ }^{1046}$, del Convenio de Bruselas sobre la distribución de señales portadoras de programas transmitidas por satélite ${ }^{1047}$, de los denominados Tratados de la OMPI (TODA y TOIEF), así como del Acuerdo sobre los ADPIC ${ }^{1048}$. Algunos son también firmantes del Tratado de Marrakech para facilitar el acceso a las obras publicadas a las personas ciegas, con discapacidad visual o con otras dificultades para acceder al texto impreso (2013), el cual, pese a su juventud, tiene como Estados Parte a Argentina, Brasil, Chile, Ecuador, El Salvador, Guatemala, Honduras, México, Paraguay, Perú y Uruguay, desde el 30 de septiembre de 2016; a Honduras, desde el 29 de junio de 2017; y a Panamá, desde el 10 de mayo de 2017. Asimismo, Colombia, Costa Rica, El Salvador, Guatemala, Honduras, México, Nicaragua y Perú, entre otros, han suscrito el Tratado de Beijing sobre Interpretaciones y Ejecuciones Audiovisuales (2012), aunque sólo lo han ratificado, hasta la fecha, Chile y El Salvador ${ }^{1049}$.

${ }^{1044}$ OMPI, Obligaciones internacionales en materia de propiedad intelectual: espacios para diseños..., cit., p. 12.

1045 Ibídem, p. 13.

1046 Adoptado en Ginebra, el 29 de octubre de 1971. Texto del Convenio disponible en: http://www.wipo.int/wipolex/es/treaties/text.jsp?file_id=288581 (consultado: 25.07.2017).

1047 Adoptado en Bruselas el 21 de mayo de 1974. Texto del Tratado disponible en: http://www.wipo.int/wipolex/es/treaties/text.jsp?file_id=283793 (consultado (25.07/2017).

1048 Vid. Anexo 6.

1049 El Tratado de Beijing sobre Interpretaciones y Ejecuciones Audiovisuales, adoptado el 24 de junio de

2012, no está aún en vigor. Pueden consultarse las Partes contratantes en: http://www.wipo.int/export/sites/www/treaties/en/documents/pdf/beijing.pdf (consultado: 25.07.2017). 
Todo ello ha conducido a la protección jurídica de los derechos de propiedad intelectual en la región. Sin embargo, hay que mencionar que dicha protección, especialmente a partir de finales de los años ochenta del siglo XX, con la adhesión de un gran número de países latinoamericanos al Convenio de Berna, ha sido también fruto de las presiones externas de Estados Unidos de América (EEUU). Como se reconoce doctrinalmente $^{1050}$, una vez que los EEUU pasaron a ser miembros del Convenio de Berna (1 de marzo de 1989), se incorporaron sus estándares de protección a las relaciones comerciales que involucraban derechos de propiedad intelectual, lo que ha influido de manera notable en la adopción de mayores compromisos para los países latinoamericanos, que han tenido que aceptar dichos estándares para gozar de preferencias arancelarias y buenos tratos comerciales. Recuérdese, además, que fueron los EEUU los que introdujeron la propiedad intelectual en las negociaciones de la Ronda de Uruguay ${ }^{1051}$, dando lugar a la adopción del Acuerdo sobre los ADPIC e influyendo decisivamente en el desplazamiento del debate sobre la protección y observancia de los derechos de propiedad intelectual desde las instituciones habituales como la OMPI en el marco de la OMC. Sin embargo, la tendencia a enfocar la defensa de la propiedad intelectual en el contexto del Derecho del comercio internacional puede ubicarse también años antes, hacia finales de la década de 1960-1970 ${ }^{1052}$.

En el plano subregional también es preciso tener en consideración otro tipo de acuerdos internacionales, algunos de ellos multilaterales y otros bilaterales, que igualmente se refieren específicamente a la propiedad intelectual.

Por un lado, están los Tratados de Libre Comercio (TLC) suscritos fundamentalmente por los países latinoamericanos con los EEUU, aunque también con Canadá y otros países. Entre ellos, pueden destacarse el Tratado de Libre Comercio de

${ }^{1050}$ Por todos, LIPSZYC, D., Nuevos temas de derecho de autor y derechos conexos, UNESCO, 2004, p. 19 y 21; CeRDa SiLVA, A. J., "Evolución histórica del Derecho de Autor...", op. cit., p. 43.

${ }^{1051}$ La Ronda de Uruguay fue la octava y última de las Rondas de negociaciones comerciales del GATT (acrónimo en inglés de General Agreement on Tariffs and Trade), donde, además de las cuestiones inherentes al mismo (aranceles, solución de diferencias, etc.) se incorporó, entre otros temas, el de los derechos de propiedad intelectual. Vid. LIPSZYC, D., Nuevos temas de derecho de autor..., op. cit., pp. $27-28$.

${ }^{1052}$ Ibídem, p. 19. 
América del Norte (TLCAN) -también conocido como NAFTA por su acrónimo en inglés- celebrado entre México, Estados Unidos y Canadá en 1993; y los respectivos Tratados suscritos por Estados Unidos conjuntamente con Chile (2003), Centro América y República Dominicana (2004), Perú (2006), Colombia (2006) y Panamá (2007) ${ }^{1053}$.

Estos Tratados han conseguido establecer una mayor protección a los derechos de propiedad intelectual. De hecho, conforme a las exigencias estadounidenses, se han establecido los estándares de protección a niveles muy elevados, más allá de los acordados en otros foros internacionales, como la Unión de Berna o la OMC. Ello, paradójicamente, representa un peligro para estos países en vías de desarrollo, por varios motivos. Así, por ejemplo, la común exigencia de estos acuerdos de elevar el plazo de protección de los derechos de autor limita la entrada más rápida de las obras en el dominio público, lo cual es especialmente importante para la libre utilización de las obras literarias, artísticas y científicas por parte de los países en vías de desarrollo; la reivindicación de proteger las obras mediante la implementación de medidas tecnológicas supone el encarecimiento de ciertos contenidos culturales y el riesgo de restringir el uso legal y legítimo de las obras y prestaciones intelectuales al amparo de una excepción o limitación al derecho de autor; o el establecimiento de regímenes diversos de responsabilidad de los prestadores de servicios en línea puede afectar el adecuado funcionamiento del mercado interior de la región en busca de costos menos elevados para la prestación de estos servicios; entre otras consecuencias ${ }^{1054}$. En definitiva, los derechos de autor tienen que aspirar a niveles de protección elevados, pero sin descuidar el papel social que cumplen las creaciones intelectuales en el desarrollo social y cultural de los pueblos y, en especial, de los pueblos menos desarrollados económicamente.

1053 Vid. ZAPATA LÓPEZ, F., "Realidad institucional del Derecho de Autor en América Latina", en FernÁndez Ballesteros, C. A. (Coord.), Diagnóstico del Derecho de Autor en América Latina, Cerlac, Bogotá, 2007, p. 28. Véase también http://www.sice.oas.org/ctyindex/USA/USAagreements_s.asp (consultada: 25.07.2017), para más detalles sobre los acuerdos comerciales en vigor suscritos por los Estados Unidos de América.

${ }^{1054}$ Para un análisis específico de los efectos sobre Perú y Colombia de los TLC acordados por Estados Unidos con estos países, en especial en relación con las medidas tecnológicas de protección y el régimen de responsabilidad de los prestadores de servicios en línea vid. CERDA Silva, A. J., "Armonización de los derechos de autor en la Comunidad Andina: Hacia un nuevo régimen común”, Revista Ius et Praxis, año 17, núm. 2, 2011, pp. 264-269. 
Por otro lado, la Comisión del Acuerdo de Cartagena ${ }^{1055}$ aprobó la Decisión № 351, de 17 de diciembre de 1993 (en adelante la Decisión) ${ }^{1056}$, con la finalidad de reconocer una adecuada y efectiva protección a los autores sobre las obras literarias, artísticas y científicas, así como a los titulares de los derechos conexos, conforme a lo establecido en el Capítulo X de la Decisión, esto es, los derechos reconocidos a los artistas intérpretes o ejecutantes, los productores de fonogramas y los organismos de radiodifusión $^{1057}$.

Esta Decisión, que actualmente vincula a Bolivia, Colombia, Ecuador y Perú, constituye para estos Estados un instrumento jurídico multilateral de regulación de los derechos de propiedad intelectual. Sin embargo, la exigencia por la Decisión de unos niveles de protección mínimos ha hecho que haya perdido relevancia como instrumento para el establecimiento de unos estándares comunes de protección de los derechos de propiedad intelectual entre sus miembros. Por el contrario, han seguido existiendo desigualdades importantes en cuanto al alcance de la protección de estos derechos intelectuales, respecto de las excepciones y limitaciones a los mismos, su observancia y plazos de protección ${ }^{1058}$.

\footnotetext{
${ }^{1055}$ El Acuerdo de Cartagena es el instrumento que origina la integración de Bolivia, Chile, Colombia, Ecuador, Perú en lo que se conoce como Pacto Andino; ahora, Comunidad Andina. Venezuela se adhirió posteriormente, en el año 1973, pero abandonó la Comunidad en 2006. Chile, también abandonó la Comunidad, en 1976. Vid. CERDA SiLVA, A. J., "Armonización de los derechos de autor en la Comunidad Andina...", op. cit., pp. 232-233.

1056 Texto disponible en: http://www.wipo.int/wipolex/es/text.jsp?file_id=223497 (consultado: 25.07.2017).

${ }^{1057}$ Así lo expresa el art. 1 de la Decisión No . 351 cuando establece: "Las disposiciones de la presente Decisión tienen por finalidad reconocer una adecuada y efectiva protección a los autores y demás titulares de derechos, sobre las obras del ingenio, en el campo literario, artístico o científico, cualquiera que sea el género o forma de expresión y sin importar el mérito literario o artístico ni su destino. Asimismo, se protegen los Derechos Conexos a que hace referencia el Capítulo X de la presente Decisión".

1058 Al respecto, Cerda Silva, A. J., "Armonización de los derechos de autor en la Comunidad Andina...”, op. cit., pp. 269 y ss., explica cómo estos factores son esenciales para la convergencia de las regulaciones sobre propiedad intelectual en los países que integran la Comunidad Andina y cómo deben ser tenidos en consideración de lege ferenda.
} 


\section{PANORAMA GENERAL DE LAS EXCEPCIONES Y LIMITACIONES A LOS DERECHOS DE AUTOR EN AMÉRICA LATINA Y EL CARIBE}

Las Convenciones adoptadas por los países de América Latina y el Caribe, desde finales del siglo XIX, ya contemplaban ciertos límites a los derechos exclusivos del autor. Tal es el caso del art. 7 del Tratado sobre Propiedad Literaria y Artística o Tratado de Montevideo (1889), que estableció la posibilidad de que los artículos de periódicos pudieran reproducirse, citando su fuente, a excepción de aquellos que versasen sobre ciencias y artes y cuya reproducción se hubiera prohibido expresamente por sus autores. Por su parte, el art. 8 incluyó una limitación referente al uso de los discursos pronunciados o leídos en las asambleas deliberantes ante los tribunales de justicia o en las reuniones públicas, al prever que podían publicarse en la prensa periódica sin necesidad de autorización alguna.

También algunas de las normas contenidas en el texto de la Convención de México (1902) contenían limitaciones a los derechos de autor. En efecto, esta Convención, en línea con lo establecido en el Tratado de Montevideo (1889), reconoció la posibilidad de reproducir artículos de periódicos, siempre que se citara su fuente y, en adición, el nombre del autor, en caso de que apareciese en ésta (art. 8). Asimismo, permitió la publicación en la prensa periódica de los discursos pronunciados o leídos en las mismas circunstancias que contenía el mencionado art. 8 del Tratado de Montevideo (art. 10); y la reproducción de fragmentos de obras literarias o artísticas en publicaciones destinadas a la enseñanza o para crestomatías (art. 11).

Del mismo modo, la Convención de Washington (1946) permitió la reproducción por la prensa de los artículos de actualidad publicados en periódicos y revistas, a menos que la reproducción quedara prohibida mediante una reserva especial o general en aquéllos, aunque debía citarse, en todo caso, de manera inconfundible, la fuente de donde se hubieran tomado (art. VI.2). Estableció, además, que la protección brindada por la Convención no era aplicable al contenido informativo de las noticias del día publicadas en la prensa (art. VI.3) y autorizó la reproducción de breves fragmentes de obras literarias, científicas y artísticas en publicaciones con fines didácticos $o$ científicos, en crestomatías, o con fines de crítica literaria o de investigación científica, siempre que se indicara de manera inconfundible la fuente de donde se hubieran tomado 
y siempre que los textos no fueran alterados (art. XII.1). Para los mismos efectos y con iguales restricciones, consintió la publicación de breves fragmentes en traducciones (art. XII.2).

Más recientemente, la firma o adhesión de los países de la región a los instrumentos internacionales fundamentales que regulan actualmente los derechos de propiedad intelectual -dígase $\mathrm{CB}, \mathrm{CR}$, Acuerdo sobre los ADPIC, TOAD y TOIEF, entre otros- les ha supuesto la obligación de cumplir con los estándares establecidos en los mismos, lo que incluye las normas que reglamentan las excepciones y limitaciones a los derechos de autor y los derechos afines a los derechos de autor y, en particular, la regla de los tres pasos del art. 9.2 del CB, que también aparece en otros Convenios, Acuerdos y Tratados internacionales ${ }^{1059}$.

En el ámbito subregional, la Decisión № 351 de la Comisión del Acuerdo de Cartagena también contiene ciertos límites a los derechos de propiedad intelectual. En efecto, el régimen común establecido para los países integrantes de la Comunidad Andina en virtud de esta Decisión, contiene una lista de excepciones obligatorias para sus países miembros (art. 22), sin perjuicio del reconocimiento de nuevas excepciones en sus respectivas leyes internas, siempre que cumplan los criterios de la regla de los tres pasos $(\text { art. 21) })^{1060}$.

Finalmente, la legislación interna vigente en materia de propiedad intelectual de los distintos países latinoamericanos y caribeños, asimismo, regula las limitaciones y excepciones a los derechos de autor. Al respecto, son de interés los datos obtenidos por

1059 Vid. supra Capítulo II, epígrafe 2, apartado 4.1.1. Para un examen de las limitaciones a los derechos de autor y conexos y la regla de los tres pasos en el contexto de los Convenios y Tratados internacionales (CB, Acuerdo sobre los ADPIC, TODA, CR, TOIEF) OMPI, véase también OMPI, Estudio sobre las limitaciones o excepciones al derecho de autor y los derechos conexos en beneficio de las actividades educativas y de investigación en América Latina y el Caribe [SCCR/19/4], documento preparado por Juan Carlos Monroy Rodríguez, Comité Permanente de Derecho de Autor y Derechos Conexos (19a sesión), Ginebra, 2009, pp. 27-35, disponible en: http://www.wipo.int/edocs/mdocs/copyright/es/sccr_19/sccr_19 4.pdf (consultado: 02.07.2017).

${ }^{1060}$ Como consecuencia de la doble regulación, comunitaria e interna, se generan importantes asimetrías en cuanto a los usos libres de las obras dentro de la comunidad; y en particular, en cuanto a los límites a estos derechos establecidos para las personas con discapacidad y en relación con el préstamo público de obras por bibliotecas. Vid. CERDA SILVA, A. J., "Armonización de los derechos de autor en la Comunidad Andina...", op. cit., pp. 258-261. 
la Secretaría de la OMPI, resultado de las respuestas a un cuestionario sobre limitaciones y excepciones preparado por la propia institución, en cumplimiento de la iniciativa adoptada en la decimoséptima sesión del Comité Permanente de Derecho de Autor y Derechos Conexos (SCCR, por su acrónimo en inglés), celebrada en Ginebra, en noviembre de 2008. En efecto, las respuestas a este cuestionario constituyen una fuente de información relevante, pues permiten obtener una visión general sobre la regulación de los límites a los derechos de propiedad intelectual en los distintos países.

Como cuestión preliminar, valga señalar que los Estados miembros de la OMPI que decidieron responder a este cuestionario pudieron hacerlo hasta el 12 de agosto de 2010. No obstante, las respuestas dadas siguen siendo válidas para ilustrar el panorama legislativo sobre las limitaciones y excepciones a los derechos de autor en la región, puesto que las legislaciones no han sufrido variaciones significativas. En particular, se hace referencia aquí a las respuestas ofrecidas por Argentina, Brasil, Chile, Colombia, Guatemala, México, Perú, República Dominicana y Uruguay ${ }^{1061}$, relativas a la primera parte de dicho cuestionario ${ }^{1062}$, pues abordan, precisamente, los límites a los derechos de autor. Del análisis de las mismas, se pueden extraer las siguientes conclusiones:

1. La totalidad de estos países contienen en su legislación interna limitaciones específicas a los derechos de autor, es decir, una lista cerrada de límites, siendo Chile el único país que, además de establecer excepciones taxativas en la ley, incorpora una excepción general de naturaleza flexible, con lo cual, pudiera decirse que contiene un sistema mixto.

2. No puede decirse que la prueba de los tres pasos sea un criterio recogido por todas estas legislaciones. Por el contrario, algunos de estos países (Chile y Uruguay) no incluyen esta regla como criterio general de regulación de las excepciones. Otros, por su parte, sólo lo hacen parcialmente. Así sucede, por ejemplo, con México, que alude expresamente sólo al segundo escalón de la

1061 Las respuestas recibidas de los Estados miembros están disponibles en: http://www.wipo.int/copyright/en/limitations/limitations_replies.html (consultadas: 27.07.2017).

${ }^{1062}$ Vid. Anexo 7. En el mismo se recogen las veinte preguntas que integran la primera parte del cuestionario y las respuestas ofrecidas por Argentina, Brasil, Chile, Colombia, Guatemala, México, Perú, República Dominicana y Uruguay. 
prueba al autorizar la utilización de la obra ya divulgada sin autorización del titular y sin remuneración "siempre que no se afecte la normal explotación" de la misma, así como al primer escalón, al considerar "determinados casos especiales" aquellos que taxativamente contiene el art. 148 de la Ley Federal de Derechos de Autor (LFDA). Brasil, por su parte, hace referencia parcial al triple test al regular la reproducción de pequeños extractos de la obra preexistente en una obra nueva. Todo ello, sin perjuicio de la observancia debida a esta regla por los países miembros del CB.

3. Existe unanimidad en cuanto al reconocimiento de excepciones de uso libre, es decir, sin autorización del autor y sin remuneración. Normalmente, estas limitaciones se asocian al uso de breves fragmentos para cita, fines educativos, uso por personas con discapacidad, fines informativos, parodia, usos judiciales o administrativos y por bibliotecas o archivos.

4. La mayoría de los países latinoamericanos referenciados no disponen en sus ordenamientos jurídicos de ningún tipo de limitaciones y excepciones basadas en licencias legales, es decir, una autorización legal para utilizar la obra a cambio de una remuneración establecida en la propia ley. México, reconoce que, según el art. 147 de la LFDA, cuando no sea posible obtener el consentimiento del titular de los derechos patrimoniales correspondientes y mediante el pago de una remuneración compensatoria, el Ejecutivo Federal, por conducto de la Secretaría de Cultura, de oficio o a petición de parte, podrá autorizar la publicación o traducción de obras literarias o artísticas necesarias para el adelanto de la ciencia, la cultura y la educación nacionales. Argentina, por su parte, también reconoce la posibilidad de conceder licencias no exclusivas al amparo del Decreto 1155/58, reglamentario del artículo V de la Convención Universal sobre Derecho de Autor, que faculta a cada Estado contratante a restringir en su legislación nacional el derecho de traducción para los escritos, si bien este Decreto ha perdido su virtualidad, toda vez que Argentina es Estado parte del CB y, por tanto, no aplica, a día de hoy, la citada Convención.

Por su parte, únicamente Argentina y Colombia manifiestan contener licencias obligatorias en sus leyes sobre propiedad intelectual. 
5. Todos los países mencionados limitan la posibilidad de restringir contractualmente actos que estarían permitidos en virtud de excepciones y limitaciones a los derechos de autor. En el caso de Perú se especifica que, puesto que no hay disposición legal al respecto, las partes tienen la libertad de excluir, por contrato, las limitaciones y excepciones.

6. El ejercicio de las limitaciones y excepciones a los derechos de autor no siempre se supedita a la condición de que la utilización se realice a partir de una fuente lícita o autorizada. Así, sucede en Brasil, México y Uruguay, que no imponen en sus ordenamientos jurídicos tal condición. Por el contrario, en otros casos esta condición sí se exige, pero no como presupuesto general que acompañe a todos los límites a los derechos de propiedad intelectual, sino más bien con respecto a determinados límites. Por ejemplo, la ley argentina establece que la reproducción y distribución de las obras científicas y literarias en sistemas especiales para ciegos $\mathrm{y}$ otros discapacitados perceptivos sea hecha por entidades autorizadas y la ley guatemalteca autoriza la libre publicación y traducción de leyes, decretos, reglamentos, órdenes, acuerdos, resoluciones, así como de las decisiones judiciales y de órganos administrativos, siempre que se realice a partir de la publicación oficial.

Chile, por otro lado, se distingue de los casos anteriores, pues parte del presupuesto de que todas las excepciones de la ley se autorizan respecto de obras a las que se haya accedido legalmente. En Colombia, sin embargo, se presume que el ejercicio de las limitaciones y excepciones a los derechos de autor se establece a partir de ejemplares lícitamente adquiridos, aun cuando expresamente sólo lo señala el art. 22.b) de la Decisión No 351 en lo que atañe a la reproducción por medios reprográficos para la enseñanza o para la realización de exámenes en instituciones educativas, en la medida justificada por el fin que se persiga, de artículos lícitamente publicados en periódicos o colecciones periódicas, o breves extractos de obras lícitamente publicadas. Por su parte, Perú, si bien nada estipula en su legislación al respecto, reconoce la posibilidad de que las partes puedan establecer pactos expresos sobre el particular.

7. Salvo Chile, que nada responde, y Argentina, que contesta que su legislación no cuenta con disposiciones relativas a las medidas tecnológicas de protección, el resto de los países latinoamericanos que respondieron al cuestionario de la 
OMPI reconocen que sus ordenamientos jurídicos sí protegen la implementación de medidas tecnológicas. A su vez, sólo Guatemala y Perú contemplan mecanismos para garantizar que se puedan realizar actos cubiertos por limitaciones y excepciones a pesar de la existencia de medidas tecnológicas de protección. Perú reconoce, además, supuestos concretos en que prevalecen determinadas limitaciones o excepciones sobre la prohibición de eludir las medidas de protección y sobre los sistemas de información para la gestión de derechos ${ }^{1063}$. Colombia, además, acepta la posibilidad de eludir una medida tecnológica para un uso autorizado, lo cual no está expresamente estipulado, pero se deriva de la redacción de los arts. 272 y 271 del Código Penal, que castigan la violación de una medida tecnológica de protección y la utilización de las obras sin autorización, salvo en los casos autorizados legalmente.

8. La mayoría de los países citados no dispone en sus ordenamientos jurídicos de excepciones o limitaciones para el uso temporal de obras digitales. Sólo Brasil y Chile establecen alguna regulación al respecto. Brasil permite la reproducción, siempre que esta sea temporal y tenga, solamente, el propósito de hacer la obra, el fonograma o la interpretación perceptible en un medio electrónico o cuando sea de naturaleza transitoria o incidental, siempre que ocurra en el curso del uso debidamente autorizado de la obra. Chile, por su parte, específica que autoriza la reproducción provisional de una obra, que sea transitoria y accesoria, como parte de un proceso tecnológico.

${ }^{1063}$ El art. 1 del Decreto Legislativo 1076, de 27 de junio de 2008, que aprueba la modificación del Decreto Legislativo 822, Ley sobre el Derecho de Autor, y que incorpora nuevas definiciones al art. 2 de éste, define a la información sobre la gestión de derechos como "I. información que identifica la obra, interpretación o ejecución o fonograma; al autor de la obra, al artista intérprete o ejecutante de la interpretación o ejecución, o al productor del fonograma; o al titular de cualquier derecho sobre la obra, interpretación o ejecución de fonograma; II. Información sobre los términos y condiciones de utilización de las obras, interpretaciones o ejecuciones o fonogramas; o, III. Cualquier número o código que represente dicha información, cuando cualquiera de estos elementos estén adjuntos a un ejemplar de la obra, interpretación o ejecución o fonograma o figuren en relación con la comunicación o puesta a disposición al público de una obra, interpretación o ejecución o fonograma".

Asimismo, el art. 1 citado define la medida tecnológica efectiva como "cualquier tecnología, dispositivo o componente que, en el curso normal de su operación, controla el acceso legal a una obra, interpretación o ejecución o fonograma, o que protege cualquier derecho de autor o conexo". 


\section{LA COPIA PRIVADA}

La mayoría de los países analizados contienen en sus legislaciones normas que limitan el derecho exclusivo de reproducción del autor para fines privados o personales, con excepción de Argentina, Bolivia, Chile, Cuba, Guatemala ${ }^{1064}$ y Uruguay, que carecen de una regulación al respecto ${ }^{1065}$.

El hecho de que las legislaciones de estos últimos países no contemplen la copia privada como límite a los derechos de propiedad intelectual pudiera estar relacionado, en algunos casos, con el momento en que estas leyes fueron dictadas, pues algunas datan de épocas en las que apenas se comercializaban equipos, aparatos y soportes reproductores para uso doméstico y, menos aún, las tecnologías de reproducción habían alcanzado las dimensiones actuales, como es el caso de las leyes de Argentina y de Uruguay, e incluso, de las de Chile y Cuba. Sin embargo, a día de hoy, parece más una cuestión de falta o fracaso de iniciativas legislativas al respecto que de la antigüedad de las normas, pues nada impide que estas leyes puedan ser objeto de modificaciones o actualizaciones como, de hecho, ha venido sucediendo en otros países del contexto Latinoamericano.

En el caso de Cuba, y como cuestión añadida, quizás repercuta el hecho de que la reproducción con fines privados no haya llegado a convertirse en un fenómeno de masas de grandes magnitudes, en contraste con los países desarrollados e incluso, con países en vías de desarrollo, pero con economías de corte más mercantilista, en los que la demanda de equipos y aparatos de reproducción estimula la oferta de estos y la competencia entre fabricantes y distribuidores, haciendo que, cada vez más, los precios

\footnotetext{
${ }^{1064} \mathrm{El}$ art. 64 de la Ley de Derecho de Autor y Derechos Conexos y sus reformas (Decreto No. 33-98) de Guatemala permite "la reproducción para uso personal de una obra de arte expuesta en forma permanente en lugares públicos o en la fachada exterior de edificios, ejecutada por medio de un arte que sea distinto al empleado para la elaboración del original, siempre que se indique el nombre del autor, si se conociere, así como el título de la obra, si lo tiene, y el lugar donde se encuentra". No obstante, esta reproducción no se corresponde, propiamente, con la excepción de copia privada en el sentido de reproducción realizada por quien posee o adquiere un ejemplar o soporte de la obra o prestación intelectual. En el mismo sentido, por ejemplo, el art. 52 de la Ley de Derechos de Autor y Derechos Conexos de Honduras autoriza la reproducción para uso personal de obras de arte expuestas permanentemente en lugares públicos.

${ }^{1065}$ Vid. Anexo 8. Este anexo contiene una tabla con los preceptos que, en su caso, regulan el límite de copia privada en cada una de las legislaciones estudiadas.
} 
de estos productos disminuyan y, consecuentemente, se amplíe el número de personas que pueden adquirirlos. En cambio, ello no impide la comercialización de equipos y soportes de reproducción en este país y su uso, cada vez más extendido entre las personas (ordenadores, móviles, tabletas, memorias USB, etc.), lo que estimula la copia privada de obras protegidas por la propiedad intelectual, con lo cual, cabe la reflexión sobre la necesidad de dotar de cobertura legal a esta práctica que, en ausencia de la excepción, sería ilegal. En todo caso, debe resaltarse que gran cantidad de las reproducciones que se producen en el ámbito privado no derivan de una fuente lícita, sino de copias de procedencia ilegítima que, como norma general, no quedan amparadas en el límite de copia privada ${ }^{1066}$.

Por otra parte, la falta de inclusión del límite de copia privada en los países mencionados pudiera también obedecer a las presiones de la industria tecnológica, así como a la presión popular que sufren los Gobiernos frente a iniciativas legislativas al respecto, cuando pretenden establecer un mecanismo compensatorio asociado al límite de copia privada. No obstante, la mayor parte de países sí regula la copia privada como excepción al derecho de reproducción del autor. Tal es el caso de Brasil, Colombia, Costa Rica, Ecuador, El Salvador, Honduras, México, Nicaragua, Panamá, Paraguay, Perú, República Dominicana y Venezuela.

Así pues, la configuración legal de la copia privada en las distintas legislaciones presenta similitudes. Del mismo modo, también ostenta diferencias que vienen dadas, en general, por el alcance de las expresiones empleadas en las normas (v. gr. "uso personal" y "uso privado"), por las obras y prestaciones sobre las que recae este límite, así como por los requisitos exigidos para su aplicación.

En efecto, el alcance del límite de copia privada deriva del marco más o menos amplio de actuación que tiene quien reproduce la obra al amparo de la excepción, esto

${ }^{1066}$ En el ámbito de la UE, si bien la DDASI no exige expresamente el requisito de acceso legal, la STJUE, (Sala Cuarta), de 10 de abril de 2014, ACI Adam BV y otros contra Stichting de Thuiskopie y otros (asunto C-435/12) concluyó que era necesario distinguir entre fuentes lícitas e ilícitas respecto de la copia privada; cuestión esta que, como se ha visto, exige el art. 31.2.B9 del TRLPI. Vid. supra, Capítulo 3, epígrafe III, apartado 2.2.3. 
es, de si la copia permitida es para "uso personal" o para "uso privado" de quien la realiza. En efecto, uno y otro vocablo no tienen el mismo significado y, por tanto, su empleo delimita unos contornos diferentes de aplicación de la excepción.

Según el Glosario de Derecho de Autor y Derechos Conexos de la OMPI, la voz "utilización personal" -o lo que es lo mismo, uso personal- resulta de alcance más restringido que el término "uso privado". Este último comprende, en relación con una obra publicada, la realización de una reproducción, traducción, adaptación u otra transformación de la obra, en uno o varios ejemplares, no exclusivamente para uso individual de una sola persona (como en el caso de la llamada utilización o uso personal), sino para fines comunes de un determinado círculo de personas, siempre que no se hagan accesibles al público ${ }^{1067}$.

Así, mientras las leyes de Brasil y Colombia emplean la expresión “uso privado", las leyes de El Salvador, Honduras, Nicaragua, Panamá, Paraguay, Perú, República Dominicana y Venezuela emplean el término "personal” para referirse al carácter de la utilización. Costa Rica, utiliza la expresión "para su propio uso", aludiendo a la persona que realiza la copia; mientras que Ecuador consigna "el uso [...] de la persona natural que la realiza". México, por su parte, se distingue de los anteriores países, toda vez que contempla tanto uno u otro tipo de usos ("para uso personal y privado"). Además, en algunos casos destaca el empleo del adjetivo "exclusivo" o del adverbio “exclusivamente" para remarcar el aludido carácter personal ${ }^{1068}$.

En segundo lugar, estas legislaciones tampoco coinciden en el objeto del límite de copia privada. Algunas de ellas (Brasil, El Salvador) permiten la copia privada o personal sin hacer mención al tipo de obras que pueden ser reproducidas a tal fin. Por tanto, habrá que entender que estas leyes autorizan la copia privada, con carácter general, en relación con las obras a las que confieren protección legal, siempre que sean

\footnotetext{
1067 Vid. OMPI, Glosario de Derecho de Autor y Derechos Conexos, Ginebra, 1980, voz 194 ("uso privado"), disponible en: ftp://ftp.wipo.int/pub/library/ebooks/wipopublications/wipo pub 816 efs-ocrsp-image.pdf (consultado 10.08.2017). Véase también la voz 181 ("utilización personal") en la misma fuente. Asimismo, vid. supra Capítulo 3, epígrafe III, apartado 2.1, donde se hace alusión al uso del vocablo "privado" en relación con "público" y su connotación en el Derecho de la UE.

${ }^{1068}$ Véanse en el Anexo 8 los artículos pertinentes de las leyes de El Salvador, Honduras, Panamá, Paraguay y Venezuela.
} 
susceptibles de reproducirse bajo los requisitos que exige la excepción. De manera similar sucede en México, donde la Ley Federal de Derecho de Autor autoriza la reproducción con fines personales y privados de "las obras literarias o artísticas", es decir, de las creaciones intelectuales a las que esta ley confiere protección conforme a su art. 1, siempre que se cumplan los requisitos establecidos en su art. 148 en virtud del cual se autoriza esta excepción.

Sin embargo, en otros casos, la excepción se circunscribe a determinados tipos de creaciones intelectuales, unas veces abarcando un número mayor de tipologías de obras; otras veces, un número más restringido. Ecuador, por ejemplo, lo hace en términos amplios, toda vez que autoriza la copia doméstica de fonogramas, videogramas, así como de obras literarias. De igual modo, Venezuela considera lícita la reproducción de la obra impresa, sonora y audiovisual; o Panamá, de la obra en forma de grabación sonora o audiovisual, así como de reproducción reprográfica. Paraguay, admite la copia personal de obras publicadas en forma gráfica, o en grabaciones sonoras o audiovisuales; y Perú, tanto la reproducción de obras publicadas en forma gráfica aunque restringidas a la reproducción por reprografía de breves fragmentos o de obras agotadas- como de obras, interpretaciones o producciones publicadas en grabaciones sonoras o audiovisuales.

Colombia y República Dominicana, por su parte, autorizan la copia privada de la "obra literaria o científica”, excluyendo a las obras artísticas. Habrá que tener en cuenta que, según el Glosario de Derecho de Autor y Derechos Conexos de la OMPI, la referencia a las obras literarias se entiende generalmente que alude a todas las formas de obras escritas originales, cualquiera que sea su carácter (literario, científico, técnico o meramente práctico) y prescindiendo de su valor y finalidad ${ }^{1069}$, así como que la obra científica es aquella que trata los problemas de una manera adaptada a los requisitos del método científico, pero sin que por ello deba restringirse esta categoría al campo de las ciencias naturales, ni a las obras literarias de carácter científico ${ }^{1070}$.

1069 OMPI, Glosario..., cit., voz 146.

${ }^{1070}$ Ibídem, voz 231. 
Ahora bien, lo previsto en la ley colombiana se ha visto alterado por la sentencia de la Sala de Casación Penal de la Corte Suprema Colombiana, de 30 de abril de 2008 que, admitió la legalidad de la copia privada de fonogramas ${ }^{1071}$. La sentencia absuelve al acusado de la sanción prevista en el art. 51.4 de la Ley N. ${ }^{\circ} 44$, de 5 de febrero de 1993, por la cual se modifica y adiciona la Ley N. ${ }^{\circ} 23$ de 1982 y se modifica la Ley N. ${ }^{\circ}$ 29 de $1944^{1072}$, que castiga con penas de prisión y multa a "quien reproduzca fonogramas, videogramas, soporte lógico u obras cinematográficas sin autorización previa y expresa del titular, o transporte, almacene, conserve, distribuya, importe, venda, ofrezca, adquiera para la venta o distribución o suministre a cualquier título dichas reproducciones", considerando aplicable la excepción de uso privado prevista en el art. 37 de la Ley N. ${ }^{\circ}$ 23, de 28 de enero de 1982, sobre Derechos de Autor. El argumento de la Corte se sustenta en el hecho de que la actuación del acusado no se dirigía a causar un perjuicio irrazonable o desmedido, ni atentaba contra la normal explotación de la obra sino, más bien, cumplía con el encargo que le hacía el propietario del soporte de reproducirlo en un formato diferente. Lo perjudicial del fallo radica, sin embargo, en la laxitud con que se juzga la conducta de quien "ofrecía copiar CDs y DVDs a título de 'servicio a la comunidad' para que ésta pudiera ejercer libremente su 'derecho a la copia privada'”, considerando a esta infracción como un mal menor, al que le faltan los atributos necesarios para ser considerada una conducta antijurídica ${ }^{1073}$. El problema no está, concretamente, en orientar el camino a autorizar, también, la copia privada, lícita, de fonogramas; el problema radica en incurrir en "defraudación, derechos patrimoniales de autor, reproducción de obras de carácter literario, científico o artístico; descarga de archivos musicales desde Internet; ánimo de lucro (!); uso de

\footnotetext{
${ }^{1071}$ Los aspectos más destacados del caso son esbozados por CANOSA CRIADO, M. A., "El derecho de copia privada para fonogramas: Comentario a una sentencia reciente de la Corte Suprema de Colombia", Revista Foro Derecho Mercantil, núm. 25, 2009, p. 1 (versión en línea), disponible en: http://legal.legis.com.co/document?obra=rmercantil\&document=rmercantil_7bce657e07d4a034e0430a01 0151a034. Básicamente, el acusado se dedicaba a la duplicación en CD de fonogramas originales en soporte de vinilo, anunciando el servicio en el diario colombiano "El Tiempo" y cobrando por dicho servicio a los interesados.

${ }^{1072}$ Disponible en: http://www.wipo.int/wipolex/es/text.jsp?file id=126031 (consultada: 24.09.2017).

${ }^{1073}$ FERNÁNDEZ BALLESTEROS, C., "El nuevo contexto del derecho del autor en el siglo XXI", Revista Jurídica de Propiedad Intelectual, Universidad Católica de Santiago de Guayaquil, Tomo 1, julio, 2009, p. 128.
} 
software sin licencia; uso personal; intención de lesionar patrimonio ajeno; principio de 'uso justo' (institución propia del derecho anglosajón ajena a nuestro sistema jurídico); principio de tipicidad", como destaca FERNÁNDEZ BALLESTEROS; y lo que es peor, como también señala este autor, la pretensión de unificar la jurisprudencia dentro de numerosas excepciones al derecho de autor ${ }^{1074}$.

Costa Rica, por otra parte, autoriza la reproducción con fines personales de la "obra didáctica o científica". A dicho ámbito limita también la ley hondureña la reproducción para uso personal realizada de forma manuscrita o mecanografiada. No obstante, la ley hondureña permite que la copia se extienda más allá de estas categorías de obras. Así se desprende de la amplia formulación de su art. $47^{1075}$.

En la ley nicaragüense aparece delimitado el alcance objetivo de la excepción de forma negativa, al autorizar la reproducción para uso personal de una obra con carácter general, pero excluyendo determinados supuestos concretos; por ejemplo, las reproducciones de obras arquitectónicas, de libros íntegros o de una obra musical en forma gráfica (partituras).

Con todo, por una parte, se observa que las leyes latinoamericanas examinadas suelen tener un ámbito más restringido de aplicación del límite de copia privada que la ley española, considerando que dicha excepción se autoriza (en la mayoría de los casos) sólo para uso personal y no para uso privado. Por otro lado, se aprecia que algunas de estas leyes siguen el ejemplo de la ley española en lo que respecta a la delimitación del objeto de dicho límite, permitiendo la reproducción de obras literarias, de fonogramas y de videogramas sin autorización del titular de derechos de autor (v. gr. Ecuador, Venezuela, Panamá); mientras que otras, o bien no especifican el tipo de obras que pueden ser reproducidas (Brasil y El Salvador) o restringen mucho más el ámbito de la excepción.

\footnotetext{
${ }^{1074}$ Ibídem, p. 130.

1075 "Respecto de ejemplares de obras adquiridas lícitamente por una persona, es permitida sin autorización del autor ni remuneración, reproducción de una copia de la obra para el uso personal y exclusivo de esa persona, realizada por él, con sus propios medios, siempre que se trate de casos especiales, que no atente a la explotación normal de la obra ni cause un perjuicio injustificado a los intereses legítimos del autor".
} 
Por último, tampoco coinciden exactamente los requisitos exigidos para la aplicación de la excepción en las distintas leyes, aun cuando sí existen algunos comunes o que se repiten mayoritariamente. Así sucede con el hecho de que la copia privada o personal la puedan llevar a cabo, sólo las personas físicas o naturales ${ }^{1076}$. De hecho, en algunos casos este requisito está expresamente establecido en la norma (p. ej. la ley ecuatoriana), aunque en otros es una condición que se infiere de la redacción de la norma ( $v$. gr. la ley brasileña, al emplear el término "copista"; la ley colombiana, al usar la expresión "ordenada u obtenida por el interesado"; la ley costarricense cuando señala "efectuada personal y exclusivamente por el interesado para su propio uso"; la ley hondureña al expresar "realizada por él", etc.).

Asimismo, la mayoría de las leyes requieren que la reproducción se efectúe en un solo ejemplar o copia (Brasil, Colombia, Costa Rica, Ecuador, México, Nicaragua, República Dominicana); y sin ánimo de lucro (Brasil, Colombia, Costa Rica, Ecuador, Honduras, México y República Dominicana). Es constante, además, la exclusión de los programas de ordenador entre las obras susceptibles de reproducirse con fines personales o privados (Costa Rica, Nicaragua, República Dominicana y Venezuela; así como Bolivia, Colombia, Ecuador y Perú, en virtud de lo dispuesto en el art. 25 de la

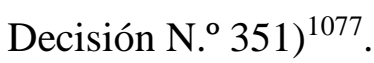

El requisito de que la reproducción se efectúe u obtenga directamente por el interesado para la aplicación de la excepción por copia privada también es común en la mayor parte de las leyes. Sin embargo, no lo exigen las leyes de Nicaragua, Paraguay, Perú y República Dominicana. Algunos países requieren que la reproducción sólo se haga de pequeñas partes de una obra protegida o de obras agotadas (Brasil, El Salador,

\footnotetext{
${ }^{1076}$ México, sin embargo, contempla la posibilidad de que una institución educativa, de investigación, o que no esté dedicada a actividades mercantiles, reproduzca por una sola vez, y en un sólo ejemplar, una obra literaria o artística, para su uso, sin fines lucrativos (art. 148, párrafo $2^{\circ}$ LFDA).

1077 Paraguay, en cambio, autoriza la reproducción de estos programas para uso personal. El art. 70 de la Ley 1328/1998 de Derecho de Autor y Derechos Conexos establece: "A los efectos de esta ley no constituye reproducción ilegal de un programa de ordenador, su introducción en la memoria interna del respectivo aparato, por parte del usuario lícito y para su exclusivo uso personal. La anterior utilización lícita no se extiende al aprovechamiento del programa por varias personas, mediante la instalación de redes, estaciones de trabajo u otro procedimiento análogo, a menos que se obtenga el consentimiento expreso del titular de los derechos".
} 
Honduras, Perú y Venezuela), entre tanto, otros, imponen condiciones todavía más restrictivas, como el hecho de que la copia sea manuscrita o mecanografiada (Costa Rica).

Cabe agregar que las leyes de El Salvador, México, Nicaragua, Panamá y Perú (esta última respecto a la reproducción reprográfica) precisan expresamente que la copia se haga de obras ya divulgadas, mientras que las de Brasil, Colombia, Costa Rica, República Dominicana y Venezuela nada establecen al respecto. En el caso de Ecuador, Honduras, y Panamá, las expresiones "obra literaria de circulación lícita” y "ejemplares de obras adquiridas lícitamente" y "ya divulgadas lícitamente", respectivamente, permiten inferir que la divulgación (como presupuesto de la circulación y la adquisición) se haya efectuado de manera legítima.

Debe destacarse que la licitud que se requiere por algunas de estas leyes suele estar vinculada, precisamente, a la divulgación de la obra. Es decir, se autoriza la copia con fines personales o privados de la obra ya divulgada lícitamente (El Salvador, Panamá y Perú). En estrictos términos, esto comporta que una vez que la obra es divulgada por el titular en el ejercicio de su derecho moral, queda satisfecho este requisito de licitud. Sin embargo, sería más adecuado que el calificativo de lícito acompañara a la fuente a partir de la cual se realiza la copia y no a su divulgación, toda vez que lo lógico es que sea la copia la que tenga que hacerse a partir de un soporte de procedencia legítima. Es probable que éste haya sido el sentido deseado al introducir este condicionante, si bien su redacción no ha sido acertada.

Una redacción más afortunada es la de la ley ecuatoriana. La misma circunscribe la copia privada a "la copia doméstica de fonogramas o videogramas, o la reproducción reprográfica en un solo ejemplar realizada por el adquirente original de un fonograma o videograma u obra literaria de circulación lícita [... "1078. En consecuencia, el énfasis no se coloca exclusivamente sobre el acto de divulgación, pues la circulación de la obra va más allá de dicho acto, asociándose también a la forma en que ésta se transmite en el tráfico comercial. En similares términos se establece en la ley hondureña cuando

1078 Énfasis añadido. 
permite que, sin autorización del autor ni remuneración, se copien las "obras adquiridas lícitamente", así como la ley panameña, al autorizar la reproducción reprográfica para uso personal de "un ejemplar legítimo".

Así pues, si bien en términos generales existen similitudes en las distintas normas, cada una tiene sus propias condiciones. No obstante, coinciden, en mayor o menor medida, con las establecidas por el art. 31.2 del TRLPI. En consecuencia, se evidencia claramente la influencia que ha tenido esta ley en la configuración del límite legal de copia privada o personal en las distintas disposiciones. En efecto, los países de América Latina y del Caribe han optado por la inclusión del límite de copia privada de manera expresa en sus normas, precisando su objeto y los presupuestos concretos, lo que es propio de los sistemas cerrados de excepciones.

Sin perjuicio de lo anterior, las leyes de El Salvador, Honduras, México y Nicaragua contienen la regla de los tres pasos del art. 9.2 del CB en la regulación específica de la excepción; lo mismo que la ley ecuatoriana con el empleo de la expresión "usos honrados"1079. Puesto que el legislador ha autorizado la reproducción con fines personales o privados en el texto de estas leyes, no queda sino admitir que el juez debe valorar, caso de que sea sometida a su consideración, si la reproducción ha sido efectuada lícitamente al amparo de la excepción, pues sólo así tendría sentido la inclusión de las disposiciones del triple test en la reglamentación concreta de este límite. Por tanto, la copia para uso personal o privado adquiere aquí la flexibilidad que puede imprimirle el intérprete judicial, quien la aplicará en la solución del conflicto que se produzca entre quien reproduce la obra e invoca la excepción de uso personal y el titular de derechos.

Finalmente, sólo algunas leyes establecen como condición para la licitud de la copia personal o privada la satisfacción de una compensación o remuneración al titular de derechos de autor. Así resulta exclusivamente en las leyes de Ecuador, Paraguay,

\footnotetext{
1079 Según el Glosario de Derecho de Autor y Derechos Conexos de la OMPI, cit., voz 111: "De conformidad con los requisitos previstos en el Convenio de Berna, los usos honrados no deben interferir con la explotación normal de la obra ni deben causar perjuicio irrazonable a los intereses legítimos del autor".
} 
Perú y República Dominicana, normalmente expresada bajo la denominación de "remuneración equitativa" o "remuneración compensatoria", con excepción de Perú que, con mayor similitud a la denominación empleada actualmente por la ley española, se refiere a "compensación por copia privada".

\section{LA COMPENSACIÓN POR COPIA PRIVADA}

\section{Introducción}

Del conjunto de países de América Latina y el Caribe, sólo Ecuador, Paraguay, Perú y República Dominicana han seguido la tendencia europea - presente también en el contexto internacional- de establecer una compensación a favor del titular de derechos de autor por la introducción del límite de copia privada o personal en sus respectivas leyes internas ${ }^{1080}$. De ellos, sólo Paraguay y República Dominicana han desarrollado decretos complementarios que reglamentan de manera particular esta obligación legal. Por el contrario, en los otros ordenamientos no existe, de momento, un desarrollo reglamentario al respecto. En el caso de Perú se da la peculiaridad de que la compensación por copia privada no se establece en el Decreto Legislativo 822, de 23 de abril de 1996, sobre el Derecho de Autor, sino mediante la Ley N. ${ }^{\circ}$ 28131, de 18 de diciembre de 2003, Ley del Artista Intérprete y Ejecutante, que introduce la figura en dicho ordenamiento jurídico.

Por el contrario, la remuneración o compensación por copia privada no debe confundirse con la remuneración que establece la Ley sobre el Derecho de Autor venezolana, en su art. 44.2, ni con la que contiene el art. 27 de la Ley 98, de 22 de diciembre de 1993, por medio de la cual se dictan normas sobre democratización y fomento del libro colombiano. En el caso de Venezuela, la particularidad de la remuneración asociada a la reproducción que fija la ley radica en que la misma no está asociada a la copia de la obra para la utilización personal y exclusiva del usuario,

\footnotetext{
${ }^{1080}$ Vid. Anexo 8, que hace referencia a los preceptos concretos de las leyes de derechos de autor estudiadas que regulan la compensación por copia privada, así como la referencia a otras regulaciones, en su caso.
} 
realizada por éste con medios propios, sino - por el contrario- a la copia efectuada por las empresas, instituciones y demás organizaciones que prestan servicios de reproducción fotomecánica al público, como la fotocopia y el microfilme. Por tanto, se trata de una remuneración que es consecuencia de una licencia no voluntaria para la reproducción de pequeñas partes de una obra protegida o de obras agotadas, sin perjuicio de que también, en este caso, dicha reproducción se autorice para el exclusivo uso personal ${ }^{1081}$. En el caso de Colombia, la remuneración compensatoria que se reconoce a los autores de obras literarias científicas o culturales, conjuntamente con los editores de las mismas por la reproducción de tales obras, deriva de las reproducciones efectuadas en establecimientos que pongan a disposición de cualquier usuario aparatos para la reproducción de las obras o que efectúen copias que sean objeto de utilización colectiva y/o lucrativa ${ }^{1082}$.

Hay que advertir, también, que la Ley Federal del Derecho de Autor de México $^{1083}$ (en adelante LFDA) contiene en su art. 40 una disposición peculiar, por cuanto la remuneración compensatoria que establece y que desarrollan los arts. 19 y 20 del Reglamento de la citada ley bajo la denominación "remuneración compensatoria por copia privada" no es aquella que deriva de la "reproducción por una sola vez, y en un sólo ejemplar, de una obra literaria o artística, para uso personal y privado de quien la hace y sin fines de lucro" (artículo 148.IV), sino la que resulta de la realización de cualquier copia o reproducción hecha sin autorización de los titulares de derechos

${ }^{1081}$ Art. 44: "Son reproducciones lícitas: [...] 2. Las reproducciones fotomecánicas para el exclusivo uso personal, como la fotocopia y el microfilme, siempre que se limiten a pequeñas partes de una obra protegida o a obras agotadas, y sin perjuicio de la remuneración equitativa que deban abonar las empresas, instituciones y demás organizaciones que presten ese servicio al público, a los titulares del respectivo derecho de reproducción. Se equipara a la reproducción ilícita, toda utilización de las piezas reproducidas para un uso distinto del personal que se haga en concurrencia con el derecho exclusivo del autor de explotar su obra".

1082 Art. 26: "Todo establecimiento que ponga a disposición de cualquier usuario aparatos para la reproducción de las obras de que trata esta Ley o que efectúe copias que sean objeto de utilización colectiva y/o lucrativa, deberá obtener autorización previa de los titulares de los derechos correspondientes a tales obras, bien sea directamente o bien mediante licencia otorgada por la entidad de gestión colectiva que designe para tal efecto la Cámara Colombiana del Libro".

Art. 27: "Los autores de obras literarias científicas o culturales conjuntamente con los editores de las mismas, tendrán derecho a participar de una remuneración compensatoria por la reproducción de tales obras al amparo del artículo anterior".

1083 D.O.F. de 24 de diciembre de 1996. 
patrimoniales de autor y conexos y no comprendida en alguna de las limitaciones previstas en los artículos 148 y 151 de la LFDA. Por tanto, lo que a priori parecería corresponderse con la compensación equitativa por copia privada vigente en España ${ }^{1084}$ y regulada en otros ordenamientos jurídicos -incluso de la región latinoamericana- no deja de ser, sino, un supuesto distinto y controvertido, en tanto lo que hace es legitimar la copia ilícita, no amparada en una excepción legal, a cambio de una remuneración.

En efecto, el art. 40 de la LFDA establece que "Los titulares de los derechos patrimoniales de autor y de los derechos conexos podrán exigir una remuneración compensatoria por la realización de cualquier copia o reproducción hecha sin su autorización y sin estar amparada por alguna de las limitaciones previstas en los artículos 148 y 151 de la presente Ley”. A su vez, el art. 19 de su Reglamento ${ }^{1085}$ dispone que "La remuneración compensatoria por copia privada es aquella que corresponde al autor, al titular de derechos conexos o sus causahabientes por la copia o reproducción realizada en los términos del artículo 40 de la Ley”, es decir, al margen de la copia personal o privada, legitimada por el art. 148.IV de la misma. Por su parte, el art. 20 del Reglamento faculta a los autores, a los titulares de derechos conexos y a sus causahabientes, para que, personalmente o por conducto de una entidad de gestión colectiva, recauden la referida remuneración.

Por tanto, es evidente que el Reglamento de la LFDA de México no prevé compensación alguna frente al límite de copia privada o personal establecido en el art. 148.IV de dicha ley, pese a la denominación que utiliza el art. 19 (remuneración compensatoria por copia privada). Por el contrario, contiene una remuneración por la realización de copias sin autorización de los titulares de derechos de autor y conexos que, difícilmente, puedan estos controlar.

Con todo, se muestra la incongruencia del art. 40 con el art. 148 de la LFDA, pues, en tanto este último contiene ciertos límites al derecho de autor (entre ellos la copia privada), aquél legitima la utilización no autorizada de la obra, por demás, no

${ }^{1084}$ Vid. supra Capítulo 5.

${ }^{1085}$ D.O.F. de 22 de mayo de 1998. 
amparada dentro de las excepciones a este derecho, estableciendo, sin más, una remuneración que legaliza, en cierto modo, la reproducción. Por ello, debe destacarse que se han promovido iniciativas legislativas para reformar los arts. 40 y 148 de la LFDA $^{1086}$, aunque hasta la fecha no se ha llevado a cabo. Así pues, la LFDA de México, si bien regula la copia privada como límite a los derechos patrimoniales de autor no establece un mecanismo compensatorio al efecto ${ }^{1087}$.

\section{Examen comparativo de las legislaciones}

Como se ha expuesto, sólo los ordenamientos jurídicos de Ecuador, Paraguay, Perú y República Dominicana regulan la compensación por copia privada, sin perjuicio de que dichas legislaciones empleen expresiones diferentes para referirse a esta figura jurídica ("remuneración compensatoria", "compensación por copia privada" y “remuneración equitativa”). Asimismo, en el examen de estas legislaciones se aprecian tanto elementos comunes como divergentes, como seguidamente se analizará con el objetivo de sistematizar el estado de la regulación de la compensación por copia privada en los citados países de la región latinoamericana.

\footnotetext{
${ }^{1086}$ Como ejemplo de estas iniciativas consúltese el Dictamen de la Comisión de Cultura de la Cámara de Diputados del Congreso de la Unión de Estados Mexicanos, de 29 de abril de 2003 [Apartado IV (Modificaciones a la Minuta)], realizado con motivo de la iniciativa presentada como Proyecto de Decreto por el que se reforma, adiciona y derogan diversos artículos de la Ley Federal del Derecho de Autor por los Senadores de distintos grupos parlamentarios: Guillermo Herbert Pérez, del Partido Acción Nacional; José Natividad González Parás, del Partido Revolucionario Institucional; Jesús Ortega y Armando Chavarría Barrera, del Partido de la Revolución Democrática; y Sara Castellanos, del Partido Verde Ecologista de México (Gaceta Parlamentaria, Cámara de Diputados, núm. 1240-IV, martes 29 de abril de 2003), disponible en línea: http://gaceta.diputados.gob.mx/Gaceta/58/2003/abr/20030429-IV.html\#Autor (consultado: 20.09.2017).

Consúltese también el Dictamen de la Comisión de Cultura de la Cámara de Diputados del Congreso de la Unión de Estados Mexicanos, de 21 de abril de 2009, derivado de la iniciativa de Proyecto de Decreto presentada por el diputado José Antonio Cabello Gil, integrante del Grupo Parlamentario del Partido Acción Nacional, en fecha 2 de febrero de 2006 (Gaceta Parlamentaria, Cámara de Diputados, núm. 2748-XI, jueves 30 de abril de 2009), disponible en: http://gaceta.diputados.gob.mx/Gaceta/60/2009/abr/20090430-XI.html (consultada: 20.09.2017).

${ }^{1087}$ Señala el desacierto que supuso la no introducción de la figura de la compensación por copia privada en la LFDA de México mediante la reforma a esta ley que tuvo lugar por Decreto publicado en el DOF el 23 de julio de 2003, PARra Trujillo, E., "Comentarios a las reformas a la Ley Federal del Derecho de Autor”, Revista de Derecho Privado, nueva época, año III, 2004, pp. 109-110.
} 
Una primera semejanza existente en las distintas leyes se encuentra en el hecho de que la compensación o remuneración por copia privada se determina en función de los soportes y los equipos o aparatos de reproducción. Al respecto, la legislación ecuatoriana se refiere a "equipos y soportes"; la paraguaya, a "equipos, aparatos y materiales"; y la dominicana, a "soportes materiales, equipos, aparatos y materiales", expresiones que, pese a sus diferencias, permiten afirmar que las tarifas de la remuneración se establecen tanto en relación con los soportes en que se fija la obra, como en relación con los equipos que facilitan la reproducción; igual que en España ${ }^{1088}$. A excepción de lo anterior, el art. 20.1 de la Ley del artista intérprete y ejecutante de Perú, Ley N. 28131 de 10 de diciembre de 2003, se refiere a "materiales o soportes". Concretamente, este precepto estipula el pago de una compensación por "la reproducción realizada exclusivamente para uso privado de obras, interpretaciones o ejecuciones artísticas en forma de videogramas o fonogramas, en soportes o materiales susceptibles de contenerlos ${ }^{1089}$ [...]", a lo que agrega, su art. 20.5: "la compensación se determina en función de los soportes ${ }^{1090}$ idóneos, creados o por crearse [...]”. En consecuencia, al menos en sentido estricto, ello excluiría el establecimiento de la compensación respecto de los equipos o aparatos de reproducción. Sin embargo, el Reglamento de Tarifas de la Unión Peruana de Productores Fonográficos (UNIMPRO) para la compensación por copia privada ${ }^{1091}$ sí que establece tarifas para reproductores (reproductor de audio con memoria interna tipo mp3 o similares y reproductor de audio con memoria interna tipo mp4 o similares) y teléfonos móviles, los cuales no son, estrictamente, soportes de reproducción ${ }^{1092}$, de manera tal que, reglamentariamente, la legislación contempla tanto soportes como equipos de reproducción ${ }^{1093}$.

\footnotetext{
${ }^{1088}$ Vid. supra Capítulo 5, epígrafe VI, apartado 3.2.3.

1089 Énfasis añadido.

1090 Énfasis añadido.

1091 Disponibles en: http://www.unimpro.org/sitio/usuarios/reglamento-general-de-tarifas/ (consultadas: 19.08.2017).

1092 Precisamente, el Glosario anexo a la Ley N. ${ }^{\circ}$ 28131, de 10 de diciembre de 2003, define el soporte como "Elemento material susceptible de contener una obra, producción o servicio artístico fijado o impreso (casetes de audio a video, CD, CVD, cinta cinematográfica, etc.)". Una crítica al respecto puede leerse en ComexPerú, “Tarifas sin control”, Revista Negocios Internacionales (Actualidad), núm. 12-141,
} 
También las leyes de derechos de autor de Ecuador, Paraguay, Perú y República Dominicana, al igual que el TRLPI español, aplican el criterio de idoneidad para la determinación de los equipos y soportes sujetos a la compensación ${ }^{1094}$. Al respecto, el art. 20.3 de la Ley N. ${ }^{\circ} 28131$, de 10 de diciembre de 2003, de Perú, alude a los soportes idóneos de reproducción, adjetivo que reitera su art. 20.5. Asimismo, determinan la remuneración en función de los equipos, aparatos, materiales y soportes "idóneos" para realizar la reproducción, el art. 34 de la Ley de Derecho de Autor y Derechos Conexos de Paraguay y el art. 2 del Decreto No. 548-04, de 17 de junio de 2004, que reglamenta la remuneración compensatoria por copia privada en República Dominicana. Por su parte, la ley de Ecuador, aunque no utiliza propiamente el término "idoneidad", se refiere a "soportes susceptibles de incorporar una fijación sonora o audiovisual" (art. 105), lo cual también evoca este criterio, en tanto se refiere a la aptitud de los soportes para su utilización para la reproducción de obras sonoras, visuales y audiovisuales. Ello con independencia de que la ley determine como hecho causante de la remuneración no sólo la distribución de estos soportes, sino también de los equipos reproductores de fonogramas o videogramas, o de los equipos para la reproducción reprográfica (art. 105), de los cuales no se predica su capacidad para reproducir la obra. No obstante, la idoneidad de estos para la reproducción está implícita al tratarse, precisamente, de equipos que permiten la obtención de copias.

\footnotetext{
2009, $\quad$ p. $42 . \quad$ Disponible en línea: http://www.comexperu.org.pe/busqueda.aspx?st=tarifas\%20sin\%20control (consultada: 18.09.2017).

${ }^{1093}$ Esta situación ha sido sostenida en denuncias como la interpuesta por TECH DATA PERÚ S.A.C. contra UNIMPRO (Expediente $\mathrm{N}^{\circ} 2-2009 / \mathrm{DDA}$ ) y MOTOROLA DEL PERÚ S.A. contra la Asociación Nacional de Artistas Intérpretes y Ejecutantes (ANAIE), la Asociación Peruana de Artistas Visuales (APSAV), la Asociación Peruana de Autores y Compositores (APDAYC), la Entidad de Gestión de Derechos de los Productores Audiovisuales (EGEDA Perú) y UNIMPRO (Expediente $\mathrm{N}^{\circ}$ 2-2009/DDA), tramitadas por la presunta infracción del art. 153 literal e) del Decreto Legislativo 822 y del art. 20 de la Ley 28131, del Artista Intérprete y Ejecutante. Sin embargo, en estos casos el Tribunal de Defensa de la Competencia y de la Propiedad Intelectual de Perú no se pronunció al respecto, toda vez que habiendo sido declarado ilegal el "Tarifario de la Compensación de la Copia Privada de Nuevos Soportes" de UNIMPRO por la Resolución No 341-2009/CDA-INDECOPI de fecha 30 de junio de 2009, por incumplimiento de ciertas formalidades legales en su aprobación, consideró que no correspondía pronunciarse respecto de presuntas infracciones en referencia a un tarifario que había sido aprobado sin cumplir con las formalidades legales y que, en consecuencia, no resultaba exigible frente a terceros. Vid. respectivamente, Resolución $\mathrm{N}^{\circ}$ 2146-2010/TPI-INDECOPI, de 20.09.2010, y Resolución $\mathrm{N}^{\circ} 2221$ 2010/TPI-INDECOPI, de 29.09.2010, dictadas por el Tribunal de Defensa de la Competencia y de la Propiedad Intelectual de Perú.

${ }^{1094}$ Vid. supra Capítulo 5, epígrafe VI, apartado 1.
} 
En todo caso, los beneficiarios de la compensación son los titulares de derechos de propiedad intelectual afectados por la reproducción para uso personal o privado. El TRLPI español identifica a estos beneficiarios como "acreedores"1095; término que también utiliza, expresamente, el art. 11.2 del Reglamento de la ley del artista intérprete y ejecutante de Perú.

Coinciden también estas leyes en la determinación de los obligados al pago de la compensación. En efecto, con carácter general reconocen como deudores de la compensación por copia personal o privada al fabricante nacional o importador de los soportes y equipos de reproducción que se determinen legalmente ${ }^{1096}$. En adición, Perú (art. 11.1 del Reglamento de la Ley del artista intérprete y ejecutante) y República Dominicana (art. 3, párrafo $2^{\circ}$, del Decreto No. 548-04, de 17 de junio de 2004) establecen también como deudores solidarios del pago, a los distribuidores de dichos soportes y equipos, al igual que sucede en España (art. 25.3 TRLPI) ${ }^{1097}$. Por su parte, el art. 37 de la Ley de Derechos de Autor y Derechos Conexos de Paraguay, faculta a la Dirección Nacional de Derecho de Autor para ampliar la responsabilidad por el pago de la remuneración a quienes distribuyan estos equipos y soportes, aunque actualmente el art. 3 del Decreto N. ${ }^{\circ}$ 4212, de 12 de octubre de 2015, sólo contempla como deudores a los fabricantes nacionales o importadores.

Otro elemento común es la gestión colectiva de la compensación por copia privada o personal, excluyéndose, por tanto, la gestión individual. Para ello, algunas de estas leyes obligan a la creación de una entidad recaudatoria única, bien que agrupe diferentes modalidades de reproducción o bien, que se encargue sólo de alguna de éstas.

\footnotetext{
1095 Vid. supra Capítulo 5, epígrafe III, apartado 1.

1096 Vid. supra Capítulo 5, epígrafe III, apartado 2.

${ }^{1097}$ Es significativa la semejanza que guarda la redacción del art. 11.1 del Reglamento de la ley del artista intérprete y ejecutante de Perú respecto al art. 25.4 del TRLPI, en su versión dada por la Ley 23/2006, de 7 de julio (sin perjuicio de su parecido con el art. 25.3 de éste, a partir de la última reforma al TRLPI a tenor de la modificación operada por el Real Decreto-ley 12/2017, de 3 de julio). En este sentido, no sólo es similar el precepto en cuanto a estructura, o por referirse a los obligados al pago como "deudores", sino también porque trata a los importadores como "los adquirentes fuera del territorio" (peruano, en este caso) siguiendo la fórmula empleada por la ley española; lo mismo que cuando se refiere a "los distribuidores, mayoristas y minoristas, sucesivos adquirentes" como deudores solidarios de esta obligación "con los deudores que se los hubieran suministrado, salvo que acrediten haber satisfecho efectivamente a éstos la compensación".
} 
En concreto, el art. 105 de la Ley de Propiedad Intelectual ecuatoriana determina la creación de una entidad dedicada exclusivamente a la recaudación colectiva de la remuneración compensatoria por copia privada de fonogramas y videogramas de autores, intérpretes y productores ${ }^{1098}$, así como la creación de otra entidad para la recaudación de los derechos compensatorios derivados de la reproducción reprográfica de autores y editores ${ }^{1099}$. En ambos casos, las entidades de gestión han de ser autorizadas por el Instituto Ecuatoriano de la Propiedad Intelectual (IEPI), que es el organismo estatal encargado de regular y controlar la aplicación de las leyes de propiedad intelectual en dicho país. De modo similar sucede en Paraguay, donde el art. 36 de la Ley de Derecho de Autor y Derechos Conexos estipula que la recaudación se unifique, bien delegando la cobranza en una de las entidades de gestión colectiva correspondiente a las modalidades de reproducción autorizadas para uso personal (gráfica, videográfica, fonográfica o cualquier clase de grabación sonora o audiovisual), o bien constituyendo un ente recaudador con personalidad jurídica propia a este fin ${ }^{1100}$. Al respecto, debe recordarse que en España, si bien la gestión de la compensación equitativa por copia privada se hace efectiva a través de las distintas entidades de gestión colectiva de los derechos de propiedad intelectual, se han concentrado en una

\footnotetext{
1098 Esta función corresponde a la Entidad Recaudatoria Única por Copia Privada de Fonogramas y Videogramas del Ecuador (ENRUCOPI), creada el 28 de enero de 2003.

${ }^{1099}$ Esta función corresponde a la Asociación Ecuatoriana para la Gestión Colectiva de los Derechos Reprográficos de Autor (AEDRA), constituida el 1 de agosto de 2001.

${ }^{1100}$ El art. 2 del Decreto No 4212, de 12 de octubre de 2015, por el cual se Reglamenta el Capítulo IV 'De los Derechos de Remuneración Compensatoria' de la Ley No 1328/98, de Derecho de Autor y Derechos Conexos y se deroga el Decreto $\mathrm{N}^{\circ}$ 6780/2011 determina que la recaudación y distribución de las cuantías percibidas en concepto de derechos de remuneración compensatoria por copia privada serán efectivas a través de la entidad de gestión colectiva reconocida por la Dirección Nacional de Propiedad Intelectual (DINAPI) que sea designada por sus pares a través de una nota formal dirigida a la autoridad de aplicación de las normas de Propiedad Intelectual o bien a través de la creación, por parte de tales entidades de un ente recaudador con personalidad jurídica propia para el efecto.

Las entidades reconocidas por la DINAPI son: Autores Paraguayos Asociados (APA), Sociedad de Gestión de Productores Fonográficos del Paraguay (SGP), Entidad Paraguaya de Artistas Intérpretes o Ejecutantes (AIE Paraguay) y Entidad de Gestión Colectiva de Actores, Intérpretes de Obras Audiovisuales (INTERARTIS Paraguay). Pero, a tenor de la Resolución No. 21/2015, de 9 de noviembre de 2015, de la DIPNAPI, la entidad designada como encargada de la recaudación y distribución de las cuantías percibidas en concepto de derechos de remuneración compensatoria por copia privada, a partir del 12 de octubre de 2015, es la Entidad Paraguaya de Artistas, Intérpretes o Ejecutantes (AIE). Resolución 21/2015 disponible línea: https://www.dinapi.gov.py/application/files/5314/4715/8690/RESOLUCION_RG-2115 DESIGNA A AIE_COMO ENTIDAD_DE_RECAUDACION_REMINERACION_COMPENSAT ORIA_POR_COPIA_PRIVADA.pdf (consultada: 19.09.2017).
} 
única entidad ciertas funciones relativas a la gestión, como por ejemplo la gestión de las exceptuaciones del pago y de los reembolsos y la comunicación unificada de la facturación, según dispone el art. 25.10 del TRLPI ${ }^{1101}$.

Por su parte, en Perú, la entidad encargada de la recaudación y reparto de la compensación por copia privada es la Unión Peruana de Productores Fonográficos (UNIMPRO), por mandato expreso otorgado por la Sociedad Nacional de Intérpretes y Ejecutantes de la Música (SONIEM), la Asociación Peruana de Autores y Compositores (APDAYC), la Asociación Peruana de Artistas Visuales (APSAV) y la Entidad de Gestión de Derecho para los productores Audiovisuales (EGEDA), así como por derecho propio de UNIMPRO ${ }^{1102}$, en virtud de lo dispuesto en la Ley $\mathrm{N}^{\circ}$. 28131, de 10 de diciembre de 2003, del artista intérprete y ejecutante ${ }^{1103}$. Y en República Dominicana se prevé que la recaudación y distribución de la remuneración se haga efectiva a través de las entidades de gestión colectiva constituidas según la categoría de las obras, prestaciones y producciones de que se trate (art. 3, párrafo $2^{\circ}$, del Decreto No. 548-04 de 17 de junio de 2004), con lo cual, la ley no exige la creación de una única entidad al efecto $^{1104}$.

Sin embargo, también existen diferencias en la regulación de la compensación por copia privada en las leyes analizadas. Una de estas radica en la determinación de los

\footnotetext{
${ }^{1101}$ Vid. supra Capítulo 5, epígrafe VI.

1102 Información disponible en: http://www.unimpro.org/sitio/usuarios/copia-privada/ (consultada: 18.08.2017). Véanse también el art. 3 de los Estatutos de la Unión Peruana de Productores Fonográficos (UNIMPRO) disponible en línea: http://www.unimpro.org/sitio/marco-legal/estatutos-y-codigo-de-etica/ (consultado: 18.08.2017) que establece que, entre los fines de esta entidad, está "Administrar, gestionar, y/o cobrar la compensación por copia privada a que se refiere la Ley 28131 del Artista Intérprete y Ejecutante, así como las normas reglamentarias y modificatorias pertinentes, en la parte que corresponda a los productores de fonogramas y/o a los productores de videos musicales y/o a otros titulares en caso de mandato expreso con tal fin otorgado por las entidades de gestión colectiva correspondientes, debiendo para ello obtener la autorización correspondiente de parte de la autoridad competente".

${ }^{1103}$ El art. 20.6 de la Ley $N^{\circ} 28131$, de 10 de diciembre de 2003, del artista intérprete y ejecutante deja a desarrollo reglamentario la forma de recaudación de la compensación. El Reglamento de esta ley establece que, a falta de acuerdo entre las entidades de gestión colectiva correspondientes, esta compensación será percibida y distribuida por una entidad recaudadora de derechos, cuya constitución será promovida por la Oficina de Derechos del Autor del Instituto Nacional de Defensa de la Competencia y de la Protección de la Propiedad Intelectual (INDECOPI).

${ }^{1104}$ Entre las entidades de gestión colectiva existentes en República Dominicana están la Sociedad General de Autores, Compositores y Editores Dominicanos de Música (SGACEDOM), la Sociedad Dominicana de Productores Fonográficos (SODINPRO) y EGEDA Dominicana.
} 
sujetos excluidos de la obligación de compensación. No obstante, debe señalarse que las distintas normas coinciden en liberar del pago de esta compensación a los productores de fonogramas y videogramas, de manera similar a lo que establece el ordenamiento jurídico español, donde dichos sujetos se exoneran del pago en la medida en que adquieren equipos, aparatos y soportes materiales de reproducción, bajo la preceptiva autorización para llevar a efecto la reproducción de obras, prestaciones artísticas, fonogramas o videogramas, según proceda, en el ejercicio de su actividad [art. 25.7.c) TRLPI] ${ }^{1105}$.

Ahora bien, en concreto, la Ley ecuatoriana de Propiedad Intelectual establece que los productores de fonogramas o los titulares de derechos sobre las obras que comportan una fijación sonora o audiovisual, o sus licenciatarios, no están sujetos a esta remuneración por las importaciones que realicen (entiéndase de los soportes y equipos reproductores gravados) (art. 107). En Paraguay, además de la exclusión que recae sobre los equipos y soportes que sean utilizados por los productores de obras audiovisuales y de fonogramas, o sus respectivos licenciatarios, quedan también exentos del pago aquellos que sean utilizados por los editores, así como por los estudios de fijación de sonido o de sincronización de sonidos e imágenes y las empresas que trabajen por encargo de cualquiera de ellos, para la producción o reproducción legítima de las obras y producciones de aquellos, siempre que tales equipos o soportes sean destinados exclusivamente para esas actividades (art. 35) ${ }^{1106}$. En el caso de Perú, están exceptuados del pago de la compensación los productores de fonogramas o videogramas y las empresas de radiodifusión, por los materiales o soportes de reproducción de fonogramas y videogramas destinados a sus actividades, siempre que estén debidamente autorizados para llevar a efecto la correspondiente reproducción de obras [art. 20.4 Ley $\mathrm{N}^{\mathrm{o}}$. 28131, de 10 de diciembre de 2003, del artista intérprete y ejecutante y art. 11.4.a)

\footnotetext{
${ }^{1105}$ Vid. supra Capítulo 5, epígrafe V.

${ }^{1106} \mathrm{Al}$ respecto, el art. 6 del Decreto $\mathrm{N}^{\mathrm{o}}$ 4212, de 12 de octubre de 2015, por el cual se reglamenta la remuneración por copia privada en Paraguay, exige que los sujetos exentos del pago de la remuneración justifiquen que tales equipos o soportes se destinan exclusivamente para la producción o reproducción legítima de las obras y producciones de aquellos ante la entidad de gestión encargada de la percepción o ante el ente recaudador que, en su caso, se constituya, la cual deberá expedir, con carácter previo, un certificado que acredite tal circunstancia. Una certificación similar se expide en España a estos efectos [Vid. art. 25.7.c) del TRLPI].
} 
de su Reglamento]. La ley también exceptúa del pago de la compensación por copia privada a las personas naturales que adquieren fuera del territorio peruano los referidos soportes y los introduzcan en país como equipaje personal, y en una cantidad tal que permita presumir razonablemente que los destinarán al uso privado en dicho territorio; previsión que guarda estrecha similitud con lo dispuesto en el art. 25.7.d) del TRLPI español. Por su parte, República Dominicana exceptúa del pago de la remuneración compensatoria a los productores de fonogramas o de obras audiovisuales expresadas en videogramas, así como a las entidades de radiodifusión, por los equipos, aparatos o materiales destinados al uso de su actividad, siempre que cuenten con la correspondiente autorización expedida por los titulares de derecho para llevar a efecto la correspondiente reproducción de obras, prestaciones artísticas, fonogramas u obras audiovisuales expresadas en videogramas, según proceda (art. 6 del Decreto No. 54804, de 17 de junio de 2004) ${ }^{1107}$.

También se distinguen estas legislaciones en cuanto al modo de establecer la compensación por copia privada, aunque resulta común la fijación de un valor porcentual respecto al precio del equipo o soporte reproductor (o su valor de importación), sin perjuicio, en algún caso, del establecimiento de un precio fijo. Así, en Ecuador, este valor porcentual lo determina el Consejo Directivo del IEPI, por mandato del art. 106 de la Ley de Propiedad Intelectual ${ }^{1108}$ y se fija, no sobre el precio de venta al público del equipo o soporte, sino sobre el precio que el importador paga al distribuidor mayorista o al fabricante antes de que el producto ingrese al país ${ }^{1109}$. En Paraguay, este porcentaje lo determina el art. 5 del Decreto $N^{\circ} 4212$, de 12 de octubre de 2015, por el

\footnotetext{
${ }^{1107}$ Además, debe tenerse en cuenta lo dispuesto en el art. 7 del citado Decreto No. 548-04, de 17 de junio de 2004 que, refiriéndose a la remuneración compensatoria, establece que "Lo dispuesto anteriormente no será de aplicación a los programas de ordenador, cuyas únicas reproducciones permitidas se regirán por lo pautado expresamente en las disposiciones especiales de la Ley No. 65-00, del 21 de agosto del 2000, sobre Derecho de Autor, sobre tales obras".

${ }^{1108}$ La cuantía porcentual de la remuneración compensatoria por copia privada propuesta por el IEPI es de un $10 \%$ para soportes y un $4 \%$ para equipos reproductores Vid. https://www.propiedadintelectual.gob.ec/wp-

content/uploads/downloads/2013/12/Comunicado_remuneracion_compensatoria_copia_privada.pdf (consultada: 19.08.2017).

1109 Vid. Comunicación del IEPI https://www.propiedadintelectual.gob.ec/wpcontent/uploads/downloads/2013/12/comunicado_version_oficial.pdf (consultada: 19.08.2017).
} 
cual se Reglamenta el Capítulo IV 'De los Derechos de Remuneración Compensatoria' de la Ley No $1328 / 98$, de Derecho de Autor y Derechos Conexos y se deroga el Decreto $\mathrm{N}^{\mathrm{o}} 6780 / 2011$. Este precepto dispone que el importe de la remuneración compensatoria será del 0,50\%, determinado de sobre el valor de ingreso en el territorio nacional de los productos y dispositivos, de acuerdo con las constancias administrativas y aduaneras, en los casos de importaciones que consten en la factura de origen y sobre la primera comercialización en el país que realicen los obligados al pago, en el caso de productos fabricados en la República del Paraguay. No obstante, las entidades de gestión colectiva podrán celebrar, a través de la entidad designada por Resolución de la Dirección Nacional de Propiedad Intelectual (DINAPI) acuerdos supletorios con organismos representantes de los importadores y fabricantes, en los que se determinen tarifas diferenciales para cada producto o dispositivo, en función de los equipos, aparatos, soportes y materiales idóneos para reproducir, ya sea los fabricados en territorio nacional, o adquiridos fuera de éste para la distribución comercial o utilización dentro del territorio nacional ${ }^{1110}$. Asimismo, conforme a dicho precepto, se establece un descuento del $25 \%$ para los equipos y soportes de fabricación nacional.

En Perú, el art. 9 del Reglamento de la Ley del artista intérprete y ejecutante remite la fijación de las tarifas de la remuneración por copia privada al acuerdo común de las entidades de gestión colectiva y, a falta de acuerdo, a la Oficina de Derechos de Autor, que podrá establecer tarifas temporales, que tendrán la vigencia de un año, con posibilidad de ser prorrogadas por igual término si las entidades de gestión colectiva no hubiesen acordado las tarifas a cobrar. Estas tarifas, en unos casos, constituyen una cuantía fija por soporte y, en otros, un porcentaje del precio FOB (Free on Board) de importación del equipo o soporte ${ }^{1111}$.

\footnotetext{
${ }^{1110}$ El art. 5 del Decreto No 4212, de 12 de octubre de 2015, dispone también la supletoriedad de los eventuales acuerdos que se celebren con la entidad de gestión colectiva designada, o la entidad a crearse especialmente según lo que dispone el art. 2 de dicho Decreto, en representación de los titulares de derechos autorizados y los fabricantes e importadores de equipos y soportes, a las tarifas establecidas en el mismo, por el plazo establecido entre las partes.

${ }^{1111}$ Vid. Reglamento de Tarifas de la Unión Peruana de Productores Fonográficos (UNIMPRO), cit., p. 18.
} 
En República Dominicana, conforme al art. 4 del Decreto No. 548-04, de 17 de junio de 2004, la remuneración se determina mediante un acuerdo concertado entre los fabricantes e importadores y los respectivos titulares de los derechos afectados, o las sociedades de gestión colectiva a las que hayan otorgado mandato para su representación y que se encuentren constituidas según la categoría de las obras, prestaciones y producciones de que se trate para cada modalidad de reproducción, en función de los equipos, aparatos y materiales aptos para realizar la misma.

También existen diferencias en las distintas normas en la relación de los equipos y soportes que determinan la compensación por copia privada, debido a que cada país incluye en el listado de soportes y equipos de reproducción gravados aquellos que considera idóneos para la reproducción. Lo mismo sucede respecto a las tarifas establecidas, pues dependen de los acuerdos a los que se llegue entre los fabricantes y los importadores y los respectivos titulares de los derechos afectados; entre los fabricantes y los importadores y las distintas entidades de gestión colectiva; o de lo que dispongan los organismos autorizados en cada caso. En ocasiones, no existen normas que determinen los equipos y soportes sobre los que se cuantifica la compensación por copia privada, así como las tarifas respectivas. Ecuador, es un ejemplo de lo anterior. El vacío legal existente actualmente comporta el incumplimiento de la obligación de compensar por copia privada ${ }^{1112}$, pese a que desde hace algunos años se viene trabajando en la elaboración de un proyecto que regule la remuneración compensatoria por copia privada establecida en los arts. 105-107 de la Ley de Propiedad Intelectual ${ }^{1113}$.

No obstante, en la práctica totalidad de países las tarifas se fijan sobre dispositivos de reproducción tanto analógicos como digitales, entre los cuales se encuentran los CD,

\footnotetext{
${ }^{1112}$ La Resolución CD-IEPI-03-133 del Consejo Directivo del IEPI, de 20 de octubre de 2003, publicada en el Registro Oficial $N^{\circ} 193$, de 20 de octubre de 2003, puso en vigor las tarifas de la remuneración compensatoria por copia privada en Ecuador. Sin embargo, ha devenido inaplicable en la práctica pues determina unas tarifas fijas, en contra de lo dispuesto en el art. 106 de la Ley de Propiedad Intelectual, que obliga al establecimiento de valores porcentuales.

1113 Así lo informa el IEPI, mediante una comunicación firmada en Quito, el 10 de diciembre de 2013, realizada con la finalidad de aclarar algunas cuestiones relativas a la remuneración compensatoria por copia privada frente a las publicaciones realizadas por los medios de comunicación al respecto. Disponible en línea: https://www.propiedadintelectual.gob.ec/wpcontent/uploads/downloads/2013/12/comunicado_version_oficial.pdf (consultada: 19.09.2017).
} 
DVD, minidiscs, audio y vídeo casetes, reproductores de audio y vídeo, dispositivos de almacenamiento, como memorias USB o tarjetas de memoria y teléfonos móviles ${ }^{1114}$.

Debe resaltarse, además, que sólo la legislación peruana determina, si bien vagamente, algunas pautas a tener en cuenta en la fijación de los importes de la compensación. Establece el art. 9 del Reglamento de la ley del artista intérprete y ejecutante que para fijar las tarifas "la Oficina de Derechos de Autor fundamentará su decisión en criterios técnicos, económicos, estudios de mercado, entre otros"1115. Sin embargo, se trata de criterios indeterminados, de manera que el legislador no ayuda en el establecimiento de unas tarifas justas y equitativas, considerando criterios como el grado de uso o la capacidad de almacenamiento de los soportes de reproducción, por ejemplo, que podrían ser más objetivos. Por su parte, en República Dominicana, el art. 4 (párrafo 4) del Decreto No. 548-04 simplemente se limita a obligar a la Oficina Nacional de Derecho de Autor a definir el valor porcentual a pagar por remuneración por copia privada "mediante resolución conforme a los principios de equidad y fundándose en la información que la parte que haya comparecido en el proceso haya presentado en los plazos citados". Así, se echa en falta unos criterios orientados a conseguir unas tarifas que realmente contribuyan a compensar a los autores, a la vez que no limiten a los usuarios en la adquisición de equipos y soportes de reproducción. Quizás, en este sentido, pueda ayudar la experiencia que tiene España legislando sobre la cuestión, pese a las críticas que también se han objetado sobre su regulación ${ }^{1116}$.

Por lo que respecta a la forma en que se distribuye entre los beneficiarios de la compensación por copia privada la cantidad recaudada por este concepto, según las diferentes modalidades de reproducción, se trata de una cuestión que no siempre está

\footnotetext{
1114 Para más detalles sobre los equipos y soportes sujetos a la compensación por copia privada consúltese: art. 4 del Decreto $\mathrm{N}^{\circ}$ 4212, de 12 de octubre de 2015, para Paraguay; apartado XI del Reglamento de Tarifas de la Unión Peruana de Productores Fonográficos (UNIMPRO) de Perú (cit.) y art. 2 del Decreto No. 548-04, de 17 de junio de 2004, de República Dominicana. Curiosamente, a diferencia de Perú y República Dominicana (también de la legislación española), entre los equipos y soportes sujetos al pago de la compensación por copia privada en Paraguay se encuentran los ordenadores de sobremesa y los ordenadores portátiles.

${ }^{1115}$ La Oficina de Derechos de Autor interviene en la fijación de las tarifas, a falta de acuerdo entre las entidades de gestión colectiva.

1116 Vid. supra Capítulo 5, epígrafe VII, apartado 2.
} 
establecida en las leyes de derechos de autor y conexos de estos países, quedando a desarrollo legislativo posterior. Así sucede en el caso de Paraguay, Perú y República Dominicana, a diferencia de la Ley de Propiedad Intelectual ecuatoriana que lo precisa en su art. 105 (párrafo $2^{\circ}$ ). Conforme a dicho precepto, la remuneración corresponderá por partes iguales a los autores, a los artistas, intérpretes o ejecutantes y a los productores de fonogramas en el caso de fonogramas y videogramas. Asimismo, se dividirá entre los autores y los editores, en el caso de obras literarias.

En el caso de Perú, el art. 20.1 de la Ley del artista intérprete y ejecutante remite al Reglamento dictado en su desarrollo la determinación de la forma y porcentajes en que será distribuida la compensación por copia privada entre el artista, el autor y el productor del videograma y/o del fonograma. Sin embargo, dicho Reglamento (Decreto Supremo 058-2004-PCM, de 28 de julio de 2004) no regula esta cuestión. Tampoco establece nada al respecto el Reglamento de Distribución de UNIMPRO ${ }^{1117}$. Así, parece que hay que estar a lo que determine el Consejo Directivo o la Asamblea General de UNIMPRO, de conformidad con el mandato del art. 21, párrafo quinto del citado Reglamento de Distribución de esta entidad ${ }^{1118}$.

En Paraguay, el art. 37 de la Ley de Derechos de Autor y Derechos Conexos encomienda al Poder Ejecutivo, a propuesta de la DINAPI, la determinación de los titulares a quienes corresponde la remuneración por copia privada, así como la reglamentación del procedimiento para determinar los equipos y soportes sujetos a la misma, su importe y los sistemas de recaudación y distribución.

\footnotetext{
${ }^{1117}$ Éste sólo determina que cuando se trate del reparto de derechos diferentes a los establecidos en los arts. 133 (remuneración equitativa por la comunicación pública del fonograma publicado con fines comerciales) y 137 (remuneración por la comunicación del fonograma al público) de la Ley sobre el Derecho de Autor, esta entidad procederá al reparto de los derechos recaudados según corresponda a cada categoría de titulares y según la naturaleza de los derechos de que se trate, previa deducción de los gastos de administración y de gestión que correspondan (art. 6.1 en relación con el art. 15). Reglamento de Distribución de UNIMPRO disponible en: http://www.unimpro.org/sitio/distribucion/reglamento-dedistribucion/ (consultado: 25.09.2017).

1118 "Para todo lo no previsto en el presente Reglamento de Distribución, se estará a las disposiciones de la Ley sobre el Derecho de Autor, y en su defecto, a lo que determine el Consejo Directivo o la Asamblea General de UNIMPRO".
} 
En República Dominicana el art. 3 del Decreto No. 548-04, de 17 de junio de 2004, precisa que, en el caso de fonogramas y videogramas, el $50 \%$ corresponderá a los autores y compositores, el $25 \%$ a los artistas intérpretes o ejecutantes y el restante $25 \%$ a los respectivos productores. Por su parte, en el caso de la reproducción de obras expresadas en forma gráfica, el $50 \%$ será para los autores y el otro $50 \%$ para los editores.

También sobre el destino de las cantidades recaudadas en concepto de remuneración compensatoria por copia privada, el art. 10 del Decreto $\mathrm{N}^{\circ} 4212$, de 12 de octubre de 2015, de Paraguay reserva una parte de la cuantía total ingresada por este concepto a la realización de actividades encaminadas a promover la observancia de los derechos de autor. En concreto, se prevé que el $80 \%$ de lo recaudado se destine a las entidades de gestión colectiva reconocidas por la DINAPI ${ }^{1119}$ y se distribuya entre éstas, según el tipo de derecho que administran, para su reparto posterior entre los titulares de derechos respectivos. Por su parte, el restante $20 \%$, se dedica a la promoción y respeto de los derechos de propiedad intelectual y a lucha contra la piratería, a través del apoyo a las actividades y programas desarrollados por la DINAPI. En sentido similar, el art. 153.j) del Decreto Legislativo 822, de 23 de abril de 1996, Ley sobre el Derecho de Autor de Perú, dispone que las entidades de gestión colectiva pueden destinar hasta un $10 \%$ de su recaudación neta, una vez deducidos los gastos administrativos, para satisfacer fines sociales y culturales, lo que significa que parte de la cuantía recaudada por UNIMPRO (que incluye lo ingresado en concepto de compensación por copia privada) se destine a estos propósitos. Así también lo establece el art. $6.2^{\circ} .3$ del Reglamento de Distribución de dicha entidad. Se trata de un régimen muy similar al contenido en España, donde se prevé que un porcentaje de lo recaudado por compensación por copia privada se dedique a la promoción de actividades y servicios en beneficio de los miembros de las entidades de gestión colectiva, así como a la

\footnotetext{
${ }^{1119}$ Entiéndase AIE Paraguay, entidad encargada de la gestión de la recaudación de la remuneración en este país.
} 
realización de actividades de formación y promoción de autores y artistas, intérpretes y ejecutantes (art. 155.2 TRLPI) ${ }^{1120}$.

Sin embargo, no se observan disposiciones similares en las leyes de Ecuador y República Dominicana.

Otro aspecto a resaltar es que algunas leyes estudiadas establecen sanciones específicas frente al impago de la compensación por copia privada. Así pues, la Ley de Propiedad Intelectual ecuatoriana establece en su art. 107 que la falta de pago de la remuneración compensatoria será sancionada con una multa equivalente al trescientos por ciento de lo que se debió pagar, sin perjuicio, además, de que cautelarmente se permite retirar del comercio los soportes susceptibles de incorporar una fijación sonora o audiovisual o los equipos reproductores que no hayan pagado la remuneración compensatoria. La legislación dominicana, por su parte, prevé en el art. 5 del Decreto No. 548-04, de 17 de junio de 2004, la imposición de una sanción administrativa, de conformidad con los arts. 187 de la Ley No. 65-00, de 21 de agosto de 2000, sobre Derecho de Autor y los arts. 107, 115, 116, y 117 del Reglamento No. 362-01, de 14 de marzo del 2001, sin perjuicio de las acciones judiciales correspondientes y de las medidas cautelares que se dicten para retirar del comercio los bienes y equipos objeto de la misma, hasta tanto se efectúe la cancelación de la remuneración respectiva. En el resto de los casos, donde ninguna sanción administrativa se establece, la falta de previsión legal no excluye la posibilidad de que se condene a los deudores de esta compensación al pago, ejercitando las acciones judiciales que, en cada caso, establecen los diferentes ordenamientos jurídicos.

En fin, debe señalarse que no existen en las leyes de derechos de autor de Ecuador, Paraguay, Perú y República Dominicana normas que establezcan o definan los posibles efectos de la imposición de medidas tecnológicas de protección del copiado sobre la compensación por copia privada ${ }^{1121}$. Sensu contrario, la ley española sí

${ }^{1120}$ Vid. supra Capítulo 5, epígrafe VIII, apartado 3.

${ }^{1121}$ La posibilidad de que los titulares de derechos implementen medidas tecnológicas de restricción del copiado está prevista expresamente en el art. 25 de la Ley de Propiedad Intelectual de Ecuador y en el art. 34 de la Ley de Derechos de Autor y Derechos Conexos de Paraguay. 
evidencia esta relación cuando, entre los criterios a considerar para la determinación de los equipos, aparatos y soportes sujetos al pago de la compensación, las cantidades que los deudores deberán abonar por este concepto a los acreedores y la distribución de dicha compensación entre las distintas modalidades de reproducción, instituye el de "la disponibilidad, grado de aplicación y efectividad de las medidas tecnológicas [...] y su impacto en las reproducciones realizadas al amparo del límite legal de copia privada" [art. 25.5.a). $6^{\circ}$ del TRLPI] ${ }^{1122}$.

Tampoco estos países prevén en sus ordenamientos jurídicos mecanismos específicos para garantizar que prevalezca el límite de copia privada sobre la aplicación de medidas tecnológicas por parte de los titulares de derechos de autor y derechos conexos, ni sobre la prohibición de eludir estas medidas, razón de peso para que, ante la aplicación de medidas tecnológicas de control del acceso a la obra o control del copiado, se elimine, o al menos se module, la cuantía de la compensación.

Ahora bien, lo cierto es que pese a la existencia de un marco general de regulación de la compensación equitativa por copia privada o personal en los cuatro países a los que se ha estado haciendo alusión, en la práctica, la recaudación efectiva de esta compensación entre los titulares de derechos, acreedores de la misma, no siempre se hace efectiva o tiende a decaer, a excepción de Paraguay, donde la Memoria de AIE Paraguay, del año $2016^{1123}$, muestra un crecimiento histórico, con un aumento del $300 \%$ con relación al año anterior.

Según esta Memoria, el aumento se debe a que, tras la derogación del Decreto 6780/2011 de Copia Privada (norma que había dado lugar a diversas acciones de inconstitucionalidad y había provocado una sustancial disminución de la

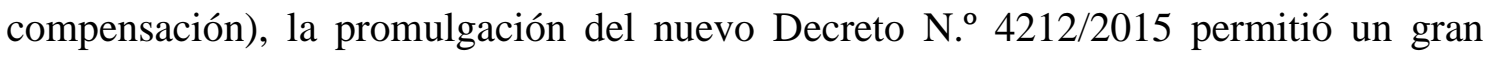
incremento de la recaudación, debido a la inclusión de nuevos soportes y equipos sujetos al pago del canon. Así pues, la evolución ha sido muy significativa, pasando de

${ }^{1122}$ Vid. Supra Capítulo 5, epígrafe VII, apartado 2.2.5.

1123 Disponible en: http://aieparaguay.org.py/wp-content/uploads/2017/06/Revista-AIE-2017.pdf (consultada: 15.12.2017). 
recaudarse 1.153.605.027,00 guaraníes en 2015 a 4.696.995.846,00 guaraníes en $2016^{1124}$.

En Perú, por su parte, la última Memoria publicada por UNIMRO ${ }^{1125}$ que se ha podido consultar es la relativa al año 2015. Sin embargo, en este caso los datos obtenidos no son alentadores, pues se aprecia una evidente disminución de la recaudación, que experimenta una caída de 68.021,23 soles, recaudados en 2014, a $19.846,46$ soles, recaudados en $2015^{1126}$.

En Ecuador, sin embargo, esta compensación no se hace efectiva. ENRUCOPI, entidad encargada de la gestión en Ecuador, ni siquiera publica sus balances anuales conforme establece el art. 114 de su Ley de Propiedad Intelectual, ni tiene una página web habilitada que muestre el resultado de su gestión. A su vez, el último comunicado aclaratorio relativo a la remuneración compensatoria por copia privada hecho público por el IEPI data de diciembre de 2013 y anuncia, desde entonces, que el organismo trabaja en un proyecto que reglamentará cómo se va a distribuir e implementar esta remuneración, pero aún no existe la misma ${ }^{1127}$.

Similar es el caso de República Dominicana. Las distintas entidades encargadas de la gestión de los derechos de autor y derechos conexos en el país gestionan otros derechos distintos a la remuneración equitativa por copia privada. En efecto, las SGACEDOM y SODIMPRO gestionan derechos derivados de actos de comunicación pública de obras musicales, con lo cual, no gestionan el cobro de remuneración para uso personal contemplada legalmente. La última Memoria publicada por SGACEDOM ${ }^{1128}$ pone de manifiesto que los rubros distribuidos en 2015 provienen de derechos generales y música en vivo, sin ninguna referencia a la recaudación por copia privada. En efecto, su gestión va encaminada a la recaudación derivada de la comunicación pública de la

\footnotetext{
${ }^{1124}$ Vid. Anexo 9.

${ }^{1125}$ Disponible en http://www.unimpro.org/sitio/comunicacion/memorias/ (consultada: 20.12.2017).

${ }^{1126}$ Vid. Anexo 10.

1127 Cit.

1128 Disponible en: file:///D:/mcmcloudmedia/Cosas\%20Escritorio\%20PC\%20Casa\%2004-112017/Am\%C3\%A9rica\%20Latina\%20\%20\%C3\%BAltima\%20actualizaci\%C3\%B3n\%20de\%20la\%20ca rpeta/Am\%C3\%A9rcia\%20Latina/Rep\%C3\%BAblica\%20Dominicana/memoria-sgacedom-2015.pdf (consultada: 14.12.2017).
} 
música en hoteles, espectáculos, radiodifusión, restaurantes y otros locales. En el caso de la Memoria publicada por SODINPRO, relativa a la gestión del año $2016^{1129}$, tampoco se hace mención alguna a ingresos por copia privada. Únicamente contempla ingresos derivados de la comunicación pública, por radiodifusión y por cable. La SODAIE, por su parte, se encarga de la gestión colectiva de los derechos conexos al derecho de autor correspondientes a los artistas intérpretes y ejecutantes, pero ningún dato publicado en su página web u otras publicaciones revela que se encargue de la gestión de la remuneración por copia privada que establece la ley. Finalmente, EGEDA Dominicana centra su gestión en algunas modalidades del derecho de comunicación pública de obras audiovisuales, tales como la proyección, exhibición, transmisión y retransmisión.

\section{BREVE EXAMEN DE LA SITUACIÓN ACTUAL DE ALGUNOS PAÍSES EN LOS QUE NO ESTÁ AUTRIZADA LA COPIA PRIVADA}

\section{Argentina}

La ley que regula el régimen legal de la propiedad intelectual en Argentina (Ley $\mathrm{N}^{\circ} 11.723$, de 28 de septiembre) data del año 1933, lo que explica que, en el momento de su promulgación, a falta de aparatos tecnológicos que facilitaran la reproducción de obras impresas, musicales o audiovisuales, no se contemplara el límite de copia privada. A día de hoy, sin embargo, el desarrollo tecnológico ha masificado la capacidad de reproducción, haciendo accesible la copia a un sinnúmero de personas mediante la utilización de procedimientos diversos, pese a lo cual, para la legislación argentina, la reproducción para uso privado de las obras literarias, artísticas y científicas continúa siendo una actividad ilícita, toda vez que no queda amparada en las limitaciones al derecho de autor que contempla la citada ley.

1129 Disponible en: http://sodinpro.org/wp-content/uploads/2017/03/memorias-2016.pdf (consultado:
14/12/2017). 
Consecuentemente, la reproducción de una obra con fines privados y sin ánimo de lucro sigue siendo una utilización que requiere de autorización, puesto que cae dentro de la órbita de las facultades que la ley reconoce al titular de derechos de autor de autorizar o prohibir la reproducción, conforme se deriva del art. 2. En efecto, este precepto dispone: "El derecho de propiedad de una obra científica, literaria o artística comprende para su autor la facultad de [...] reproducirla en cualquier forma”.

A su vez, como contrapartida, esta ley reprime con la pena establecida en el art. 172 del Código Penal a quien de cualquier manera o en cualquier forma defraude los derechos de propiedad intelectual que la ley reconoce, considerando como actos de defraudación, entre otros, la edición, venta o reproducción por cualquier medio o instrumento, de una obra inédita o publicada sin autorización de su autor o derechohabientes [art. 72.a) en relación con su art. 71]. No obstante, en la práctica judicial penal existen ejemplos en los que no se ha determinado la existencia de infracción penal alguna por la fotoduplicación de obras literarias efectuadas para uso personal, sin ánimo de lucro y con destino al estudio, la investigación o la docencia. Sin embargo, la eventual exoneración de responsabilidad a quien realiza una copia para uso privado no significa la legalidad de esta práctica.

Debe destacarse que, no sin detractores, se han impulsado varios proyectos legislativos a fin de incorporar la compensación equitativa por copia privada en Argentina y, con ello, lograr el reconocimiento de esta excepción en dicho país ${ }^{1130}$. Estos proyectos han sido impulsados desde el año 2008, aunque hasta la fecha ninguno ha resultado aprobado.

El último de ellos fue tramitado por el Senado en el año 2010, mediante expediente S-3732/10 y enviado al archivo el 26 de marzo de 2012, luego de que caducara el 29 de febrero de $2012^{1131}$. En síntesis, como se describe en sus

1130 Información de la página web del Senado de Argentina, disponible en: http://www.senado.gov.ar/parlamentario/parlamentaria/avanzada (consultada: 29.09.2017).

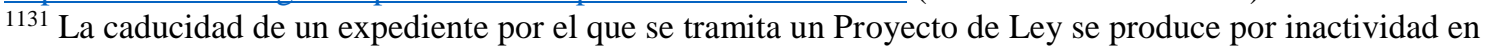
la tramitación del mismo, de acuerdo a las distintas circunstancias que informa la Ley 13.640, de 30 de septiembre de 1949 (Boletín Oficial, 5 de noviembre de 1949). Sobre el trámite parlamentario vid. Ficha 
fundamentos, "el proyecto busca el más adecuado equilibrio entre los derechos de propiedad intelectual y el uso de la tecnología a fin de evitar que su uso indebido genere perjuicios injustificados". Y adiciona “[...] no debe olvidarse que la legislación vigente no permite la copia privada que, como tal, constituye un uso indebido que quedará legitimado con la excepción que reconoce el presente proyecto"1132.

En definitiva, dicho Proyecto de Ley ha sido un intento frustrado por legalizar la copia privada de las obras dramáticas, musicales y audiovisuales en los términos siguientes:

“ARTICULO 1: Las obras dramáticas, musicales y audiovisuales, incluyendo las cinematográficas y los fonogramas, pueden ser reproducidas por una persona física sin la necesaria autorización de sus titulares, siempre que se realice una única copia y la misma:

(I) se efectúe para uso privado y personal del copista;

(II) no sea objeto de utilización colectiva ni lucrativa;

(III) se efectúe a partir de un ejemplar legítimamente adquirido, o de un acto de comunicación al público debidamente autorizado por los respectivos titulares de derechos involucrados.

El alcance de esta excepción al derecho exclusivo de reproducción es de interpretación restrictiva a los casos previstos en esta ley y en ningún caso su ejercicio podrá extenderse a otros usos, ni afectar la normal explotación de la obra, ni causar un perjuicio injustificado a los intereses legítimos de los titulares de derechos.

Las eventuales medidas tecnológicas de protección eficaz adoptadas por los titulares de derechos sobre las obras comprendidas serán plenamente válidas sin perjuicio de la excepción establecida en el presente artículo, quedando incluidas dentro de las mismas las tecnologías, dispositivos y componentes que de acuerdo con su normal funcionamiento están destinadas a impedir o limitar actos no autorizados".

Cabe significar que en dicho Proyecto se establecía un "derecho de remuneración" a favor de los autores, los artistas intérpretes o ejecutantes, los productores de fonogramas y los productores de obras audiovisuales [art. 2 en relación con el art. 4.b)].

resumen oficial disponible en: http://www.senado.gov.ar/parlamentario/comisiones/verExp/3732.10/S/PL (consultada: 29.09.2017).

1132 Puede consultarse el texto original del proyecto http://www.senado.gov.ar/parlamentario/comisiones/verExp/3732.10/S/PL (consultado: 29.09.2017). 
Instituía como deudores de la remuneración a los fabricantes o importadores de soportes, aparatos o elementos aptos para la reproducción, así como también a los distribuidores, mayoristas y minoristas de los mencionados soportes, aparatos o elementos, conjuntamente con los deudores que se los hubieren suministrado [art. 4.a)]. Además, preveía la gestión colectiva de esta compensación (art. 6) y precisaba los equipos, aparatos y soportes materiales de reproducción sujetos al pago de la remuneración, así como el importe a satisfacer por cada deudor por cada uno de ellos (art. 12), sin perjuicio de la posibilidad de ampliar y/o modificar los dispositivos gravados y sus correspondientes tarifas por el Poder Ejecutivo de la Nación (art. 5).

En definitiva, el texto seguía unas pautas similares a las presentes en otras legislaciones del entorno latinoamericano en la configuración del límite de copia privada y la correspondiente compensación, mostrando también sus puntos coincidentes con la legislación española. De hecho, los propios considerandos del proyecto advertían de la incidencia de otras orientaciones legislativas al respecto como un referente para dar impulso a la iniciativa legislativa comentada. Sin embargo, su falta de aprobación ha mantenido en vigor la Ley $\mathrm{N}^{\circ} 11.723$ y, consecuentemente, la copia privada queda sin amparo legal en la legislación argentina.

\section{Chile}

La Ley chilena sobre Propiedad Intelectual, Ley $\mathrm{N}^{\circ} 17.336$, de 28 de agosto de 1970, constituye otro ejemplo de leyes latinoamericanas que no consagran el límite de copia privada dentro de su catálogo de limitaciones y excepciones al derecho de autor.

En cambio, bajo su Título III, denominado "Limitaciones a los derechos de autor y a los derechos conexos" contiene una amplia enumeración de otras excepciones, entre ellas algunas específicamente relacionadas con el derecho de reproducción. Por ejemplo, se encuentran, la reproducción de una obra lícitamente publicada en favor de personas con discapacidad (art. 71.C); la reproducción de obras de arquitectura por medio de la fotografía, el cine, la televisión y cualquier otro procedimiento análogo, así como la publicación de las correspondientes fotografías en diarios, revistas y libros y textos destinados a la educación, siempre que no esté en colección separada, completa o parcial (art. 71.F, párrafo $1^{\circ}$ ); la reproducción mediante la fotografía, dibujo o cualquier 
otro procedimiento, de monumentos, estatuas $\mathrm{y}$, en general, las obras artísticas que adornan permanentemente plazas, avenidas y lugares públicos (art. 71.F, párrafo $2^{\circ}$ ); la reproducción por bibliotecas y archivos que no tengan fines lucrativos, de obras que no se encuentren disponibles en el mercado, para determinados fines concretos previstos en el precepto (art. 71.I); entre otras.

A su vez, dentro de este conjunto de limitaciones y, sin perjuicio de lo sostenido en cuanto a la falta de consagración de una excepción genérica que autorice la reproducción con fines privados y sin ánimo de lucro, interesa destacar dos supuestos que, si bien tienen un marco más restringido de aplicación que aquel que normalmente incluye la copia privada como excepción, legitiman la realización de copias con la finalidad de uso personal. Así, por una parte, está la limitación contenida en el art. 71.D, párrafo $1^{\circ}$, que permite que las lecciones dictadas en instituciones de educación superior, colegios y escuelas, puedan ser anotadas o recogidas en cualquier forma por aquellos a quienes van dirigidas, si bien no permite su publicación, total o parcial, sin autorización de sus respectivos autores. Por otra parte, el art. 71.J autoriza a que las bibliotecas y archivos que no tengan fines lucrativos puedan efectuar copias de fragmentos de obras que se encuentren en sus colecciones, a solicitud de un usuario de la biblioteca o archivo exclusivamente para su uso personal; copias que sólo podrán ser realizadas por la respectiva biblioteca o archivo. En ambos casos, estos actos pueden ser realizados sin la autorización previa del titular de derechos y sin pago de remuneración $\operatorname{alguna}^{1133}$.

En cuanto al primer supuesto, la similitud con la copia privada la determina la posibilidad de realizar una reproducción de las lecciones dictadas en el seno de instituciones educativas por los alumnos. La diferencia radica, sin embargo, en que la reproducción se circunscribe a dicho ámbito institucional y personal, sin extenderse a cualquier otra persona que tenga interés en reproducir la lección para uso personal y sin

\footnotetext{
${ }^{1133}$ En España, el TRLPI prevé una excepción al mismo efecto, contemplada en su art. 31.7. Señala dicho precepto: "Los titulares de los derechos de autor no podrán oponerse a las reproducciones de las obras, cuando aquéllas se realicen sin finalidad lucrativa por los museos, bibliotecas, fonotecas, filmotecas, hemerotecas o archivos de titularidad pública o integradas en instituciones de carácter cultural o científico y la reproducción se realice exclusivamente para fines de investigación o conservación".
} 
ánimo de lucro. En cuanto al segundo, la copia sólo se permite de fragmentos de obras integrantes de la colección de la biblioteca o archivo, pero se impide que el usuario realice copias, quedando autorizada únicamente la copia efectuada por la biblioteca o archivo.

Cabe añadir que el art. 71. $\mathrm{N}$ autoriza la copia de un programa de ordenador (“programa computacional” según la expresión del texto legal), efectuada por su tenedor, siempre que esta copia sea esencial para su uso, o para fines de archivo o respaldo y no para otros ${ }^{1134}$.

\section{Uruguay}

Tampoco el ordenamiento jurídico uruguayo reconoce una excepción legal al derecho de reproducción del autor en favor de la copia privada.

La Ley sobre Derechos de Autor de Uruguay, Ley No 9.739, de 17 de diciembre de 1937, es también una legislación envejecida, forjada en una época donde la copia privada tenía escasa o ninguna repercusión, lo que explica que no prevea nada sobre este límite al derecho de autor.

Inquieta que, a día de hoy, la realización de copias de obras protegidas por la propiedad intelectual, realizadas sin ánimo de lucro y para uso personal o privado, siga siendo considerada una práctica ilegal. Sin embargo, hay que señalar que se encuentra en trámite un Proyecto de Ley que tiene, entre sus propósitos, legalizar la práctica de la copia para uso personal en el país. Este Proyecto ha sido fruto de la iniciativa impulsada por la Federación de Estudiantes Universitarios del Uruguay (FEUU), fundamentalmente dirigida a facilitar el acceso a materiales de estudios, a raíz de que

\footnotetext{
${ }^{1134}$ En sentido similar al art. 71.Ñ de la ley chilena sobre Propiedad Intelectual, el art. 100 del TRLPI establece límites a los derechos del titular de un programa de ordenador, entre ellos, para la reproducción o transformación de un programa de ordenador incluida la corrección de errores, cuando dichos actos sean necesarios para la utilización del mismo por parte del usuario legítimo, con arreglo a su finalidad propuesta (salvo disposición contractual en contrario) y para la realización de una copia de seguridad por parte de quien tiene derecho a utilizar el programa no podrá impedirse por contrato en cuanto resulte necesaria para dicha utilización, actos para los que se podrá prescindir de autorización.
} 
fueran cerrados varios centros de fotocopiado cercanos a la Facultad de Derecho de la Universidad de la República (Montevideo) debido a la incoación de causas penales contra sus dueños por violación de los derechos de autor, en el año 2013. A partir de entonces, comenzó a reivindicarse por el estudiantado universitario un derecho a realizar fotocopias de los libros de texto y otros materiales para el estudio que culminó con la presentación del referido Proyecto de Ley ante el Senado, el 1 de julio de $2015^{1135}$. Este Proyecto fue aprobado por unanimidad por la Cámara de Senadores el 13 de abril de 2016, pero aún está pendiente de su consideración por la Cámara de Diputados $^{1136}$.

En particular, el art. 4 del Proyecto de Ley contiene la modificación del art. 45 de la Ley 9.739, de 17 de diciembre de 1937, en el sentido de agregar varios numerales al precepto, entre ellos, el numeral $15^{\circ}$ en el que se autoriza "la reproducción hecha por cualquier medio, sin autorización del autor o titular, de una obra o prestación protegida, ordenada y obtenida por una persona física, en un solo ejemplar para su uso personal y sin fines de lucro”. El Proyecto no prevé, en cambio, compensación alguna.

Esta propuesta es peligrosa, ya no sólo porque no contempla una compensación frente a la copia privada -realidad que se repite en los países del entorno- sino también porque tampoco matiza si la fuente de la que proviene la copia ha de ser lícita, lo que una vez más da lugar a la legalización e incremento de la piratería, lo cual tampoco es extraño a la mayoría de las leyes estudiadas.

\footnotetext{
1135 Pueden consultarse los detalles del trámite parlamentario en: https://parlamento.gub.uy/documentosyleyes/ficha-asunto/125292/tramite. El Proyecto de Ley está disponible en: http://proeva.edu.uy/files/2017/05/Proyecto-de-Ley-aprobado-por-Senadores-abril2016.pdf (consulados: 30.09.2017).

1136 Vid., por todas, la noticia titulada "Derecho a Estudiar. Senado aprobó proyecto de la FEUU", publicada el 13 de abril de 2016 en el portal de la Universidad de la República (Montevideo, Uruguay), disponible en: http://www.universidad.edu.uy/prensa/renderItem/itemId/38777 (consultada: 30.09.2017).
} 


\section{CUBA. LA PROTECCIÓN DEL DERECHO DE AUTOR Y SU SUBORDINACIÓN A LOS INTERESES SOCIALES Y CULTURALES}

Cuba se define en el art. 1 de su Constitución, proclamada el 24 de febrero de 1976, como un Estado socialista ${ }^{1137}$ y esta connotación impregna la vida política, económica, social y cultural de la nación.

Por mandato constitucional, el Estado asegura "[...] el avance educacional, científico, técnico y cultural del país" [art. 9.a) de la Constitución]. Asimismo, garantiza "[...] que no haya persona que no tenga acceso al estudio, la cultura y el deporte" [art. 9.b) de la Constitución].

A su vez, el Estado "orienta, fomenta y promueve la educación, la cultura y las ciencias en todas sus manifestaciones", para lo cual "fundamenta su política educacional y cultural en los avances de la ciencia y la técnica, el ideario marxista y martiano, la tradición pedagógica progresista cubana y la universal; [...] se ocupa de fomentar y desarrollar la educación artística, la vocación para la creación y el cultivo del arte y la capacidad para apreciarlo; [...] estimula y viabiliza la investigación y prioriza la dirigida a resolver los problemas que atañen al interés de la sociedad y al beneficio del pueblo; [...] defiende la identidad de la cultura cubana y vela por la conservación del patrimonio cultural y la riqueza artística e histórica de la nación y [...] promueve la participación de los ciudadanos a través de las organizaciones de masas y sociales del país en la realización de su política educacional y cultural” (art. 39 de la Constitución).

Todos estos postulados han marcado el devenir de las políticas culturales de la Revolución, entendida como el proceso de cambios políticos, económicos y sociales seguidos luego de que Cuba derrocara la dictadura de Fulgencio Batista el 1 de enero de 1959. A propósito, como escribiera Graziella PogolotTi: "Proyectada hacia el mundo exterior, la isla, hasta entonces circunscrita a su condición periférica, se convertía en

${ }^{1137}$ El art. 1 de la Constitución de la República de Cuba, de 24 de febrero de 1976, proclama: "Cuba es un Estado socialista de trabajadores, independiente y soberano, organizado con todos y para el bien de todos, como república unitaria y democrática, para el disfrute de la libertad política, la justicia social, el bienestar individual y colectivo y la solidaridad humana". 
imagen simbólica de una nueva realidad política con repercusiones en el campo

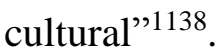

En este contexto, el papel del Estado como garante de la cultura determinó la conformación de un espacio social de difusión cultural, propiciado por la Constitución socialista de 1976, pero generado desde los albores mismos del triunfo de la Revolución y especialmente desarrollado en la década de los sesenta, con el surgimiento de las principales instituciones rectoras de la política cultural del país. Algunas de estas instituciones datan incluso del propio año 1959, como la Casa de las Américas, encargada de la promoción, desde Cuba, de la literatura y las artes en el continente americano; el Instituto Cubano del Arte e Industria Cinematográficos, baluarte de la cinematografía cubana; o la Imprenta Nacional de Cuba, precursora de la Editora Nacional y del Instituto Cubano del Libro. Sin embargo, otras, dan continuidad a los primeros pasos de este proceso institucional, entre las cuales se encuentra el Consejo Nacional de Cultura, fundado en enero 1961 como gestor principal de la política cultural del país ${ }^{1139}$; la Unión Nacional de Escritores y Artistas de Cuba, nacida en el año 1961 como estandarte de los valores de los artistas y escritores cubanos; o la Escuela Nacional de Arte, forjada en 1962, y que hasta hoy es pilar de la enseñanza artística en artes plásticas, danza, música y teatro.

También marcó el desarrollo social y cultural cubano el proceso de institucionalización de la enseñanza en Cuba. Este proceso estuvo marcado, especialmente, por la llamada Campaña de Alfabetización ${ }^{1140}$, una iniciativa encaminada a erradicar el analfabetismo de los niños, jóvenes y adultos cubanos y

${ }^{1138}$ PogOlotTi, G., "Los polémicos Sesenta" (Prólogo a la antología de ensayos Polémicas culturales de los 60), La Jiribilla, Año V, La Habana, 2007, disponible en línea: http://epoca2.1ajiribilla.cu/2007/n300_02/300_46.html (consultado: 16.09.2017).

${ }^{1139}$ Sustituyó a la Dirección de Cultura del Ministerio de Educación y lideró la política cultural del país hasta que el Ministerio de Cultura asumiera sus funciones en 1976.

${ }^{1140}$ La Campaña de Alfabetización se inicia en 1961 como resultado de la declaración de iniciación del Plan Urgente de Alfabetización de Cuba, el 17 de febrero de 1959. Para más detalles sobre el desarrollo de esta etapa vid. PÉREZ-CruZ, F., "La Campaña Nacional de Alfabetización en Cuba", Varona, núm. 53, 2011, pp. 16-18. 
democratizar la enseñanza escolar en el país. Como resultado, se logró la proclamación de Cuba como "Territorio Libre de Analfabetismo" a finales del año $1961^{1141}$.

En tales circunstancias, se va ampliando -al tiempo que se consolida- la creación literaria y artística cubana, haciéndose necesaria una legislación de derechos de autor propia, eco de los nuevos valores y principios revolucionarios. Es así como aparece en el ordenamiento jurídico cubano la Ley No. 14, de 28 de diciembre de 1977, Ley de Derecho de Autor (vigente en la actualidad), luego de un período de inactividad legislativa en la materia, pues pocas normas relacionadas con el derecho de autor se dictaron con posterioridad al triunfo revolucionario. Sólo se había promulgado la Ley No. 860, publicada en la Gaceta Oficial, número anual 154 de 11 de agosto de 1960, por la cual se creó el Instituto Cubano de Derechos Musicales (ICDM), con el fin de salvaguardar los derechos de los autores de obras musicales y dramático-musicales y como consecuencia de la cual se creó la Sociedad Cubana de Autores Musicales (SCAM), con funciones propias de una entidad de gestión colectiva de derechos de autor. También, la Resolución No. 269, de 30 de agosto de 1966, del Presidente del Consejo Nacional de Cultura, por la que se creó la Oficina de Derechos Musicales y Propiedad Intelectual, con funciones bastante homólogas a las del ICDM, lo que provocó que este organismo terminara por extinguirse. Por lo demás, continuaban vigentes, al menos formalmente, la LPI española de 1879 y su Reglamento, de 3 de septiembre de 1880, aunque con algunas modificaciones.

En el plano internacional, Cuba había ratificado la Convención de Washington sobre Derecho de Autor de 1946, en 1955 ${ }^{1142}$; y había firmado la Convención Universal sobre Derecho de Autor en $1957^{1143}$.

\footnotetext{
${ }^{1141}$ Emblemáticas fueron las palabras de Fidel Castro en su discurso de 22 de diciembre de 1961 al decir: "Vamos a proceder a izar la bandera con la que el pueblo de Cuba proclama ante el mundo que Cuba es ya Territorio Libre de Analfabetismo (Aplausos)", publicado por el Departamento de Versiones Taquigráficas del Gobierno Revolucionario y disponible en línea: http://www.cuba.cu/gobierno/discursos/1961/esp/f221261e.html (consultado 26.09.2017).

$\begin{array}{ccccc}1142 & \text { Información } & \text { disponible } & \text { WIPO }\end{array}$ http://www.wipo.int/wipolex/es/other_treaties/parties.jsp?treaty_id=378\&group id=21 (consultada el 28.09.2017).
} 
La Ley No. 14/1977, Ley de Derecho de Autor, en aquello que podría considerarse su exposición de motivos, formulada a modo de "Por Cuantos" en la primera parte del texto legal ${ }^{1144}$, deja patente la postura del Estado acerca del papel que deben desempeñar los valores culturales y la creación intelectual y científica. Al respecto, manifiesta claramente su posición a favor de que estos se proyecten en beneficio universal, a la vez que reconoce la necesidad de garantizar jurídicamente el ejercicio del derecho de autor, tanto en su vertiente moral como patrimonial, sin perjuicio de su adecuación al interés supremo de la sociedad. Respecto a esto último, proclama el último de los "Por Cuanto" de la ley:

"El interés supremo de la sociedad por el desarrollo y la difusión científica, técnica, educacional y cultural en general, constituye un principio de nuestra Revolución al que el derecho de autor tiene necesariamente que adecuarse".

En línea con lo anterior, dispone el art. 3 de la Ley No. 14/1977:

"La protección al derecho de autor que se establece en esta Ley está subordinada al interés superior que impone la necesidad social de la más amplia difusión de la ciencia, la técnica, la educación y la cultura en general. El ejercicio de los derechos reconocidos en esta Ley no puede afectar estos intereses sociales y culturales"1145.

Este precepto ilustra claramente la relación de subordinación que establece la ley de derechos de autor cubana entre la protección de los derechos de autor y la protección de los intereses socioculturales. Dicho de otro modo, los intereses sociales y culturales prevalecen frente a las prerrogativas que otorga la ley a los titulares de derechos de autor y derechos conexos. Consecuentemente, ello no puede sino conducir a reflexionar sobre la influencia que ejerce el precepto citado sobre la configuración del sistema legal de límites a estos derechos en el ordenamiento jurídico cubano.

\footnotetext{
1143 Información en disponible WIPO Lex: http://www.wipo.int/wipolex/es/other_treaties/parties.jsp?treaty_id=208\&group_id=22 (consultada el 28.09.2017).

${ }^{1144}$ En Cuba, las leyes exponen por medio de "Por Cuantos", los motivos que llevan a su aprobación, siendo su contenido equivalente a lo que en las leyes españolas sería el Preámbulo o la Exposición de Motivos.

1145 A propósito de dicho precepto, destaca Álvarez NaVARrete, L., Derecho de ¿Autor? El debate de hoy, Editorial de Ciencias Sociales, La Habana, 2006, p. 269, la importancia que ha supuesto para el logro de los resultados educacionales y culturales en Cuba.
} 
Así, el Capítulo VII de la Ley No. 14/1977, titulado "De las limitaciones al derecho de autor", contiene varios preceptos que reconocen límites a los derechos del autor, al igual que las disposiciones que integran el Capítulo VI a las cuales, sin embargo, la ley denomina "De las licencias para la utilización de las obras", aunque claramente constituyan límites a estos derechos.

En efecto, en el Capítulo VI se prevén situaciones donde la utilización de la obra es libre y gratuita, aunque subordinada a la autorización de la "autoridad competente". Así sucede en el art. 36, que prevé que la autoridad competente puede autorizar la utilización de una obra científica, técnica, artística, literaria o educacional, en cualquiera de las formas autorizadas por la ley, a favor de una institución oficial, entidad, empresa u organización social o de masas de un país que no se encuentre en condiciones de adquirir determinado derecho de utilización sobre la misma, siempre que haya sido creada por un ciudadano cubano; que su distribución o utilización se realice exclusivamente dentro del territorio del Estado a cuya institución oficial, entidad, empresa u organismo social o de masas se le haya otorgado la licencia; que se haga constar el nombre del autor y que se respete la integridad de la obra. Por mandato del propio precepto no cabe la cesión de esta licencia. Por su parte, el art. 37 -que integra también el Capítulo VI- permite que, por razones de interés social, la autoridad competente conceda una licencia para reproducir y publicar en forma impresa $u$ otra análoga una obra publicada en la misma forma, o para traducirla y editarla, o para difundirla por la radio, la televisión u otros medios sonoros o visuales, en su idioma original o en traducción, o para reproducir en forma audiovisual toda fijación de la misma naturaleza. En estos casos, no será necesaria la autorización del autor ni el pago de una remuneración, siempre "a) que la obra sea necesaria para el desarrollo de la ciencia, la técnica, la educación o la superación profesional; b) que su distribución o difusión sea gratuita o, en caso de venta de materiales impresos, ésta se realice sin ánimo de lucro; y c) que su distribución o difusión se realice exclusivamente en el territorio del Estado cubano". No obstante, lo cierto es que estas limitaciones no tienen aplicación práctica actualmente, a falta de una norma que reglamente a quién corresponde esta facultad.

Por su parte, los arts. del 38 al 41 integran el contenido del Capítulo VII. De ellos, el art. 41 reserva la declaración de obras como patrimonio estatal, mientras que el art. 39 
hace una aclaración en cuanto a la posibilidad de utilizar las obras, bajo los límites establecidos en el precepto que le precede, tanto en su idioma original como traducidas al español. Ahora bien, la relación de aquellas conductas específicas que restringen la facultad exclusiva del titular de derechos de autor de autorizar o prohibir la utilización de sus obras, se encuentra contenida en los arts. 38 y 40 de la ley autoral.

El art. 38 contempla utilizaciones libres y gratuitas, es decir, utilizaciones que pueden realizarse sin el consentimiento del autor y sin remuneración al mismo, pero con obligada referencia a su nombre y a la fuente de la obra, siempre que ésta sea de conocimiento público, y respetando, en todo caso, sus valores específicos. Regula pues, la cita, la utilización de la obra a título de ilustración de la enseñanza, la reproducción de las obras situadas permanentemente en lugares públicos, la representación o ejecución, la reproducción por bibliotecas o centros análogos y los usos con fines informativos de informes, conferencias, debates judiciales, u otras obras del mismo carácter comunicadas o dadas a conocer en público.

En adición, el art. 41 contiene lo que la doctrina denomina licencias legales, es decir, autorizaciones libres pero sujetas a una remuneración establecida por la ley. Específicamente, el precepto autoriza la representación o ejecución en público de una obra; la utilización de una obra literaria como texto de una obra musical; la grabación o ejecución de una obra musical, con o sin letra, y su difusión por cualquier medio; y la grabación y difusión, o ejecución, de fragmentos de una obra musical, con o sin letra, exclusivamente como fondo o presentación musical de programas de radio y televisión, noticieros radiales, televisivos o cinematográficos y presentaciones artísticas. En todos estos casos el precepto exige que la obra esté divulgada, así como que se mencione el nombre del autor y el título de la obra, a no ser que por razones técnicas o de costumbres en la difusión no resulte posible o adecuado.

De esta forma, siguiendo la tradición continental europea, la ley de derechos de autor cubana enumera taxativamente los límites a los derechos de autor en los preceptos citados, que habrán de ser interpretados de forma restrictiva y no serán otros que los enunciados en la propia ley. Sin embargo, el art. 3 establece una limitación más amplia que aquellas expresamente establecidas en los arts. 36 a 41, al subordinar la protección del derecho de autor a los intereses sociales y culturales de la nación. Consecuentemente, cualquier ejercicio de los derechos de autor que impida o restrinja la 
difusión de la ciencia, la técnica, la educación y la cultura en general, quedará vetado y justificará la utilización de la obra con esta finalidad.

La cuestión es quién determina en qué casos se impide o restringe la difusión de la ciencia, la técnica, la educación y la cultura por aplicación de los derechos de autor. Así pues, a falta de previsión legal, se entiende que cualquier labor de ponderación del interés del autor respecto al interés superior social y cultural corresponde a la autoridad competente que conozca del conflicto en cuestión. Al respecto, la solución de conflictos por la violación o incumplimiento de la legislación vigente en Cuba sobre derechos de autor corresponde, por una parte, al Director General del Centro Nacional de Derecho de Autor (CENDA), en virtud de la Resolución No. 156, de 13 de noviembre de 2002, del Ministro de Cultura y, por otra, a los jueces de la Salas de lo Civil y lo Administrativo del Tribunal Provincial Popular competente ${ }^{1146}$.

No es de extrañar una disposición como la del art. 3 en la ley autoral cubana. Su contenido se desprende del propio papel del Estado en la promoción y fomento de la educación y la cultura, en correspondencia, asimismo, con el objeto de la misma. Este objeto no es otro que "brindar la debida protección al derecho de autor en la República de Cuba, en armonía con los intereses, objetivos y principios de nuestra Revolución Socialista", tal y como enuncia su art. 1. Lo mismo puede interpretarse de la formulación de su art. 4.d), que dispone que el autor tiene derecho a recibir una remuneración por la utilización de su obra, pero sujeta a los límites y condiciones que dicha ley y otras normas complementarias establezcan.

Con todo, puede concluirse que el sistema social cubano fundamenta la apertura del sistema de límites a los derechos de autor en el país como garantía del cumplimiento

${ }^{1146}$ El CENDA es el órgano rector de la política de derechos de autor en el país, creado por el Decreto No. 20, de 21 de febrero de 1978, con diversas funciones, entre ellas, la de "contribuir a la aplicación de los planteamientos de la Revolución Cubana de que los valores culturales y la creación intelectual y científica deben ser de beneficio universal, y que todos los pueblos deben tener el más amplio acceso a la cultura y la ciencia"; y la de "velar por la aplicación de la política y la legislación aprobadas en materia de derecho de autor, y someter al Ministerio de Cultura cuantas recomendaciones y proyectos de disposiciones sean necesarios a estos efectos".

El procedimiento para la presentación, el análisis y la solución de estas reclamaciones ante el CENDA se establece por la Resolución No. 162, de 15 de noviembre de 2002, del Ministro de Cultura. 
de los fines sociales y culturales del Estado. Sin embargo, la ley no reconoce, al menos expresamente, otras excepciones más allá de las enunciadas en los arts. 36 a 41, con lo cual, no hay espacio para la aplicación de nuevas excepciones distintas a las enunciadas en la ley, al menos mientras no haya un fin superior de carácter social o cultural que así lo justifique. Consecuentemente, la copia privada no está autorizada y, en correspondencia, tampoco el pago de una compensación al autor por este concepto, pues nada regula la Ley No. 14/1977 al respecto.

Sería conveniente, no obstante que, en aras de dotar de mayor seguridad jurídica a los autores y demás titulares de derechos, así como a los usuarios de las obras, la ley se modificara en el sentido de reconocer un catálogo de límites más amplios acorde ya no sólo con otras experiencias internacionales en la regulación de las excepciones y limitaciones a los derechos de autor, sino también con los avances tecnológicos. Además, los compromisos internacionales asumidos por Cuba en virtud de su adhesión al CB y al Acuerdo sobre los ADPIC justifican la actualización de su legislación en la materia, cuya ley cuenta ya con casi cuatro décadas de vigencia. 


\section{CONCLUSIONES}

PRIMERA. - Para los países de tradición continental o civilista, la propiedad intelectual ha sido una construcción jurídica que ha puesto en su centro al autor, donde la propiedad literaria y artística ha mostrado un fuerte componente moral debido al estrecho vínculo existente entre éste y su obra. Por su parte, la tradición anglosajona, con una postura utilitarista y de acentuación de los derechos patrimoniales, ha buscado establecer condiciones favorables para la producción de las obras y para la prohibición de aquellas conductas que puedan entorpecer el acceso del público a la creación. Ello en modo alguno significa que, en el Derecho continental, no sea también importante instituir espacios de utilización y acceso libre a la creación intelectual. En efecto, la utilidad social de la creación constituye un presupuesto esencial para el reconocimiento de los derechos de propiedad intelectual y, como tal, sirve como fundamento para el establecimiento de límite a estos. Por tanto, en la regulación de la propiedad intelectual no sólo es importante considerar el vínculo entre la obra y el autor, sino también la existencia de otros intereses colectivos, sociales y culturales.

SEGUNDA. - La propiedad intelectual confiere al autor un derecho exclusivo sobre la obra que es, además, oponible frente a terceros y que se manifiesta tanto en una vertiente moral como patrimonial. La naturaleza inmaterial de su objeto de protección, esto es, la creación literaria, artística o científica, que necesariamente ha de exteriorizarse a través de un soporte tangible o intangible, hace de este derecho un derecho de naturaleza peculiar, que se manifiesta en la facultad de autorizar o prohibir la explotación de la obra, siendo, especialmente relevante, el ejercicio del ius prohibendi como forma de impedir que terceros realicen actos de reproducción, distribución, comunicación pública y transformación de ésta sin el consentimiento del titular de los derechos. A través del ejercicio de los derechos patrimoniales, la propiedad intelectual garantiza al autor y demás titulares de derechos un beneficio económico derivado de la explotación de su obra, de acuerdo con el desarrollo tecnológico de cada momento histórico.

Sin embargo, los derechos de explotación no son el único modo en que los titulares de derechos reciben un beneficio o compensación económica por su creación. El desarrollo tecnológico ha tendido a alterar la estructura clásica del sistema de 
propiedad intelectual que garantizaba el ejercicio del ius prohibendi. Por tanto, las leyes contemplan otros derechos de carácter remuneratorio y/o compensatorio, dirigidos a satisfacer los intereses económicos de los titulares de derechos cuando, por diversas razones (información, imposibilidad de control, etc.), no se puede impedir que terceros utilicen la obra o prestación intelectual. Entre estos derechos se encuentra la compensación equitativa por copia privada.

TERCERA. - El derecho de reproducción alcanza paulatinamente su reconocimiento como facultad del autor con la creación de la imprenta y la posibilidad de obtención de ejemplares de la obra. Sin embargo, la noción clásica de este derecho, tradicionalmente relacionada con la idea de multiplicación y de obtención de copias, ha ido evolucionando con el paso de los años y el progreso tecnológico hasta llegar a alcanzar, actualmente, unos contornos mucho más amplios, amparando actos que trascienden de la mera obtención de ejemplares. Coherente con esta evolución, el art. 18 del TRLPI define este derecho como la fijación de la obra en un medio, con independencia de que el resultado sea la obtención de copias o la comunicación de la obra al público.

Los contornos del ejercicio del derecho de reproducción vienen delimitados por diversas excepciones o limitaciones legales que, como tales, han de ser interpretadas con carácter restrictivo. Al respecto, el límite legal establecido en el art. 31.1 del TRLPI resulta especialmente relevante en el contexto de las tecnologías digitales, pues concreta -en sentido negativo- el contenido de este derecho, convirtiéndose en un importante complemento al art. 18 del mismo texto legal, en tanto delimita ciertos actos de reproducción provisionales que, debido a su carácter transitorio y accesorio y a su carente significación económica, devienen lícitos aun sin el consentimiento previo del autor, siempre que tengan por finalidad la comunicación púbica o puesta a disposición de la obra en Internet.

Más allá del límite mencionado, el derecho de reproducción es objeto de otros límites legales que operan como mecanismos de pervivencia del clásico equilibrio de intereses propio de la propiedad intelectual (el de los derechohabientes, por una parte y el de la sociedad, por otro); necesarios -además- considerando que en su regulación confluyen otros derechos fundamentales como el derecho de acceso a la cultura, a la educación y a la información. 
CUARTA. - Es unánimemente aceptado que el desarrollo tecnológico y, en particular, el advenimiento de Internet y de las tecnologías digitales, ha supuesto un gran impacto sobre la propiedad intelectual. Las tecnologías digitales han conllevado una reconfiguración de la protección de los titulares de derechos de autor en cuanto al ejercicio de sus derechos de explotación y a los límites a estos derechos para mantener el justo equilibrio de intereses entre el autor y los beneficiarios de dichos límites.

Así ha sucedido con el límite de copia privada. Su adaptación a los avances tecnológicos ha comportado, inexorablemente, el reconocimiento de una compensación asociada al mismo, dirigida a mitigar los perjuicios económicos sufridos por los titulares de derechos frente al ejercicio masivo e incontrolado de la reproducción de sus obras para uso privado.

No obstante, el reconocimiento legal de dicha compensación no ha estado ligado, propiamente, al desarrollo de las tecnologías digitales, sino que es anterior a la masificación del uso de equipos, aparatos y soportes digitales y de Internet. Con todo, la digitalización ha impuesto una readaptación y perfeccionamiento de los mecanismos legales para garantizar que, al mismo tiempo que se legitima la copia privada, los titulares de derechos de autor reciban una compensación por los perjuicios sufridos como consecuencia de la reproducción de sus obras para uso privado.

QUINTA. - La doctrina del fair use, aplicable en EE.UU, se inscribe dentro de los sistemas de límites abiertos a los derechos de propiedad intelectual y, como tal, es un mecanismo flexible para adaptar los derechos de autor a la evolución del entorno digital. En estos sistemas, el análisis de la existencia de una infracción o no al derecho de autor en virtud de una limitación es casuístico, dejando un amplio margen a la discrecionalidad de los tribunales y, permitiendo, además del análisis de la concurrencia de cada uno de sus factores de manera individual, su evaluación de forma global. Por su parte, los sistemas cerrados de límites, vigentes en España y en los países de América Latina y el Caribe estudiados, por ejemplo, son de más difícil adecuación a un desarrollo tecnológico cambiante, si bien ofrecen mayor seguridad jurídica, pues los límites están fijados legalmente de modo taxativo. Por ello, para modificar dicha estructura cerrada es necesaria la intervención del legislador. 
De conformidad con lo anterior, los continuos cambios tecnológicos que el escenario digital comporta conllevan a plantearse la necesidad de flexibilizar el sistema cerrado de límites, a cuyo fin, la aplicación judicial de la regla de los tres pasos podría contribuir. En su virtud, sería posible admitir como lícitas determinadas conductas no expresamente previstas por el legislador y ampliar el alcance de aquellas ya establecidas, siendo, pues, una manera de "abrir" el sistema cerrado de límites a los derechos de propiedad intelectual para adaptarlo a las circunstancias del desarrollo tecnológico. Esta es una postura que asoma tímidamente en algunas sentencias españolas que abogan por una interpretación más flexible de los límites a los derechos de propiedad intelectual, así como un reclamo, más bien reciente, de algunos profesores e investigadores del área de la propiedad intelectual, que se manifiesta en algunas iniciativas adoptadas en el contexto de la UE.

Bajo esta tendencia, se persigue que el art. 5 de la DDASI opere como una norma semi-abierta que, conjugada con el catálogo de excepciones previstas expresamente en la ley, permita declarar, por vía judicial, determinados usos como no infractores, siempre que respeten la regla de los tres pasos. De esta forma, dicha regla serviría como un mecanismo de apertura de los sistemas cerrados de límites a los derechos de propiedad intelectual.

SEXTA. - En la legislación española en la actualidad el límite de copia privada opera tanto en el entorno analógico como en el digital. Los presupuestos básicos que concretan este límite están establecidos en el art. 31 (apartados 2 y 3) del TRLPI. No obstante, este precepto no puede considerarse de forma aislada, pues debe ser examinado a la luz de otros, en especial, en relación con el art. 25, que regula la compensación equitativa por copia privada y el art. 161 que regula la relación entre los límites a la propiedad intelectual y las medidas tecnológicas de protección.

La regulación del límite de copia privada en la legislación de propiedad intelectual española no ha permanecido invariable, sino que ha sufrido distintas modificaciones con el curso de los años, desde su implementación en el año 1987. Con todo, puede decirse que la modificación del art. 31.2, donde se regula este límite, ha sido menos sustancial que la del art. 25 relativo a la compensación equitativa. 
Este límite conserva, a día de hoy, sus presupuestos básicos, es decir, que la copia se realice con fines privados y que no sea objeto de utilización colectiva ni lucrativa. Además, el art. 31.2 del TRLPI específica que el uso no sea profesional, ni empresarial y que la reproducción se realice a partir de una fuente lícita, sin vulnerar las condiciones de acceso a la obra o prestación. Ahora bien, puede afirmarse que, desde la modificación del TRLPI llevada a cabo por la Ley 21/2014, de 4 de noviembre, los contornos de la copia privada han quedado más reducidos. En efecto, la exigencia de que la copia privada se realice sin asistencia de terceros limita el alcance de la excepción. Esta previsión, que fue introducida por la Ley 21/2014, con la intención de reducir los supuestos de aplicación de la excepción para justificar la exigua asignación presupuestaria destinada a la compensación equitativa, se mantiene en el actual art. 31.2 del TRLPI, pese al retorno al sistema de canon.

También afecta al alcance de este límite la exclusión que del mismo hace el art. 31.3.a) de TRLPI. Se trata de una exclusión injustificada en tanto impide al usuario de servicios interactivos en línea la realización de reproducciones para uso privado. Éste queda sometido a lo dispuesto contractualmente y, por tanto, limitado por la aplicación de medidas tecnológicas que no deberían impedir, sin embargo, la copia privada como límite legal que es a los derechos de propiedad intelectual.

SÉPTIMA. - El reconocimiento legal de los límites al derecho de reproducción debe superar la prueba de los tres pasos del art. 9.2 del CB, prevista en el art. 40.bis del TRLPI español y aplicable al resto de los límites a los derechos de explotación, a tenor del art. 13 del Acuerdo sobre los ADPIC. El límite de copia privada sólo alcanza a superar dicha prueba cuando se establece una compensación equitativa asociada a éste. $\mathrm{Y}$ es que, en efecto, la masificación de la copia a escala privada puede atentar contra la explotación normal de la obra y causar un perjuicio injustificado a los titulares de derechos de propiedad intelectual, únicamente salvable si se consigue que sean compensados, de alguna manera, por los perjuicios que soportan, al no poder autorizar por sí mismos, ni controlar las copias realizadas en el ámbito privado. No obstante, también debe tenerse en cuenta que el establecimiento de una compensación asociada a un límite no siempre justificará una restricción al derecho del autor, pues junto a los intereses patrimoniales conviven los intereses morales y, de atenderse únicamente al 
aspecto patrimonial, se estaría vaciando de contenido su derecho, convirtiendo el derecho del autor en un mero derecho compensatorio o remuneratorio.

Pues bien, aun cuando la compensación por copia privada está regulada por el art. 5.2.b) de la DDASI, en concordancia con su art. 5.5, no existe una definición en el Derecho de la UE. La doctrina del TJUE ha afirmado que se trata de un concepto autónomo del derecho de la UE y que, como tal, ha de ser interpretado de forma uniforme en todos los Estados miembros, siendo, por consiguiente, un concepto que no se define por remisión al Derecho nacional sino conforme al Derecho comunitario, de ahí la importancia de la doctrina del TJUE en su interpretación.

Pese a ello, se echa en falta una regulación más armonizada en los Estados miembros de la UE, más allá de la mera exigencia de la implementación legal de esta compensación en el caso de que se autorice el límite de copia privada. En este sentido, es fundamental el establecimiento en el ámbito europeo de criterios comunes respecto de los equipos, aparatos y soportes sujetos a compensación, que garantice un sistema transparente, equitativo y uniforme tanto para los usuarios como para los autores.

OCTAVA. - La aplicación eficaz de medidas tecnológicas de protección destinadas a impedir o restringir la reproducción de obras protegidas repercute en la configuración del límite de copia privada y de la compensación equitativa. La implementación de estas medidas podría limitar la exigencia de dicha compensación, en tanto sean capaces de permitir al titular de los derechos un control sobre la reproducción de su obra, sobre todo en un entorno donde los equipos, aparatos y soportes materiales de reproducción que se utilizan son esencialmente digitales.

Sin embargo, hasta el momento, el control de la copia por medio de la aplicación de medidas tecnológicas de protección no ofrece las garantías necesarias como para ser un medio de control absolutamente eficaz. En primer lugar, estas medidas tecnológicas no se implementan siempre; en segundo lugar, son quebrantables. Pero más allá de lo anterior -y esto es una cuestión aún más esencial- es difícil alcanzar un punto de equilibrio entre la implementación de estas medidas y la existencia de los límites a los derechos de propiedad intelectual y, en particular, en relación con el límite de copia privada. Y es que, si estas medidas tecnológicas pueden contribuir a la gestión de la 
propiedad intelectual, no puede perderse de vista que también limitan el acceso a las creaciones y suponen costes añadidos que incrementan el precio de las mismas.

La consideración de la copia privada como un derecho del usuario va en contra del presupuesto de la propiedad intelectual, esto es, de que corresponde al autor el derecho de reproducción de su obra, que sólo debe ser limitado en la medida en que deba ceder espacio al ejercicio de otros derechos fundamentales, en razón del interés social o, en su caso, por la imposibilidad de controlar la utilización de la obra, como sucede en el caso de la copia privada, con lo que no tendría sentido prohibirla. Así pues, es legítimo el establecimiento de límites a las facultades del autor. Pero ello no significa la concesión de derechos a favor del usuario, a quien, más bien, se le reconoce la posibilidad de hacer valer dichos límites en los casos en que el acceso a la obra o la utilización de ésta dentro de los contornos que las limitaciones permiten, se vean restringidos por la aplicación de dichas medidas tecnológicas.

La satisfacción de una cantidad en concepto de compensación equitativa por copia privada no confiere, pues, en ningún caso un "derecho de copia".

NOVENA. -La regulación de las medidas tecnológicas de protección frente a la copia privada pone en peligro los intereses colectivos y sociales que se han tratado de proteger históricamente mediante los límites a la propiedad intelectual, sobre todo considerando que la tendencia es la contractualización del uso de las obras en línea, así como el predominio de las medidas tecnológicas de protección. De este modo, la realidad del "pago por uso" para las obras y prestaciones que circulan en línea impide la desarticulación de las medidas tecnológicas de protección sin el consentimiento del titular de los derechos, ni siquiera para hacer valer las excepciones que la propia ley establece.

Es cuestionable que en aquellos supuestos en que la obra o prestación intelectual es protegida con medidas tecnológicas, el único mecanismo legal establecido en la legislación española para que el usuario pueda realizar reproducciones de la obra sin incurrir en una violación del derecho de autor sea acudir a la tutela judicial. Ni siquiera la DDASI establece la obligatoriedad para los Estados miembros de establecer normas imperativas que garanticen la utilización de la obra por parte de los usuarios cuando los titulares de los derechos de autor no facilitan la utilización de sus obras al amparo de 
este límite. Por consiguiente, puede decirse que la legislación beneficia a los autores, ya que el recurso a la justicia es normalmente una solución dilatada y costosa, por lo que se restringe indebidamente la copia que pudiera ser realizada al amparo de dicha excepción.

DÉCIMA. - La legislación española, del mismo modo que la gran mayoría de las legislaciones europeas (a excepción de Finlandia cuyo régimen jurídico es de carácter presupuestario), establece un sistema de compensación equitativa por copia privada que sigue el criterio de idoneidad objetiva de los equipos, aparatos y soportes de reproducción para la copia privada.

La aplicación de este criterio como solución para hacer efectiva dicha compensación ha sido ampliamente controvertida, pues quedan sujetos al canon los equipos, aparatos y soportes de reproducción por su mera aptitud para realizar reproducciones de obras protegidas y no porque se efectúe realmente la copia.

No obstante, el criterio de idoneidad objetiva ha sido aceptado por la doctrina del TJUE que, al mismo tiempo, ha precisado que el verdadero sujeto compelido al pago de la compensación es quien realiza la copia, si bien por una cuestión, más bien fáctica que jurídica, las leyes establecen como deudores directos de la misma a quienes fabrican y comercializan los equipos, aparatos y soportes materiales de reproducción, toda vez que estos sujetos tienen la posibilidad de repercutir la compensación equitativa a los usuarios privados que son quienes, efectivamente, realizan las copias.

A falta de otros criterios más apropiados, el criterio de idoneidad objetiva que acompaña al sistema de canon es una solución adecuada frente a la imposibilidad de controlar la reproducción a escala individual. Además, con acierto, la legislación española actual recoge reglas de exclusión del pago de la compensación y mecanismos de reembolso que consiguen un sistema compensatorio más equilibrado.

UNDÉCIMA. - La decisión del asunto Padawan por el TJUE (21 de octubre de 2010) significó un punto de inflexión en la regulación española del sistema de compensación equitativa por copia privada. Esta decisión se pronunció en contra el diseño del sistema español de compensación equitativa por copia privada, que no discriminaba, a efectos del pago, en función de la finalidad con que ciertos sujetos, como empresarios y profesionales, por ejemplo, adquirían los equipos, aparatos y 
soportes materiales de reproducción. Esta sentencia fue contundente dejando claramente determinada la oposición del art. 5.2.b) de la DDASI a una legislación que, como la española, aplicaba el canon de forma indiscriminada, sin establecer una vinculación entre dicho canon y el presumible uso de los equipos, aparatos y soportes de reproducción digital para realizar reproducciones privadas. En definitiva, puso de relieve la necesidad de implantar un mecanismo legal que permitiera tener en cuenta el destino de los equipos, aparatos y soportes de reproducción material.

Tras la sentencia del TJUE, se aprecia una flexibilización en la aplicación del criterio de idoneidad objetiva por los Tribunales españoles en relación con el presumible uso de estos equipos, aparatos y soportes para la copia privada.

DUODÉCIMA. - La evidente contradicción entre el art. 5.2.b) de la DDASI y el sistema español de compensación por copia privada, por una parte, y los intereses políticos ligados a las fuertes presiones ejercidas por las empresas tecnológicas y por ciertos grupos sociales en contra del canon, por otra, dieron lugar a un cambio radical en el modelo de satisfacción de la compensación equitativa por copia privada. Así pues, con la promulgación del Real Decreto-ley 20/2011, de 30 de diciembre, de medidas urgentes en materia presupuestaria, tributaria y financiera para la corrección del déficit público, España abrió un nuevo capítulo en la historia legislativa de la regulación de la compensación equitativa por copia privada al pasar a ser financiada con cargo a los Presupuestos Generales del Estado.

La instauración de este modelo, inédito en España y ajeno al mecanismo compensatorio de los países de la UE, fue fuertemente criticada al socializar una obligación de derecho privado, pues tanto personas físicas como jurídicas terminaban satisfaciendo dicha obligación.

Pese a la intención del legislador de presentarlo como un modelo equilibrado y acorde con el Derecho de la UE, así como de dotarlo de cierta vocación de permanencia con la Ley 21/2014, de 4 de noviembre, este modelo de financiación de la compensación con cargo a los Presupuestos Generales del Estado, vigente desde el 2011, devino inaplicable por la STJUE (Sala Cuarta), de 9 de junio de 2016. Como consecuencia, se produjo en España el retorno al sistema de canon con la reforma del TRLPI por el Real Decreto-ley 12/2017, de 3 de julio. 
DECIMOTERCERA. - Las sucesivas reformas legislativas en la regulación de la compensación equitativa por copia privada en España demuestran las dificultades de establecer un sistema equilibrado para la satisfacción de esta compensación. No obstante, lo cierto es que, pese a los avatares del canon, la última modificación del TRLPI, tras su reciente reforma por el Real Decreto-ley 12/2017, de 3 de julio, ha otorgado a la compensación equitativa por copia privada un marco legal mucho más acorde con la doctrina del TJUE, siendo una regulación mucho más perfeccionada.

En primer lugar, destacan las exceptuaciones al pago de la compensación equitativa; en segundo lugar, el sistema de reembolso establecido; y, finalmente el sistema de ventanilla única para la gestión del pago de la compensación.

DECIMOCUARTA. - La regulación vigente del sistema de canon por copia privada en la legislación española conserva la mayoría de los presupuestos que inspiraban este sistema bajo el TRLPI, en su versión por la Ley 23/2006. Es cierto que las reformas posteriores han incorporado algunos cambios. Sin embargo, se mantienen cuestiones esenciales de aquel modelo como el objeto de la compensación; los sujetos deudores y acreedores de la misma; el momento de nacimiento de la obligación; la atribución de su gestión a las entidades de gestión colectiva de los derechos de propiedad intelectual; el listado de los equipos, aparatos y soportes sujetos al canon; o los criterios para la fijación de la cuantía de la compensación que, pese a algunas modificaciones o matices, no varían considerablemente; así como el sistema de autoliquidación de esta compensación.

Se espera que la aprobación del Real Decreto por el que se desarrollen reglamentariamente, entre otras cuestiones, los equipos, aparatos y soportes materiales sujetos al pago de la compensación equitativa, las cantidades que los deudores deberán abonar por este concepto a los acreedores y la distribución de dicha compensación entre las distintas modalidades de reproducción, ofrezca una regulación más acabada de la compensación equitativa por copia privada.

DECIMOQUINTA. - El listado de los equipos, aparatos y soportes sujetos a la compensación equitativa por copia privada está establecido en la regulación actual con carácter transitorio siguiendo la Orden PRE/1743/2008, pues guarda una gran similitud con ésta. No obstante, las tarifas compensatorias se reducen significativamente, en la 
mayoría de los casos, a excepción de la prevista para los dispositivos reproductores de fonogramas, videogramas o de otros contenidos sonoros, visuales o audiovisuales en formato comprimido y para los teléfonos móviles con funcionalidad de reproducción de fonogramas en formato comprimido. Por su parte, las tarifas no revelan grandes diferencias entre los soportes regrabables y no regrabables, con lo cual, parece que la capacidad de almacenamiento de estos soportes no es debidamente tenida en cuenta para la determinación de la compensación, pese a que el canon debe ser expresión del perjuicio causado a los titulares de derechos por la copia privada.

Llama la atención, además, que el legislador no catalogue los equipos, aparatos y soportes gravados distinguiendo entre aquellos aptos para la reproducción de libros y publicaciones asimiladas, fonogramas y videogramas, salvo en el caso de los primeros, para los que sí prevé un régimen particular en el apartado $1^{\circ}$.a), de la Disposición Transitoria segunda del Real Decreto-ley 12/2017. Al respecto, esta norma establece la compensación correspondiente a los equipos o aparatos de reproducción de libros y publicaciones asimiladas reglamentariamente a libros que califica como "digitales". Sin embargo, hay que entender que no están excluidas las impresoras o fotocopiadoras, pese a que normalmente utilizan una tecnología analógica. No tiene sentido exceptuarlas de esta compensación toda vez que la reprografía por estos medios es una importante fuente de la copia realizada para uso privado, por lo que, en definitiva, pueden quedar incluidas en la previsión que recogen los ordinales $1^{\circ}$ y $2^{\circ}$, del apartado 1.a) de la mencionada Disposición transitoria segunda.

Como una importante novedad, quedan gravados los discos duros de ordenador, cuya exclusión había sido siempre objeto de polémica, al no quedar justificado el sentido de dicha exclusión en las regulaciones precedentes. No obstante, no puede perderse de vista la mención que hace la Disposición Transitoria segunda del Real Decreto-ley 12/2017 en su apartado $1^{\circ}$ in fine, al señalar que no podrá aplicarse más de una cantidad de las previstas en este apartado a los ordenadores portátiles o de sobremesa. Ello podría excluir que los discos duros de ordenador den lugar, efectivamente, a una compensación cuando el ordenador tenga otros dispositivos integrados que también resulten sujetos al canon. De momento, ninguna mención hace el legislador sobre si se aplicará la cantidad mayor o menor de la que pueda 
corresponder al gravamen en estos casos. Por el contrario, sí excluye los discos que estén integrados en equipos descodificadores de señales de televisión digital, así como los discos integrados en videoconsolas, puesto que no permiten realizar reproducciones amparadas por el límite de copia privada.

Respecto a los teléfonos móviles, la Orden PRE/1743/2008 sólo incluía aquellos que tenían capacidad de reproducción de fonogramas. Ahora la norma es más amplia, pues comprende también los que tienen entre sus funciones la reproducción de videogramas y textos u otros contenidos sonoros, visuales o audiovisuales. También quedan sujetos al canon los dispositivos electrónicos portátiles con pantalla táctil.

DECIMOSEXTA. - El estudio de la legislación latinoamericana demuestra que, pese a que la mayoría de los países establecen el límite de copia privada, pocos han regulado una compensación equitativa asociada al mismo, si bien también es cierto que existe un desarrollo muy desigual en la regulación de la propiedad intelectual en este ámbito geográfico, en comparación con los países europeos. Esta situación hace que se admita la copia para uso privado sin que el autor reciba ninguna compensación por los perjuicios que dicha copia le genera, lo que contraviene la regla de los tres pasos contenida en el art. 9.2 del CB, que estos países deberían respetar por haber asumido los compromisos internacionales que este Convenio implica.

Por su parte, aquellos países que han establecido normas al respecto, carecen en la práctica de mecanismos eficientes de recaudación o de normas complementarias que garanticen la satisfacción efectiva del canon, salvo Paraguay, donde tras el Decreto N. ${ }^{\circ}$ 4212, de 12 de octubre de 2015, ha existido una recaudación en 2016 que representa un incremento del $300 \%$ aproximadamente frente a los años anteriores.

En otros casos, como Chile, Argentina y Uruguay, ni siquiera se autoriza la copia privada, lo que implica que las reproducciones no autorizadas son ilegales. Ahora bien, ello no contrarresta la realidad de la copia, dando auge a la piratería, cuando lo mejor sería intentar educar en el respeto a los derechos de autor y conexos y concienciar sobre la importancia que tiene para el creador recibir una compensación por aquellas utilizaciones de las obras que escapan a su control. Además, en el caso de los dos últimos países mencionados tampoco han prosperado los proyectos que han pretendido regular la copia privada, ya tan reconocida en otras legislaciones. 
DECIMOSÉPTIMA. - Las leyes de derechos de autor y conexos en América Latina y el Caribe siguen un sistema similar al español en materia de límites, en general, y respecto a la copia privada, en particular.

Los países estudiados se inscriben en el sistema cerrado de límites y, los que regulan la copia privada, autorizan la reproducción de una obra o prestación intelectual sin autorización del autor, cuando se hace por una persona física y no media un fin lucrativo. No obstante, en estas legislaciones es bastante habitual que la copia se autorice sólo para uso personal, lo que restringe el alcance de la excepción. Asimismo, con independencia de las particularidades que puedan darse en cada caso, lo cierto es que estas legislaciones no suelen exigir la necesidad de acceso lícito a la creación intelectual que se reproduce, lo cual atenta contra el respeto a los derechos de propiedad intelectual.

En el caso de la ley de México es peculiar y perjudicial para los titulares de derechos de autor y conexos la disposición contenida en su art. 40, por cuanto instrumenta una remuneración por copia privada que no viene a compensar la copia privada por reproducciones realizadas por una persona física, para uso privado, sin ánimo de lucro, sino que, por el contrario, remunera la reproducción derivada de cualquier copia hecha sin autorización de los titulares de derechos patrimoniales de autor y conexos. Por tanto, lo que a priori parecería corresponderse con la compensación equitativa por copia privada vigente en España y regulada en otros ordenamientos jurídicos -incluso de la región latinoamericana- no deja de ser, sino, un supuesto distinto y controvertido, en tanto lo que hace es legitimar la copia ilícita, no amparada en una excepción legal, a cambio de una remuneración.

DECIMOCTAVA. - El sistema social en Cuba garantiza constitucionalmente que "no haya persona que no tenga acceso al estudio y la cultura y estimula el acceso a la educación, el saber y la creación artística”.

En este contexto, la Ley No. 14, de 28 de diciembre de 1977, Ley de Derecho de Autor, apoya la protección de los valores culturales y de la creación intelectual y científica en la nación. Lo hace, con respeto y garantía al ejercicio del derecho de autor, tanto en su vertiente moral como patrimonial, pero con obligada observancia del interés supremo de la sociedad. Subordina pues, esta ley, la protección del derecho de autor "al 
interés superior que impone la necesidad social de la más amplia difusión de la ciencia, la técnica, la educación y la cultura en general", de ahí que el ejercicio de los derechos patrimoniales del autor no puede afectar los intereses sociales y culturales. Dicho de otro modo, los intereses sociales y culturales prevalecen frente a las prerrogativas que otorga la ley a los titulares de derechos de autor y derechos conexos, influyendo en la configuración del sistema legal de límites a estos derechos.

Por tanto, aun cuando Cuba se inscribe en un sistema cerrado de límites, que no contempla la excepción de copia privada, el sistema social cubano sirve como justificación a una ley que subordina la protección del autor a los intereses sociales, educacionales y culturales. 


\section{FUENTES}

\section{BIBLIOGRAFÍA}

Alemán EzCARAy, C., "Los huecos de la Ley Sinde y el miedo a la tecnología", Actualidad Jurídica Aranzadi, núm. 813/2011 (Parte Tribuna), 2011, p. 4.

Alonso García, R., Sistema Jurídico de la Unión Europea, $3^{\mathrm{a}}$ ed., Aranzadi, Madrid, 2012.

Álvarez Navarrete, L., Derecho de ¿Autor? El debate de hoy, Editorial de Ciencias Sociales, La Habana, 2006.

Álvarez Álvarez, H., “Aspectos jurídicos de las descargas de música en Internet”, en GARcíA PÉREZ, R. y LÓPEZ SUÁREZ, M. A. (Eds.), Nuevos retos para la propiedad intelectual. (II Jornadas sobre la propiedad intelectual y el derecho de autor/a), Universidad de La Coruña, A Coruña, 2008, pp. 103-140.

Anguita Villanueva, L. A. (Coord.), En torno a la reforma de la Ley de Propiedad Intelectual, Reus, Madrid, 2013.

ANTEQUera PARILl, R., "Los límites del derecho subjetivo y del derecho de autor (Los 'usos honrados', el 'fair use' y el 'ius usus innocui'. El supuesto de abuso de derecho a la no divulgación de la obra. Los límites al derecho de autor y la sociedad de la información)", en Rogel VIDE, C. (Coord.), Los límites del derecho de autor, Reus, Madrid, 2006, pp. 7-82.

AÑón CAlvete, J., "Primacía del Derecho de la Unión Europea (a propósito de la STC 232/2015, de 5 de noviembre)", Noticias Jurídicas (Artículos Doctrinales), 23 de febrero de 2016, disponible en: http://noticias.juridicas.com/conocimiento/articulosdoctrinales/10895-primacia-del-derecho-de-la-union-europea-a-proposito-de-la-stc-2322015-de-5-de-noviembre/ (consultado: 25.06.2017).

Augsburger, A. E., "La Convención Universal sobre Derecho de Autor en el ámbito de los países de América Latina y el Caribe", Boletín de Derecho de Autor, Vol. XXI, núm. 3, UNESCO, 1987, pp. 8-17.

AVILÉS GARCíA, J., "La socialización de la compensación equitativa por copia privada: ¿un desatino inconstitucional?, Pe. I. Revista de Propiedad Intelectual, núm. 41, 2015, pp. 13-62.

AVILÉS GARCÍA, J., El derecho de compensación equitativa por copia privada, un debate abierto en la jurisprudencia, Reus, Madrid, 2015.

Baylos Corroza, H., Tratado de Derecho Industrial, Aranzadi, Pamplona, 2009.

Belloso Martín, N., "Los derechos de autor en la sociedad tecnológica: contenido, tutela y límites”, en MAta Y MARTín, R. M. (Dir.) y JaVAto Martín, A. M. (Coord.), La Propiedad Intelectual en la Era Digital. Límites e infracciones a los derechos de autor en Internet, La Ley, Madrid, 2011, pp. 63-128. 
Bercovitz Rodríguez-CANO, R. (Coord.), "Artículo 1", en Bercovitz RodríGuezCANO, R. (Coord.), Comentarios a la Ley de Propiedad Intelectual, Tecnos, $3^{\mathrm{a}}$ ed., Tecnos, Madrid, 2007, pp. 17-24.

- “Artículo 129”, en Bercovitz Rodríguez-Cano, R., (Coord.), Comentarios a la Ley de Propiedad Intelectual, $3^{\mathrm{a}}$ ed., Tecnos, Madrid, 2007, pp. 1627-1635.

- "La Ley Sinde”, Revista Doctrinal Aranzadi Civil-Mercantil, Vol. 1, núm. 1/2011 (Parte Tribuna), 2011, pp. 11-16.

- "La regulación legal de los límites en las legislaciones comunitarias y española", en O’CAllaghan, X. (Coord.), Los derechos de propiedad intelectual en la obra audiovisual", Dykinson, Madrid, 2011, pp. 337-352.

- (Coord.) et al., Manual de Propiedad Intelectual, Tirant Lo Blanch, $5^{\text {a }}$ ed., Valencia, 2012.

- "Cambio de rumbo en el canon de copia privada", Revista Aranzadi Civil-Mercantil, núm. 10, 2012, pp. 17-21.

- "El nuevo procedimiento de pago de la compensación equitativa por copia privada", Revista Aranzadi Civil-Mercantil, núm. 10, 2013, pp. 27-33.

- "La copia privada", en Bercovitz RodríGuez-CANO, R. (Coord.), La reforma de la Ley de Propiedad Intelectual, Tirant Lo Blanch, Valencia, 2015, pp. 61-87.

- “Artículo 10.1", en Bercovitz Rodríguez-CAno, R. (Coord.), Comentarios a la Ley de Propiedad Intelectual, $4^{\mathrm{a}}$ ed., Tecnos, Madrid, 2017, pp. 159-193.

Bercovitz Rodríguez-CANO, R., GARrote FernÁndez-DíEZ, I., GonzÁlez Gonzalo, A. y SÁnchez Aristi, R., Las reformas de la Ley de Propiedad Intelectual, Tirant lo Blanch, Valencia, 2006.

Bondía Román, F., Propiedad Intelectual. Su significado en la sociedad de la información, Trivium, Madrid, 1988.

BugAnZA, C., "Las medidas de protección tecnológicas y la información para la gestión de derechos", en Buganza C. (Dir.), Novedades en la Ley de Propiedad Intelectual, J. M. Bosch, Barcelona, 2007, pp. 127-160.

BuITRAGo DíAZ, E., El concepto de cánones y/o regalías en los convenios para evitar la doble Tributación sobre la Renta, CISS (Wolters Kluwer), Valencia, 2007.

CABedo Serna, L. L., "Los consumidores y las medidas tecnológicas de protección incorporadas en soportes digitales", en Moreno MARTíneZ, J. A. (Coord.), Límites a la propiedad intelectual y nuevas tecnologías, Dykinson, Madrid, 2008, pp. 63-118.

- El derecho de remuneración del autor, Dykinson, Madrid, 2011.

CADARSO PALAU, J., "Sobre algunos límites del derecho de reproducción: Reproducciones para constancia en un procedimiento. Reproducciones para uso privado. La remuneración compensatoria por copia privada. Reproducciones hechas por 
bibliotecas y entidades del género", en ROGEL VIDE, C. (Coord.), Los límites del derecho de autor, Reus, Madrid, 2006, pp. 109-129.

Calvo Soler, R., "La ineficacia de las normas jurídicas en la Teoría Pura del Derecho", Isonomía, núm. 27, 2007, pp. 171-191.

CANOSA CRIADO, M. A., "El derecho de copia privada para fonogramas: Comentario a una sentencia reciente de la Corte Suprema de Colombia", Revista Foro Derecho Mercantil, núm. 25, 2009, pp. 143-154.

Carbajo Cascón, F., Publicaciones electrónicas y Propiedad Intelectual, Colex, A Madrid, 2002.

- "La 'larga marcha' de la compensación equitativa por copia privada. A propósito de la sentencia (Sala Primera) del Tribunal Supremo de 25 de octubre de 2005", Pe. I. Revista de Propiedad Intelectual, núm. 22, 2006, pp. 13-62.

- "Creación, edición y lectura en la Sociedad de la Información: entre la Propiedad Intelectual y el acceso a la cultura”, Pliegos de Yuste, núm. 11-12, 2010, pp. 127-134.

- "Consideraciones sobre la nulidad de la Orden PRE/1743/2008, de 18 de junio, de reglamentación del canon digital (Sentencias de la Audiencia Nacional, Sala Tercera de lo Contencioso-Administrativo, de 22 de marzo de 2011)", Pe. I., Revista de propiedad Intelectual, núm. 39, 2011, pp. 117-140.

- "Desafíos de la propiedad intelectual en el «nuevo» ámbito digital. Ideas para una reforma de la LPI", Vasos Comunicantes, núm. 44, 2013, pp. 63-74.

- "Delimitación de la responsabilidad de los servicios de intermediación de la sociedad de la información (I). (Primera Parte: Origen del problema y régimen jurídico general en EE.UU. y UE)", Iustitia, 2014, pp. 245-278.

- "Enlaces de prensa (press linking): entre la flexibilización y la regulación del derecho de autor en la era digital", Pe. i. Revista de Propiedad Intelectual, núm. 47, 2014. pp. $13-74$

- "El retorno del canon digital. Consecuencias previsibles de la STJUE de 9 de junio de 2016”, Ars Iuris Salmanticensis, Tribuna de Actualidad, Vol. 4, 2016, pp. 11-20.

- "Artículo 25. Compensación equitativa por copia privada" (Comentario), en PALAU Ramírez, F. y Palao Moreno, G. (Dirs.), Comentarios a la Ley de Propiedad Intelectual, Tirant Lo Blanch, Valencia, 2017, pp. 403-442.

Casas Vallés, R., “Artículo 40 bis”, en Bercovitz RodríGuez-Cano, R. (Coord.), Comentarios a la Ley de Propiedad Intelectual, $3^{\mathrm{a}}$ ed., Tecnos, Madrid, 2007, pp. 669707.

- "La Comisión de Propiedad Intelectual", en BerCovitz RodríGuez-CANO, R. (Coord.), La reforma de la Ley de Propiedad Intelectual, Tirant lo Blanch, Valencia, 2015, pp. 267-346.

- "Artículo 40 bis", en Bercovitz Rodríguez-CANo, R. (Coord.), Comentarios a la Ley de Propiedad Intelectual, $4^{\mathrm{a}}$ ed., Tecnos, Madrid, 2017, pp. 791-836. 
CAstelló PAstor, J. J., Los snippets (o fragmentos de texto) en la Reforma de la Ley de Propiedad Intelectual: ¿por qué tu sí y yo (Thumbnails) no?”, Revista Doctrinal Aranzadi Civil-Mercantil (Parte Estudio), núm. 6, 2015, pp. 57-72.

- "Evolución histórica del Derecho de Autor en América Latina", Revista Ius et Praxis, año 22, núm. 1, 2016, pp. 19-58.

- Motores de búsqueda y derechos de autor: infracción y responsabilidad, Aranzadi, Navarra, 2016.

- "Artículo 18. Reproducción (Comentario)", en Palau Ramírez, F. y PAlao Moreno, G. (Dirs.), Comentarios a la Ley de Propiedad Intelectual, Tirant Lo Blanch, Valencia, 2017, pp. 321-338.

Cerda Silva, A. J., “Armonización de los derechos de autor en la Comunidad Andina: Hacia un nuevo régimen común”, Revista Ius et Praxis, año 17, núm. 2, 2011, pp. 231282.

Colin, C., Droit d'utilisation des ouvres, Larcier, Bruselas, 2012.

Córdoba Marentes, J. F., "El fin no justifica la excepción. Propiedad Intelectual, educación y fair use estadounidense", Boletín Mexicano de Derecho Comparado, nueva serie, año XLV, núm. 134, 2012, pp. 437-466.

Correas, O., Metodología Jurídica II. Los saberes y las prácticas de los abogados, Ediciones Coyoacán, México, D.F., 2006.

Corsaro, V., "From Betamax to YouTube: How Sony Corporation of America v. Universal City Studios, Inc. could still be a standard for new technology", Federeal Communications Law Journal, núm. 2, Vol. 64, Nebraska, 2012, pp. 449-475.

CuAdros AÑAZCO, A., "Derechos patrimoniales de reproducción y comunicación pública del autor en Internet: Intercambio de archivos digitales a través de las redes P2P”, Revista Jurídica de Propiedad Intelectual, Guayaquil, 2010, pp. 19-28.

De Fuentes, J., "Un enfoque jurídico. Razón de ser de la remuneración por copia privada. Un septenio legislando sobre la materia”, en Ministerio DE CUlTURA, La copia privada a examen: el derecho de remuneración compensatoria en el ámbito de la Propiedad Intelectual, Colección de Análisis y Documentos, núm. 6, Madrid, 1995, pp. 57-78.

De la Puente García, E., "Notas sobre la Ley 20/1992, de 7 de julio, de modificación de la Ley 22/87, de 11 de noviembre, de Propiedad Intelectual", Boletín de Información del Ministerio de Justicia, núm. 1655, 1992, pp. 72-89.

De Miguel Asensio, P. A., Derechos de Propiedad Intelectual, Aranzadi, Madrid, 2015.

De Palacios Caro, E., "La negociación como necesidad. Sujetos del derecho y de la obligación. Nacimiento de la remuneración. Responsabilidad solidaria", en MINISTERIO DE CULTURA, La copia privada a examen: el derecho de remuneración compensatoria en el ámbito de la Propiedad Intelectual, Colección de Análisis y Documentos, núm. 6, Madrid, 1995, pp. 79-99. 
Delgado Porras, A., "La gestión colectiva de los Derechos de Autor", en Estudios sobre Derecho Industrial. Homenaje a H. Baylos (Colección de trabajos sobre propiedad industrial e intelectual y derecho de la competencia), Grupo español de la AIPPI, Barcelona, 1992, pp. 195-238.

Díez Picazo, L. y Gullón, A., Sistema de Derecho Civil, Vol. I, 12a ed., Tecnos, Madrid, 2012.

- Sistema de Derecho Civil, Vol. II, Tomo 2, 10ª ed., Tecnos, Madrid, 2012.

Dusollier, S., Droit d'auteur et protection des ceuvres dans l'univers numérique. Droits et exceptions à a lumière des dispositifs de verrouillage des auvres, Larcier, Bruselas, 2005.

Dusollier, S., Pullet, Y. y Buydens, M., "Derecho de autor y acceso a la información en el entorno numérico", Boletín de Derecho de Autor, UNESCO, Vol. 34, núm. 4, 2000, pp. 4-38.

ERdozain, J. C., Derechos de autor y propiedad intelectual en Internet, Tecnos, Madrid, 2002.

Esteve Pardo, M. A., "Comentario a la sentencia de la Audiencia Provincia de Barcelona (Sección 15 ) de 2 de marzo de 2011, 'Caso Padawan'. La compensación equitativa por copia privada a examen", en EsTEVE PARDO, M. A. (Coord.), Cuestiones de actualidad sobre propiedad intelectual. Iniciativas legales frente a las descargas ilegales en Internet y consecuencias del "caso Padawan" sobre la compensación equitativa por copia privada, Tirant lo Blanch, Valencia, 2013, pp. 126-141.

FALCón Y TELLA, R., "La compensación equitativa por copia privada. (Copyright Levy) tras la Ley 23/2006 (RCL 2006, 1386): una exacción parafiscal de dudosa constitucionalidad", Revista española de Derecho Tributario y Financiero, núm. 137, 2008, pp. 87-105.

FERnÁndez BALlesteros, C., "El nuevo contexto del derecho del autor en el siglo XXI", Revista Jurídica de Propiedad Intelectual, Universidad Católica de Santiago de Guayaquil, Tomo 1, julio, 2009, pp. 107-132.

FERNÁNDEZ BALlESTEROS, C., "La remuneración por copia privada", Revista Jurídica de Propiedad Intelectual, Tomo III, Guayaquil, 2010, pp. 15-38.

FERNÁNDEZ SANTILlÁN, J., El despertar de la sociedad civil. Una perspectiva histórica, Océano, México D.F., 2003.

FERNÁNDEZ SHAW, F., "Derecho de autor y derechos conexos en la radiodifusión española”, Anuario de Derecho Civil, 1975, pp. 337-422.

FICSOR, M., The Law of Copyright and the Internet. The 1996 WIPO Treaties, their Interpretation and Implementation, University Press, Oxford, 2002.

FISHER, W., “Theories on Intellectual Property", disponible en: http://cyber.law.harvard.edu/people/tfisher/iptheory.pdf (consultado: 10.11. 2015). 
GALlARDo PÉREZ, L., "El necesario ajuste entre los límites a los derechos de propiedad intelectual y la protección de las medidas tecnológicas", Opinión Jurídica, Vol. 6, núm. 12, Medellín, 2007, pp. 85-104.

Garrote FernándeZ- DíEz, I., El Derecho de Autor en Internet, 2a ed., Comares, Granada, 2003.

- "Artículo 25”, en Bercovitz Rodríguez-CAno, R. (Coord.), Comentarios a la Ley de Propiedad Intelectual, $3^{\mathrm{a}}$ ed., Tecnos, Madrid, 2007, pp. 445-505.

- "Artículo 31", en Bercovitz Rodríguez-CAno, R. (Coord.), Comentarios a la Ley de Propiedad Intelectual, $3^{\mathrm{a}}$ ed., Tecnos, Madrid, 2007, pp. 533-571.

- “Artículo 161”, en Bercovitz RodríGuez-Cano, R. (Coord.), Comentarios a la Ley de Propiedad Intelectual, $3^{\mathrm{a}}$ ed., Tecnos, Madrid, 2007, pp. 2076-2105.

- “Artículo 162”, en Bercovitz Rodríguez-Cano, R. (Coord.), Comentarios a la Ley de Propiedad Intelectual, $3^{\mathrm{a}}$ ed., Tecnos, Madrid, 2007, pp. 2106-2123.

- La reforma de la copia privada en la Ley de Propiedad Intelectual, Comares, Granada, 2010.

- "Artículo 9", en Bercovitz RodríGuez-CANo, R. (Coord.), Comentarios al Convenio de Berna para la Protección de las Obras Literarias y Artísticas, Tecnos, Madrid, 2013, pp.705-832.

- “Artículo 25”, en Bercovitz RodríGuez-CANo, R. (Coord.), Comentarios a la Ley de Propiedad Intelectual, $4^{\mathrm{a}}$ ed., Tecnos, Madrid, 2017, pp. 513-549.

- "Artículo 31", en Bercovitz RodríGuez-CAno, R. (Coord.), Comentarios a la Ley de Propiedad Intelectual, $4^{\mathrm{a}}$ ed., Tecnos, Madrid, 2017, pp. 577-601.

GiBlin, R., "The P2P Wars: How Code Beat Law", IEEE Internet Computing, núm. 3, Vol. 16, 2012, pp. 91-93.

Ginsburg, J. C., "European Copyright Code - Back to First Principles (with Some Additional Detail)", Columbia Public Law Research, paper núm. 11-261, 2011, pp. 2627.

GóMEZ JiMÉNEZ, C., "La responsabilidad patrimonial del Estado legislador y canon digital”, Revista de Contabilidad y Tributación, núm. 338, 2011, pp. 85-114.

GonzÁlez de Alaiza CARdona, J. J., La copia privada. Sus fundamentos y tratamiento en el entorno digital, Comares, Granada, 2008.

GonZÁlez NAVARro, B. A., "Copia privada y canon digital: conclusiones del abogado general del TJUE”, Revista Aranzadi Doctrinal, núm. 3/2016 (Parte Comentario), 2016, pp. 87-94.

GONZÁLEZ, A., "La compensación equitativa por copia privada digital en la Ley 23/2006, de 7 de julio", Actualidad Jurídica Uría Menéndez, núm. 15, 2016, pp. 31-44.

GuiBAult, L., "Discussion paper on the question of Exceptions to and limitations on copyright and neighbouring rights in the digital era", Steering Committee on the Mass 
Media [MM-S-PR(98)7], Estrasburgo, 1998, disponible en: http://www.ivir.nl/publicaties/download/336 (consultado: 21.12.2015).

GuZMÁn BRITO, A., "El Código Civil de Chile en sus ciento cincuenta años y crónica de un congreso internacional de conmemoración celebrado en Santiago de Chile", Anuario de Derecho Civil (B.O.E), 2006, pp. 1283-1301.

Habermas, J., The Structural Transformation of the Public Sphere, obra traducida por Thomas Burger con la asistencia de Frederick Lawrence, MIT Press, Cambridge, 1991.

HadDadin, S., Essai sur une Théorie Générale en Droit d'Auteur, tesis doctoral, Universidad de Poitiers, Facultad de Derecho y Ciencias Sociales, presentada y leída públicamente el 22 de noviembre de 2008.

HARVEY, E. R., "Derecho de autor y derecho a la cultura en los países iberoamericanos", I Congreso Iberoamericano de Derecho de la Cultura, Madrid, 29 de noviembre - 2 de diciembre, 1999, disponible en: https://cdn.educ.ar/repositorio/Download/file?file_id=a2ed19e1-7a09-11e1-8123ed15e3c494af (consultado: 19.07.2017).

Hugenholtz, P. B., (Ed.), Harmonizing European Copyright Law. The Challenges of Better Lawmarking, Wolters Kluwer, Alphen aan den Rijn, 2009.

- "Copyright in Europe: Twenty Years Ago, Today and What the Future Holds", Fordham Intellectual Property, Media and Entertainment Law Journal (503-524), núm. 2, Vol. 23, 2013, pp. 503-524.

- "Fierce creatures. Copyright exemptions: Towards extinction?", en Rights, Limitations and Exceptions: Striking a Propert Balance, Amsterdam, 1997, disponible en: http://www.ivir.nl/publicaties/download/1082 (consultado: 21.12.2015).

- The Wittem Group's European Copyright Code, disponible en: https://www.ivir.nl/publicaties/download/ILS_29_chapter17.pdf 14.03.2017).

Hugenholtz, P. B. y Senftleben, M., "Fair use in Europe. In search of flexibilities", Amsterdam Law School Research Paper No. 2012-39, disponible en: https://papers.ssrn.com/sol3/papers.cfm?abstract_id=1959554 (consultado: 13.03.2017).

KARAPAPA, S., Private Copying, Routledge, Oxon, 2012.

LACRUZ MANTECÓN, M. L., "Copias privadas y calamidades públicas", en Rogel VIDE, C. (Dir.), Anuario de Propiedad Intelectual 2005, Reus, Madrid, 2006, pp. 449-490.

LANDES, W. M. y Posner, R. A., La estructura económica del derecho de propiedad intelectual e industrial (traducción de SÁNCHEZ Álvarez, V. M.), Fundación Cultural del Notariado, 2006.

LETAI, P., La infracción de derechos de propiedad intelectual sobre la obra musical en Internet, Comares, Granada, 2012.

Leval, P. N., "Toward a Fair Use Standard”, Harvard Law Review, Vol. 103, núm. 5, 1990, pp. 1105-1136. 
LEWINSKI, S., "El papel de la Convención Universal sobre Derecho de Autor y su futuro", e.Boletín de derecho de autor, UNESCO, octubre-diciembre 2006, disponible en: http://unesdoc.unesco.org/images/0015/001578/157846s.pdf (consultado: 14.05.2017).

LINK, B., "Drawing a line in alternate universes: exposing the inadequacies of the current four factor fair use test through chanslash", Thomas Jefferson Law Review, Vol. 33, núm. 139, 2010, pp. 139-180.

LIPINSKI, T. A., "Toward a Functional Understanding of Fair Use in U.S. Copyright Law", Annual Review of Information Science and Technology, Vol. 45, Sección 1, 2011, pp. 523-621.

LIPSZYC, D., Derecho de Autor y Derechos Conexos, Félix Varela, Vol. 1, La Habana, 1998.

- Nuevos temas de derechos de autor y derechos conexos, UNESCO-CERLACZAVALIA, Buenos Aires, 2004.

López MAZA, S. y Minero AlejAndre, G., "El carácter equitativo de la compensación por copia privada. Comentario a la sentencia de TJUE de 11 de octubre de 2010 (caso Padawan)”, Pe. I. Revista de Propiedad Intelectual, núm. 36, 2010, pp. 89-116.

LÓPEZ MAZA, S., "Estudio de los criterios del art. 25.6.4 LPI y su aplicación a la Orden ministerial PRE/1743/2008, de 18 de junio", Pe. I. Revista de Propiedad Intelectual, núm. 32, 2009, pp. 13-96.

- Límites al derecho de reproducción en el entorno digital, COMARES, Granada 2009.

- "La posibilidad de utilización directa por el Juez de la regla de los tres pasos", en AA.VV., Estudios sobre la Ley de Propiedad Intelectual: últimas reformas y materias pendientes, Dykinson, Madrid, 2016, pp. 297-342.

LÓPEZ RICHART, J., "La copia privada ante los desafíos de la tecnología digital", en MoReno MARTínez, J. A. (Coord.), Limites a la propiedad intelectual y nuevas tecnologías, Dykinson, Madrid, 2008, pp. 177-235.

LÓPEZ SÁNCHEZ, C., "Consecuencias jurídicas de la sentencia del TJUE en el caso Padawan", en ESTEVE PARDO, M. A. (Coord.), Cuestiones de actualidad sobre propiedad intelectual. Iniciativas legales frente a las descargas ilegales en Internet y consecuencias del "caso Padawan" sobre la compensación equitativa por copia privada, Tirant lo Blanch, Valencia, 2013, pp. 111-125.

LuCAS, A. y CÁmara Águila, P., "Por una interpretación razonable de la regla de los tres pasos, o por qué hay que evitar la imprecisión: Un estudio sobre la `Declaración por una interpretación equilibrada de la regla de los tres pasos en derecho de autor'", Pe. I. Revista de Propiedad Intelectual, núm. 33, 2009, pp. 13-37.

Manger, W., El Panamericanismo y las Conferencias Panamericanas, Serie sobre Congresos y Conferencias núm. 22, Unión de Repúblicas Americanas, 1930.

Marco Molina, J., "Bases históricas y filosóficas y precedentes legislativos del Derecho de autor”, Anuario de Derecho Civil, núm. 1, Madrid, 1994, pp. 121-208. 
- La propiedad intelectual en la legislación española, Marcial Pons, Madrid, 1995.

Marcos Fernández, F., Santalo Mediavilla, J., SÁnchez Graells, A., Consideraciones sobre el Dictamen de la Comisión Asesora de la Sociedad de la Información: "Evaluación crítica de la propuesta del derecho a compensación por copia privada (canon) en el marco del proyecto de reforma de la Ley de Propiedad Intelectual”, Madrid, 2006.

MARÍN LÓPEZ, J. J., "La copia privada frente a las medidas tecnológicas de protección", Pe. i.: Revista de propiedad intelectual, núm. 20, 2005, pp. 9-76.

- “Artículo 153”, en Bercovitz Rodríguez-Cano, R. (Dir.), Comentarios a la Ley de Propiedad Intelectual, $3^{\text {a }}$ ed., Tecnos, Madrid, 2007, pp. 1888-1915.

Mariscal GarRIDO-FAlla, P., Derecho de transformación y obra derivada, Tirant Lo Blanch, Valencia, 2013.

Martín Alonso, N., "Contradicción entre los ordenamientos jurídicos nacional y comunitario. El papel del juez nacional y la cuestión prejudicial", Noticias Jurídicas, 2 de septiembre de 2014, disponible en: http://noticias.juridicas.com/conocimiento/articulos-doctrinales/4926-contradiccionentre-los-ordenamientos-juridicos-nacional-y-comunitario-el-papel-del-juez-nacional-yla-cuestion-prejudicial/ (consultado: 27.06.2017).

Martín Salamanca, S., “Artículo 31”, en RodríGuez Tapia, J. M., Comentarios a la Ley de Propiedad Intelectual, 2a ed., Aranzadi, Navarra 2009, pp. 237-251.

Martín Salamanca, S., "Límites a los derechos de explotación (II)", en Esteve PARDo. Ma. A. (Coord.), Propiedad Intelectual. Doctrina, Jurisprudencia, Esquemas y Formularios, Tirant Lo Blanch, Valencia, 2009, pp. 227-250.

Martín ViLlarejo, A., "Derechos de los productores de grabaciones audiovisuales", en Esteve Pardo. Ma . A. (Coord.), Propiedad Intelectual. Doctrina, Jurisprudencia, Esquemas y Formularios, Tirant Lo Blanch, Valencia, 2009, pp. 663-674.

MARTÍNEZ ESPÍN, P., "El nuevo régimen de la compensación equitativa por copia privada en España", en AA. VV., Estudios sobre la Ley de Propiedad Intelectual: Últimas Reformas y Materias Pendientes, Dykinson, Madrid, 2016, pp. 441-492.

MARTíneZ LAGE, S., "El acuerdo ente las partes como instrumento primordial para hacer efectiva la remuneración por copia privada", en MINISTERIO DE CULTURA, La copia privada a examen: el derecho de remuneración compensatoria en el ámbito de la Propiedad Intelectual, Colección de Análisis y Documentos, núm. 6, Madrid, 1995, pp. 103-114.

Masouye, C., Guía del Convenio de Berna para la protección de las obras literarias y artísticas (Acta de París, 1971), OMPI, Ginebra, 1978.

Mazziotti, G., EU Digital Copyright Law and the End-User, Springer, Berlín, 2008.

MiLES, E., "In re Aimster \& MGM, Inc. v. Grokster, Ltd.: Peer-to-Peer and the Sony Doctrine", Berkeley Technology Law Journal, núm. 1, Vol. 19, 2004, pp. 21-57. 
Moreno Martínez, J. A. (Coord.), Límites a la propiedad intelectual y nuevas tecnologías, Dykinson, Madrid, 2008.

Moscoso del Prado Hernández, A. (Coord.), Practicum Propiedad Intelectual 2016, Aranzadi, Pamplona, 2016.

O`Callaghan Muñoz, X., Compendio de Derecho Civil, Tomo 2 (Derecho de Obligaciones), Editorial Universitaria Ramón Areces, Madrid, 2012.

Ortega DíAz, J. F., Los enlaces en Internet. Propiedad intelectual e industrial y responsabilidad de los prestadores, Aranzadi, Cizur Menor, Navarra, 2006.

PADRÓs ReIG, C., "Debilidades y retos del régimen jurídico vigente de protección de la copia privada", en PADrós ReIG, C. y LóPEZ SinTAS, J. (Dirs.), El canon digital a debate. Revolución tecnológica y consumo cultural en un nuevo marco jurídicoeconómico, Atelier, Barcelona, 2011, pp. 169-246.

Parra TrujiLlo, E., "Comentarios a las reformas a la Ley Federal del Derecho de Autor”, Revista de Derecho Privado, nueva época, año III, 2004, pp. 95-110.

PAVÓN CADAVID, J. A., "Aproximación a la historia del derecho de autor: antecedentes normativos", La propiedad inmaterial, Revista del Departamento de la Propiedad Intelectual de la Universidad Externado de Colombia, núm. 13, 2009, pp. 59-104.

Pérez De Ontiveros Baquero, C., "Artículo 31”, en BercovitZ-RodríGuez-CANO, R. (Coord.), Comentarios a la Ley de Propiedad Intelectual, $2^{\mathrm{a}}$ ed., Tecnos, Madrid, 1997, pp. 593-606.

- "Aproximación al significado de la expresión ámbito estrictamente doméstico en la regulación legal de la facultad patrimonial de comunicación pública", Pe. i. Revista de Propiedad Intelectual, núm. 12, 2002, pp. 25-52.

PÉREZ GARCÍA, J., La industria electrónica ante el canon y la copia privada digital: solidaridad entre empresas, internautas y consumidores, Dykinson, Madrid, 2015.

PÉREZ GonZÁlez, C., "La cuestión prejudicial", en Grandes Tratados: Practicum Proceso Contencioso - Administrativo 2015, Aranzadi, Madrid, 2014, disponible en: http://aranzadi.aranzadidigital.es/maf/app/document?docguid=Ie531be505f1211e49d43 $\underline{010000000000 \& \text { srguid }=\mathrm{i} 0 \mathrm{ad} 82 \mathrm{~d} 9 \mathrm{a} 00000161 \mathrm{f08c} 17769 \mathrm{c} 5996 \mathrm{~b} 6 \& \mathrm{src}=\text { withinResuts\&sp }}$ $\mathrm{os}=3 \&$ epos $=3 \&$ displayid $=\&$ publicacion $=\&$ clasificationMagazines $=\&$ fechacomun $=\& n u$ meropub-tiponum $=$ (consultado: 18.10 .2017$)$.

PÉREZ-Cruz, F., "La Campaña Nacional de Alfabetización en Cuba", Varona (10-23), núm. 53, 2011, pp. 10-23.

PICARD, E., "Embryologie Juridique", Journal du droit international privé, Clunet, 1883 , pp. 565-585.

PinA, C. y MuÑoz Vico, A., "Comentario a la sentencia del Tribunal de Justicia de la Unión Europea de 21 de octubre de 2010 (Asunto C-467/08)”, Actualidad Jurídica Aranzadi, núm. 809, 2010, pp. 12-13. 
PIÑA GARRIDO, L., "El canon digital español y el derecho comunitario: Conclusiones de la abogada general en el asunto C-467/08, Sociedad General de Autores y Editores (SGAE) contra Padawan S.L., pendientes de la sentencia del TJUE", Crónica Tributaria: Boletín de Actualidad, núm. 7, 2010, pp. 19-44.

Plaza Penadés, J., El derecho de autor y su protección en el art. 20.1.b) de la Constitución, Tirant lo Blanch, Valencia, 1997.

- Propiedad Intelectual y Sociedad de la Información (Tratados de la OMPI, Directiva 2001/29/CE y Responsabilidad Civil en la Red), Aranzadi, Navarra, 2002.

- "Artículo 25", en RodríGuez TAPIA, J. M. (Dir.), Comentarios a la Ley de Propiedad Intelectual, $2^{\mathrm{a}}$ ed., Aranzadi, Pamplona, 2009, pp. 204-220.

Pogolotti, G., "Los polémicos Sesenta" (Prólogo a la antología de ensayos Polémicas culturales de los 60), La Jiribilla, Año V, La Habana, 2007.

Renouard, A. Ch., Traité des droits d'auteurs: dans la littérature, les sciences et les beaux-arts, Libraire de Jules Renouard et C., Vol. I, tomo 1, Paris, 1838.

RIBAS, X., "Usos permitidos en Internet", disponible en: http://www.onnet.es/01005006.htm (consultado 26.01.2017).

RIBERA BLANES, B., El derecho de reproducción del autor y sus límites, Tesis doctoral, Facultad de Derecho, Universidad de Alicante, Alicante, 2002.

- El derecho de reproducción en la propiedad intelectual, Dykinson, Madrid, 2002.

Rivero Hernández, F., “Artículo 17”, en Bercovitz RodrígueZ-Cano, R. (Coord.), Comentarios a la Ley de Propiedad Intelectual, $3^{\mathrm{a}}$ ed., Tecnos, Madrid, 2007, pp. 269283.

- "Artículo 21", en Bercovitz RodríGuez-CANo, R. (Coord.), Comentarios a la Ley de Propiedad Intelectual, $3^{\mathrm{a}}$ ed., Tecnos, Madrid, 2007, pp. 378-395.

RodrígueZ TAPIA, J. M., La Ley de Propiedad Intelectual tras las reformas efectuadas por la Ley 19/2006, de 5 de junio y 23/2006, de 7 de julio, Aranzadi, Navarra, 2006.

- "Artículo 18”, en RodríGuez TAPiA, J. M., Comentarios a la Ley de Propiedad Intelectual, $2^{\mathrm{a}}$ ed., Aranzadi, Madrid, 2009, pp. 154-157.

Rogel Vide, C. y Serrano Gómez, E., Manual de Derecho de Autor, Reus, Madrid, 2008.

Rogel VIDE, C., Estudios sobre Propiedad Intelectual, 1ª ed., Bosch, Barcelona, 1995.

- Estudios completos de Propiedad Intelectual, Vol. IV, Reus, Madrid, 2013.

Ruiz Hidalgo, C., "Aproximación tributaria a la naturaleza del canon analógico y digital”, Crónica Tributaria, núm. 135, 2010, pp. 215-229.

Ruiz ZAPATERO, G. G., "Naturaleza y límites constitucionales de la compensación equitativa por copia digital privada establecida en la Ley 23/2006 (RCL 2006, 1386) de 
modificación del Texto Refundido de la Ley de Propiedad Intelectual”, Repertorio de jurisprudencia Aranzadi, núm. 7, 2007, pp. 185-229.

SAG, M., “The Prehistory of Fair Use”, Brooklyn Law Review, Vol. 76, núm. 4, 2011, pp. 1371-1412.

SAIZ GARCíA, C., Obras audiovisuales y derecho de autor, Aranzadi, 2002.

- "Artículo 5. Autores y otros beneficiarios" (Comentario), en PALAU RAMíREZ, F. y Palao Moreno, G. (Dirs.), Comentarios a la Ley de Propiedad Intelectual, Tirant Lo Blanch, Valencia, 2017, pp. 123-134.

SAlas Carceller, A., "Los casos Google en las diferentes jurisprudencias", en O’Callaghan, X. (Coord.), Los derechos de propiedad intelectual en la obra audiovisual, Dykinson, Madrid, 2011, pp. 389-405.

SALAZAR ReYes-Zumeta, L., "Aproximación teórica a la naturaleza jurídica de los bienes intelectuales y del Derecho de Propiedad Intelectual", Revista Propiedad Intelectual, núm. 13, Mérida, 2010, pp. 50-71.

SÁNCHEZ ARISTI, R., "La copia privada digital", Pe. i.: Revista de Propiedad Intelectual, núm. 14, 2003, pp. 9-40.

- "Artículo 18", en Bercovitz RodríGuez-CAno, R. (Coord.), Comentarios a la Ley de Propiedad Intelectual, $3^{\mathrm{a}}$ ed., Tecnos, Madrid, 2007, pp. 283-303.

- El intercambio de obras protegidas a través de las plataformas peer-to-peer, Instituto de Derecho de Autor, Madrid, 2007.

- SÁNCHEZ ARISTI, R., "Enlazadores y seudoenlazadores en Internet: del rol de intermediarios hacia el de proveedores de contenidos que explotan obras y prestaciones intelectuales", Revista Doctrinal Aranzadi Civil-Mercantil, núm. 5, 2012, pp. 91-135.

- “Artículo 17”, en Bercovitz RodríGuez-Cano, R. (Coord.), Comentarios a la Ley de Propiedad Intelectual, $4^{\mathrm{a}}$ ed. Tecnos, Madrid, 2017, pp. 293-308.

- “Artículo 18”, en Bercovitz Rodríguez-CAno, R. (Coord.), Comentarios a la Ley de Propiedad Intelectual, $4^{\mathrm{a}}$ ed., Tecnos, Madrid, 2017, pp. 309-337.

Senftleben, M., Copyright, Limitations and the Three-Step Test, Wolters Kluwer, La Haya, 2004.

- "Bridging the differences between Copyright's Legal Traditions - The Emerging EC Fair Use Doctrine", Journal of the Copyright Society of the U.S.A., 2010, pp. 521-552.

- "The International Three-Step Test: A Model Provision for EC Fair Use Legislation", JIPITEC, núm. 1, 2010, pp. 67-82.

SERrano CAÑAS, J. M. "La transposición de la Directiva 2001/29/CE. Una visión comparada", en GARCÍA PÉREZ, R. y LÓPEZ SUÁREZ, M. A. (Eds.), Nuevos retos para la Propiedad Intelectual. (II Jornadas sobre la Propiedad Intelectual y el Derecho de autor/a), Universidad de La Coruña, A Coruña, 2008, pp. 49-72.

Serrano Gómez, E., Los derechos de remuneración de la Propiedad Intelectual, Dykinson, Madrid, 2000. 
- “Napster y la propiedad intelectual: ¿una relación imposible?”, Actualidad Civil, núm. 31, 2001, pp. 1109-1121.

SEYMOUR, A. Ch., Fair Dealing: a quaint footnote to the British copyright regime?, Durham theses, Durham University, 2003.

SHIFFRIN, S.V., "Lockean Arguments for Private Intellectual Property", New Essays in the Legal and Political Theory of Property, Cambridge University Press, Cambridge, 2001, pp. 138-167.

SIRINELLI, P., Taller sobre cuestiones de aplicación del Tratado de la OMPI sobre Derecho de Autor (WCT) y el Tratado de la OMPI sobre Interpretación o Ejecución y Fonogramas (WPPT). Excepciones y limitaciones al derecho de autor y los derechos conexos [WCT-WPPT/IMP/1], OMPI, Ginebra, 1999.

Soto Pino, A. y Ramírez Silva, P., "La reclamación del canon por copia privada" (Comentario), Actualidad Jurídica Aranzadi, núm. 859, 2013, p. 10.

SouliÉ, Ch., "La protección de la obra audiovisual: El caso 'Que choisir' y la cuestión de la copia privada", en CAMINAL BADíA, F. de P. (Dir.), Cuadernos de Derecho Judicial, núm. 3 (Protección de la obra audiovisual), Madrid, 2007, pp. 49-86.

Strowel, A., Droit d'auteur et copyright. Divergences et Convergences. Étude de droit comparé, Bruylant, Bruselas, 1993.

Tato Plaza, A. y Torres Pérez, F., “Artículo 31. Reproducciones provisionales y copia privada" (Comentario), en PAlau Ramírez, F. y Palao Moreno, G. (Dirs.), Comentarios a la Ley de Propiedad Intelectual, Tirant Lo Blanch, Valencia, 2017, pp. 489-521.

TAto PlazA, A., "La reforma de la ley de Propiedad Intelectual y los límites al derecho de autor: copia privada, canon digital y press clipping”, en GARCÍA PÉREZ, R. y LÓPEZ SUÁREZ, M. A. (Eds.), Nuevos retos para la propiedad intelectual. (II Jornadas sobre la propiedad intelectual y el derecho de autor/a), Universidad de La Coruña, A Coruña, 2008, pp. 9-29.

Tremblay, J. M. (ed.), Two Treatises of Government [LOCKE, J. 1690, traducción francesa de David MAZEL (1795), a partir de la $5^{\text {a }}$ edición de Londres de 1725], Québec, 2002.

Triaille, J. P. (Ed.), Study on the application of Directive 2001/29/EC on Copyright and Related Rights in the Information Society, European Commission, 2013, p. 252.

VALlÉs RodríGUEZ, M., “Artículo 25”, en BERCOVITZ RodRÍGUEZ-CANO, R. (Coord.), Comentarios a la Ley de Propiedad Intelectual, Tecnos, Madrid, $1^{\text {a }}$ ed., 1989, pp. 456472.

VAllÉs Rodríguez, M., “Artículo 25”, en BercovitZ-RodríGUEZ-CANO, R. (Coord.), Comentarios a la Ley de Propiedad Intelectual, $2^{\mathrm{a}}$ ed., Tecnos, Madrid, 1997, pp. 517563.

Vattier Fuenzalida, C., "La Propiedad Intelectual (Estudio sistemático de la Ley 22/1987)", Anuario de Derecho Civil, núm. 3, Madrid, 1993, pp. 1041-1108. 
Xalabarder Plntada, R. (Mod.); Martín-Prat, M.; Malmierca, M. y Ramírez, J., "La copia privada digital. Mesa redonda", IDP. Revista de Internet, Derecho y Política, núm. 1, 2005, pp. 35-55.

Xalabarder Plantada, R, Declaración por una Interpretación Equilibrada de la Regla de los Tres Pasos en el Derecho de Autor, traducción de la obra en inglés de GEIGER, C.; GRIFFITHS, J.; HILTY, R. M., disponible en: http://in3.uoc.edu/opencms_portalin3/export/sites/default/galleries/docs/INTERDRET/ Xalabarder_2008_trad_Decl_3ST_SPANISH.pdf (consultado: 29.08.2016).

XIOL Ríos, J. A., "La regla de los tres pasos en la jurisprudencia española", en O'Callaghan, X. (Coord.), Los derechos de propiedad intelectual en la obra audiovisual, Dykinson, Madrid, 2011, pp. 373-388.

Zapata LóPeZ, F., "Realidad institucional del Derecho de Autor en América Latina", en Fernández Ballesteros, C. A. (Coord.), Diagnóstico del Derecho de Autor en América Latina, Cerlac, Bogotá, 2007, pp. 23-42.

\section{DOCUMENTOS}

ADEPI, Nota informativa, disponible en http://adepi.net/2017/11/13/sede-electronicaventanilla-unica-fabricantes-distribuidores-importadores-copia-privada-canon-digital/ (consultada: 20 de noviembre de 2017).

AMETIC, Las tecnologías de la información en España, Madrid, 2016, disponible en: http://ametic.es/sites/default/files//TI2016_Vf.pdf (consultado 36.10.2017).

Cámara de Diputados del Congreso de la Unión de Estados Mexicanos (Comisión de Cultura), Dictamen, 29 de abril de 2003 (Gaceta Parlamentaria, Cámara de Diputados, núm. 1240-IV, martes 29 de abril de 2003), disponible en línea: http://gaceta.diputados.gob.mx/Gaceta/58/2003/abr/20030429-IV.html\#Autor

(consultado: 20.09.2017).

Cámara de Diputados del Congreso de la Unión de Estados Mexicanos (Comisión de Cultura), 21 de abril de 2009 (Gaceta Parlamentaria, Cámara de Diputados, núm. 2748XI, jueves 30 de abril de 2009), disponible en: http://gaceta.diputados.gob.mx/Gaceta/60/2009/abr/20090430-XI.html (consultada: 20.09.2017).

ComexPerú, "Tarifas sin control”, Revista Negocios Internacionales (Actualidad), núm. 12-141, 2009, pp. 42-43.

Comisión de las Comunidades Europeas, Libro Verde sobre los derechos de autor y el desafio tecnológico: problemas de derechos de autor que requieren una acción inmediata [COM (88) 172 final], Bruselas, 1988, versión en inglés disponible en: http://aei.pitt.edu/1209/1/COM_(88)_172_final.pdf (consultado: 17.10.2016).

Comisión de las Comunidades Europeas, Libro Verde sobre los Derechos de autor en la economía del conocimiento [COM (2008) 466 final], Bruselas, 2008, versión en inglés 
disponible

en:

http://eurlex.europa.eu/LexUriServ/LexUriServ.do?uri=COM:2008:0466:FIN:EN:PDF (consultado: 17.10.2016).

Comisión de las Comunidades Europeas, Libro Verde. Los derechos de autor y los derechos afines en la Sociedad de la Información [COM (95) 382 final], Bruselas, 1995, disponible en: http://eur-lex.europa.eu/legalcontent/ES/TXT/HTML/?uri=LEGISSUM:124152\&from=EN (consultado: 17.10.2016).

Comisión de las Comunidades Europeas, Los derechos de autor en la economía del conocimiento (Comunicación) [COM (2009) 532 final], Bruselas, 2009, disponible en: http://ec.europa.eu/transparency/regdoc/rep/1/2009/ES/1-2009-532-ES-F1-1.Pdf

(consultado: 17.10.2016).

Comisión Europea (Directorate General Internal Market and Services), Report on the responses to the Public Consultation on the Review of the EU Copyright Rules, julio 2014, disponible en: http://ec.europa.eu/internal_market/consultations/2013/copyrightrules/docs/contributions/consultation-report_en.pdf (consultado: 14.03.2017).

Comisión Europea, Fair compensation for acts of private copying (Background Document), Bruselas, 14 de febrero de 2008, disponible en: http://ec.europa.eu/internal_market/copyright/docs/levy_reform/background_en.pdf (consultado: 29.10.2016).

Comisión Europea, Hacia un marco moderno y más europeo de los derechos de autor, Comunicación de la Comisión al Parlamento Europeo, al Consejo, al Comité Económico y Social Europeo y al Comité de las Regiones [COM (2015) 626 final], Bruselas, 2015, disponible en: https://ec.europa.eu/transparency/regdoc/rep/1/2015/ES/1-2015-626-ES-F1-1.PDF (consultado: 20.10.2016).

Comisión Europea, Propuesta de Directiva del Parlamento Europeo y del Consejo sobre los Derechos de Autor en el Mercado Único Digital [COM (2016) 593 final], Bruselas, 2016, disponible en: https://ec.europa.eu/transparency/regdoc/rep/1/2016/ES/1-2016-593-ES-F1-1.PDF (consultado: 15.03.2017).

Comisión Europea, Public Consultation on the Review of the EU Copyright Rules, 5 de diciembre de 2013 y 5 de febrero de 2014, disponible en: http://ec.europa.eu/internal_market/consultations/2013/copyright-

rules/docs/consultation-document_en.pdf (consultado: 14.03.2017).

Comisión Europea, Stakeholder Consultation on Copyright Levies in a Converging World, 2006, disponible en: http://ec.europa.eu/internal_market/copyright/docs/levy_reform/stakeholder_consultatio n_en.pdf (consultado: 18.11. 2016).

Comisión Europea, Un mercado único de los derechos de propiedad intelectual. Estimular la creatividad y la innovación para generar crecimiento económico, empleos de calidad y productos y servicios de excelencia en Europa, Comunicación al Parlamento Europeo, al Consejo, al Comité Económico y Social Europeo y al Comité de 
las Regiones [COM (2011) 287 final], Bruselas, 2011, disponible en: http://ec.europa.eu/transparency/regdoc/rep/1/2011/ES/1-2011-287-ES-F1-1.Pdf

(consultado: 12.03.2017).

Comisión Europea, Una Estrategia para el Mercado Único Digital de Europa, Comunicación de la Comisión al Parlamento Europeo, al Consejo, al Comité Económico y Social Europeo y al Comité de las Regiones 2015 [COM (2015) 192 final] Bruselas, 2015, disponible en: http://eur-lex.europa.eu/legalcontent/ES/TXT/PDF/?uri=CELEX:52015DC0192\&from=ES $\quad$ (consultado: 12.03.2017).

Committee on Intellectual Property Rights and The Emerging Information Infrastructure, The Digital Dilemma: Intellectual Property in the Information Age, National Academy Press, Washington, D.C., 2000.

Conclusiones de la Abogada General, Sra. Eleanor SHARPSTON, de 24 de enero de 2013 (Asuntos acumulados C-457/11, C-458/11, C-459/11 y C-460/11) [ECLI:EU:C:2013:34].

Conclusiones del Abogado General Sr. Maciej SzPunAR, de 7 de septiembre de 2017 [ECLI:EU:C:2017:649].

Conclusiones del Abogado General Sr. Maciej SzPunAR, de 19 de enero de 2016 [ECLI:EU:C:2016:24].

Consejo de Estado, Dictamen del Anteproyecto de Ley de Modificación del Texto Refundido de la Ley de Propiedad Intelectual, aprobado por Real Decreto Legislativo 1/1996, de 12 de abril, y de la Ley 1/2000, de 7 de enero, de Enjuiciamiento Civil, 28 de noviembre de 2013 [Documento CE-D-2013-1064], disponible en: http://www.boe.es/buscar/doc.php?id=CE-D-2013-1064 (consultado: 03.09.2016).

Consejo de Estado, Dictamen núm. 187/2005: Expediente de Anteproyecto de Ley por la que se modifica el texto refundido de la Ley de Propiedad Intelectual, aprobado por Real Decreto Legislativo 1/1996 de 12 de abril, 10 de marzo de 2005, disponible en: https://www.boe.es/buscar/doc.php?id=CE-D-2005-187 (consultado: 17.11.2016).

Consejo General del Poder Judicial (Comisión de Estudios e Informes), Informe al Anteproyecto de Ley de Modificación de la Ley de Propiedad Intelectual aprobada por el RDL 1/1996, de 12 de abril y de la Ley 1/2000, de 7 de enero, de Enjuiciamiento Civil, 5 de julio de 2013, disponible en: http://www.poderjudicial.es/cgpj/es/Poder_Judicial/Consejo_General_del_Poder_Judici al/Actividad_del_CGPJ/Informes/Informe_al_Anteproyecto_de_Ley_de_modificacion_ del_Texto_Refundido_de_la_Ley_de_Propiedad_Intelectual aprobado_por_Real_decr eto_Legislativo_1_1996_de_12_de_abril_y_de_la_ley_1_2000_de 7_de_enero_de _Enjuiciamiento_Civil (consultado: 24.03.2017).

DG MARKT AND EUROPEAN COMMISSION, Assessing the economic impacts of adapting certain limitations and exceptions to copyright and related rights in the EU. Analysis of specific policy options, 2014, disponible en: 
http://ec.europa.eu/internal_market/copyright/docs/studies/140623-limitationseconomic-impacts-study_en.pdf (consultado: 11.12.2016).

FiDel CAStro, "Discurso de 22 de diciembre de 1961, Departamento de Versiones Taquigráficas del Gobierno Revolucionario", La Habana, 1961, disponible en: http://www.cuba.cu/gobierno/discursos/1961/esp/f221261e.html (consultado 26.09.2017).

GIU-IV-ICV, Enmienda núm. 44 presentada al Congreso de los Diputados en relación con el Proyecto de Ley por el que se modifica el TRLPI, aprobado por el Real Decreto Legislativo 1/1996, de 12 de abril, B.O.C.G. núm. 44-10, de 30 de noviembre de 2005.

Instituto Autor, Informe de la misión de la revisión de la Directiva 2001/29/CE sobre la armonización de ciertos aspectos del derecho de autor y los derechos afines en la sociedad de la información (resumen y traducción de Luis Riera Ramírez), 2015, disponible en: http://www.institutoautor.org/uploads/website/docs/4283-1Informe \%20de\%20la\%20mision\%20de\%20la\%20revision\%20de\%201a\%20Directiva\% 20200129CE\%20-\%20Pierre\%20Sirinelli.pdf (consultado: 16.03.2017).

MC.CREEVY (Comisario de Mercado Interior de la UE), Respuesta formulada en nombre de la Comisión Europea frente a la pregunta escrita del parlamentario europeo D. Raúl ROMEVA I RUEDA, sobre la aplicación del canon digital en España, disponible en: http://www.europarl.europa.eu/sides/getAllAnswers.do?reference=E2007-2864\&language $=\mathrm{ES}$ (consultado: 02.10.2016).

OMC, Informe del Grupo Especial (WT/DS160/R), 15 de junio de 2000, disponible en: https://docs.wto.org/dol2fe/Pages/FE_Search/FE_S_S006.aspx?Query=(\%40Symbol\%3 $\underline{\mathrm{d}+\mathrm{wt} \% 2 \mathrm{fds} 160 \% 2 \mathrm{f} *) \& \text { Language }=\text { SPANISH\&Context=FomerScriptedSearch \&languag }}$ eUIChanged=true, (consultado: 26.06. 2016).

OMC, Informe del Grupo Especial de la OMC, Estados Unidos - Artículo 110(5) de la Ley de Derecho de Autor de los Estados Unidos, de 15 junio de 2000 [2000 WT/DS160/R].

OMPI y Stichting de Thuiskopie, International Survey on Private Copying: Law \& $\begin{array}{lll}\text { Practice, } & 2016 . & \text { Disponible }\end{array}$ http://www.wipo.int/edocs/pubdocs/en/wipo_pub_1037_2017.pdf

OMPI, "Glosario de términos y expresiones sobre Derecho de Autor y Derechos Conexos", Guía sobre los Tratados de Derecho de Autor y Derechos Conexos administrados por la OMPI, Ginebra, 2003, disponible en: http://www.wipo.int/edocs/pubdocs/es/copyright/891/wipo_pub_891.pdf (consultado: 20.12.2016), pp. 272-329.

OMPI, Estudio sobre las limitaciones o excepciones al derecho de autor y los derechos conexos en beneficio de las actividades educativas y de investigación en América Latina y el Caribe [SCCR/19/4], documento preparado por Juan Carlos Monroy Rodríguez, Comité Permanente de Derecho de Autor y Derechos Conexos (19ª sesión), Ginebra,

2009 , disponible en: 
http://www.wipo.int/edocs/mdocs/copyright/es/scer_19/sccr_19_4.pdf (consultado: 02.07.2017).

OMPI, Estudio sobre las limitaciones y excepciones relativas al derecho de autor y a los derechos conexos en el entorno digital [SCCR/9/7], preparado por RICKETSON, S., Ginebra, 2003, disponible en: http://www.wipo.int/edocs/mdocs/copyright/es/sccr_9/sccr_9 7.pdf $\quad$ (consultado: 15/08.2017).

OMPI, Glosario de Derecho de Autor y Derechos Conexos, Ginebra, 1980.

OMPI, International Survey on Private Copying: Law \& Practice, 2015, disponible en: http://www.wipo.int/edocs/pubdocs/en/wipo_pub_1037_2016.pdf $\quad$ (consultado: 24.03.2017)

OMPI, La protección internacional del derecho de autor y de los derechos conexos, disponible en: http://www.wipo.int/export/sites/www/copyright/es/activities/pdf/international_protecti on.pdf (consultado: 14.02.2016).

OMPI, Los derechos de autor y los derechos conexos desde la perspectiva de su gestión colectiva, Séptimo Curso Académico Regional de la OMPI sobre derecho de autor y derechos conexos para países de América Latina [OMPI-SGAE/DA/COS/OO/16e], San José, 28 de agosto a 5 de septiembre de 2000, disponible en: http://www.wipo.int/mdocsarchives/OMPI-SGAE_DA_COS_00/OMPISGAE_DA_COS_00_16e_S.pdf (consultado: 23.06.2017).

OMPI, Obligaciones internacionales en materia de propiedad intelectual: espacios para diseños de políticas nacionales [OMPI/JPI/BUE/06/5], documento preparado por el Sr. Juan José Marín López, Reunión Regional de Directores de Oficinas de Propiedad Industrial y de Oficinas de Derecho de Autor de América Latina, Buenos Aires, 30 de mayo - 2 de junio de 2006.

Parlamento Europeo, Informe sobre los cánones por copia privada, ponente: Françoise Castex, aprobado por la Comisión de Asuntos Jurídicos el 17 de febrero de 2014 [A70114/2014].

Report of the Register of Copyrights on the General Revision of the U.S. Copyright Law, U.S. Government Printing Office, Washington, 1961, disponible en: https://www.copyright.gov/history/1961_registers_report.pdf (consultado: 14.02.2017).

Subdirección General de Estadística y Estudios, Secretaría General Técnica del Ministerio de Educación, Cultura y Deporte, Encuesta de hábitos y prácticas culturales en España 2014-2015, Madrid, 2015, disponible en: https://www.mecd.gob.es/mecd/dms/mecd/servicios-al-ciudadanomecd/estadisticas/cultura/mc/ehc/20142015/Encuesta_de_Habitos_y_Practicas_Culturales_2014-2015.pdf (consultada: 26.10.2017). 


\section{LEGISLACIÓN}

\section{Internacional}

Convenio de la Unión de París para la protección de la Propiedad Industrial, aprobado el 20 de marzo de 1883.

Declaración Universal de Derechos Humanos, de10 de diciembre de 1948.

Convención de Roma sobre la protección de los artistas intérpretes o ejecutantes, los productores de fonogramas y los organismos de radiodifusión, de 26 de octubre de 1961.

Pacto Internacional de Derechos Económicos, Sociales y Culturales, de 16 de diciembre de 1966.

Convenio de Viena sobre Derecho de los Tratados, de 23 de mayo de 1969.

Convenio de Berna para la Protección de las Obras Literarias y Artísticas (1886), revisado en París el 24 de julio de 1971 y enmendado el 28 de septiembre de 1979.

Acuerdo sobre los Aspectos de los Derechos de Propiedad Intelectual relacionados con el Comercio (Acuerdo sobre los ADPIC), de 15 de abril de 1994.

Tratado de la OMPI sobre Derecho de Autor (TODA), de 20 de diciembre de 1996.

Tratado de la OMPI sobre Interpretación o Ejecución y Fonogramas (TOIEF), de 20 de diciembre de 1996.

Tratado de Beijing sobre Interpretaciones y Ejecuciones Audiovisuales, de 24 de junio de 2012.

\section{Unión Europea}

Directiva 91/250/CEE del Consejo, de 14 de mayo de 1991, sobre la protección jurídica de programas de ordenador (D.O.C.E. núm. L 122, de 17 de mayo de 1991).

Directiva 92/100/CEE del Consejo, de 19 de noviembre de 1992, sobre derechos de alquiler y préstamo y otros derechos afines a los derechos de autor en el ámbito de la propiedad intelectual (D.O.C.E. núm. L 346, de 27 de noviembre de 1992).

Directiva 93/83/CEE del Consejo, de 27 de septiembre de 1993, sobre coordinación de determinadas disposiciones relativas a los derechos de autor y derechos afines a los derechos de autor en el ámbito de la radiodifusión vía satélite y de la distribución por cable (D.O.C.E. núm. L 248, de 6 de octubre de 1993).

Directiva 96/9/CE del Parlamento Europeo y del Consejo, de 11 de marzo de 1996, sobre la protección jurídica de las bases de datos (D.O.C.E. núm. L 077, de 27 de marzo de 1996). 
Directiva 98/84/CE del Parlamento Europeo y del Consejo de 20 de noviembre de 1998, relativa a la protección jurídica de los servicios de acceso condicional o basados en dicho acceso (D.O.C.E. núm. L 320/54, de 28 noviembre de 1998).

Directiva 2000/31/CE del Parlamento Europeo y del Consejo, de 8 de junio de 2000, relativa a determinados aspectos jurídicos de los servicios de la sociedad de la información, en particular el comercio electrónico en el mercado interior (D.O.U.E. núm. 178, de 17 de julio de 2000).

Directiva 2001/29/CE del Parlamento Europeo y del Consejo, de 22 de mayo de 2001, relativa a la armonización de determinados aspectos de los derechos de autor y derechos afines a los derechos de autor en la sociedad de la información. (D.O.U.E núm. L 167, de 22 de junio de 2001).

Directiva 2006/115, 12 de diciembre, sobre derechos de alquiler y préstamo y otros derechos afines a los derechos de autor en el ámbito de la propiedad intelectual (D.O.U.E. núm. 376, de 27 de diciembre de 2006).

Directiva 2009/24/CE del Parlamento Europeo y del Consejo, de 23 de abril de 2009, sobre la protección jurídica de programas de ordenador (D.O.U.E. núm. 111, de 5 de mayo de 2009).

European Copyright Code (Proyecto Wittem), 2010.

Directiva 2014/26/UE del Parlamento Europeo y del Consejo, de 26 de febrero de 2014, relativa a la gestión colectiva de los derechos de autor y derechos afines y a la concesión de licencias multiterritoriales de derechos sobre obras musicales para su utilización en línea en el mercado interior (D.O.U.E. núm. L 84/72, de 20 de marzo de 2014).

Resolución de 9 de julio de 2015 del Parlamento Europeo [P8_TA (2015)0273].

\section{España}

\subsection{Leyes Orgánicas}

Ley Orgánica 3/1980, de 22 de abril, del Consejo de Estado (B.O.E. núm. 100, de 25 de abril de 1980).

Ley Orgánica 1/1982, de 5 de mayo, sobre protección civil del derecho al honor, a la intimidad personal y familiar y a la propia imagen (B.O.E. núm. 115, de 14 de mayo de 1982).

\subsection{Leyes}

Código Civil (B.O.E. núm. 206, de 25 julio 1889).

Ley de 10 de enero de 1879 sobre Propiedad Intelectual (B.O.E. núm. 12, de 12 de enero de 1879).

Constitución Española (B.O.E núm. 311, de 29 de diciembre de 1978). 
Ley 22/1987, de 11 de noviembre, de Propiedad Intelectual. (B.O.E. núm. 275, de 17 de noviembre de 1987).

Ley 20/1992, de 7 de julio, de modificación de la Ley 22/1987, de 11 de noviembre de Propiedad Intelectual (B.O.E. núm. 168, de 14 de julio de 1992).

Ley 43/1994, de 30 de diciembre, de incorporación al Derecho español de la Directiva 92/100/CEE, de 19 de noviembre de 1992, sobre derechos de alquiler y préstamo y otros derechos afines a los derechos de autor en el ámbito de la propiedad intelectual (B.O.E. núm. 313, de 31 de diciembre de 1994).

Ley 27/1995, de 11 de octubre, de incorporación al derecho español de la Directiva 93/98/CEE del Consejo, de 29 de octubre de 1993, relativa a la armonización del plazo de protección del derecho de autor y de determinados derechos afines. (B.O.E. núm. 245 , de 13 de octubre de 1995).

Ley 50/1997, de 27 de noviembre, del Gobierno (B.O.E. núm. 285, de 28 de noviembre de 1997).

Ley 5/1998, 6 marzo, de incorporación al Derecho español de la Directiva 96/9/CE, del Parlamento Europeo y del Consejo, de 11 de marzo de 1996, sobre la protección jurídica de las bases de datos (B.O.E. núm. 57, de 7 de marzo de 1998).

Ley 34/2002, de 11 de julio, de servicios de la sociedad de la información y de comercio electrónico (B.O.E. núm. 166, de 12 de julio de 2002).

Ley 58/2003, de 17 de diciembre, General Tributaria (B.O.E. núm. 302, de 18 de diciembre de 2003).

Ley 23/2006, de 7 de julio, por la que se modifica el texto refundido de la Ley de Propiedad Intelectual, aprobado por el Real Decreto Legislativo 1/1996, de 12 de abril (B.O.E. núm. 162, de 8 de julio de 2006).

Ley 10/2007, de 22 de junio, de la lectura, del libro y de las bibliotecas (B.O.E. núm. 150, de 23 de junio de 2007).

Ley 3/2008, de 23 de diciembre, relativa al derecho de participación en beneficio del autor de una obra de arte original (B.O.E. núm. 310, de 25 de diciembre de 2008).

Ley 2/2011, de 4 de marzo, Ley de Economía Sostenible (B.O.E. núm. 55, de 5 de marzo de 2011).

Ley 9/2017, de 8 de noviembre, de Contratos del Sector Público, por la que se transponen al ordenamiento jurídico español las Directivas del Parlamento Europeo y del Consejo 2014/23/UE y 2014/24/UE, de 26 de febrero de 2014 (B.O.E. núm. 272, de 9 de noviembre de 2017).

Ley 21/2014, de 4 de noviembre, por la que se modifica el texto refundido de la Ley de Propiedad Intelectual, aprobado por Real Decreto Legislativo 1/1996, de 12 de abril, y 
la Ley 1/2000, de 7 de enero, de Enjuiciamiento Civil (B.O.E. núm. 268, de 5 de noviembre de 2014).

\subsection{Reales Decretos}

Real Decreto 287/1989, de 21 de marzo, por el que se desarrolla el artículo 25 de la Ley 22/1987, de 11 de noviembre, de Propiedad Intelectual (B.O.E. núm. 72, de 25 de marzo de 1989).

Real Decreto 1584/1991, de 18 de octubre, por el que se aprueba el Reglamento del Registro General de la Propiedad Intelectual (B.O.E. núm. 269, de 9 de noviembre de 1991).

Real Decreto 1434/1992, de 27 de noviembre, de desarrollo de los artículos 24, 25 y 140 de la Ley 22/1987, de 11 de noviembre, de Propiedad Intelectual, en la versión dada a los mismos por la Ley 20/1992, de 7 de julio (B.O.E. núm. 301, de 16 de diciembre de 1992).

Real Decreto 325/1994, de 25 de febrero, por el que se modifica el artículo 15.2 del Real Decreto 1434/1992, de 27 de noviembre, de desarrollo de los artículos 24, 25 y 140 de la Ley 22/1987, de 11 de noviembre, de Propiedad Intelectual, en la versión dada a los mismos por la Ley 20/1992, de 7 de julio (B.O.E. núm. 63, de 15 de marzo de 1994).

Real Decreto 1657/2012, de 7 de diciembre, por el que se regula el procedimiento de pago de la compensación equitativa por copia privada con cargo a los Presupuestos Generales del Estado (B.O.E. núm. 295, de 8 de diciembre de 2012).

\subsection{Reales Decretos Legislativos}

Real Decreto Legislativo 1/1996, de 12 de abril, por el que se aprueba el texto refundido de la Ley de Propiedad Intelectual, regularizando, aclarando y armonizando las disposiciones legales vigentes sobre la materia (B.O.E. núm. 97, de 22 de abril de 1996).

\subsection{Reales Decretos-ley}

Real Decreto-ley 20/2011, de 30 de diciembre, de medidas urgentes en materia presupuestaria, tributaria y financiera para la corrección del déficit público (B.O.E. núm. 315, de 31 de diciembre de 2011).

Real Decreto-ley 12/2017, de 3 de julio, por el que se modifica el texto refundido de la Ley de Propiedad Intelectual, aprobado por el Real Decreto Legislativo 1/1996, de 12 de abril, en cuanto al sistema de compensación equitativa por copia privada (B.O.E. núm. 158, de 4 de julio de 2017).

\section{6. Órdenes}

Orden PRE/1743/2008, de 18 de junio, por la que se establece la relación de equipos, aparatos y soportes materiales sujetos al pago de la compensación equitativa por copia 
privada, las cantidades aplicables a cada uno de ellos y la distribución entre las diferentes modalidades de reproducción (B.O.E. núm. 148, de 19 de junio de 2008).

Orden ECD/2128/2013, de 14 de noviembre, por la que se determina la cuantía de la compensación equitativa por copia privada correspondiente al ejercicio 2012 con cargo a los Presupuestos Generales del Estado y su distribución entre las tres modalidades de reproducción referidas legalmente (B.O.E. núm. 275, de 16 de noviembre de 2013).

Orden ECD/2166/2014, de 14 de noviembre, por la que se determina la cuantía de la compensación equitativa por copia privada correspondiente al ejercicio 2013, con cargo a los Presupuestos Generales del Estado y su distribución entre las tres modalidades de reproducción referidas legalmente (B.O.E. núm. 281, de 20 de noviembre de 2014).

Orden ECD/2226/2015, de 19 de octubre, por la que se determina la cuantía de la compensación equitativa por copia privada correspondiente al ejercicio 2014, con cargo a los presupuestos generales del estado y su distribución entre las tres modalidades de reproducción referidas legalmente (B.O.E. núm. 256, de 26 de octubre de 2015).

\subsection{Resoluciones}

Resolución de 1 de marzo de 1993, de la Secretaría General Técnica, por la que se ordena la publicación del texto del Acuerdo, suscrito por los deudores y acreedores de los bloques fonogramas y demás soportes sonoros y videogramas y demás soportes visuales o audiovisuales, presentes en la Mesa de Negociación del Convenio sobre remuneración compensatoria por copia privada y forma de adherirse a dicho Acuerdo (B.O.E. núm. 53, de 3 de marzo de 1993).

Resolución de 9 de marzo de 1993, de la Secretaría General Técnica, por la que se ordena la publicación del texto del Acuerdo, suscrito por los deudores y acreedores del bloque de publicaciones en forma de libro o asimiladas, presentes en la Mesa de Negociación del Convenio sobre remuneración compensatoria por copia privada y forma de adherirse a dicho Acuerdo (B.O.E. núm. 61, de 12 de marzo de 1993).

Resolución de 29 de marzo de 1994, de la Secretaría General Técnica, por la que se ordena la publicación del texto del acuerdo, suscrito por los deudores y acreedores de los bloques fonogramas y demás soportes sonoros y videogramas y demás soportes visuales o audiovisuales, presentes en la Mesa de Negociación del Convenio sobre remuneración compensatoria por copia privada y forma de adherirse a dichos acuerdos (B.O.E. núm. 77, de 31 de marzo de 1994).

Resolución de 29 de marzo de 1994, de la Secretaría General Técnica, por la que se ordena la publicación del texto del acuerdo, suscrito por los deudores y acreedores del bloque de publicaciones en forma de libro o asimiladas, presentes en la Mesa de Negociación del Convenio sobre remuneración compensatoria por copia privada y forma de adherirse a dichos acuerdos (B.O.E. núm. 77, de 31 de marzo de 1994).

Resolución de 29 de marzo de 1995, de la Secretaría General Técnica, por la que se ordena la publicación del texto del Acuerdo, suscrito por los deudores y acreedores de los bloques fonogramas y demás soportes sonoros y videogramas y demás soportes 
visuales o audiovisuales, presentes en la Mesa de Negociación del Convenio sobre remuneración compensatoria por copia privada ratificado el 27 de febrero de 1995 y forma de adherirse al mismo (B.O.E. núm. 86, de 11 de abril de 1995).

Resolución conjunta de 7 de agosto de 2006, de la Secretaría General Técnica del Ministerio de Cultura y de la Dirección General para el Desarrollo de la Sociedad de la Información del Ministerio de Industria (B.O.E. núm. 202, de 24 de agosto de 2006).

\section{Legislación de otros Estados}

\subsection{Estados Unidos}

Constitution (1787).

United States Copyright Act (1976).

Audio Home Recording Act (1992).

United States Digital Millennium Copyright Act (1998).

\subsection{Francia}

Arrêt du Conseil du Roi, portant règlement sur la durée des privilèges en librairie du 30 août 1777.

Loi $n^{\circ}$ 85-660 du 3 juillet 1985 relative aux droits d'auteur et aux droits des artistesinterpretes, des producteurs de phonogrammes et de videogrammes et des entreprises de communication audiovisuelle.

Loi $n^{\circ} 92-597$ du ler juillet 1992 relative au code de la propriété intellectuelle (J.O.R.F. núm. 0153, 3 julio 1992).

\subsection{Italia}

Legge 22 aprile 1941 n. 633 "Protezione del diritto d'autore e di altri diritti connessi al suo esercizio” (G.U. n. 166 del 16 luglio 1941).

\subsection{Reino Unido}

United Kingdom Copyright, Designs and Patents Act (1988).

United Kingdom Copyright Act (1911).

United States Copyright Act (1909). 


\section{JURISPRUDENCIA}

\section{Internacional}

Folsom v. Marsh 9 F. Cas. 342 (C.C.D. Mass. 1841).

Sony Corp. of Am. v. Universal City Studios, Inc., 464 U.S. 417 (1984).

Harper \& Row Publishers, Inc. v. Nation Enterprises, 471 U.S. 539 (1985).

Salinger v. Random House, Inc., 811 F.2d 90 (2d Cir. 1987).

Wright v. Warner Books, Inc., 953 F.2d 731 (2d Cir. 1991).

American Geophysical Union v. Texaco Inc., 60 F.3d 913 (2nd Cir. 1994).

Campbell v. Acuff-Rose Music, Inc., 510 U.S. 569 (1994).

Norse v. Henry Holt \& Co., 847 F. Supp. 142 (N.D. Cal. 1994).

Dior v. Evora, Dutch Supreme Court (Hoge Raad) 20 October 1995, [1996] Nederlandse Jurisprudentie 682.

Princeton Univ. Press v. Mich. Document Servs., Inc., 99 F.3d 1381 (6th Cir. 1996).

Germania 3 Gespenster am toten Mann, Federal Constitutional Court 29 June 2000, Zeitschrift für Urheber- und Medienrecht (ZUM) 2000.

A\&M Records, Inc. v. Napster, Inc., 239 F.3d 1004 (9th Cir. 2001).

Suntrust Bank v. Houghton Mifflin Co., 268 F.3d 1257 (11th Cir. 2001).

L.A. News Serv. v. CBS Broad., Inc., 305 F.3d 924 (9th Cir. 2002).

In re Aimster Copyright Litigation, 334 F.3d 643 (2003).

Kelly v. Arriba Soft Corp., 336 F.3d 811 (9th Cir. 2003).

Mattel Inc. v. Walking Mountain Prods., 353 F.3d 792 (9th Cir. 2003).

Compaq Computer Corp. v. Ergonome, Inc., 387 F.3d 403 (5th Cir. 2004).

Metro-Goldwyn-Mayer Studios Inc. v. Grokster, Ltd., 545 U.S. 913 (2005).

L'ASBL Association Belge del Consomateurs Test Achast v. La SA EMI Recorded Music Belgium et al., Brussels Court of Appeal, 9 September 2005, case 2004/AR/1649 (Belgium).

Bill Graham Archives v. Dorling Kindersley Ltd., 448 F.3d 605 (2d Cir. 2006).

Blanch v. Koons, 467 F.3d 244 (2d Cir. 2006). 
Studio Canal et al. V. S. Penguin and Union Federale des Consommateurs Que Choisir, Cour de Cassation, 19 June 2008, No. 07-142777 (France).

Warren Publ'g Co. v. Spurlock, 645 F. Supp. 2d 402 (E.D. Pa. 2009).

Righthaven, L.L.C. v. Realty One Grp., Inc., No. 2:10-cv-1036-LRH-PAL. (D. Nev. Oct. 19, 2010).

Associated Press v. Meltwater U.S. Holdings, Inc., 931 F. Supp. 2d 537 (S.D.N.Y. 2013).

Cambridge Univ. Press v. Patton, 769 F.3d 1232 (11th Cir. 2014).

Swatch Grp. Mgmt. Servs. Ltd. v. Bloomberg L.P., 742 F.3d 17 (2d Cir. 2014).

Sentence of the Royal Courts of Justice, 9 de junio de 2015, caso CO/5444/2014, [2015] EWHC 1723 (Admin).

Cambridge University Press v. Mark P. Becker No. 1:08-cv-01425-ODE (N.D. Ga. Mar. 31, 2016).

\section{Tribunal de Justicia de la Unión Europea}

STJCE (TJUE en la actualidad), de 5 de febrero de 1963, NV (Sociedad Anónima) Algemene Transport- en Expeditie Onderneming van Gend \& Loos vs. Nederlandse administratie der belastingen (Administración Tributaria neerlandesa), asunto 26/62.

STJCE (TJUE en la actualidad), de 15 de julio de 1964, Flaminio Costa vs. ENEL (Ente Nazionale Energía Elettrica), asunto 6/64.

STJUE (Gran Sala), de 29 de enero de 2008, Productores de Música de España (Promusicae) vs. Telefónica de España, S.A.U., asunto C-275/06 [ECLI:EU:C:2008:54].

STJUE (Sala Cuarta), de 16 de julio de 2009, Infopaq International A/S y Danske Dagblades Forening, asunto C-5/08 [ECLI:EU:C:2009:465].

STJUE (Sala Tercera), de 21 de octubre de 2010, Padawan S.L. vs. Sociedad General de Autores y Editores de España (SGAE), asunto C- 467/08 [TJCEl2010\312].

STJUE (Sala Tercera), de 16 de junio de 2011, Stichting de Thuiskopie vs. Opus Supplies Deutschland GmbH y otros, asunto C-462/09 [ECLI:EU:C:2011:397].

STJUE (Gran Sala), de 4 de octubre de 2011, Football Association Premier League Ltd y otros, asuntos acumulados C-403/08 y C-429/08 [ECLI:EU:C:2011:631].

STJUE (Sala Tercera), de 1 de diciembre de 2011, Eva-Maria Painer contra Standard VerlagsGmbH y otros, asunto C-145/10 [ECLI:EU:C:2011:798].

STJUE (Sala Segunda), de 11 de julio de 2013. Amazon.com International Sales Inc., Amazon EU Sàrl, Amazon.de GmbH, Amazon.com GmbH, en liquidación, y Amazon Logistik GmbH vs. Austro-Mechana Gesellschaft zur Wahrnehmung mechanisch- 
musikalischer Urheberrechte Gesellschaft $m b H$, asunto C-521/11 [ECLI:EU:C:2013:515].

STJUE (Sala Cuarta), de 27 de junio de 2013, Verwertungsgesellschaft Wort (VG Wort) contra Kyocera, anteriormente Kyocera Mita Deutschland GmbH, Epson Deutschland $G m b H$ y Xerox $G m b H$ en el asunto C-457/11, contra Canon Deutschland GmbH en el asunto C-458/11, y Fujitsu Technology Solutions contra VG Wort en el asunto C-459/11 y Hewlett Packard GmbH contra VG Wort en el asunto C-460/11 (Asuntos acumulados C-457/11 a C-460/11) [ECLI:EU:C:2013:426].

STJUE (Sala Cuarta), de 10 de abril de 2014, ACI Adam BV y otros contra Stichting de Thuiskopie y otros, asunto C-435/12 [TJCE\2014\15].

STJUE (Sala Cuarta), de 5 de junio de 2014, Public Relations Consultants Association Ltd vs. Newspaper Licensing Agency Ltd y otros, asunto C-360/13 [ECLI:EU:C:2014:1195].

STJUE (Sala Cuarta), de 11 de septiembre de 2014, Technische Universität Darmstadt vs. Eugen Ulmer KG, asunto C-117/13 [ECLI:EU:C:2014:2196].

STJUE (Sala Cuarta), de 5 de marzo de 2015, Copydan Båndkopi vs. Nokia Danmark $A / S$, asunto C-463/12 [ECLI:EU:C:2015:144].

STJUE (Sala Cuarta), de 12 de noviembre de 2015, Hewlett-Packard Belgium SPRL vs. Reprobel SCRL, con intervención de Epson Europe BV, asunto C-572/13 [ECLI:EU:C:2015:750].

STJUE (Sala Cuarta), de 9 de junio de 2016, EGEDA, DAMA y VEGAP vs. Administración del Estado y AMETIC, asunto C-470/2014 [ECLI:EU:C:2016:418].

STJUE (Sala Tercera), de 29 de noviembre de 2017, VCAST Limited vs. RTI, asunto C265/16 [ECLI:EU:C:2017:913].

\section{España}

\subsection{Tribunal Constitucional}

STC 196/2009, de 28 de septiembre (B.O.E. núm. 254, de 21 de octubre de 2009).

STC 123/2010, de 29 de noviembre (B.O.E. núm. 4, de 5 de enero de 2011).

\subsection{Tribunal Supremo}

\subsubsection{Sentencias}

STS (Sala de lo Civil), de 3 de junio de 1991 [ECLI: ES:TS:1991:2898].

STS (Sala Civil), de 2 de marzo de 1992 [ECLI: ES:TS:1992:12588]. 
STS (Sala de lo Contencioso-Administrativo), de 10 de febrero de 1997 [Roj: STS 820/1997].

STS (Sala de lo Civil), de 11 de abril del 2000 (RJ 2000\2434).

STS (Sala de lo Civil, Sección Primera) núm. 764/2005, de 25 de octubre de 2005 [Roj: STS 7953/2005].

STS (Sala de lo Contencioso-Administrativo), de 3 de noviembre de 2008 (Roj: STS 6061/2008).

STS (Sala de lo Civil, Sección 1ª), de 3 abril de 2012 (RJ\2012\5272).

STS (Sala de lo Contencioso-Administrativo, Sección Cuarta), de 13 de noviembre de 2012 (RJ\2013\152).

STS (Sala de lo Contencioso-Administrativo, Sección Cuarta), de 13 de noviembre de 2012 (RJ\2013\153).

STS (Sala de lo Contencioso-Administrativo, Sección Cuarta), de 27 de noviembre de 2012 (RJ 2013\431).

STS (Sala de lo Contencioso-Administrativo, Sección Cuarta), de 22 de marzo de 2013 (RJ\2013\2812).

STS (Sala de lo Contencioso-Administrativo, Sección Cuarta), de 22 de marzo de 2013 (RJV2013 \3014).

STS (Sala de lo Contencioso-Administrativo, Sección Cuarta), de 10 de enero de 2014 (RJ\2014\568).

STS (Sección Cuarta, Sala de lo Contencioso-Administrativo), de 10 de noviembre de 2016 [Roj: STS 4832/2016].

\subsubsection{Autos}

ATS (Sala de lo Contencioso-Administrativo, Sección 4ª), 10 septiembre 2014 (ATS 6659/2014).

ATS (Sala de lo Contencioso-Administrativo, Sección 4a), de 10 de septiembre de 2014 (ATS 6659/2014).

\subsection{Audiencia Nacional}

SAN (Sala de lo Contencioso-Administrativo, Sección Tercera), de 22 de marzo de 2011, Recurso contencioso-administrativo 769/2008 (JUR\2011194692).

SAN (Sala de lo Contencioso-Administrativo, Sección Tercera), de 22 de marzo de 2011, Recurso contencioso-administrativo 774/2008 (JUR\2011194693). 
SAN (Sala de lo Contencioso-Administrativo, Sección Tercera), de 22 de marzo de 2011, Recurso contencioso-administrativo 731/2008 (JUR\2011\94694).

SAN (Sala de lo Contencioso-Administrativo, Sección Tercera), de 22 de marzo de 2011, Recurso contencioso-administrativo 755/2008 (JUR\2011194695).

SAN (Sala de lo Contencioso-Administrativo, Sección Tercera), de 22 de marzo de 2011, Recurso contencioso-administrativo 766/2008 (JUR\2011\94696).

SAN (Sala de lo Contencioso-Administrativo, Sección Tercera), de 22 de marzo de 2011, Recurso contencioso-administrativo 704/2008 (JT\2011\202).

SAN (Sala de lo Contencioso-Administrativo, Sección Tercera), de 29 de mayo de 2013 [Roj: SAN 2538/2013].

\subsection{Audiencias Provinciales}

\subsubsection{Sentencias}

SAP Barcelona (Sección 15ª), de 31 de octubre de 2002 (JUR\2004\54771).

SAP Madrid (Sección 14 ${ }^{\mathrm{a}}$ ), de 23 de diciembre de 2003 (JUR\2004\90140).

SAP Málaga (Sección 5ª), de 19 de septiembre de 2006 [SAP MA 952/2006].

SAP Madrid (Sección 28 a), de 8 de febrero de 2007 [Roj: SAP M 3944/2007].

SAP Málaga (Sección 6a) núm. 115, de 20 de febrero de 2007 [Roj: SAP MA 111/2007].

SAP Murcia (Sección 4a) núm. 52/2007, de 22 de febrero de 2007 [Roj: SAP MU 411/2007].

SAP Alicante (Sección 8a), de 17 de julio de 2008 [Roj: SAP A 3307/2008].

SAP Barcelona (Sección 15ª), de 17 de septiembre de 2008 (ACl2008\1773-)].

SAP Barcelona (Sección 15ª), de 15 diciembre de 2009 (JUR 2010\117178).

SAP Madrid (Sección 28 ), de 12 abril de 2010 (AC 2010\1001).

SAP Madrid (Sección 28ª), de 12 noviembre de 2010 (AC 2010\2305).

SAP Barcelona (Sección 15ª), de 24 febrero de 2011 (AC 2011\86).

SAP Barcelona (Sección 15ª), de 2 marzo de 2011 [Roj: SAP B 2/2011].

SAP Barcelona (Sección 15ª), de 7 julio de 2011 (AC 2011\1505).

SAP Oviedo (Sección 1ª), de 8 de julio de 2011 [Roj: SAP O 1179/2011]. 
SAP Murcia (Sección 4ª), de 21 julio de 2011 [Roj: SAP MU 1812/2011].

SAP Barcelona (Sección 15ª), de 30 noviembre de 2011 [Roj: SAP B 13125/2011].

SAP Barcelona (Sección 15ª), de 22 diciembre de 2011 [Roj: SAP B 11458/2011].

SAP Santa Cruz de Tenerife (Sección 4a), de 7 septiembre de 2012 [Roj: SAP TF 2591/2012].

SAP Madrid (Sección 28a), de 22 abril de 2013 [Roj: SAP M 7677/2013].

SAP Madrid (Sección 28a), de 31 marzo de 2014 (AC 2014l652).

SAP Barcelona (Sección 15ª), de 21 mayo de 2014 (JUR\2014\179317).

SAP Guadalajara (Sección 1a), de 4 enero de 2016 (JURL2016132147).

SAP Zaragoza a (Sección 2a), de 8 marzo de 2005 (JUR\2005\100643).

\subsubsection{Autos}

AAP Barcelona, de 15 de septiembre de 2008 [Roj: AAP B 5301/2008].

\subsection{Juzgados de Primera Instancia}

Sentencia del Juzgado de Primera Instancia núm. 22 de Barcelona, de 2 de enero de 2002 [Roj: SJPI 2/2002].

Sentencia del Juzgado de Primera Instancia núm. 7 de Alcalá de Henares, de 15 de junio de 2005 [Roj: SJPI 2/2005].

Sentencia del Juzgado de lo Mercantil núm. 1 de Sevilla, 2 septiembre de 2009 (AC 2009\1970).

Sentencia del Juzgado de lo Mercantil núm. 1 de Bilbao, de 16 de marzo de 2007 [Roj: SJM BI 9/2007].

\section{Otras}

MOTOROLA DEL PERÚ S.A. contra la Asociación Nacional de Artistas Intérpretes y Ejecutantes (ANAIE), la Asociación Peruana de Artistas Visuales (APSAV), la Asociación Peruana de Autores y Compositores (APDAYC), la Entidad de Gestión de Derechos de los Productores Audiovisuales (EGEDA Perú) y UNIMPRO (Expediente $\mathrm{N}^{\circ}$ 2-2009/DDA).

TECH DATA PERÚ S.A.C. contra UNIMPRO (Expediente N² 2-2009/DDA). 


\section{ANEXOS}

\section{ANEXO 1}

\section{MAPA EUROPEO DE COMPENSACIÓN EQUITATIVA POR COPIA PRIVADA}

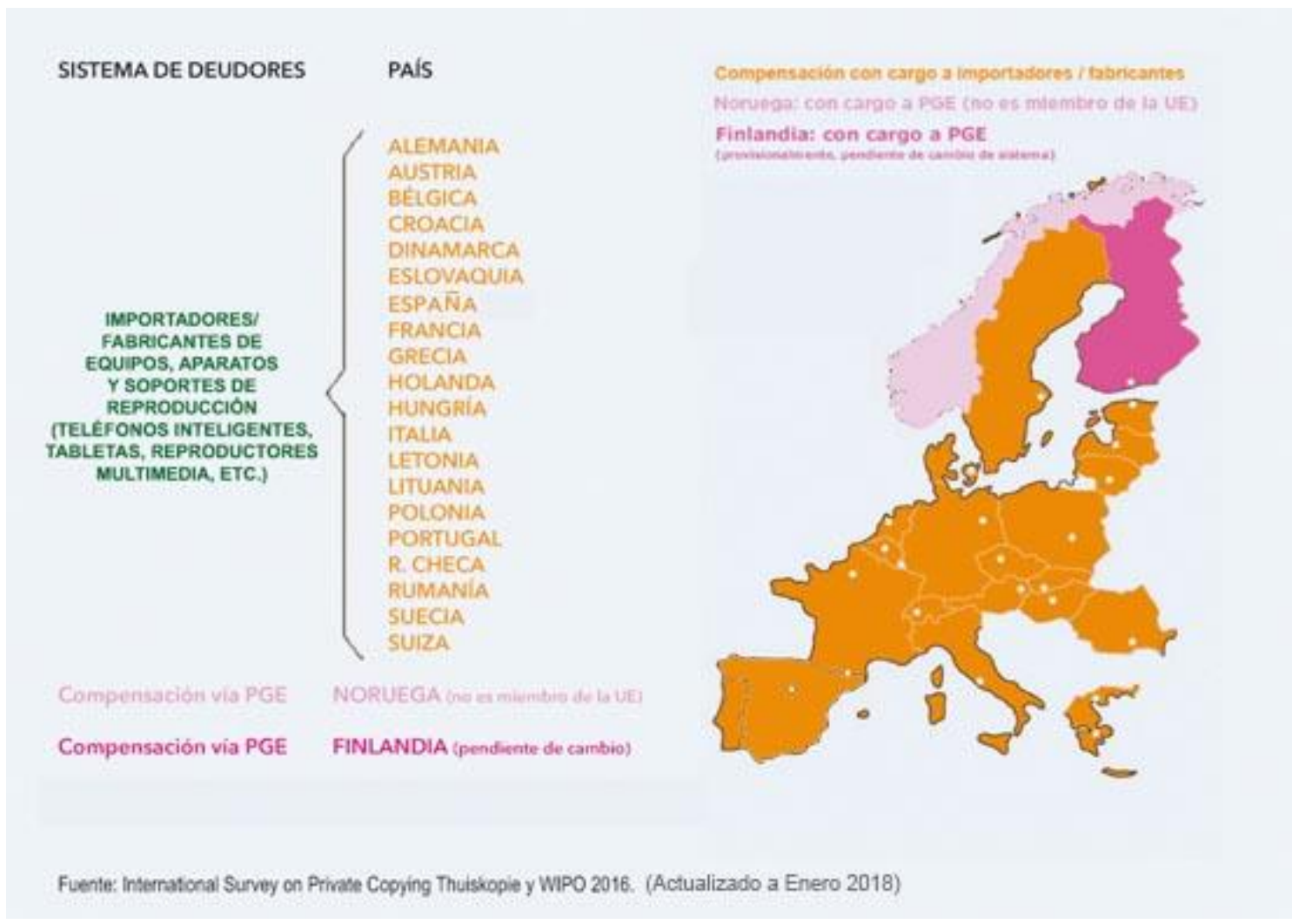


ANEXO 2

TARIFA FIJA PARA EQUIOS, APARATOS Y SOPORTES DE REPRODUCCIÓN ESTANDARIZADOS EN CATORCE PAÍSES DE LA UE*

\begin{tabular}{|c|c|c|c|c|c|c|c|c|c|c|c|c|c|c|c|c|}
\hline & & $\frac{2}{3}$ & $\frac{m}{g}$ & $\frac{8}{5}$ & $\frac{9}{3}$ & $\frac{0}{8}$ & 를 & $\frac{\frac{3}{3}}{\frac{3}{3}}$ & $\frac{3}{3}$ & $\frac{z}{\frac{2}{2}}$ & $\frac{\pi}{2}$ & $\frac{\frac{2}{8}}{\frac{2}{20}}$ & $\begin{array}{l}\text { क्ष } \\
\text { है } \\
\text { e }\end{array}$ & $\frac{\frac{6}{5}}{\frac{8}{8}}$ & $\frac{\frac{b}{3}}{\frac{d}{2}}$ & $\frac{2}{\frac{8}{2}}$ \\
\hline \multirow[t]{8}{*}{2013} & $\mathrm{CD}(700 \mathrm{Mb})$ & 0.24 & 0.12 & 0.21 & 0.01 & 0.32 & 0.20 & 0.35 & 0.06 & 0.15 & 0.15 & 0.03 & 0.05 & 0.07 & 0.08 & 0.15 \\
\hline & DVD (4.7 GB) & 0.36 & 0.40 & & 0.01 & 0.50 & 0.20 & 0.90 & 0.27 & 0.25 & 0.41 & 0.03 & 0.14 & 0.31 & 0.25 & 0.31 \\
\hline & External HDD (1 TB) & 24.30 & 6.75 & & 0.40 & & 18.00 & 20.00 & 17.00 & 7.70 & 10.24 & 1.00 & & 9.25 & & 11.46 \\
\hline & MP3 player (8 GB) & 6.00 & 2.50 & & 1.85 & & 7.00 & 12.00 & 5.00 & 13.99 & 0.15 & 2.00 & & 0.92 & 4.23 & 5.06 \\
\hline & PC (500 GB) & & & & 0.79 & & & & 17.07 & & 0.41 & 5.00 & & 9.25 & & 6.50 \\
\hline & Set-top box (500 GB) & 22.50 & 10.75 & & 5.28 & & 25.00 & 45.00 & 34.00 & 25.19 & 14.81 & 5.00 & & 37.00 & 36.56 & 23.74 \\
\hline & Smartphone (16 GB) & & 2.50 & & 1.32 & & & 8.00 & 5.66 & 16.16 & 0.90 & 5.00 & & 6.47 & 2.84 & 5.43 \\
\hline & Tablet (16 GB) & & 2.50 & & 1.32 & & & 8.40 & 6.13 & & 1.90 & 5.00 & & 1.85 & 2.28 & 3.67 \\
\hline \multirow[t]{8}{*}{2014} & $\mathrm{CD}(700 \mathrm{MB})$ & 0.24 & 0.12 & 0.20 & 0.01 & 0.32 & 0.20 & 0.35 & 0.06 & 0.14 & 0.10 & 0.03 & 0.05 & 0.07 & 0.08 & 0.14 \\
\hline & DVD (4.7 MB) & 0.36 & 0.40 & & 0.01 & 0.50 & 0.20 & 0.90 & 0.27 & 0.24 & 0.20 & 0.03 & 0.14 & 0.29 & 0.26 & 0.29 \\
\hline & External HDD (1 TB) & 15.00 & 6.75 & & 0.39 & & 18.00 & 20.00 & 17.00 & 7.41 & 10.24 & 1.00 & & 8.79 & & 10.46 \\
\hline & MP3 player (8 GB) & 6.00 & 2.50 & & 1.84 & & 7.00 & 12.00 & 5.00 & 13.47 & 6.44 & 2.00 & & 0.88 & 3.77 & 5.54 \\
\hline & $P C(500 \mathrm{~GB})$ & 12.00 & & & 0.79 & & & & 13.19 & & 5.20 & 5.00 & & 8.79 & & 7.49 \\
\hline & Set-top box ( $500 \mathrm{~GB})$ & 20.00 & 10.75 & & 5.25 & & 25.00 & 45.00 & 34.00 & 19.39 & 14.81 & 5.00 & & 35.16 & 31.88 & 22.38 \\
\hline & Smartphone (16 GB) & 18.00 & 2.50 & & 1.31 & & & 8.00 & 6.25 & 10.89 & 4.00 & 5.00 & & 6.15 & 2.88 & 6.50 \\
\hline & Tablet (16 GB) & 12.00 & 2.50 & & 1.31 & & & 8.40 & 7.44 & 10.89 & 4.00 & 5.00 & & 1.76 & 2.30 & 5.56 \\
\hline \multirow[t]{8}{*}{2015} & $\mathrm{CD}(700 \mathrm{MB})$ & 0.24 & 0.12 & 0.20 & 0.01 & 0.32 & & 0.35 & 0.06 & 0.14 & 0.10 & 0.02 & 0.05 & 0.06 & 0.09 & 0.14 \\
\hline & DVD $(4.7 \mathrm{~GB})$ & 0.36 & 0.40 & & 0.01 & 0.50 & & 0.90 & 0.27 & 0.24 & 0.20 & 0.02 & 0.10 & 0.28 & 0.29 & 0.30 \\
\hline & External HDD (1 TB) & 15.00 & 6.75 & & 0.39 & & & 20.00 & 17.00 & 6.79 & 10.24 & 0.70 & 4.10 & 8.55 & & 8.95 \\
\hline & MP3 player (8 TB) & 6.00 & 2.50 & & 1.84 & & & 12.00 & 5.00 & 13.42 & 6.44 & 1.40 & 1.60 & 0.86 & 4.29 & 5.03 \\
\hline & $P C(500 \mathrm{~GB})$ & 12.00 & & & 0.79 & & & & 13.19 & & 5.20 & 3.50 & 2.00 & 8.55 & & 6.46 \\
\hline & Set-top box (500 GB) & 20.00 & 10.75 & & 5.26 & & & 45.00 & 34.00 & 19.32 & 14.81 & 3.50 & 8.00 & 34.21 & 36.31 & 21.01 \\
\hline & Smartphone (16 GB) & 18.00 & 2.50 & & 1.31 & & & 8.00 & 6.25 & 10.30 & 4.00 & 3.50 & 1.92 & 5.99 & 1.20 & 5.72 \\
\hline & Tablet (16 GB) & 12.00 & 2.50 & & 1.31 & & & 8.40 & 8.75 & 10.30 & 4.00 & 3.50 & 1.92 & 1.71 & 2.25 & 5.15 \\
\hline \multirow[t]{8}{*}{2016} & $\mathrm{CD}(700 \mathrm{MB})$ & 0.24 & 0.12 & 0.20 & 0.01 & 0.32 & & 0.35 & 0.06 & 0.14 & 0.10 & 0.02 & 0.05 & 0.06 & 0.09 & 0.14 \\
\hline & DVD $(4.7 \mathrm{~GB})$ & 0.36 & 0.40 & & 0.01 & 0.50 & & 0.90 & 0.27 & 0.24 & 0.20 & 0.02 & 0.10 & 0.28 & 0.28 & 0.30 \\
\hline & External HDD (1 TB) & 4.50 & 6.75 & & 0.40 & & & 20.00 & 17.00 & 6.75 & 10.24 & 0.70 & 4.10 & 8.47 & & 7.89 \\
\hline & MP3 player (8 TB) & 5.25 & 2.50 & & 1.86 & & & 12.00 & 5.00 & 13.35 & 6.44 & 1.40 & 1.60 & 0.85 & 4.20 & 4.95 \\
\hline & $P C(500 \mathrm{~GB})$ & 5.00 & & & 0.80 & & & & 13.19 & & 5.20 & 3.50 & 2.00 & 8.47 & & 5.45 \\
\hline & Set-top box (500 GB) & 20.00 & 10.75 & & 5.31 & & & 45.00 & 34.00 & 19.22 & 14.81 & 3.50 & 8.00 & 33.87 & 22.91 & 19.76 \\
\hline & Smartphone (16 GB) & 2.50 & 2.50 & & 1.33 & & & 8.00 & 6.25 & 10.25 & 4.00 & 3.50 & 1.92 & 5.93 & 1.17 & 4.30 \\
\hline & Tablet (16 GB) & 3.75 & 2.50 & & 1.33 & & & 8.40 & 8.75 & 10.25 & 4.00 & 3.50 & 1.92 & 1.69 & 2.20 & 4.39 \\
\hline
\end{tabular}

* Además de los catorce países de la UE, la tabla incluye a Canadá.

Fuente: OMPI y Stichting de Thuiskopie, International Survey on Private Copying: Law \& Practice 2016, pp. 10 y 11.

Disponible en: http://www.wipo.int/edocs/pubdocs/en/wipo_pub_1037_2017.pdf 


\section{ANEXO 3}

CUANTÍA DE LA COMPENSACIÓN EQUITATIVA POR COPIA PRIVADA APLICABLE A LOS EQUIPOS, APARATOS Y SOPORTES DE REPRODUCCIÓN SEGÚN EL RÉGIMEN TRANSITORIO DEL REAL DECRETO-LEY 12/2017, DE 3 DE JULIO*

\begin{tabular}{|c|c|c|c|}
\hline DESCRIPCIÓN DEL EQUIPO & EJEMPLOS & TIPO & $\begin{array}{l}\text { CUANTÍA DE LA } \\
\text { COMPENSACIÓN }\end{array}$ \\
\hline Audio Casette & Casette & Audio & $0,00 €$ \\
\hline MiniDisc & MiniDisc & Audio & $0,08 €$ \\
\hline CD-R & $\mathrm{CD} 700 \mathrm{MB}$ & Poli & $0,08 €$ \\
\hline CD-RW & CD RW $700 \mathrm{MB}$ & Poli & $0,10 €$ \\
\hline MemoryCards <2GB & $(\mathrm{SD}, \mathrm{MicroSD})<2 \mathrm{~GB}$ & Poli & $0,24 €$ \\
\hline MemoryCards 2GB-4GB & $\begin{array}{l}\text { (SD, MicroSD) 2GB- } \\
4 \mathrm{~GB}\end{array}$ & Poli & $0,24 €$ \\
\hline MemoryCards 4GB -8GB & $\begin{array}{l}\text { (SD, MicroSD) 4GB- } \\
8 \mathrm{~GB}\end{array}$ & Poli & $0,24 €$ \\
\hline MemoryCards >8GB & $(\mathrm{SD}, \mathrm{MicroSD})>8 \mathrm{~GB}$ & Poli & $0,24 €$ \\
\hline VHS 180 & CINTA VHS 180 & Video & $0,00 €$ \\
\hline VHS 240 & CINTA VHS 240 & Video & $0,00 €$ \\
\hline DVD-R 4,7GB & DVD R 4,7GB & Poli & $0,21 €$ \\
\hline DVD-RW 4,7GB & DVD RW 4,7GB & Poli & $0,28 €$ \\
\hline DVD-DL 25GB & DVD DL 25GB & Poli & $0,21 €$ \\
\hline Blu-Ray 25GB & Blu-Ray & Poli & $0,21 €$ \\
\hline Reproductor MP3 <512MB & MP3 512 & Audio & $3,15 €$ \\
\hline Reproductor MP3 <1GB & MP3 1GB & Audio & $3,15 €$ \\
\hline Reproductor MP3 1GB- 2GB & MP3 2GB & Audio & $3,15 €$ \\
\hline Reproductor MP3 2GB- 4GB & MP3 4GB & Audio & $3,15 €$ \\
\hline Reproductor MP3 4GB- 8GB & MP3 8GB & Audio & $3,15 €$ \\
\hline Reproductor MP3 8GB-16GB & MP3 16GB & Audio & $3,15 €$ \\
\hline
\end{tabular}




\begin{tabular}{|c|c|c|c|}
\hline Reproductor MP3 16GB-32GB & MP3 32GB & Audio & $3,15 €$ \\
\hline Reproductor MP3 32GB-64GB & MP3 64GB & Audio & $3,15 €$ \\
\hline Reproductor MP3 >-64GB & MP3 128GB & Audio & $3,15 €$ \\
\hline Reproductor MP4 < 2GB & MP4 2GB & Video & $3,15 €$ \\
\hline Reproductor MP4 2GB- 4GB & MP4 4GB & Video & $3,15 €$ \\
\hline Reproductor MP4 4GB- 8GB & MP4 8GB & Video & $3,15 €$ \\
\hline Reproductor MP4 8GB-16GB & MP4 16GB & Video & $3,15 €$ \\
\hline Reproductor MP4 16GB-32GB & MP4 32GB & Video & $3,15 €$ \\
\hline Reproductor MP4 32GB-64GB & MP4 64GB & Video & $3,15 €$ \\
\hline Reproductor MP4 >-64GB & MP4 128GB & Video & $3,15 €$ \\
\hline Disco no integrado $>120 \mathrm{~GB}$ & $\begin{array}{l}\text { Discos duros o SSD } \\
\text { externos }\end{array}$ & Poli & $6,45 €$ \\
\hline Disco no integrado 120GB - 320GB & $\begin{array}{l}\text { Discos duros o SSD } \\
\text { externos }\end{array}$ & Poli & $6,45 €$ \\
\hline Disco no integrado 320GB - 500GB & $\begin{array}{l}\text { Discos duros o SSD } \\
\text { externos }\end{array}$ & Poli & $6,45 €$ \\
\hline Disco no integrado 500GB - 1TB & $\begin{array}{l}\text { Discos duros o SSD } \\
\text { externos }\end{array}$ & Poli & $6,45 €$ \\
\hline Disco no integrado $>1 \mathrm{~TB}$ & $\begin{array}{l}\text { Discos duros o SSD } \\
\text { externos }\end{array}$ & Poli & $6,45 €$ \\
\hline Grabador PC CD & Grabadora ordenados & Poli & $0,33 €$ \\
\hline Grabador salón CD & Grabador salón & Poli & $0,33 €$ \\
\hline Grabador PC DVD & Grabadora ordenados & Poli & $1,86 €$ \\
\hline Grabador salón DVD & Grabador salón & Video & $1,86 €$ \\
\hline Set-Top Box & $\begin{array}{l}\text { Grabador } \quad \text { Video } \\
\text { Digital }\end{array}$ & Video & $0,00 €$ \\
\hline Disco Multimedia <250 GB & $\begin{array}{l}\text { Disco duro o SSD } \\
\text { Multimedia }\end{array}$ & Poli & $6,45 €$ \\
\hline Disco Multimedia <500GB & $\begin{array}{l}\text { Disco duro o SSD } \\
\text { Multimedia }\end{array}$ & Poli & $6,45 €$ \\
\hline
\end{tabular}




\begin{tabular}{|c|c|c|c|}
\hline Disco Multimedia <750 GB & $\begin{array}{l}\text { Disco duro o SSD } \\
\text { Multimedia }\end{array}$ & Poli & $6,45 €$ \\
\hline Disco Multimedia $<1 \mathrm{~TB}$ & $\begin{array}{ll}\text { Disco } & \text { duro } \\
\text { Multimedia } & \end{array}$ & Poli & $6,45 €$ \\
\hline Disco Multimedia >1TB & $\begin{array}{l}\text { Disco duro } \\
\text { Multimedia }\end{array}$ & Poli & $6,45 €$ \\
\hline Llave USB <1GB & Llave USB & Poli & $0,24 €$ \\
\hline Llave USB <4GB & Llave USB & Poli & $0,24 €$ \\
\hline Llave USB $<\mathbf{8 G B}$ & Llave USB & Poli & $0,24 €$ \\
\hline Llave USB $<16 G B$ & Llave USB & Poli & $0,24 €$ \\
\hline Llave USB <32GB & Llave USB & Poli & $0,24 €$ \\
\hline Llave USB >32GB & Llave USB & Poli & $0,24 €$ \\
\hline Teléfonos móviles no inteligentes & Teléfono móvil & Poli & $1,10 €$ \\
\hline Smart Phone > 2GB & Smartphone & Poli & $1,10 €$ \\
\hline Smart Phone 2GB - 16GB & Smartphone & Poli & $1,10 €$ \\
\hline Smart Phone 16GB- 32GB & Smartphone & Poli & $1,10 €$ \\
\hline Smart Phone 32GB-64GB & Smartphone & Poli & $1,10 €$ \\
\hline Smart Phone 64GB-128GB & Smartphone & Poli & $1,10 €$ \\
\hline Smart Phone >128GB & Smartphone & Poli & $1,10 €$ \\
\hline $\begin{array}{l}\text { Libro electrónico } \quad \text { (reproducción } \\
\text { libros, audio, video) }\end{array}$ & Ebook & Poli & $3,15 €$ \\
\hline Tableta $<2$ GB & Tableta & Poli & $3,15 €$ \\
\hline Tableta 2GB - 16GB & Tableta & Poli & $3,15 €$ \\
\hline Tableta 16GB - 32GB & Tableta & Poli & $3,15 €$ \\
\hline Tableta 32GB-64GB & Tableta & Poli & $3,15 €$ \\
\hline Tableta 64GB-128GB & Tableta & Poli & $3,15 €$ \\
\hline Tableta >128GB & Tableta & Poli & $3,15 €$ \\
\hline $\begin{array}{l}\text { Ordenador con disco integrado } \\
<250 G B\end{array}$ & Ordenador personal & Poli & $5,45 €$ \\
\hline
\end{tabular}




\begin{tabular}{|c|c|c|c|}
\hline $\begin{array}{l}\text { Ordenador con } \quad \text { disco } \\
<500 G B\end{array}$ & Ordenador personal & Poli & $5,45 €$ \\
\hline $\begin{array}{l}\text { Ordenador con disco integrado } \\
<750 \mathrm{~GB}\end{array}$ & Ordenador personal & Poli & $5,45 €$ \\
\hline $\begin{array}{l}\text { Ordenador con disco integrado } \\
>750 \mathrm{~GB}\end{array}$ & Ordenador personal & Poli & $5,45 €$ \\
\hline $\begin{array}{l}\text { Ordenador portátil con disco } \\
\text { integrado }<250 \mathrm{~GB}\end{array}$ & Ordenador personal & Poli & $5,45 €$ \\
\hline $\begin{array}{l}\text { Ordenador portátil con disco } \\
\text { integrado }<500 \mathrm{~GB}\end{array}$ & Ordenador personal & Poli & $5,45 €$ \\
\hline $\begin{array}{l}\text { Ordenador portátil con disco } \\
\text { integrado }<750 \mathrm{~GB}\end{array}$ & Ordenador personal & Poli & $5,45 €$ \\
\hline $\begin{array}{l}\text { Ordenador portátil con disco } \\
\text { integrado }>750 \mathrm{~GB}\end{array}$ & Ordenador personal & Poli & $5,45 €$ \\
\hline TV con disco integrado & TV con disco duro & Video & $5,45 €$ \\
\hline Copiadora monofuncional 1-39 ppm & Copiadora & Reprografía & $4,50 €$ \\
\hline $\begin{array}{l}\text { Copiadora monofuncional más de } 39 \\
\text { ppm }\end{array}$ & Copiadora & Reprografía & $4,50 €$ \\
\hline $\begin{array}{l}\text { Copiadoras blanco } y \quad \text { negro } 1-9 \\
\text { páginas por minuto }\end{array}$ & Copiadora & Reprografía & $4,50 €$ \\
\hline $\begin{array}{l}\text { Copiadoras blanco y negro } 10 \quad-19 \\
\text { páginas por minuto }\end{array}$ & Copiadora & Reprografía & $4,50 €$ \\
\hline $\begin{array}{l}\text { Copiadoras blanco y negro } 20 \quad-39 \\
\text { páginas por minuto }\end{array}$ & Copiadora & Reprografía & $4,50 €$ \\
\hline $\begin{array}{l}\text { Copiadoras blanco y negro más de } 39 \\
\text { páginas por minuto }\end{array}$ & Copiadora & Reprografía & $4,50 €$ \\
\hline $\begin{array}{l}\text { Copiadoras color } 1-39 \text { páginas por } \\
\text { minuto }\end{array}$ & Copiadora & Reprografía & $4,50 €$ \\
\hline $\begin{array}{l}\text { Copiadoras color de más de } 39 \\
\text { páginas por minuto }\end{array}$ & Copiadora & Reprografía & $4,50 €$ \\
\hline Escáner monofuncional de 1- 39 ppm & Escáner & Reprografía & $4,50 €$ \\
\hline $\begin{array}{l}\text { Escáner monofuncional de más de } 39 \\
\text { ppm }\end{array}$ & Escáner & Reprografía & $4,50 €$ \\
\hline
\end{tabular}




\begin{tabular}{|c|c|c|c|}
\hline $\begin{array}{l}\text { Escáner de } 13 \text { a } 39 \text { páginas por } \\
\text { minuto }\end{array}$ & Escáner & Reprografía & $4,50 €$ \\
\hline Escáner de 1 a 12 páginas por minuto & Escáner & Reprografía & $4,50 €$ \\
\hline $\begin{array}{l}\text { Escáner de más de } 39 \text { páginas por } \\
\text { minuto }\end{array}$ & Escáner & Reprografía & $4,50 €$ \\
\hline Escáneres de mano & Escáner & Reprografía & $4,50 €$ \\
\hline Máquina de fax con escáner & Multifuncional & Reprografía & $5,25 €$ \\
\hline Máquina de fax con impresión & Multifuncional & Reprografía & $5,25 €$ \\
\hline Impresora monofuncional 1 - 39 ppm & Impresora & Reprografía & $4,50 €$ \\
\hline $\begin{array}{l}\text { Impresora monofuncional de más de } \\
39 \mathrm{ppm}\end{array}$ & Impresora & Reprografía & $4,50 €$ \\
\hline Impresora tinta & Impresora & Reprografía & $4,50 €$ \\
\hline Impresoras laser & Impresora & Reprografía & $4,50 €$ \\
\hline $\begin{array}{l}\text { Multifuncionales de inyección para } \\
\text { impresión, copia y escaneo }\end{array}$ & Multifuncional & Reprografía & $5,25 €$ \\
\hline $\begin{array}{l}\text { Multifuncionales láser para } \\
\text { impresión, copia y escaneo }\end{array}$ & Multifuncional & Reprografía & $5,25 €$ \\
\hline $\begin{array}{l}\text { Multifuncional de } 1-9 \text { páginas por } \\
\text { minuto tinta }\end{array}$ & Multifuncional & Reprografía & $5,25 €$ \\
\hline $\begin{array}{l}\text { Multifuncional de } 1-9 \text { páginas por } \\
\text { minuto laser }\end{array}$ & Multifuncional & Reprografía & $5,25 €$ \\
\hline $\begin{array}{l}\text { Multifuncional de } 10-19 \text { páginas por } \\
\text { minuto tinta }\end{array}$ & Multifuncional & Reprografía & $5,25 €$ \\
\hline $\begin{array}{l}\text { Multifuncional de } 10-19 \text { páginas por } \\
\text { minuto laser }\end{array}$ & Multifuncional & Reprografía & $5,25 €$ \\
\hline $\begin{array}{l}\text { Multifuncional } 20-39 \text { páginas por } \\
\text { minuto tinta }\end{array}$ & Multifuncional & Reprografía & $5,25 €$ \\
\hline $\begin{array}{l}\text { Multifuncional } 20-39 \text { páginas por } \\
\text { minuto laser }\end{array}$ & Multifuncional & Reprografía & $5,25 €$ \\
\hline $\begin{array}{l}\text { Multifuncional de más de } 39 \text { páginas } \\
\text { por minuto tinta }\end{array}$ & Multifuncional & Reprografía & $5,25 €$ \\
\hline
\end{tabular}


Multifuncional de más de 39 páginas Multifuncional

Reprografía

$5,2500 €$ por minuto laser

* Fuente: http://ventanillaunica.digital/VU_CopiaPrivada.aspx (consultado: 08/12/2017). 


\section{ANEXO 4}

\section{DEDUCCIONES PARA FINES SOCIALES Y CULTURALES}

\begin{tabular}{|l|l|l|}
\hline \multicolumn{1}{|c|}{ Country with social and cultural funds } & $\%$ Social and cultural purposes & Determined by \\
\hline Austria & $50 \%$ & Law \\
\hline Bulgaria & $30 \%$ & Law \\
\hline Burkina Faso & $50 \%$ & Law \\
\hline Croatia & $30 \%$ & Law, music rightholders \\
\hline Czech Republic & $0 \%$ & Rightholders \\
\hline Denmark & $33 \%$ & Law \\
\hline Estonia & $10 \%$ & Law \\
\hline Finland & $50 \%$ video, 35\% audio & Law \\
\hline France & $25 \%$ & Law \\
\hline Hungary & $7 \%$ national cultural fund & Law, rightholders \\
\hline Italy & $3 \%$ Artisjus fund & \\
\hline Japan & $10 \%$ Cultural promotion activities* & Law \\
\hline Latvia & $50 \%$ of video for performing & Performing artists \\
\hline Lithuania & $20 \%$ & Law \\
\hline Paraguay & $10 \%$ & Music authors \\
\hline
\end{tabular}

Fuente: OMPI y Stichting de Thuiskopie, International Survey on Private Copying: Law \& Practice 2016, p. 14.

Disponible en: http://www.wipo.int/edocs/pubdocs/en/wipo_pub_1037_2017.pdf 
ANEXO 5

\section{PRINCIPALES LEYES SOBRE PROPIEDAD INTELECTUAL VIGENTES EN ALGUNOS DE LOS PAÍSES DE AMÉRICA LATINA Y EL CARIBE*}

\begin{tabular}{|c|c|c|c|}
\hline PAÍS & LEY & $\begin{array}{c}\text { FECHA DE } \\
\text { PROMULGACIÓN }\end{array}$ & MODIFICACIONES \\
\hline Argentina & $\begin{array}{l}\text { Ley } \mathrm{N}^{\circ} 11.723 \text {, sobre } \\
\text { el Régimen Legal de } \\
\text { la } \quad \text { Propiedad } \\
\text { Intelectual }\end{array}$ & $\begin{array}{l}28 \text { de septiembre de } \\
1933\end{array}$ & $\begin{array}{l}\text { Ley } \mathrm{N}^{\circ} 26.570 \text {, de } 25 \text { de noviembre, } \\
\text { de } 2009 \text { que modifica la Ley } \mathrm{N}^{\circ} \\
11.723 \text {, de } 28 \text { de septiembre } 1933 \text {, } \\
\text { sobre el Régimen Legal de Propiedad } \\
\text { Intelectual } \\
\text { Ley } \mathrm{N}^{\circ} 26.285 \text {, de } 15 \text { de agosto del } \\
2007 \text {, sobre la Eximición del Pago de } \\
\text { Derechos de Autor, a la Reproducción } \\
\text { y Distribución de Obras Científicas o } \\
\text { Literarias en Sistemas Especiales para } \\
\text { Ciegos y Personas con Otras } \\
\text { Discapacidades Perceptivas } \\
\text { Ley } \mathrm{N}^{\circ} 25.847 \text {, de } 3 \text { de diciembre de } \\
2003 \text {, que sustituye el artículo } 20 \text { de la } \\
\text { Ley } \mathrm{N}^{\circ} 11.723 \text {, de } 28 \text { de septiembre } \\
1933 \text {, sobre el Régimen Legal de la } \\
\text { Propiedad Intelectual } \\
\text { Ley } \mathrm{N}^{\circ} 25.006 \text {, de } 15 \text { de julio de } 1998 \text {, } \\
\text { que modifica la Ley } \mathrm{N}^{\circ} 11.723 \text {, de } 28 \\
\text { de septiembre de } 1933 \text {, sobre el } \\
\text { Régimen Legal de la Propiedad } \\
\text { Intelectual }\end{array}$ \\
\hline $\begin{array}{l}\text { Bolivia } \\
\text { (Estado } \\
\text { Plurinacional } \\
\text { de) }\end{array}$ & $\begin{array}{l}\text { Ley } N^{\circ} 1322 \text {, sobre } \\
\text { el Derecho el Autor }\end{array}$ & 13 de abril de 1992 & - \\
\hline Brasil & $\begin{array}{l}\text { Ley } \mathrm{N}^{\circ} 9.610 \text {, sobre } \\
\text { Derechos de Autor }\end{array}$ & 19 de febrero de 1998 & - \\
\hline
\end{tabular}




\begin{tabular}{|c|c|c|c|}
\hline Chile & $\begin{array}{lr}\text { Ley } \mathrm{N}^{\circ} & 17.336, \text { sobre } \\
\text { la } & \text { Propiedad } \\
\text { Intelectual } & \end{array}$ & 28 de agosto de 1970 & $\begin{array}{l}\text { Ley } \mathrm{N}^{\circ} 20.750, \text { que permite la } \\
\text { Introducción de la Televisión Digital } \\
\text { Terrestre } \\
\text { Ley } \mathrm{N}^{\circ} 20.435 \text {, que modifica la Ley } \\
\mathrm{N}^{\circ} 17.336 \text {, sobre la Propiedad } \\
\text { Intelectual } \\
\text { Ley } \mathrm{N}^{\circ} 19.912 \text {, que adecúa la Ley } \mathrm{N}^{\circ} \\
17.3376 \text { conforme a los Acuerdos de la } \\
\text { Organización Mundial del Comercio } \\
\text { OMC Suscritos por Chile } \\
\text { Ley } \mathrm{N}^{\circ} 19.914 \text {, que adecúa algunas } \\
\text { leyes chilenas al Tratado de Libre } \\
\text { Comercio con los Estados Unidos de } \\
\text { América }\end{array}$ \\
\hline Colombia & $\begin{array}{l}\text { Ley } \mathrm{N}^{\circ} 23, \text { sobre } \\
\text { Derechos de Autor }\end{array}$ & 28 de enero de 1982 & $\begin{array}{l}\text { Ley } \mathrm{N}^{\circ} 1450 \text { de } 2011 \text { ( } 16 \text { de junio) - } \\
\text { Por la cual se expide el Plan Nacional } \\
\text { de Desarrollo, 2010-2014 } \\
\text { Ley } \mathrm{N}^{\circ} 1403 \text { de } 2010 \text { ( } 19 \text { de julio) - } \\
\text { Por la cual se adiciona la Ley } \mathrm{N}^{\circ} 23 \text { de } \\
1982 \text { sobre derechos de autor, se } \\
\text { establece una remuneración por } \\
\text { comunicación pública a los artistas, } \\
\text { intérpretes o ejecutantes de obras y } \\
\text { grabaciones Audiovisuales o "Ley } \\
\text { Fanny Mikey" } \\
\text { Ley } \mathrm{N}^{\circ} 719 \text { de } 2001 \text { ( } 24 \text { de diciembre) } \\
\text { - Por la cual se modifican las Leyes } \mathrm{N}^{\circ} \\
23 \text { de } 1982 \text { y } \mathrm{N}^{\circ} 44 \text { de } 1993 \text { y se } \\
\text { dictan otras disposiciones }\end{array}$ \\
\hline
\end{tabular}




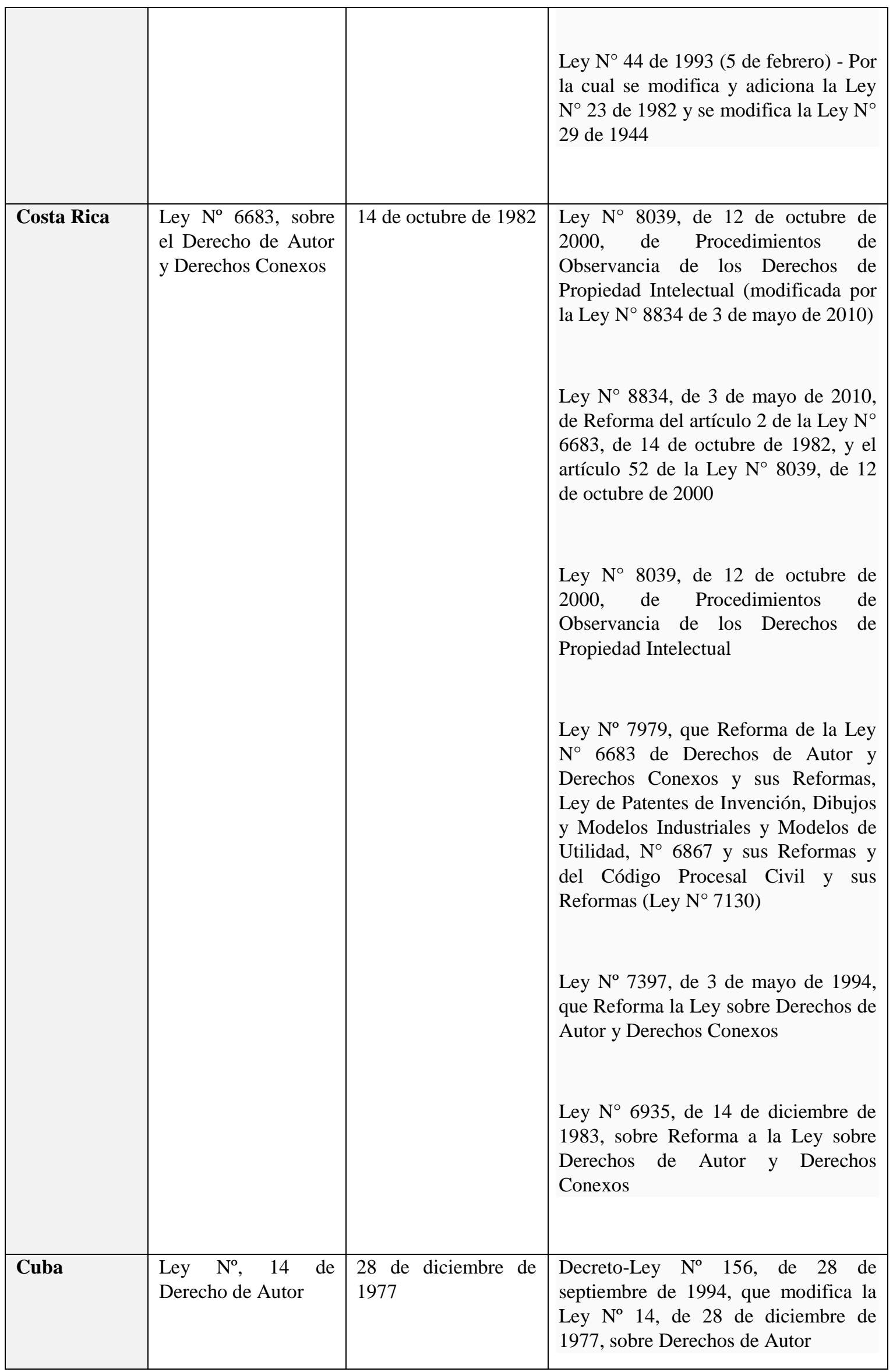




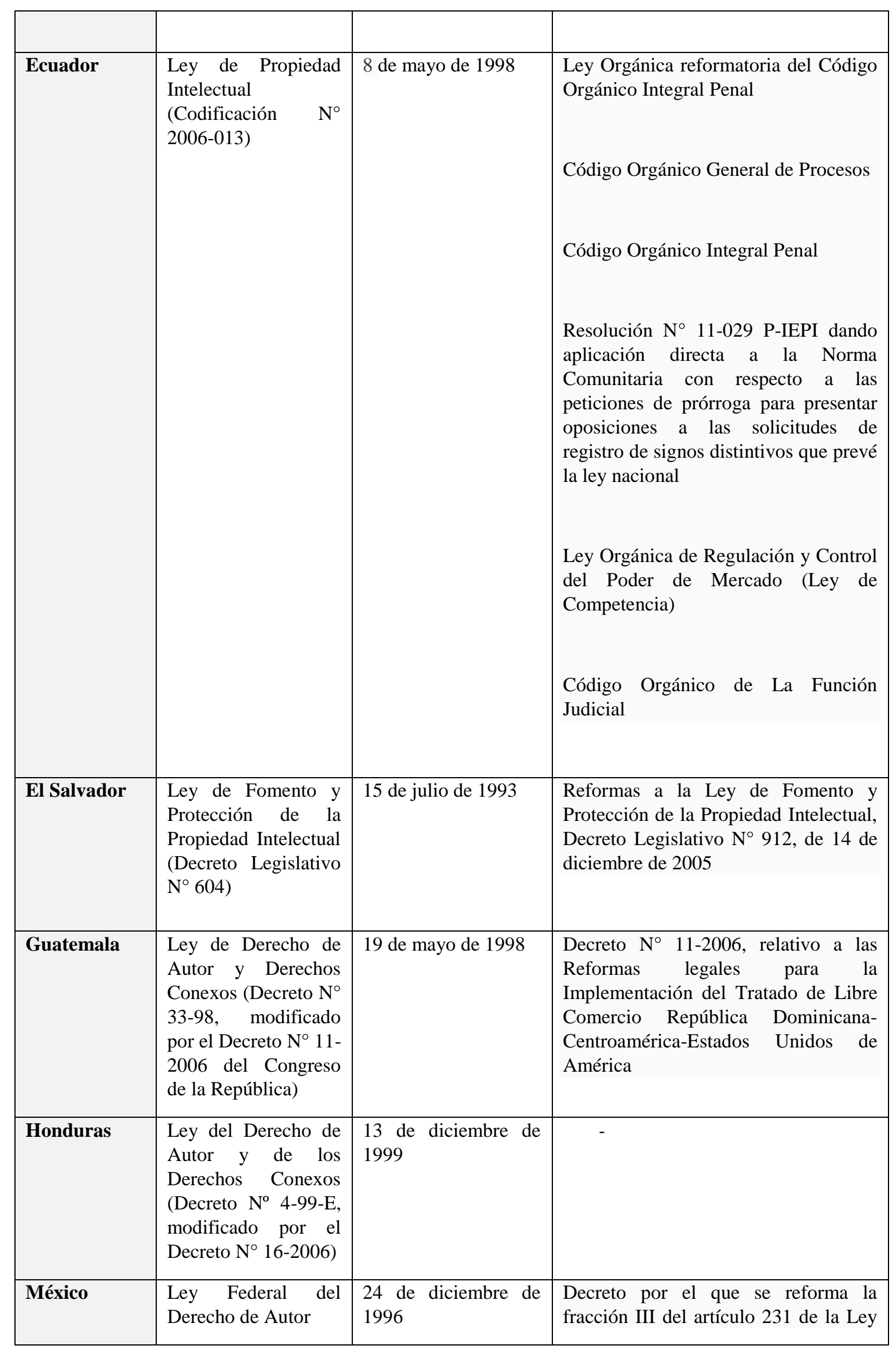




\begin{tabular}{|c|c|c|c|}
\hline & & & $\begin{array}{l}\text { Federal del Derecho de Autor } \\
\text { Decreto por el que se adiciona la } \\
\text { fracción VIII al artículo } 148 \text { de la Ley } \\
\text { Federal del Derecho de Autor } \\
\text { Decreto por el que se reforman los } \\
\text { artículos 210, fracción I; } 218 \text {, fracción } \\
\text { III; 235; y se adiciona un último } \\
\text { párrafo al artículo 213 de la Ley } \\
\text { Federal del Derecho de Autor } \\
\text { Decreto por el que se reforman } \\
\text { diversas disposiciones de la Ley de la } \\
\text { Propiedad Industrial y el artículo } 232 \\
\text { de la Ley Federal del Derecho de } \\
\text { Autor } \\
\text { Decreto por el que se reforma la Ley } \\
\text { Federal del Derecho de Autor } \\
\text { (publicado en el Diario Oficial de la } \\
\text { Federación el } 23 \text { de julio de 2013) }\end{array}$ \\
\hline Nicaragua & $\begin{array}{l}\text { Ley } \mathrm{N}^{\circ} 312, \text { de } \\
\text { Derecho de Autor y } \\
\text { Derechos Conexos }\end{array}$ & 6 de julio de 1999 & $\begin{array}{l}\text { Ley } N^{\circ} 577 \text { de 2006, de Reformas y } \\
\text { Adiciones a la Ley No } 312 \text {, de } 1999 \text { de } \\
\text { Derecho de Autor y Derechos Conexos }\end{array}$ \\
\hline Panamá & $\begin{array}{l}\text { Ley } \mathrm{N}^{\circ} 64, \text { sobre el } \\
\text { Derecho de Autor y } \\
\text { Derechos Conexos }\end{array}$ & 10 de octubre de 2012 & - \\
\hline Paraguay & $\begin{array}{l}\text { Ley } \mathrm{N}^{\circ} 1328 / 1998, \\
\text { de Derecho de Autor } \\
\text { y Derechos Conexos }\end{array}$ & 27 de agosto de 1998 & $\begin{array}{l}\text { Ley } \mathrm{N}^{\circ} 4798 \text {, que crea la Dirección } \\
\text { Nacional de Propiedad Intelectual } \\
\text { (DINAPI) } \\
\text { Ley } \mathrm{N}^{\circ} 3.440 / 2008 \text {, que modifica } \\
\text { varias disposiciones de la Ley } \mathrm{N}^{\circ} \\
1.160 / 1997 \text {, Código Penal }\end{array}$ \\
\hline Perú & 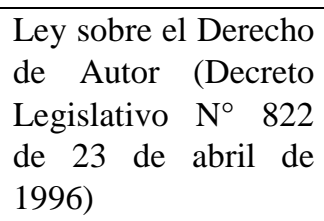 & 23 de abril de 1996 & $\begin{array}{l}\text { Ley } N^{\circ} 30276 \text {, de } 13 \text { de noviembre de } \\
\text { 2014, que modifica la Ley de Derecho } \\
\text { de Autor (Decreto Legislativo } N^{\circ} 822 \\
\text { de } 23 \text { de abril de 1996) }\end{array}$ \\
\hline
\end{tabular}




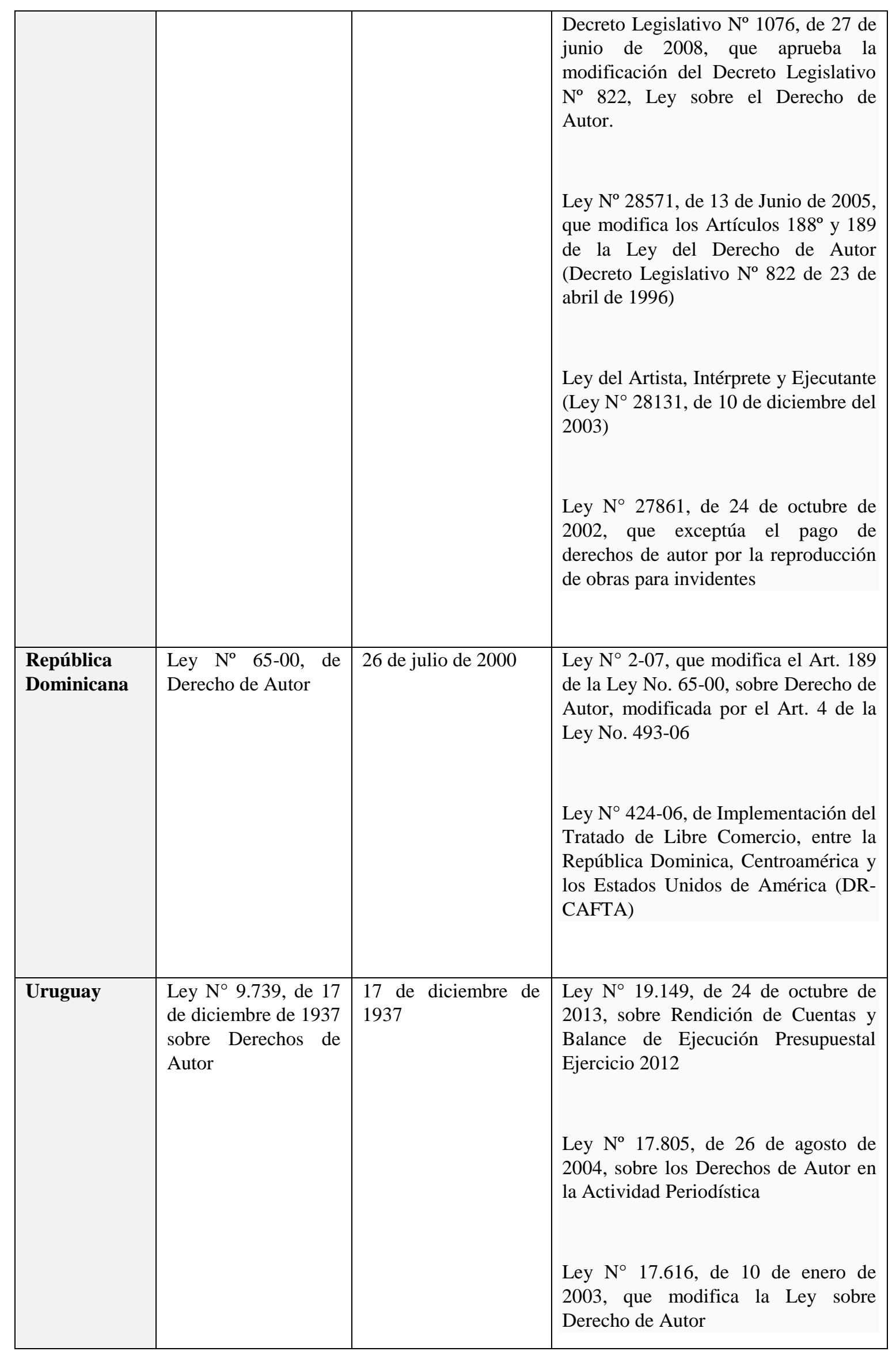




\begin{tabular}{|l|l|l|l|}
\hline & & & \\
\hline $\begin{array}{l}\text { Venezuela } \\
\text { República } \\
\text { Bolivariana } \\
\text { de) }\end{array}$ & $\begin{array}{l}\text { Ley sobre el Derecho } \\
\text { de Autor }\end{array}$ & 14 de agosto de 1993 & - \\
\hline
\end{tabular}

*Fuente: Elaboración propia a partir de información disponible en WIPO Lex (http://www.wipo.int/wipolex/es/) 


\section{ANEXO 6}

VIGENCIA DE LOS PRINCIPALES CONVENIOS Y ACUERDOS INTERNACIONALES SOBRE DERECHO DE AUTOR Y DERECHOS CONEXOS EN ALGUNOS DE LOS PAÍSES DE AMÉRICA LATINA Y EL CARIBE*

\begin{tabular}{|c|c|c|c|c|c|c|c|}
\hline PAÍS & $\begin{array}{l}\text { Convenio de } \\
\text { Berna (CB) }\end{array}$ & $\begin{array}{c}\text { Convención de } \\
\text { Roma (CR) }\end{array}$ & $\begin{array}{l}\text { Convenio para la } \\
\text { protección de los } \\
\text { productores de } \\
\text { fonogramas } \\
\text { contra la } \\
\text { reproducción no } \\
\text { autorizada de sus } \\
\text { fonogramas } \\
\text { (Convenio de } \\
\text { Fonogramas) }\end{array}$ & $\begin{array}{c}\text { Convenio de } \\
\text { Bruselas sobre la } \\
\text { distribución de } \\
\text { señales } \\
\text { portadoras de } \\
\text { programas } \\
\text { transmitidas por } \\
\text { satélite (Convenio } \\
\text { de Bruselas o } \\
\text { Convenio } \\
\text { Satélites) }\end{array}$ & $\begin{array}{l}\text { Acuerdo sobre los } \\
\text { Derechos de } \\
\text { Propiedad } \\
\text { Intelectual } \\
\text { relacionados con } \\
\text { el Comercio } \\
\text { (ADPIC) }\end{array}$ & $\begin{array}{c}\text { Tratado de la } \\
\text { OMPI sobre } \\
\text { Derecho de Autor } \\
\text { (TODA) }\end{array}$ & $\begin{array}{l}\text { Tratado de la } \\
\text { OMPI sobre } \\
\text { Interpretación y } \\
\text { Ejecución de } \\
\text { Fonogramas } \\
\text { (TOIEF) }\end{array}$ \\
\hline Argentina & 19/061967 & 02/03/1992 & $30 / 06 / 1973$ & - & $06 / 03 / 2002$ & $20 / 05 / 2002$ & $20 / 05 / 2002$ \\
\hline Bolivia & 04/09/1973 & 24/11/1993 & - & - & - & - & - \\
\hline Brasil & $09 / 02 / 1922$ & 29/09/1965 & - & - & - & - & - \\
\hline
\end{tabular}




\begin{tabular}{|c|c|c|c|c|c|c|c|}
\hline Chile & $05 / 061970$ & $05 / 09 / 1974$ & $24 / 03 / 1977$ & $08 / 06 / 2011$ & $06 / 03 / 2002$ & $06 / 03 / 2002$ & $20 / 05 / 2002$ \\
\hline Colombia & $07 / 03 / / 1978$ & $17 / 09 / 1976$ & $16 / 05 / 1994$ & $20 / 03 / 2014$ & $06 / 03 / 2002$ & $06 / 03 / 2002$ & $20 / 05 / 2002$ \\
\hline Costa Rica & 10/06/1978 & 09/11/ 1971 & $17 / 06 / 1982$ & $25 / 06 / 1999$ & $06 / 03 / 2002$ & $06 / 03 / 2002$ & $20 / 05 / 2002$ \\
\hline Cuba & 20/02/1977 & - & - & - & - & - & - \\
\hline Ecuador & $09 / 10 / 1991$ & $18 / 05 / 1964$ & $14 / 09 / 1974$ & - & $06 / 03 / 2002$ & $06 / 03 / 2002$ & $20 / 05 / 2002$ \\
\hline El Salvador & $19 / 02 / 1994$ & $29 / 06 / 1979$ & $09 / 02 / 1979$ & $22 / 07 / 2008$ & $06 / 03 / 2002$ & $06 / 03 / 2002$ & $20 / 05 / 2002$ \\
\hline Guatemala & $28 / 07 / 1997$ & $14 / 01 / 1977$ & $01 / 02 / 1977$ & - & $04 / 02 / 2003$ & $04 / 02 / 2003$ & $08 / 01 / 2003$ \\
\hline Honduras & 05/06/1990 & 16/02/1990 & 06/03/1990 & $07 / 04 / 2008$ & $20 / 05 / 2002$ & $20 / 05 / 2002$ & $20 / 05 / 2002$ \\
\hline México & 11/06/1977 & $18 / 05 / 1964$ & $21 / 12 / 1973$ & $25 / 08 / 1979$ & $06 / 03 / 2002$ & $06 / 03 / 2002$ & $20 / 05 / 2002$ \\
\hline Nicaragua & $23 / 08 / 2000$ & $10 / 08 / 2000$ & $10 / 08 / 2000$ & $25 / 08 / 1979$ & $06 / 03 / 2002$ & $06 / 03 / 2002$ & $06 / 03 / 2003$ \\
\hline
\end{tabular}


EL RÉGIMEN JURÍDICO DE LA COMPENSACIÓN EQUITATIVA...

\begin{tabular}{|c|c|c|c|c|c|c|c|}
\hline Panamá & $08 / 06 / 1966$ & $02 / 09 / 1983$ & $29 / 06 / 1974$ & $25 / 09 / 1985$ & $06 / 03 / 2002$ & $06 / 03 / 2002$ & $20 / 05 / 2002$ \\
\hline Paraguay & $02 / 01 / 1992$ & $16 / 02 / 1970$ & $13 / 02 / 1979$ & - & $06 / 03 / 2002$ & $06 / 03 / 2002$ & $18 / 07 / 2002$ \\
\hline Perú & $20 / 08 / 1988$ & $07 / 08 / 1985$ & $24 / 08 / 1985$ & $07 / 08 / 1985$ & $06 / 03 / 2002$ & $06 / 03 / 2002$ & - \\
\hline $\begin{array}{l}\text { República } \\
\text { Dominicana }\end{array}$ & $24 / 12 / 1997$ & $27 / 01 / 1987$ & - & - & $10 / 01 / 2006$ & $10 / 01 / 2006$ & $10 / 01 / 2006$ \\
\hline Uruguay & $10 / 07 / 1967$ & $04 / 07 / 1977$ & $18 / 01 / 1983$ & - & $05 / 06 / 2009$ & $05 / 06 / 2009$ & $28 / 08 / 2008$ \\
\hline Venezuela & $30 / 12 / 1982$ & $30 / 01 / 1996$ & $18 / 11 / 1982$ & - & - & - & - \\
\hline
\end{tabular}

*Fuente: Elaboración propia a partir de información disponible en la página web de la OMPI (http://www.wipo.int/wipolex/es/) 


\section{ANEXO 7}

\section{PREGUNTAS Y RESPUESTAS AL CUESTIONARIO DE LA SECRETARÍA DE LA OMPI (PRIMERA PARTE)}

(Preguntas generales sobre limitaciones y excepciones)

\begin{tabular}{|c|c|}
\hline CUESTIONES & $\begin{array}{l}\text { 1. ¿Establece el ordenamiento jurídico de su país un número de limitaciones y excepciones legales específicas restringido, un sistema } \\
\text { de limitaciones y excepciones abierto (como el uso leal o las prácticas leales), o una mezcla de ambos sistemas? }\end{array}$ \\
\hline Argentina & Específicas \\
\hline Brasil & Específicas \\
\hline Chile & $\begin{array}{l}\text { Existe un catálogo de excepciones específicas, pero contiene una norma que incluye varias finalidades que le dan un carácter flexible (art. } \\
\text { 71Q). }\end{array}$ \\
\hline Colombia & Específicas \\
\hline Guatemala & $\begin{array}{l}\text { Específicas } \\
\text { Art. } 63 \text { de la Ley de D.A. }\end{array}$ \\
\hline México & Específicas \\
\hline Perú & Específicas \\
\hline República Dominicana & Específicas \\
\hline Uruguay & Específicas \\
\hline
\end{tabular}




\begin{tabular}{|c|c|}
\hline CUESTIONES & $\begin{array}{l}\text { 2. ¿Contempla el ordenamiento jurídico de su país la prueba del criterio triple como disposición general en materia de limitaciones y } \\
\text { excepciones al derecho de autor? }\end{array}$ \\
\hline Argentina & Sí \\
\hline Brasil & $\begin{array}{l}\text { No } \\
\text { Hay una limitación que permite la reproducción de pequeños extractos de obra preexistente en una obra nueva, en el que hay una referencia al } \\
\text { criterio triple (art. 46.VIII). }\end{array}$ \\
\hline Chile & No \\
\hline Colombia & Sí \\
\hline Guatemala & $\begin{array}{l}\text { Sí } \\
\text { Art. } 63 \text { de la Ley de D.A }\end{array}$ \\
\hline México & $\begin{array}{l}\text { Parcialmente. } \\
\text { El art. } 148 \text { de la LFDA dispone que las obras literarias y artísticas ya divulgadas, podrán utilizarse siempre que no se afecte la normal } \\
\text { explotación de la obra, sin autorización del titular del derecho patrimonial y sin remuneración, citando invariablemente la fuente y sin alterar } \\
\text { la obra sólo en los siguientes casos (...) } \\
\text { Como puede observarse, el citado precepto señala que las obras literarias y artísticas podrán utilizarse, siempre que no se afecte la explotación } \\
\text { normal de la obra. Asimismo, la expresión prevista en la parte final de la citada disposición podría interpretarse como que "se trata de } \\
\text { determinados casos especiales". Sin embargo, el citado artículo en ningún momento especifica que no se cause un perjuicio injustificado a los } \\
\text { intereses legítimos del autor. } \\
\text { Bajo este contexto, se considera que la regla de los tres pasos se aplica parcialmente. }\end{array}$ \\
\hline Perú & $\begin{array}{l}\text { Sí } \\
\text { Cualquiera de las limitaciones previstas en la ley no puede aplicarse a aquellos casos que interfieran con la explotación normal de la obra, o } \\
\text { causen un perjuicio injustificado a los intereses legítimos del autor o del titular del respectivo derecho. }\end{array}$ \\
\hline República Dominicana & Sí \\
\hline
\end{tabular}




\begin{tabular}{|c|c|}
\hline Uruguay & No \\
\hline CUESTIONES & $\begin{array}{l}\text { 3. ¿Establece el ordenamiento jurídico de su país limitaciones y excepciones como libre utilización (no se precisa autorización, pago o } \\
\text { remuneración)? }\end{array}$ \\
\hline Argentina & $\begin{array}{l}\text { Sí. } \\
\text { Ley 11.723: } \\
\text { Cita (art. 10). } \\
\text { Libre utilización con fines informativos (arts. } 27 \text { y 28). } \\
\text { Libre utilización con fines educativos (limitación al derecho de representación, ejecución y recitación públicas, art. 36). } \\
\text { Limitación al derecho de reproducción y distribución de obras literarias en sistemas especiales para ciegos y otras personas con discapacidad } \\
\text { perceptiva (art. } 36 \text { in fine). }\end{array}$ \\
\hline Brasil & $\begin{array}{l}\text { Sí } \\
\text { Los usos previstos en las limitaciones no son considerados ofensa a los derechos autorales. }\end{array}$ \\
\hline Chile & $\begin{array}{l}\text { Sí } \\
\text { Recientemente, la Ley } \mathrm{N}^{\circ} 20.435 \text { promulgada el día } 23 \text { de abril de } 2010 \text {, reformó la ley de propiedad intelectual de Chile (las referencias a las } \\
\text { normas sobre E\&L en este cuestionario son de dicha ley modificatoria). Hoy existe un amplio catálogo (arts. } 71 \mathrm{~B} \text { a } 71 \mathrm{~S} \text { ), dentro de las cuales } \\
\text { podemos destacar: i) utilización de fragmentos breves para cita o con fines de crítica, ilustración, enseñanza e investigación; ii) excepción } \\
\text { amplia para discapacitados; iii) excepción para lecciones de clase y discursos públicos; iv) excepción para demostración al público en salas de } \\
\text { venta; v) excepción para reproducción de obras instaladas en espacios públicos; vi) diversas excepciones para bibliotecas y archivos sin fines } \\
\text { de lucro; vii) excepciones para fines educacionales; viii) excepción para comunicación al público en espacios domésticos, educacionales, y } \\
\text { culturales; ix) excepción de ingeniería reversa, copia de seguridad y estudio y compatibilidad de programas computacionales; x) excepción de } \\
\text { copias temporales; xi) excepción para sátira o parodia; xii) excepción de usos justos o incidentales; xiii) excepción de traducción para uso } \\
\text { privado; xiv) excepción para usos administrativos, judiciales y legislativos, etc. }\end{array}$ \\
\hline Colombia & Sí \\
\hline
\end{tabular}




\begin{tabular}{|c|c|}
\hline & $\begin{array}{l}\text { Todas las limitaciones y excepciones establecidas en la Decisión Andina } 351 \text { de } 1993 \text { (art. 22) y en la Ley } 23 \text { de } 1982 \text { (art. } 31 \text { a 44), son de } \\
\text { libre utilización sin necesidad de remuneración o autorización. }\end{array}$ \\
\hline Guatemala & $\begin{array}{l}\text { Sí } \\
\text { Arts. } 63 \text { al } 71 \text { Ley de D.A }\end{array}$ \\
\hline México & $\begin{array}{l}\text { Sí } \\
\text { Art. } 148 \text { de la LFDA dispone que las obras literarias y artísticas ya divulgadas podrán utilizarse, siempre que no se afecte la explotación } \\
\text { normal de la obra, sin autorización del titular del derecho patrimonial y sin remuneración, citando invariablemente la fuente y sin alterar la } \\
\text { obra, sólo en los siguientes casos... }\end{array}$ \\
\hline República Dominicana & Sí \\
\hline Uruguay & $\begin{array}{l}\text { Sí } \\
\text { Se encuentran establecidas en el art. } 45 \text { de la Ley } 9739 \text { y su modificativa Ley 17.616, una vez configurada la hipótesis que en el referido } \\
\text { artículo se plantea el usuario puede ampararse a la excepción y limitación sin requerir autorización o pago. La publicación o difusión por } \\
\text { radio o prensa, de obras destinadas a la enseñanza, de extractos, fragmentos de poesías y artículos sueltos, siempre que se indique el nombre } \\
\text { del autor; a publicación o transmisión por radio o en la prensa, de las lecciones orales de los profesores, de los discursos, informes o } \\
\text { exposiciones pronunciadas en las asambleas deliberantes, en los Tribunales de Justicia o en las reuniones públicas; Noticias, reportajes, } \\
\text { informaciones periodísticas o grabados de interés general, siempre que se mantenga su versión exacta y se exprese el origen de ellos; Las } \\
\text { transcripciones hechas con propósitos de comentarios, críticas o polémicas; La reproducción fiel de las leyes códigos, actas oficiales y } \\
\text { documentos públicos de cualquier género; La reproducción de las obras teatrales enajenadas, cuando hayan transcurrido dos años sin llevarse } \\
\text { a cabo la representación por el cesionario; La impresión o reproducción, por orden del autor o sus causahabientes, de las obras literarias } \\
\text { enajenadas; La reproducción fotográfica de cuadros, monumentos, o figuras alegóricas expuestas en los museos, parques o paseos públicos, } \\
\text { siempre que las obras de que se trata se consideren salidas del dominio privado; Las transmisiones de sonidos o figuras por estaciones } \\
\text { radiodifusoras del Estado, o por cualquier otro procedimiento, cuando esas estaciones no tengan ninguna finalidad comercial y estén }\end{array}$ \\
\hline
\end{tabular}




\begin{tabular}{|l|l|}
\hline & $\begin{array}{l}\text { destinadas exclusivamente a fines culturales; La ejecución, por bandas u orquestas del Estado, de pequeños trozos musicales o de partes de } \\
\text { obras en música, en programas públicos, siempre que se lleve a cabo sin fin de lucro }\end{array}$ \\
\hline
\end{tabular}

\begin{tabular}{|l|l|}
\hline CUESTIONES & $\begin{array}{l}\text { 4. ¿Contempla el ordenamiento jurídico de su país limitaciones y excepciones basadas en licencias legales (permiso directo concedido } \\
\text { por ley a cambio de una remuneración)? }\end{array}$ \\
\hline Argentina & $\begin{array}{l}\text { Sí } \\
\text { Decreto } 1155 / 58, \text { reglamentario del artículo V de la Convención Universal sobre Derecho de Autor (Ginebra 1952), hoy solamente aplicable a } \\
\text { los Estados que, siendo miembros de la citada Convención, no sean miembros del Convenio de Berna }\end{array}$ \\
\hline Brasil & No \\
\hline Chile & No \\
\hline Colombia & No \\
\hline Guatemala & No \\
\hline México & $\begin{array}{l}\text { Sí } \\
\text { Art. 147 de la LFDA establece que cuando no sea posible obtener el consentimiento del titular de los derechos patrimoniales } \\
\text { correspondientes, y mediante el pago de una remuneración compensatoria, el Ejecutivo Federal, por conducto de la Secretaría de Cultura, de } \\
\text { oficio o a petición de parte, podrá autorizar la publicación o traducción de obras literarias o artísticas necesarias para el adelanto de la ciencia, } \\
\text { la cultura y la educación nacionales. A este tipo de limitación se le conoce como limitación por causa de utilidad pública. }\end{array}$ \\
\hline Perú & No \\
\hline República Dominicana & No \\
\hline Uruguay & No \\
\hline
\end{tabular}

\begin{tabular}{|l|l|}
\hline CUESTIONES & $\begin{array}{l}\text { 5. iContempla el ordenamiento jurídico de su país limitaciones y excepciones basadas en licencias obligatorias (obligación por ley a } \\
\text { los titulares de derechos a conceder licencias a cambio de una remuneración)? }\end{array}$ \\
\hline
\end{tabular}


EL RÉGIMEN JURÍDICO DE LA COMPENSACIÓN EQUITATIVA...

\begin{tabular}{|l|l|}
\hline Argentina & Sí \\
\hline Brasil & No \\
\hline Chile & No \\
\hline Colombia & Sí \\
\hline Guatemala & No \\
\hline México & No \\
\hline Perú & No \\
\hline República Dominicana & No \\
\hline Uruguay & No \\
\hline
\end{tabular}

\begin{tabular}{|l|l|}
\hline CUESTIONES & $\begin{array}{l}\text { 6. ¿Contempla el ordenamiento jurídico de su país limitaciones o excepciones específicas que permitan el uso de obras protegidas por } \\
\text { derecho de autor con fines privados o personales, sin la autorización previa del titular de los derechos de autor o de los derechos } \\
\text { conexos? }\end{array}$ \\
\hline Argentina & No \\
\hline Brasil & $\begin{array}{l}\text { Sí } \\
\text { Está permitida la reproducción de pequeños extractos de toda obra, en un solo ejemplar, para el uso privado del que la hace, sin fines de lucro: } \\
\text { de obras intelectuales para uso exclusivo de deficientes visuales mediante procedimientos del sistema Braille u otros; la representación teatral } \\
\text { y la ejecución musical, cuando se realicen en el marco familiar o para fines exclusivamente didácticos en establecimientos de enseñanza; } \\
\text { retratos u otra forma de representación de imagen hechos por encargo, cuando no haya oposición de la persona retratada; y el conjunto de } \\
\text { lecciones en establecimientos de enseñanza, por aquellos a quienes sean dirigidas. }\end{array}$ \\
\hline Chile & Sí \\
\hline Colombia & Sí \\
\hline
\end{tabular}




\begin{tabular}{|c|c|}
\hline & Ley 23 de 1982, artículo 37. - Ley 23 de 1982, artículo 44. - Ley 23 de 1982, artículo 178, literal a). \\
\hline Guatemala & $\begin{array}{l}\text { Sí } \\
\text { Art. } 63 \text { Ley de D.A }\end{array}$ \\
\hline México & $\begin{array}{l}\text { Sí } \\
\text { Art. } 148 \text { de la LFDA dispone que las obras literarias y artísticas ya divulgadas podrán utilizarse, siempre que no se afecte la explotación } \\
\text { normal de la obra, sin autorización del titular del derecho patrimonial y sin remuneración, citando invariablemente la fuente y sin alterar la } \\
\text { obra, sólo en los siguientes casos... IV Reproducción por una sola vez, y en un sólo ejemplar, de una obra literaria o artística, para uso } \\
\text { personal y privado de quien la hace y sin fines de lucro. } \\
\text { Las personas morales no podrán valerse de lo dispuesto en esta fracción salvo que se trate de una institución educativa, de investigación, o } \\
\text { que no esté dedicada a actividades mercantiles. }\end{array}$ \\
\hline Perú & $\begin{array}{l}\text { Sí } \\
\text { Son permitidos determinados actos de reproducción, comunicación al público, etc. sin autorización previa del autor o del titular de los } \\
\text { derechos conexos. }\end{array}$ \\
\hline República Dominicana & $\begin{array}{l}\text { Sí } \\
\text { De las obras literarias o científicas y de los programas de computadoras en una sola copia (arts. } 37 \text { y } 74 \text { ley 65-00). }\end{array}$ \\
\hline Uruguay & No \\
\hline
\end{tabular}

\begin{tabular}{|l|l|}
\hline CUESTIONES & $\begin{array}{l}\text { 7. ¿Establece el ordenamiento jurídico de su país una remuneración por el uso con fines privados o personales (por ejemplo, } \\
\text { gravámenes por derecho de autor)? }\end{array}$ \\
\hline Argentina & No \\
\hline Brasil & No \\
\hline
\end{tabular}




\begin{tabular}{|c|c|}
\hline Chile & $\begin{array}{l}\text { Sí } \\
\text { Los usos no amparados expresamente por alguna excepción o limitación están sujetos al régimen general de autorización previa y eventual } \\
\text { pago, sin perjuicio de ello, no existen derechos específicos de remuneración por usos privados o personales. }\end{array}$ \\
\hline Colombia & No \\
\hline Guatemala & No \\
\hline México & No \\
\hline Perú & $\begin{array}{l}\text { Sí } \\
\text { En caso afirmativo, descríbase: El derecho de COPIA PRIVADA, constituye un mecanismo de compensación por el uso con fines privados o } \\
\text { personales. La Ley del Artista del año 2004, ha previsto la Institución de la copia privada en el Perú y se viene aplicando a la importación de } \\
\text { soportes vírgenes. Es lícita la copia, para uso exclusivamente personal de obras, interpretaciones o producciones publicadas en grabaciones } \\
\text { sonoras o audiovisuales. Sin embargo, las reproducciones permitidas en este artículo no se extienden: a) A la de una obra de arquitectura en } \\
\text { forma de edificio o de cualquier otra construcción. b) A la reproducción integral de un libro, de una obra musical en forma gráfica, o del } \\
\text { original o de una copia de una obra plástica, hecha y firmada por el autor. c) A una base o compilación de datos. }\end{array}$ \\
\hline República Dominicana & No \\
\hline Uruguay & No \\
\hline
\end{tabular}

\begin{tabular}{|l|l|}
\hline CUESTIONES & $\begin{array}{l}\text { 8. ¿Contempla el ordenamiento jurídico de su país que, en el marco de acuerdos de licencia o de otros contratos vinculantes, las } \\
\text { partes se comprometan a no llevar a cabo actos que en caso contrario estarían permitidos en virtud de las excepciones y limitaciones } \\
\text { de dicho ordenamiento jurídico? }\end{array}$ \\
\hline Argentina & No \\
\hline Brasil & No \\
\hline Chile & No \\
\hline
\end{tabular}




\begin{tabular}{|l|l|}
\hline Colombia & No \\
\hline Guatemala & No \\
\hline México & No \\
\hline Perú & Si bien el Decreto Legislativo 822 no lo contempla expresamente, es susceptible de ser pactado entre las partes. \\
\hline República Dominicana & No \\
\hline Uruguay & No \\
\hline
\end{tabular}

\begin{tabular}{|l|l|}
\hline CUESTIONES & $\begin{array}{l}\text { 9. ¿Supedita el ordenamiento jurídico de su país el ejercicio de las limitaciones y las excepciones a la condición de recurrir } \\
\text { obligatoriamente a una fuente legítima o autorizada (por ejemplo, que las copias se realicen a partir de una fuente legítima)? }\end{array}$ \\
\hline Argentina & $\begin{array}{l}\text { Sí. } \\
\text { Único caso: la reproducción y distribución de las obras científicas y literarias en sistemas especiales para ciegos y otros discapacitados } \\
\text { perceptivos debe ser hecha por entidades autorizadas. }\end{array}$ \\
\hline Brasil & No \\
\hline Chile & $\begin{array}{l}\text { Sí } \\
\text { Todas las excepciones de la ley parten del supuesto de que se ha accedido legítimamente a la obra sobre la cual se realizarán las acciones } \\
\text { permitidas. }\end{array}$ \\
\hline Colombia & $\begin{array}{l}\text { Sí } \\
\text { Se presume que el uso de las limitaciones y excepciones debe hacerse de ejemplares lícitamente adquiridos, sin embargo expresamente solo lo } \\
\text { señala el artículo 22, literal b, de la Decisión Andina 351 de 1993. }\end{array}$ \\
\hline Guatemala & $\begin{array}{l}\text { Sí } \\
\text { La publicación de leyes, decretos, reglamentos, órdenes, acuerdos, resoluciones, las decisiones judiciales y de órganos administrativos, así } \\
\text { como las traducciones oficiales de esos textos, podrá efectuarse libremente siempre que siga fielmente la publicación oficial (Art. 63 y 68 Ley }\end{array}$ \\
\hline
\end{tabular}




\begin{tabular}{|l|l|}
\hline México & de Derecho de Autor y Derechos Conexos). \\
\hline Perú & No \\
\hline República Dominicana & $\begin{array}{l}\text { La legislación sobre Derecho de Autor prevista en el Decreto Legislativo 822 - Ley sobre el Derecho de Autor - no lo prevé expresamente. } \\
\text { Sin embargo, las partes pueden establecer pactos expresos sobre el particular. }\end{array}$ \\
\hline Uruguay & En caso de los artículos y extractos de obras lícitamente publicadas (art. 32 ley 65-009). \\
\hline
\end{tabular}

\begin{tabular}{|c|c|}
\hline CUESTIONES & 10. ¿Protege el ordenamiento jurídico de su país las medidas tecnológicas? \\
\hline Argentina & No \\
\hline Brasil & Sí \\
\hline Colombia & Sí \\
\hline Guatemala & $\begin{array}{l}\text { Sí } \\
\text { Art. } 133 \text { sexties, de la Ley de D.A. }\end{array}$ \\
\hline México & Sí \\
\hline Perú & $\begin{array}{l}\text { Sí } \\
\text { Decreto Legislativo } 1076\end{array}$ \\
\hline República Dominicana & Sí \\
\hline
\end{tabular}




\begin{tabular}{|c|c|}
\hline CUESTIONES & 11. ¿Protege el ordenamiento jurídico de su país la información sobre la gestión de los derechos? \\
\hline Argentina & No \\
\hline Brasil & Sí \\
\hline Chile & Sí \\
\hline Colombia & Sí \\
\hline Guatemala & $\begin{array}{l}\text { Sí } \\
\text { Art. } 133 \text { septies, de la Ley de D.A }\end{array}$ \\
\hline México & No \\
\hline Perú & $\begin{array}{l}\text { Sí } \\
\text { Decreto Legislativo } 1076\end{array}$ \\
\hline República Dominicana & Sí \\
\hline Uruguay & $\begin{array}{l}\text { Sí } \\
\text { ART. } 46 \text {.D }\end{array}$ \\
\hline
\end{tabular}

\begin{tabular}{|l|l|}
\hline CUESTIONES & $\begin{array}{l}\text { 12. ¿Establece el ordenamiento jurídico de su país mecanismos específicos para garantizar que se sigan aplicando las limitaciones o } \\
\text { las excepciones pese a la existencia de algún tipo de medida tecnologica que pueda haber aplicado el titular de los derechos de autor o } \\
\text { derechos conexos? }\end{array}$ \\
\hline Argentina & No \\
\hline Brasil & No \\
\hline Chile & No \\
\hline
\end{tabular}




\begin{tabular}{|c|c|}
\hline Colombia & No \\
\hline Guatemala & $\begin{array}{l}\text { Sí } \\
\text { Artículo } 133 \text { sexties del Decreto 33-98 y sus reformas. Adicionado por el artículo } 107 \text { del Decreto 11-2006 Reformas Legales para la } \\
\text { Implementación del Tratado de Libre Comercio República Dominicana- Centroamérica- Estados Unidos de América. }\end{array}$ \\
\hline México & No \\
\hline Perú & 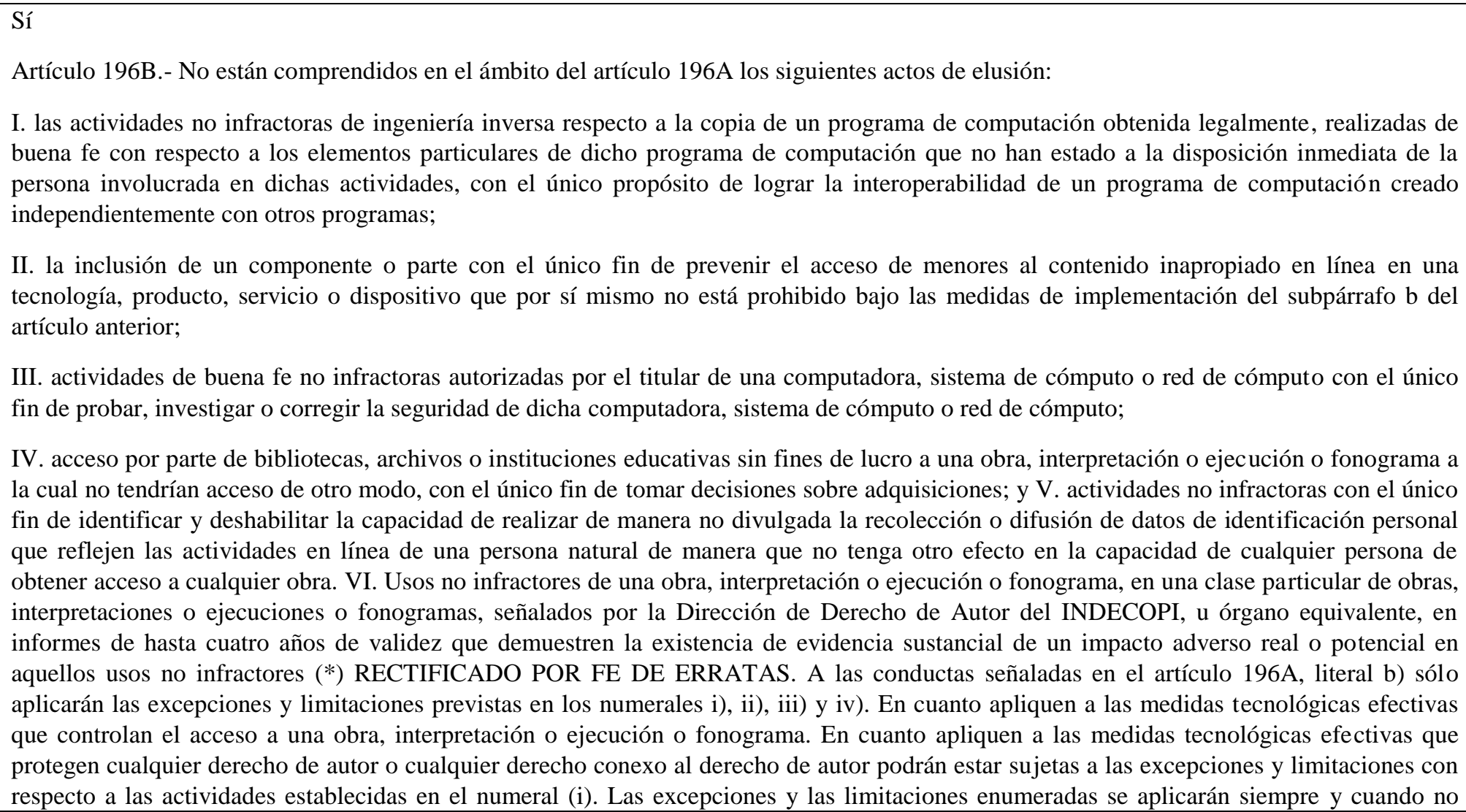 \\
\hline
\end{tabular}




\begin{tabular}{|l|l|}
\hline & menoscaben la adecuada protección legal o la efectividad de los recursos legales contra la elusión de medidas tecnológicas efectivas. \\
\hline República Dominicana & No \\
\hline Uruguay & No \\
\hline
\end{tabular}

\begin{tabular}{|l|l|}
\hline CUESTIONES & $\begin{array}{l}\text { 13. Si fuera necesario recurrir a procedimientos judiciales, iqué promedio de tiempo es necesario para garantizar el ejercicio de las } \\
\text { limitaciones y las excepciones en caso de que el titular de los derechos de autor o los derechos conexos aplique algún tipo de medida } \\
\text { tecnológica de protección? }\end{array}$ \\
\hline Argentina & - \\
\hline Brasil & $\begin{array}{l}\text { Todavía no se conoce jurisprudencia respecto del tema. Sin embargo, se reconoce que los pleitos son desestimulados por la morosidad del } \\
\text { sistema judicial del país. }\end{array}$ \\
\hline Chile & No existen datos estadísticos. \\
\hline Colombia & El Consejo Superior de la Judicatura ha establecido que estos procesos tienen una duración promedio de 2 años. \\
\hline Guatemala & La Ley de Derecho de Autor y Derechos Conexos Artículo 129 establece un plazo no mayor a los 10 días. \\
\hline México & - \\
\hline Perú & En el Perú los procedimientos judiciales en el ámbito civil pueden durar entre 12 y 36 meses. \\
\hline República Dominicana & No aplica. \\
\hline Uruguay & $\begin{array}{l}\text { No existe procedimiento específico previsto al respecto. Nuestra legislación procesal a los efectos de lograr una sentencia que declare tales } \\
\text { derechos sería por medio del proceso civil ordinario, el cual entre primera instancia y segunda puede llegar a durar } 2 \text { años aproximadamente. }\end{array}$ \\
\hline
\end{tabular}




\begin{tabular}{|c|c|}
\hline CUESTIONES & $\begin{array}{l}\text { 14. ¿Establece el ordenamiento jurídico de su país que prevalezcan determinadas limitaciones o excepciones sobre la prohibición de } \\
\text { eludir las medidas tecnológicas de protección o sobre los sistemas de información para la gestión de derechos? }\end{array}$ \\
\hline Argentina & No \\
\hline Brasil & No \\
\hline Chile & - \\
\hline Colombia & $\begin{array}{l}\text { Sí } \\
\text { El artículo } 272 \text { del Código Penal Colombiano establece que es delito violar una medida tecnológica, siempre y cuando se haga para un uso no } \\
\text { autorizado. Así mismo, el artículo } 271 \text { del Código Penal Colombiano establece que salvo las excepciones señaladas en la ley una utilización } \\
\text { de la obra sin autorización puede constituir delito. En este sentido eludir una medida tecnológica para un uso autorizado es aceptable. } \\
\text { Expresamente no está estipulado pero por la redacción de los artículos anteriormente señalados se presume. }\end{array}$ \\
\hline Guatemala & No \\
\hline México & No \\
\hline Perú & $\begin{array}{l}\text { Sí } \\
\text { Decreto Legislativo } 1076 \text { Artículo 196D.- No están comprendidas en los alcances los artículos } 196^{\mathrm{a}} \text { y 196C las actividades legalmente } \\
\text { autorizadas de investigación, protección, seguridad de la información o inteligencia, llevadas a cabo por empleados, agentes o contratistas del } \\
\text { gobierno. Para los efectos de este párrafo, el término "seguridad de la información" significa actividades llevadas a cabo para identificar y } \\
\text { abordar la vulnerabilidad de una computadora, un sistema de cómputo o una red de cómputo gubernamentales. }\end{array}$ \\
\hline República Dominicana & No \\
\hline Uruguay & No \\
\hline
\end{tabular}

\begin{tabular}{|l|l|}
\hline CUESTIONES & $\begin{array}{l}\text { 15. Si fuera necesario recurrir a procedimientos judiciales en relación con las limitaciones y excepciones, ¿cuál es el promedio de } \\
\text { tiempo necesario para solventar una controversia con respecto a la prohibición de eludir las medidas tecnológicas de protección o con } \\
\text { respecto a los sistemas de información para la gestión de los derechos? }\end{array}$ \\
\hline Argentina & - \\
\hline
\end{tabular}




\begin{tabular}{|l|l|}
\hline Brasil & $\begin{array}{l}\text { Todavía no se conoce jurisprudencia a respecto del tema. Sin embargo, se reconoce que los pleitos son desestimulados por la morosidad del } \\
\text { sistema judicial del país. }\end{array}$ \\
\hline Chile & No existen datos estadísticos. \\
\hline Colombia & El Consejo Superior de la Judicatura ha establecido que estos procesos tiene una duración promedio de 2 años. \\
\hline Guatemala & 6 meses Art. 133 septies, Ley de D.A. \\
\hline México & - \\
\hline Perú & El procedimiento judicial en el Perú podría durar entre 12 y 36 meses aproximadamente. \\
\hline República Dominicana & No aplica. \\
\hline Uruguay & Ídem respuesta a pregunta n..$^{\circ} 13$. \\
\hline
\end{tabular}

\begin{tabular}{|l|l|}
\hline Cuestiones & $\begin{array}{l}\text { 16. ¿Contempla el ordenamiento jurídico de su país limitaciones y excepciones aplicadas específicamente al uso de programas } \\
\text { informáticos? }\end{array}$ \\
\hline Argentina & No \\
\hline Brasil & $\begin{array}{l}\text { Sí } \\
\text { Está permitida la copia de salvaguardia, en un solo ejemplar, para programas de ordenador }\end{array}$ \\
\hline Chile & $\begin{array}{l}\text { Sí } \\
\text { Art. 71Ñ: a) Adaptación o copia de programas computacionales, esencial para su uso, o para su respaldo; b) Ingeniería inversa de un } \\
\text { programa computacional, para lograr compatibilidad operativa entre programas computacionales, o para fines de investigación y desarrollo; y } \\
\text { c) Actividades sobre un programa computacional para probar, investigar o corregir su funcionamiento o la seguridad del mismo u otros } \\
\text { programas (security testing). }\end{array}$ \\
\hline Colombia & Sí \\
\hline
\end{tabular}




\begin{tabular}{|l|l|}
\hline & Decisión Andina 351 de 1993, artículo 24. - Decisión Andina 351 de 1993, artículo 27 \\
\hline Guatemala & Sí \\
\hline México & No \\
\hline Perú & Sí \\
\hline Lepública Dominicana & Sí \\
& Art. 74 ley 65-00. \\
\hline Uruguay & No \\
\hline
\end{tabular}

\begin{tabular}{|c|c|}
\hline CUESTIONES & 17. ¿Establece el ordenamiento jurídico de su país limitaciones y excepciones al uso temporal de obras digitales? \\
\hline Argentina & No \\
\hline Brasil & $\begin{array}{l}\text { Sí } \\
\text { La legislación nacional no trata como limitación o excepción la copia efímera necesaria para hacer una obra, una interpretación o un } \\
\text { fonograma perceptible en medio electrónico, sino como un acto que se desarrolla fuera del ámbito del derecho exclusivo de reproducción. Por } \\
\text { lo tanto, está permitida la reproducción siempre que esta sea temporaria y tenga, solamente, el propósito de hacer la obra, el fonograma o la } \\
\text { interpretación perceptible en medio electrónico o cuando sea de naturaleza transitoria o incidental, siempre que ocurra en el curso del uso } \\
\text { debidamente autorizado de la obra. }\end{array}$ \\
\hline Chile & $\begin{array}{l}\text { Sí } \\
\text { Las normas no hacen distinguen entre obras digitales y obras en otros soportes. Por otro lado, existe una norma específica que autoriza la }\end{array}$ \\
\hline
\end{tabular}




\begin{tabular}{|l|l|}
\hline & reproducción provisional de una obra, que sea transitoria y accesoria, como parte de un proceso tecnológico (art. 71, O). \\
\hline Colombia & No \\
\hline Guatemala & No \\
\hline México & No \\
\hline Perú & No \\
\hline República Dominicana & No \\
\hline Uruguay & No \\
\hline
\end{tabular}

\begin{tabular}{|l|l|}
\hline CUESTIONES & $\begin{array}{l}\text { 18. ¿Contempla el ordenamiento jurídico de su país limitaciones y excepciones, o cláusulas de salvaguardia ("safe harbors", } \\
\text { disposiciones jurídicas en virtud de las cuales una persona no es responsable por haber tomado determinadas medidas) en favor de } \\
\text { las actividades de los proveedores de servicios de transmisiones digitales de obras? }\end{array}$ \\
\hline Argentina & No \\
\hline Brasil & No \\
\hline Chile & Sí \\
En los artículos $85 \mathrm{~L}$ a $85 \mathrm{U}$. \\
\hline Colombia & No \\
\hline Guatemala & No \\
\hline México & No \\
\hline Perú & No \\
\hline República Dominicana & No \\
\hline Uruguay & No \\
\hline
\end{tabular}




\begin{tabular}{|c|c|}
\hline CUESTIONES & $\begin{array}{l}\text { 19. ¿Establece el ordenamiento jurídico de su país que prevalezcan determinadas limitaciones o excepciones sobre la prohibición de } \\
\text { traficar con dispositivos o prestar servicios que permitan eludir las medidas tecnológicas de protección o los sistemas de información } \\
\text { sobre la gestión de derechos? }\end{array}$ \\
\hline Argentina & No \\
\hline Brasil & No \\
\hline Chile & No \\
\hline Colombia & No \\
\hline Guatemala & No \\
\hline México & No \\
\hline Perú & No \\
\hline República Dominicana & No \\
\hline Uruguay & No \\
\hline
\end{tabular}

\begin{tabular}{|l|l|}
\hline CUESTIONES & $\begin{array}{l}\text { 20. Si fuera necesario recurrir a procedimientos judiciales en relación con las excepciones y limitaciones, ¿cuál es el promedio de } \\
\text { tiempo necesario para solventar una controversia en lo que respecta a la prohibición del comercio de dispositivos o la prestación de } \\
\text { servicios que permitan la elusión de las medidas tecnológicas de protección o los sistemas de información sobre la gestión de los } \\
\text { derechos? }\end{array}$ \\
\hline Argentina & - \\
\hline Brasil & $\begin{array}{l}\text { Todavía no se conoce jurisprudencia respecto del tema. Sin embargo, se reconoce que los pleitos son desestimulados por la morosidad del } \\
\text { sistema judicial del país. }\end{array}$ \\
\hline Chile & No existen datos estadísticos. \\
\hline
\end{tabular}




\begin{tabular}{|l|l|}
\hline Colombia & El Consejo Superior de la Judicatura ha establecido que estos procesos tienen una duración promedio de 2 años. \\
\hline Guatemala & 6 meses Art. 133 septies, Ley de D.A \\
\hline México & - \\
\hline Perú & Aproximadamente entre 12 y 36 meses. \\
\hline República Dominicana & No aplica. \\
\hline Uruguay & Ídem respuesta a pregunta $n .^{\circ} 13$. \\
\hline
\end{tabular}




\section{ANEXO 8}

EL LÍMITE DE COPIA PRIVADA Y LA COMPENSACIÓN POR COPIA PRIVADA EN LAS LEYES DE AMÉRICA LATINA Y EL

\section{CARIBE}

\begin{tabular}{|c|c|c|}
\hline PAÍS & COPIA PRIVADA & COMPENSACIÓN \\
\hline Bolivia & - & - \\
\hline Chile & $\begin{array}{l}\text { No reconoce el límite de copia privada. } \\
\text { No obstante, debe tenerse en cuenta que el art.71.D de la Ley } \\
17336 \text { de } 1970 \text {, sobre la Propiedad Intelectual, establece: "Las } \\
\text { lecciones dictadas en instituciones de educación superior, } \\
\text { colegios y escuelas, podrán ser anotadas o recogidas en } \\
\text { cualquier forma por aquellos a quienes van dirigidas, pero no }\end{array}$ & - \\
\hline
\end{tabular}




\begin{tabular}{|c|c|c|}
\hline & $\begin{array}{l}\text { podrán ser publicadas, total o parcialmente, sin autorización } \\
\text { de sus autores". Además, el art. } 71 \text {.J dispone: "Las bibliotecas } \\
\text { y archivos que no tengan fines lucrativos podrán, sin que se } \\
\text { requiera autorización del autor o titular, ni pago de } \\
\text { remuneración alguna, efectuar copias de fragmentos de obras } \\
\text { que se encuentren en sus colecciones, a solicitud de un } \\
\text { usuario de la biblioteca o archivo exclusivamente para su uso } \\
\text { personal. } \\
\text { Las copias a que se refiere el inciso anterior sólo podrán ser } \\
\text { realizadas por la respectiva biblioteca o archivo". }\end{array}$ & \\
\hline Colombia & $\begin{array}{l}\text { Ley } 23 \text { de 1982. Artículo 37.- "Es lícita la reproducción, por } \\
\text { cualquier medio, de una obra literaria o científica, ordenada u } \\
\text { obtenida por el interesado en un solo ejemplar para su uso } \\
\text { privado y sin fines de lucro". }\end{array}$ & - \\
\hline Costa Rica & $\begin{array}{l}\text { Ley } 6.683 \text { de 1982. Artículo } 74 \text {. (Reformado por el artículo } 1^{\circ} \text { de la } \\
\text { ley } \mathrm{N}^{\circ} 7397 \text {, del } 3 \text { de mayo de 1994.) "También es libre la } \\
\text { reproducción de una obra didáctica o científica, efectuada personal } \\
\text { y exclusivamente por el interesado para su propio uso y sin ánimo } \\
\text { de lucro directo o indirecto. Esa reproducción deberá realizarse en } \\
\text { un solo ejemplar, mecanografiado o manuscrito. Esta disposición no }\end{array}$ & - \\
\hline
\end{tabular}




\begin{tabular}{|c|c|c|}
\hline & se aplicará a los programas de computación". & \\
\hline Cuba & - & - \\
\hline Ecuador & $\begin{array}{l}\text { Ley de Propiedad Intelectual (Codificación No. 2006-013). } \\
\text { Artículo 108.- "Se entenderá por copia privada la copia } \\
\text { doméstica de fonogramas o videogramas, o la reproducción } \\
\text { reprográfica en un solo ejemplar realizada por el adquirente } \\
\text { original de un fonograma o videograma u obra literaria de } \\
\text { circulación lícita, destinada exclusivamente para el uso no } \\
\text { lucrativo de la persona natural que la realiza. Dicha copia no } \\
\text { podrá ser empleada en modo alguno contrario a los usos } \\
\text { honrados. } \\
\text { La copia privada realizada sobre soportes o con equipos } \\
\text { reproductores que no hayan pagado la remuneración } \\
\text { compensatoria constituye una violación del derecho de autor y } \\
\text { de los derechos conexos correspondientes". }\end{array}$ & $\begin{array}{l}\text { Ley de Propiedad Intelectual (Codificación No. 2006-013). } \\
\text { Artículo 105.- "La copia privada de obras fijadas en } \\
\text { fonogramas o videogramas, así como la reproducción } \\
\text { reprográfica de obras literarias impresas estará sujeta a una } \\
\text { remuneración compensatoria de conformidad con las } \\
\text { disposiciones de este parágrafo. Esta remuneración se causará } \\
\text { por el hecho de la distribución de soportes susceptibles de } \\
\text { incorporar una fijación sonora o audiovisual o de equipos } \\
\text { reproductores de fonogramas o videogramas, o de equipos para } \\
\text { reproducción reprográfica. } \\
\text { La remuneración corresponderá por partes iguales a los autores, } \\
\text { a los artistas, intérpretes o ejecutantes y, a los productores de } \\
\text { fonogramas en el caso de fonogramas y videogramas y, } \\
\text { corresponderá así mismo, por partes iguales a los autores y } \\
\text { editores en el caso de obras literarias. } \\
\text { La remuneración compensatoria por copia privada de } \\
\text { fonogramas y videogramas será recaudada por una entidad } \\
\text { recaudadora única y común de autores, intérpretes y } \\
\text { productores de fonogramas y videogramas, cuyo objeto social } \\
\text { será exclusivamente la recaudación colectiva de la } \\
\text { remuneración compensatoria por copia privada. Igualmente, la }\end{array}$ \\
\hline
\end{tabular}




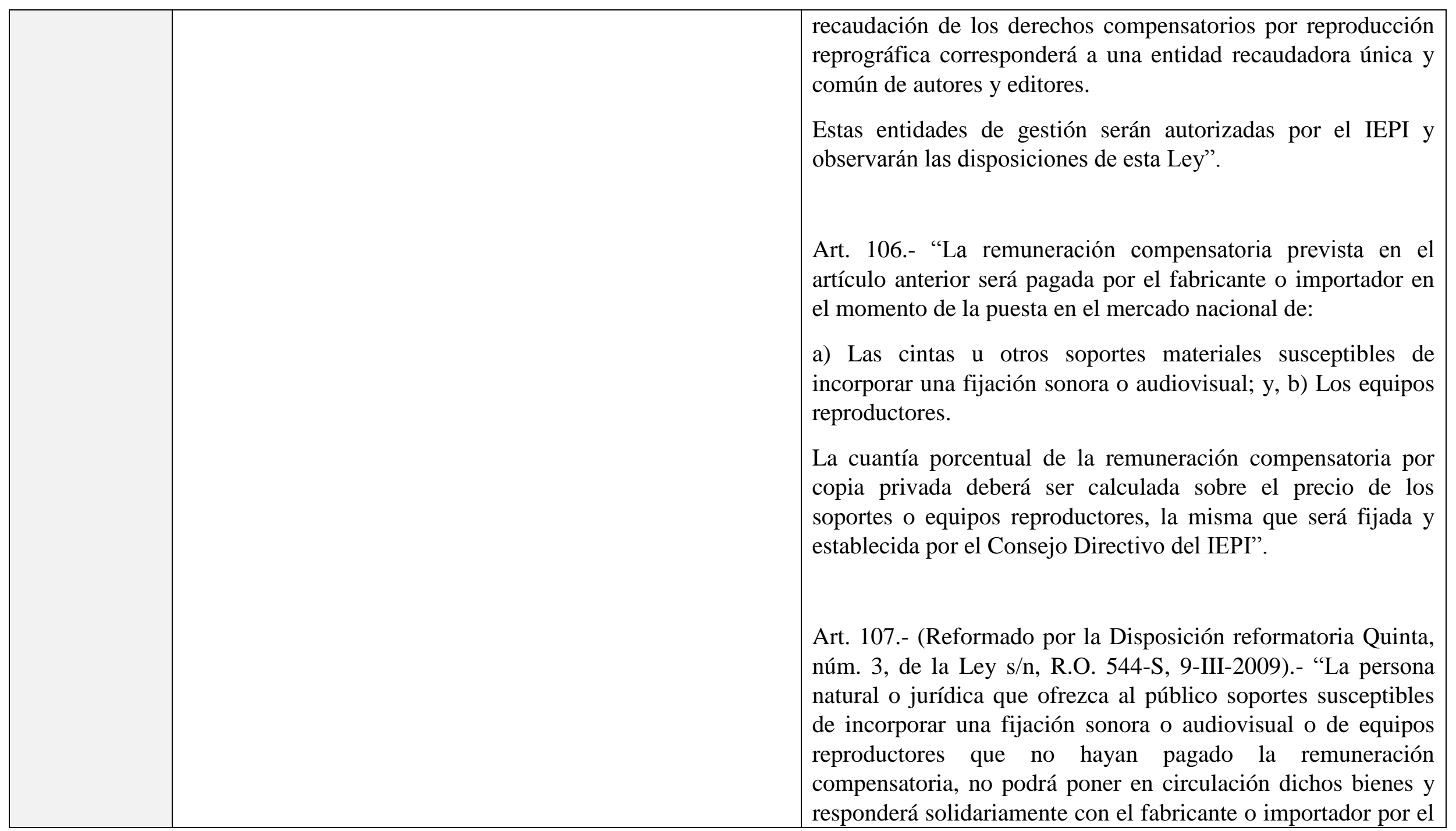




\begin{tabular}{|c|c|c|}
\hline & & $\begin{array}{l}\text { pago de dicha remuneración, sin perjuicio de que el IEPI, o las } \\
\text { juezas o jueces competentes, según el caso, retiren del comercio } \\
\text { los indicados bienes hasta la solución de la remuneración } \\
\text { correspondiente. } \\
\text { La falta de pago de la remuneración compensatoria será } \\
\text { sancionada con una multa equivalente al trescientos por ciento } \\
\text { de lo que debió pagar. } \\
\text { Los productores de fonogramas o los titulares de derechos } \\
\text { sobre las obras a que se refiere este parágrafo, o sus } \\
\text { licenciatarios, no están sujetos a esta remuneración, por las } \\
\text { importaciones que realicen". }\end{array}$ \\
\hline El Salvador & $\begin{array}{l}\text { Decreto } 604 \text { de 1993. Artículo } 45 .- \text { "Respecto de las obras ya } \\
\text { divulgadas lícitamente, es permitida sin autorización del autor } \\
\text { y sin remuneración: } \\
\text { a) La reproducción de una copia de la obra para el uso } \\
\text { personal y exclusivo del usuario, realizada por el } \\
\text { propio interesado por sus propios medios, siempre que } \\
\text { no atente contra la explotación normal de la obra, ni } \\
\text { cause un perjuicio injustificado a los intereses } \\
\text { legítimos del autor; } \\
\text { b) Las reproducciones fotomecánicas para el exclusivo } \\
\text { uso personal, como la fotocopia y el microfilm, } \\
\text { siempre que se limiten a pequeñas partes de una obra } \\
\text { protegida o a obras agotadas. Se equipara a la }\end{array}$ & - \\
\hline
\end{tabular}




\begin{tabular}{|c|c|c|}
\hline & $\begin{array}{l}\text { reproducción ilícita toda utilización de las piezas } \\
\text { reproducidas por cualquier medio o procedimiento, } \\
\text { para un uso distinto del personal que se haga en } \\
\text { concurrencia con el derecho exclusivo del autor de } \\
\text { explotar su obra; [...]". }\end{array}$ & \\
\hline Honduras & $\begin{array}{l}\text { Decreto } N^{\circ} 4-99-E \text {, modificada por el Decreto } N^{\circ} 16-2006 \text {. } \\
\text { Artículo 47.- "Respecto de ejemplares de obras adquiridas } \\
\text { lícitamente por una persona, es permitida sin autorización del } \\
\text { autor ni remuneración, reproducción de una copia de la obra } \\
\text { para el uso personal y exclusivo de esa persona, realizada por } \\
\text { él, con sus propios medios, siempre que se trate de casos } \\
\text { especiales, que no atente a la Explotación normal de la obra ni } \\
\text { cause un perjuicio injustificado a los intereses legítimos del } \\
\text { autor". } \\
\text { Artículo 48.- "También son lícitas las reproducciones } \\
\text { fotomecánicas para el exclusivo uso personal, como la } \\
\text { fotocopia y el microfilme siempre que se limiten a pequeñas } \\
\text { partes de una obra protegida o a obras agotadas". } \\
\text { Artículo 51.- "Es libre la reproducción en un solo ejemplar } \\
\text { manuscrito o mecanografiado efectuada personal o } \\
\text { exclusivamente por el interesado, de una obra didáctica o } \\
\text { científica, para su propio uso y sin ánimo de lucro, directo o } \\
\text { indirecto". }\end{array}$ & - \\
\hline México & Ley Federal del Derecho de Autor de 1996. Artículo 148.- & Ley Federal del Derecho de Autor de 1996. Artículo 40.- "Los \\
\hline
\end{tabular}




\begin{tabular}{|c|c|c|}
\hline & $\begin{array}{l}\text { "Las obras literarias y artísticas ya divulgadas podrán } \\
\text { utilizarse, siempre que no se afecte la explotación normal de } \\
\text { la obra, sin autorización del titular del derecho patrimonial y } \\
\text { sin remuneración, citando invariablemente la fuente y sin } \\
\text { alterar la obra, sólo en los siguientes casos: (...) IV. } \\
\text { Reproducción por una sola vez, y en un sólo ejemplar, de una } \\
\text { obra literaria o artística, para uso personal y privado de quien } \\
\text { la hace y sin fines de lucro. } \\
\text { Las personas morales no podrán valerse de lo dispuesto en } \\
\text { esta fracción salvo que se trate de una institución educativa, } \\
\text { de investigación, o que no esté dedicada a actividades } \\
\text { mercantiles; }(. . .) " \text {. }\end{array}$ & $\begin{array}{l}\text { titulares de los derechos patrimoniales de autor y de los } \\
\text { derechos conexos podrán exigir una remuneración } \\
\text { compensatoria por la realización de cualquier copia o } \\
\text { reproducción hecha sin su autorización y sin estar amparada por } \\
\text { alguna de las limitaciones previstas en los artículos } 148 \text { y } 151 \\
\text { de la presente Ley". } \\
\text { Reglamento de la Ley Federal de Derecho de Autor. Artículo } \\
\text { 19.- "La remuneración compensatoria por copia privada es } \\
\text { aquella que corresponde al autor, al titular de derechos conexos } \\
\text { o sus causahabientes por la copia o reproducción realizada en } \\
\text { los términos del artículo } 40 \text { de la Ley". } \\
\text { Artículo 20.- "La remuneración compensatoria por copia } \\
\text { privada podrá ser recaudada por los autores, titulares de } \\
\text { derechos conexos y sus causahabientes, personalmente o por } \\
\text { conducto de una sociedad". }\end{array}$ \\
\hline
\end{tabular}




\begin{tabular}{|c|c|c|}
\hline & $\begin{array}{l}\text { 3) La reproducción de la totalidad o de partes importantes de } \\
\text { bases de datos en forma numérica. } \\
\text { 4) La reproducción de programas de ordenador, salvo en los } \\
\text { casos previstos en el Artículo } 39 \text { de la presente Ley. } \\
\text { 5) } \mathrm{Ni} \text {, a ninguna otra reproducción de una obra que pudiera } \\
\text { afectar a la explotación normal de la obra o que pudiera } \\
\text { perjudicar de forma injustificada a los intereses legítimos del } \\
\text { autor". }\end{array}$ & \\
\hline Panamá & $\begin{array}{l}\text { Ley } N^{\circ} 64 \text { de 2012. Artículo 68.- "Respecto a las obras, } \\
\text { prestaciones o producciones ya divulgadas lícitamente, se } \\
\text { permite sin necesidad de autorización: } \\
\text { 1. La reproducción del original o de una copia de la obra en } \\
\text { forma de grabación sonora o audiovisual para el uso personal } \\
\text { y exclusivo del usuario. } \\
\text { 2. La reproducción reprográfica de un ejemplar legítimo para } \\
\text { el exclusivo uso personal, siempre que se limite a pequeñas } \\
\text { partes de una obra protegida o a obras agotadas. } \\
\text { 3. Se equipara a la utilización ilícita todo uso de las piezas } \\
\text { reproducidas por cualquier medio o procedimiento para un } \\
\text { uso distinto del personal, efectuado en concurrencia con el } \\
\text { derecho exclusivo de reproducción". }\end{array}$ & - \\
\hline Paraguay & $\begin{array}{l}\text { Ley } 1.328 \text { de } 1998 \text { de Derechos de Autor y Derechos } \\
\text { Conexos. Artículo 44.- "Es lícita la copia para uso }\end{array}$ & $\begin{array}{l}\text { Ley } 1.328 \text { de } 1998 \text { de Derechos de Autor y Derechos Conexos. } \\
\text { Artículo 34.- "Los titulares de los derechos sobre las obras }\end{array}$ \\
\hline
\end{tabular}




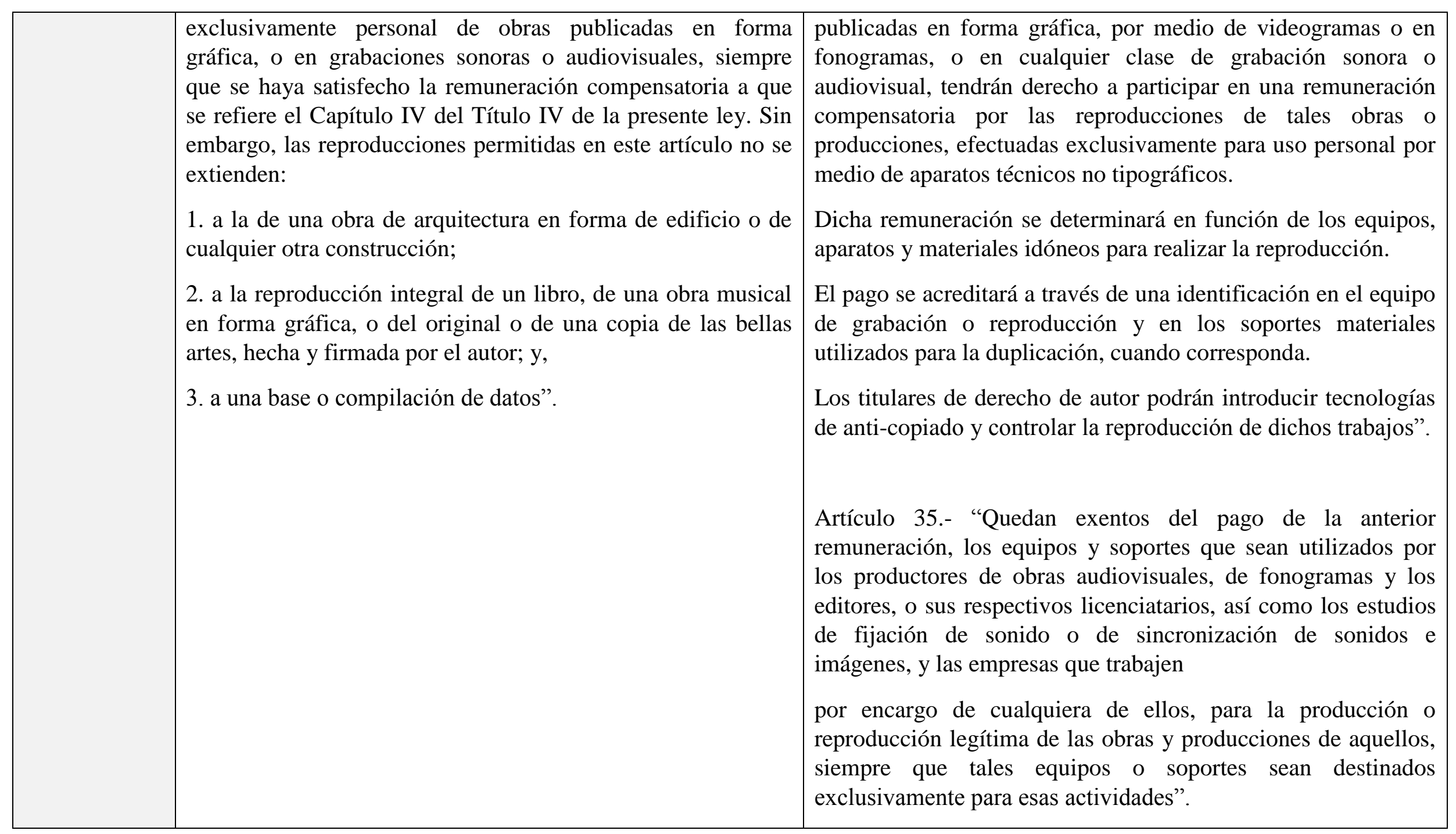




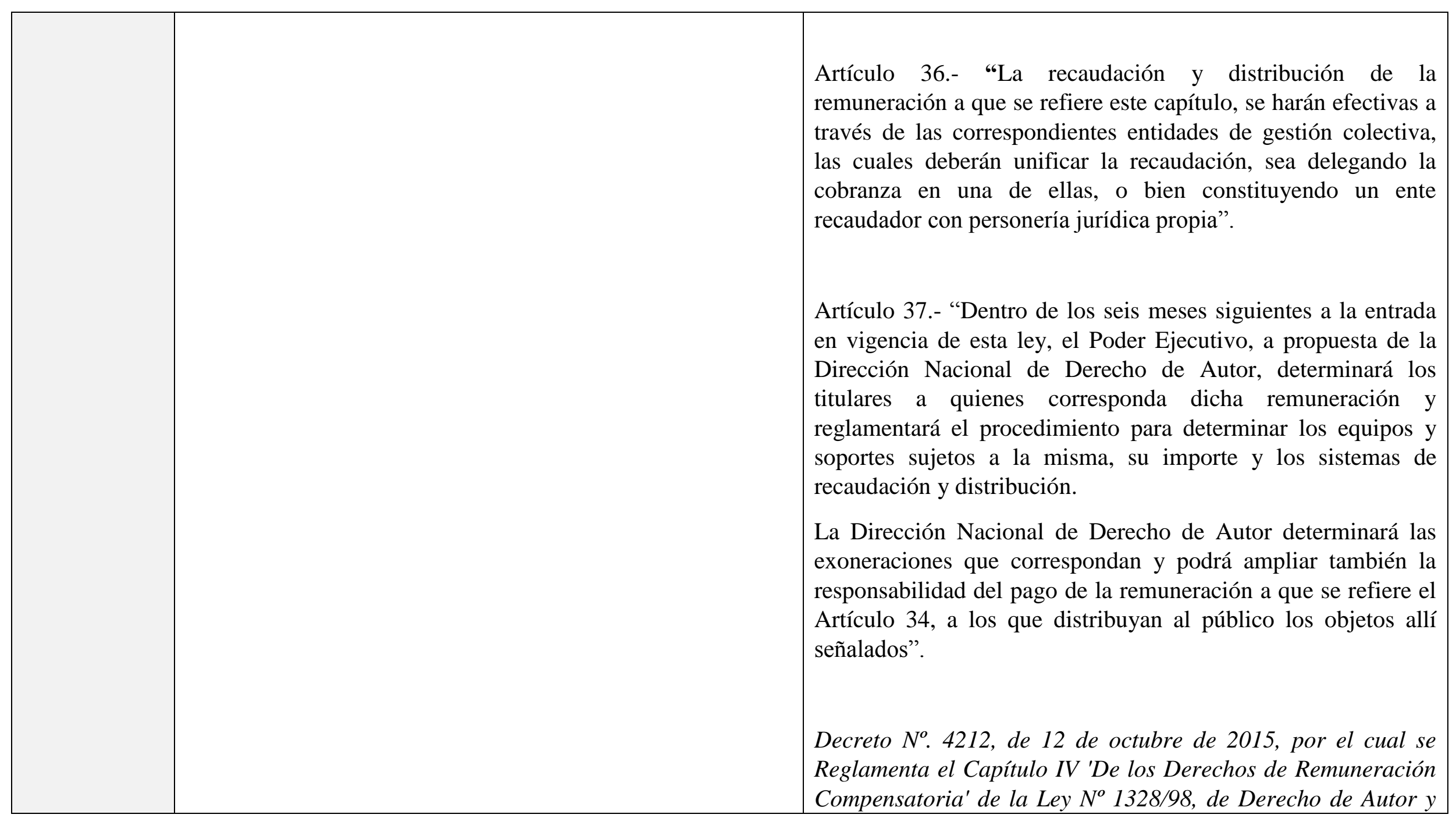




\begin{tabular}{|c|c|c|}
\hline & & Derechos Conexos y se deroga el Decreto $N^{o} .6780 / 2011$. \\
\hline Perú & $\begin{array}{l}\text { Decreto Legislativo 822, de } 23 \text { de abril de 1996, Ley sobre el } \\
\text { Derecho de Autor. } \\
\text { Artículo 2.- "Definiciones. (...) Uso personal: Reproducción u } \\
\text { otra forma de utilización de la obra de otra persona, en un sólo } \\
\text { ejemplar, exclusivamente para el propio uso de un individuo. } \\
\text { Artículo 43.- "Respecto de las obras ya divulgadas } \\
\text { lícitamente, es permitida sin autorización del autor: (...) b) La } \\
\text { reproducción por reprografía de breves fragmentos o de obras } \\
\text { agotadas, publicadas en forma gráfica, para uso } \\
\text { exclusivamente personal". } \\
\text { Artículo 48.- "Es lícita la copia, para uso exclusivamente } \\
\text { personal de obras, interpretaciones o producciones publicadas } \\
\text { en grabaciones sonoras o audiovisuales. Sin embargo, las } \\
\text { reproducciones permitidas en este artículo no se extienden: } \\
\text { a) A la de una obra de arquitectura en forma de edificio o de } \\
\text { cualquier otra construcción. }\end{array}$ & $\begin{array}{l}\text { Ley } N^{o} 28131 \text {, de } 10 \text { de diciembre de 2003, del artista } \\
\text { intérprete y ejecutante. } \\
\text { "Artículo 20.- Compensación por copia privada. } \\
20.1 \text { La reproducción realizada exclusivamente para uso } \\
\text { privado de obras, interpretaciones o ejecuciones artísticas en } \\
\text { forma de videogramas o fonogramas, en soportes o materiales } \\
\text { susceptibles de contenerlos, origina el pago de una } \\
\text { compensación por copia privada, a ser distribuida entre el } \\
\text { artista, el autor y el productor del videograma y/o del } \\
\text { fonograma, en la forma y porcentajes que establezca el } \\
\text { Reglamento. } \\
20.2 \text { La compensación por copia privada no constituye un } \\
\text { tributo. Los ingresos que se obtengan por dicho concepto se } \\
\text { encuentran regulados por la normatividad tributaria aplicable. } \\
20.3 \text { Están obligados al pago de esta compensación el } \\
\text { fabricante nacional, así como el importador del material es o } \\
\text { soportes idóneo s que permitan la reproducción a que se refiere } \\
\text { el párrafo anterior. } \\
20.4 \text { Están exceptuados del pago el productor de videograma o }\end{array}$ \\
\hline
\end{tabular}




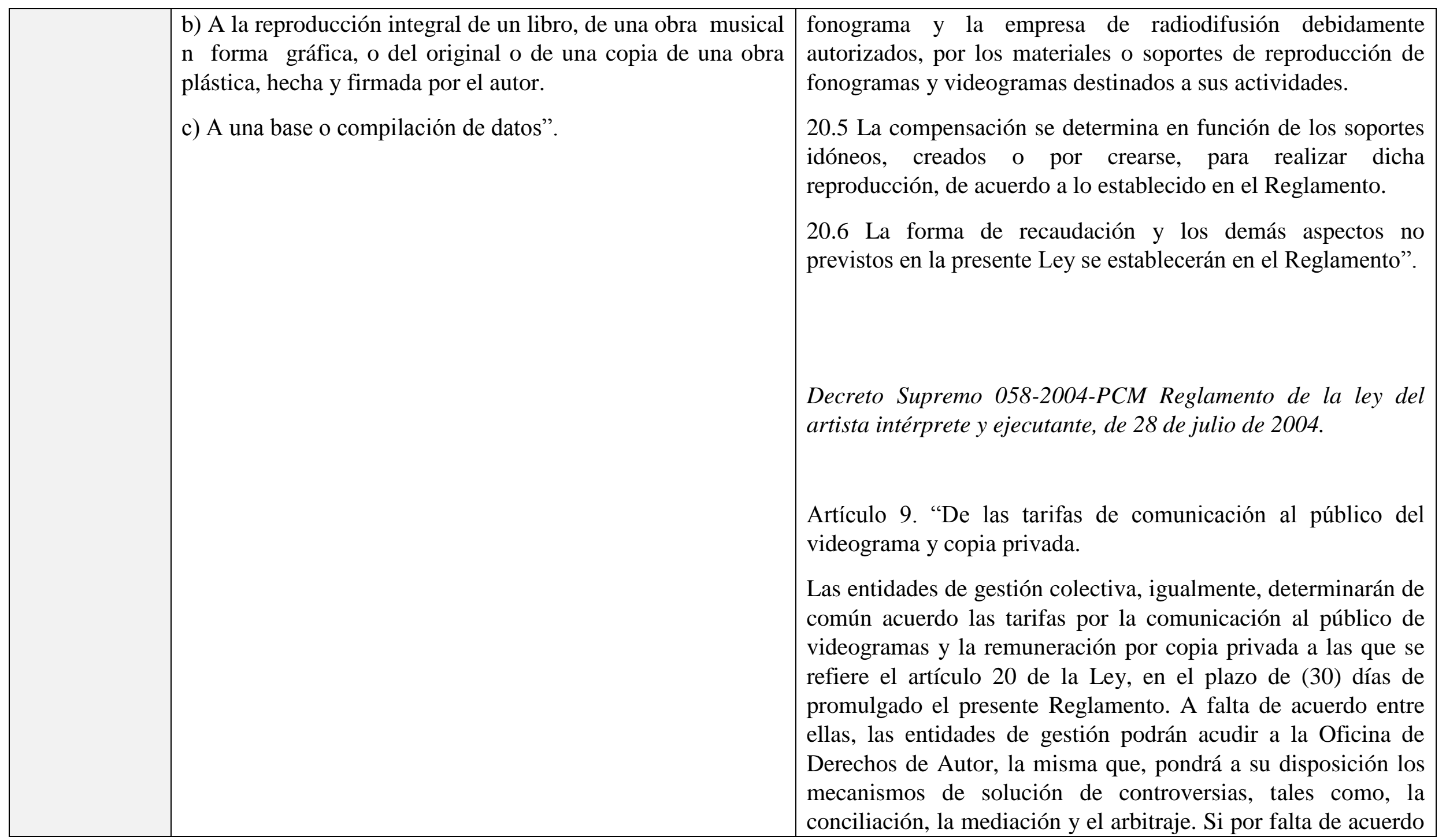




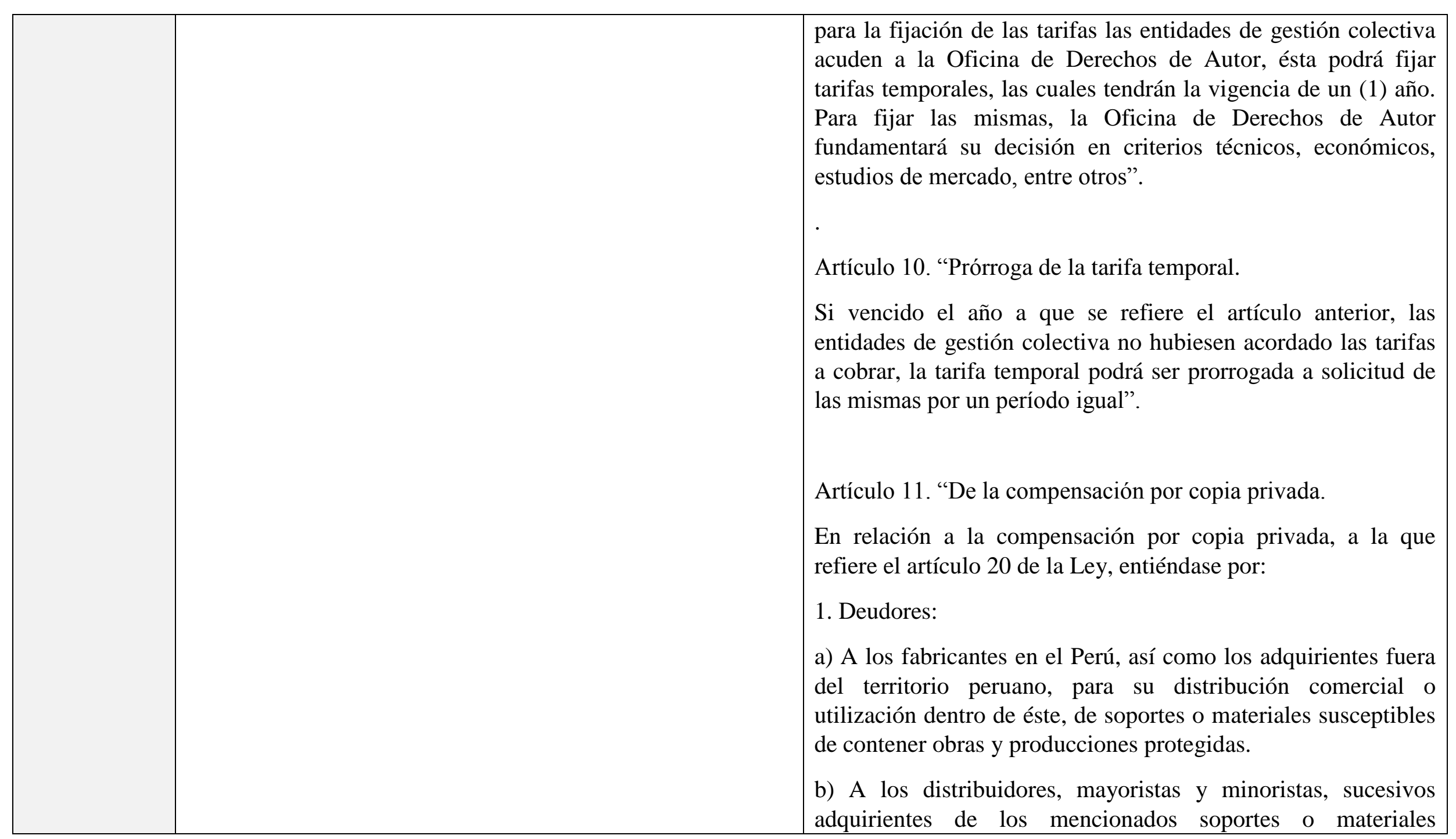




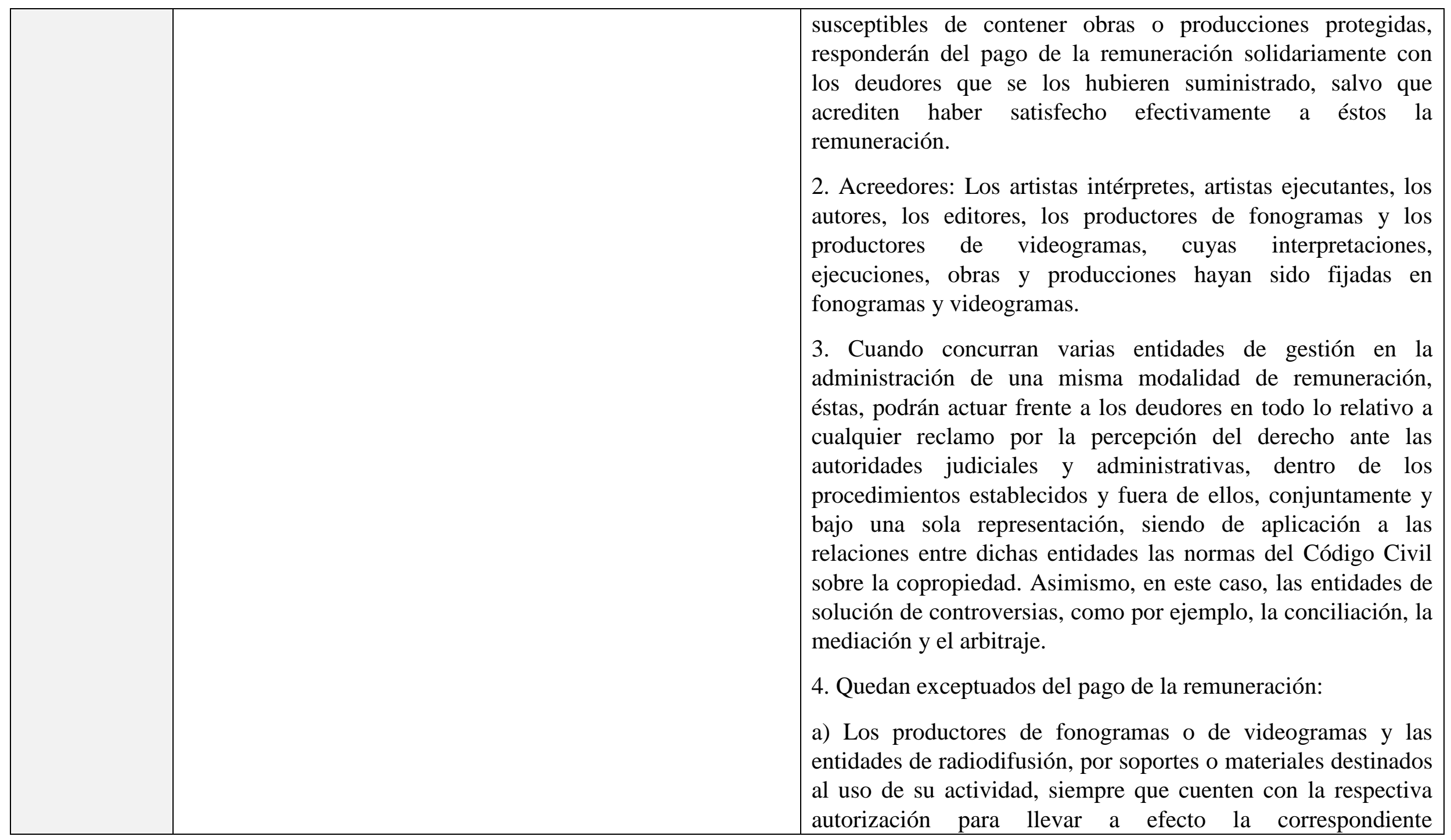




\begin{tabular}{|c|c|c|}
\hline & & $\begin{array}{l}\text { reproducción de obras, prestaciones artísticas, fonogramas y } \\
\text { videogramas, según proceda en el ejercicio de tal actividad; lo } \\
\text { que deberán acreditar a los fabricantes e importadores y, en su } \\
\text { caso, a sus responsables solidarios, mediante certificación de la } \\
\text { entidad o entidades de gestión correspondientes, en el supuesto } \\
\text { de adquirir soportes o materiales dentro del territorio peruano. } \\
\text { b) Las personas naturales que adquieran fuera del territorio } \\
\text { peruano los referidos soportes y lo ingresen al país como } \\
\text { equipaje personal, y en una cantidad tal, que permita presumir } \\
\text { razonablemente que los destinarán al uso privado en dicho } \\
\text { territorio". }\end{array}$ \\
\hline $\begin{array}{l}\text { República } \\
\text { Dominicana }\end{array}$ & $\begin{array}{l}\text { Ley No. 65-00 de 2000. Artículo 37.- "Es lícita la } \\
\text { reproducción, por una sola vez y en un solo ejemplar, de una } \\
\text { obra literaria o científica, para uso personal y sin fines de } \\
\text { lucro, sin perjuicio del derecho del titular a obtener una } \\
\text { remuneración equitativa por la reproducción reprográfica o } \\
\text { por la copia privada de una grabación sonora o audiovisual, en } \\
\text { la forma que determine el reglamento. Los programas de } \\
\text { computadoras se regirán por lo pautado expresamente en las } \\
\text { disposiciones especiales de esta ley sobre tales obras". }\end{array}$ & $\begin{array}{l}\text { Decreto } N^{\circ} \text { 362-01 que establece el Reglamento de Aplicación } \\
\text { de la Ley } N^{\circ} \text { 65-00 sobre Derecho de Autor. } \\
\text { Artículo 53.- "El derecho de remuneración equitativa que } \\
\text { corresponde a los titulares de derechos sobre las obras } \\
\text { publicadas en forma gráfica, videogramas o fonogramas, o en } \\
\text { toda otra clase de grabación sonora o audiovisual, para } \\
\text { compensar a dichos titulares por las remuneraciones dejadas de } \\
\text { percibir en razón de esas reproducciones, de conformidad con } \\
\text { lo dispuesto en el artículo } 37 \text { de la Ley, será objeto de } \\
\text { reglamentación especial". }\end{array}$ \\
\hline
\end{tabular}




\begin{tabular}{|c|c|c|}
\hline & & $\begin{array}{l}\text { Decreto No. 548-04, de } 17 \text { de junio de 2004, que establece una } \\
\text { remuneración equitativa y única por la reproducción realizada } \\
\text { exclusivamente para uso personal y sin fines de lucro, } \\
\text { conforme lo dispone el Artículo } 37 \text { de la Ley No. 65-00 del } \\
2000, \text { sobre Derecho de Autor. }\end{array}$ \\
\hline Uruguay & $\begin{array}{l}\text { Proyecto de Ley que modifica las limitaciones y excepciones } \\
\text { al Derecho de Autor (iniciativa conocida como Ley de } \\
\text { Fotocopias), Carpeta } N^{o} 293 \text { de } 2015 \text {, Repartido } N^{\circ} 237 \text {, abril } \\
\text { de } 2016 \\
\text { Artículo 4.- "Agréguense al artículo } 45 \text { de la Ley } 9.739 \text {, de } 17 \\
\text { de diciembre de } 1937 \text { los siguientes numerales: (...) 15) La } \\
\text { reproducción hecha por cualquier medio, sin autorización del } \\
\text { autor o titular, de una obra o prestación protegida, ordenada y } \\
\text { obtenida por una persona física, en un solo ejemplar para su } \\
\text { uso personal y sin fines de lucro". }\end{array}$ & - \\
\hline
\end{tabular}




\begin{tabular}{|l|l|l|}
\hline personal, como la fotocopia y el microfilme, siempre que se \\
limiten a pequeñas partes de una obra protegida o a obras \\
agotadas, y sin perjuicio de la remuneración equitativa que \\
deban abonar las empresas, instituciones y demás \\
organizaciones que presten ese servicio al público, a los \\
titulares del respectivo derecho de reproducción. Se equipara \\
a la reproducción ilícita, toda y utilización de las piezas \\
reproducidas para un uso distinto del personal que se haga en \\
concurrencia con el derecho exclusivo del autor de explotar su \\
obra".
\end{tabular} \mid




\begin{abstract}
ANEXO 9
INGRESOS POR REMUNERACIÓN COMPENSATORIA POR COPIA PARA USO PERSONAL EN PARAGUAY
\end{abstract}

\title{
COMPARATIVO DE INGRESOS DE COPIA PRIVADA
}

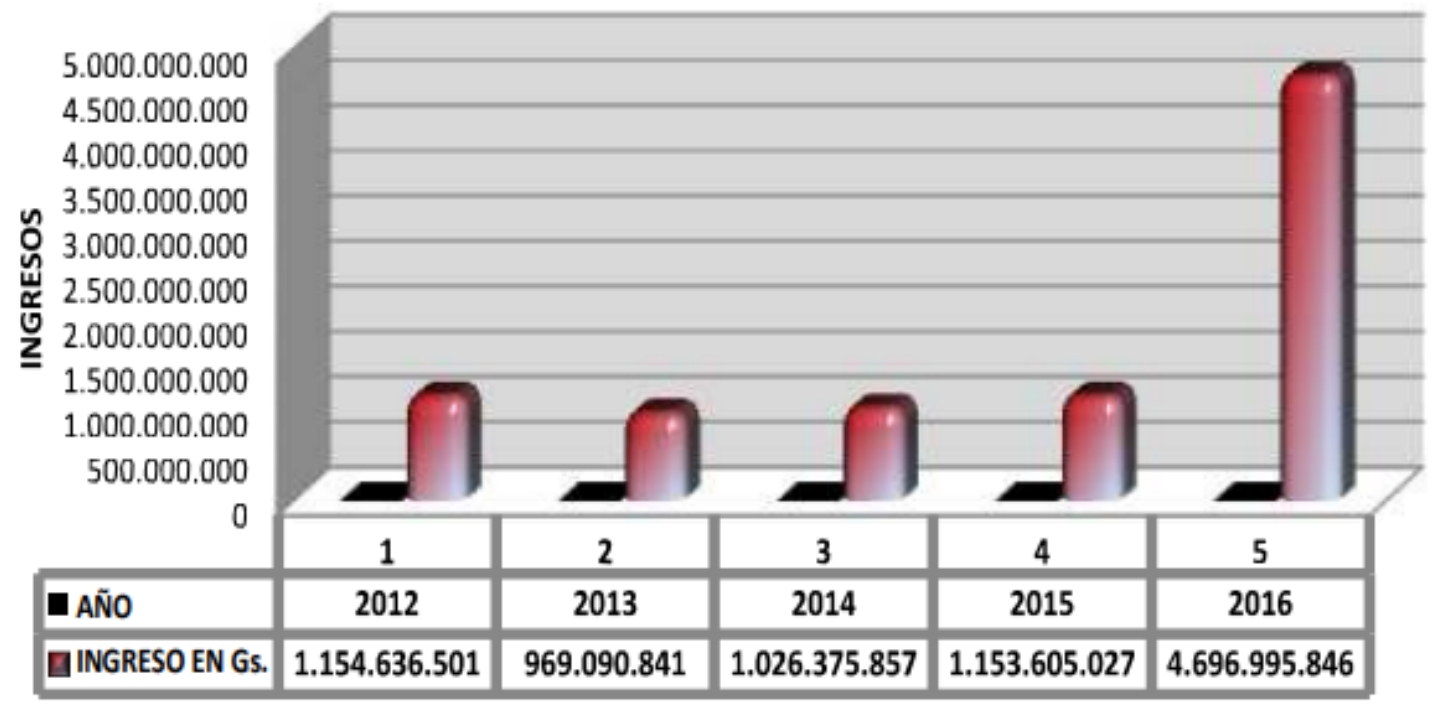




\section{ANEXO 10}

\section{RECAUDACIÓN NACIONAL EN PERÚ}

(Años 2015 y comparativa 2014-2015)

\section{Recaudación Nacional 2015}

\begin{tabular}{|l|r|}
\hline \multicolumn{1}{|c|}{ COMUNICACIONN PUBLICA } & $\begin{array}{r}\text { EJECUTADO A DIC 2015 } \\
\text { EXPRESADO EN SI. }\end{array}$ \\
\hline LOCALES PERMANENTES & $5,672.352 .94$ \\
\hline RADIO & $1,679,279.55$ \\
\hline TELEVISION & $2,308,291.04$ \\
\hline OPERADORES DE CABLE & $3,059,502.05$ \\
\hline BAILES & $1,055.008 .28$ \\
\hline ESPECTACULOS & $991,988.57$ \\
\hline WEBCASTING/NTERNET & $25,044.78$ \\
\hline RECUPERACION LEGAL & $5,003.14$ \\
\hline TOTAL COMUNICACIÓN PUBLICA & $14,796,470.35$ \\
\hline CONTRATO DE LICENCIA AEGIONAL & 100.823 .00 \\
\hline REPRODUCCION & $1,000.00$ \\
\hline COPIA PRIVADA & $19,846.46$ \\
\hline EGEDA PERU & $83,721.24$ \\
\hline TOTAL GENERAL & $15,001,861.05$ \\
\hline
\end{tabular}


Recaudación Nacional Comparativa 2014-2015

\begin{tabular}{|l|r|r|}
\hline COMUNICACION PUBLICA & $\begin{array}{r}\text { EJECUTADO } \\
\text { A DIC 2014 } \\
\text { EXPRESADO } \\
\text { EN S/. }\end{array}$ & $\begin{array}{r}\text { EJECUTADO } \\
\text { A DIC 2015 } \\
\text { EXPRESADO } \\
\text { EN S/. }\end{array}$ \\
\hline LOCALES PERMANENTES & $6,589,485.90$ & $5,672.352 .94$ \\
\hline RADIO & $1,600,305.67$ & $1,679,279.55$ \\
\hline TELEVISION & $2,224,752.37$ & $2.308,291.04$ \\
\hline OPERADORES DE CABLE & $2,145,716.75$ & $3.059,502.05$ \\
\hline BAILES & $889,552.54$ & $1,055,008.28$ \\
\hline ESPECTACULOS & $1,173,969.61$ & $991,988.57$ \\
\hline WEBCASTING/NTERNET & $15,902.14$ & $25,044.78$ \\
\hline RECUPERACION LEGAL & $214,183.27$ & $5,003.14$ \\
\hline TOTAL COMUNICACIONN & $14,853,868.25$ & $14,796,470.35$ \\
\hline PUBLICA & $115,238.35$ & $100,823.00$ \\
\hline CONTRATO DE LICENCIA & $10,240.00$ & $1,000.00$ \\
\hline REGIONAL & $68,021.23$ & $19,846.46$ \\
\hline REPRODUCCION & $95,907.42$ & $83,721.24$ \\
\hline COPIA PRIVADA & $15,143,275.25$ & $15,001,861.05$ \\
\hline EGEDA PERU & &
\end{tabular}

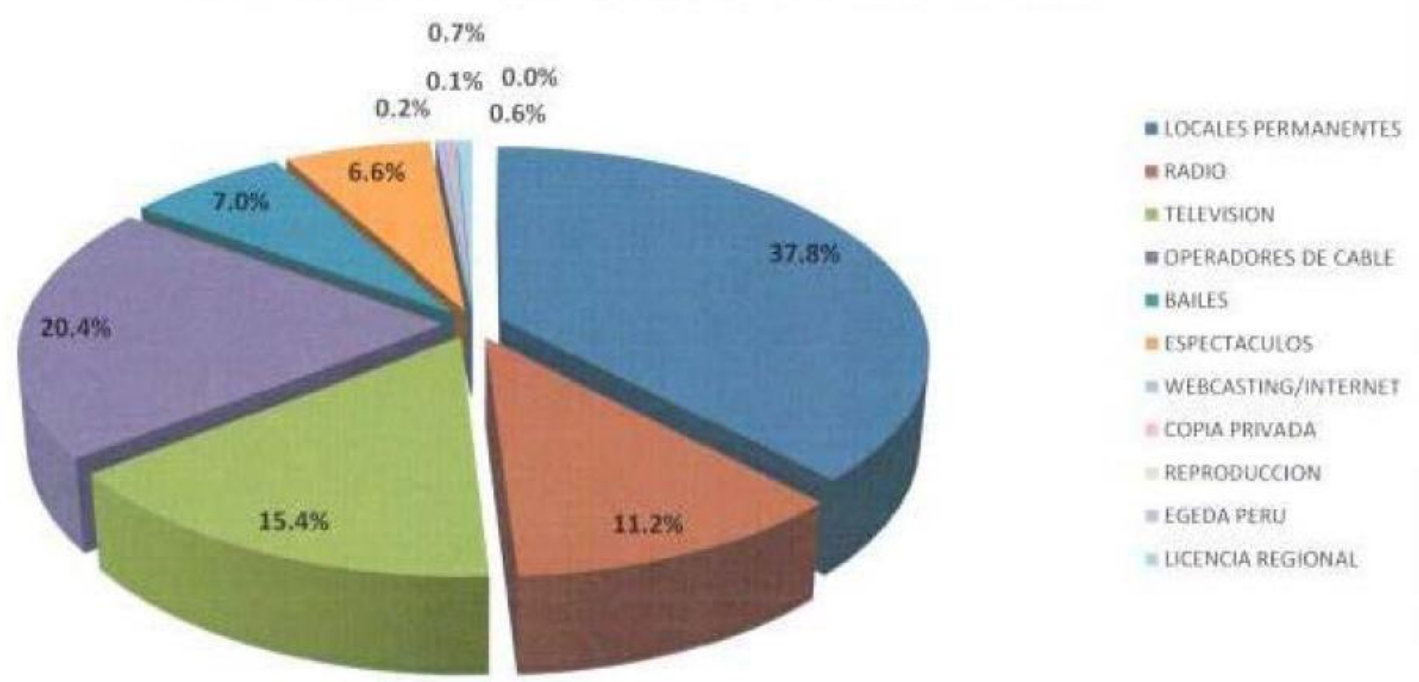

